\author{
Tobias A. Jopp
}

\title{
War, Bond Prices, and Public Opinion
}

How Did the Amsterdam Bond Market Perceive the Belligerents' War Effort During World War One?

\section{Online Appendix}




\section{Table of contents}

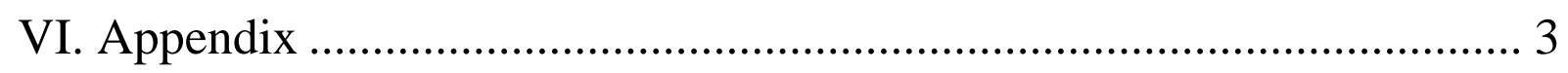

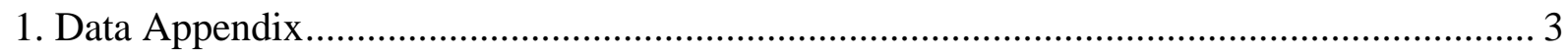

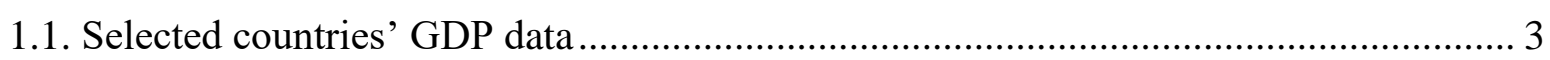

1.2. An overview of the government bonds' financial characteristics ................................ 6

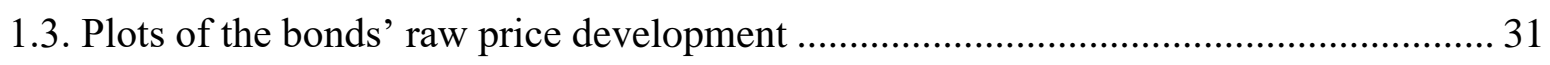

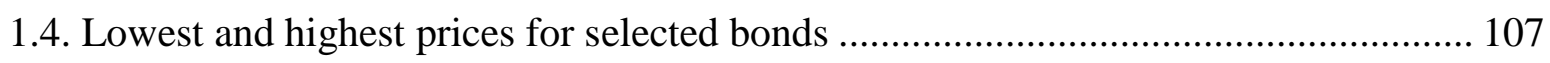

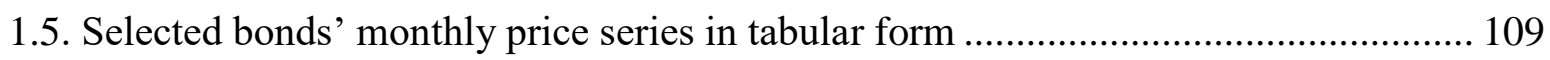

1.6. Selected monthly exchange rates in tabular form............................................... 120

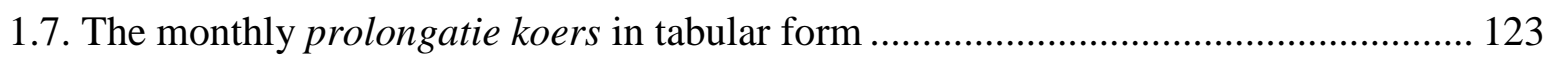

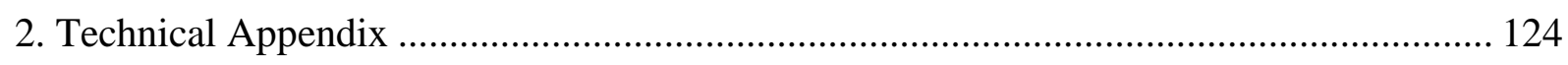

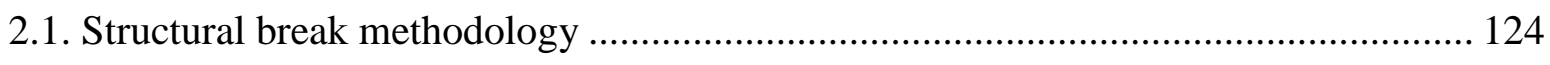

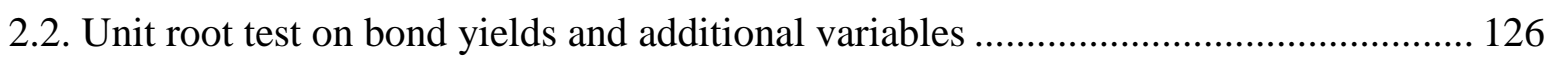

2.3. Pairwise correlations among representative bonds............................................ 128

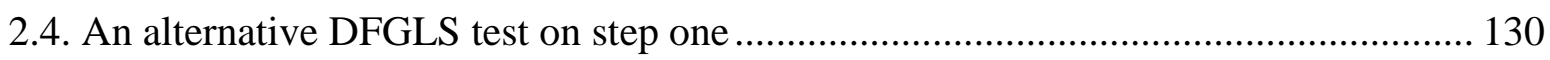

2.5. Intermediate cointegration results on the "global test" on alliance integration........... 131 


\section{Appendix}

\section{Data Appendix}

\subsection{Selected countries' GDP data}

Table A.1 provides the data on GDP per capita used to compute the indices that are depicted in Figure 1.1 in this study's introductory chapter. Computing indices provides the basis for assessing changes in a time series over time in an illustrative way. But this advantage comes at the cost of a loss of information on the depicted data's levels. Therefore, I provide the original data that I took from the Maddison database along with the computed indices. Given are the absolute GDP per capita figures corresponding to the series in the Maddison database that is labeled "rgdpnapc". This series is described as "real GDP per capita in 2011US\$, 2011 benchmark (suitable for cross-country growth comparisons)". For additional information on the database and the data themselves, I refer the reader to the homepage of the Maddison Project at Groningen University as well as to Bolt et al. (2018). Finally, the country abbreviations used in the following are: AUT = Austria; FRA = France; GER = Germany; ITA = Italy; RUS = Russia; TUR = Turkey; and UK = United Kingdom. 
Table A.1: Selected countries' GDP per capita (1870-1950)

\begin{tabular}{|c|c|c|c|c|c|c|c|}
\hline Year & AUT & FRA & GER & ITA & RUS & TUR & UK \\
\hline 1870 & 3229 & 3086 & 3715 & 3143 & - & 1449 & 5716 \\
\hline 1871 & 3431 & 3125 & 3670 & 3073 & - & - & 5684 \\
\hline 1872 & 3427 & 3419 & 3902 & 3005 & - & - & 5657 \\
\hline 1873 & 3317 & 3162 & 4037 & 2989 & - & - & 5729 \\
\hline 1874 & 3435 & 3549 & 4291 & 3144 & - & - & 5760 \\
\hline 1875 & 3421 & 3651 & 4267 & 3160 & - & - & 5834 \\
\hline 1876 & 3468 & 3337 & 4183 & 3082 & - & - & 5823 \\
\hline 1877 & 3555 & 3500 & 4106 & 3102 & - & - & 5808 \\
\hline 1878 & 3642 & 3440 & 4248 & 3180 & - & - & 5764 \\
\hline 1879 & 3585 & 3213 & 4098 & 3189 & - & - & 5674 \\
\hline 1880 & 3604 & 3488 & 4023 & 3239 & - & - & 5879 \\
\hline 1881 & 3719 & 3609 & 4091 & 3337 & - & - & 6027 \\
\hline 1882 & 3710 & 3765 & 4130 & 3378 & - & - & 6147 \\
\hline 1883 & 3830 & 3764 & 4330 & 3408 & - & - & 6142 \\
\hline 1884 & 3898 & 3707 & 4401 & 3357 & - & - & 6099 \\
\hline 1885 & 3841 & 3631 & 4477 & 3406 & 1860 & - & 6012 \\
\hline 1886 & 3932 & 3680 & 4467 & 3481 & 1788 & - & 6050 \\
\hline 1887 & 4169 & 3701 & 4596 & 3569 & 2091 & - & 6235 \\
\hline 1888 & 4125 & 3733 & 4729 & 3550 & 2011 & - & 6457 \\
\hline 1889 & 4052 & 3821 & 4806 & 3442 & 1870 & - & 6743 \\
\hline 1890 & 4236 & 3909 & 4904 & 3444 & 1862 & - & 6711 \\
\hline 1891 & 4345 & 4001 & 4841 & 3490 & 1706 & - & 6648 \\
\hline 1892 & 4395 & 4101 & 4988 & 3494 & 1867 & - & 6426 \\
\hline 1893 & 4378 & 4170 & 5182 & 3549 & 2116 & - & 6360 \\
\hline 1894 & 4585 & 4320 & 5247 & 3569 & 2406 & - & 6718 \\
\hline 1895 & 4660 & 4227 & 5426 & 3598 & 2227 & - & 6859 \\
\hline 1896 & 4683 & 4418 & 5534 & 3652 & 2452 & - & 7070 \\
\hline 1897 & 4734 & 4342 & 5605 & 3658 & 2411 & - & 7088 \\
\hline 1898 & 4951 & 4540 & 5753 & 3643 & 2475 & - & 7354 \\
\hline 1899 & 5004 & 4790 & 5869 & 3683 & 2627 & - & 7578 \\
\hline 1900 & 4997 & 4731 & 6029 & 3781 & 2570 & - & 7446 \\
\hline 1901 & 4965 & 4650 & 5800 & 3843 & 2634 & - & 7370 \\
\hline 1902 & 5107 & 4566 & 5845 & 3904 & 2863 & - & 7486 \\
\hline 1903 & 5099 & 4657 & 6077 & 3939 & 2665 & - & 7337 \\
\hline 1904 & 5125 & 4683 & 6229 & 4008 & 2947 & - & 7311 \\
\hline 1905 & 5357 & 4761 & 6270 & 4091 & 2609 & - & 7456 \\
\hline 1906 & 5507 & 4842 & 6368 & 4229 & 2493 & - & 7631 \\
\hline 1907 & 5788 & 5051 & 6555 & 4304 & 2396 & - & 7702 \\
\hline 1908 & 5756 & 5009 & 6574 & 4395 & 2616 & - & 7316 \\
\hline 1909 & 5680 & 5210 & 6615 & 4430 & 2716 & - & 7410 \\
\hline 1910 & 5705 & 4878 & 6763 & 4435 & 2899 & - & 7567 \\
\hline 1911 & 5835 & 5346 & 6885 & 4483 & 2678 & - & 7721 \\
\hline 1912 & 6077 & 5782 & 7118 & 4487 & 2893 & - & 7800 \\
\hline 1913 & 6009 & 5733 & 7369 & 4698 & 3040 & 1831 & 8052 \\
\hline 1914 & 4986 & 5324 & 6180 & 4442 & 2903 & - & 7973 \\
\hline 1915 & 4600 & 5343 & 5856 & 4219 & 2987 & - & 8471 \\
\hline 1916 & 4556 & 5698 & 5928 & 4566 & 2656 & - & 8532 \\
\hline 1917 & 4484 & 4901 & 5963 & 4581 & 2332 & - & 8496 \\
\hline 1918 & 4430 & 3941 & 6026 & 4465 & 1428 & 1035 & 8462 \\
\hline
\end{tabular}


Table A. 1 continued

\begin{tabular}{|c|c|c|c|c|c|c|c|}
\hline & AUT & FRA & GER & ITA & RUS & TUR & UK \\
\hline 1919 & 3917 & 4625 & 5225 & 4286 & 1231 & - & 7456 \\
\hline 1920 & 4183 & 5309 & 5647 & 4388 & 1236 & - & 6881 \\
\hline 1921 & 4595 & 5058 & 6217 & 4239 & 1131 & - & 6660 \\
\hline 1922 & 4989 & 5939 & 6729 & 4548 & 1313 & - & 7247 \\
\hline 1923 & 4928 & 6175 & 5554 & 4920 & 1512 & 1242 & 7439 \\
\hline 1924 & 5484 & 6876 & 6462 & 5008 & 1916 & 1347 & 7691 \\
\hline 1925 & 5838 & 6854 & 7134 & 5305 & 2394 & 1490 & 8041 \\
\hline 1926 & 5918 & 6991 & 7282 & 5300 & 2688 & 1718 & 7715 \\
\hline 1927 & 6078 & 6834 & 7961 & 5159 & 2800 & 1551 & 8307 \\
\hline 1928 & 6341 & 7290 & 8262 & 5435 & 2945 & 1692 & 8373 \\
\hline 1929 & 6413 & 7748 & 8184 & 5663 & 2979 & 1931 & 8601 \\
\hline 1930 & 6217 & 7455 & 8027 & 5363 & 3114 & 1989 & 8504 \\
\hline 1931 & 5700 & 6967 & 7376 & 5257 & 3142 & 2073 & 8031 \\
\hline 1932 & 5097 & 6513 & 6791 & 5331 & 3093 & 1918 & 8047 \\
\hline 1933 & 4912 & 6974 & 7183 & 5229 & 3210 & 2136 & 8248 \\
\hline 1934 & 4944 & 6896 & 7794 & 5174 & 3504 & 2151 & 8764 \\
\hline 1935 & 5040 & 6722 & 8322 & 5410 & 4007 & 2160 & 9064 \\
\hline 1936 & 5192 & 6982 & 8991 & 5178 & 4279 & 2527 & 9433 \\
\hline 1937 & 5471 & 7381 & 9464 & 5651 & 4634 & 2566 & 9718 \\
\hline 1938 & 6172 & 7347 & 10088 & 5769 & 4621 & 2745 & 9794 \\
\hline 1939 & 7102 & 7885 & 10921 & 6076 & 4809 & 2888 & 9788 \\
\hline 1940 & 6865 & 6650 & 10914 & 5905 & 4608 & 2667 & 10716 \\
\hline 1941 & 7312 & 5444 & 11537 & 5753 & - & 2400 & 11694 \\
\hline 1942 & 6906 & 4905 & 11595 & 5398 & - & 2478 & 11939 \\
\hline 1943 & 7047 & 4705 & 11898 & 4553 & - & 2226 & 12103 \\
\hline 1944 & 7199 & 3984 & 12290 & 3663 & - & 2108 & 11574 \\
\hline 1945 & 2990 & 4233 & 9119 & 3279 & - & 1804 & 11028 \\
\hline 1946 & 3392 & 6342 & 4478 & 4406 & 4113 & 2277 & 10543 \\
\hline 1947 & 3756 & 6807 & 4921 & 5209 & 4570 & 2350 & 10322 \\
\hline 1948 & 4793 & 7228 & 5724 & 5575 & 5163 & 2606 & 10543 \\
\hline 1949 & 5710 & 8137 & 6631 & 6010 & 5639 & 2418 & 10871 \\
\hline 1950 & 6426 & 8531 & 7840 & 6465 & 6108 & 2583 & 10846 \\
\hline
\end{tabular}

Sources: Maddison dataset at https://www.rug.nl/ggdc/historicaldevelopment/maddison/releases/maddison-project-database-2018 as updated and described by Bolt et al. (2018); accessed: 3 May 2019, 18:13 o'clock. 


\subsection{An overview of the government bonds' financial characteristics}

The following Tables A.2 and A.3 inform about the main financial, or formal, characteristics of all officially and unofficially traded sovereign bond series in the cross-section that I constructed for the trading place of Amsterdam. In addition, Plates A.1 to A.3 show the price lists from which I gathered the prices.

A bond series entered my database if I could gather, at least, one price observation in the 2 191-day stretch between the beginning of 1914 and the end 1919. Note that there were few bonds that were admitted to official trade - i.e., they were described in the stock exchange handbooks of the time - but were not traded even once. These few bonds are not part of the database. The bond series are listed alphabetically by country and within country by interest rate, from the lowest to the highest. Given per bond series is the following information in the order of the appearing columns:

(1) The issuing country. Should the issuer have been the next entity below the level of the central state - e.g., the province of Minas Gerais in the case of Brazil, or the state of Prussia in the case of Germany - this is marked in the first column ("country name/state name").

(2) The interest rate, ranging, historically, between 2.5 and 6.0 whereby the majority of bonds exhibited an interest rate of $4.0,4.5$, or 5.0 percent. In some case, the country name plus the interest rate is sufficient to unequivocally identify a bond in my database (e.g., "the Belgian $2.5 \% ")$.

(3) An additional attribute following from the bonds' description in the stock exchange handbooks. Sometimes these attributes are not necessary for identification in my database, but given anyway, in accordance with the handbooks. An attribute may be one of the following: (i) an indication of the sources of revenue guaranteeing the flow of interest payments (e.g., "tobacco" referring to a tax on tobacco or "railway" possibly referring to transport revenue as a source of guarantee) or the object to be financed by issuing the bond (e.g., a certain railway line); (ii) an indication of how the interest is intended to be paid (e.g., by payment in metal i.e., "silver" or "gold" - instead of in paper money - i.e., "paper"); (iii) an indication that the bond is a "consol" which is short for "consolidated" - i.e., a bond created by having merged two or more separate bond series into a new one and/or having adjusted the interest rate; (iv) an indication of whether the bond is foreign or domestic debt; (v) an indication of whether the 
bond has been registered in a debt register (Dutch "grootboek"); (vi) an indication of whether the bond is a treasury note or a certificate; (vii) an indication of the bank house that underwrote the bond (e.g., "Rothschild" or "Hope \& Co" in the case of some Russian bonds); or (viii) the range of the serial numbers of a bond (e.g., " 1 st series").

(4) The exact year or the period in which the bond was issued. In a few instances, the year or period of issuance could not be identified or is possibly wrong (marked by "n/a" or "?") Together with the interest rate and any addition, the bond series' may be unequivocally identified in other databases than just mine.

(5) The denomination of shares - i.e., the range of standardized pieces into which the issued nominal debt was cut (e.g., pieces of "100" or "1 000 " monetary units). The standardized pieces are either reported in full - e.g., "100/1 000/10 000" - or as a range between the smallest and largest possible piece - e.g., "200-10 000". Note that the latter way of reporting does not mean that pieces could have taken any possible size in-between. The standardized pieces in-between were merely left out for reasons of space.

(6) The currency in which the bond was denominated. Predominantly this was one of the big players' currencies (e.g., mark, pound [sterling], [Austrian] Kroner, or Franc).

(7) The date(s), and therefore also the frequency, of the coupon payments. Bonds predominantly paid interest twice a year (e.g., in "Jan[uary]/Jul[y]" or "Apr[il]/Oct[ober]") to the amount of one-half of the bond's interest rate.

(8) The redemption date or redemption period. One of three scenarios may apply: (i) the issuer could, or had to, begin to redeem the bond after a specified year or sometime within a specified period, but without the necessity to do that up until a certain year (marked by, for example, "1892-“); (ii) the issuer were to redeem the bond up until a specified year, but could choose when to start (marked by, for example, “-1923”); or (iii) the issuer had to redeem within a specified period (marked by, for example, "1894-1974”). As a feature of the time, redemption was specified to be happening stepwise over long periods of time. Sometimes, the specific amount (a percentage of the issued debt) or the specific serial numbers to be redeemed that way were specified, but sometimes there were not. This information is neglected here as it bears no significance for this study, in contrast to the date up until a bond had to have been redeemed (cf. Chapter II). 
(9) The ratio between the sums of effectively gathered raw prices and of total trading days (i.e., the maximum number of recordable prices). This is a measure of the density of the price account over 1914-1919. From the 2191 days under observation, I subtracted the days on which the Amsterdam Stock Exchange was temporarily closed (i.e., late July 1914 to early February 1915), remaining Sundays, and remaining holidays (562 days overall). Thus, the density of the price account principally lies between close to zero and 100 percent.

As sources for columns (1) to (8), I used the contemporary handbooks on the Amsterdam Stock Exchange - the Gids bij de Prijscourant and the Effectenboek (cf. Chapter 2). Note that two principally important pieces of information are not reported here, namely the bond series' nominal value outstanding at, for example, the turn of 1913/1914 and the default status of the bond during the war (cf. the text for additional information).

Beside the officially traded bonds, I also gathered prices on a number of English and French war bonds unofficially traded on the grey market. These prices do not appear in the stock exchange handbooks. Table A.3 lists these bonds with a reduced set of characteristics, namely by country (1), the bond series' name as to be found in the unofficial price list, (3) the date of the first observed price quote, (4) the likely currency denomination, (5) the possible redemption date following from the name of the bond in combination with the date of the first price quote, and (6) the density of the price account. The Anglo-French war bond likely is connected with the loan that England and France received from the United States in 1915. 
Plate A.1: The official price list as printed in the Algemeen Handelsblad

(a) A full view of the page

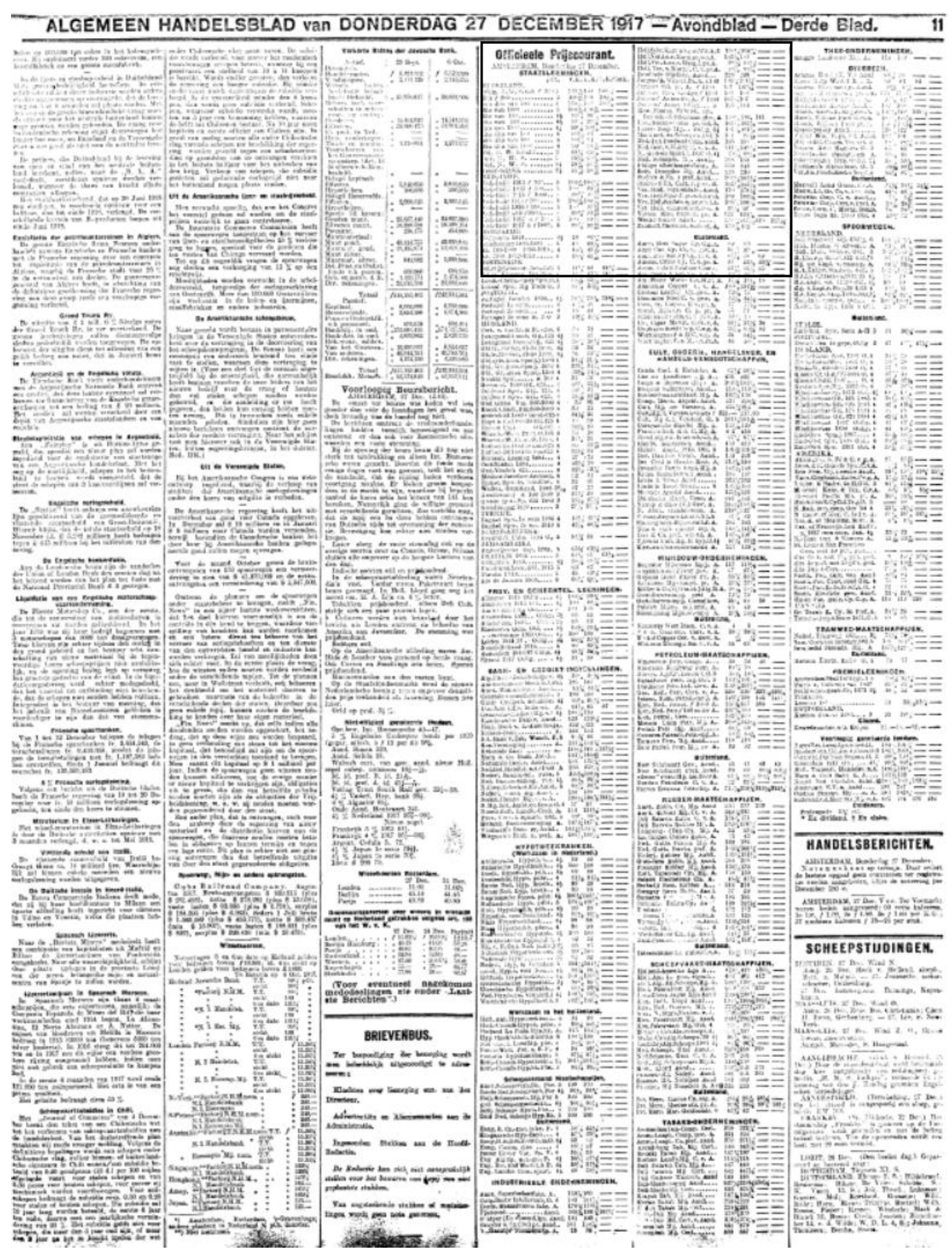


(b) The section on official prices (i.e., the highlighted box in panel (a))

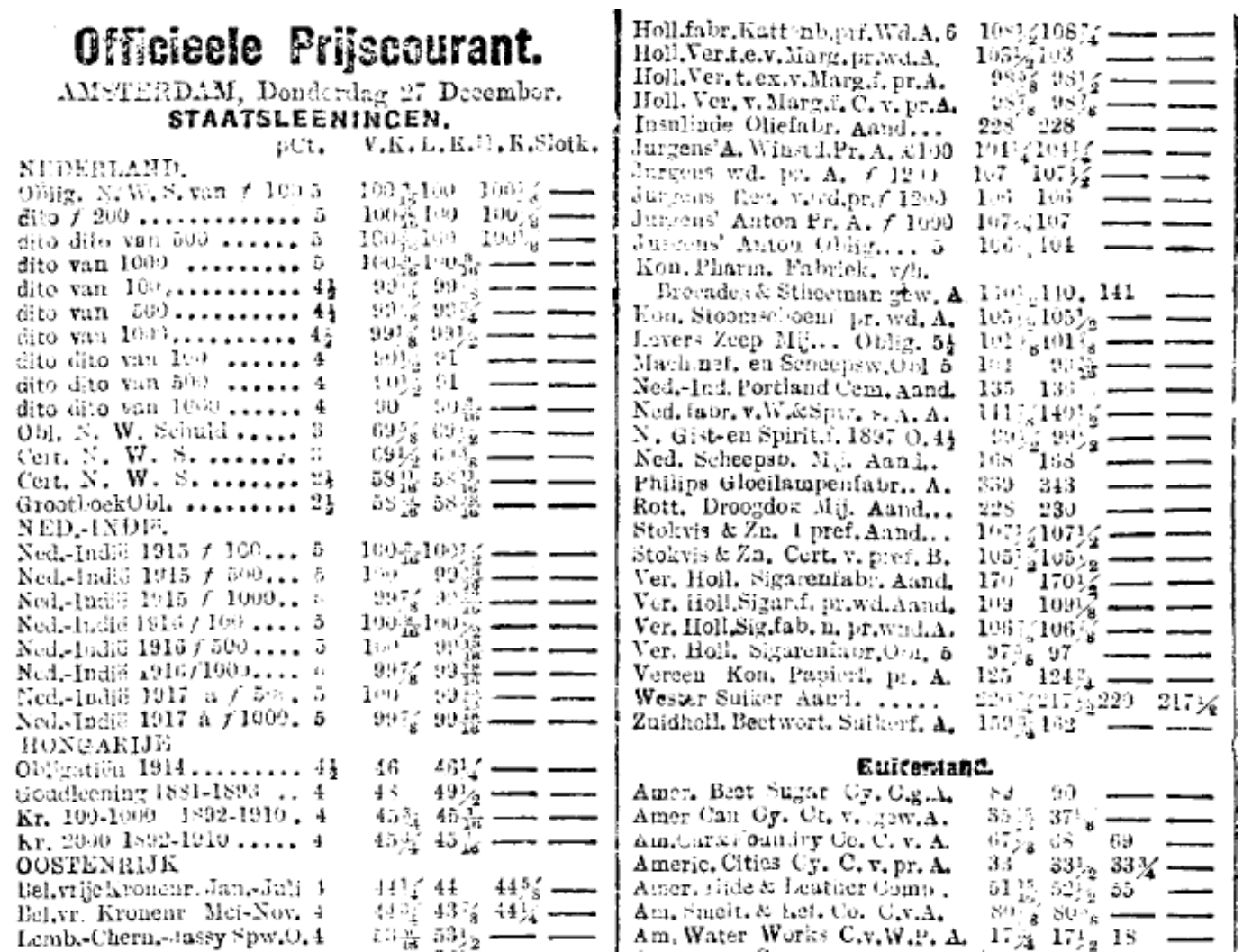

Sources: Algemeen Handelsblad, issue no. 29012 (evening issue) of 27 December 1917 showing the price list of the same day. PDF accessed via the digital collection of the Koninklijke Bibliotheek van Nederland available here: https://www.kb.nl/en. 
Plate A.2: The official price list as printed in the Het Centrum

(a) A full view of the page

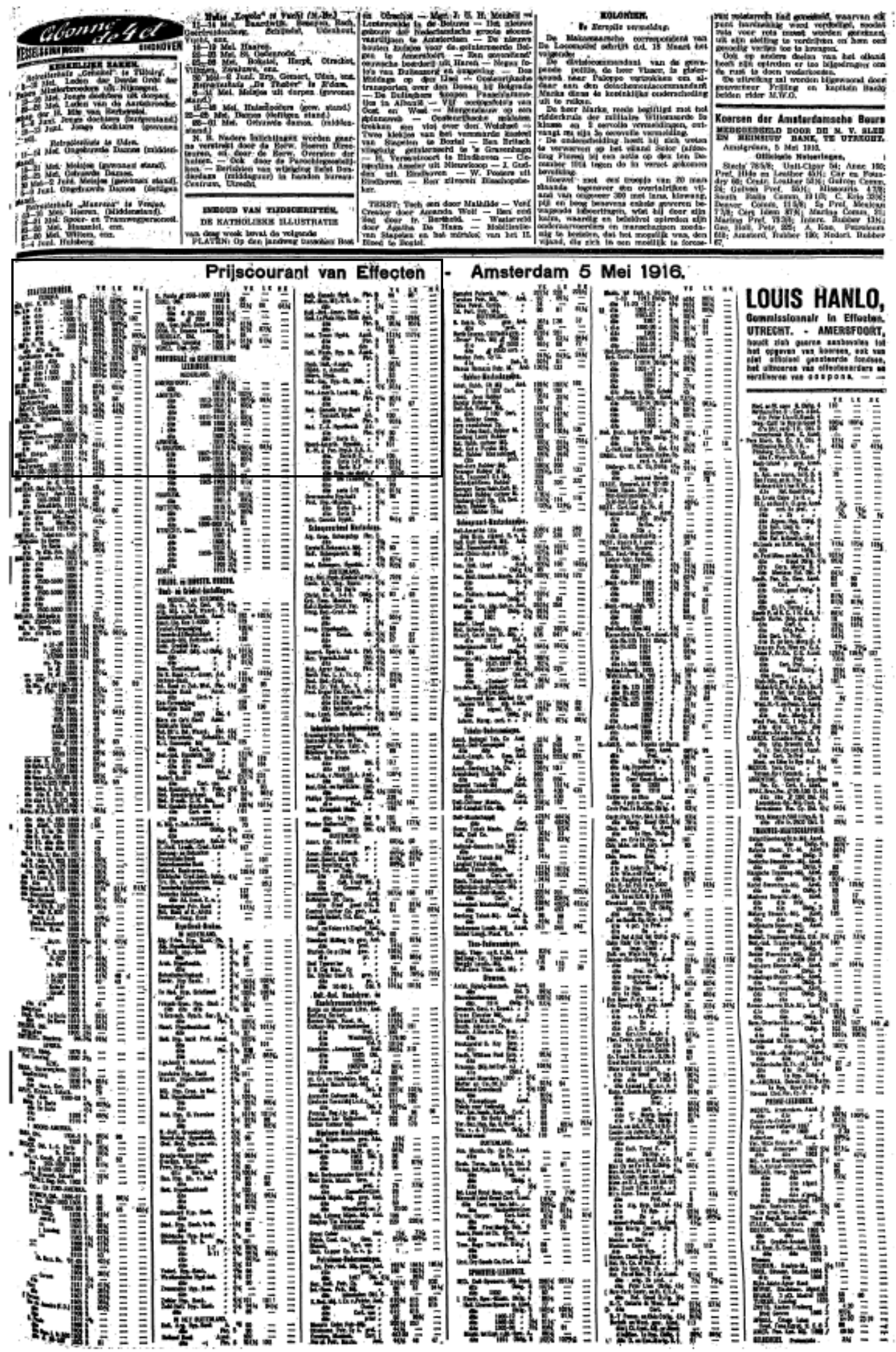


(b) The section on official prices (i.e., the highlighted box in panel (a))

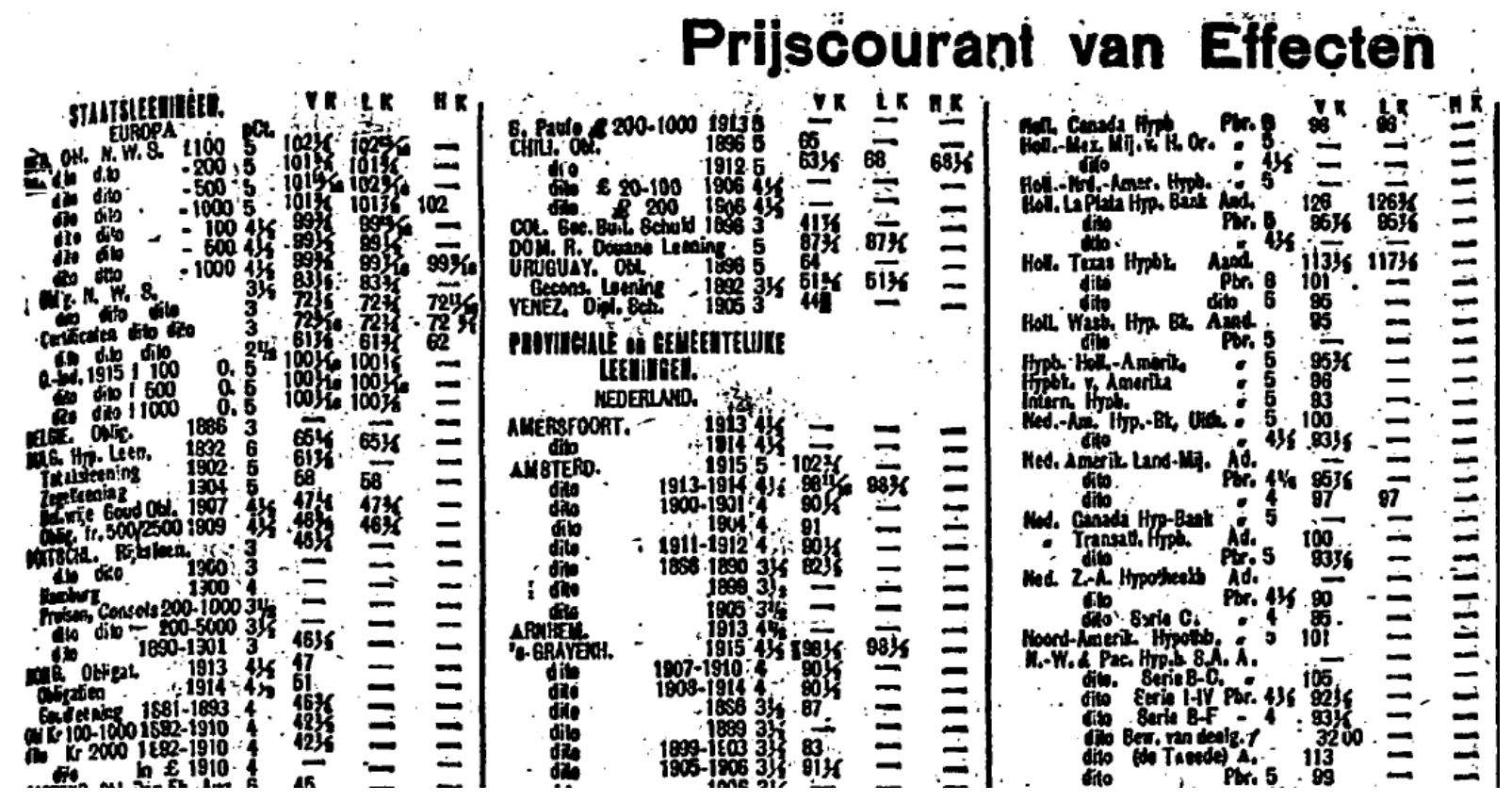

Sources: Het Centrum, issue no. 9684 of 6 May 1918 showing the price list for 5 May 1918. PDF accessed via the digital collection of the Koninklijke Bibliotheek van Nederland available here: https://www.kb.nl/en. 
Plate A.3: The section on unofficially traded securities in the Algemeen Handelsblad

(a) A full view of the page

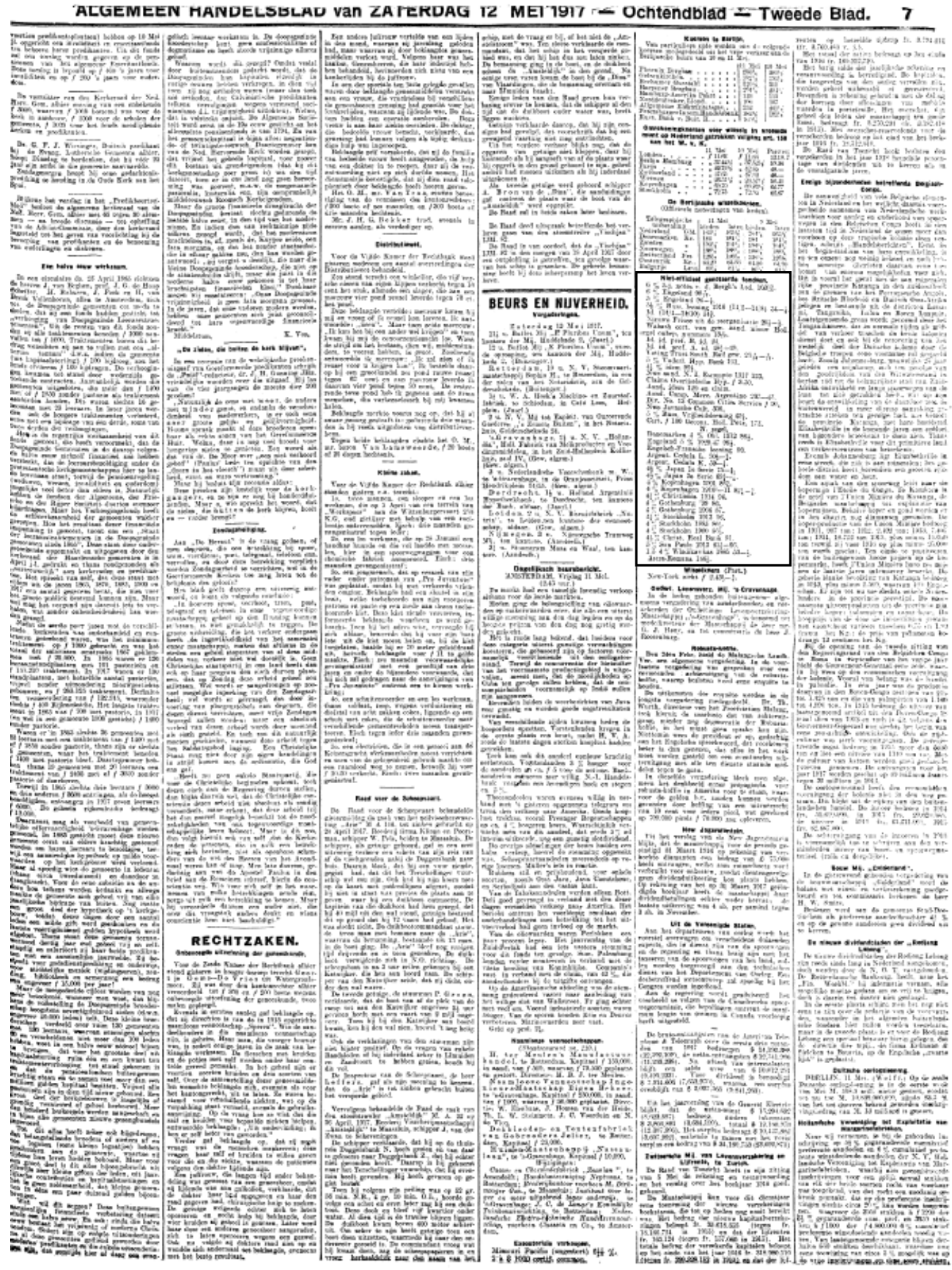


(b) The section on unofficial prices (i.e., the highlighted box in panel (a))

\section{Niet-officieal genoteerde fondsen.}

$6 \%$ j-j. notes r. d. Bergh's Ltd, $103 \frac{3}{6}$.

$6 \%$ Engeland 98

$5 \%$ Engeland $96-1$.

is. $(11 / 4-1 / 10) 54$. 516 .

Nieluke Frisco nit de reorganisatie $204-\frac{1}{4}$.

Wabash cert. van ger: aand. nieuw Holl. acgel onbep. nummers $13 \frac{1}{15}$.

11. id. pref. B. id. 24

Id. id. pref. $A$. id. 48 ? -49 .

Yoting Trust South Rail gex. $25 \frac{3}{16}-\frac{3}{16}$.

o\% Vaderl. Hyp. Bank 101.

4t. idem $99 \frac{1}{2}$.

Nwe aand. N. I. Escompto 1917 123.

Claims Overijselsche Hyp. $f 3.50$.

Aand. idem 120 en clinim.

Aand. Canmp. Merc. Argentino 23i-45.

Dir. No. 13 Common Cities Service $f 90$.
Nwe Jarasche Cult. 350.

No Javasche Cult. 3.50.

$5 \%$ Russ. Vrijheidsleening 49 s.

Cert. f 100 Gecons. Holl. Petr. Iis. N. zegel.

Donemarken $4 \%$ Obl. 1912 86!.

Engeland $5 \%$ \% $192947 \%$.

Engelsch-Fransche leening 93.

Argent. Cedula L. $701-3$.

Argent. Cedula K. $59-\frac{1}{4}$.

$41 \%$ Japan le Seric $7 \pi^{4}$

$4 \frac{1}{2} \%$ Japan $2 \theta$ Seric 69 \%

$4 \%$ Kopenhagen $10018 \%$.

4 , Kopenhagen 1910-11 8:21-

43 ' Christiania 191491.

$4 \%$ Gothenburg ' 99 86.

$4 \%$ Gothenburg 1906 s\%.

$41 \%$ Stockholm 191396.

$4 \%$ Stockholm 1885 \&6!.

$4 \%$ Stockholm 190086 ?

$4 \frac{1}{2} \%$ Christ. Real Bank 91.

$5 \%$ San Paulo 1913 6 $51-65$.

$154 \%$ Wadikarkas 1355 i3 - 1.

Astra-Romana 116!.

Sources: Algemeen Handelsblad, issue no. 28785 of 12 May 1917. PDF accessed via the digital collection of the Koninklijke Bibliotheek van Nederland available here: https://www.kb.nl/en. 
Table A.2: Characteristics of all bonds officially traded in Amsterdam

\begin{tabular}{|c|c|c|c|c|c|c|c|c|}
\hline (1) & (2) & (3) & (4) & (5) & (6) & (7) & (8) & (9) \\
\hline $\begin{array}{l}\text { Country [/Possibly } \\
\text { subnational entity] }\end{array}$ & $\begin{array}{l}\text { Interest } \\
\text { Rate }(\%)\end{array}$ & Addition & $\begin{array}{l}\text { Issued } \\
\text { in/over }\end{array}$ & Pieces & Currency & $\begin{array}{l}\text { Coupon } \\
\text { frequency }\end{array}$ & $\begin{array}{l}\text { Redemption date/ } \\
\text { Redemption period }\end{array}$ & $\begin{array}{l}\text { Density } \\
\text { of the } \\
\text { price } \\
\text { account }\end{array}$ \\
\hline [1] Austria & 3.0 & Local Railway Company & 1893 & $200-10000$ & Kroner & Jan/Jul & 1894-1974 & 0.22 \\
\hline [2] Austria & 4.0 & Consols & 1892 & $100-20000$ & Kroner & Mar/Sep & $1892-$ & 0.14 \\
\hline [3] Austria & 4.0 & Consols & 1903 & 2000 & Kroner & Jan/Jul & $1903-$ & 0.85 \\
\hline [4] Austria & 4.0 & Consols & 1903 & 2000 & Kroner & May/Nov & $1903-$ & 0.76 \\
\hline [5] Austria & 4.0 & Gold & $1876-1893$ & $200 / 1000 / 10000$ & Kroner $^{\mathrm{a}}$ & Apr/Oct & $1893-$ & 0.34 \\
\hline [6] Austria & 4.0 & Lemb.-Chern.-Jassy Rw. & 1894 & $200 / 1000 / 4000$ & Kroner $^{\mathrm{a}}$ & Jan/Jul & 1895-1955 & 0.17 \\
\hline [7] Austria & 4.5 & Railway debt & 1913 & $500-10000$ & Mark & May/Nov & 1919-1979 & 0.28 \\
\hline [8] Austria & 4.5 & Treasury notes & 1914 & $500-20000$ & Kroner & Jan/Jul & 1915-1929 & 0.30 \\
\hline [9] Austria & 5.0 & Paper & 1868 & $100 / 1000 / 10000$ & Kroner $^{\mathrm{a}}$ & Feb/Aug & $1868-$ & 0.00 \\
\hline [10] Austria & 5.0 & Silver & 1868 & $100 / 1000 / 10000$ & Kroner $^{\mathrm{a}}$ & Apr/Oct & $1868-$ & 0.49 \\
\hline [11] Argentina & 4.0 & Foreign debt & $1896-1899$ & $100 / 500 / 1000$ & Pound & Jan/Jul & $1896-1954$ & 0.41 \\
\hline [12] Argentina & 5.0 & Customs & $1886 / 87$ & $20 / 100 / 500 / 1000$ & Pound & Jan/Jul & $1886-1922$ & 0.39 \\
\hline [13] Argentina & 5.0 & Domestic debt & 1905 & $500 / 1000$ & Peso & Mar/Jun/Sep/Dec & 1911-1947 & 0.54 \\
\hline [14] Belgium & 2.5 & - & 1842 & $100-10000$ & Franc & Jan/Jul & $1842-$ & 0.06 \\
\hline [15] Belgium & 3.0 & - & 1886 & $100-10000$ & Franc & May/Nov & $1904-$ & 0.05 \\
\hline [16] Bosnia-Herzegovina & 4.5 & - & 1902 & $200-10000$ & Kroner & Jan/Jul & $1903-1963$ & 0.00 \\
\hline [17] Bosnia-Herzegovina & 5.0 & General purposes debt & 1914 & $2400 / 4800$ & Kroner & Apr/Oct & 1919-1974 & 0.02 \\
\hline [18] Bosnia-Herzegovina & 5.0 & Railway debt & 1914 & $2400 / 4800$ & Kroner & Apr/Oct & 1919-1974 & 0.02 \\
\hline [19] Brazil & 4.0 & - & 1889 & $100 / 500 / 1000$ & Pound & Apr/Oct & 1890-1945 & 0.59 \\
\hline
\end{tabular}


Table A.2 continued

\begin{tabular}{|c|c|c|c|c|c|c|c|c|}
\hline (1) & (2) & (3) & (4) & (5) & (6) & (7) & (8) & (9) \\
\hline $\begin{array}{l}\text { Country [/Possibly } \\
\text { subnational entity] }\end{array}$ & $\begin{array}{l}\text { Interest } \\
\text { Rate }(\%)\end{array}$ & Addition & $\begin{array}{l}\text { Issued } \\
\text { in/over }\end{array}$ & Pieces & Currency & $\begin{array}{l}\text { Coupon } \\
\text { frequency }\end{array}$ & $\begin{array}{l}\text { Redemption date/ } \\
\text { Redemption period }\end{array}$ & $\begin{array}{l}\text { Density } \\
\text { of the } \\
\text { price } \\
\text { account }\end{array}$ \\
\hline [20] Brazil & 4.0 & - & 1910 & 100 & Pound & Feb/Aug & $1911-$ & 0.43 \\
\hline [21] Brazil & 4.0 & - & 1910 & 5001000 & Pound & Feb/Aug & $1911-$ & 0.02 \\
\hline [22] Brazil & 4.0 & Railway guarantees & 1901 & 200/100/500/1000 & Pound & Jan/Jul & 1906-1962 & 0.59 \\
\hline [23] Brazil & 4.5 & - & 1883 & $100 / 500 / 1000$ & Pound & Jun/Dec & $1884-1922$ & 0.53 \\
\hline [24] Brazil & 4.5 & - & 1888 & $100 / 500 / 1000$ & Pound & Apr/Oct & $1889-1925$ & 0.50 \\
\hline [25] Brazil/Minas Gerais & 4.5 & Gold & 1910 & 500 & Franc & Jan/Jul & $1915-1973$ & 0.37 \\
\hline [26] Brazil /Minas Gerais & 4.5 & Gold & 1911 & 500 & Franc & Jun/Dec & $1916-1974$ & 0.37 \\
\hline [27] Brazil/Rio & 4.5 & Consol. sterling loan & 1912 & $20 / 100 / 500 / 1000$ & Pound & Apr/Oct & $1912-1951$ & 0.29 \\
\hline [28] Brazil & 5.0 & - & 1895 & $100 / 500 / 1000$ & Pound & Feb/Aug & $1897-1936$ & 0.56 \\
\hline [29] Brazil & 5.0 & - & 1898 & 20/100/500/1 000 & Pound & Jan/Apr/Jul/Oct & $1901 / 10-$ & 0.52 \\
\hline [30] Brazil & 5.0 & - & 1903 & $100 / 500 / 1000$ & Pound & May/Nov & $1903-$ & 0.52 \\
\hline [31] Brazil & 5.0 & - & 1913 & 20/100/500/1000 & Pound & Apr/Oct & $1927-$ & 0.36 \\
\hline [32] Brazil & 5.0 & - & 1914 & $20 / 100$ & Pound & Feb/May/Aug/Nov & 1917/1927- & 0.58 \\
\hline [33] Brazil & 5.0 & - & 1914 & $500 / 1000$ & Pound & Feb/May/Aug/Nov & 1917/1927- & 0.00 \\
\hline [34] Brazil/Bahia & 5.0 & - & 1889 & 500 & Franc & Jun/Dec & $1890-1927$ & 0.11 \\
\hline [35] Brazil/Bahia & 5.0 & Gold & 1904 & $20 / 100 / 500$ & Pound & May/Nov & $1905-1955$ & 0.43 \\
\hline [36] Brazil/Bahia & 5.0 & - & 1915 & $10 / 20 / 100$ & Pound & Jan/Jul & $1918-$ & 0.13 \\
\hline [37] Brazil/Para & 5.0 & Gold & 1901 & $20 / 50 / 100 / 500$ & Pound & Jan/Jul & $1902-1952$ & 0.47 \\
\hline [38] Brazil/Para & 5.0 & Gold & 1907 & $200 / 100 / 200$ & Pound & Jan/Jul & $1908-1945$ & 0.42 \\
\hline
\end{tabular}


Table A.2 continued

\begin{tabular}{|c|c|c|c|c|c|c|c|c|}
\hline (1) & $(2)$ & (3) & (4) & $(5)$ & (6) & (7) & $(8)$ & $(9)$ \\
\hline $\begin{array}{l}\text { Country [/Possibly } \\
\text { subnational entity] }\end{array}$ & $\begin{array}{l}\text { Interest } \\
\text { Rate }(\%)\end{array}$ & Addition & $\begin{array}{l}\text { Issued } \\
\text { in/over }\end{array}$ & Pieces & Currency & $\begin{array}{l}\text { Coupon } \\
\text { frequency }\end{array}$ & $\begin{array}{l}\text { Redemption date/ } \\
\text { Redemption period }\end{array}$ & $\begin{array}{l}\text { Density } \\
\text { of the } \\
\text { price } \\
\text { account }\end{array}$ \\
\hline [39] Brazil/Para & 5.0 & - & 1915 & $20 / 100$ & Pound & Jan/Jul & $1926-1956$ & 0.29 \\
\hline [40] Brazil/Parana & 5.0 & - & 1905 & $20 / 100$ & Pound & Apr/Oct & $1906-1956$ & 0.44 \\
\hline [41] Brazil/Parana & 5.0 & Gold & 1913 & $20 / 100$ & Pound & Apr/Oct & $1913-1973$ & 0.23 \\
\hline [42] Brazil/Rio & 5.0 & Gold & 1905 & 20 & Pound & Apr/Oct & $1905-1955$ & 0.57 \\
\hline [43] Brazil/Rio & 5.0 & Gold & 1909 & $20 / 50 / 100$ & Pound & Jun/Dec & $1909-1935$ & 0.27 \\
\hline [44] Brazil/Sao Paolo & 5.0 & - & 1888 & $100 / 500 / 1000$ & Pound & Apr/Oct & $1889-1928$ & 0.09 \\
\hline [45] Brazil/Sao Paolo & 5.0 & - & 1904 & $20 / 100 / 500$ & Pound & Apr/Oct & $1905-1935$ & 0.36 \\
\hline [46] Brazil/Sao Paolo & 5.0 & Mortgage loan gold & 1905 & $500 / 2500$ & Franc & Jan/Jul & $1910-1945$ & 0.35 \\
\hline [47] Brazil/Sao Paolo & 5.0 & Treasury notes & 1913 & 20 & Pound & $\mathrm{Jan} / \mathrm{Jul}$ & -1923 & 0.37 \\
\hline [48] Brazil/Sao Paolo & 5.0 & Treasury notes & 1913 & 1000 & Pound & $\mathrm{Jan} / \mathrm{Jul}$ & -1923 & 0.05 \\
\hline [49] Bulgaria & 4.5 & Gold & 1907 & $500 / 2500$ & Leva & Jul/Aug & $1908-1968$ & 0.34 \\
\hline [50] Bulgaria & 4.5 & - & 1909 & $500-10000$ & Franc & Jun/Dec & $1910-1960$ & 0.38 \\
\hline [51] Bulgaria & 5.0 & Tobacco & 1902 & 500 & Leva & Mar/Sep & $1903-1953$ & 0.50 \\
\hline [52] Bulgaria & 5.0 & Stamp gold & 1904 & 500 & Leva & May/Nov & 1905-1955 & 0.31 \\
\hline [53] Bulgaria & 6.0 & Mortgage loan gold & 1892 & $500 / 1000 / 2500$ & Franc & $\mathrm{Jan} / \mathrm{Jul}$ & $1893-1926$ & 0.38 \\
\hline [54] Chile & 4.5 & Gold & 1906 & $20 / 100$ & Pound & Apr/Oct & $1906-$ & 0.27 \\
\hline [55] Chile & 4.5 & Gold & 1906 & 200 & Pound & Apr/Oct & $1906-$ & 0.11 \\
\hline [56] Chile & 5.0 & - & 1896 & $100 / 500 / 1000$ & Pound & Jan/Jul & $1896-$ & 0.33 \\
\hline [57] Chile & 5.0 & - & 1912 & $20 / 100 / 500 / 1000$ & Pound & Jan/Jul & $1915-1944$ & 0.35 \\
\hline
\end{tabular}


Table A.2 continued

\begin{tabular}{|c|c|c|c|c|c|c|c|c|}
\hline (1) & (2) & (3) & (4) & $(5)$ & (6) & (7) & (8) & (9) \\
\hline $\begin{array}{l}\text { Country [/Possibly } \\
\text { subnational entity] }\end{array}$ & $\begin{array}{l}\text { Interest } \\
\text { Rate }(\%)\end{array}$ & Addition & $\begin{array}{l}\text { Issued } \\
\text { in/over }\end{array}$ & Pieces & Currency & $\begin{array}{l}\text { Coupon } \\
\text { frequency }\end{array}$ & Redemption & $\begin{array}{l}\text { Density } \\
\text { of the } \\
\text { price } \\
\text { account }\end{array}$ \\
\hline [58] China & 4.0 & Gold & 1895 & $500 / 2500$ & Franc & $\mathrm{Jan} / \mathrm{Jul}$ & $1896-1932$ & 0.32 \\
\hline [59] China & 4.5 & Gold & 1898 & $25 / 50 / 100 / 500$ & Pound & Mar/Sep & 1899-1944 & 0.47 \\
\hline [60] China & 5.0 & Railway loan & 1904 & 100 & Pound & Jun/Dec & $1953-$ & 0.18 \\
\hline [61] China & 5.0 & Gold & 1912 & $20 / 100 / 500 / 1000$ & Pound & Apr/Oct & $1913-$ & 0.40 \\
\hline [62] Colombia & 3.0 & - & 1896 & $100 / 500 / 1000$ & Pound & $\mathrm{Jan} / \mathrm{Jul}$ & $1910-$ & 0.45 \\
\hline [63] Cuba & 4.5 & Gold & 1909 & 1000 & Dollar & Feb/Aug & 1919-1949 & 0.32 \\
\hline [64] Cuba & 5.0 & Gold & $1904 / 05$ & $500 / 1000$ & Dollar & Mar/Sep & 1910-1944 & 0.45 \\
\hline [65] Denmark & 3.0 & Gold & 1894 & $500 / 1000 / 5000$ & Kroner & Jun/Dec & $1914-$ & 0.01 \\
\hline [66] Denmark & 3.5 & Domestic debt & 1887 & $200-5000$ & Kroner & Jun/Dec & $1888-$ & 0.08 \\
\hline [67] Denmark & 4.0 & - & 1912 & 20/100/500/1000 & Pound & Mar/Sep & 1914-1974 & 0.17 \\
\hline [68] Dominican Republic & 5.0 & Customs gold & 1908 & $50 / 100 / 500 / 1000$ & Dollar & Feb/Aug & $1918-1958$ & 0.58 \\
\hline [69] Dutch East Indies & 5.0 & - & 1915 & 100 & Guilder & Apr/Oct & 1916-1941 & 0.64 \\
\hline [70] Dutch East Indies & 5.0 & - & 1915 & 500 & Guilder & Apr/Oct & 1916-1941 & 0.64 \\
\hline [71] Dutch East Indies & 5.0 & $-{ }^{\mathrm{b}}$ & 1915 & $100 / 500$ & Guilder & Apr/Oct & $1916-1941$ & 0.16 \\
\hline [72] Dutch East Indies & 5.0 & - & 1915 & 1000 & Guilder & Apr/Oct & $1916-1941$ & 0.82 \\
\hline [73] Dutch East Indies & 5.0 & - & 1916 & 100 & Guilder & May/Nov & $1917-1957$ & 0.58 \\
\hline [74] Dutch East Indies & 5.0 & - & 1916 & 500 & Guilder & May/Nov & $1917-1957$ & 0.59 \\
\hline [75] Dutch East Indies & 5.0 & - & 1916 & 1000 & Guilder & May/Nov & $1917-1957$ & 0.61 \\
\hline [76] Dutch East Indies & 5.0 & - & 1917 & 100 & Guilder & May/Nov & $1918-1958$ & 0.39 \\
\hline
\end{tabular}


Table A. 2 continued

\begin{tabular}{|c|c|c|c|c|c|c|c|c|}
\hline (1) & (2) & (3) & (4) & (5) & (6) & (7) & (8) & (9) \\
\hline $\begin{array}{l}\text { Country [/Possibly } \\
\text { subnational entity] }\end{array}$ & $\begin{array}{l}\text { Interest } \\
\text { Rate }(\%)\end{array}$ & Addition & $\begin{array}{l}\text { Issued } \\
\text { in/over }\end{array}$ & Pieces & Currency & $\begin{array}{l}\text { Coupon } \\
\text { frequency }\end{array}$ & Redemption & $\begin{array}{l}\text { Density } \\
\text { of the } \\
\text { price } \\
\text { account }\end{array}$ \\
\hline [77] Dutch East Indies & 5.0 & - & 1917 & 500 & Guilder & May/Nov & $1918-1958$ & 0.39 \\
\hline [78] Dutch East Indies & 5.0 & - & 1917 & 1000 & Guilder & May/Nov & 1918-1958 & 0.40 \\
\hline [79] Dutch East Indies & 5.0 & - & 1919 & 100 & Guilder & $\mathrm{n} / \mathrm{a}$ & $\mathrm{n} / \mathrm{a}$ & 0.07 \\
\hline [80] Dutch East Indies & 5.0 & - & 1919 & 500 & Guilder & $\mathrm{n} / \mathrm{a}$ & $\mathrm{n} / \mathrm{a}$ & 0.07 \\
\hline [81] Dutch East Indies & 5.0 & - & 1919 & 1000 & Guilder & $\mathrm{n} / \mathrm{a}$ & $\mathrm{n} / \mathrm{a}$ & 0.07 \\
\hline [82] Egypt & 3.5 & - & 1890 & $20 / 100 / 500 / 1000$ & Pound & Apr/Oct & $1891-$ & 0.03 \\
\hline [83] Egypt & 4.0 & - & 1876 & 20/100/500/1000 & Pound & May/Nov & $1877-1942$ & 0.15 \\
\hline [84] Finland & 3.5 & Railway loan & 1889 & $500 / 2000 / 5000$ & Mark & Jun/Dec & $1890-1950$ & 0.10 \\
\hline [85] France & 3.0 & Grootboek & 1895(?) & $20-3000$ & Franc & $\mathrm{Jan} / \mathrm{Apr} / \mathrm{Jul} / \mathrm{Dec}$ & 1896(?)- & 0.04 \\
\hline [86] Germany & 3.0 & Reich & $1890-1903$ & $200-10000$ & Mark & Jan/Jul & $1904-$ & 0.41 \\
\hline [87] Germany & 3.0 & Reich & $1890-1903$ & 200-10000 & Mark & Apr/Oct & $1904-$ & 0.41 \\
\hline [88] Germany Hamburg & 3.0 & $-^{c}$ & $n / a$ & $n / a$ & Mark & $n / a$ & $n / a$ & 0.01 \\
\hline [89] Germany/Prussia & 3.0 & - & 1890-1901 & $200-10000$ & Mark & Apr/Oct & $1902-$ & 0.38 \\
\hline [90] Germany/Saxony & 3.0 & - & 1896-1899 & $500-5000$ & Mark & Mar/Sep & $1900-$ & 0.05 \\
\hline [91] Germany/Bremen & 3.5 & - & 1899 & $500-5000$ & Mark & May/Nov & $1909-$ & 0.03 \\
\hline [92] Germany/Hamburg & 3.5 & $--^{c}$ & $n / a$ & $n / a$ & Mark & $n / a$ & $n / a$ & 0.00 \\
\hline [93] Germany/Prussia & 3.5 & - & 1896 & $200 / 1000$ & Mark & Jan/Jul & $1897-$ & 0.30 \\
\hline [94] Germany/Prussia & 3.5 & - & 1896 & $2000 / 5000$ & Mark & Jan/Jul & $1897-$ & 0.24 \\
\hline [95] Germany/Hamburg & 4.0 & - & 1900 & $500-5000$ & Mark & Jan/Jul & $1909-$ & 0.10 \\
\hline
\end{tabular}


Table A. 2 continued

\begin{tabular}{|c|c|c|c|c|c|c|c|c|}
\hline (1) & (2) & (3) & (4) & (5) & (6) & (7) & (8) & (9) \\
\hline $\begin{array}{l}\text { Country [/Possibly } \\
\text { subnational entity] }\end{array}$ & $\begin{array}{l}\text { Interest } \\
\text { Rate }(\%)\end{array}$ & Addition & $\begin{array}{l}\text { Issued } \\
\text { in/over }\end{array}$ & Pieces & Currency & $\begin{array}{l}\text { Coupon } \\
\text { frequency }\end{array}$ & Redemption & $\begin{array}{l}\text { Density } \\
\text { of the } \\
\text { price } \\
\text { account }\end{array}$ \\
\hline [96] Hungary & 3.0 & Gold & 1895 & $20 / 100 / 500$ & Kroner & Jan/Jul & $1896-1984$ & 0.00 \\
\hline [97] Hungary & 3.5 & - & 1897 & $100-10000$ & Kroner & Jan/Jul & $1898-$ & 0.00 \\
\hline [98] Hungary & 4.0 & Gold & 1881-1894 & $100-10000$ & Kroner $^{\mathrm{a}}$ & Jan/Jul & $1895-$ & 0.63 \\
\hline [99] Hungary & 4.0 & - & $1892-1910$ & $100 / 1000$ & Kroner & Jun/Dec & $1911-$ & 0.66 \\
\hline [100] Hungary & 4.0 & - & $1892-1910$ & 2000 & Kroner & Jun/Dec & $1911-$ & 0.68 \\
\hline [101] Hungary & 4.0 & - & $1892-1910$ & 10000 & Kroner & Jun/Dec & $1911-$ & 0.02 \\
\hline [102] Hungary & 4.0 & - & 1910 & 20 & Pound & Mar/Sep & $1911-$ & 0.06 \\
\hline [103] Hungary & 4.0 & - & 1910 & $100 / 400$ & Pound & Mar/Sep & $1911-$ & 0.05 \\
\hline [104] Hungary & 4.5 & - & 1913 & $20 / 100 / 200 / 400$ & Pound & Apr/Oct & $1923-$ & 0.30 \\
\hline [105] Hungary & 4.5 & - & 1914 & $200 / 100 / 200 / 400$ & Pound & Mar/Sep & 1919-1974 & 0.34 \\
\hline [106] Hungary & 4.5 & Treasury notes & 1913 & $500-10000$ & Mark & $\mathrm{n} / \mathrm{a}$ & 1916 & 0.15 \\
\hline [107] Hungary & 4.5 & Treasury notes & 1913 & 500-10000 & Mark & $\mathrm{n} / \mathrm{a}$ & 1918 & 0.04 \\
\hline [108] Italy & 3.5 & - & $1862-1881$ & $100-100000$ & Lira & Jan/Jul & $1882-$ & 0.11 \\
\hline [109] Japan & 4.0 & - & 1899 & $50 / 100 / 500$ & Pound & Jun/Dec & 1909-1954 & 0.32 \\
\hline [110] Japan & 4.0 & - & 1910 & $20 / 50 / 100 / 200$ & Pound & Jun/Dec & 1920-1970 & 0.13 \\
\hline [111] Japan & 4.5 & $1^{\text {st }}$ ser. & 1905 & 100 & Pound & Feb/Aug & 1910-1925 & 0.45 \\
\hline [112] Japan & 4.5 & $1^{\text {st }}$ ser. & 1905 & $200 / 500$ & Pound & Feb/Aug & 1910-1925 & 0.16 \\
\hline [113] Japan & 4.5 & $2^{\text {nd }}$ ser. & 1905 & $20 / 100 / 200$ & Pound & Jan/Jul & 1910-1925 & 0.36 \\
\hline [114] Japan & 5.0 & Domestic debt & 1908/09 & $500 / 1000$ & Yen & Jun/Dec & 1914-1964 & 0.42 \\
\hline
\end{tabular}


Table A.2 continued

\begin{tabular}{|c|c|c|c|c|c|c|c|c|}
\hline (1) & (2) & (3) & (4) & (5) & (6) & (7) & (8) & (9) \\
\hline $\begin{array}{l}\text { Country [/Possibly } \\
\text { subnational entity] }\end{array}$ & $\begin{array}{l}\text { Interest } \\
\text { Rate }(\%)\end{array}$ & Addition & $\begin{array}{l}\text { Issued } \\
\text { in/over }\end{array}$ & Pieces & Currency & $\begin{array}{l}\text { Coupon } \\
\text { frequency }\end{array}$ & Redemption & $\begin{array}{l}\text { Density } \\
\text { of the } \\
\text { price } \\
\text { account }\end{array}$ \\
\hline [115] Japan & 5.0 & Domestic debt & 1908/09 & 5 000/10 000 & Yen & Jun/Dec & 1914-1964 & 0.10 \\
\hline [116] Liberia & 5.0 & Customs & 1913 & $100 / 500 / 1000$ & Dollar & Jan/Jul & 1913-1952 & 0.10 \\
\hline [117] Mexico & 3.0 & Consols $1^{\text {st }}$ ser. & 1886 & $100-5000$ & Dollar & Jun/Dec & $1887-$ & 0.12 \\
\hline [118] Mexico & 3.0 & Consols $2^{\text {nd }}$ ser. & 1886 & $100-5000$ & Dollar & Jun/Dec & $1887-$ & 0.02 \\
\hline [119] Mexico & 4.0 & Gold & 1904 & $500 / 1000$ & Dollar & Jun/Dec & 1904-1954 & 0.17 \\
\hline [120] Mexico & 5.0 & $1^{\text {st }}-4^{\text {th }}$ ser. & 1895 & $100 / 1000$ & Mex. Dol. & Apr/Oct & $1896-$ & 0.62 \\
\hline [121] Mexico & 5.0 & $5^{\text {th }}$ ser. & 1895 & $100 / 1000$ & Mex. Dol. & Apr/Oct & $1896-$ & 0.27 \\
\hline [122] Mexico & 5.0 & Consols gold & 1899 & $20 / 100$ & Pound & $\mathrm{Jan} / \mathrm{Apr} / \mathrm{Jul} / \mathrm{Oct}$ & $1900-$ & 0.46 \\
\hline [123] Mexico & 5.0 & Consols gold & 1899 & $200 / 1000$ & Pound & $\mathrm{Jan} / \mathrm{Apr} / \mathrm{Jul} / \mathrm{Oct}$ & $1900-$ & 0.17 \\
\hline [124] Mexico/Sinaloa & 5.0 & - & 1906 & $100 / 500 / 1000$ & Dollar & Jan/Jul & 1907-1932 & 0.01 \\
\hline [125] Mexico/Vera Cruz & 5.0 & - & 1902 & $100 / 500 / 1000$ & Dollar & Mar/Jun/Sep/Dec & 1903-1928 & 0.29 \\
\hline [126] Netherlands & 2.5 & NWS Cert. & $1814-1842$ & $100-1000$ & Guilder & Jan/Jul & $1842-$ & 0.95 \\
\hline [127] Netherlands & 2.5 & Grootboek & $1814-1842$ & 1000 & Guilder & Jan/Jul & - & 0.30 \\
\hline [128] Netherlands & 3.0 & Grootboek & $1895-1899$ & 1000 & Guilder & Mar/Sep & - & 0.26 \\
\hline [129] Netherlands & 3.0 & NWS & $1895-1899$ & $100 / 500 / 1000$ & Guilder & Mar/Sep & $1905-$ & 0.95 \\
\hline [130] Netherlands & 3.0 & NWS Cert. & $1895-1899$ & 100/200/500/1000 & Guilder & Mar/Sep & $1905-$ & 0.90 \\
\hline [131] Netherlands & 3.5 & Grootboek & 1911 & 1000 & Guilder & Jun/Dec & - & 0.05 \\
\hline [132] Netherlands & 3.5 & NWS & 1911 & $500 / 1000$ & Guilder & Jun/Dec & 1911 & 0.80 \\
\hline [133] Netherlands & 4.0 & Voluntary war loan & 1916 & 100 & Guilder & Apr/Oct & 1918-1945 & 0.43 \\
\hline
\end{tabular}


Table A.2 continued

\begin{tabular}{|c|c|c|c|c|c|c|c|c|}
\hline (1) & (2) & (3) & (4) & (5) & (6) & (7) & (8) & (9) \\
\hline $\begin{array}{l}\text { Country [/Possibly } \\
\text { subnational entity] }\end{array}$ & $\begin{array}{l}\text { Interest } \\
\text { Rate }(\%)\end{array}$ & Addition & $\begin{array}{l}\text { Issued } \\
\text { in/over }\end{array}$ & Pieces & Currency & $\begin{array}{l}\text { Coupon } \\
\text { frequency }\end{array}$ & Redemption (date) & $\begin{array}{l}\text { Density } \\
\text { of the } \\
\text { price } \\
\text { account }\end{array}$ \\
\hline [134] Netherlands & 4.0 & Voluntary war loan & 1916 & 500 & Guilder & Apr/Oct & $1918-1945$ & 0.43 \\
\hline [135] Netherlands & 4.0 & Voluntary war loan & 1916 & 1000 & Guilder & Apr/Oct & 1918-1945 & 0.53 \\
\hline [136] Netherlands & 4.5 & Voluntary war loan & 1916 & 100 & Guilder & May/Nov & 1917-1942 & 0.66 \\
\hline [137] Netherlands & 4.5 & Voluntary war loan & 1916 & 500 & Guilder & May/Nov & 1917-1942 & 0.57 \\
\hline [138] Netherlands & 4.5 & Voluntary war loan & 1916 & 1000 & Guilder & May/Nov & 1917-1942 & 0.69 \\
\hline [139] Netherlands & 4.5 & Voluntary war loan & 1917 & 100 & Guilder & Feb/Aug & 1919-1959 & 0.35 \\
\hline [140] Netherlands & 4.5 & Voluntary war loan & 1917 & 500 & Guilder & Feb/Aug & 1919-1959 & 0.35 \\
\hline [141] Netherlands & 4.5 & Voluntary war loan & 1917 & 1000 & Guilder & Feb/Aug & 1919-1959 & 0.35 \\
\hline [142] Netherlands & 5.0 & Voluntary war loan & 1914 & 100 & Guilder & Feb/Aug & ${ }^{\mathrm{e}}$ & 0.36 \\
\hline [143] Netherlands & 5.0 & Voluntary war loan & 1914 & 200 & Guilder & Feb/Aug & $-^{\mathrm{e}}$ & 0.36 \\
\hline [144] Netherlands & 5.0 & Voluntary war loan ${ }^{\mathrm{d}}$ & 1914 & $100 / 200$ & Guilder & Feb/Aug & - & 0.18 \\
\hline [145] Netherlands & 5.0 & Voluntary war loan & 1914 & 500 & Guilder & Feb/Aug & $-^{\mathrm{e}}$ & 0.35 \\
\hline [146] Netherlands & 5.0 & Voluntary war loan & 1914 & 1000 & Guilder & Feb/Aug & $\mathrm{-}^{\mathrm{e}}$ & 0.36 \\
\hline [147] Netherlands & 5.0 & Voluntary war loan ${ }^{\mathrm{d}}$ & 1914 & $500 / 1000$ & Guilder & Feb/Aug & - & 0.18 \\
\hline [148] Netherlands & 5.0 & Voluntary war loan & 1918 & 100 & Guilder & Jun/Dec & $1920-1960$ & 0.17 \\
\hline [149] Netherlands & 5.0 & Voluntary war loan & 1918 & 500 & Guilder & Jun/Dec & 1920-1960 & 0.17 \\
\hline [150] Netherlands & 5.0 & Voluntary war loan & 1918 & 1000 & Guilder & Jun/Dec & $1920-1960$ & 0.17 \\
\hline [151] Nicaragua & 5.0 & - & 1909 & $20 / 100 / 500$ & Pound & Jan/Jul & $1913-$ & 0.19 \\
\hline [152] Norway & 5.0 & - & 1888 & 20/100/5000/1000 & Pound & Feb/Aug & 1889-1963 & 0.00 \\
\hline
\end{tabular}


Table A.2 continued

\begin{tabular}{|c|c|c|c|c|c|c|c|c|}
\hline (1) & (2) & (3) & (4) & (5) & (6) & (7) & (8) & (9) \\
\hline $\begin{array}{l}\text { Country [/Possibly } \\
\text { subnational entity] }\end{array}$ & $\begin{array}{l}\text { Interest } \\
\text { Rate }(\%)\end{array}$ & Addition & $\begin{array}{l}\text { Issued } \\
\text { in/over }\end{array}$ & Pieces & Currency & $\begin{array}{l}\text { Coupon } \\
\text { frequency }\end{array}$ & Redemption (date) & $\begin{array}{l}\text { Density } \\
\text { of the } \\
\text { price } \\
\text { account }\end{array}$ \\
\hline [153] Portugal & 3.0 & $1^{\text {st }}$ ser. & 1902 & $500 / 2500$ & Franc & Jan/Jul & 1903-2002 & 0.65 \\
\hline [154] Portugal & 3.0 & $2^{\text {nd }}$ ser. & 1902 & $500 / 2500$ & Franc & Jan/Jul & 1903-2002 & 0.36 \\
\hline [155] Portugal & 3.0 & $3^{\text {rd }}$ ser. & 1902 & 500 & Franc & Jan/Jul & 1903-2002 & 0.70 \\
\hline [156] Portugal & 3.0 & $3^{\text {rd }}$ ser. & 1902 & 2500 & Franc & Jan/Jul & 1903-2002 & 0.51 \\
\hline [157] Portugal & 4.5 & Tobacco & 1891 & $500 / 2500 / 5000$ & Franc & Apr/Oct & $1900-$ & 0.73 \\
\hline [158] Romania & 4.0 & Gold & 1890 & $500 / 1000$ & Franc & Jan/Jul & 1900-1933 & 0.01 \\
\hline [159] Romania & 4.0 & Gold & 1890 & $2500 / 5000$ & Franc & Jan/Jul & 1900-1933 & 0.02 \\
\hline [160] Romania & 4.0 & Gold & 1891 & $500 / 1000$ & Franc & Jan/Jul & 1901-1945 & 0.00 \\
\hline [161] Romania & 4.0 & Gold & 1891 & $2500 / 5000$ & Franc & Jan/Jul & 1901-1945 & 0.02 \\
\hline [162] Romania & 4.0 & Gold & 1894 & $500 / 1000$ & Franc & Jan/Jul & 1905-1949 & 0.08 \\
\hline [163] Romania & 4.0 & Gold & 1894 & $2500 / 5000$ & Franc & Jan/Jul & 1905-1949 & 0.12 \\
\hline [164] Romania & 4.0 & Gold & 1896 & $500 / 1000$ & Franc & May/Nov & 1906-1950 & 0.05 \\
\hline [165] Romania & 4.0 & Gold & 1896 & $2500 / 5000$ & Franc & May/Nov & 1906-1950 & 0.07 \\
\hline [166] Romania & 4.0 & Gold & 1898 & $500 / 1000$ & Franc & May/Nov & 1908-1968 & 0.07 \\
\hline [167] Romania & 4.0 & Gold & 1898 & $2500 / 5000$ & Franc & May/Nov & 1908-1968 & 0.04 \\
\hline [168] Romania & 4.0 & Gold & 1905 & $500-20000$ & Franc & Apr/Oct & 1916-1956 & 0.05 \\
\hline [169] Romania & 4.0 & - & 1910 & $500 / 1000$ & Franc & Mar/Sep & 1910-1950 & 0.08 \\
\hline [170] Romania & 4.0 & - & 1910 & $2500 / 5000$ & Franc & Mar/Sep & 1910-1950 & 0.15 \\
\hline [171] Romania & 4.5 & Gold & 1913 & $500 / 1000 / 2500$ & Lei & Apr/Oct & 1914-1954 & 0.24 \\
\hline
\end{tabular}


Table A.2 continued

\begin{tabular}{|c|c|c|c|c|c|c|c|c|}
\hline (1) & (2) & (3) & (4) & (5) & (6) & (7) & (8) & (9) \\
\hline $\begin{array}{l}\text { Country [/Possibly } \\
\text { subnational entity] }\end{array}$ & $\begin{array}{l}\text { Interest } \\
\text { Rate }(\%)\end{array}$ & Addition & $\begin{array}{l}\text { Issued } \\
\text { in/over }\end{array}$ & Pieces & Currency & $\begin{array}{l}\text { Coupon } \\
\text { frequency }\end{array}$ & Redemption (date) & $\begin{array}{l}\text { Density } \\
\text { of the } \\
\text { price } \\
\text { account }\end{array}$ \\
\hline [172] Romania & 4.5 & Treasury notes & 1913 & $500-10000$ & Lei & Feb/Aug & 1916 & 0.10 \\
\hline [173] Romania & 5.0 & Gold & 1903 & $500 / 1000$ & Franc & Jun/Dec & $1913-1953$ & 0.10 \\
\hline [174] Romania & 5.0 & Gold & 1903 & $2500 / 5000$ & Franc & Jun/Dec & 1913-1953 & 0.12 \\
\hline [175] Russia & 3.0 & - & 1859 & $100 / 1000$ & Pound & May/Nov & $1860-$ & 0.41 \\
\hline [176] Russia & 3.0 & Great Rw. Comp. & 1880 & 125 & Gold ruble & Jun/Dec & $1881-1951$ & 0.50 \\
\hline [177] Russia & 3.0 & Great Rw. Comp. & 1880 & 625 & Gold ruble & Jun/Dec & $1881-1951$ & 0.51 \\
\hline [178] Russia & 3.0 & Gold & 1896 & 125 & Gold ruble & May/Aug & $1897-$ & 0.00 \\
\hline [179] Russia & 3.0 & Gold & 1896 & 625 & Gold ruble & May/Aug & $1897-$ & 0.01 \\
\hline [180] Russia & 3.0 & Gold & 1891 & 125 & Gold ruble & Jan/Apr/Jul/Oct & 1893-1974 & 0.05 \\
\hline [181] Russia & 3.0 & Gold & 1891 & 625 & Gold ruble & Jan/Apr/Jul/Oct & 1893-1974 & 0.07 \\
\hline [182] Russia & 3.0 & Gold $2^{\text {nd }}$ ser. & 1894 & $125 / 625$ & Gold ruble & Jan/Apr/Jul/Oct & 1894-1973 & 0.02 \\
\hline [183] Russia & 3.0 & Transcaucasian Rw. & 1882 & $125 / 625$ & Gold ruble & Jun/Dec & $1883-1953$ & 0.57 \\
\hline [184] Russia & 3.0 & - & 1889 & 125 & Gold ruble & Jan/Jul & $1891-1957$ & 0.48 \\
\hline [185] Russia & 3.5 & - & 1894 & 125 & Gold ruble & Jan/Apr/Jul/Oct & 1895-1976 & 0.13 \\
\hline [186] Russia & 3.5 & - & 1894 & 625 & Gold ruble & $\mathrm{Jan} / \mathrm{Apr} / \mathrm{Jul} / \mathrm{Oct}$ & 1895-1976 & 0.26 \\
\hline [187] Russia & 3.8 & Mutual Mortgage Comp. & 1898 & $150 / 750 / 15000$ & Ruble & $\mathrm{Jan} / \mathrm{Jul}$ & 1898-1979 & 0.45 \\
\hline [188] Russia & 4.0 & Great Rw. Comp. & 1861 & 125 & Gold ruble & Apr/Oct & $1867-1942$ & 0.44 \\
\hline [189] Russia & 4.0 & Great Rw. Comp. & 1888 & 100 & Pound & Feb/Aug & $1889-1953$ & 0.72 \\
\hline [190] Russia & 4.0 & Great Rw. Comp. & 1890 & 100 & Pound & Jan/Jul & 1891-1952 & 0.72 \\
\hline
\end{tabular}


Table A.2 continued

\begin{tabular}{|c|c|c|c|c|c|c|c|c|}
\hline (1) & (2) & (3) & (4) & (5) & (6) & (7) & (8) & (9) \\
\hline $\begin{array}{l}\text { Country [/Possibly } \\
\text { subnational entity] }\end{array}$ & $\begin{array}{l}\text { Interest } \\
\text { Rate }(\%)\end{array}$ & Addition & $\begin{array}{l}\text { Issued } \\
\text { in/over }\end{array}$ & Pieces & Currency & $\begin{array}{l}\text { Coupon } \\
\text { frequency }\end{array}$ & Redemption (date) & $\begin{array}{l}\text { Density } \\
\text { of the } \\
\text { price } \\
\text { account }\end{array}$ \\
\hline [191] Russia & 4.0 & - & 1898 & 500 & Gold ruble & Apr/Oct & 1899 & 0.76 \\
\hline [192] Russia & 4.0 & Nicolai Rw. & $1867-1869$ & 20 & Pound & May/Nov & $1867-1951$ & 0.65 \\
\hline [193] Russia & 4.0 & Nicolai Rw. & $1867-1869$ & 100 & Pound & May/Nov & $1867-1951$ & 0.74 \\
\hline [194] Russia & 4.0 & Consols & 1880 & 125 & Gold ruble & May/Nov & $1880-1961$ & 0.71 \\
\hline [195] Russia & 4.0 & Consols & 1880 & 625 & Gold ruble & May/Nov & $1880-1961$ & 0.80 \\
\hline [196] Russia & 4.0 & Tambov-Saratov Rw. & 1882 & $125 / 1250$ & Gold ruble & Jan/Jul & $1883-1956$ & 0.44 \\
\hline [197] Russia & 4.0 & Southwest Rw. & 1885 & 125 & Gold ruble & Jan/Jul & $1885-1953$ & 0.76 \\
\hline [198] Russia & 4.0 & Southwest Rw. & 1885 & 625 & Gold ruble & $\mathrm{Jan} / \mathrm{Jul}$ & $1885-1953$ & 0.82 \\
\hline [199] Russia & 4.0 & Moscow-Kursk Rw. & 1886 & $500 / 1000$ & Mark & May/Nov & $1887-1952$ & 0.46 \\
\hline [200] Russia & 4.0 & Orel-Griasi Rw. & 1887 & 600 & Mark & Apr/Oct & $1888-1951$ & 0.30 \\
\hline [201] Russia & 4.0 & Orel-Griasi Rw. & 1889 & $500 / 1000 / 2000$ & Mark & Apr/Oct & $1890-1952$ & 0.56 \\
\hline [202] Russia & 4.0 & Kursk-Chark.-Azow Rw. & 1888 & 100 & Pound & Jan/Jul & $1888-1954$ & 0.61 \\
\hline [203] Russia & 4.0 & Kursk-Chark.-Azow Rw. & 1888 & 600 & Mark & Jan/Jul & $1889-$ & 0.45 \\
\hline [204] Russia & 4.0 & Kursk-Chark.-Azow Rw. & 1889 & $500 / 1000 / 2500$ & Mark & Apr/Oct & $1890-1955$ & 0.60 \\
\hline [205] Russia & 4.0 & Kursk-Chark.-Azow Rw. & 1894 & 125 & Gold ruble & Jan/Jul & $1895-1955$ & 0.32 \\
\hline [206] Russia & 4.0 & Rothschild consols & 1889 & 125 & Gold ruble & $\mathrm{Jan} / \mathrm{Apr} / \mathrm{Jul} / \mathrm{Oct}$ & $1890-1971$ & 0.54 \\
\hline [207] Russia & 4.0 & Rothschild consols & 1889 & 625 & Gold ruble & Jan/Apr/Jul/Oct & 1890-1971 & 0.80 \\
\hline [208] Russia & 4.0 & Rothschild consols & 1889 & $1250 / 3125$ & Gold ruble & Jan/Apr/Jul/Oct & $1890-1971$ & 0.15 \\
\hline [209] Russia & 4.0 & Hope \& Co & $1889 / 90$ & 125 & Gold ruble & Mar/Jun/Sep/Dec & 1889-1970 & 0.55 \\
\hline
\end{tabular}


Table A. 2 continued

\begin{tabular}{|c|c|c|c|c|c|c|c|c|}
\hline (1) & (2) & (3) & (4) & $(5)$ & $(6)$ & (7) & $(8)$ & (9) \\
\hline $\begin{array}{l}\text { Country [/Possibly } \\
\text { subnational entity] }\end{array}$ & $\begin{array}{l}\text { Interest } \\
\text { Rate }(\%)\end{array}$ & Addition & $\begin{array}{l}\text { Issued } \\
\text { in/over }\end{array}$ & Pieces & Currency & $\begin{array}{l}\text { Coupon } \\
\text { frequency }\end{array}$ & Redemption (date) & $\begin{array}{l}\text { Density } \\
\text { of the } \\
\text { price } \\
\text { account }\end{array}$ \\
\hline [210] Russia & 4.0 & Hope \& Co & $1889 / 90$ & 625 & Gold ruble & Mar/Jun/Sep/Dec & $1889-1970$ & 0.82 \\
\hline [211] Russia & 4.0 & Rothschild $3^{\text {rd }}$ ser. & 1890 & 125 & Gold ruble & Mar/Jun/Sep/Dec & $1891-1972$ & 0.28 \\
\hline [212] Russia & 4.0 & Rothschild $3^{\text {rd }}$ ser. & 1890 & 625 & Gold ruble & Mar/Jun/Sep/Dec & $1891-1972$ & 0.47 \\
\hline [213] Russia & 4.0 & Rothschild $4^{\text {th }}$ ser. & 1890 & 125 & Gold ruble & Mar/Jun/Sep/Dec & $1891-1951$ & 0.10 \\
\hline [214] Russia & 4.0 & Rothschild $4^{\text {th }}$ ser. & 1890 & 625 & Gold ruble & Mar/Jun/Sep/Dec & $1891-1951$ & 0.47 \\
\hline [215] Russia & 4.0 & Warsaw-Vienna Rw. & 1890 & 125 & Gold ruble & Jan/Jul & $1890-1931$ & 0.52 \\
\hline [216] Russia & 4.0 & Warsaw-Vienna Rw. & 1890 & 625 & Gold ruble & Jan/Jul & $1890-1931$ & 0.57 \\
\hline [217] Russia & 4.0 & Warsaw-Vienna Rw. & 1890 & 1250 & Gold ruble & Jan/Jul & $1890-1931$ & 0.38 \\
\hline [218] Russia & 4.0 & Warsaw-V. Rw. $7^{\text {th }}$ ser. & 1890 & $100 / 500$ & Ruble & Jan/Jul & $1890-1931$ & 0.42 \\
\hline [219] Russia & 4.0 & Warsaw-V. Rw. $9^{\text {th }}$ ser. & 1894 & $125 / 625 / 1250$ & Gold ruble & Jan/Jul & $1894-1931$ & 0.31 \\
\hline [220] Russia & 4.0 & Warsaw-V. Rw. $10^{\text {th }}$ ser. & 1901 & $500 / 1000 / 2000$ & Mark & Jan/Jul & $1902-1933$ & 0.49 \\
\hline [221] Russia & 4.0 & Warsaw-V. Rw. $11^{\text {th }}$ ser. & 1901 & $500 / 1000 / 2000$ & Mark & Jan/Jul & 1901-1961 & 0.45 \\
\hline [222] Russia & 4.0 & Rothschild $3^{\text {rd }}$ ser. & 1891 & 125 & Gold ruble & Jan/Apr/Jul/Oct & $1891-1971$ & 0.34 \\
\hline [223] Russia & 4.0 & Rothschild $3^{\text {rd }}$ ser. & 1891 & 625 & Gold ruble & Jan/Apr/Jul/Oct & $1891-1971$ & 0.73 \\
\hline [224] Russia & 4.0 & Rothschild $3^{\text {rd }}$ ser. & 1891 & 1250 & Gold ruble & Jan/Apr/Jul/Oct & $1891-1971$ & 0.04 \\
\hline [225] Russia & 4.0 & Rothschild $5^{\text {th }}$ ser. & 1893 & 125 & Gold ruble & Feb/May/Aug/Nov & 1894-1975 & 0.46 \\
\hline [226] Russia & 4.0 & Rothschild $5^{\text {th }}$ ser. & 1893 & 625 & Gold ruble & Feb/May/Aug/Nov & 1894-1975 & 0.69 \\
\hline [227] Russia & 4.0 & Rothschild $6^{\text {th }}$ ser. & 1894 & 125 & Gold ruble & $\mathrm{Jan} / \mathrm{Apr} / \mathrm{Jul} / \mathrm{Oct}$ & 1895-1976 & 0.62 \\
\hline [228] Russia & 4.0 & Rothschild $6^{\text {th }}$ ser. & 1894 & 625 & Gold ruble & $\mathrm{Jan} / \mathrm{Apr} / \mathrm{Jul} / \mathrm{Oct}$ & $1895-1976$ & 0.78 \\
\hline
\end{tabular}


Table A. 2 continued

\begin{tabular}{|c|c|c|c|c|c|c|c|c|}
\hline (1) & (2) & (3) & (4) & (5) & (6) & (7) & (8) & (9) \\
\hline $\begin{array}{l}\text { Country [/Possibly } \\
\text { subnational entity] }\end{array}$ & $\begin{array}{l}\text { Interest } \\
\text { Rate }(\%)\end{array}$ & Addition & $\begin{array}{l}\text { Issued } \\
\text { in/over }\end{array}$ & Pieces & Currency & $\begin{array}{l}\text { Coupon } \\
\text { frequency }\end{array}$ & Redemption (date) & $\begin{array}{l}\text { Density } \\
\text { of the } \\
\text { price } \\
\text { account }\end{array}$ \\
\hline [229] Russia & 4.0 & Rothschild $6^{\text {th }}$ ser. & 1894 & 3125 & Gold ruble & Jan/Apr/Jul/Oct & 1895-1976 & 0.01 \\
\hline [230] Russia & 4.0 & Donetz Rw. & 1894 & 125 & Gold ruble & Jun/Dec & 1895-1960 & 0.66 \\
\hline [231] Russia & 4.0 & Domestic debt & 1894 & 100/200/500/1000 & Ruble & Mar/Jun/Sep/Nov & $1895-$ & 0.67 \\
\hline [232] Russia & 4.0 & Domestic debt cert. & 1894 & $100 / 200 / 500 / 1000$ & Ruble & Mar/Jun/Sep/Nov & $1895-$ & 0.53 \\
\hline [233] Russia & 4.0 & Orel-Viterbsk Rw. & 1894 & 125 & Gold ruble & Apr/Oct & $1895-1953$ & 0.62 \\
\hline [234] Russia & 4.0 & Orel-Viterbsk Rw. & 1894 & 625 & Gold ruble & Apr/Oct & $1895-1953$ & 0.50 \\
\hline [235] Russia & 4.0 & Mosc.-Jaros.-Arch. Rw. & 1897 & $500 / 1000 / 2000$ & Mark & Apr/Oct & $1897-1943$ & 0.45 \\
\hline [236] Russia & 4.0 & Moscow-Smolensk Rw. & 1898 & 1000 & Guilder & May/Nov & $1899-1950$ & 0.48 \\
\hline [237] Russia & 4.0 & Transcaucas. Rw. & 1898 & $500 / 2500$ & Franc & Apr/Oct & $1899-1953$ & 0.61 \\
\hline [238] Russia & 4.0 & Transcaucas. Rw. & 1898 & 5000 & Franc & Apr/Oct & $1899-1953$ & 0.20 \\
\hline [239] Russia & 4.0 & - & 1902 & $500-5000$ & Mark & Jan/Jul & $1902-1940$ & 0.50 \\
\hline [240] Russia & 4.5 & Iwangorod-Dombr. Rw. & 1881 & 125 & Gold ruble & Jan/Jul & $1882-1932$ & 0.58 \\
\hline [241] Russia & 4.5 & Iwangorod-Dombr. Rw. & 1881 & 625 & Gold ruble & Jan/Jul & $1882-1932$ & 0.63 \\
\hline [242] Russia & 4.5 & - & 1905 & $500-5000$ & Mark & Jan/Jul & $1917-$ & 0.50 \\
\hline [243] Russia & 4.5 & Ser. 31-36 & 1909 & 500 & Franc & Jan/Jul & 1920-1959 & 0.59 \\
\hline [244] Russia & 4.5 & Ser. 31-36 & 1909 & 2500 & Franc & Jan/Jul & 1920-1959 & 0.59 \\
\hline [245] Russia & 4.5 & Ser. 37 & 1909 & $500 / 2500 / 5000$ & Franc & Jan/Jul & 1920-1959 & 0.35 \\
\hline [246] Russia & 5.0 & Hamburg & 1820 & 500 & Ruble & Mar/Sep & $1821-$ & 0.24 \\
\hline [247] Russia & 5.0 & London & 1822 & $111 / 148 / 518 / 1036$ & Pound & Mar/Sep & $1823-$ & 0.18 \\
\hline
\end{tabular}


Table A.2 continued

\begin{tabular}{|c|c|c|c|c|c|c|c|c|}
\hline (1) & (2) & (3) & (4) & (5) & (6) & (7) & (8) & (9) \\
\hline $\begin{array}{l}\text { Country [/Possibly } \\
\text { subnational entity] }\end{array}$ & $\begin{array}{l}\text { Interest } \\
\text { Rate }(\%)\end{array}$ & Addition & $\begin{array}{l}\text { Issued } \\
\text { in/over }\end{array}$ & Pieces & Currency & $\begin{array}{l}\text { Coupon } \\
\text { frequency }\end{array}$ & Redemption (date) & $\begin{array}{l}\text { Density } \\
\text { of the } \\
\text { price } \\
\text { account }\end{array}$ \\
\hline [248] Russia & 5.0 & - & 1906 & 500 & Franc & May/Nov & $1917-1956$ & 0.64 \\
\hline [249] Russia & 5.0 & - & 1906 & $2500 / 5000$ & Franc & May/Nov & 1917-1956 & 0.70 \\
\hline [250] Russia & 6.0 & Grootboek cert. & $1817 / 18$ & 1000 & Ruble & Jan/Jul & - & 0.06 \\
\hline [251] Russia & 6.0 & Grootboek cert. silver & $1817 / 18$ & 1000 & Ruble & Jan/Jul & - & 0.16 \\
\hline [252] Serbia & 4.0 & - & 1895 & 500 & Franc & Jan/Jul & $1896-1968$ & 0.58 \\
\hline [253] Serbia & 4.0 & - & 1895 & 2500 & Franc & Jan/Jul & $1896-1968$ & 0.48 \\
\hline [254] Serbia & 4.0 & - & 1895 & 5000 & Franc & Jan/Jul & $1896-1968$ & 0.10 \\
\hline [255] Spain & 4.0 & - & 1881 & $1000-6000$ & Peseta & Jan/Arp/Jul/Oct & $1882-$ & 0.10 \\
\hline [256] Spain & 4.0 & - & 1881 & $12000 / 24000$ & Peseta & Jan/Arp/Jul/Oct & $1882-$ & 0.02 \\
\hline [257] Surinam & 4.5 & - & 1915 & $100 / 500$ & Guilder & Jan/Jul & $1917-$ & 0.03 \\
\hline [258] Surinam & 4.5 & - & 1915 & 1000 & Guilder & $\mathrm{Jan} / \mathrm{Jul}$ & $1917-$ & 0.03 \\
\hline [259] Sweden & 3.5 & - & 1890 & $500 / 1000 / 5000$ & Mark & Mar/Sep & 1891-1941 & 0.28 \\
\hline [260] Sweden & 3.5 & - & 1895 & $20 / 100 / 500 / 1000$ & Pounds & Apr/Oct & -1930 & 0.03 \\
\hline [261] Sweden & 3.5 & - & 1900 & $100 / 500 / 1000$ & Pounds & Feb/Aug & $1920-$ & 0.09 \\
\hline [262] Switzerland & 3.5 & Railway & 1899-1902 & 1000 & Franc & Jun/Dec & 1911-1962 & 0.24 \\
\hline [263] Turkey & 4.0 & Consols gold & 1890 & $500 / 2500$ & France & Mar/Sep & 1891-1934 & 0.14 \\
\hline [264] Turkey & 4.0 & - & 1894 & 500 & Franc & $\mathrm{Jan} / \mathrm{Jul}$ & 1895-1959 & 0.10 \\
\hline [265] Turkey & 4.0 & Customs & 1902 & $500 / 2500$ & Franc & Jan/Jul & 1903-1959 & 0.19 \\
\hline [266] Turkey & 4.0 & Unified & 1903 & 500 & Franc & Mar/Sep & 1904-1964 & 0.27 \\
\hline
\end{tabular}


Table A.2 continued

\begin{tabular}{|c|c|c|c|c|c|c|c|c|}
\hline (1) & (2) & (3) & (4) & $(5)$ & (6) & (7) & (8) & (9) \\
\hline $\begin{array}{l}\text { Country [/Possibly } \\
\text { subnational entity] }\end{array}$ & $\begin{array}{l}\text { Interest } \\
\text { Rate }(\%)\end{array}$ & Addition & $\begin{array}{l}\text { Issued } \\
\text { in/over }\end{array}$ & Pieces & Currency & $\begin{array}{l}\text { Coupon } \\
\text { frequency }\end{array}$ & Redemption (date) & $\begin{array}{l}\text { Density } \\
\text { of the } \\
\text { price } \\
\text { account }\end{array}$ \\
\hline [267] Turkey & 4.0 & Unified & 1903 & 2500 & Franc & Mar/Sep & 1904-1964 & 0.24 \\
\hline [268] Turkey & 4.0 & - & 1903 & $500 / 2500$ & Franc & May/Nov & 1903-1958 & 0.10 \\
\hline [269] Turkey & 4.0 & Baghdad Rw. $1^{\text {st }}$ ser. & 1904 & $500 / 2500$ & Franc & Mar/Sep & 1903-2001 & 0.56 \\
\hline [270] Turkey & 4.0 & - & 1905 & $500 / 2500$ & Franc & Mar/Sep & 1906-1961 & 0.13 \\
\hline [271] Turkey & 4.0 & Baghdad Rw. $2^{\text {nd }}$ ser. & 1910 & $500 / 2500$ & Franc & $\mathrm{Jan} / \mathrm{Jul}$ & 1908-2005 & 0.59 \\
\hline [272] Turkey & 4.0 & - & 1911 & $500 / 2500 / 10000$ & Franc & Jan/Jul & $1911-1952$ & 0.12 \\
\hline [273] Uruguay & 3.5 & Consols & 1892 & $20 / 100$ & Pound & Jan/Apr/Jul/Oct & $1892-$ & 0.40 \\
\hline [274] Uruguay & 5.0 & - & 1896 & $20 / 100$ & Pound & Feb/May/Aug/Nov & $1896-$ & 0.32 \\
\hline [275] USA/Louisiana & 4.0 & Consols & 1874 & $100 / 500 / 1000$ & Dollar & Jan/Jul & Originally 1914 & 0.00 \\
\hline [276 Venezuela & 3.0 & Diplomatic debt & 1905 & $20 / 100$ & Pound & Jan/Jul & 1905-1952 & 0.35 \\
\hline [277] Venezuela & 3.0 & Diplomatic debt & 1905 & 500 & Pound & Jan/Jul & $1905-1952$ & 0.21 \\
\hline
\end{tabular}

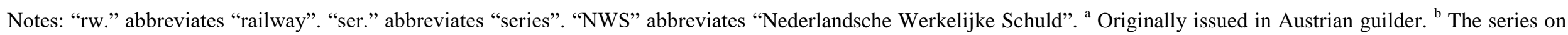

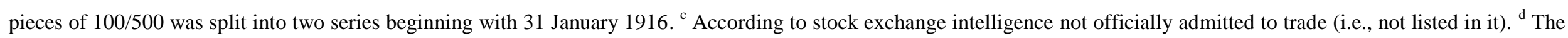
two series on pieces of 100/200 and 500/1 000 were split into four series beginning with 31 January $1916 .{ }^{e}$ Consolidated with the $4.5 \%$ of 1917 as of 1 January 1918.

Sources: Cf. Chapter II and the Appendix text. 
Table A.3: Characteristics of war bonds unofficially traded in Amsterdam

\begin{tabular}{llllll}
\hline $\begin{array}{l}(1) \\
\text { Country }\end{array}$ & $\begin{array}{l}\text { Bond series } \\
\text { (as named in the } \\
\text { unofficial price } \\
\text { list) }\end{array}$ & $\begin{array}{l}\text { First price } \\
\text { observed } \\
(\mathrm{dd} / \mathrm{mm} / \mathrm{yyyy})\end{array}$ & $\begin{array}{l}\text { (5) } \\
\text { Currency } \\
\text { denomination }\end{array}$ & $\begin{array}{l}(6) \\
\text { Redemption }\end{array}$ & $\begin{array}{l}\text { (9) } \\
\text { Density of } \\
\text { the price } \\
\text { account } \\
\text { during WWI }\end{array}$ \\
\hline England & $5.0 \% 1917$ & $02 / 03 / 1916$ & Pound & $1917(?)$ & 0.01 \\
England & $5.0 \% 1919$ & $06 / 05 / 1916$ & Pound & $1919(?)$ & 0.25 \\
England & $5.0 \% 1920$ & $15 / 06 / 1916$ & Pound & $1920(?)$ & 0.20 \\
England & $5.0 \% 1921$ & $15 / 06 / 1916$ & Pound & $1921(?)$ & 0.10 \\
England & $5.0 \% 1917-21$ & $02 / 03 / 1916$ & Pound & $1917-21(?)$ & 0.08 \\
England & $5.0 \% 1929-47$ & $18 / 01 / 1917$ & Pound & $1929-47(?)$ & 0.19 \\
England & $6.0 \% 1920$ & $07 / 10 / 1916$ & Pound & $1920(?)$ & 0.27 \\
England/France & $5.0 \%$ & $16 / 12 / 1915$ & US-Dollar(?) & $1920(?)$ & 0.17 \\
France & $4.0 \% 1917 / 18$ & $15 / 11 / 1917$ & Franc & $?$ & 0.08 \\
France & $5.0 \%$ & $29 / 11 / 1915$ & Franc & $?$ & 0.21 \\
\hline
\end{tabular}

Sources: Cf. Chapter II and the Appendix text. 


\subsection{Plots of the bonds' raw price development}

Figures A.1 and A.2 plot the raw prices as gathered from my sources for the cross-section of bonds traded at the Amsterdam Stock Exchange over 1914-1919. Prices are shown for all bond series that exhibit a density of the price account of at least ten percent, which is implying that 164 daily price observations are recorded (cf. column (9) in Tables A.2 and A.3). The plots are ordered alphabetically by country and the bonds are identified according to the way they are in Tables A.2 and A.3 (column (2)). As the raw price series naturally contain gaps and can thus be drawn only with marks, each series is shown in its own plot. This approach raises the number of plots while making it easier for the reader to assess the time patterns of the bonds of interest. 
Figure A.1: Raw price development of all bonds traded in Amsterdam over 1914-1919

(1) Austria - 3.0 \% local railway company

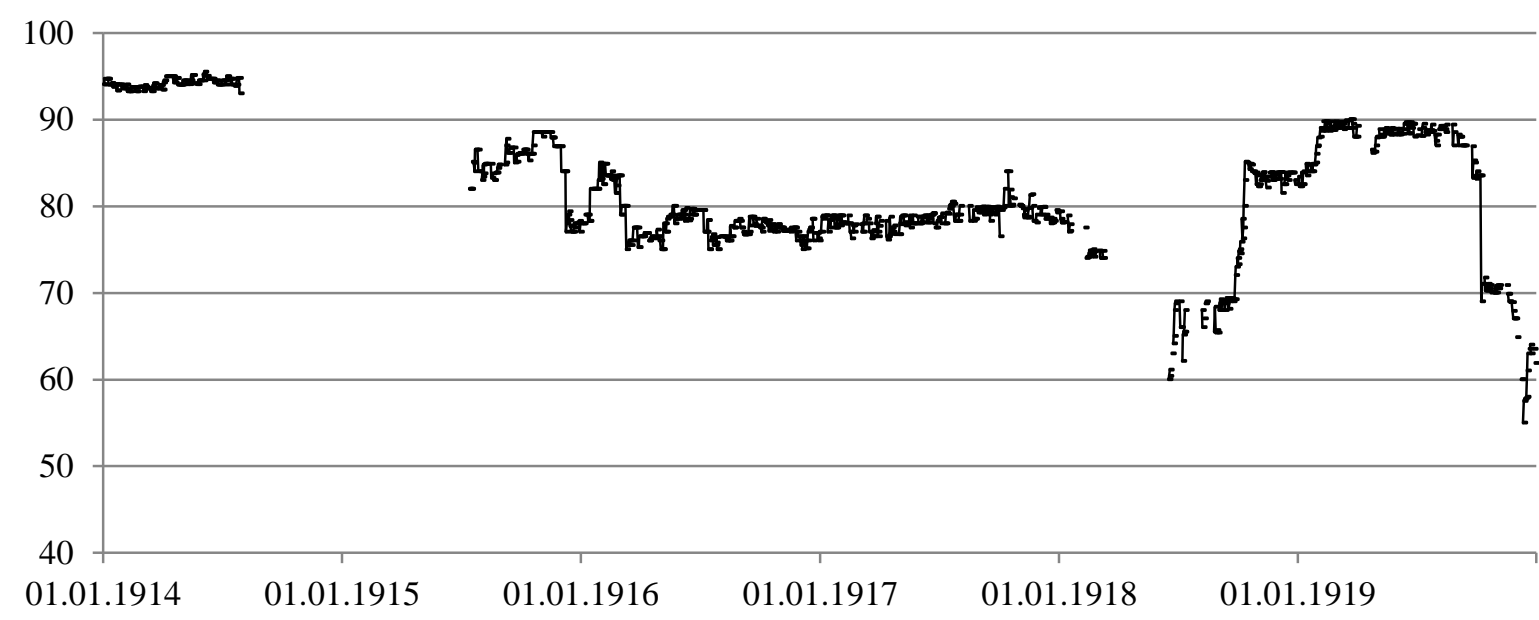

(2) Austria - $4.0 \%$ of 1903 (Jan/Jul)

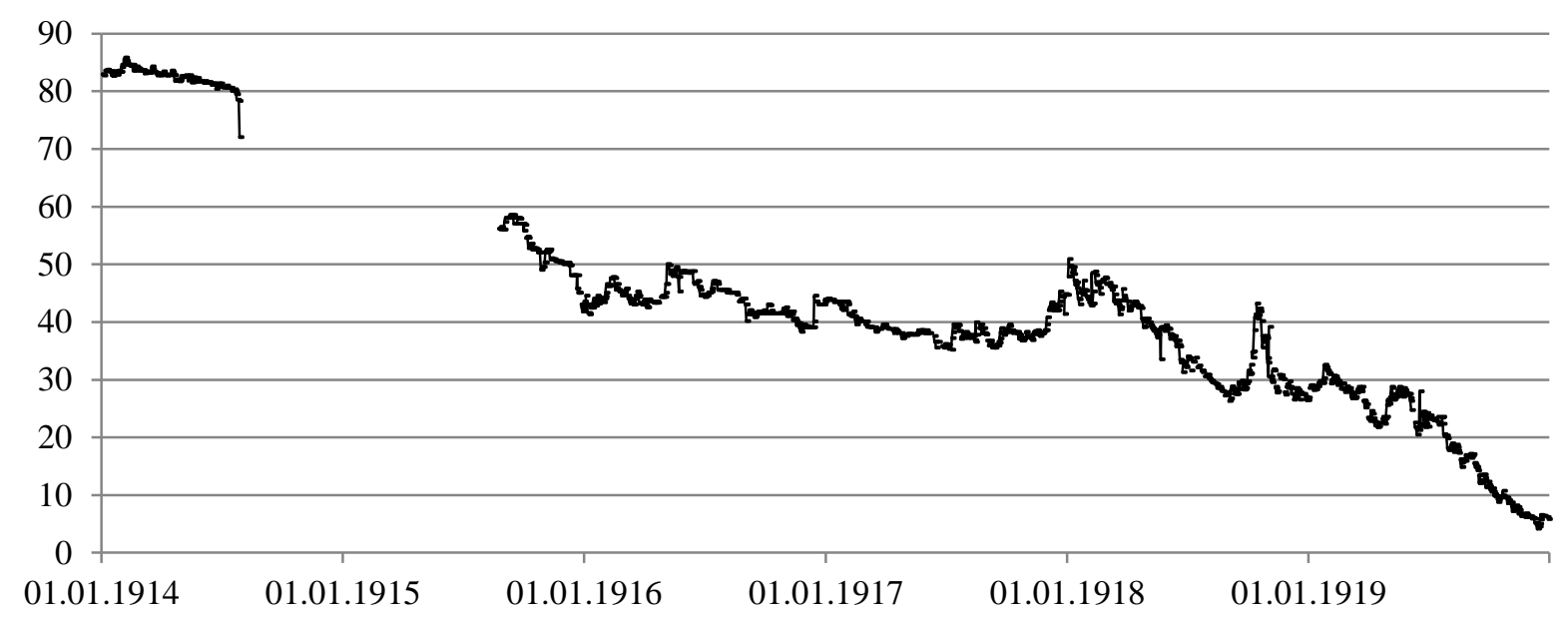

(3) Austria - $4.0 \%$ of 1892 (Mar/Sep)

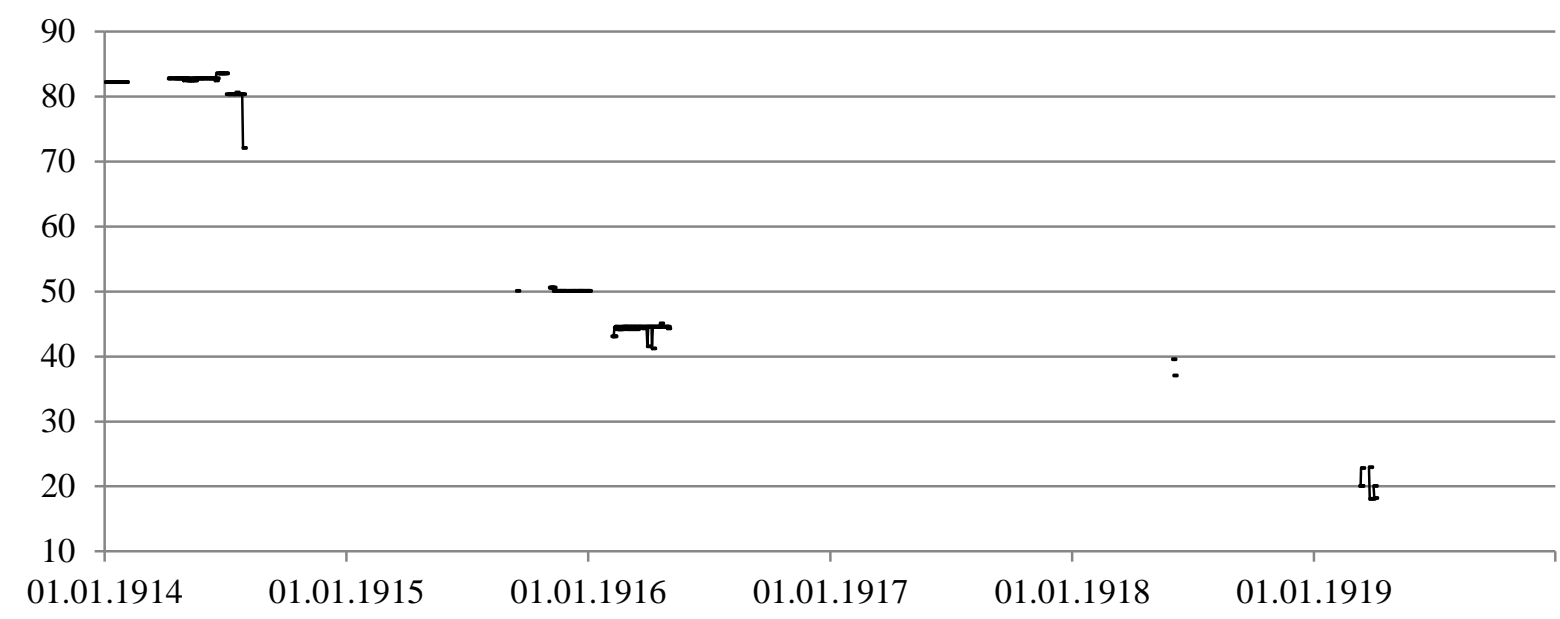


(4) Austria $-4.0 \%$ of 1903 (May/Nov)

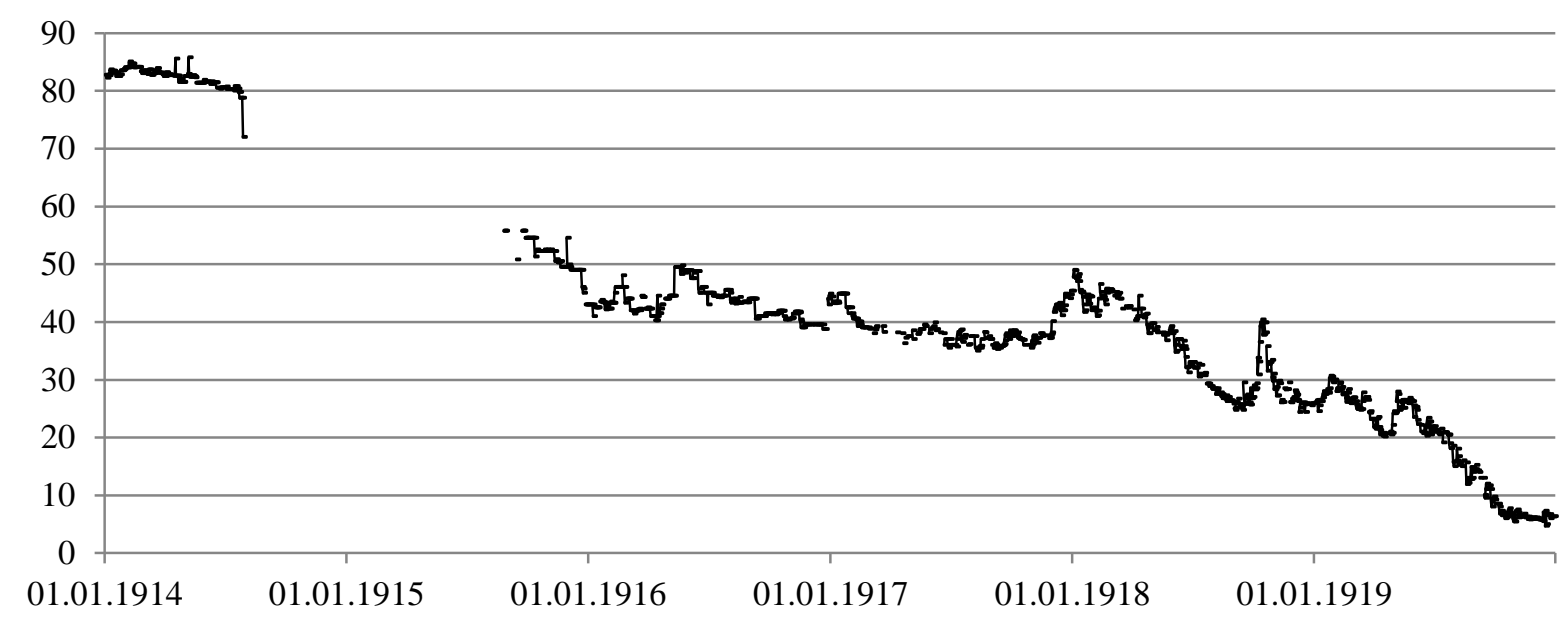

(5) Austria $-4.0 \%$ of $1867-93$

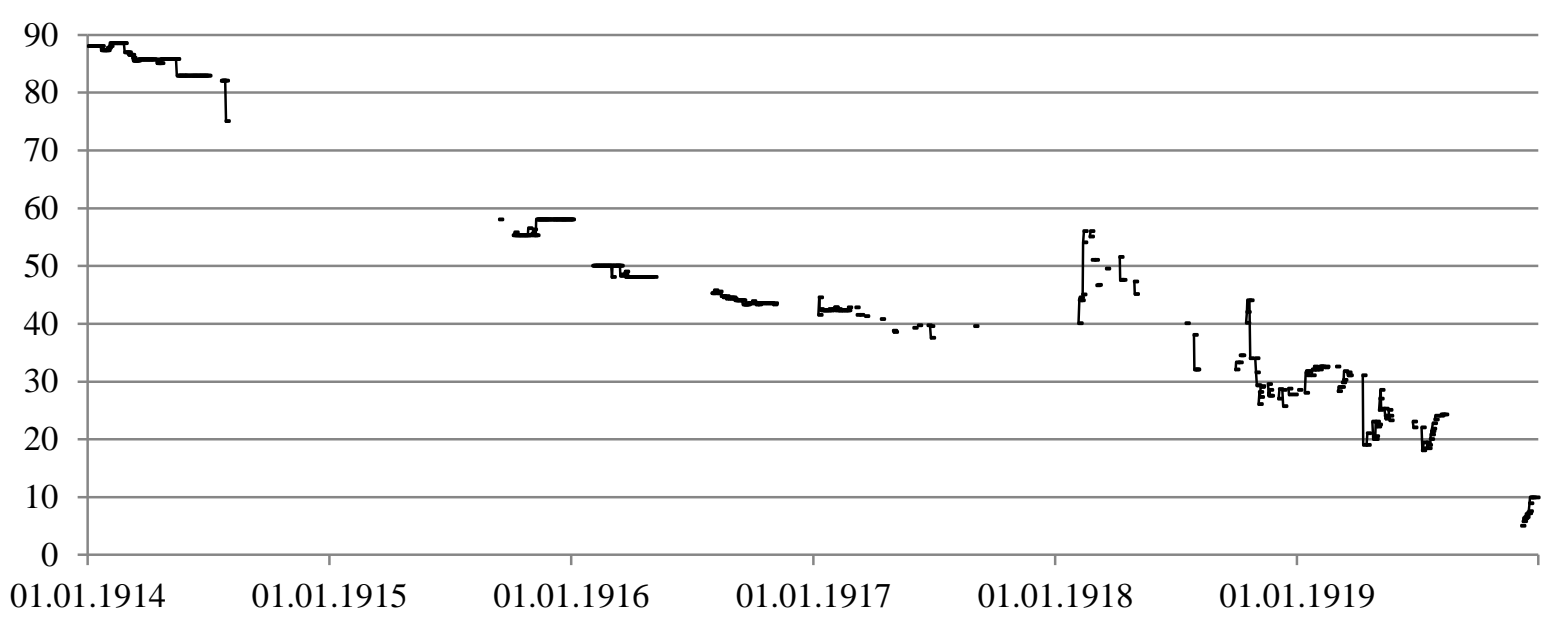

(6) Austria - $4.0 \%$ Lemberg-Chern.-Jassy Railway

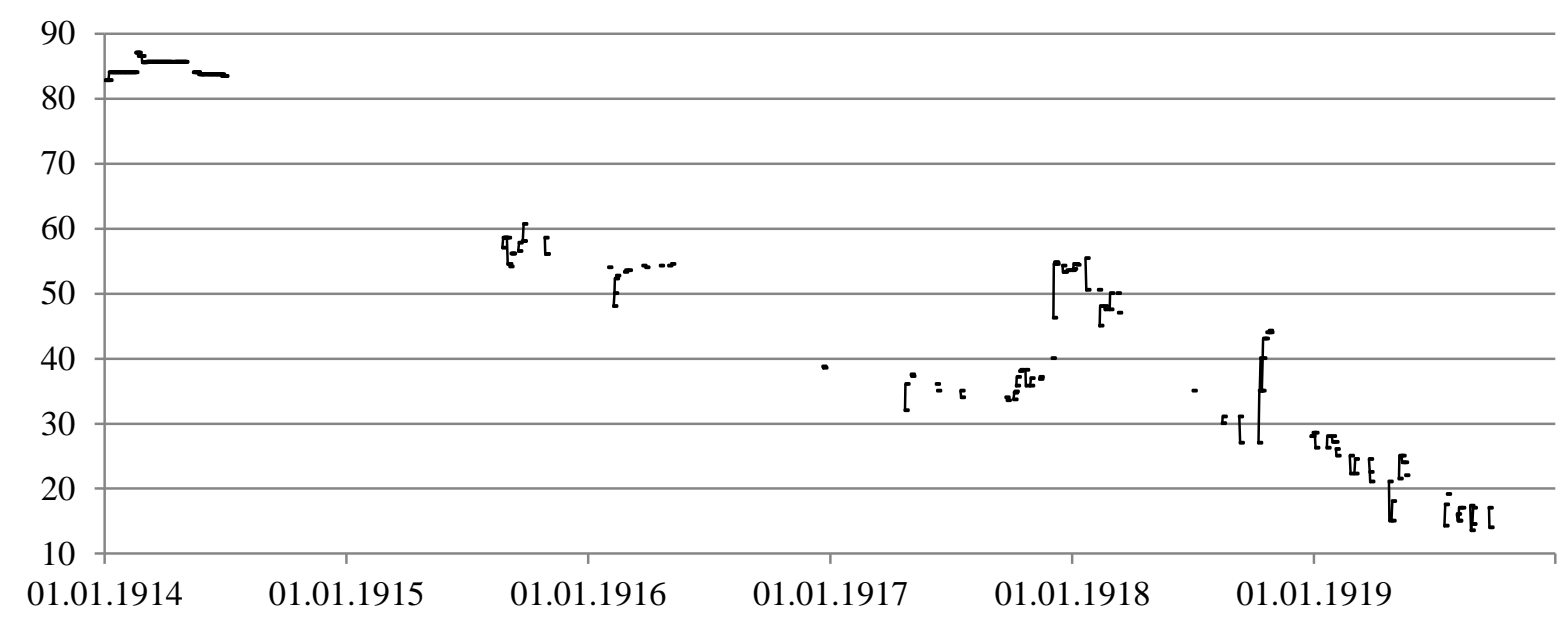


(7) Austria $-4.5 \%$ of 1913

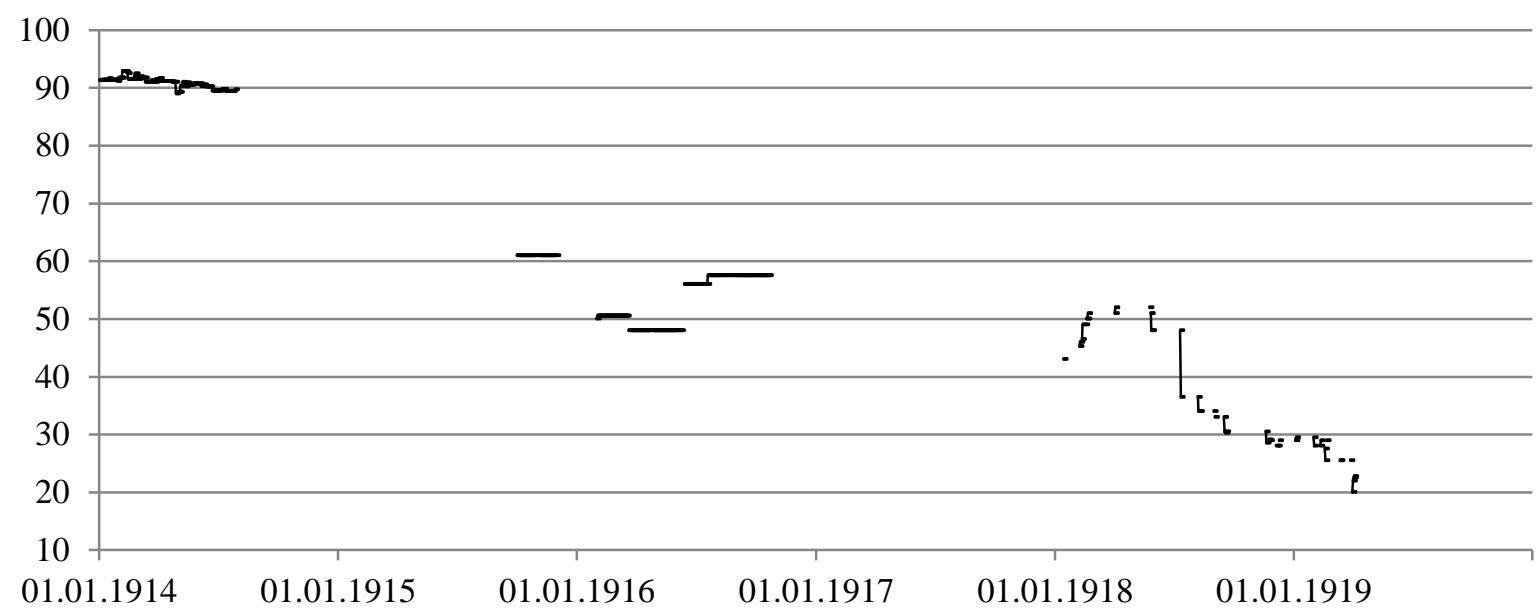

(8) Austria $-4.5 \%$ of 1914

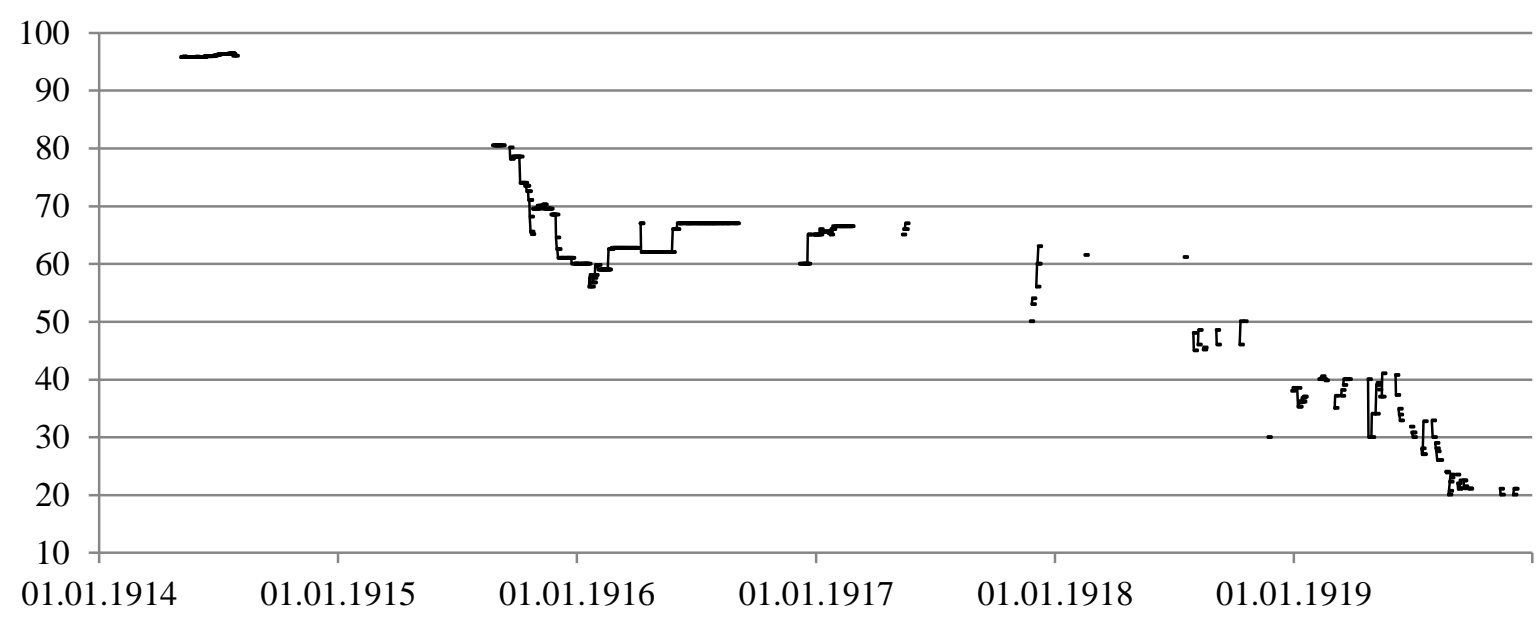

(9) Austria $-5.0 \%$ of 1868 (Paper)

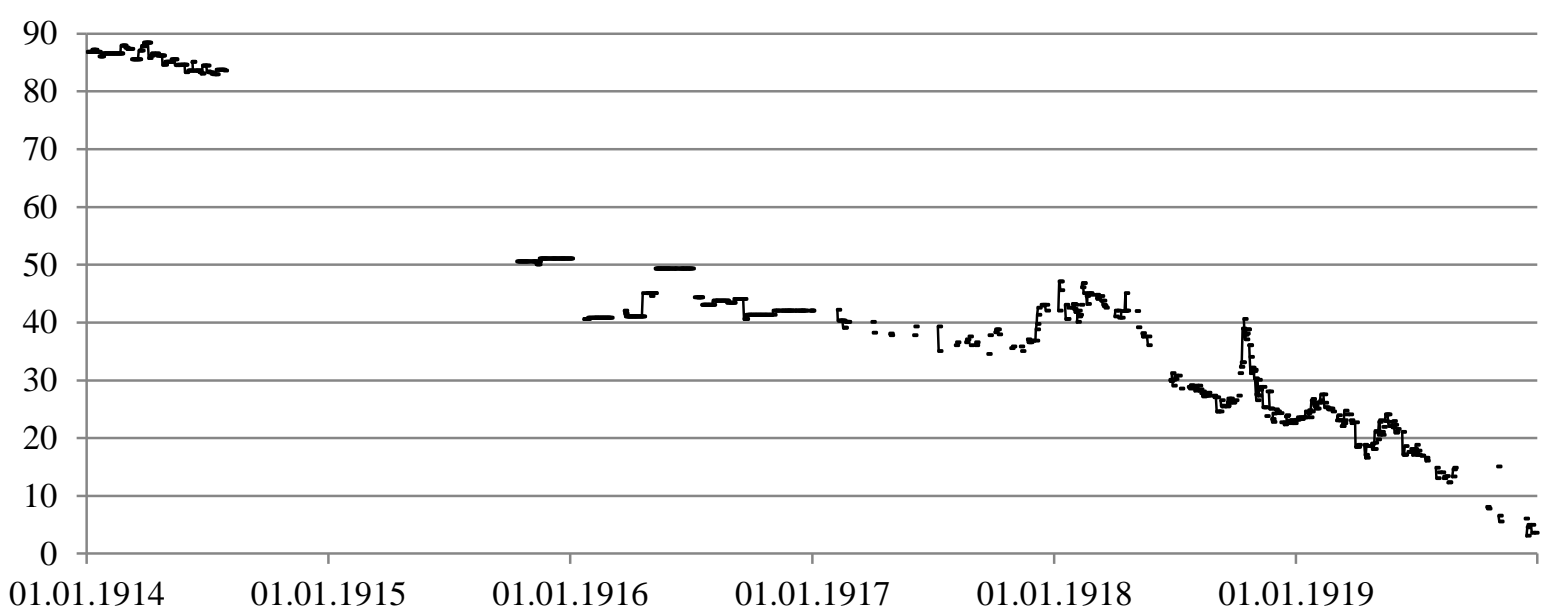


(10) Austria - $5.0 \%$ of 1868 (Silver)

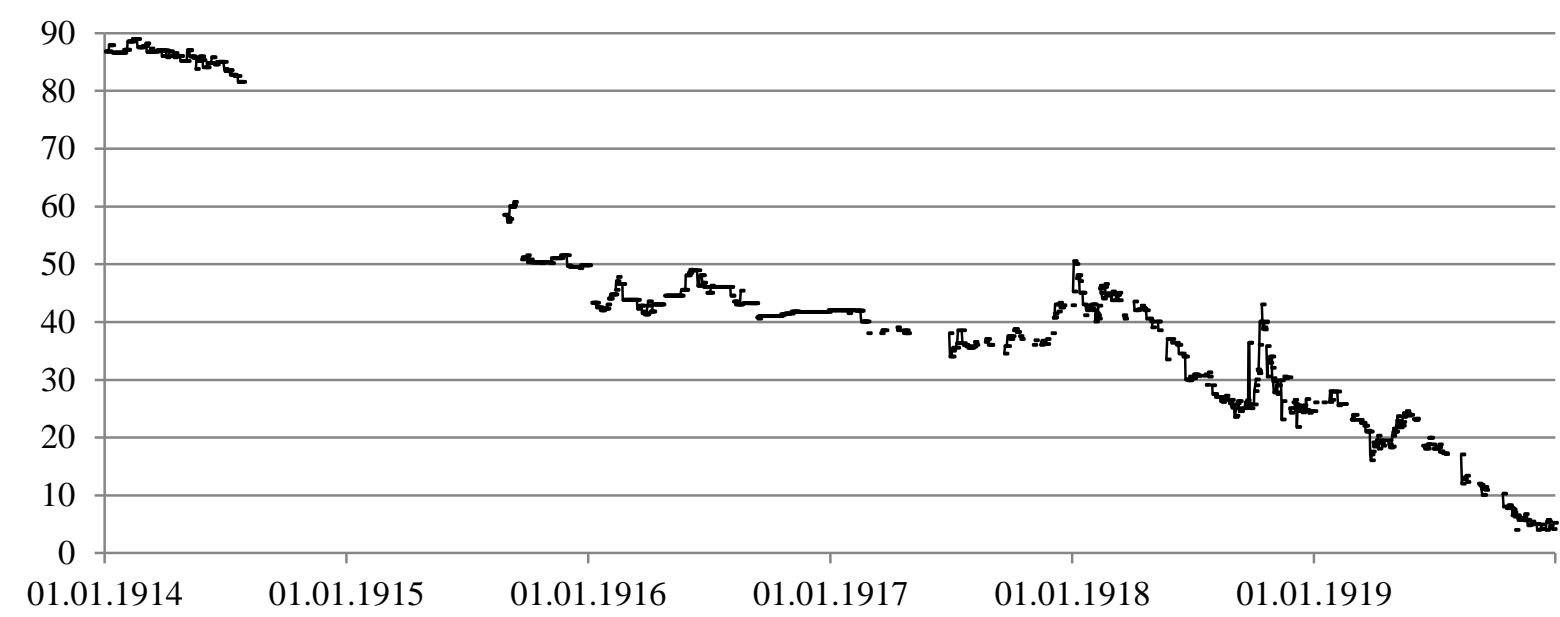

(11) Argentina $-4.0 \%$ of 1896-1899

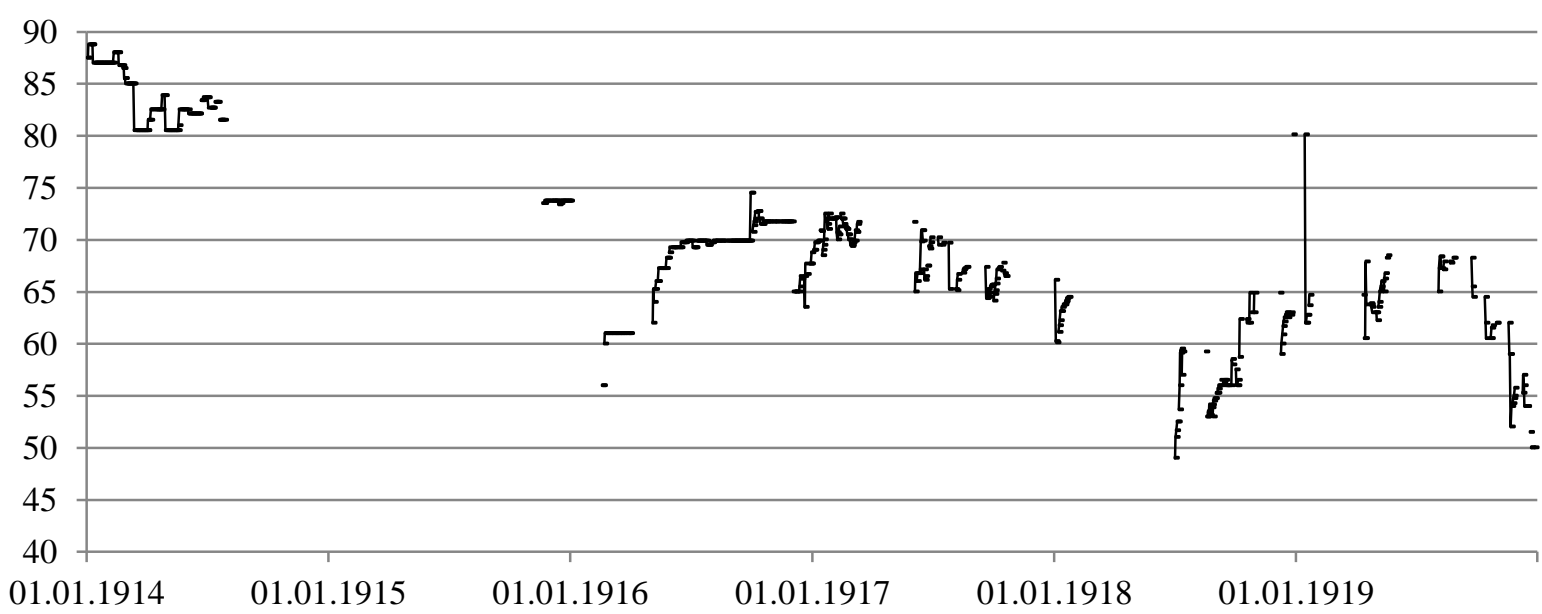

(12) Argentina $-5.0 \%$ of $1886 / 87$

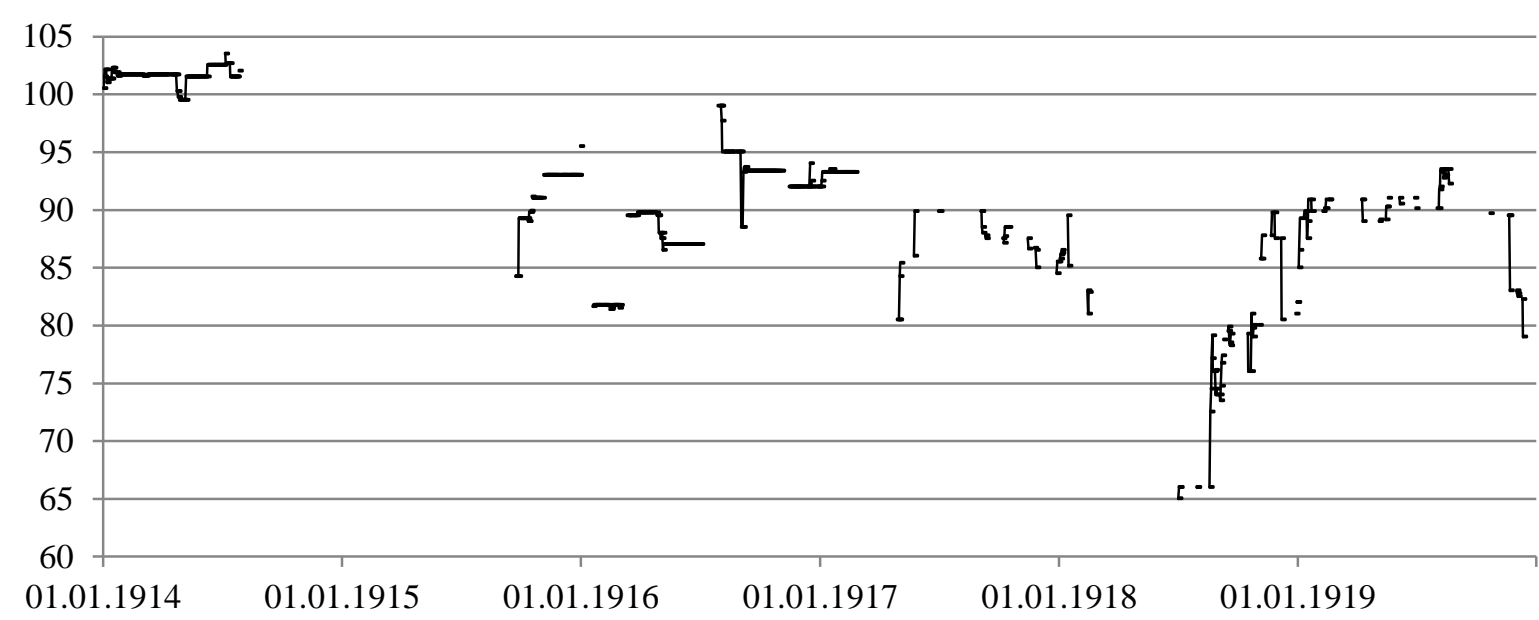


(13) Argentina $-5.0 \%$ of 1905

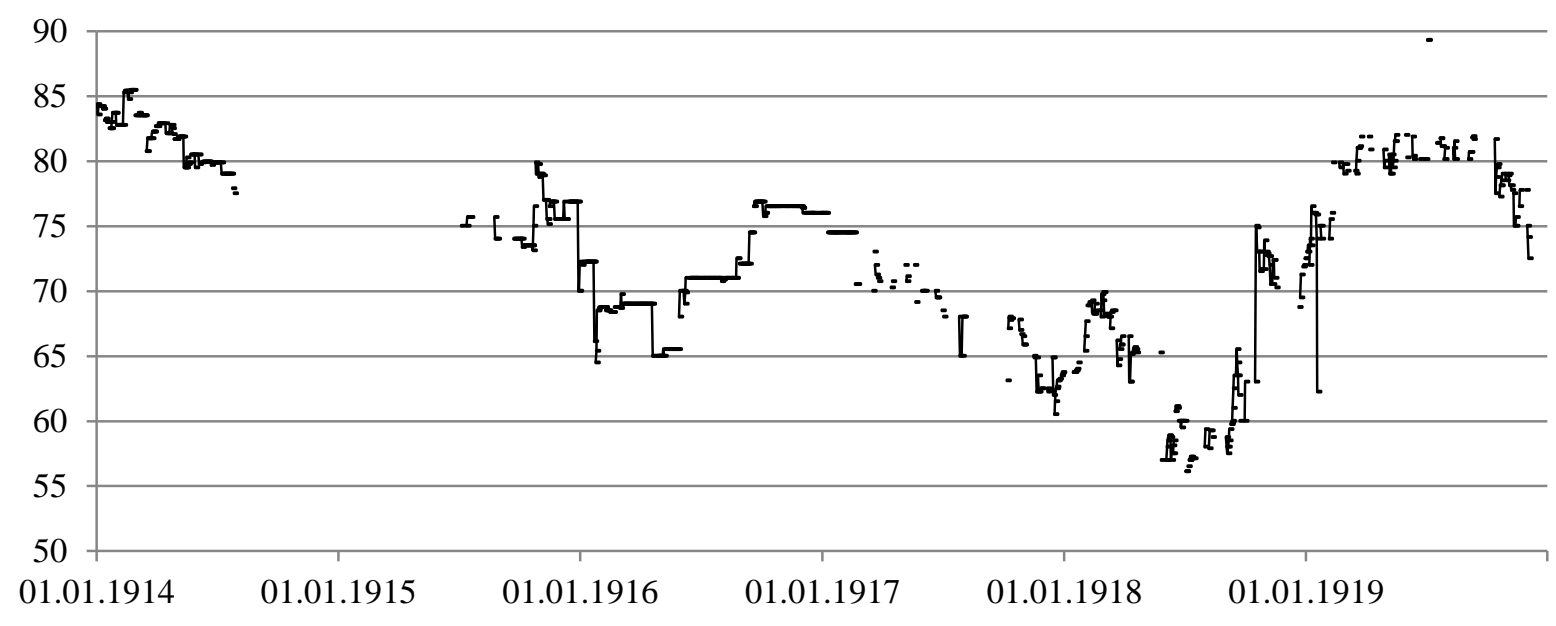

(14) Brazil $-4.0 \%$ of 1889

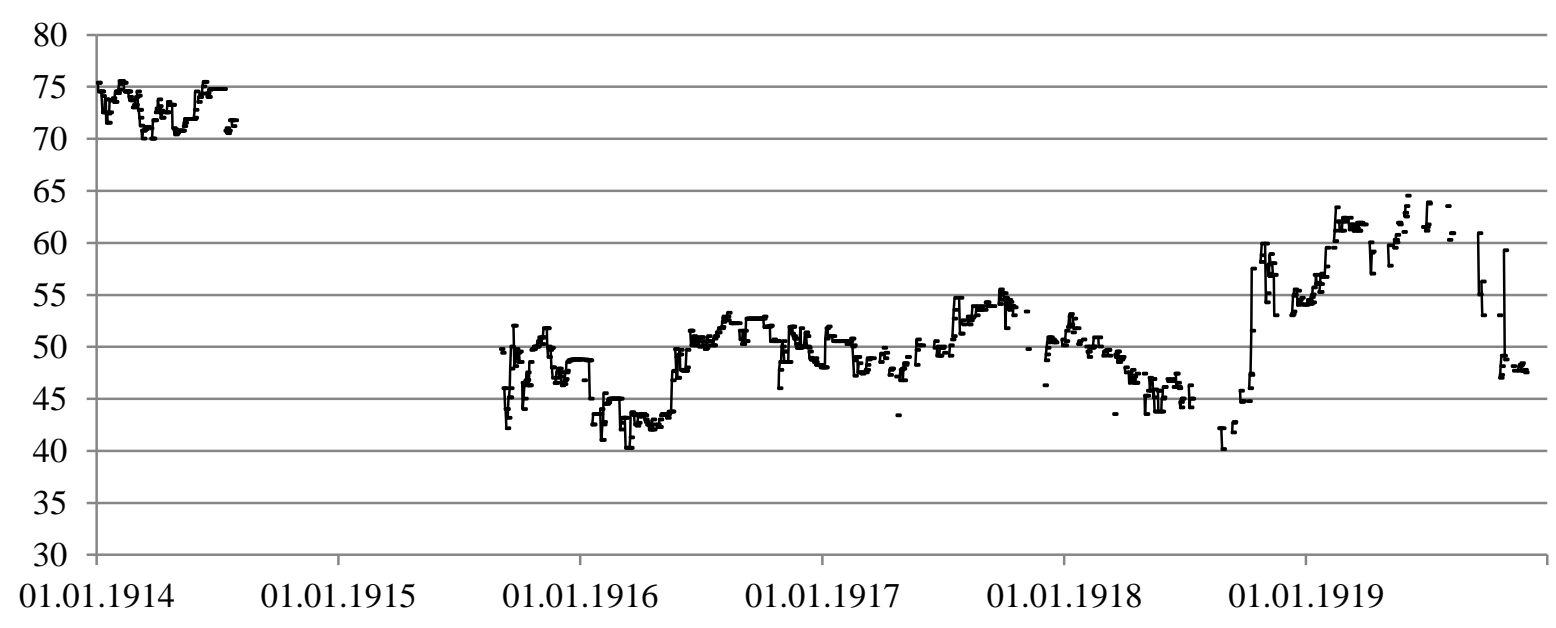

(15) Brazil - $4.0 \%$ of 1910 (100)

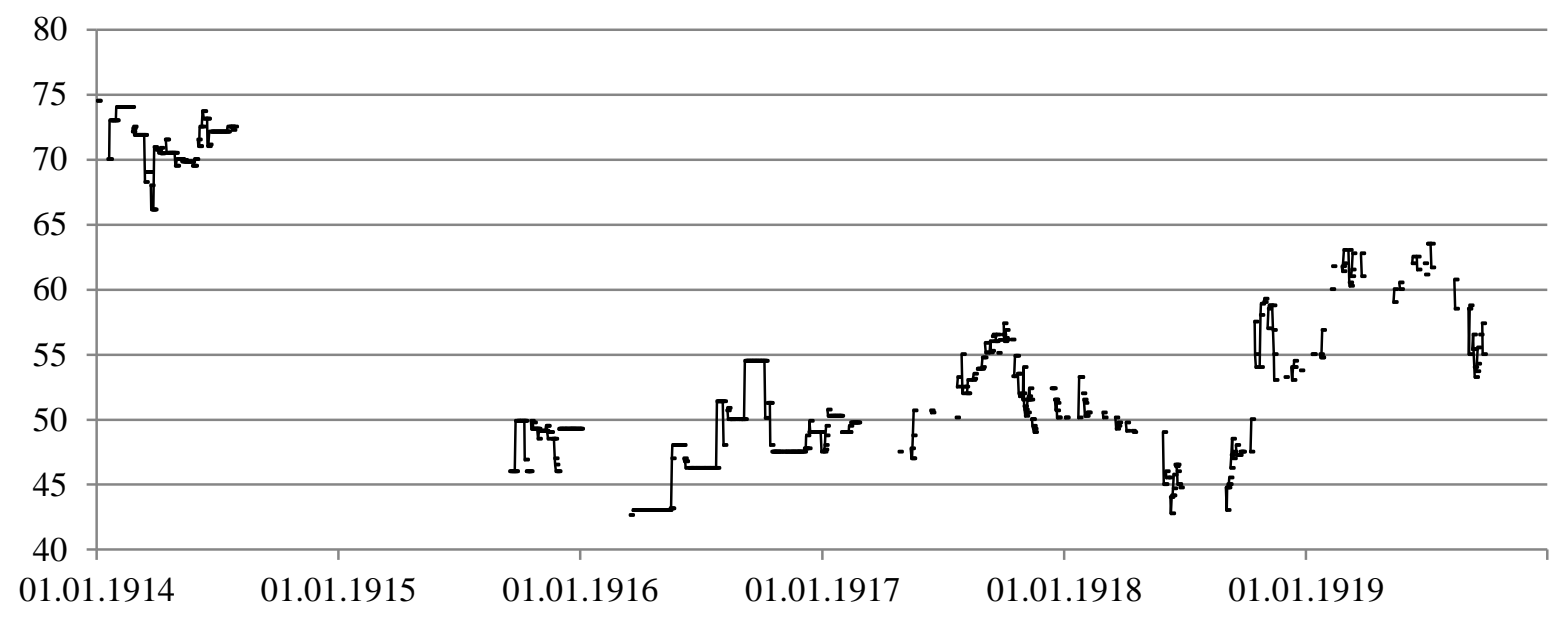

36 
(16) Brazil $-4.0 \%$ of 1901

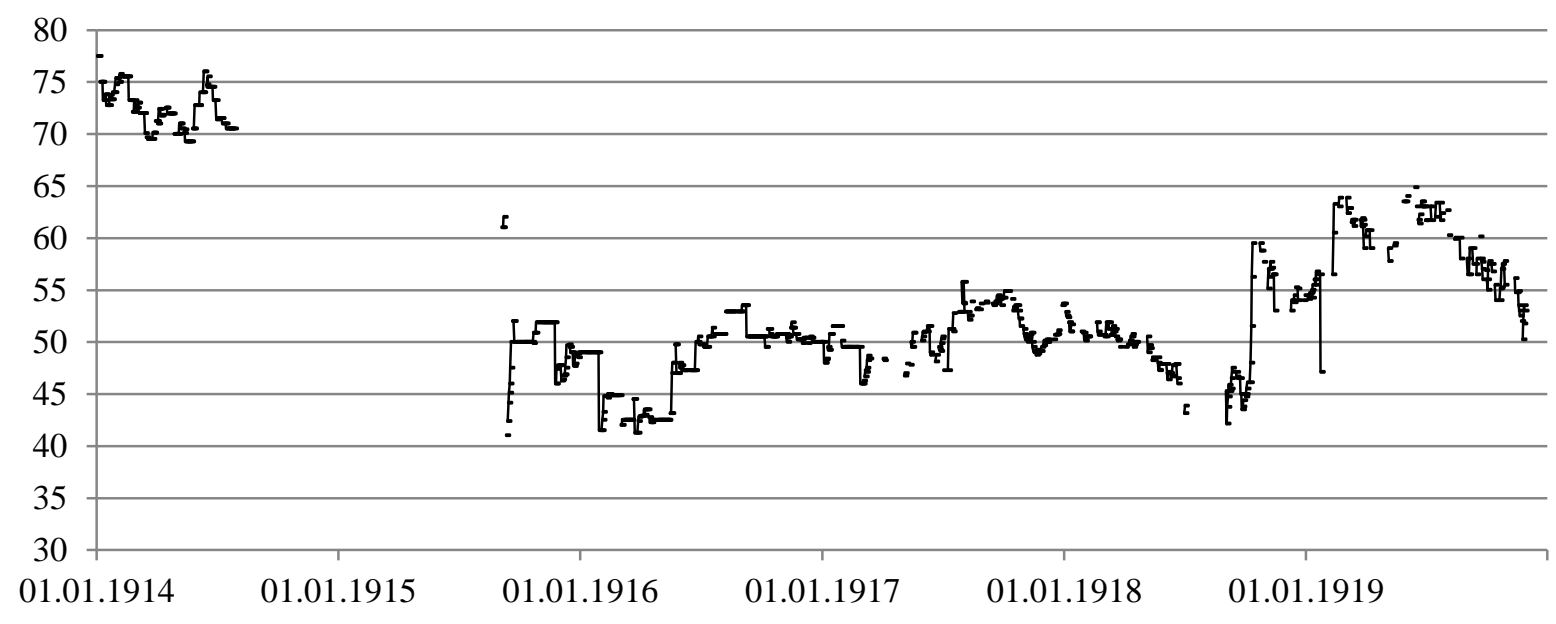

(17) Brazil $-4.5 \%$ of 1883

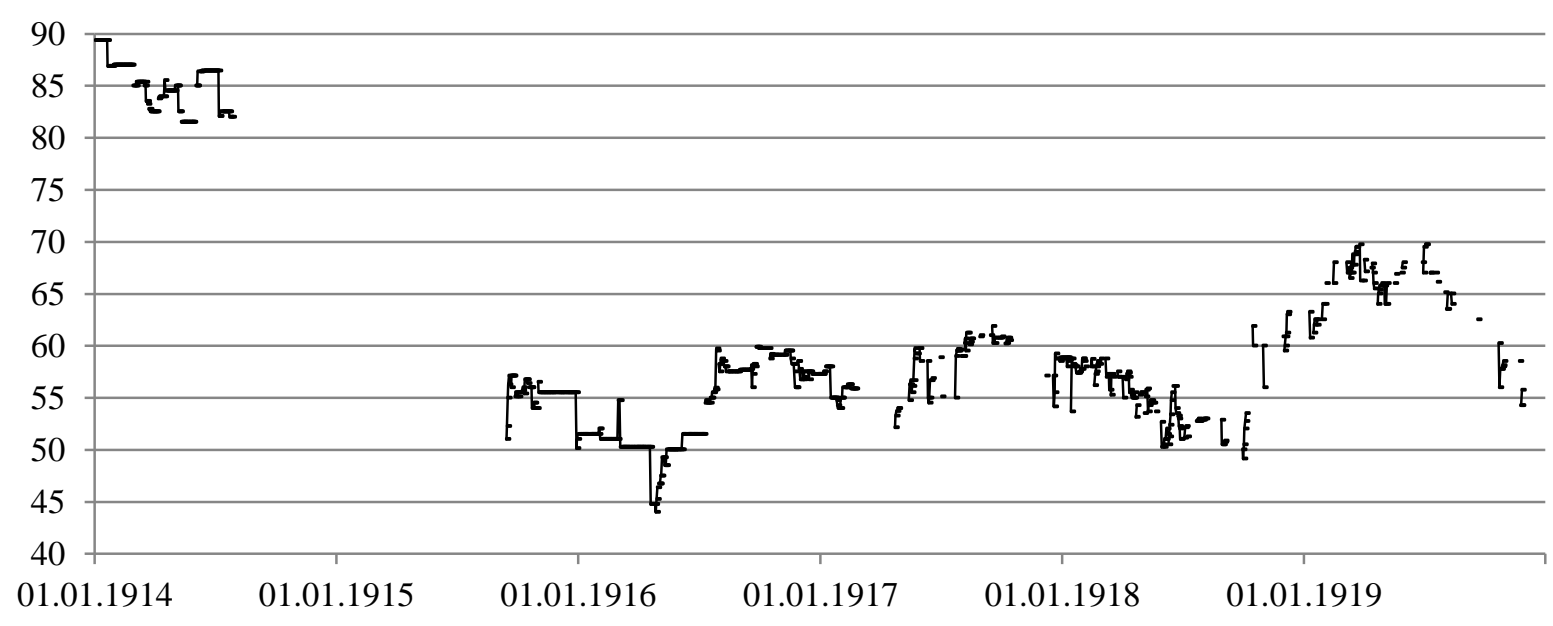

(18) Brazil $-4.5 \%$ of 1888

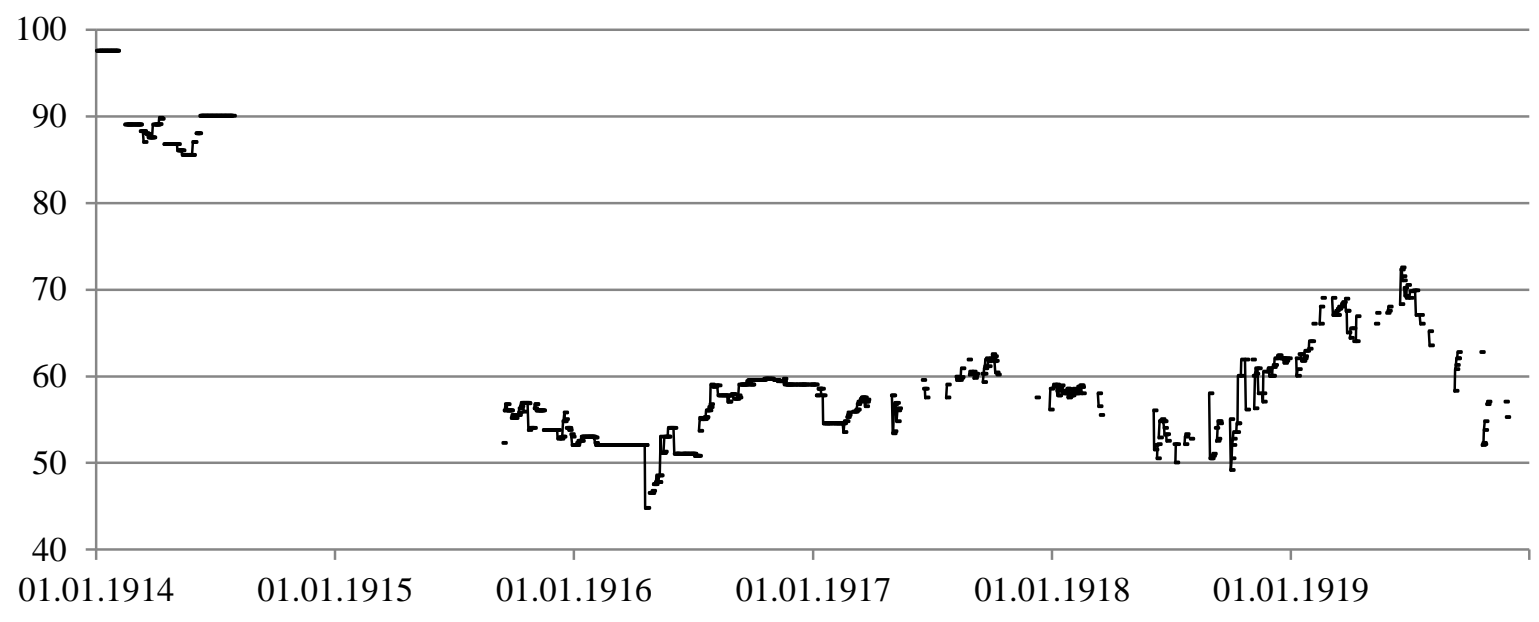

37 
(19) Brazil - 4.5 \% Minas Gerais of 1910

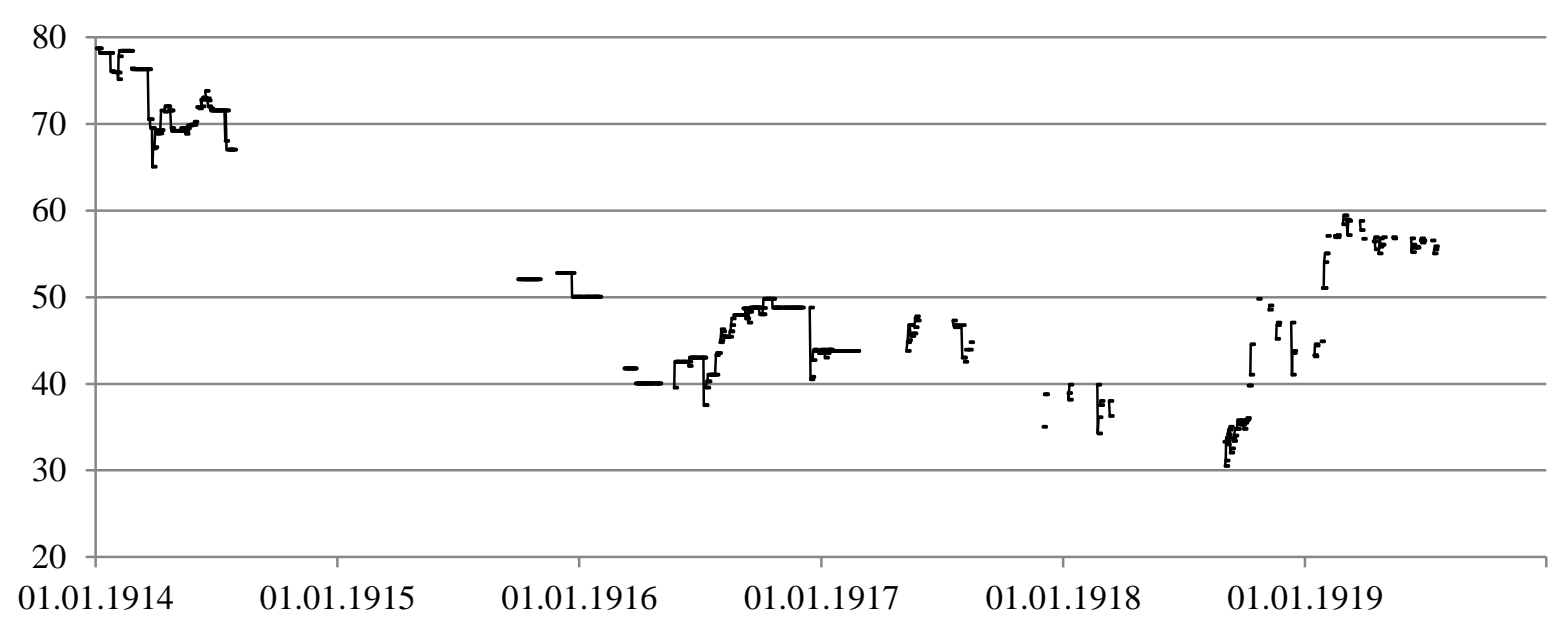

(20) Brazil - 4.5\% Minas Gerais of 1911

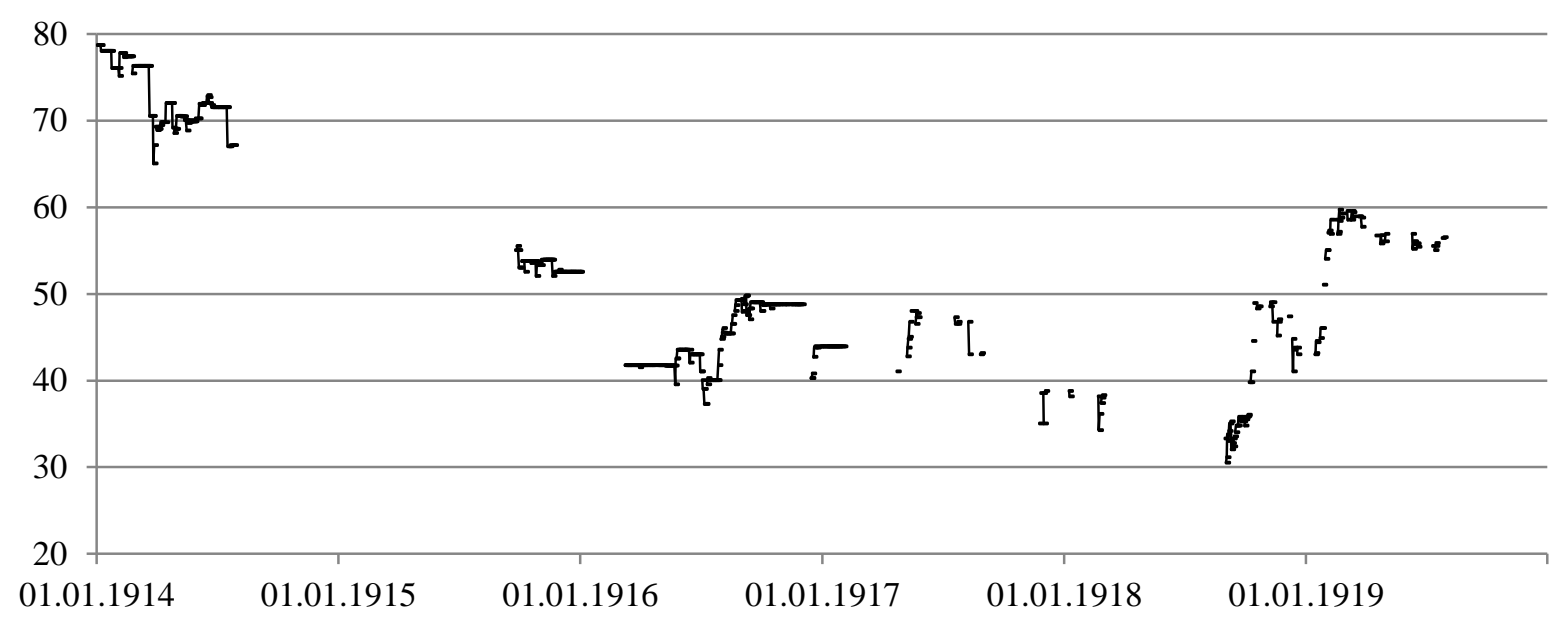

(21) Brazil - 4.5 \% Rio of 1912

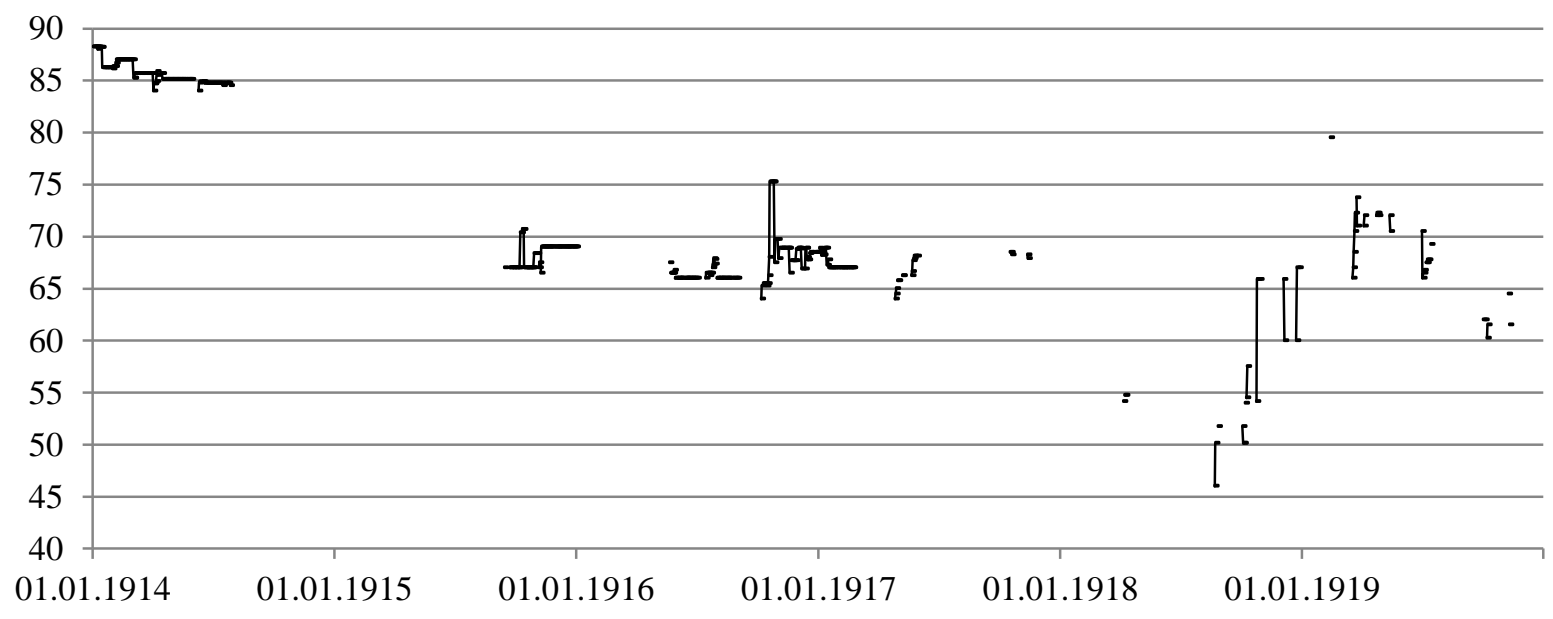

38 
(22) Brazil $-5.0 \%$ of 1895

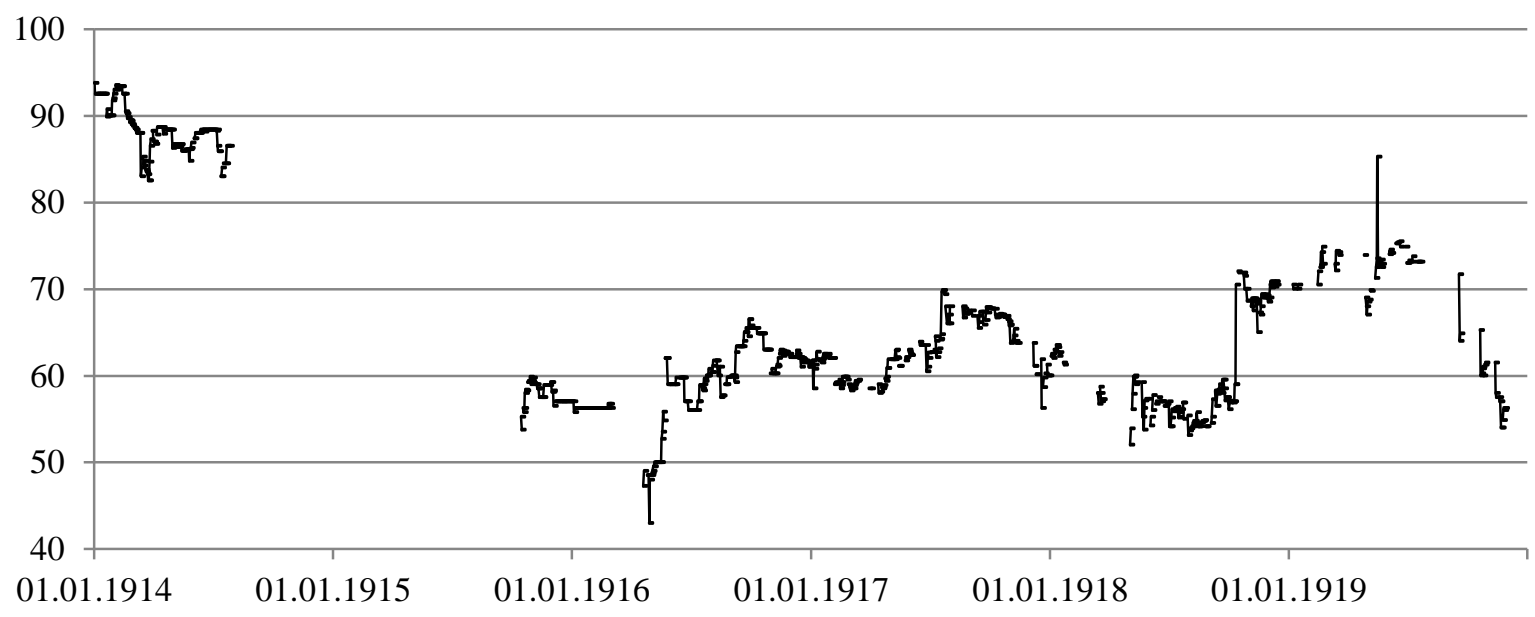

(23) Brazil $-5.0 \%$ of 1898

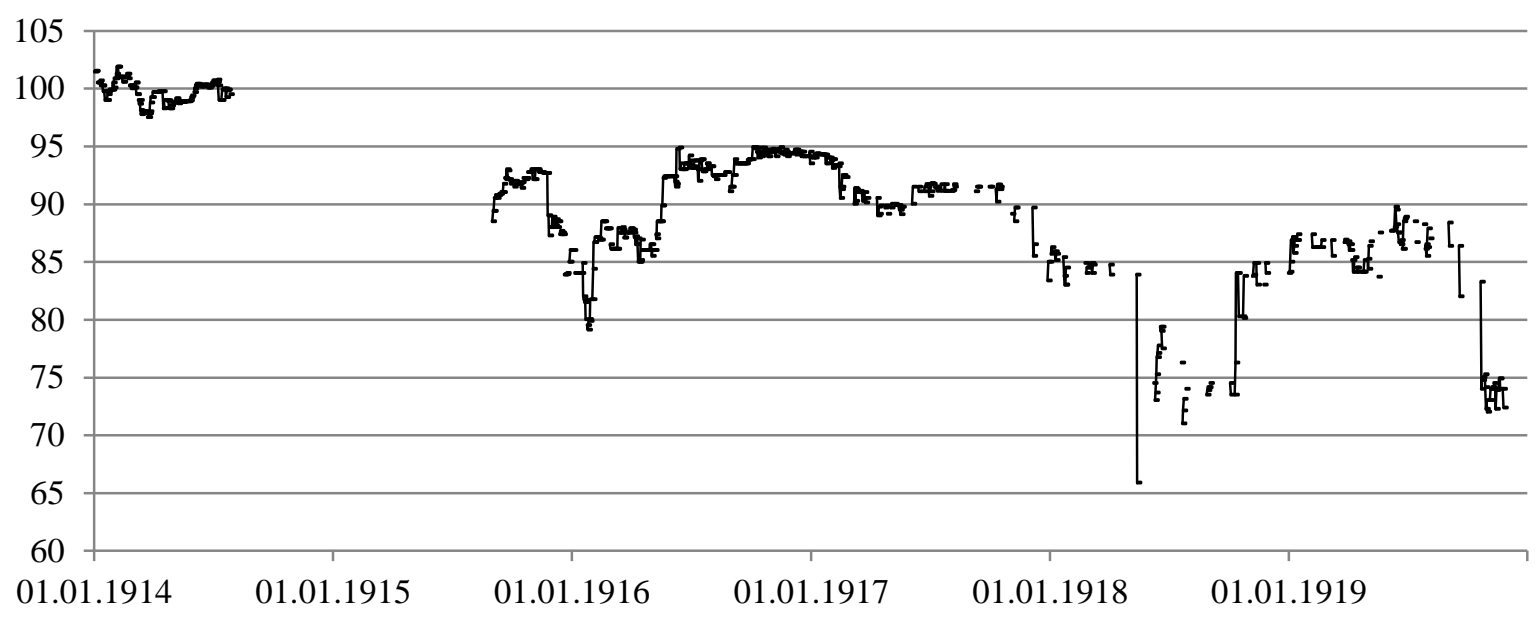

(24) Brazil $-5.0 \%$ of 1903

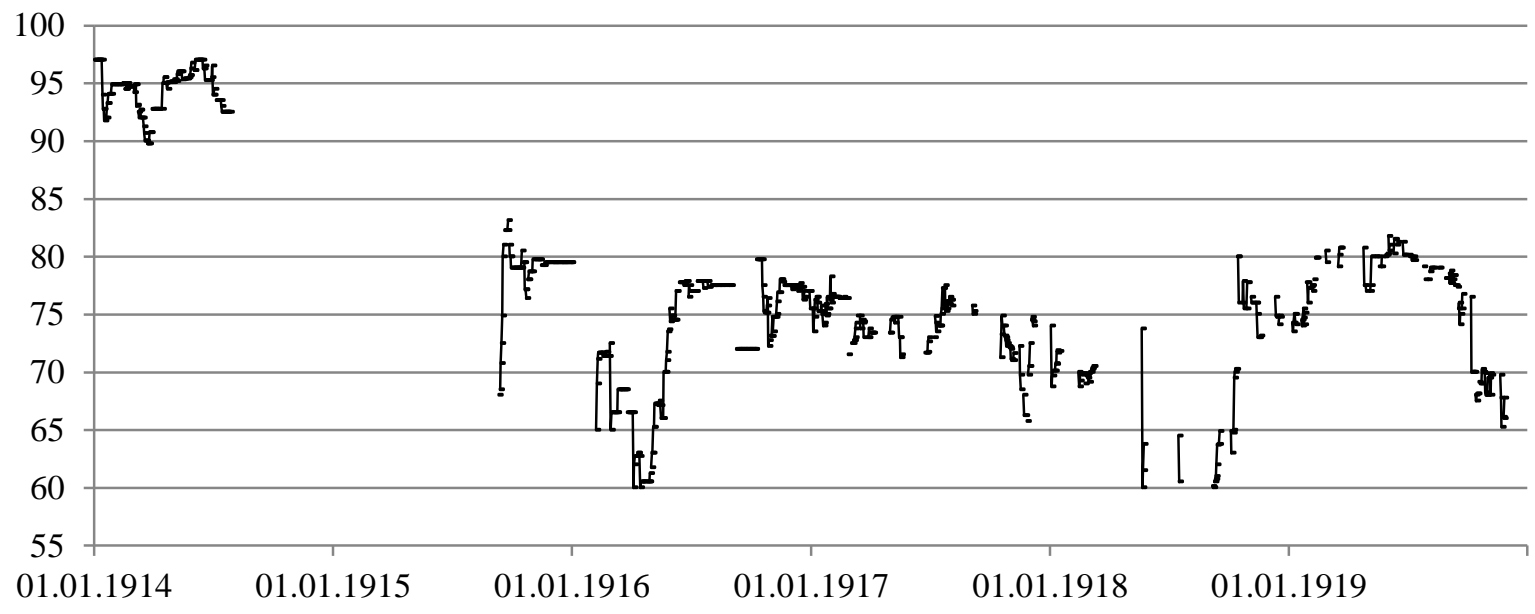

39 
(25) Brazil $-5.0 \%$ of 1913

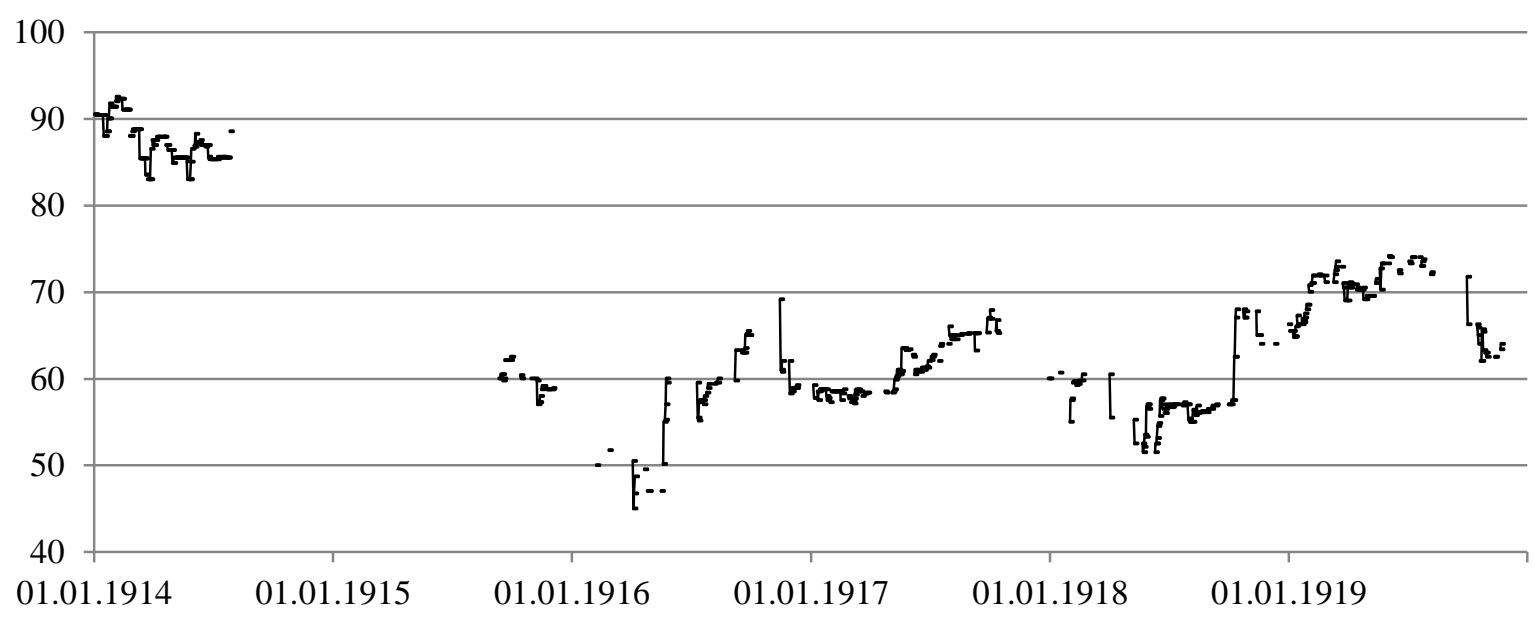

(26) Brazil - $5.0 \%$ of 1914 (20-100)

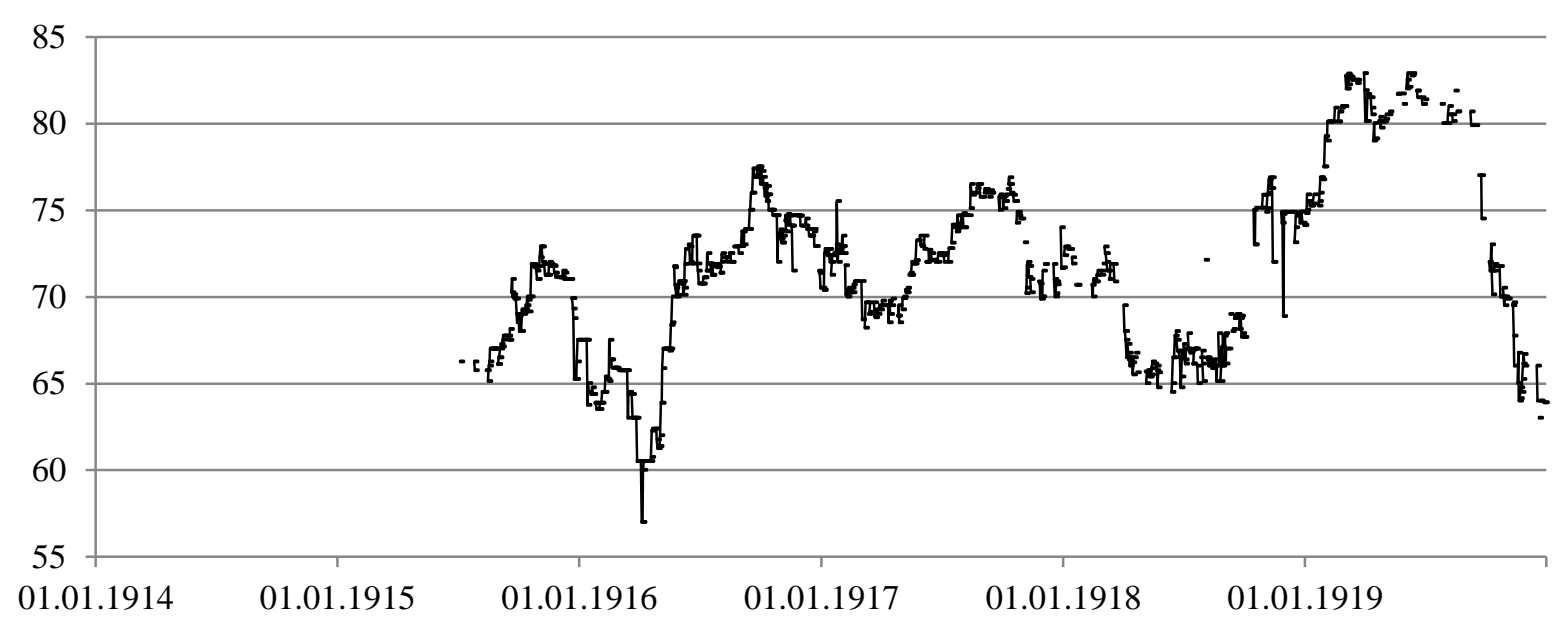

(27) Brazil - 5.0 \% Bahia of 1889

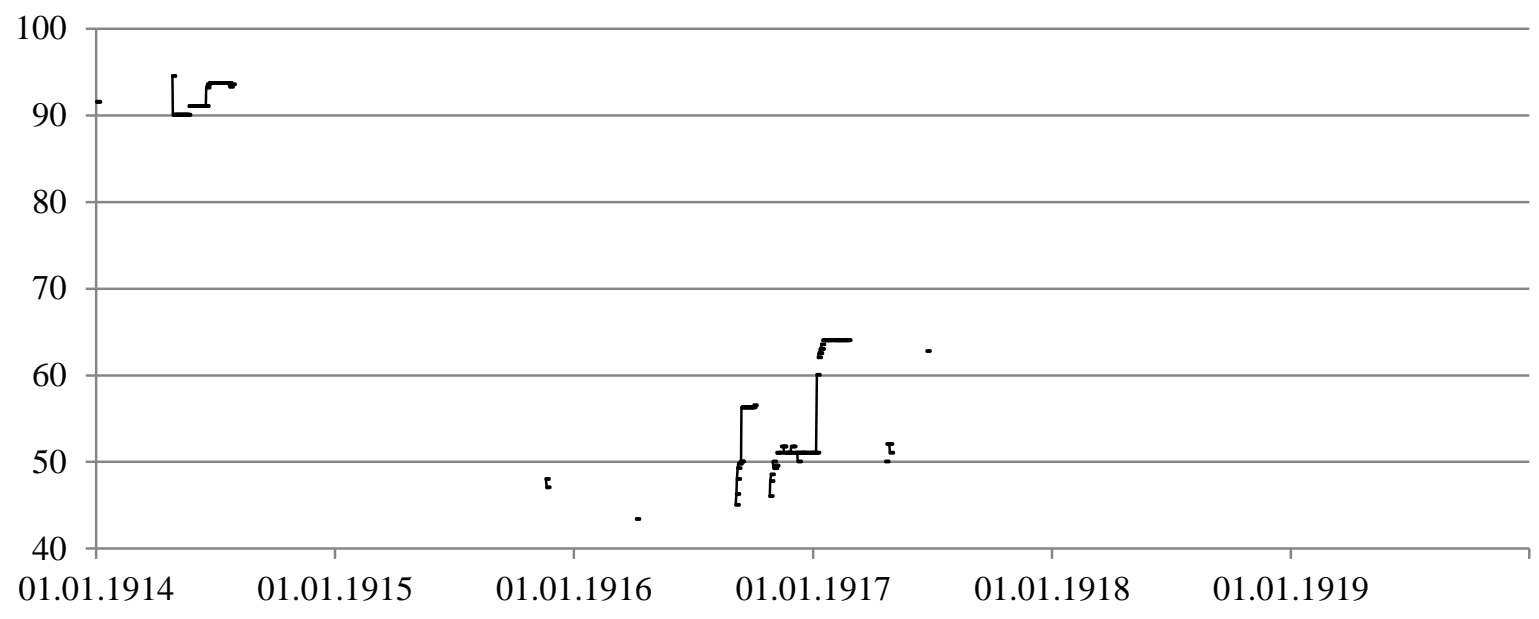

40 
(28) Brazil - 5.0 \% Bahia of 1904

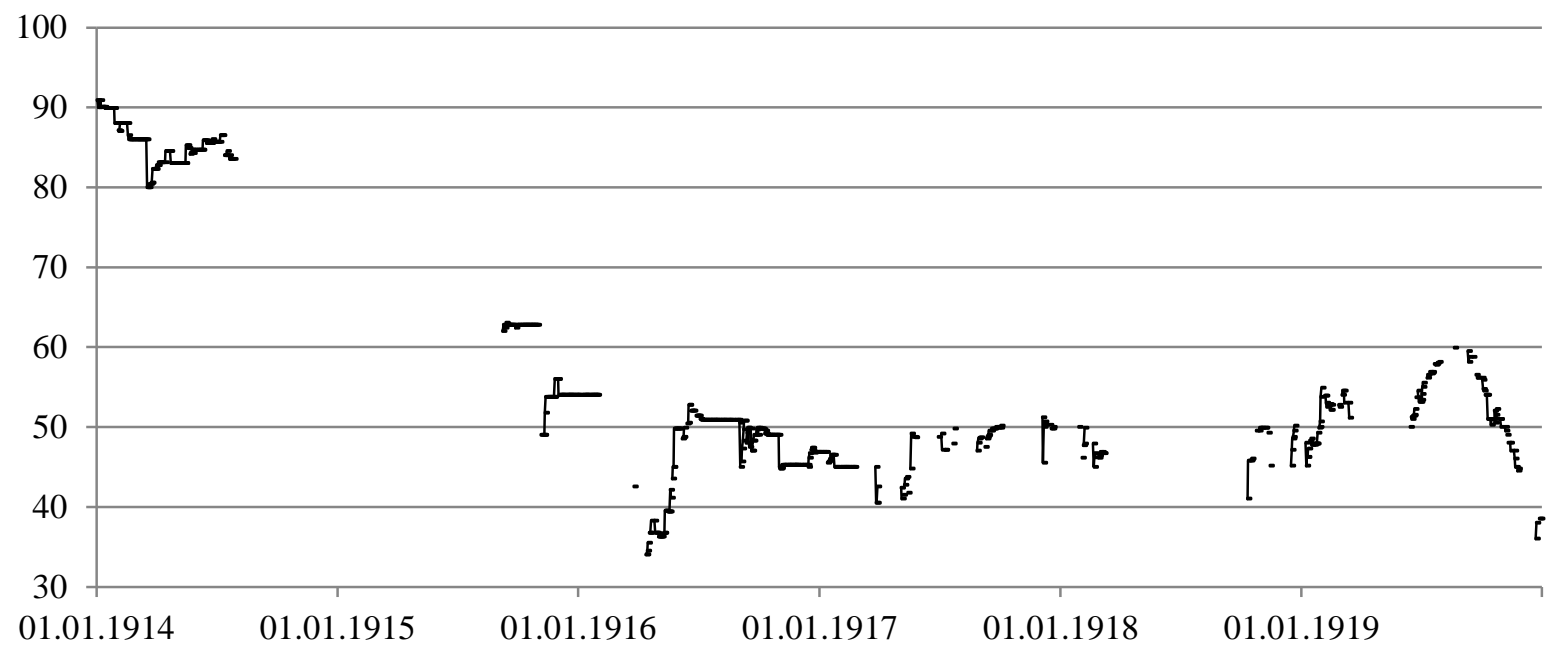

(29) Brazil - 5.0 \% Bahia of 1915

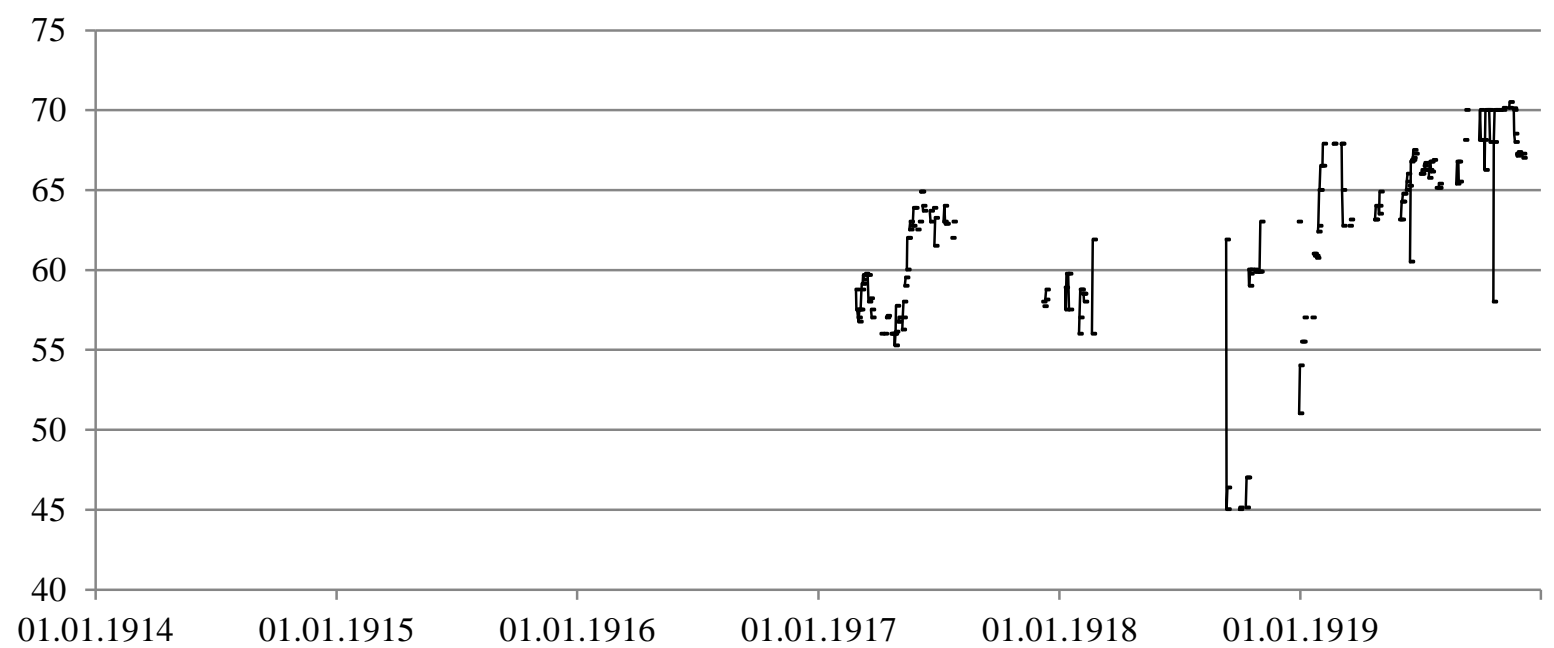

(30) Brazil - 5.0\% Para of 1901

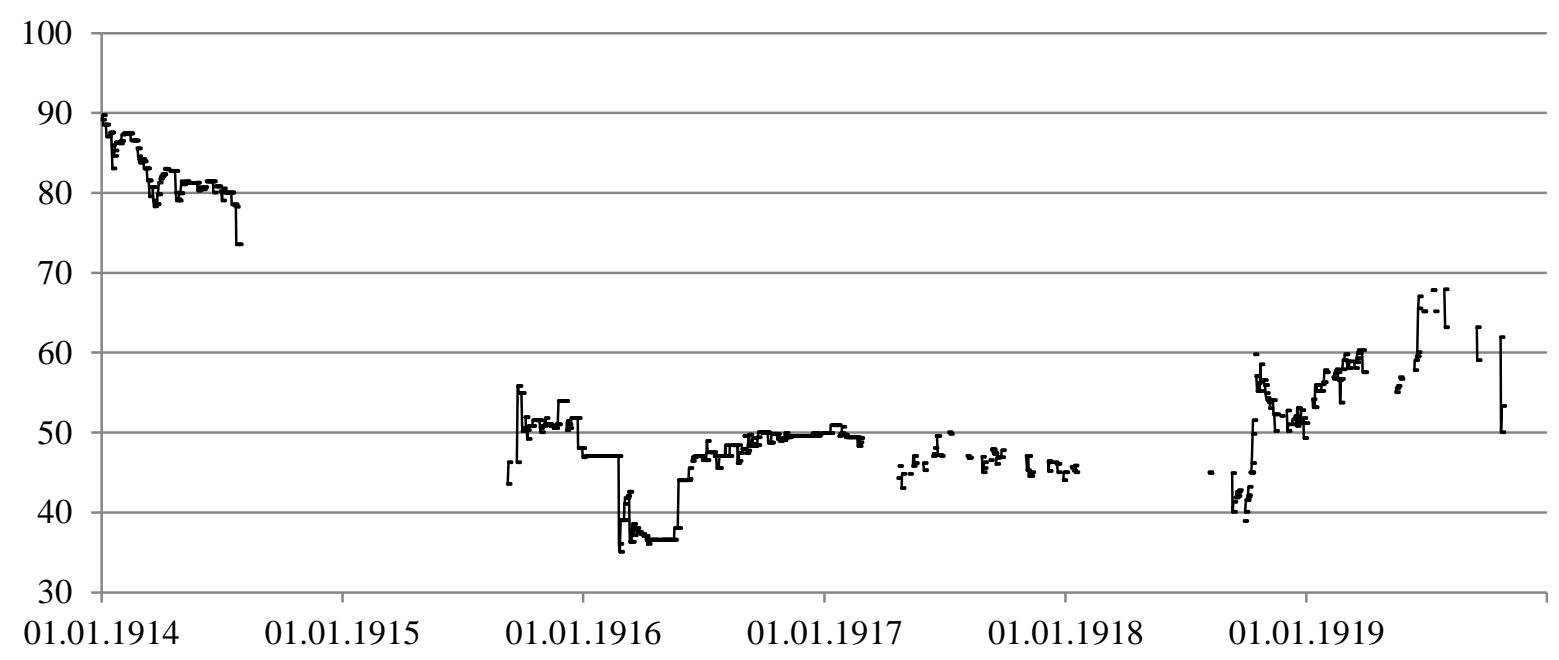


(31) Brazil - 5.0\% Para of 1907

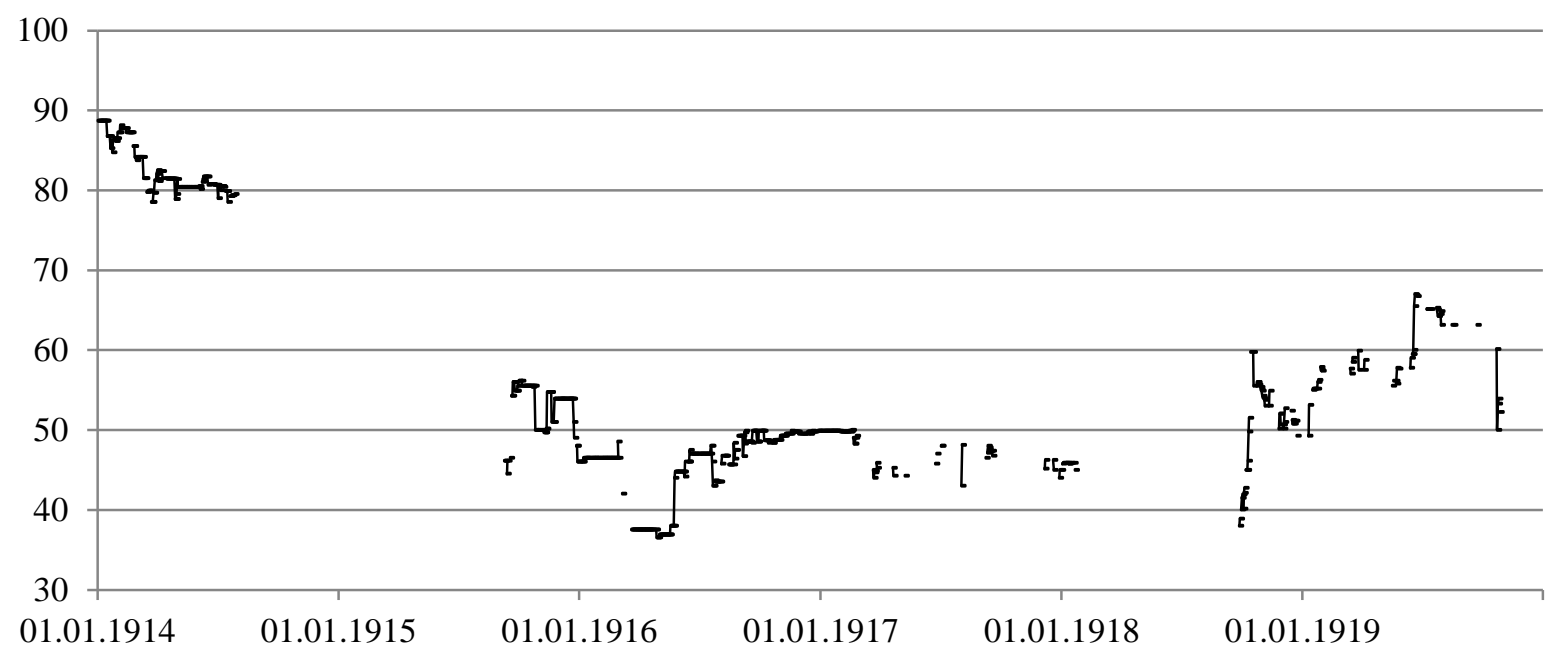

(32) Brazil - 5.0 \% Para of 1915

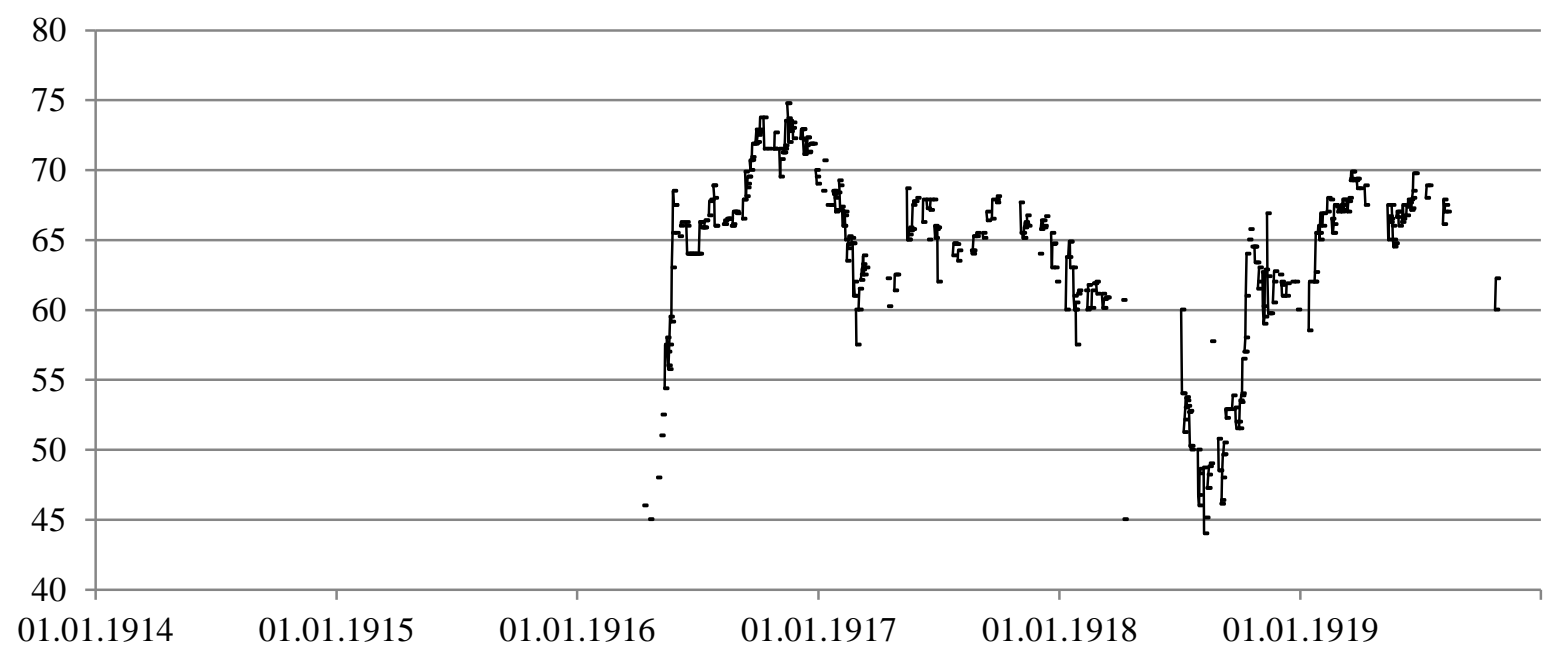

(33) Brazil - 5.0 \% Parana of 1905

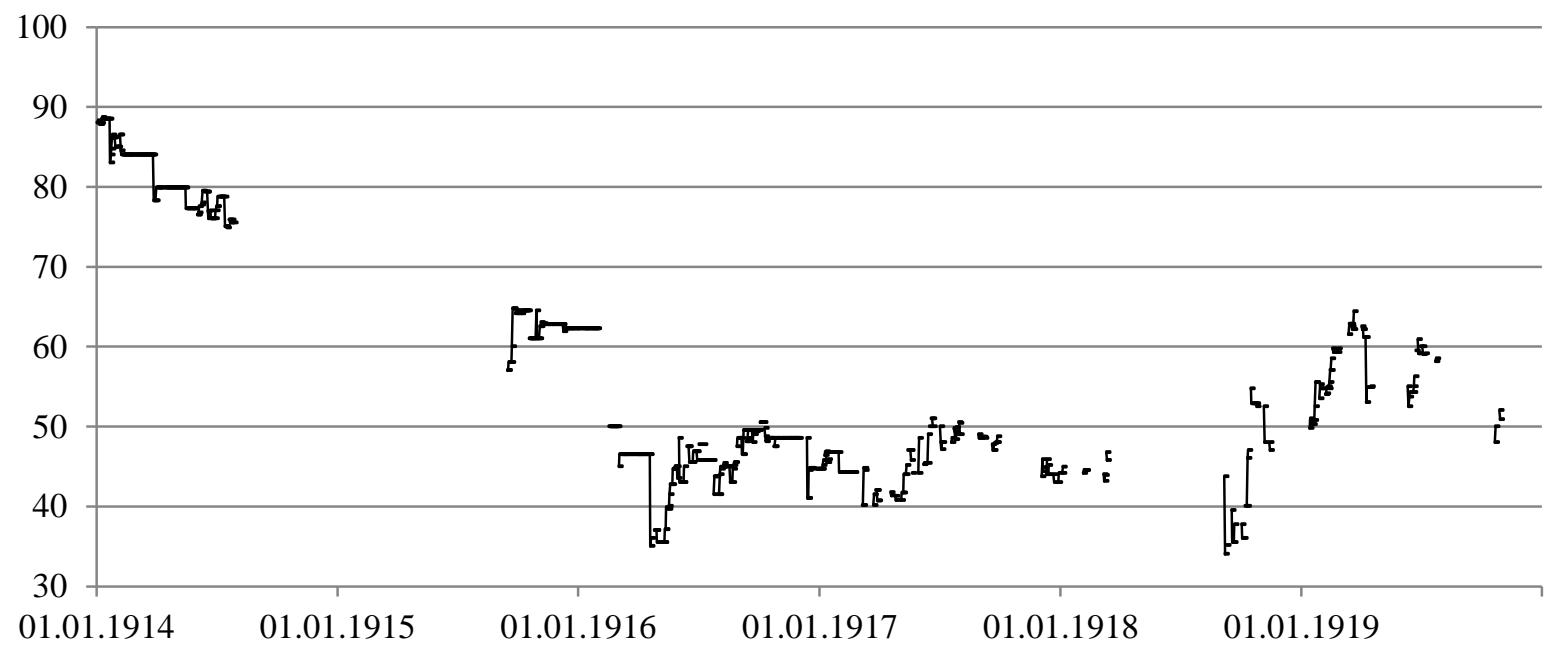


(34) Brazil - 5.0 \% Parana of 1913

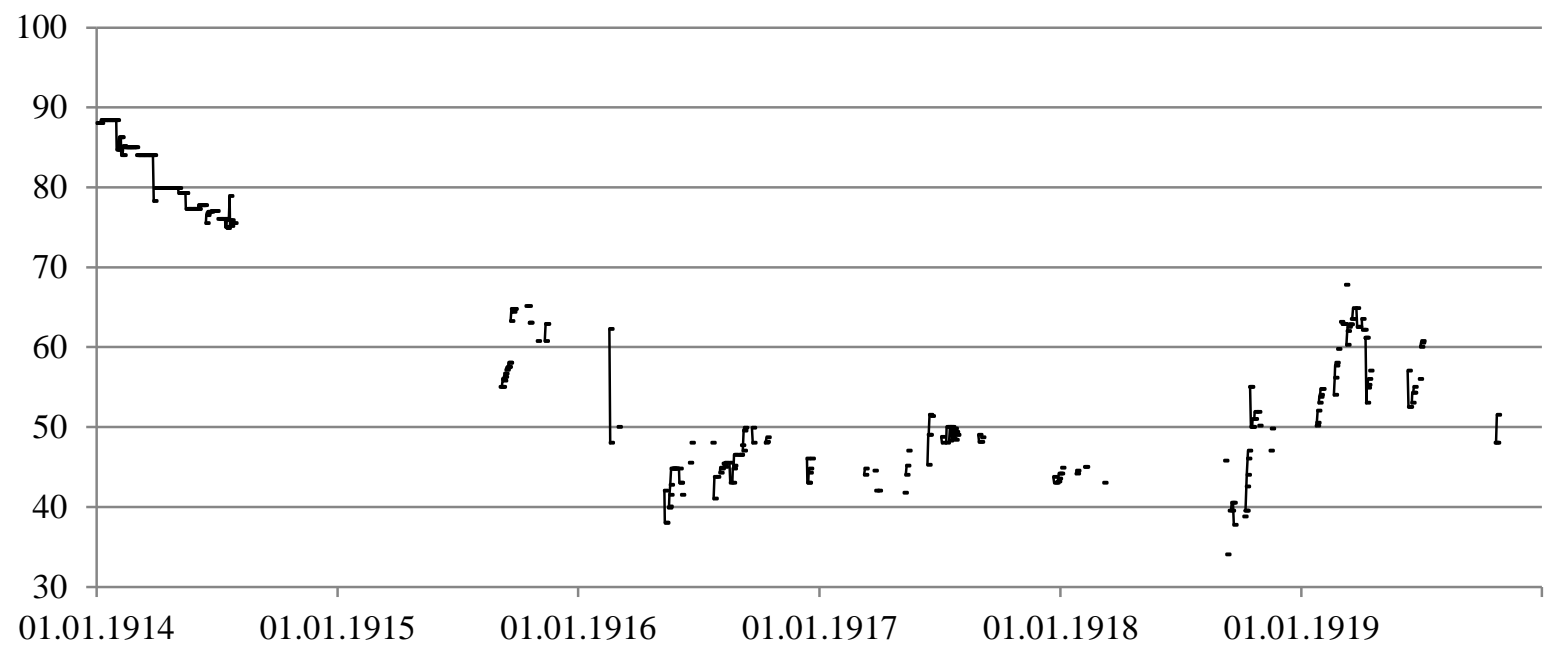

(35) Brazil - 5.0\% Rio of 1905

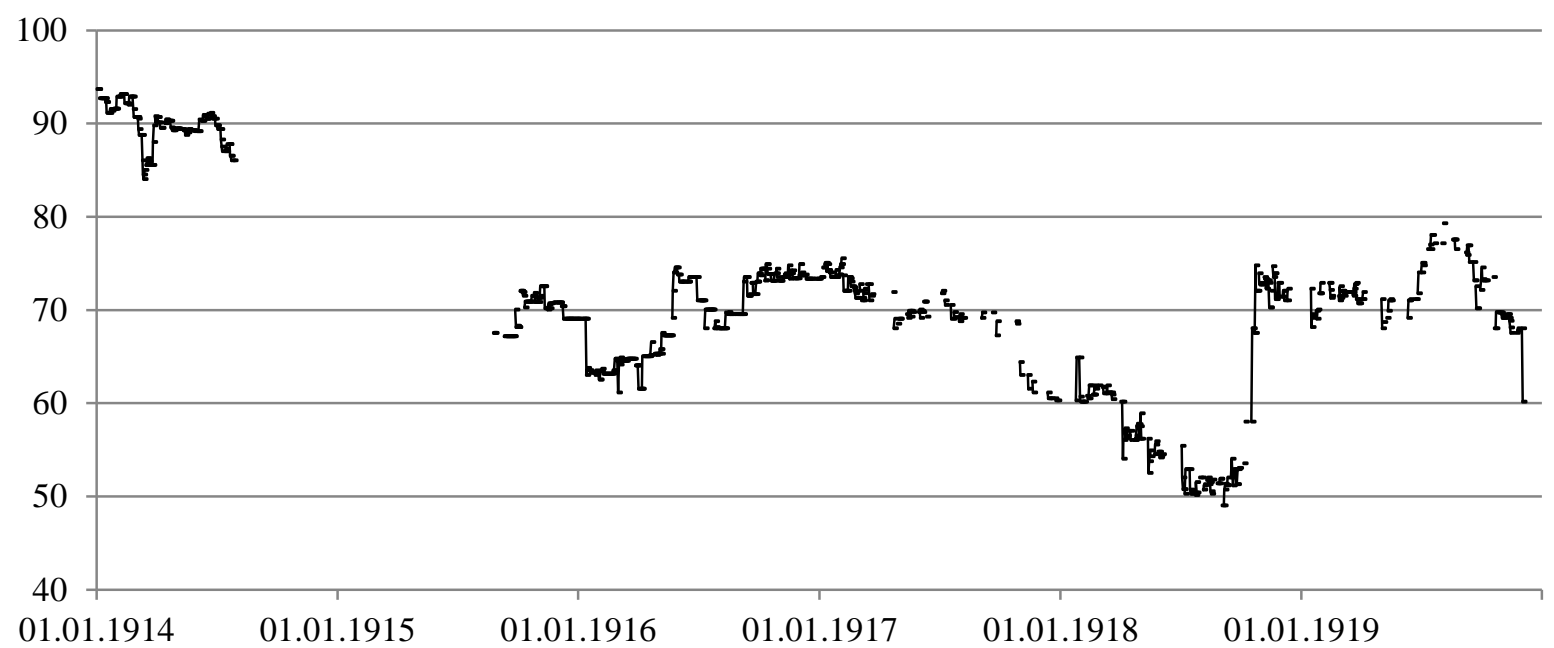

(36) Brazil - 5.0\% Rio of 1909

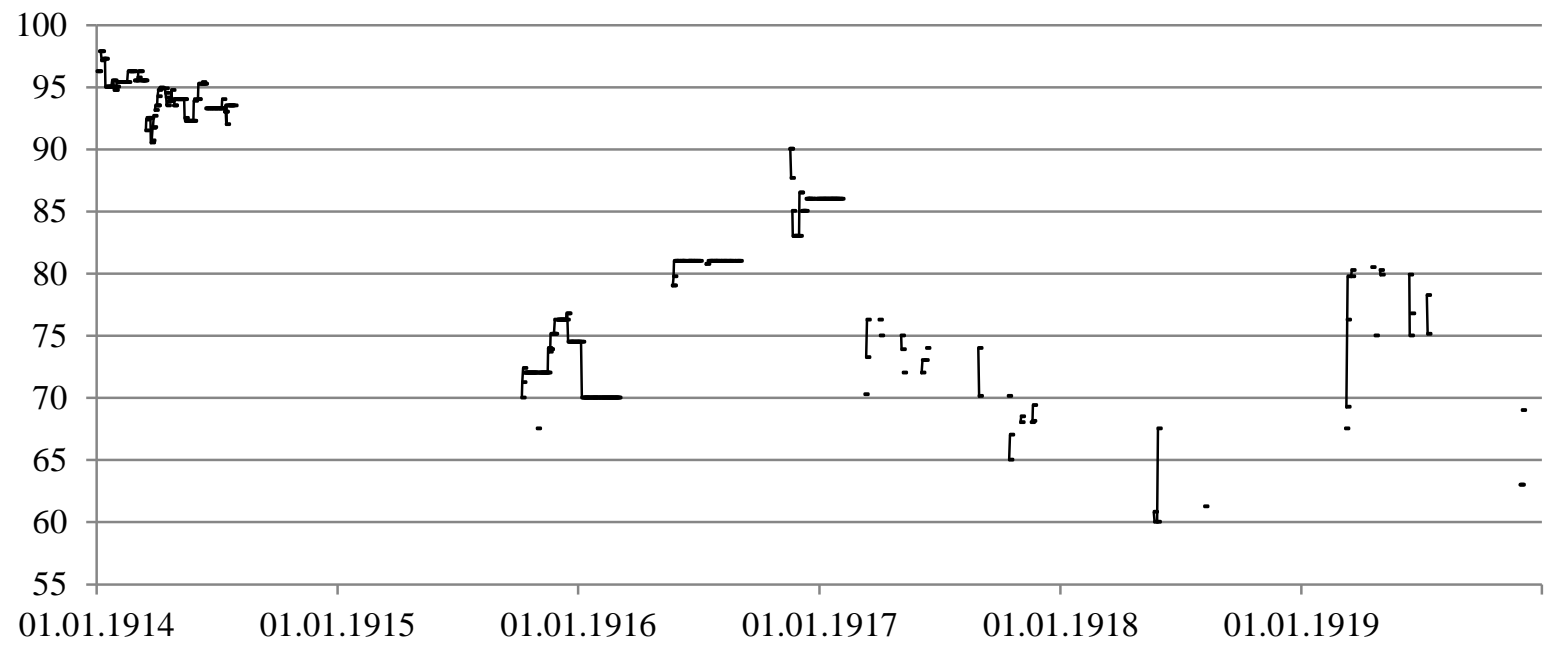


(37) Brazil - 5.0 \% Sao Paolo railway of 1904

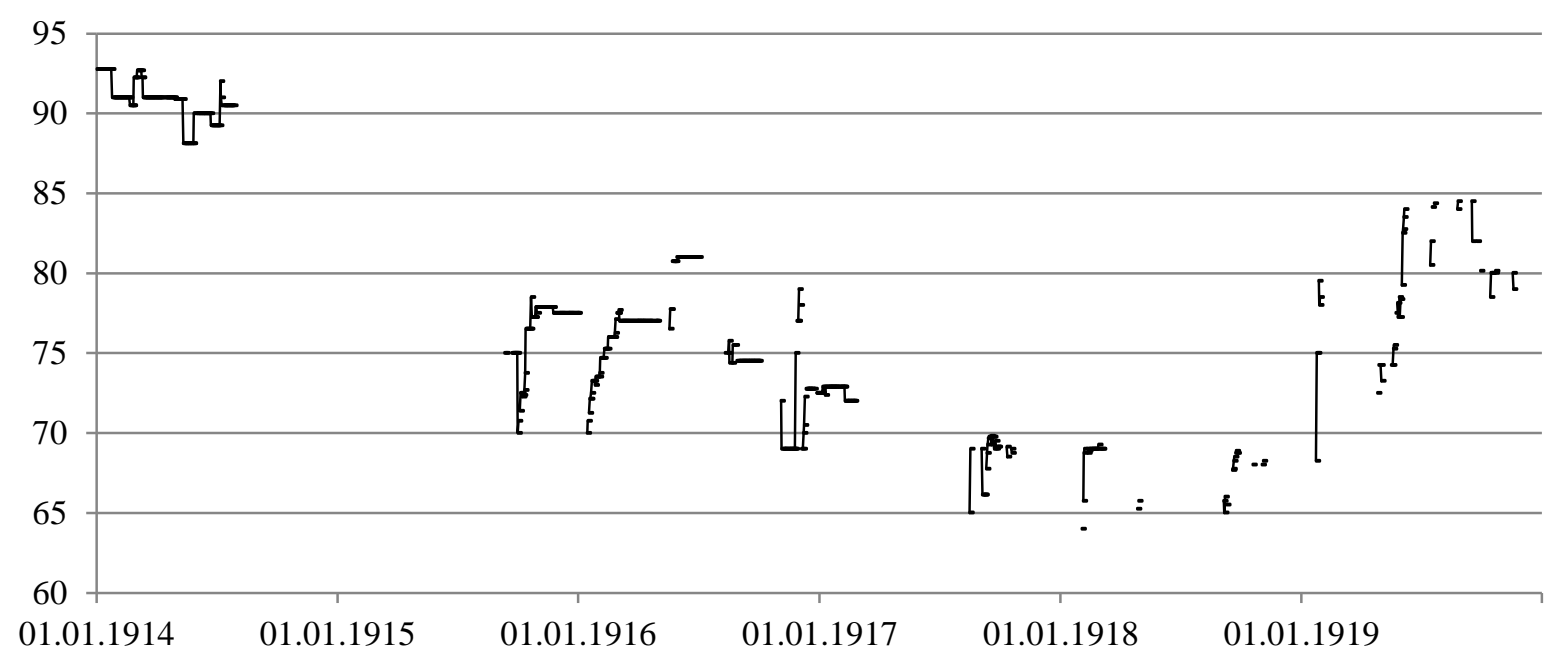

(38) Brazil - 5.0 \% Sao Paolo railway of 1905

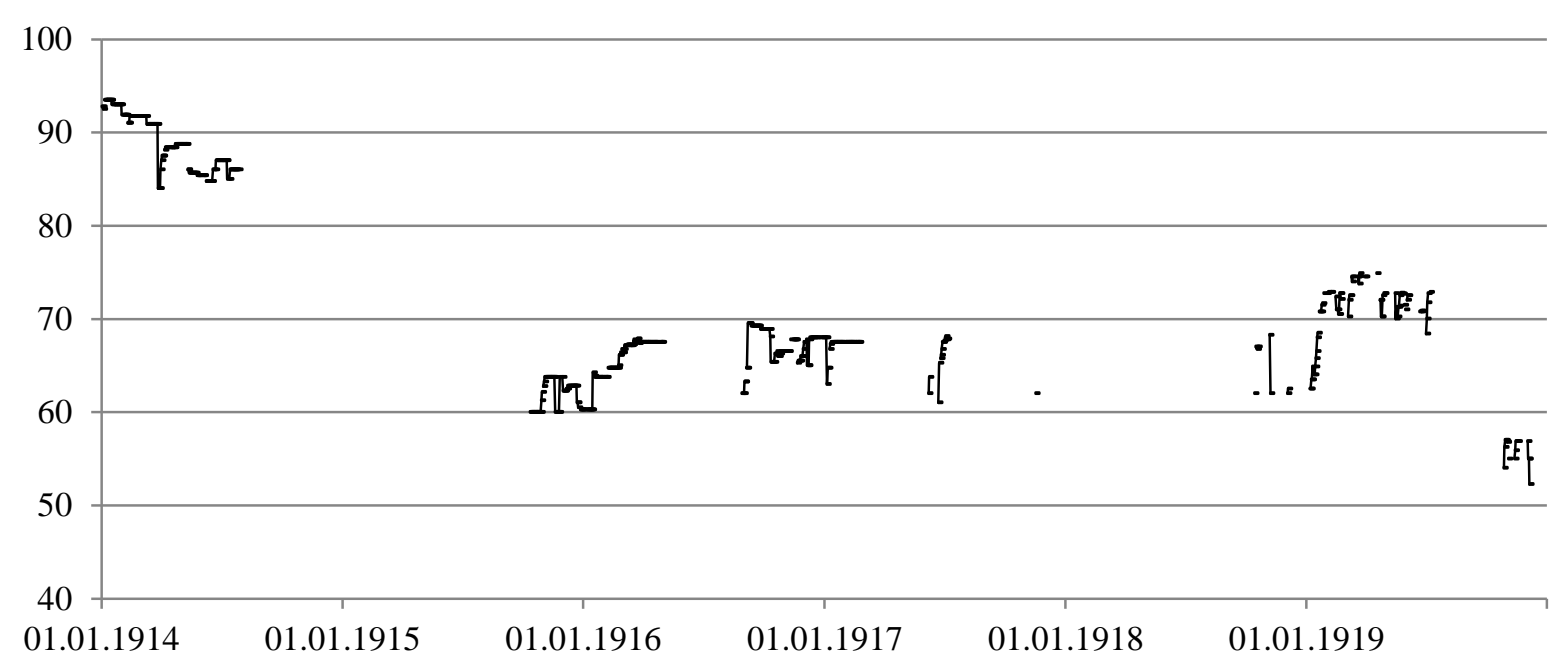

(39) Brazil - 5.0 \% Sao Paolo railway of 1913

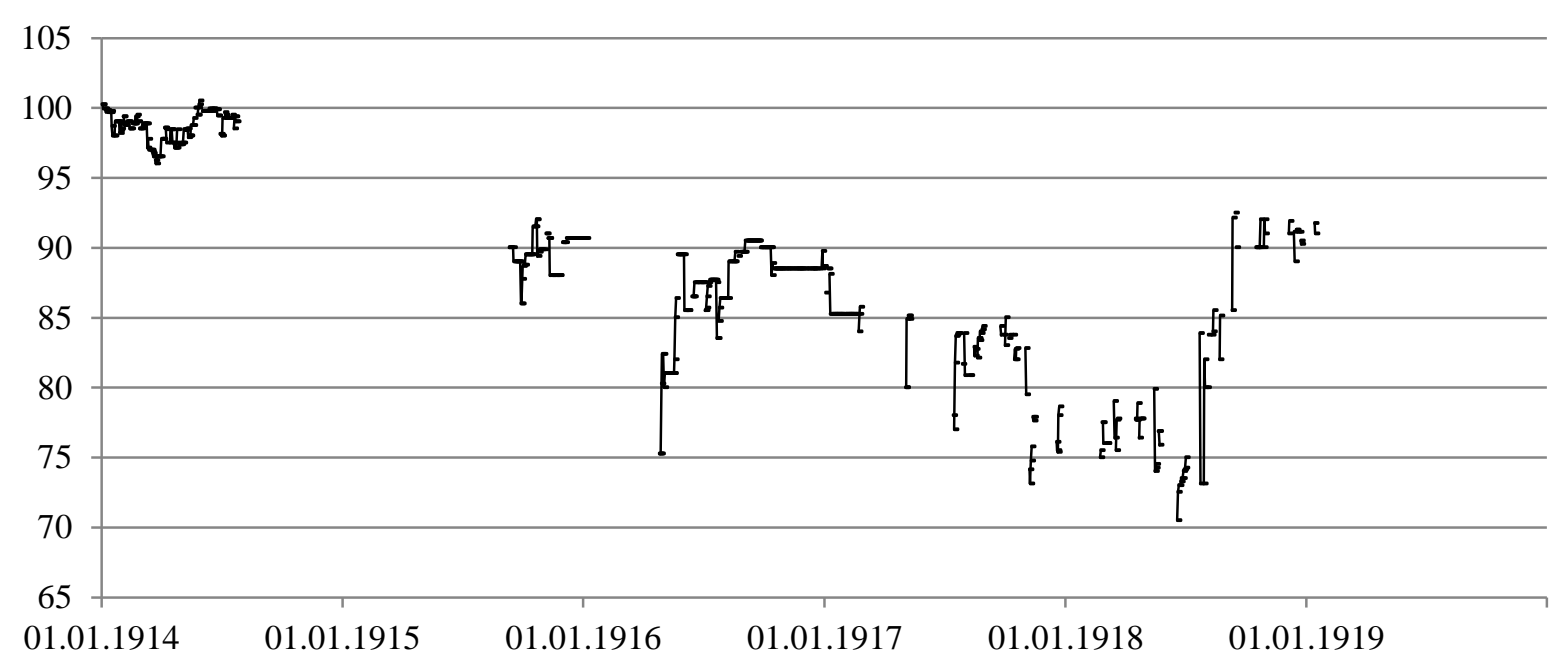


(40) Bulgaria $-4.5 \%$ of 1907

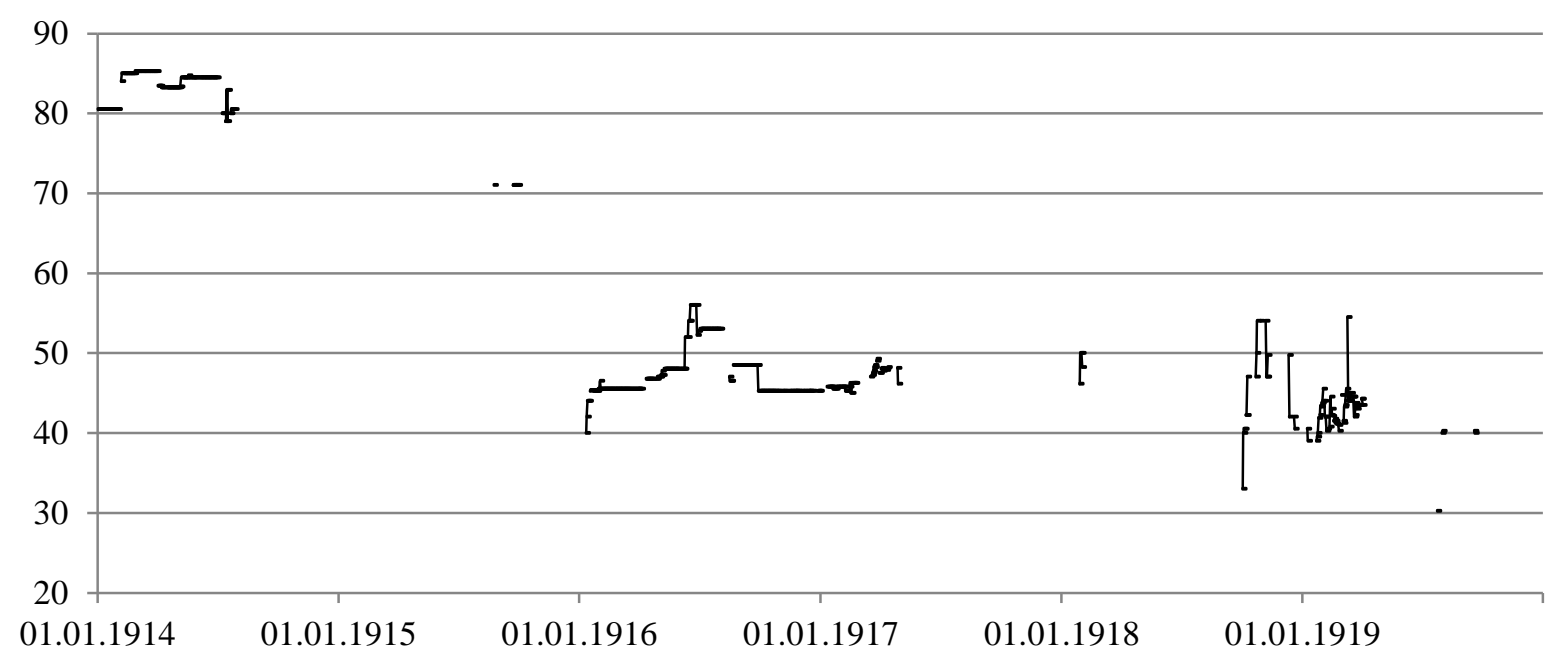

(41) Bulgaria $-4.5 \%$ of 1909

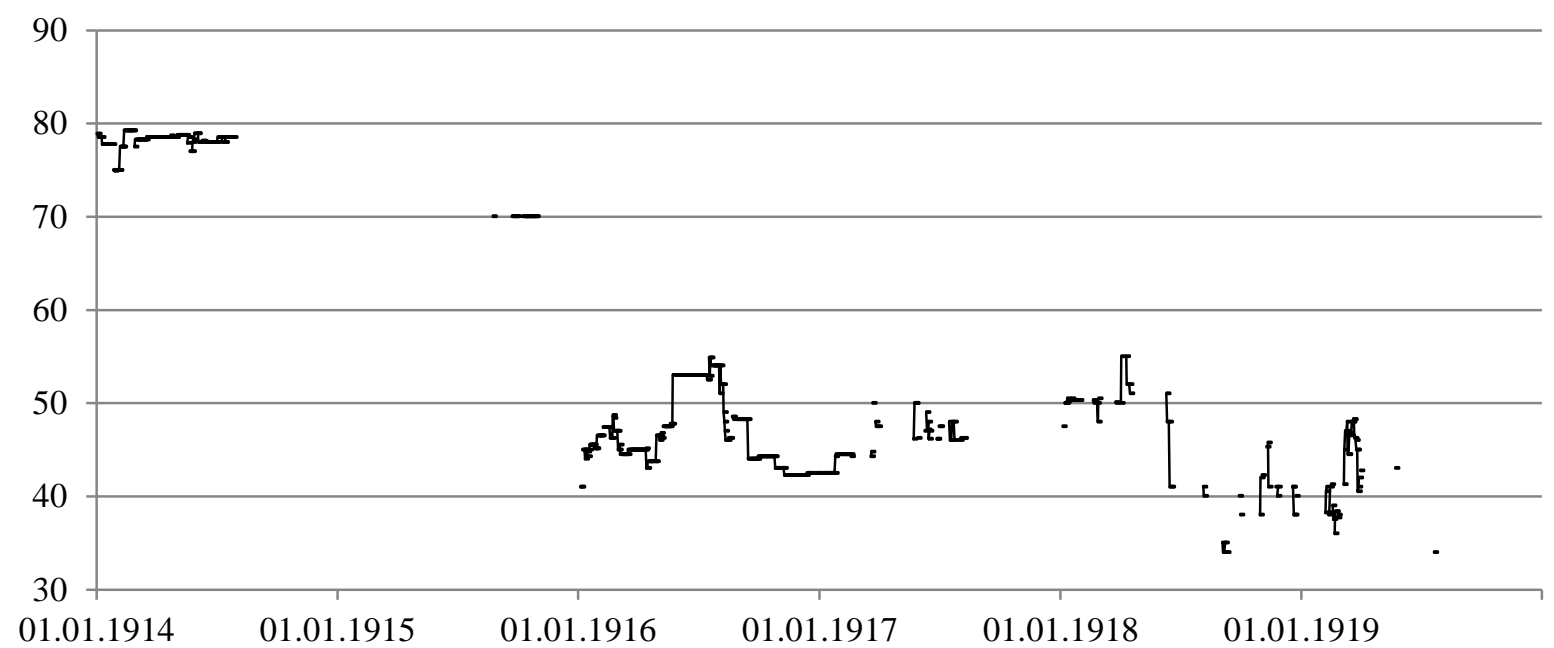

(42) Bulgaria $-5.0 \%$ of 1902

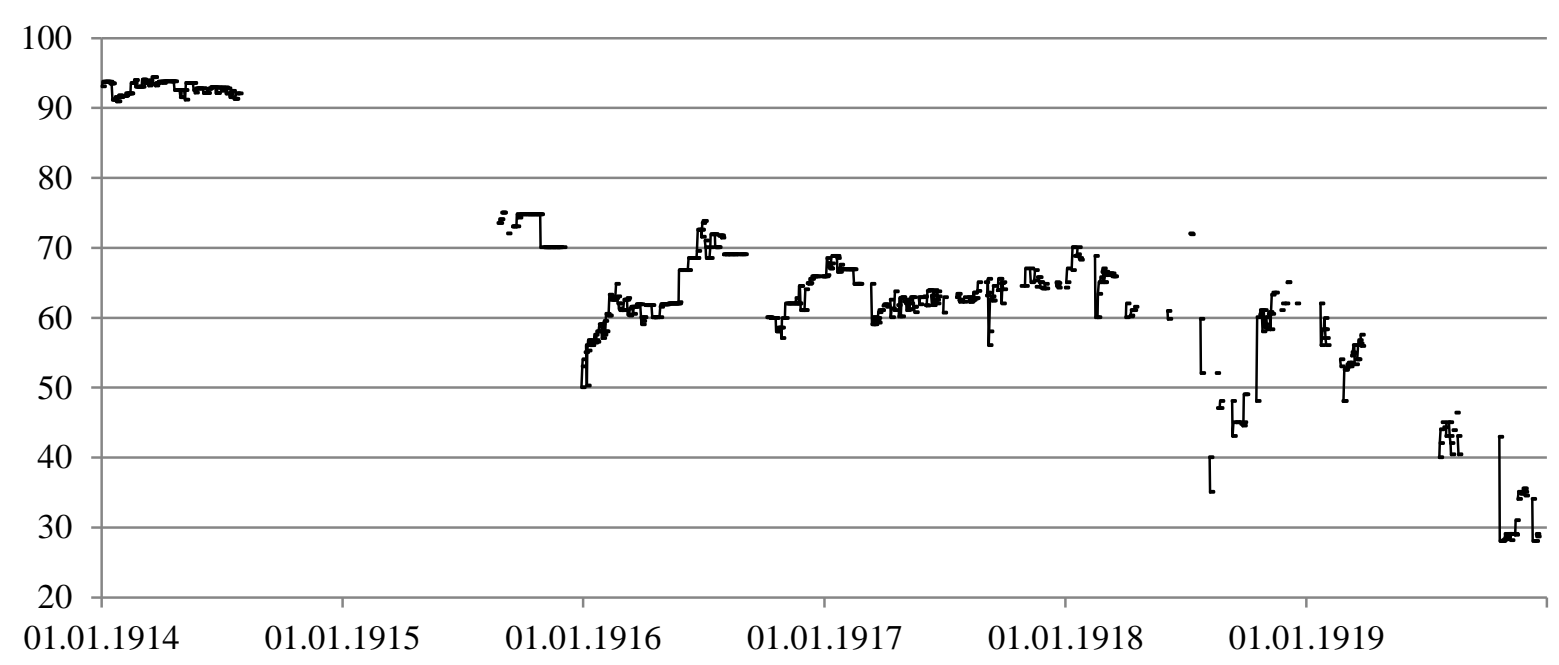


(43) Bulgaria $-5.0 \%$ of 1904

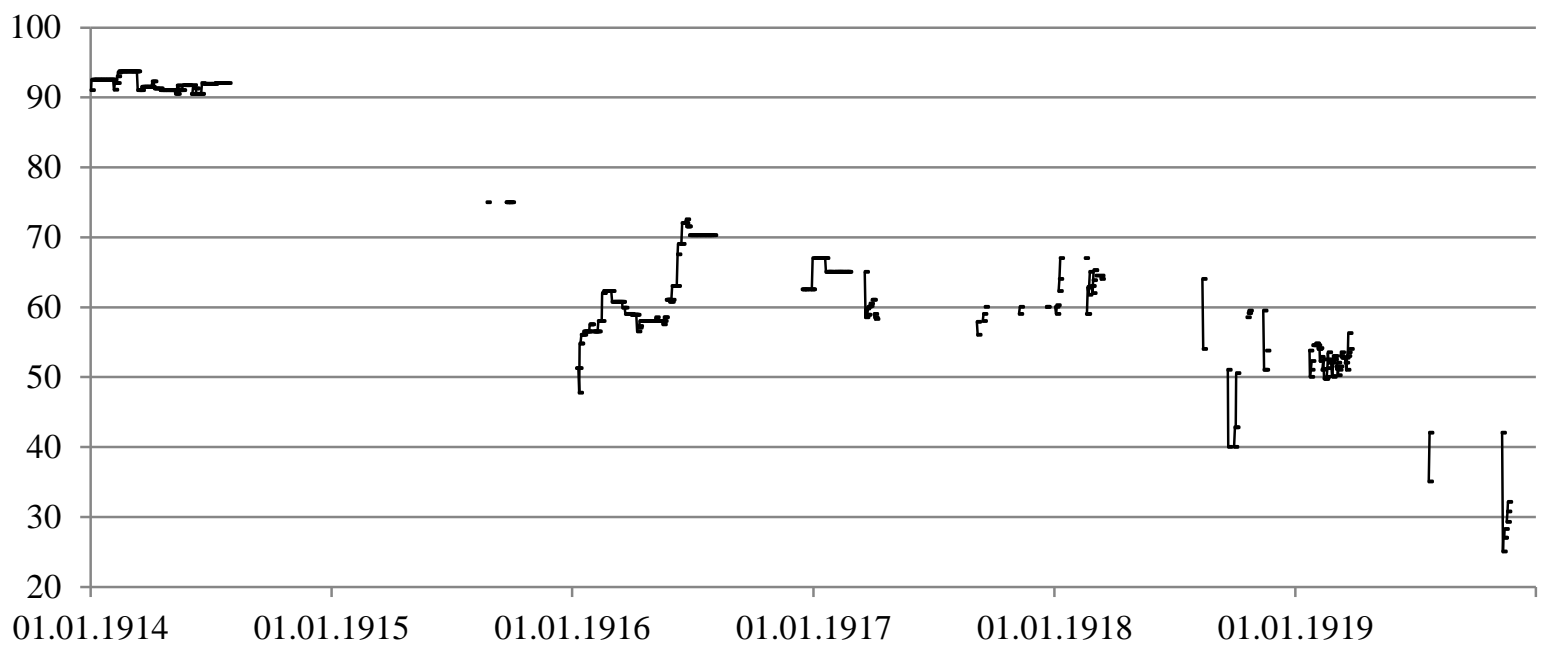

(44) Bulgaria - 6.0 of 1892

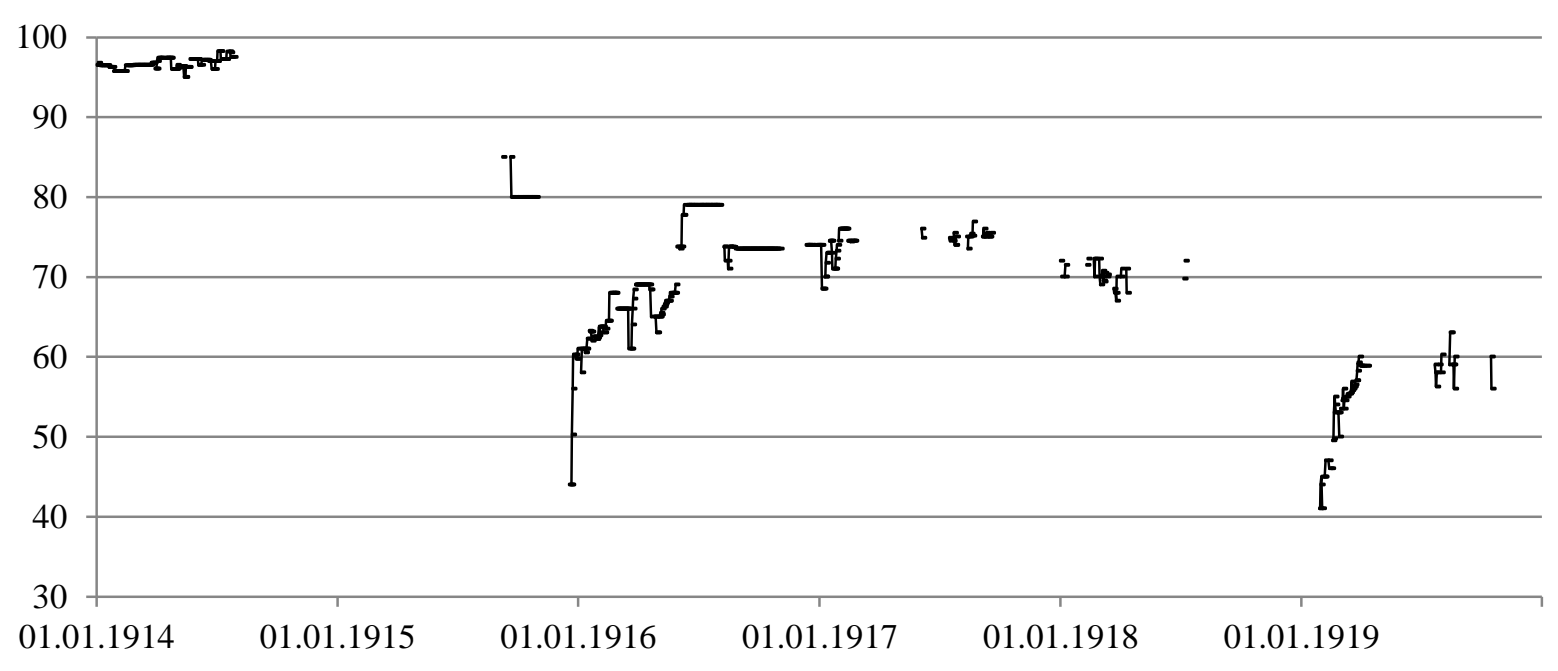

(45) Chili - $4.5 \%$ of 1906 (20/100)

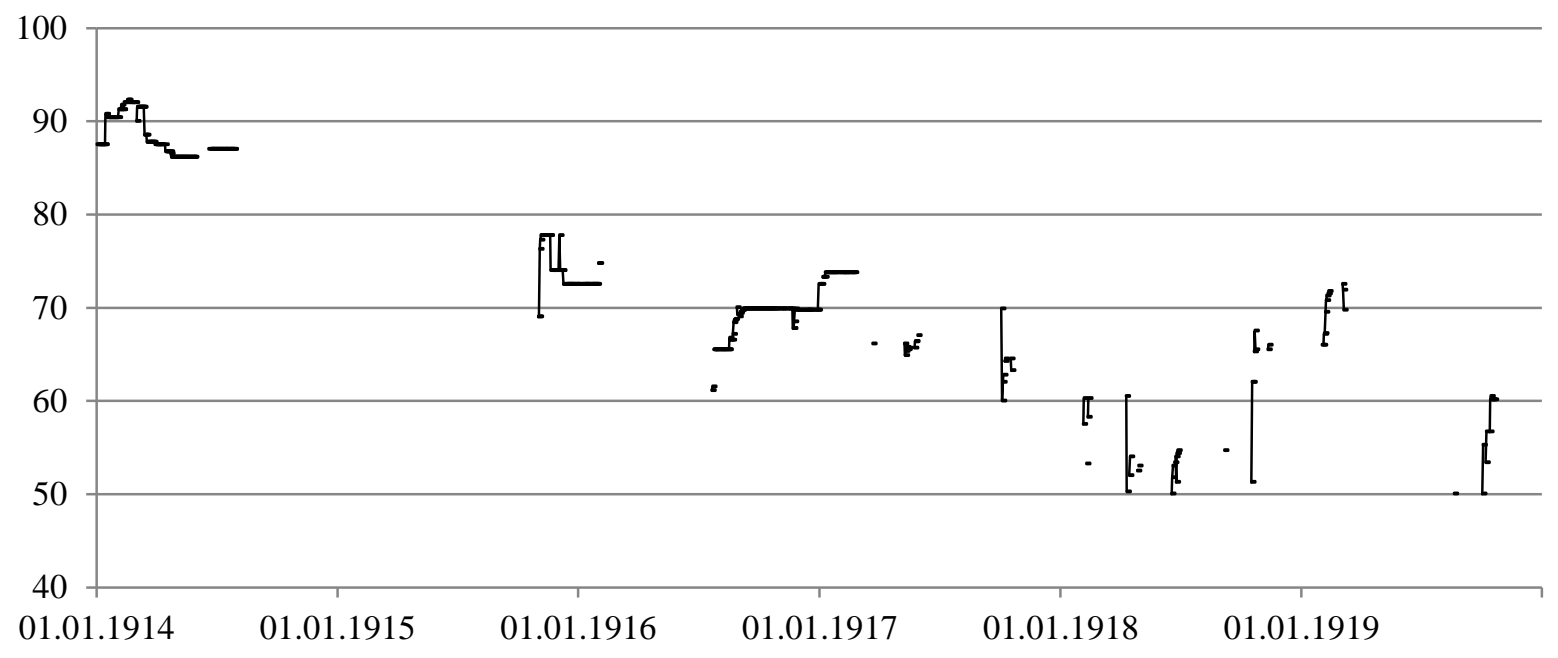

46 
(46) Chili $-4.5 \%$ of 1906 (200)

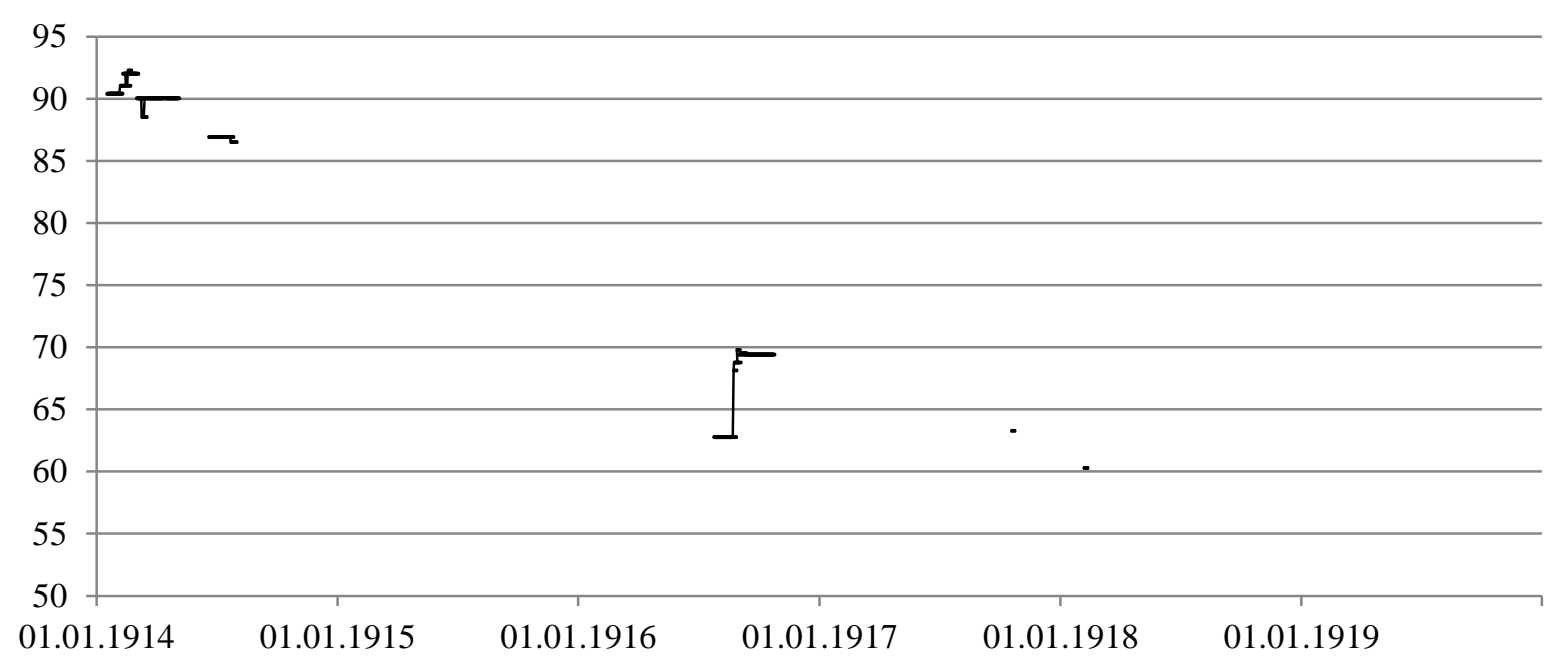

(47) Chili $-5.0 \%$ of 1896

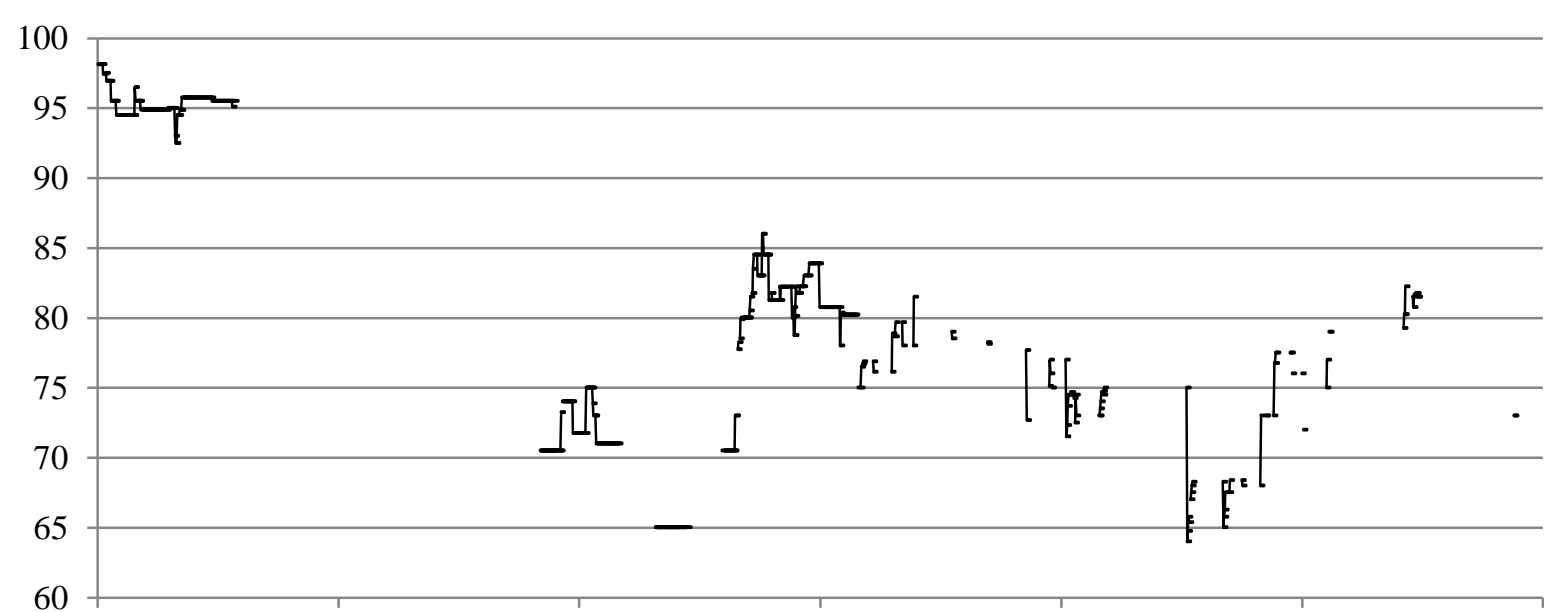

$\begin{array}{llllll}01.01 .1914 & 01.01 .1915 & 01.01 .1916 & 01.01 .1917 & 01.01 .1918 & 01.01 .1919\end{array}$

(48) Chili $-5.0 \%$ of 1912

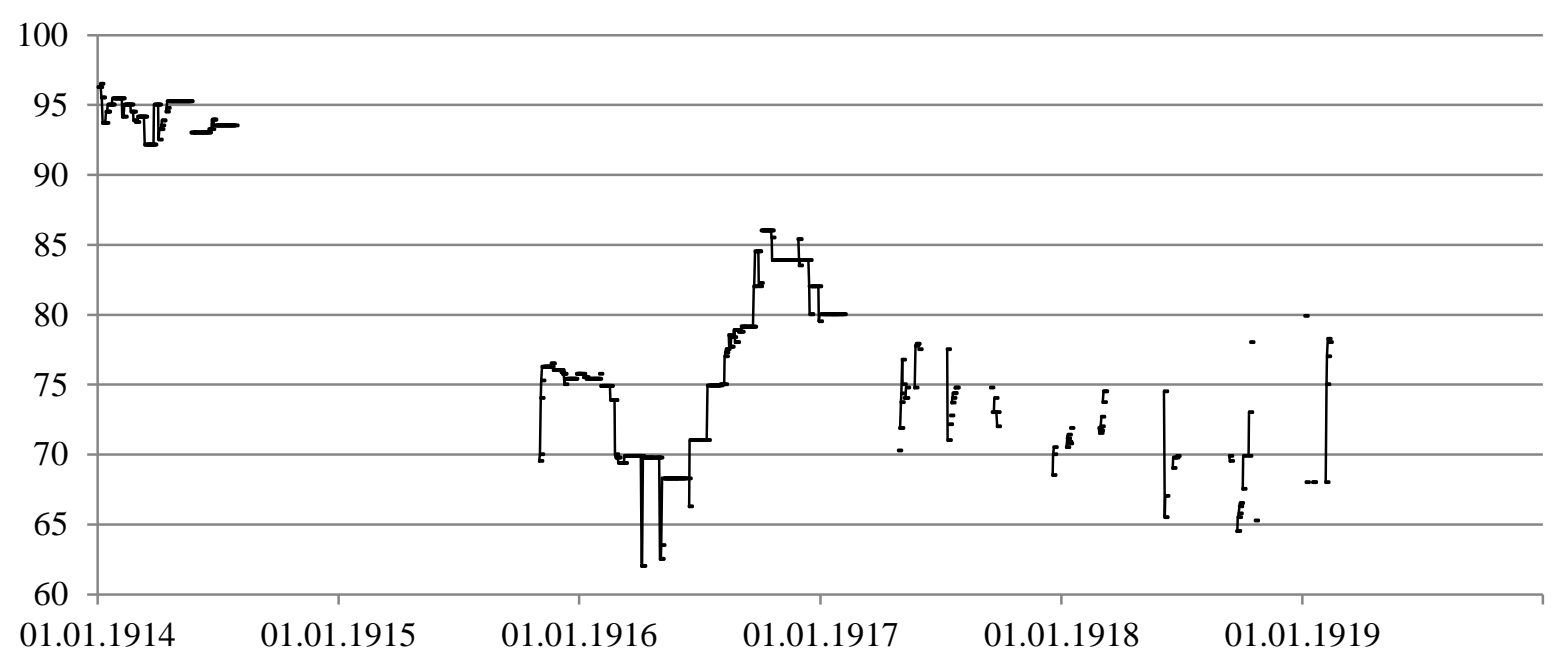


(49) China $-4.0 \%$ of 1895

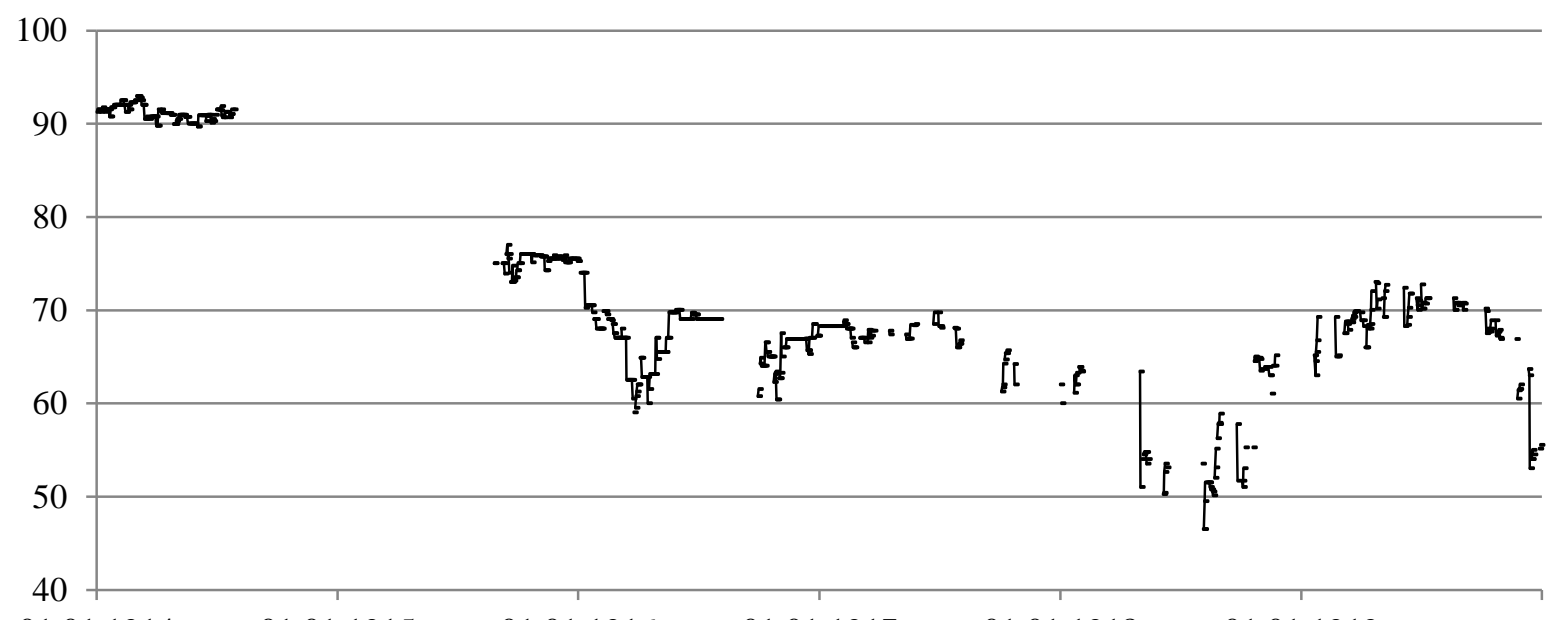

$\begin{array}{llllll}01.01 .1914 & 01.01 .1915 & 01.01 .1916 & 01.01 .1917 & 01.01 .1918 & 01.01 .1919\end{array}$

(50) China $-4.5 \%$ of 1898

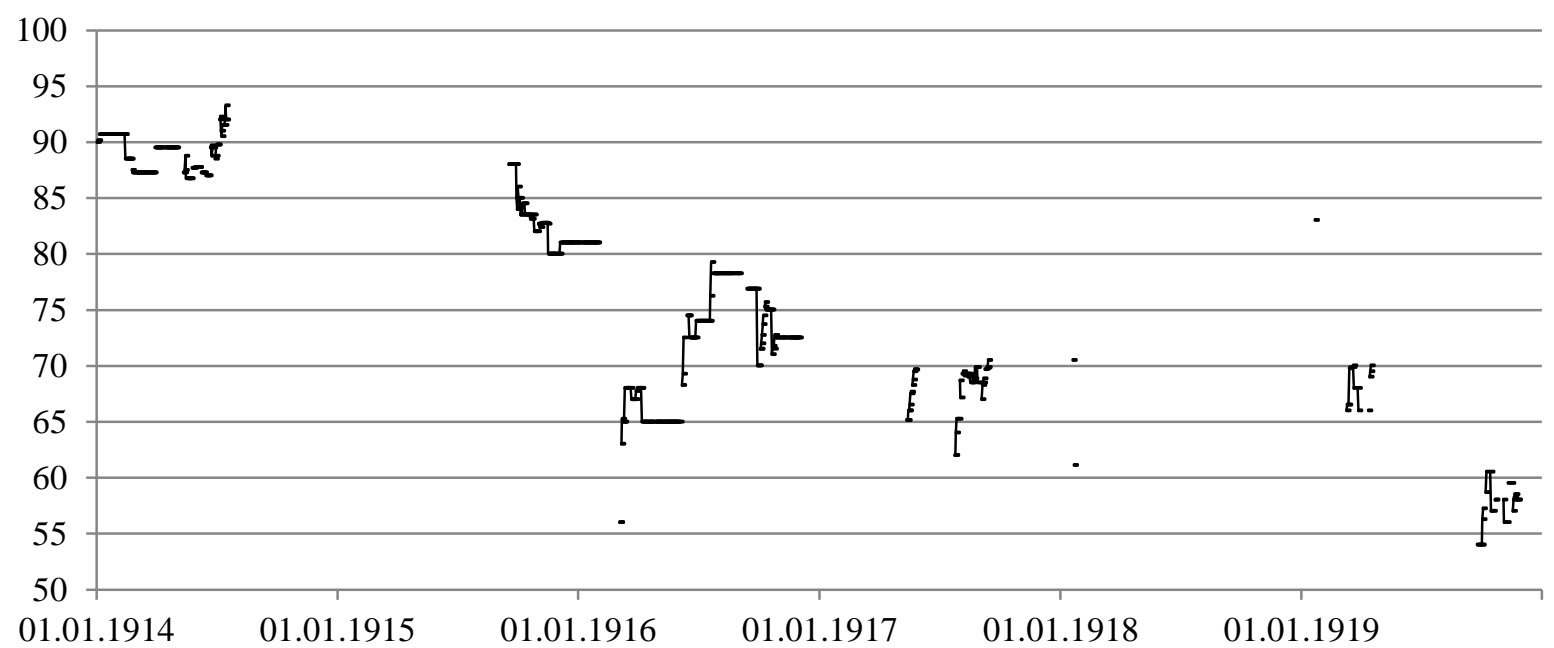

(51) China $-5.0 \%$ of 1904

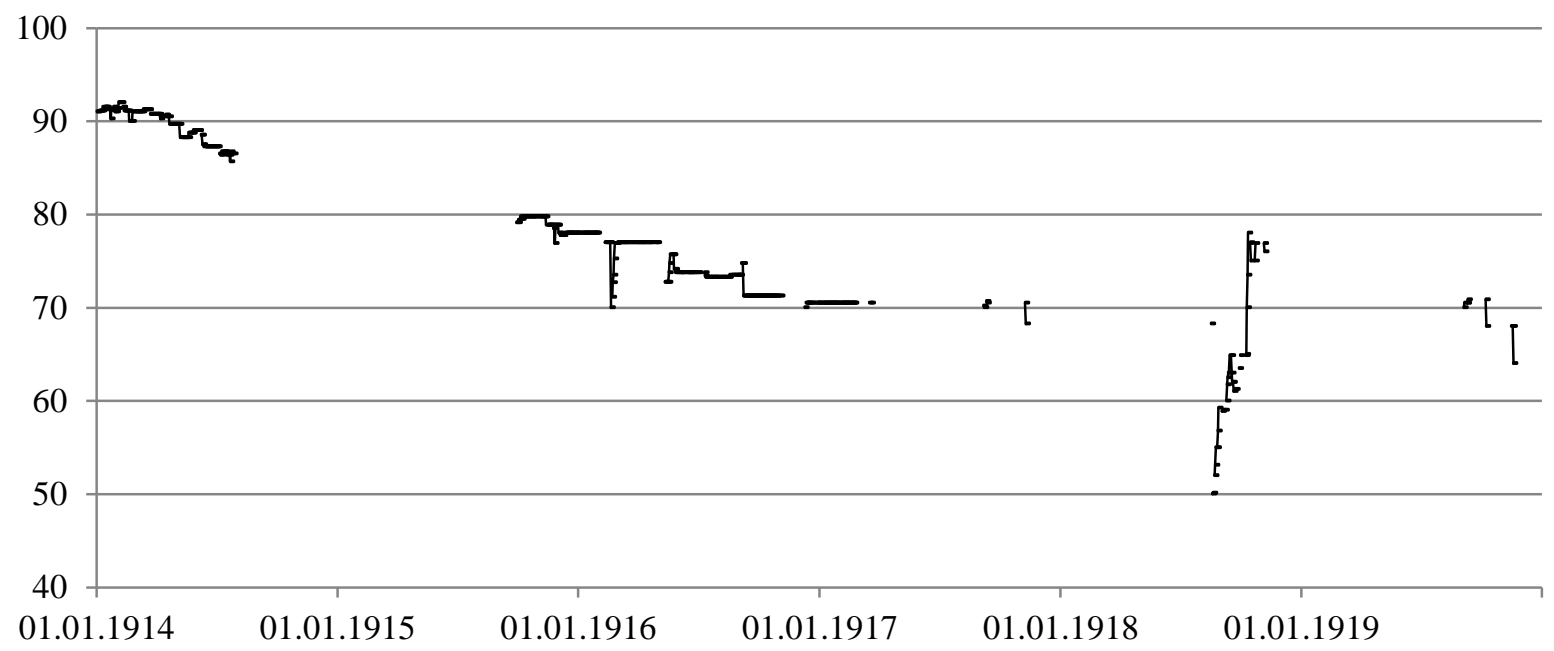


(52) China $-5.0 \%$ of 1912

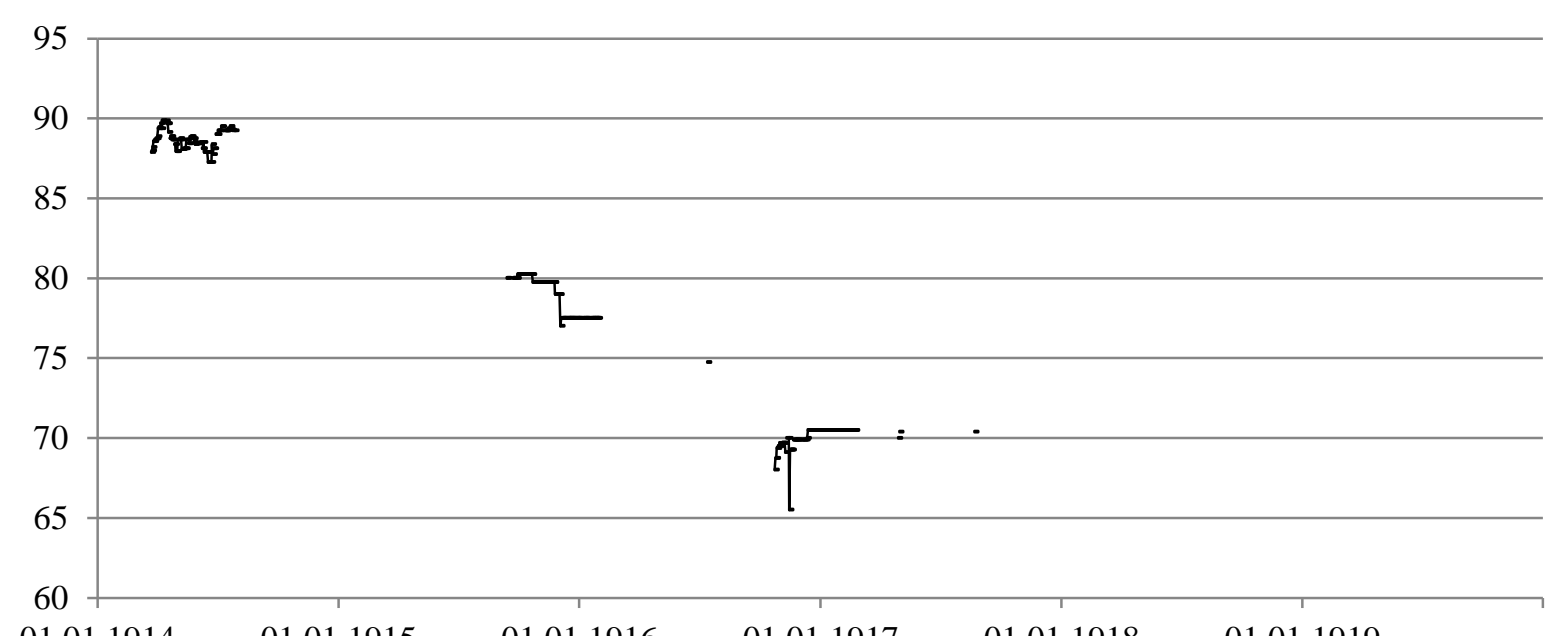

$\begin{array}{llllll}01.01 .1914 & 01.01 .1915 & 01.01 .1916 & 01.01 .1917 & 01.01 .1918 & 01.01 .1919\end{array}$

(53) Colombia $-3.0 \%$ of 1896

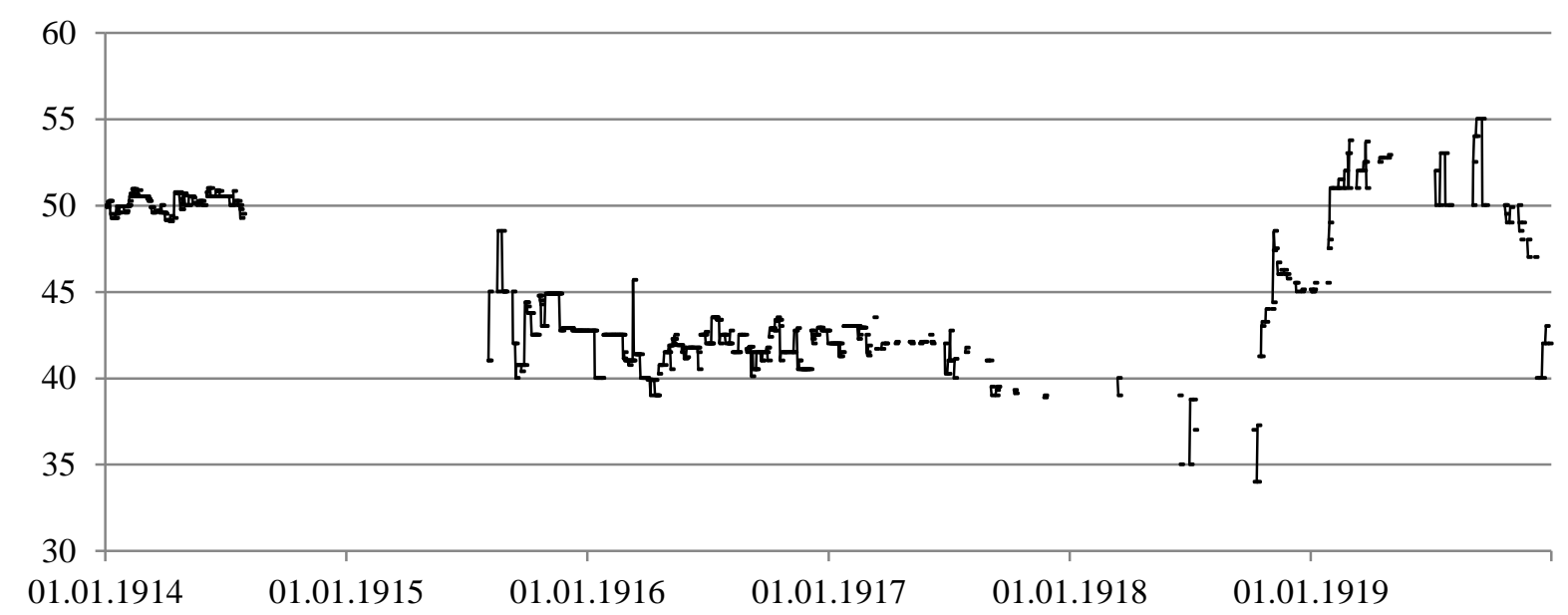

(54) Cuba $-4.5 \%$ of 1909

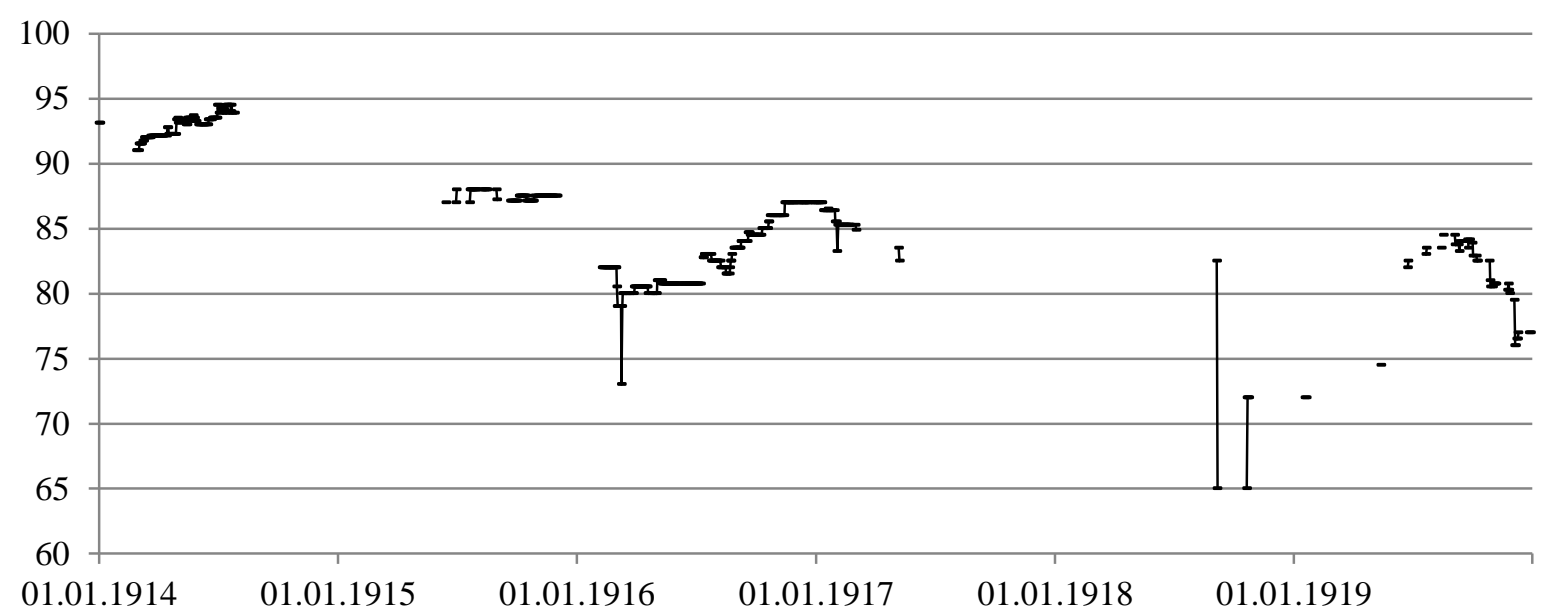


(55) Cuba $-5.0 \%$ of $1904 / 05$

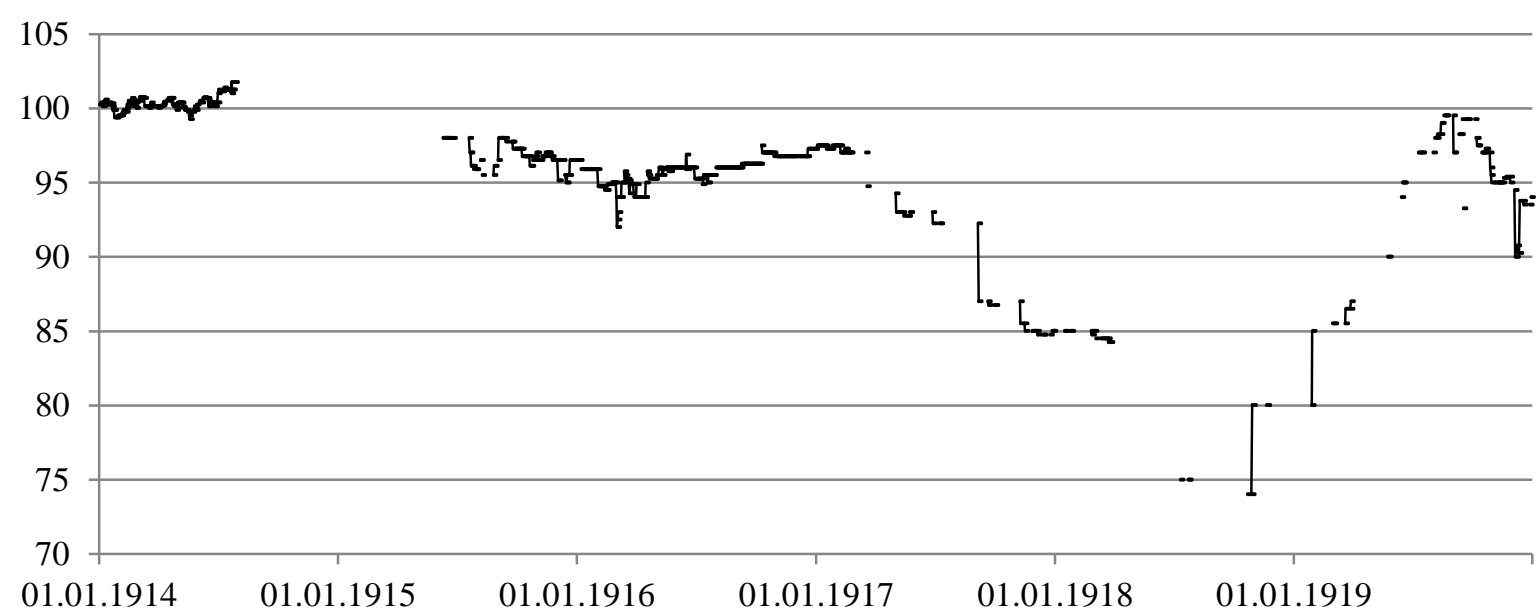

(56) Denmark - $4.0 \%$ of 1912

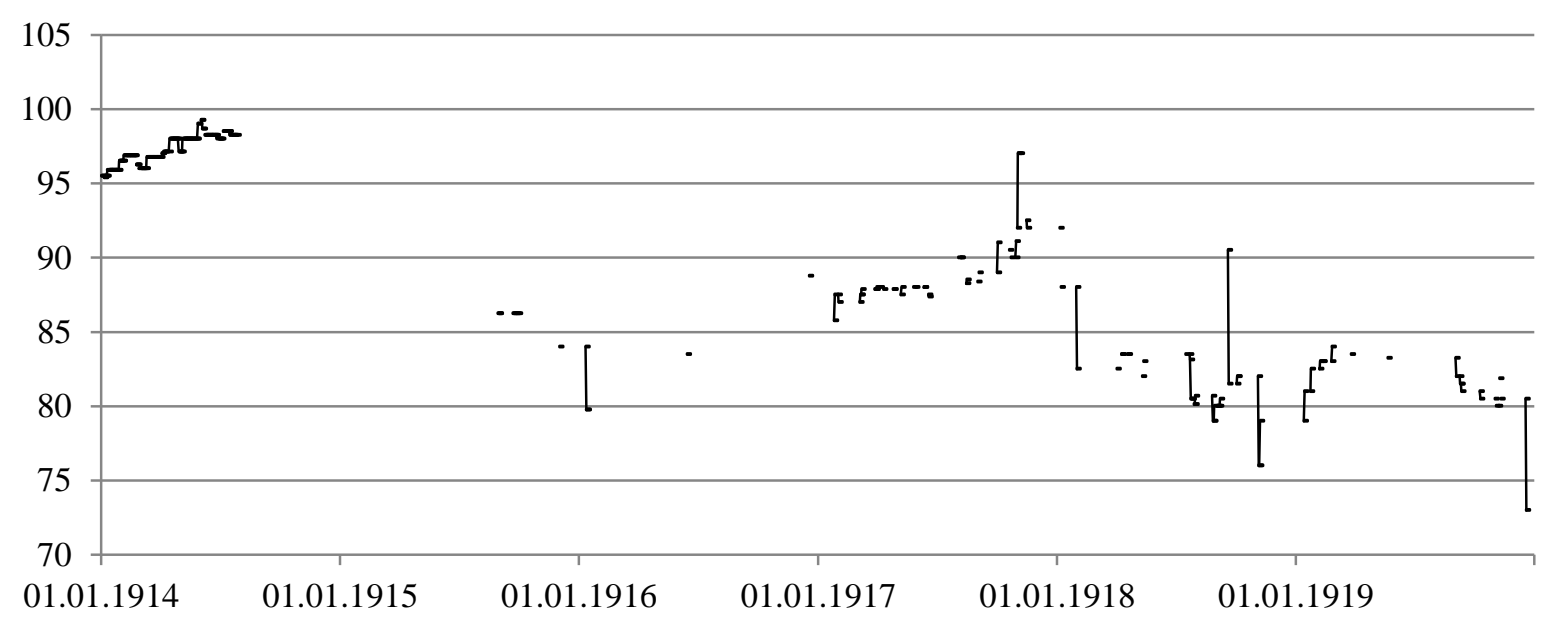

(57) Dominican Republic - $5.0 \%$ of 1908 (customs)

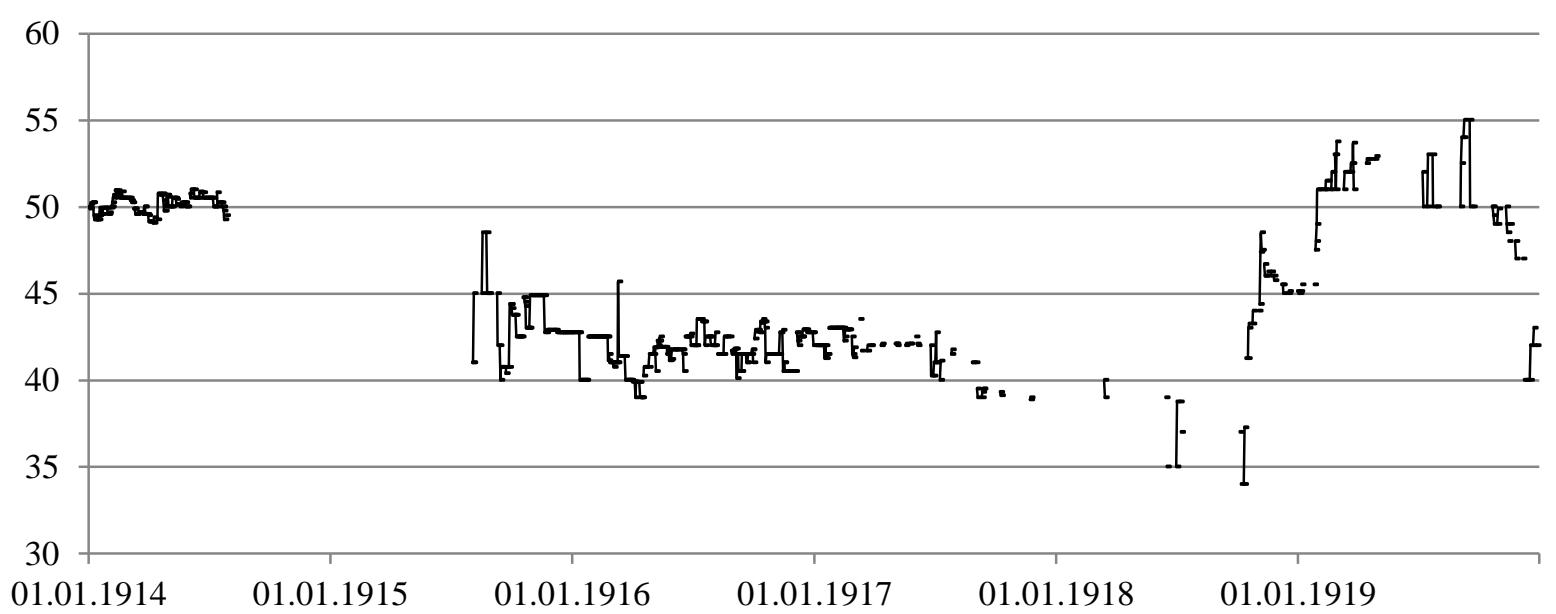


(58) Dutch East Indies - $5.0 \%$ of 1915 (100)

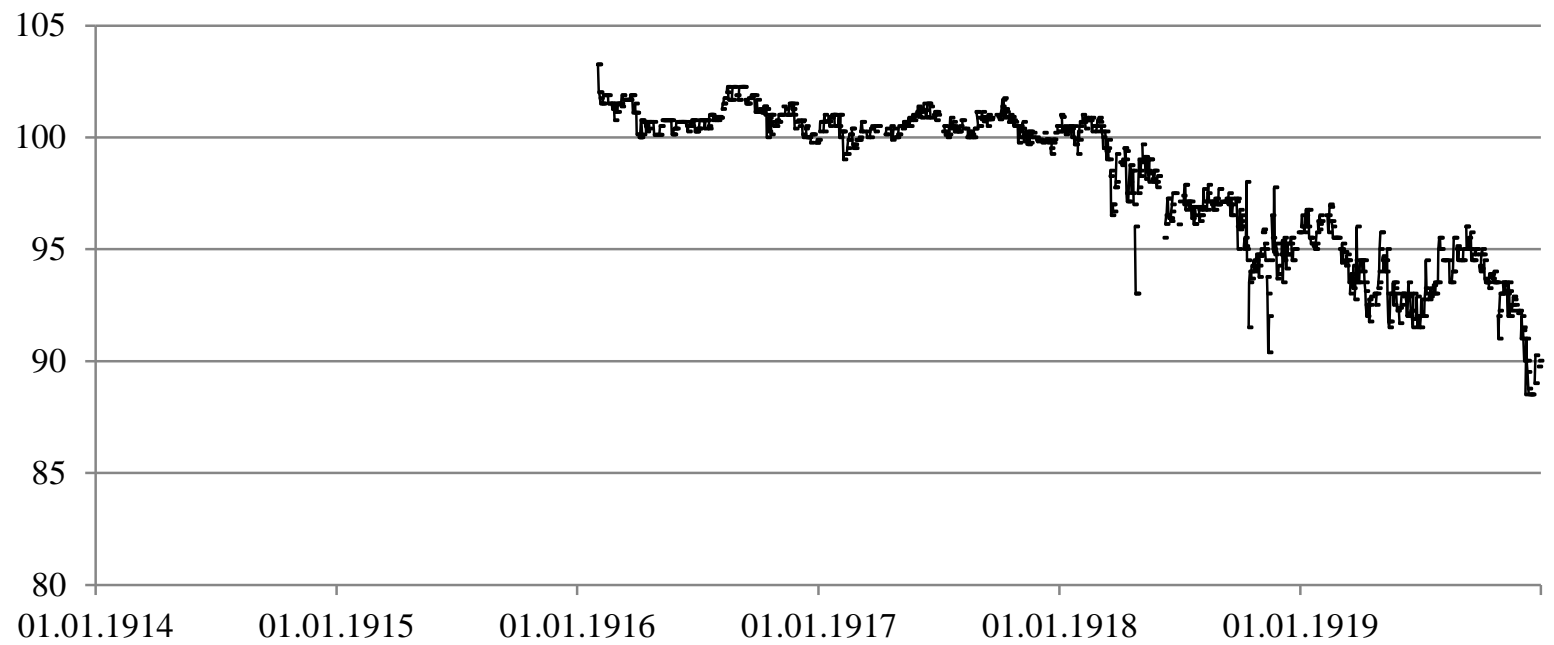

(59) Dutch East Indies - $5.0 \%$ of 1915 (500)

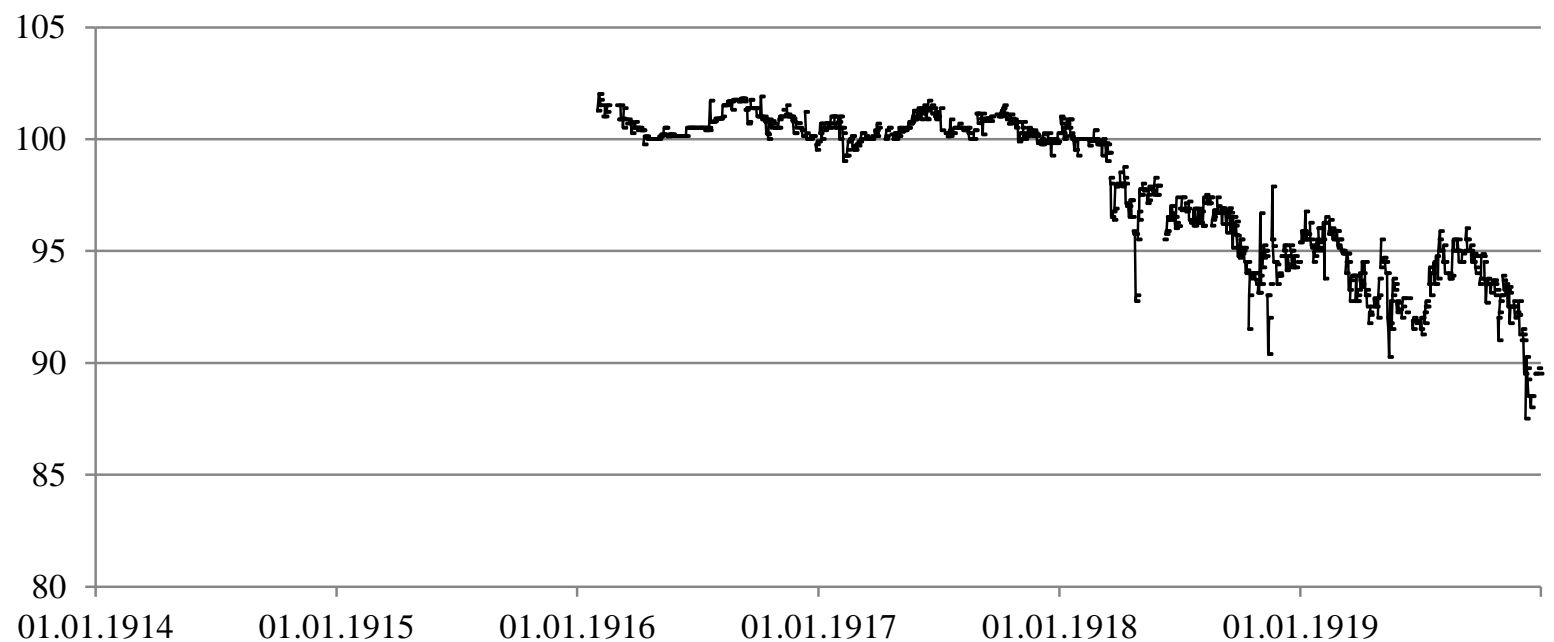

(60) Dutch East Indies - 5.0\% of 1915 (100/500)

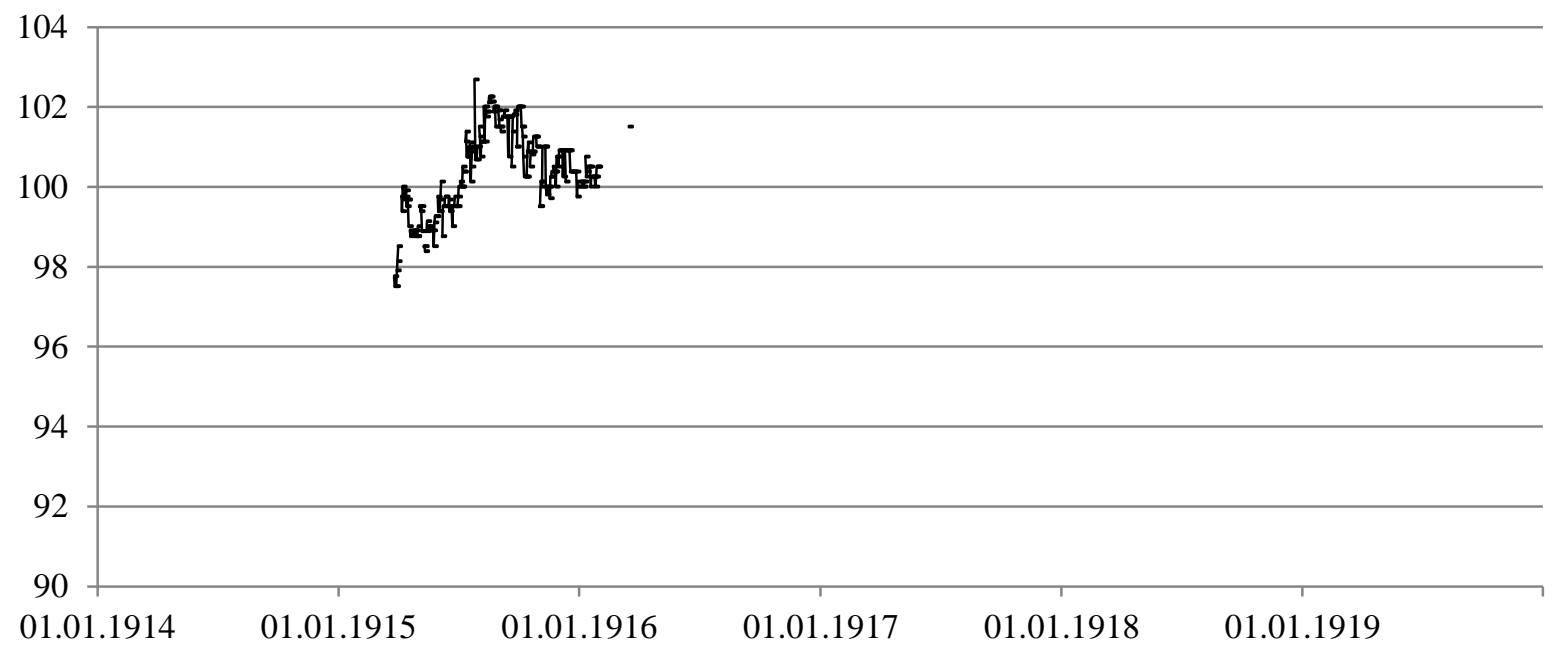


(61) Dutch East Indies - 5.0\% of 1915 (1 000)

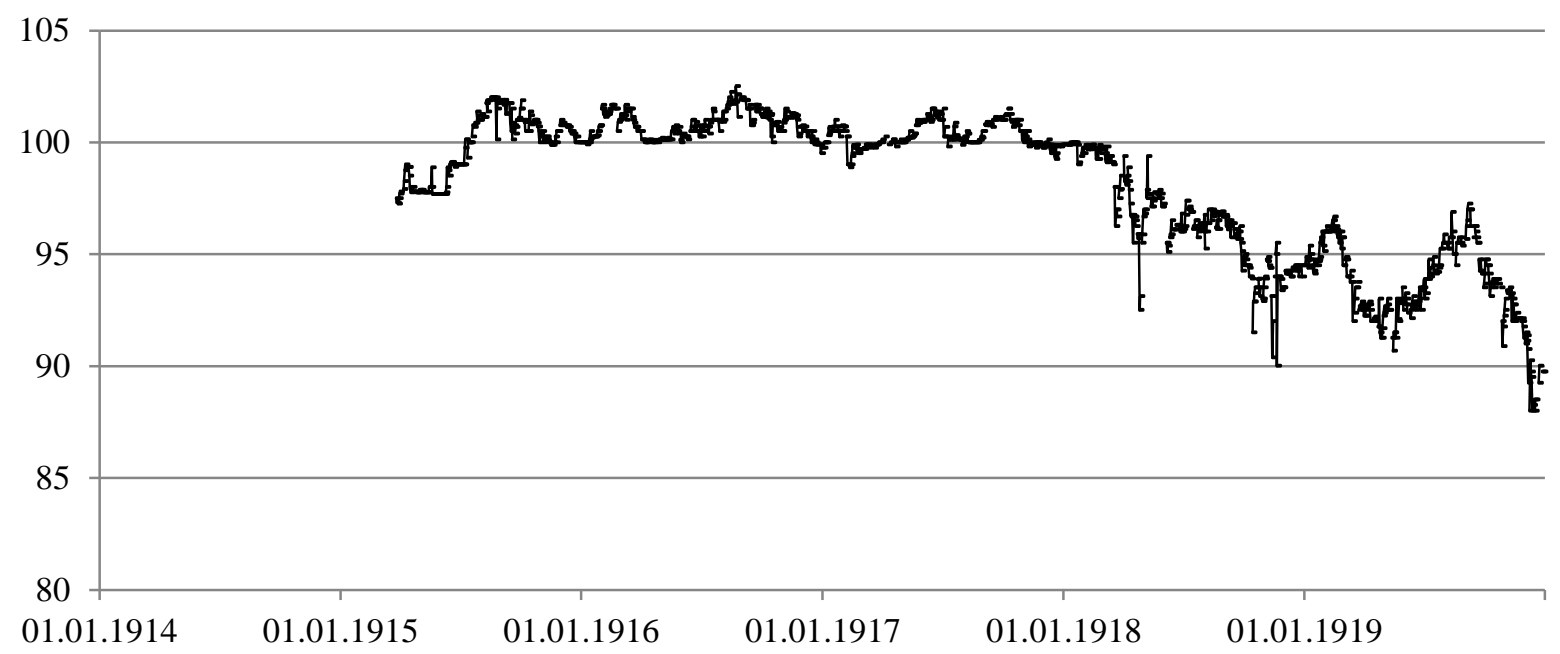

(62) Dutch East Indies - 5.0\% of 1916 (100)

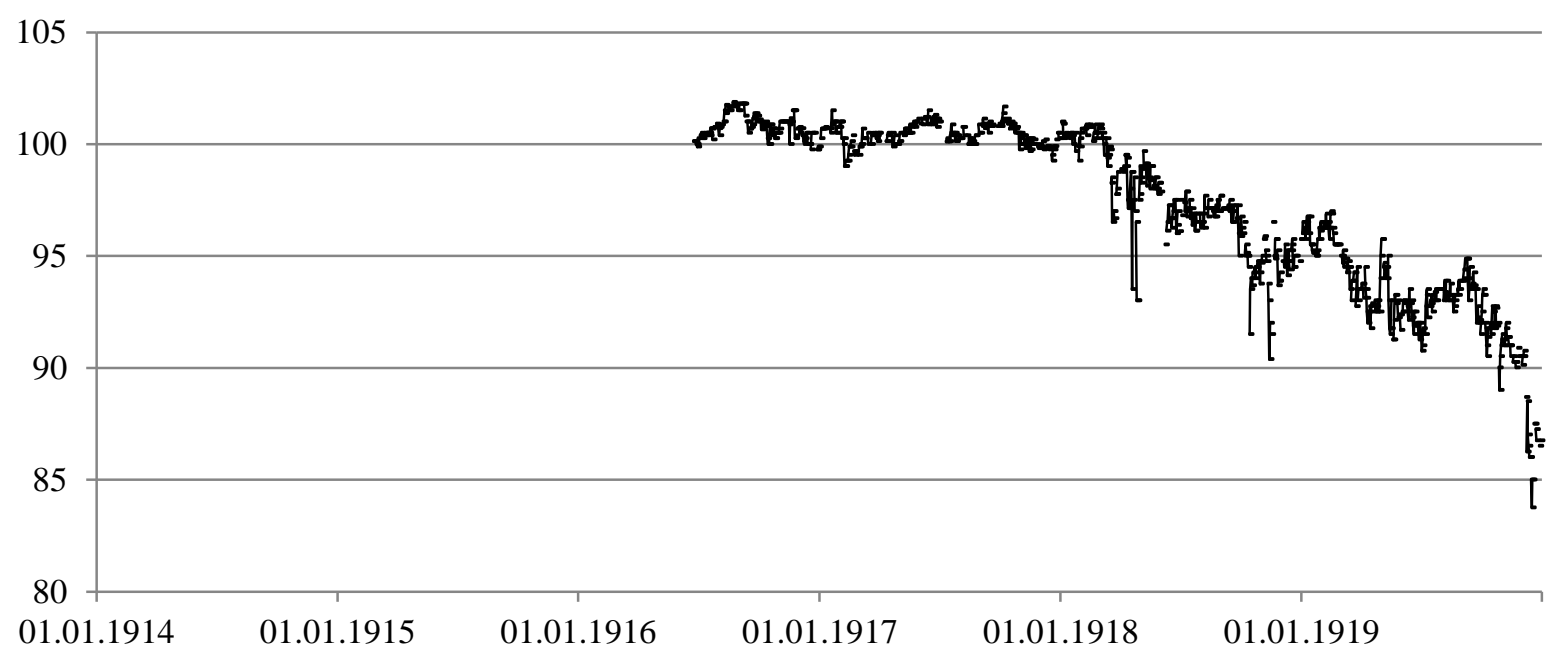

(63) Dutch East Indies - 5.0\% of 1916 (500)

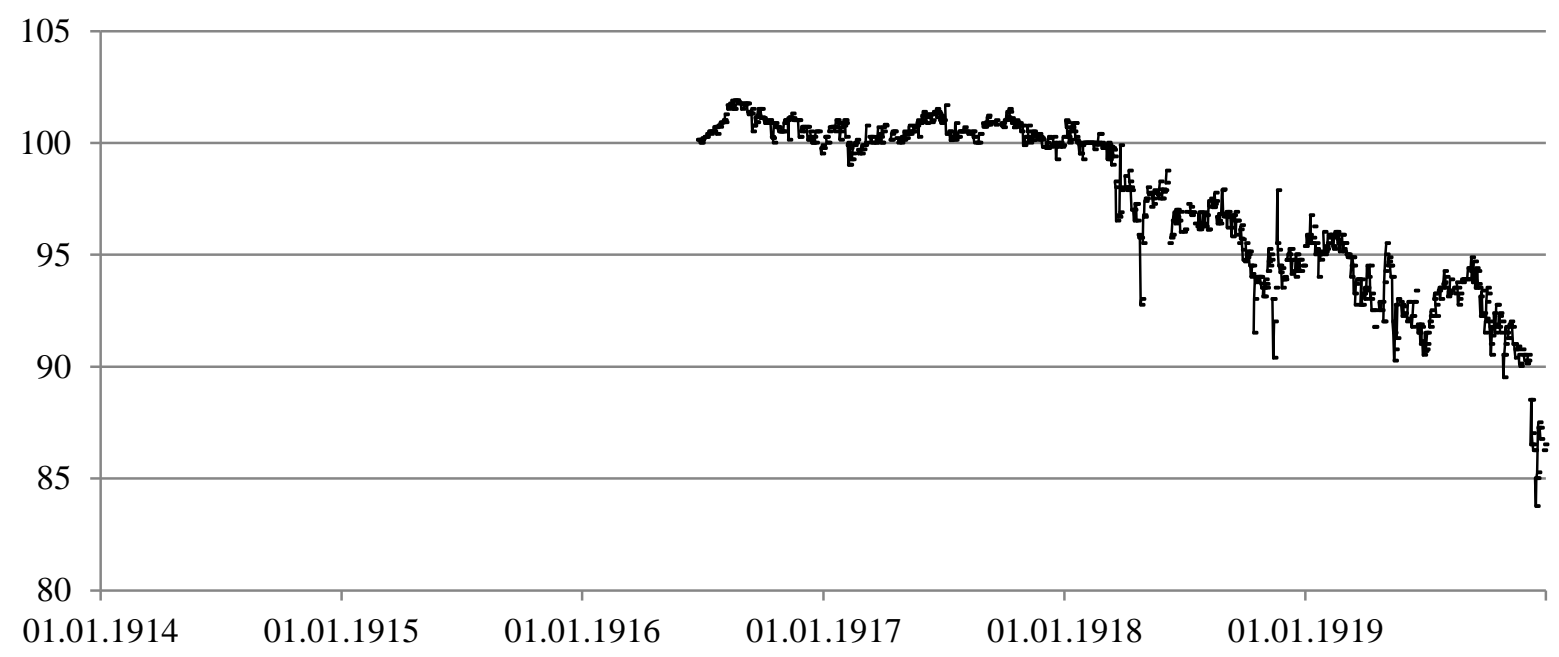


(64) Dutch East Indies - 5.0 \% of 1916 (1 000)

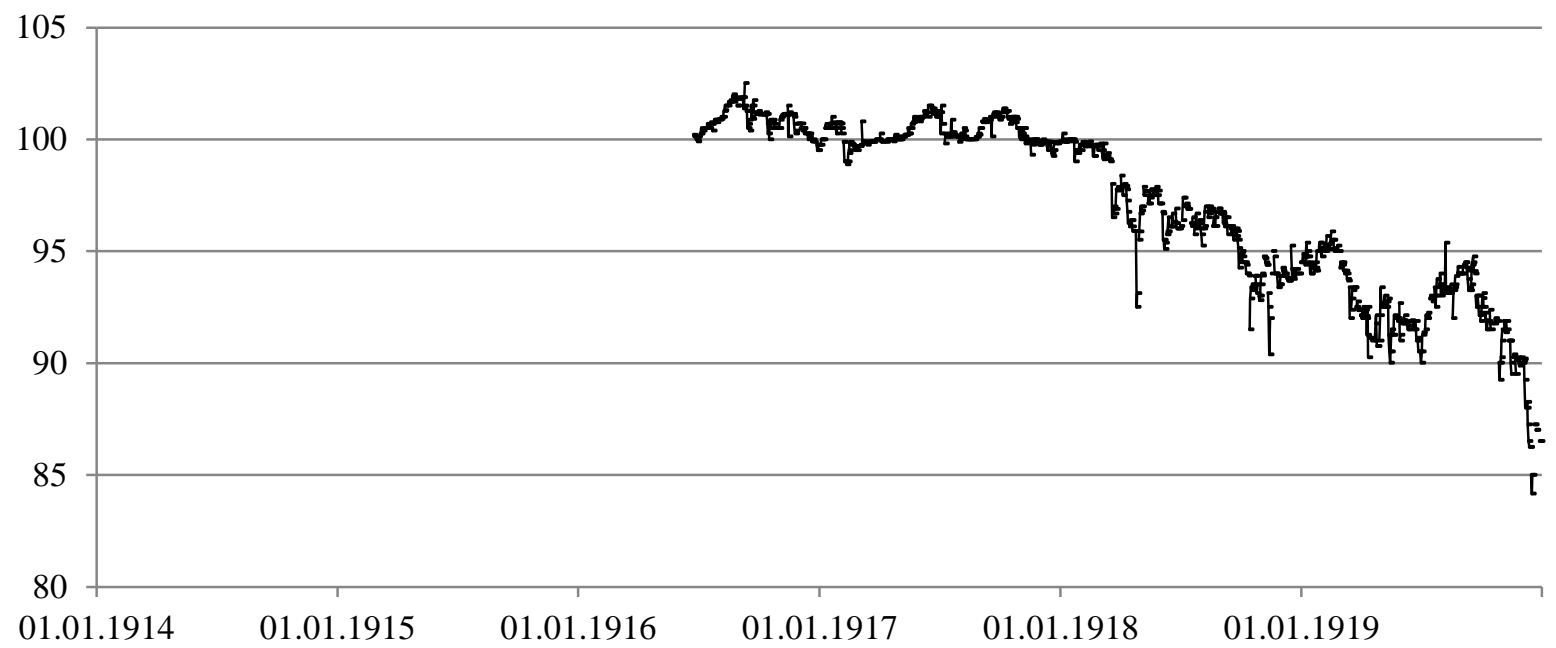

(65) Dutch East Indies - $5.0 \%$ of 1917 (100)

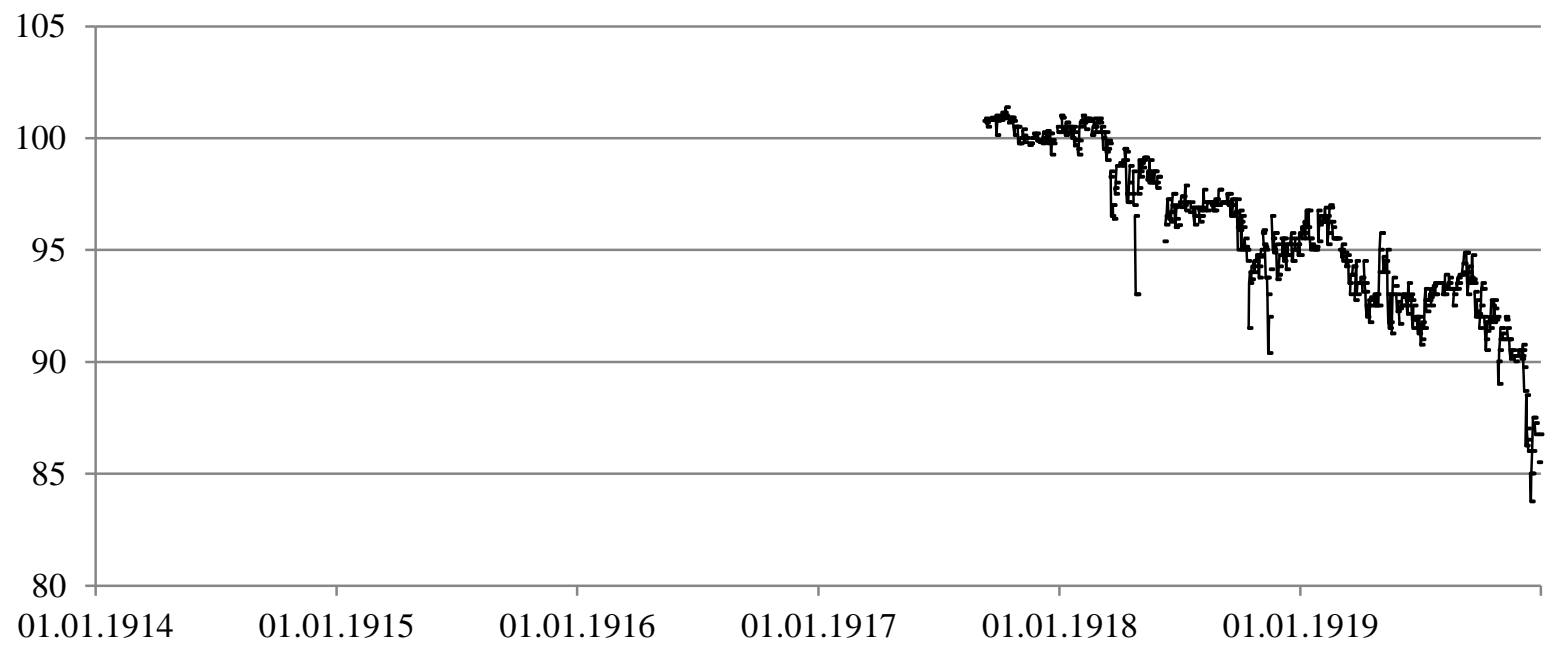

(66) Dutch East Indies - 5.0\% of 1917 (500)

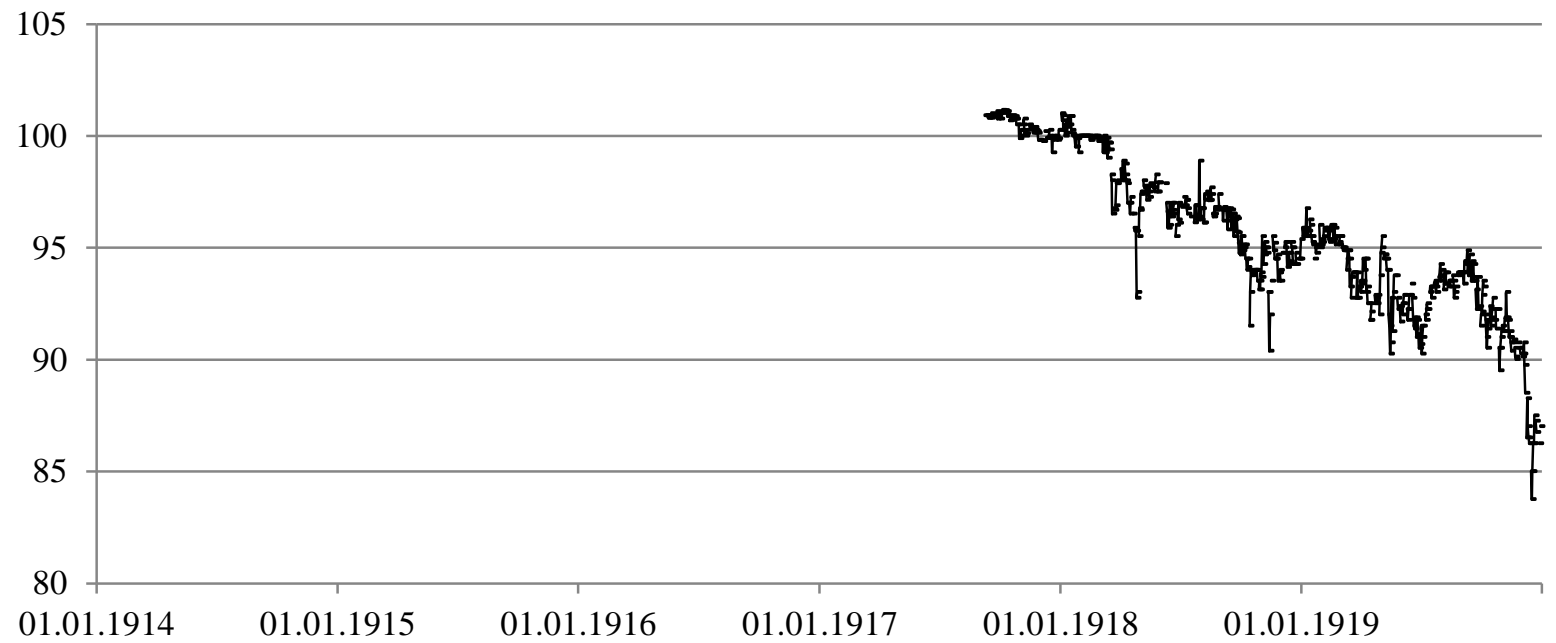


(67) Dutch East Indies - 5.0\% of 1917 (1 000)

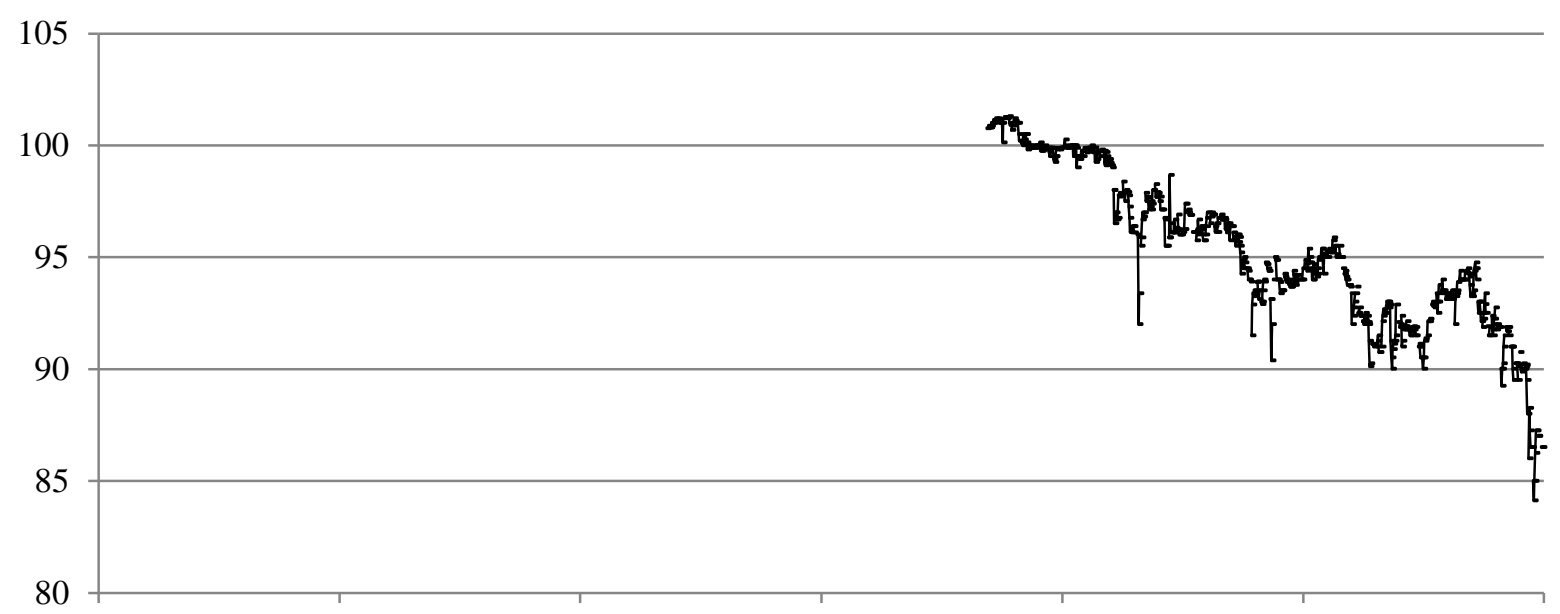

$\begin{array}{llllll}01.01 .1914 & 01.01 .1915 & 01.01 .1916 & 01.01 .1917 & 01.01 .1918 & 01.01 .1919\end{array}$

(68) Egypt $-4.0 \%$ of 1876

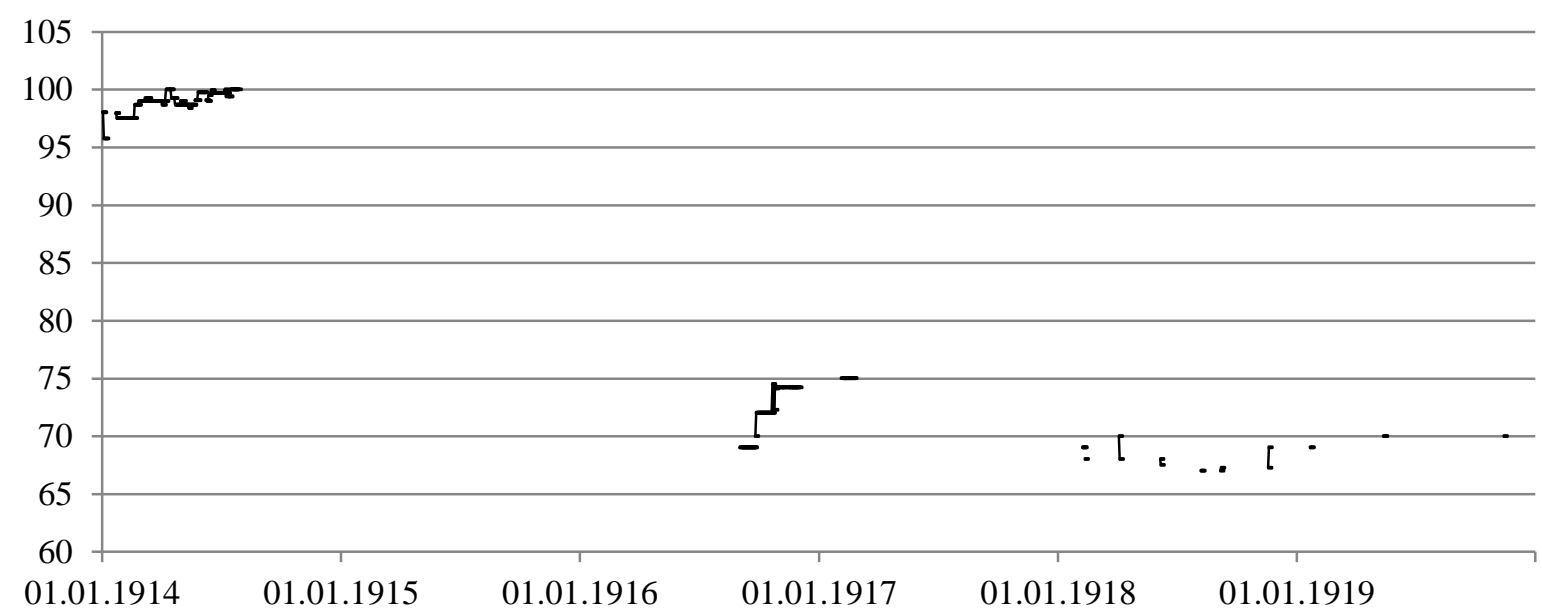

(69) Finland $-3.5 \%$ of 1889

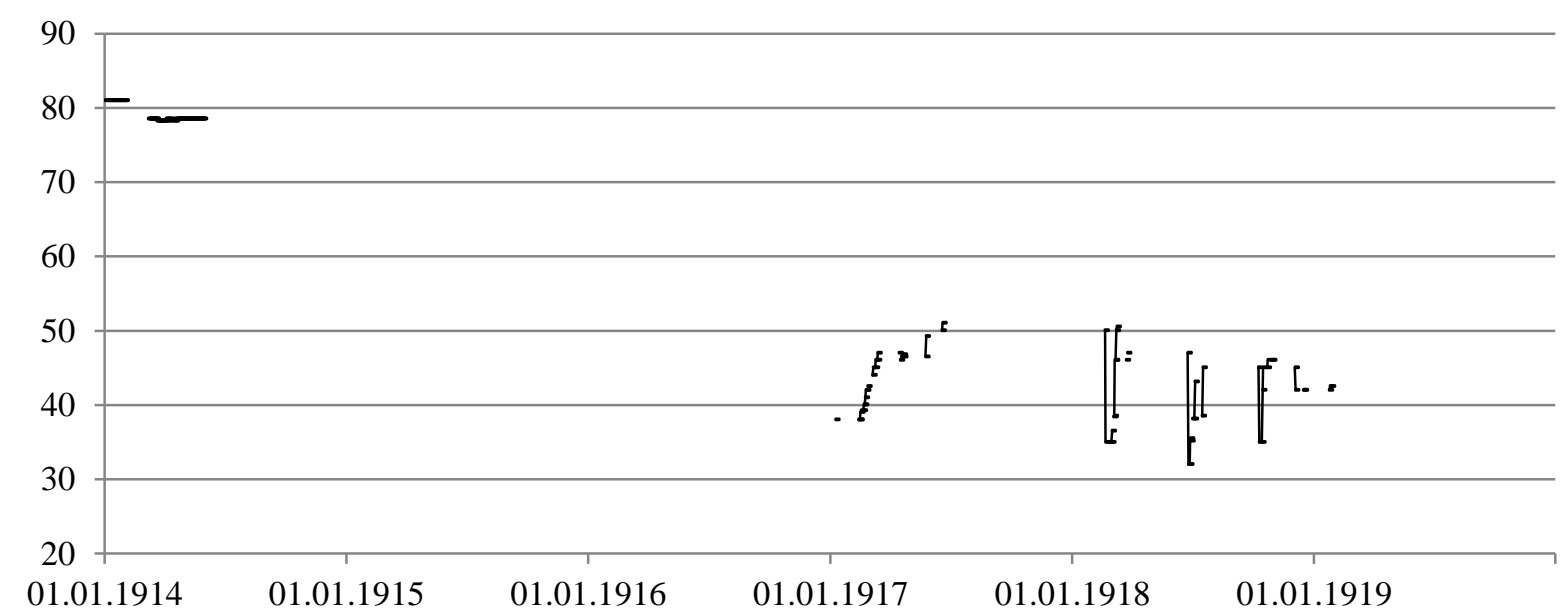


(70) Germany - 3.0 \% Reich of 1890-1901 (Jan/Jul)

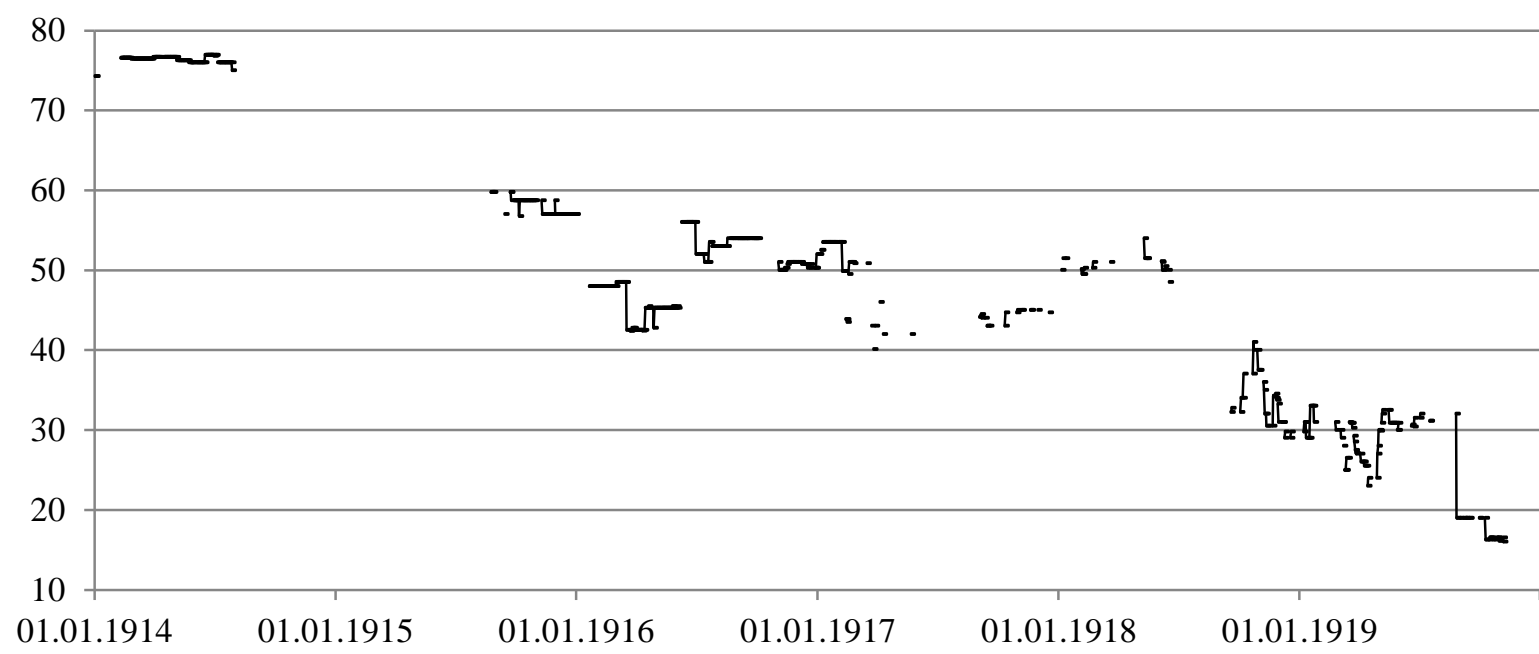

(71) Germany - 3.0\% Reich of 1890-1901 (Apr/Oct)

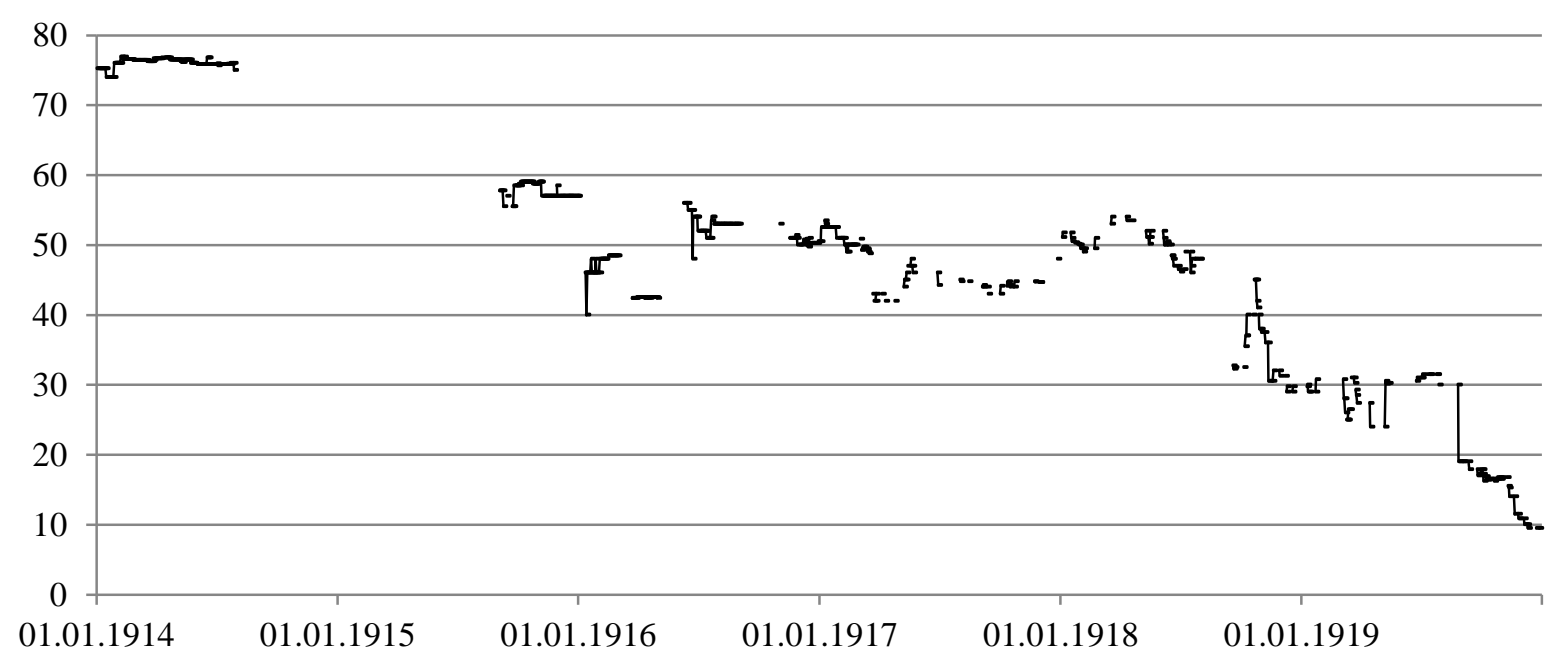

(72) Germany - 3.0 \% Prussia of 1890-1901

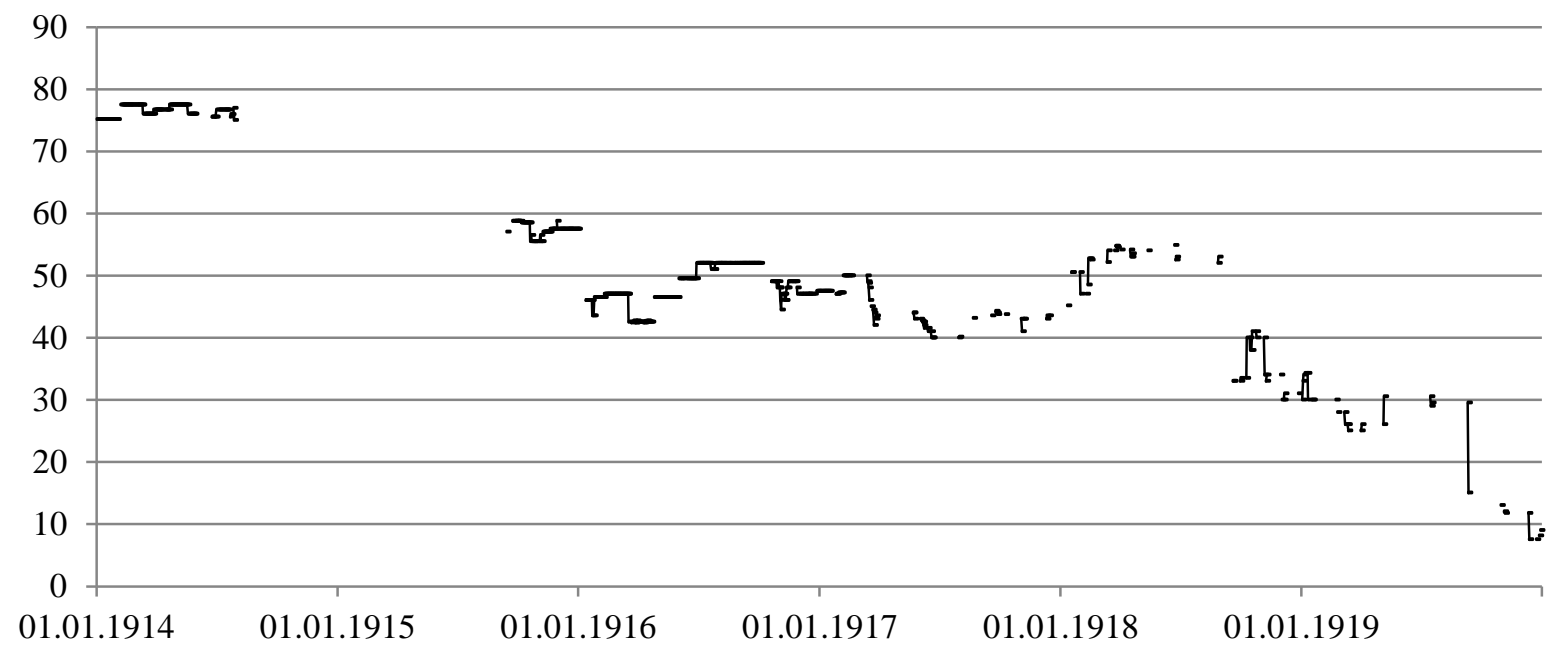


(73) Germany - 3.5 \% Prussia of 1896 (200/1 000)

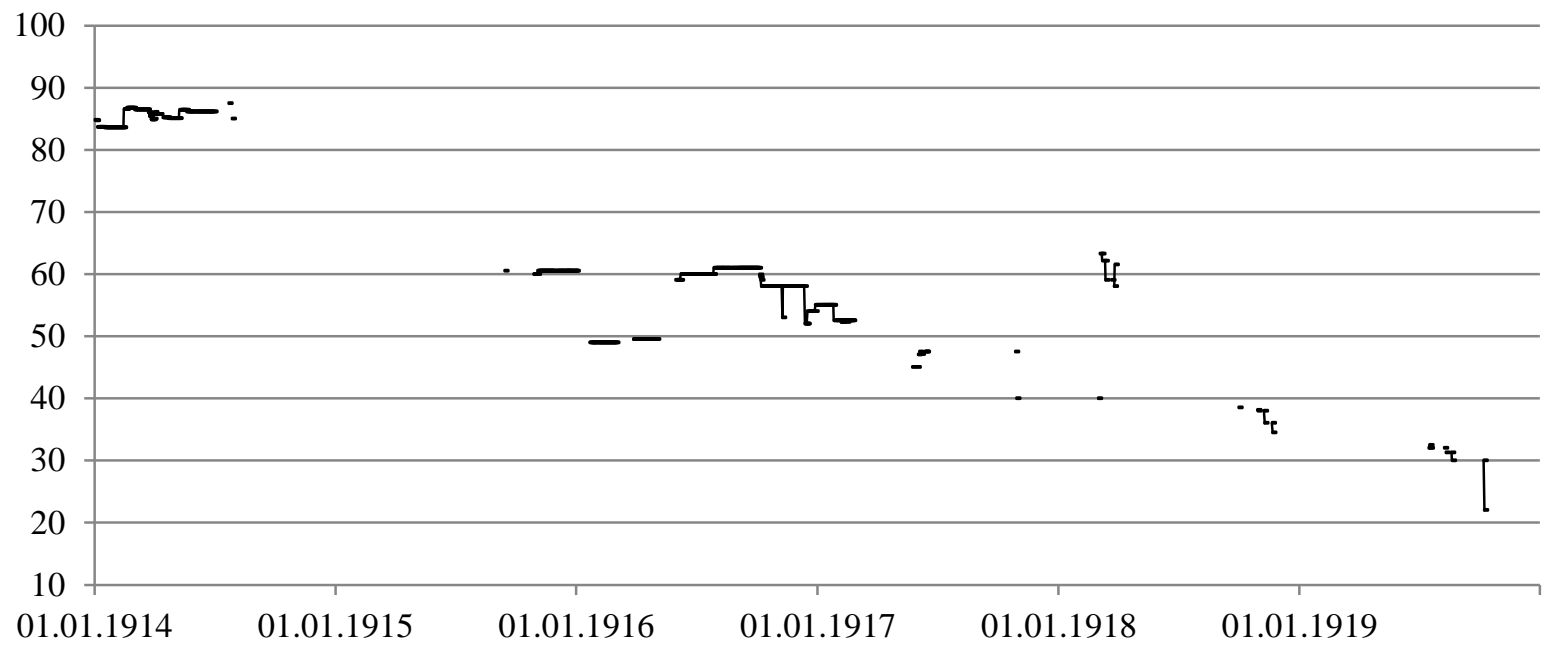

(74) Germany - 3.5 \% Prussia of 1896 (2 500/5 000)

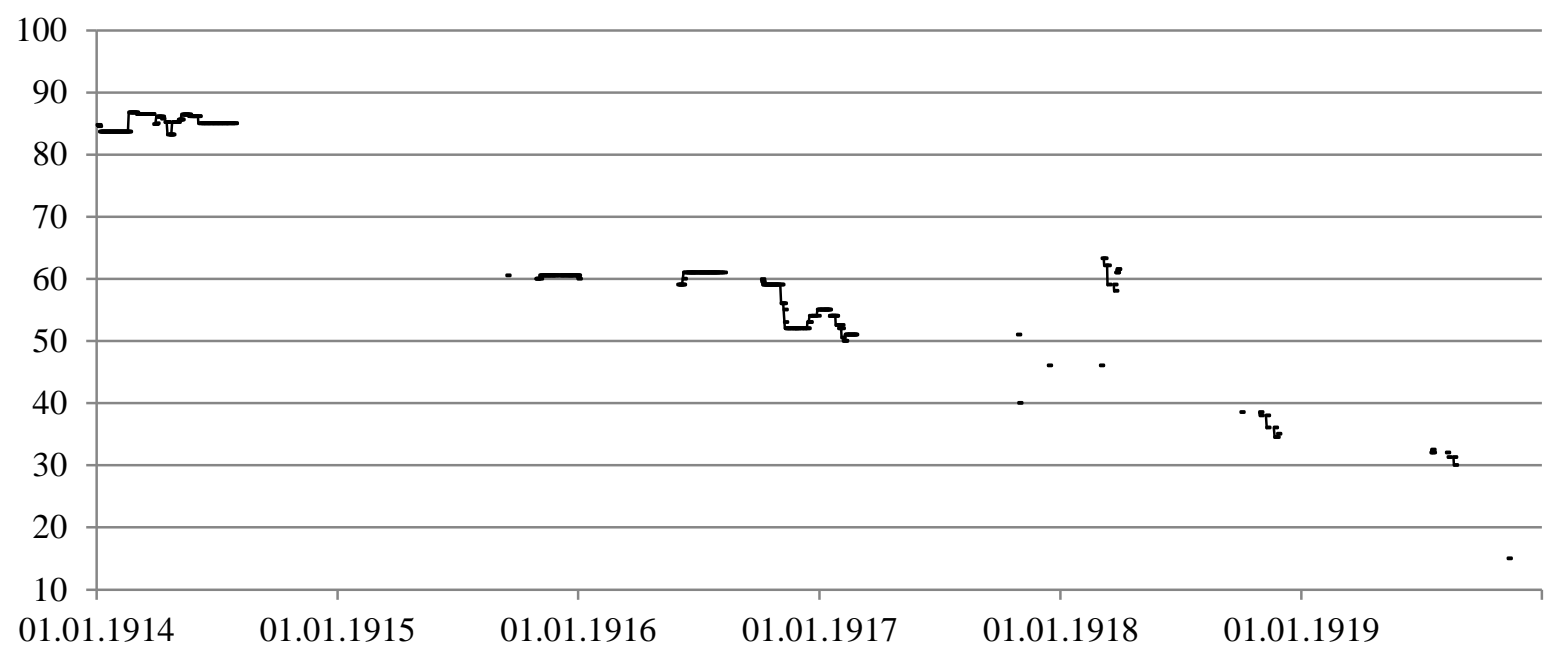

(75) Germany $-4.0 \%$ Hamburg of 1900

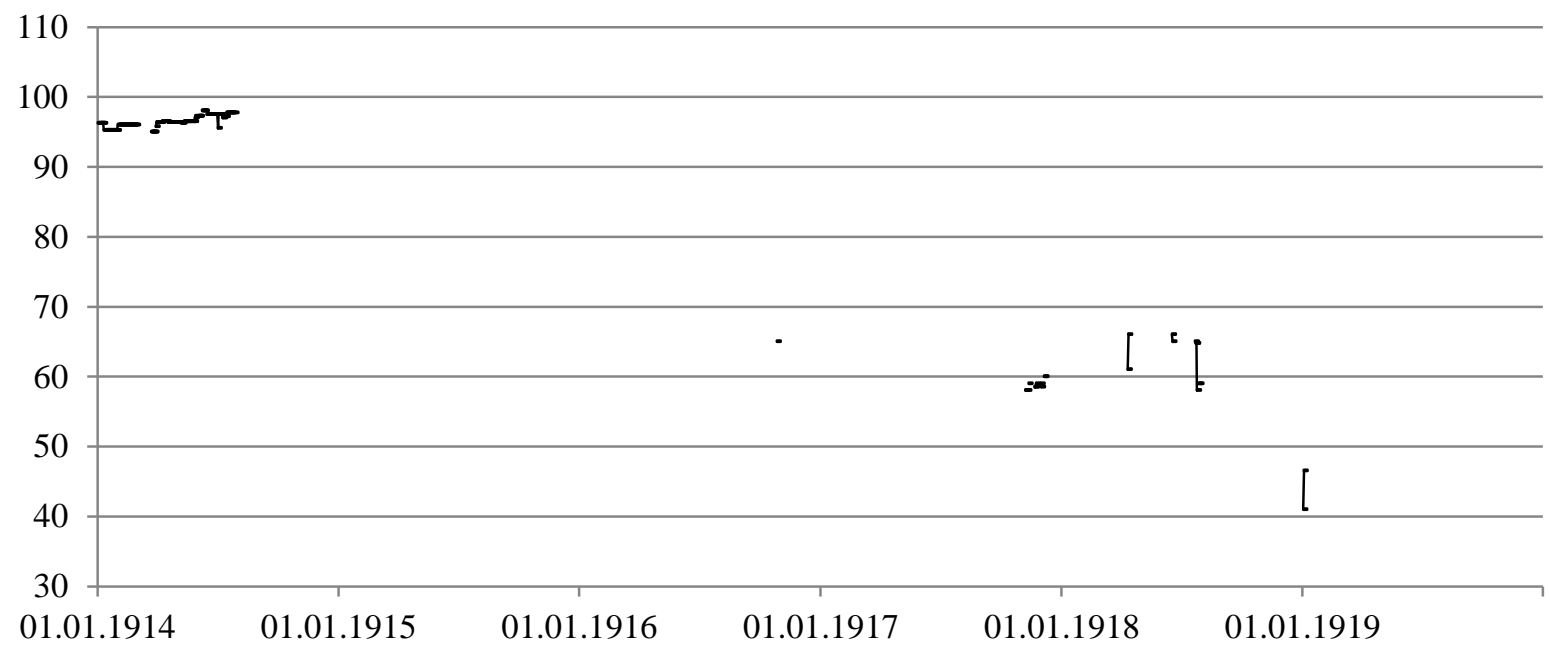


(76) Hungary $-4.0 \%$ of $1881-93$

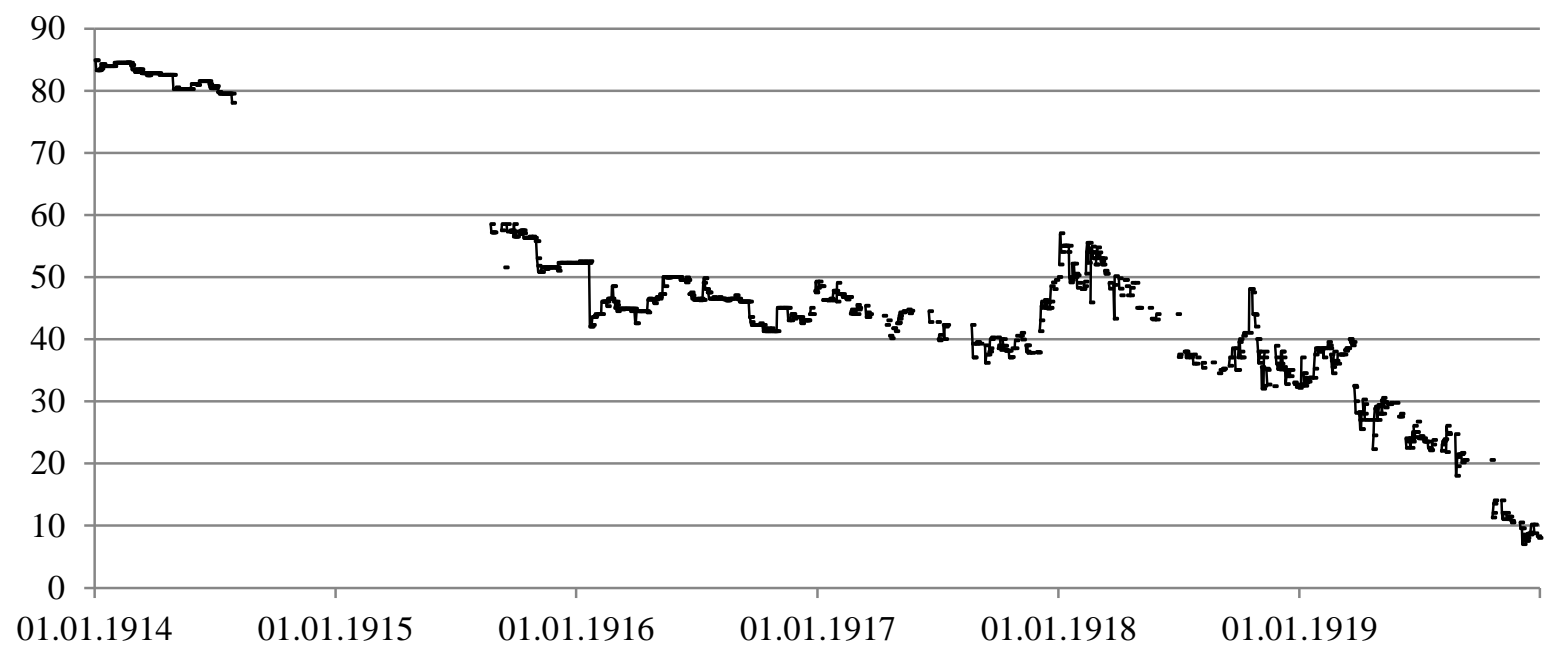

(77) Hungary $-4.0 \%$ of $1892-1910$ (100/1 000)

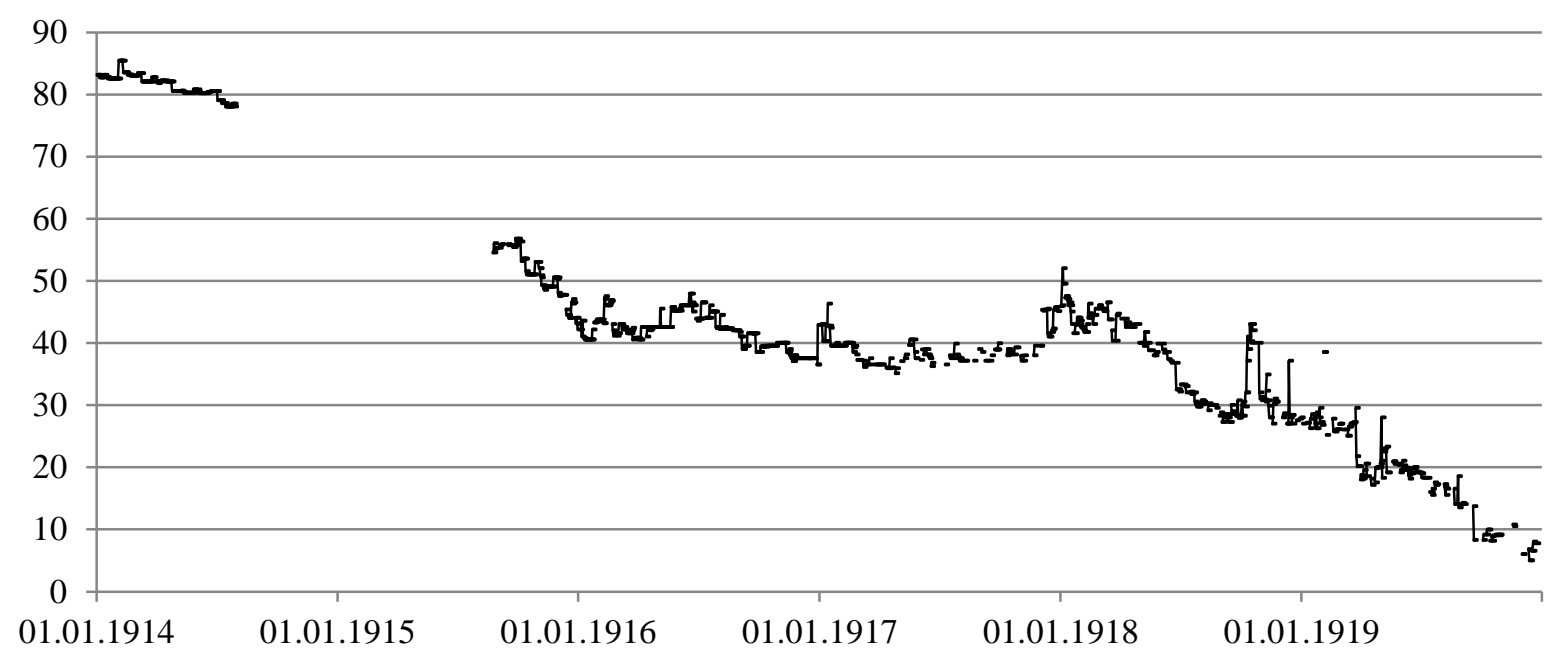

(78) Hungary $-4.0 \%$ of $1892-1910$ (2 000)

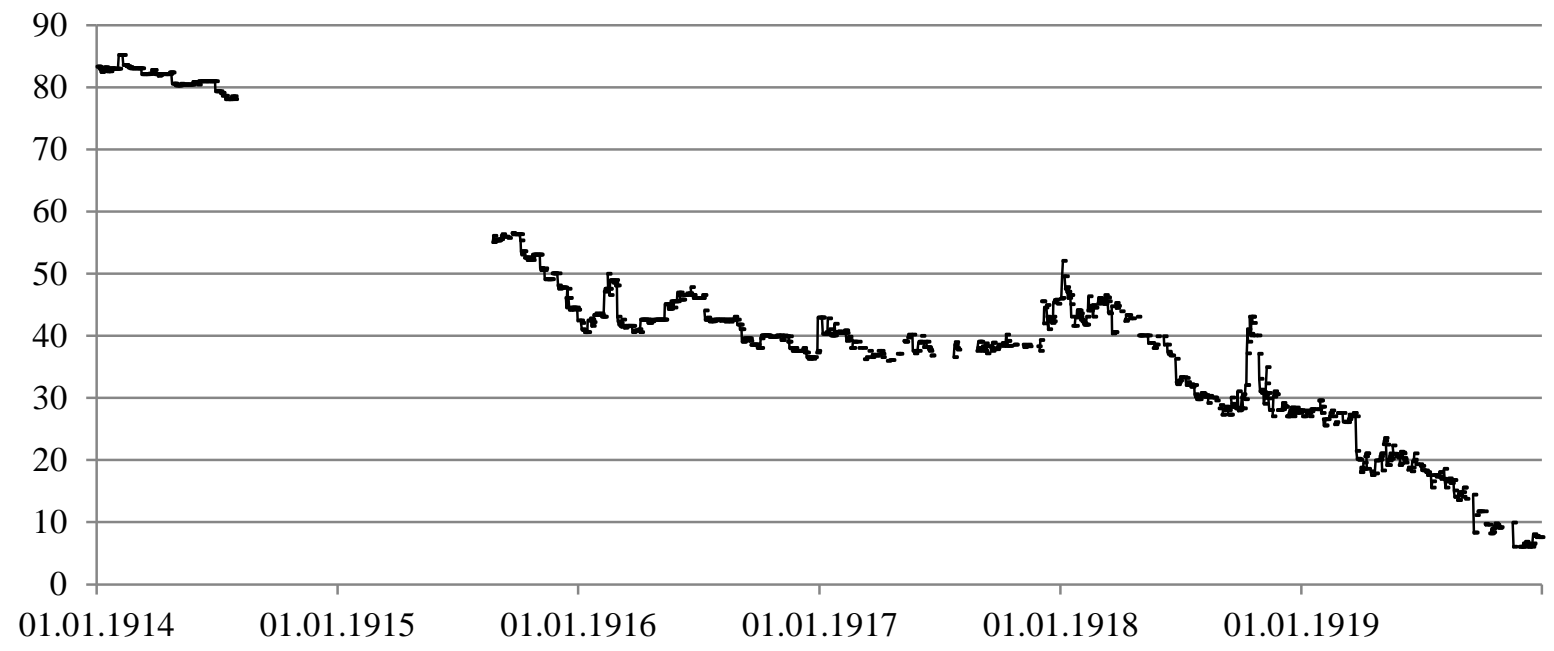


(79) Hungary $-4.5 \%$ of 1913

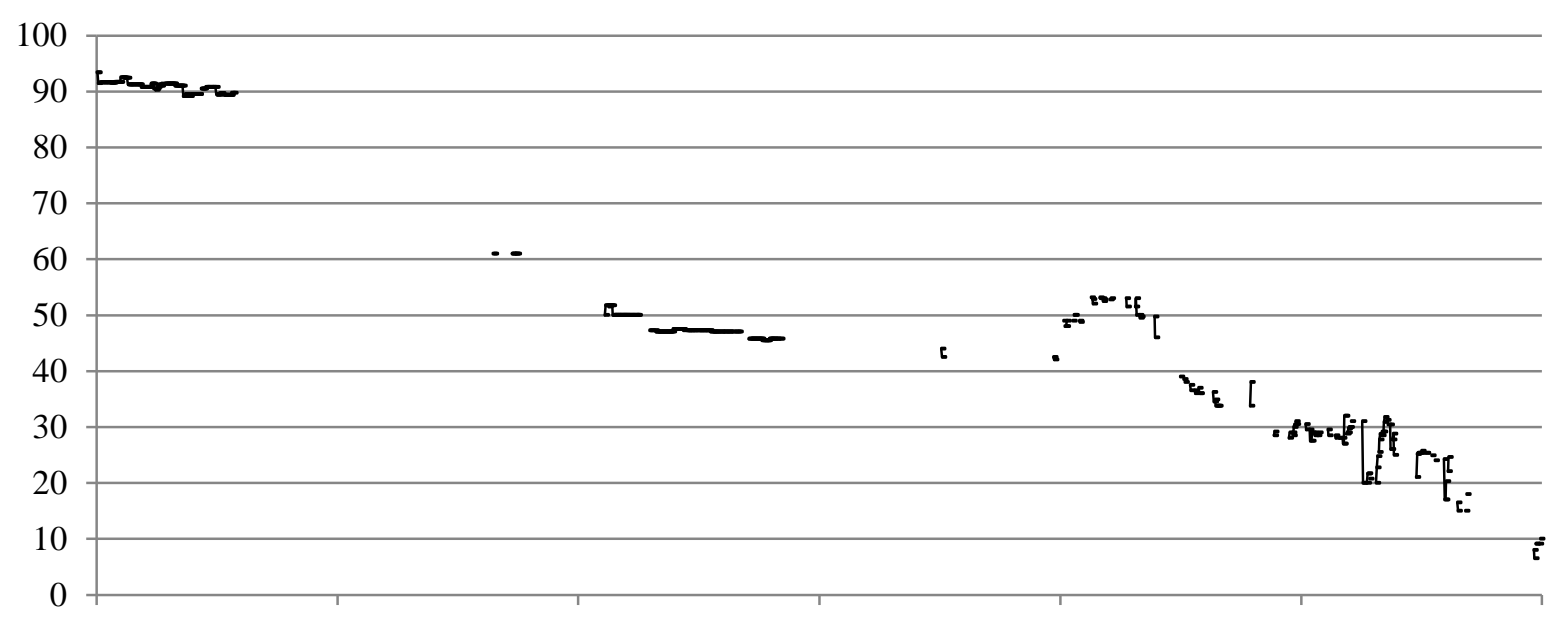

$\begin{array}{llllll}01.01 .1914 & 01.01 .1915 & 01.01 .1916 & 01.01 .1917 & 01.01 .1918 & 01.01 .1919\end{array}$

(80) Hungary $-4.5 \%$ of 1914

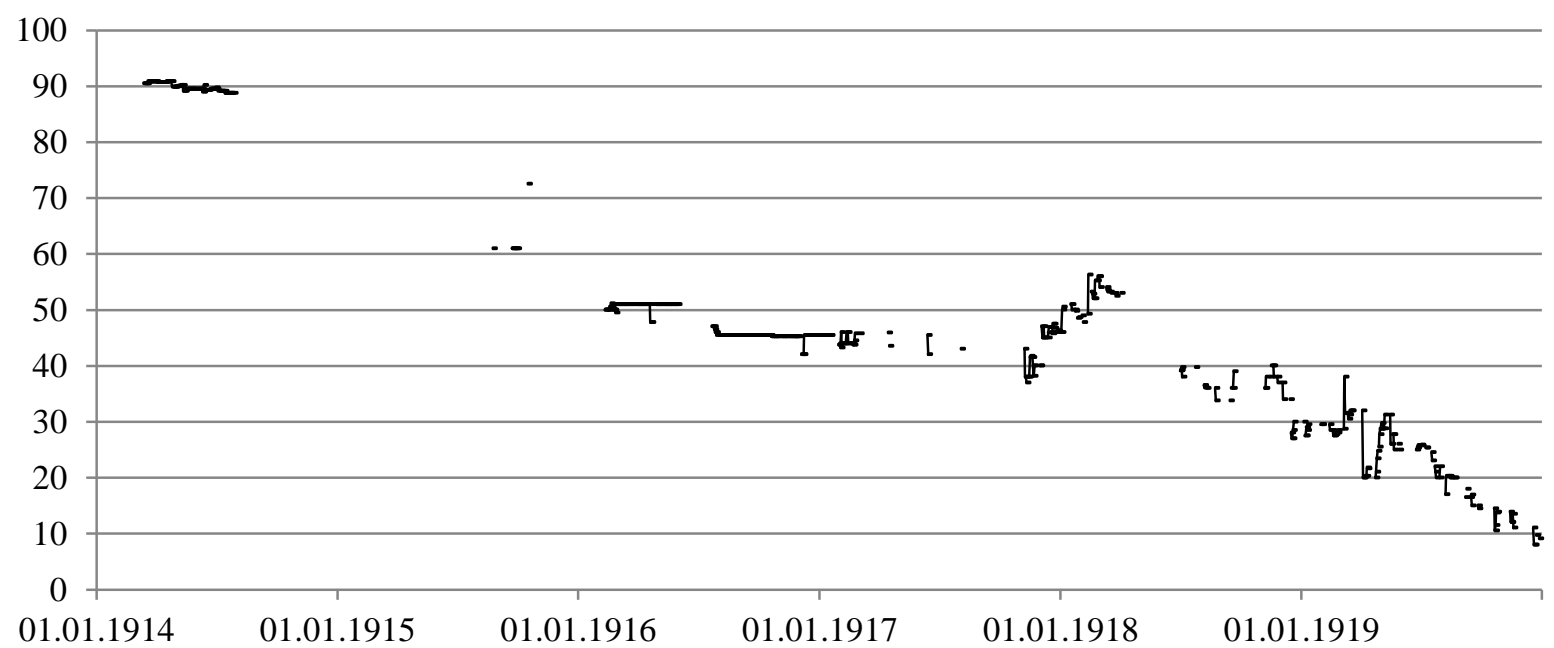

(81) Hungary $-4.5 \%$ of 1916

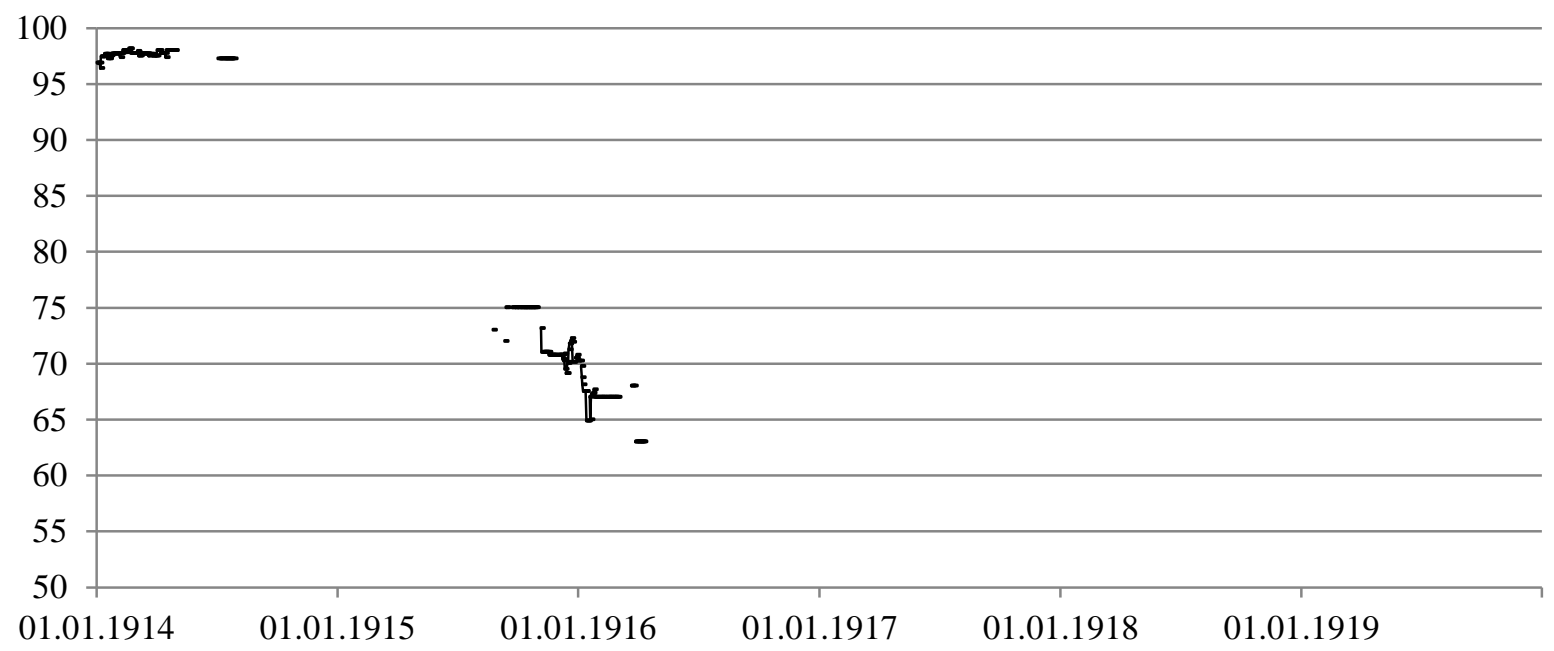


(82) Italy $-3.5 \%$ of $1861-82$

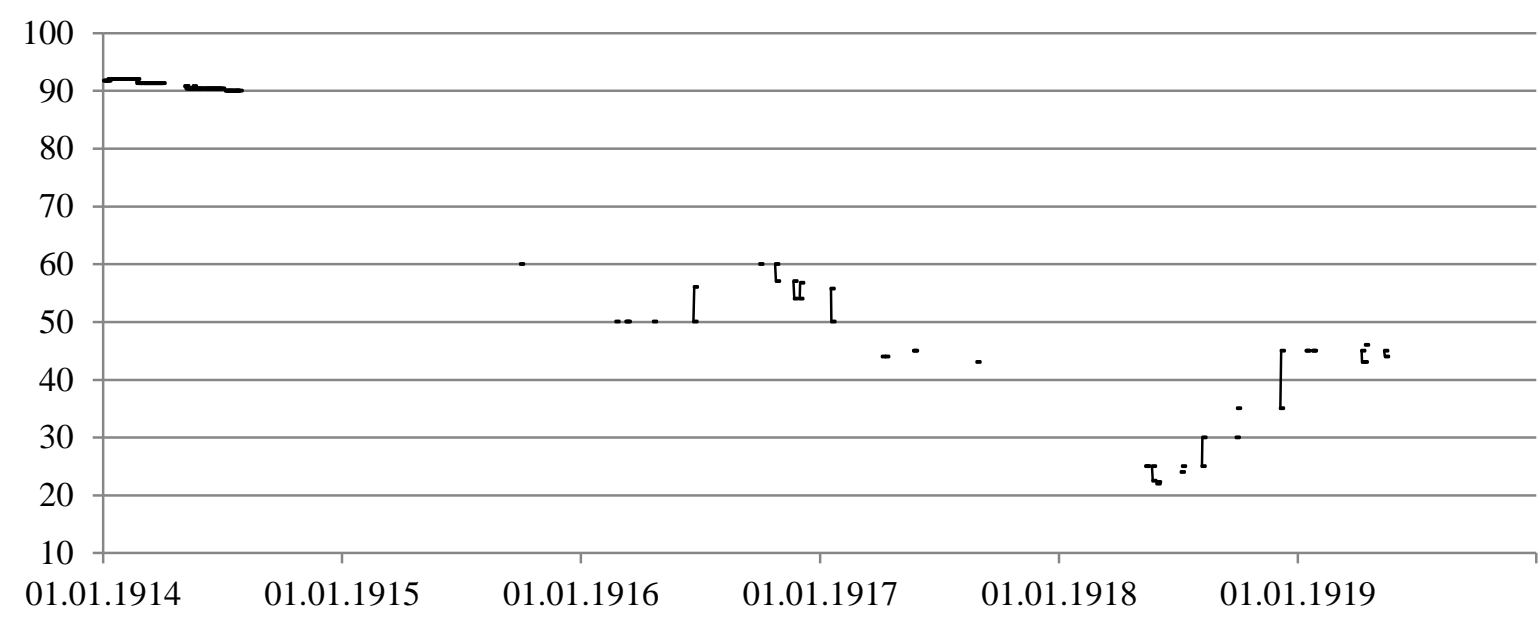

(83) Japan $-4.0 \%$ of 1899

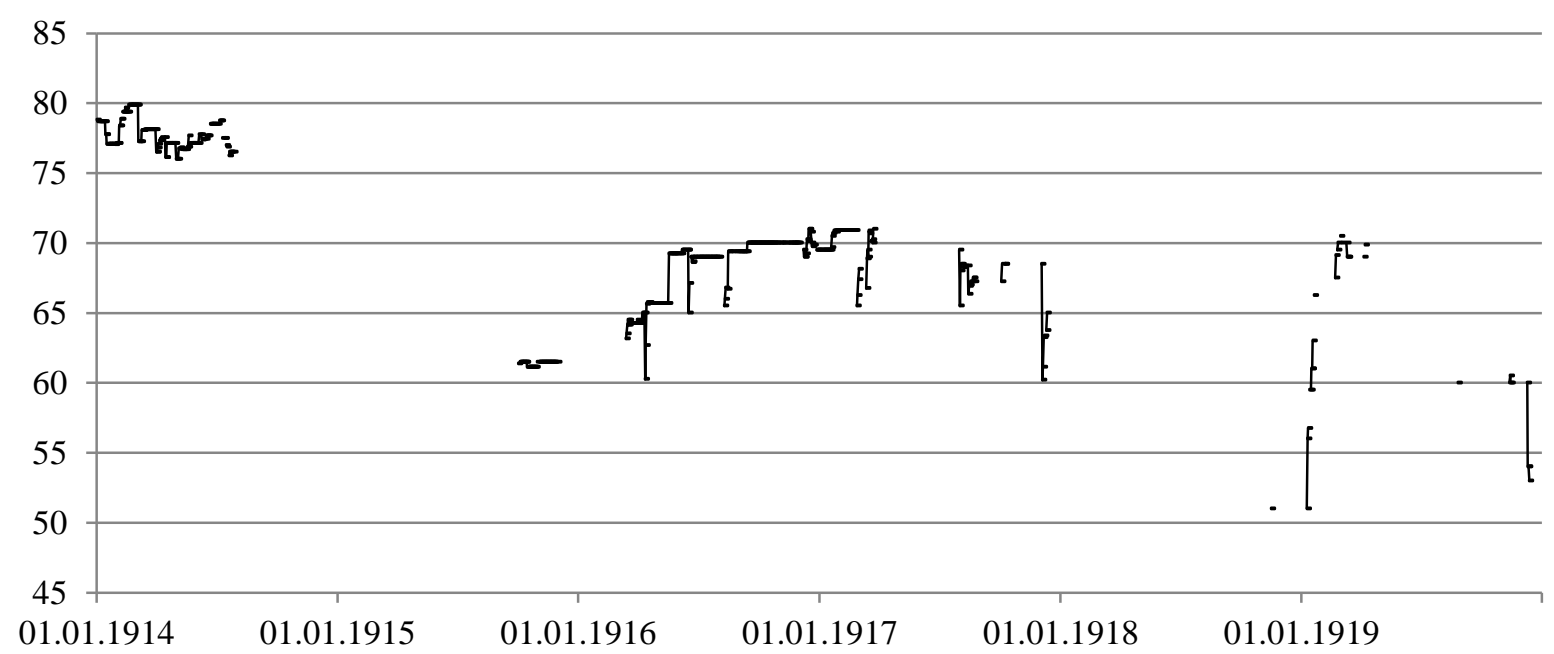

(84) Japan $-4.0 \%$ of 1910

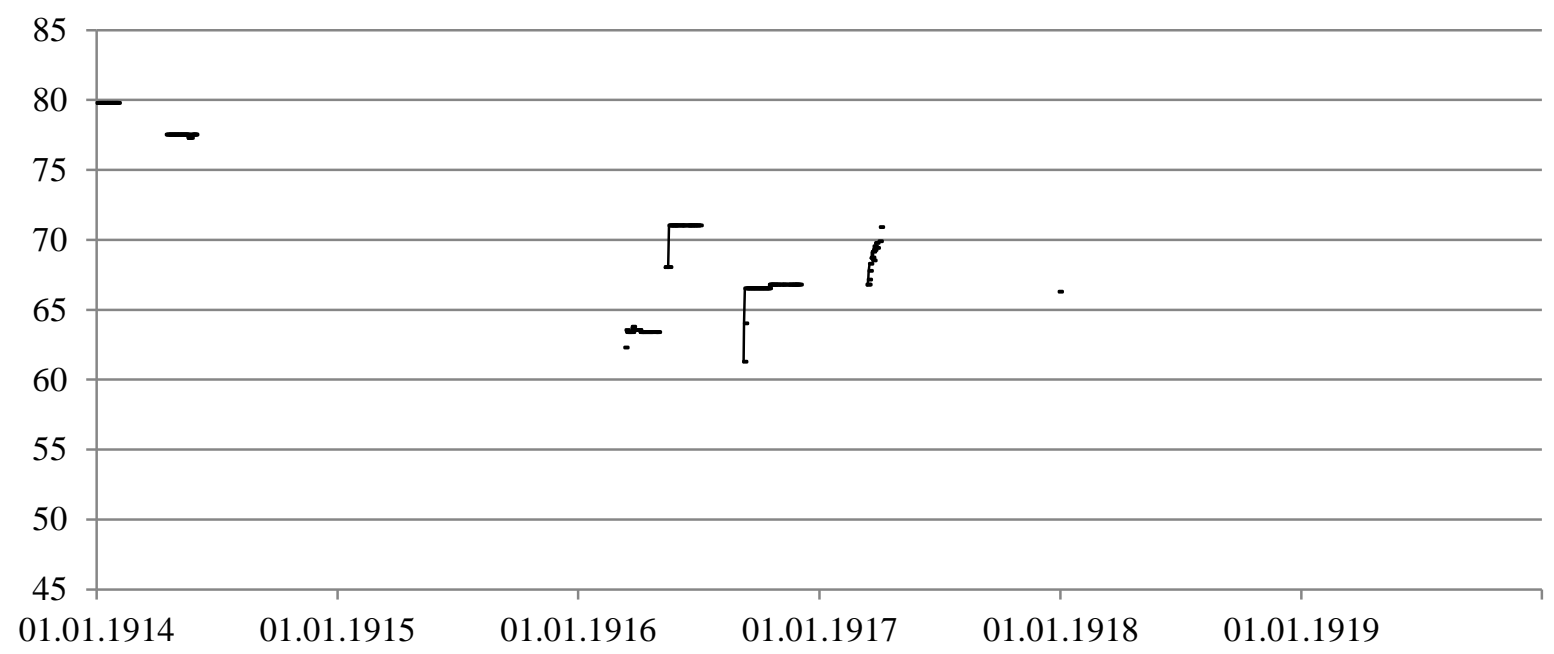


(85) Japan $-4.5 \%$ 1st series (100)

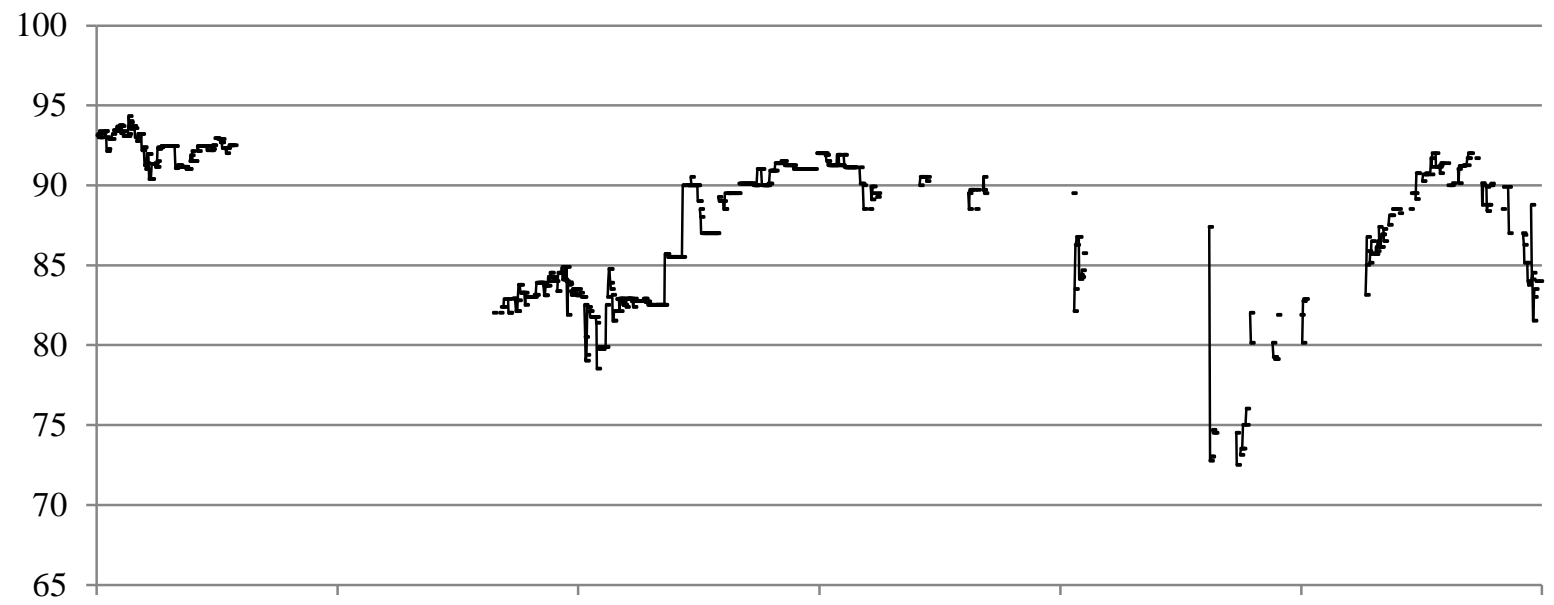

$\begin{array}{llllll}01.01 .1914 & 01.01 .1915 & 01.01 .1916 & 01.01 .1917 & 01.01 .1918 & 01.01 .1919\end{array}$

(86) Japan $-4.5 \%$ 1st series $(200 / 500)$

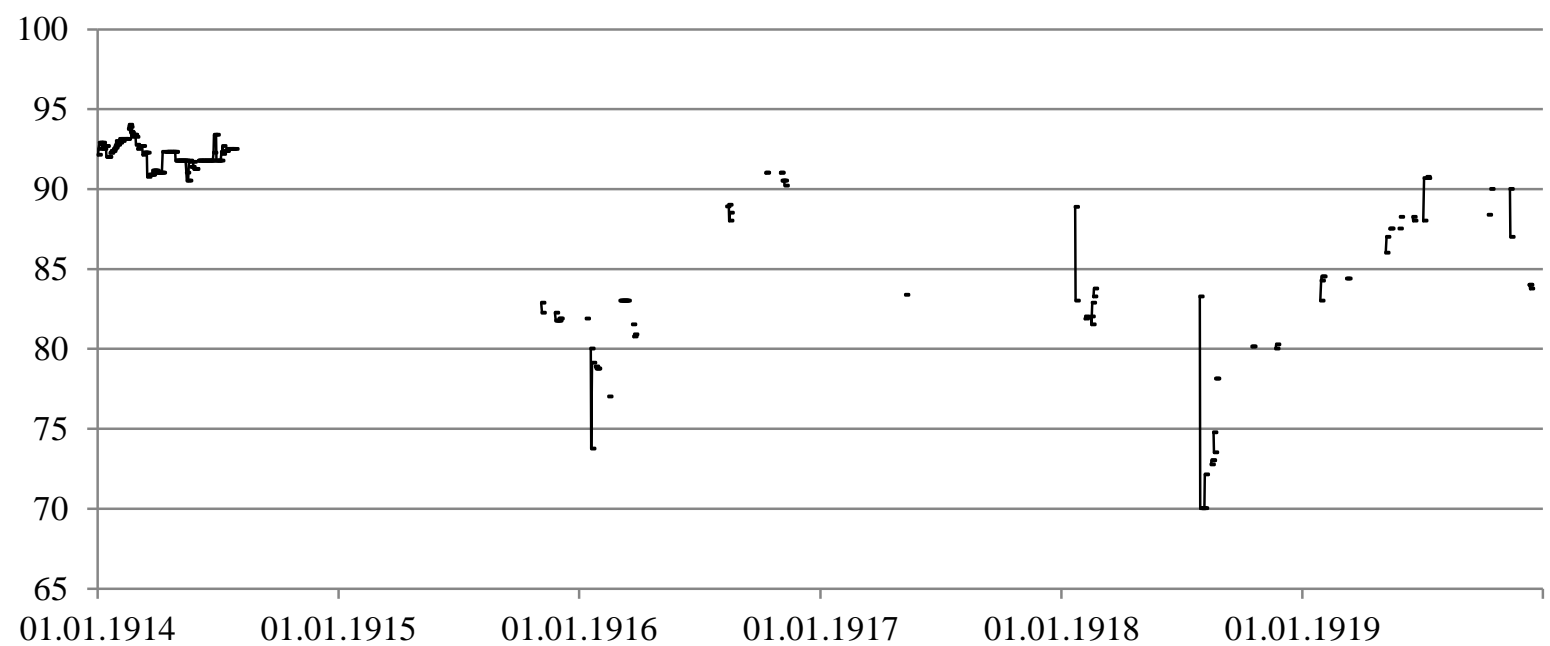

(87) Japan $-4.5 \%$ 2nd series

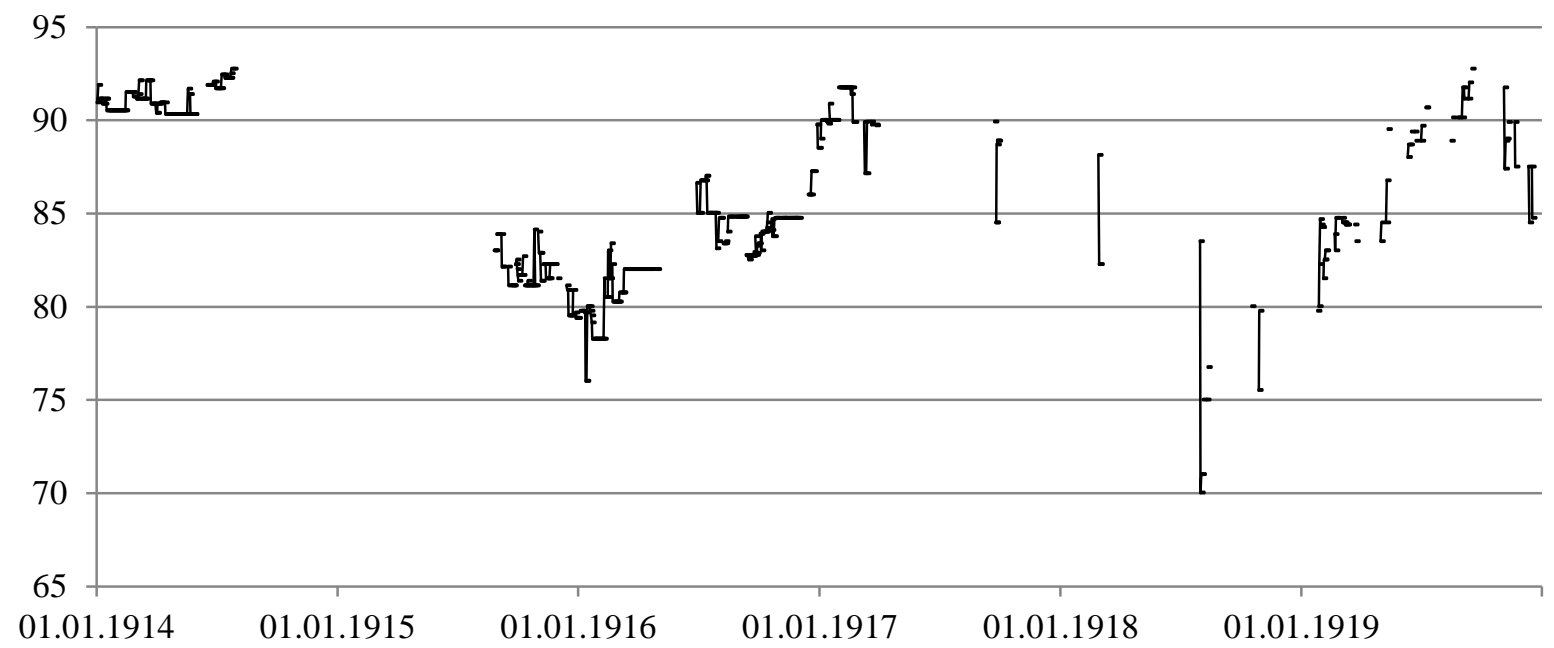


(88) Japan $-5.0 \%$ of 1908/09 (500/1 000)

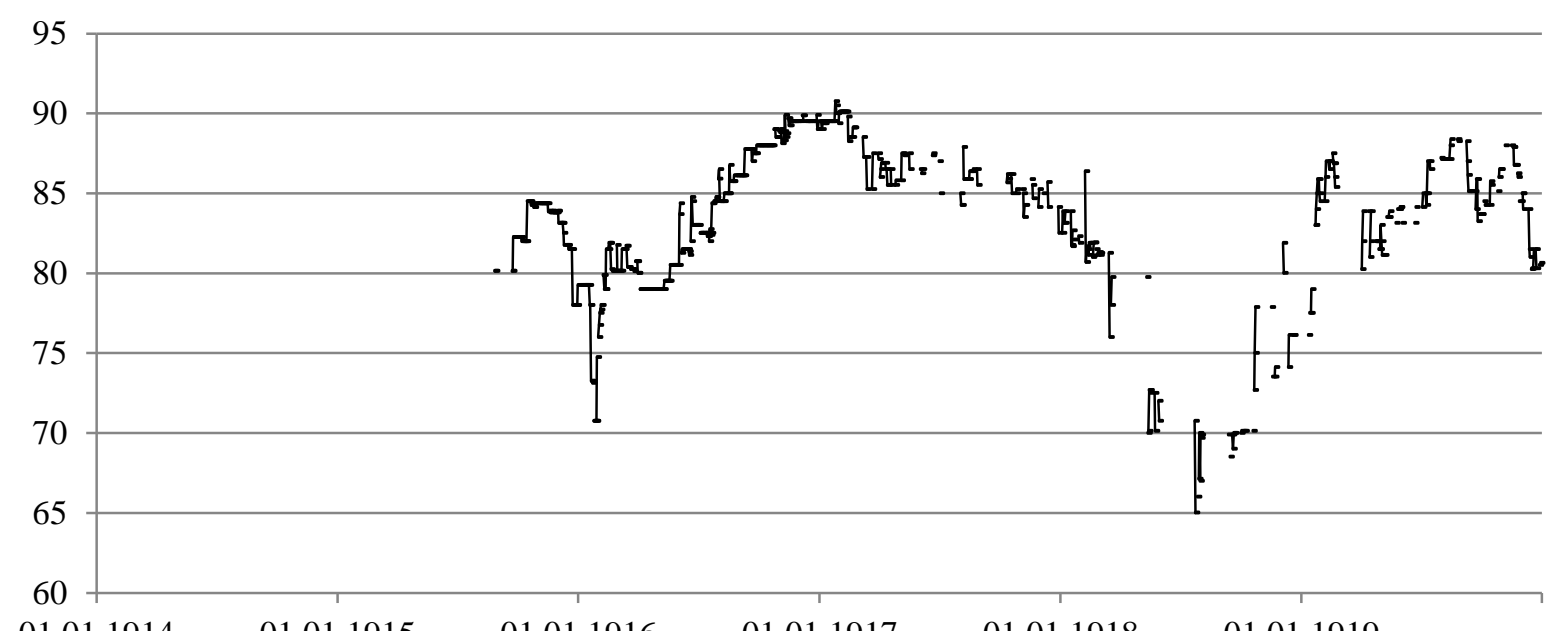

$\begin{array}{llllll}01.01 .1914 & 01.01 .1915 & 01.01 .1916 & 01.01 .1917 & 01.01 .1918 & 01.01 .1919\end{array}$

(89) Japan $-5.0 \%$ of 1908/09 (5 000/10 000)

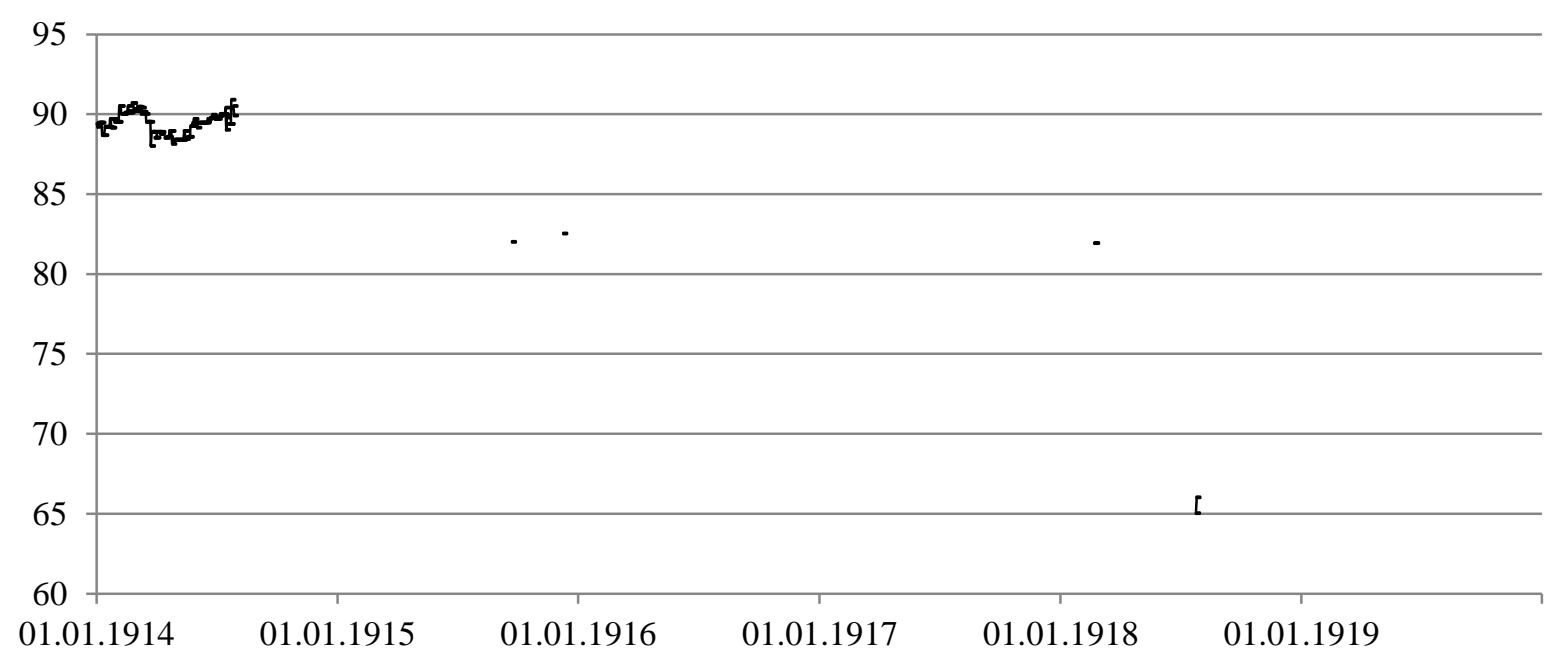

(90) Liberia $-5.0 \%$ of 1913

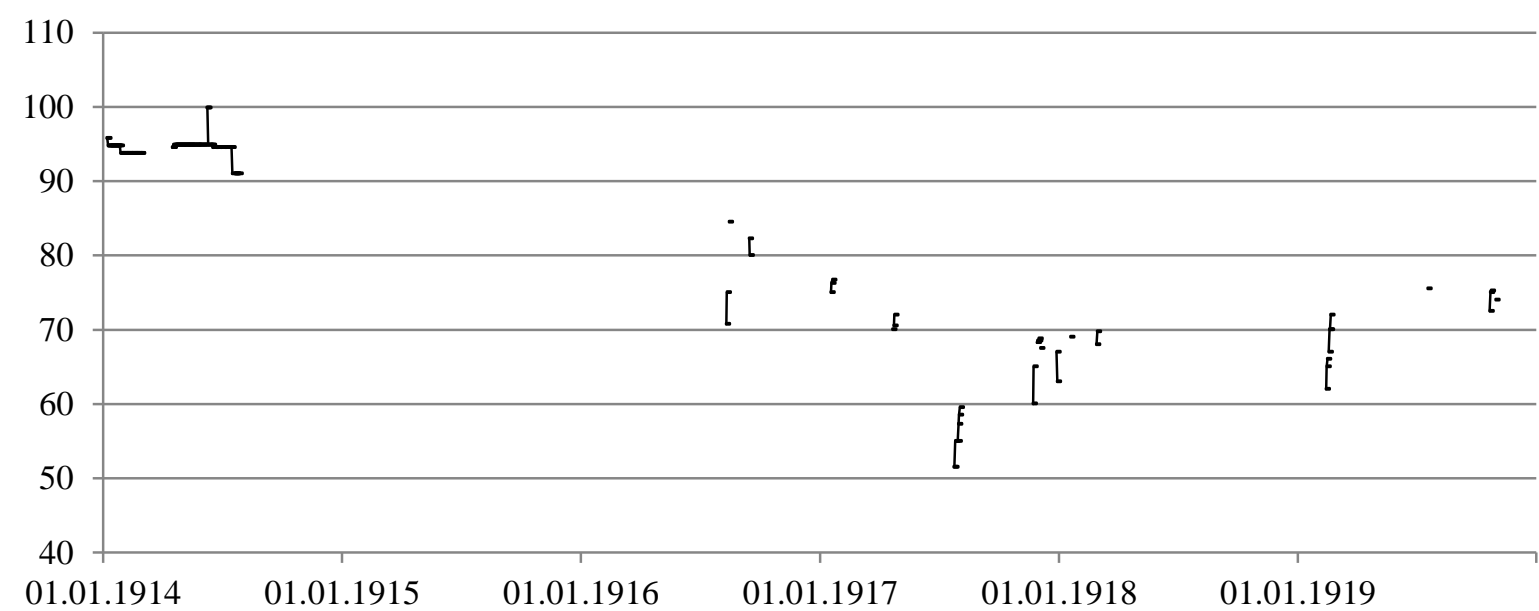


(91) Mexico $-3.0 \%$ of $1886\left(1^{\text {st }}\right.$ ser. $)$

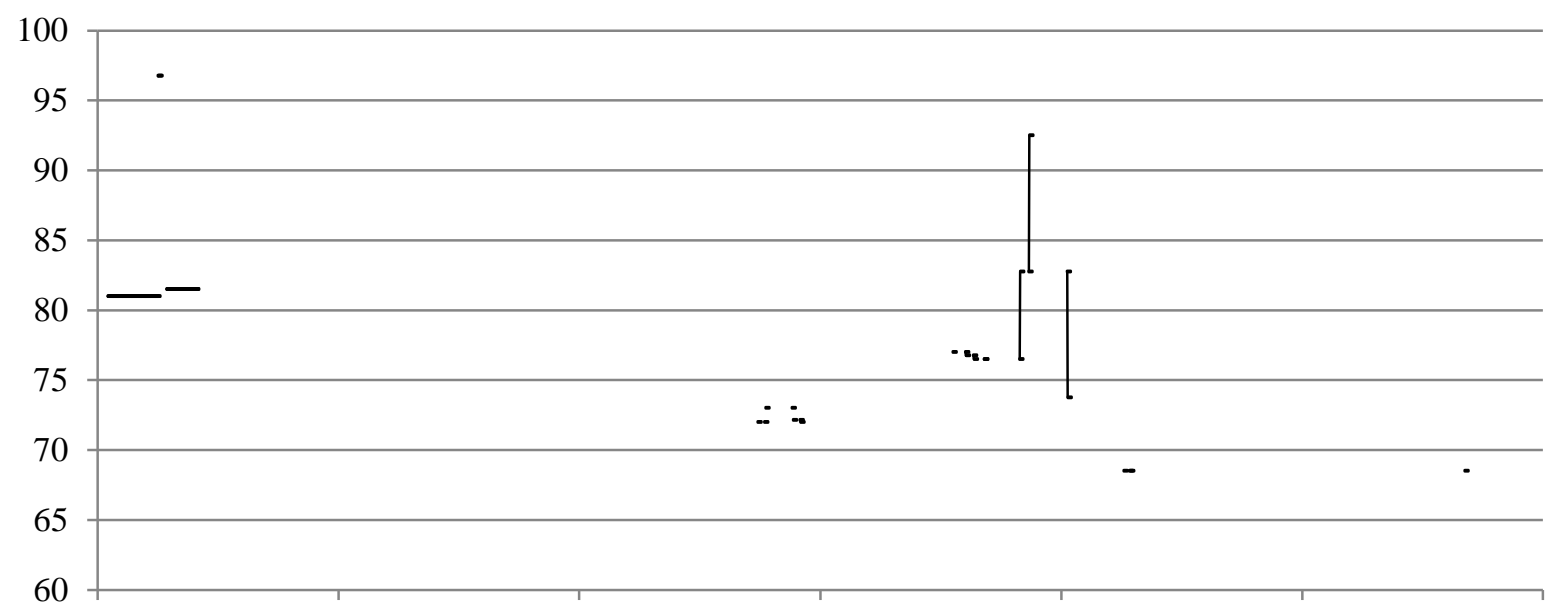

$\begin{array}{llllll}01.01 .1914 & 01.01 .1915 & 01.01 .1916 & 01.01 .1917 & 01.01 .1918 & 01.01 .1919\end{array}$

(92) Mexico $-4.0 \%$ of 1904

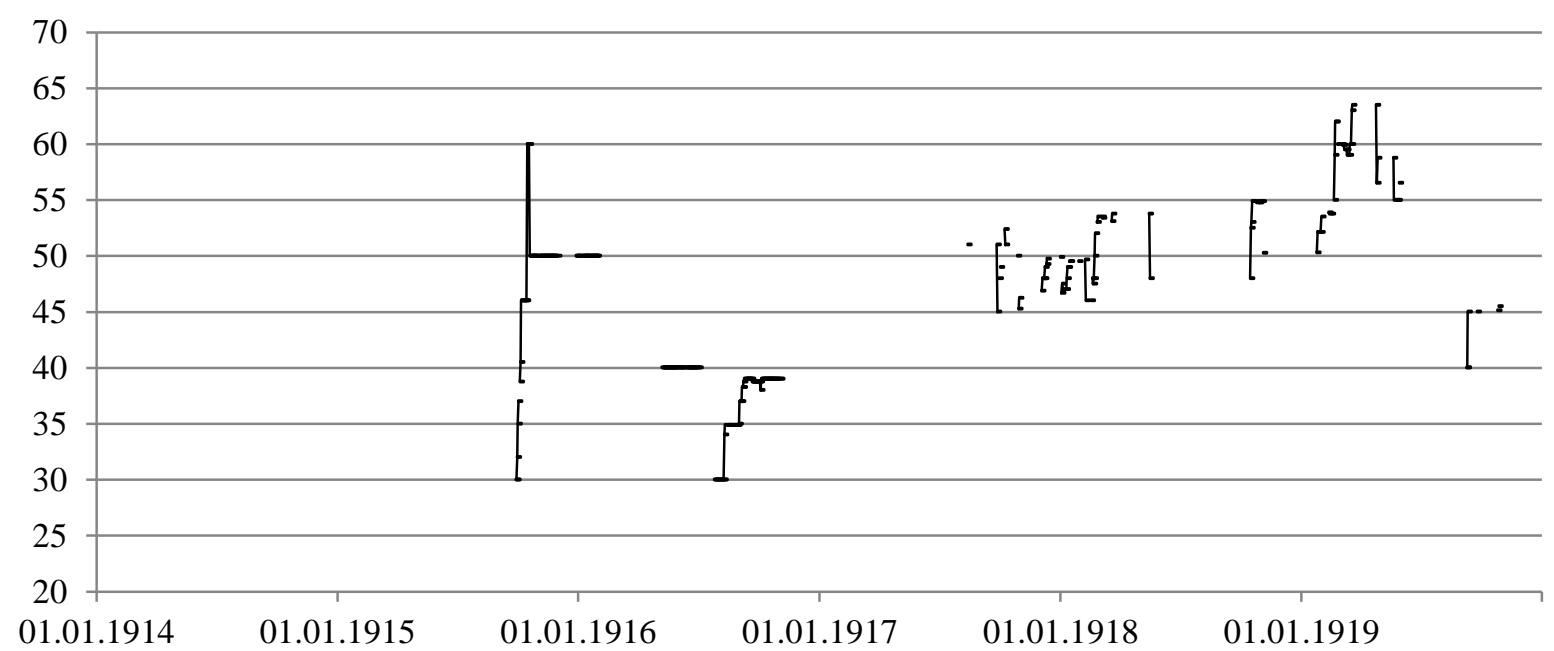

(93) Mexico $-5.0 \% 1^{\text {st }}-4^{\text {th }}$ series $(100 / 1000)$

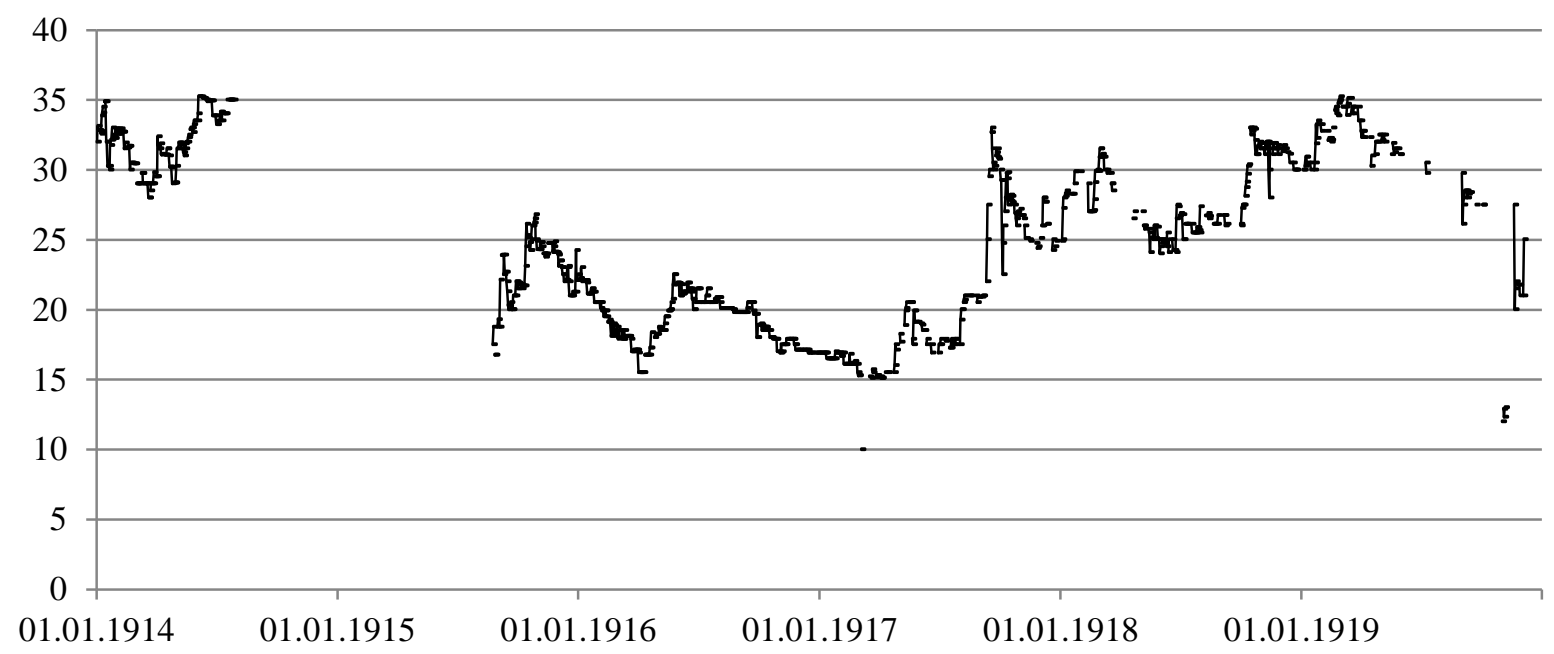


(94) Mexico $-5.0 \% 5^{\text {th }}$ series

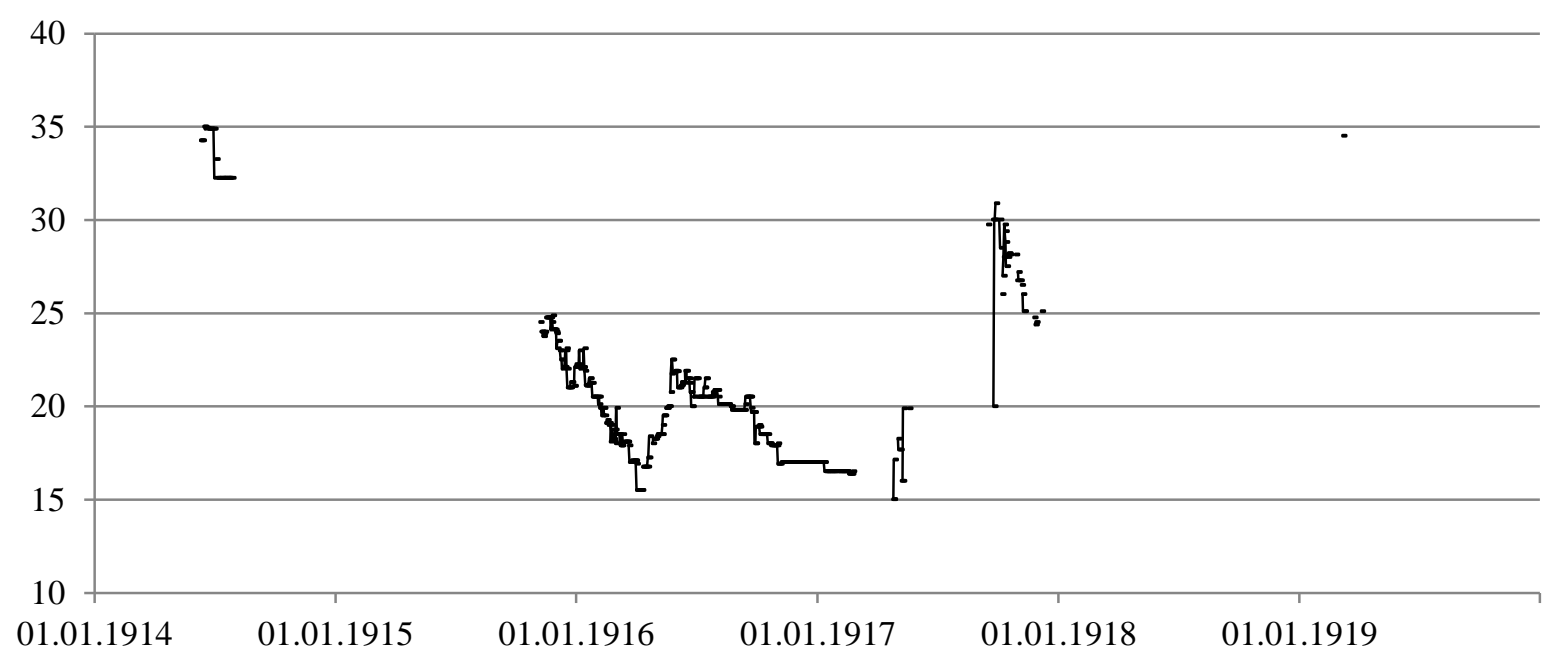

(95) Mexico - $5.0 \%$ of 1899 (20/100)

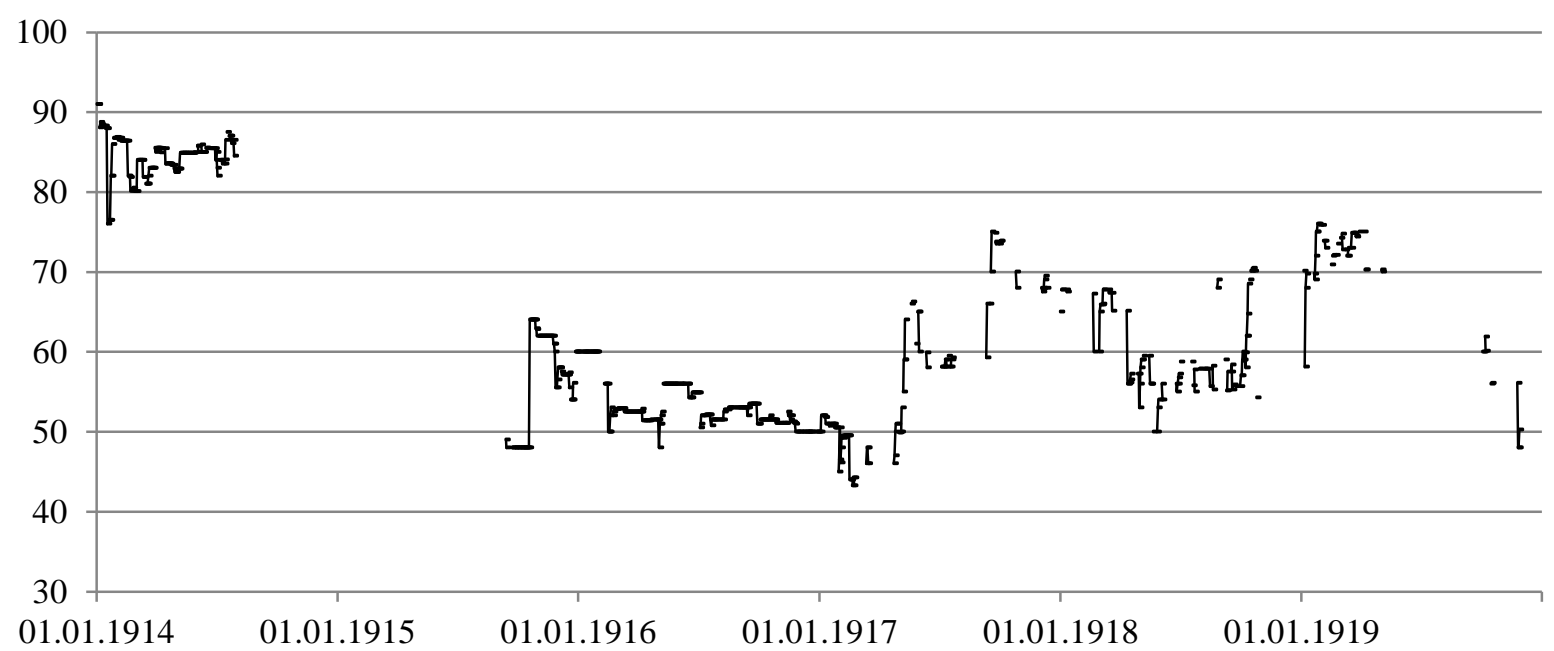

(96) Mexico - 5.0 \% of 1899 (200/1 000)

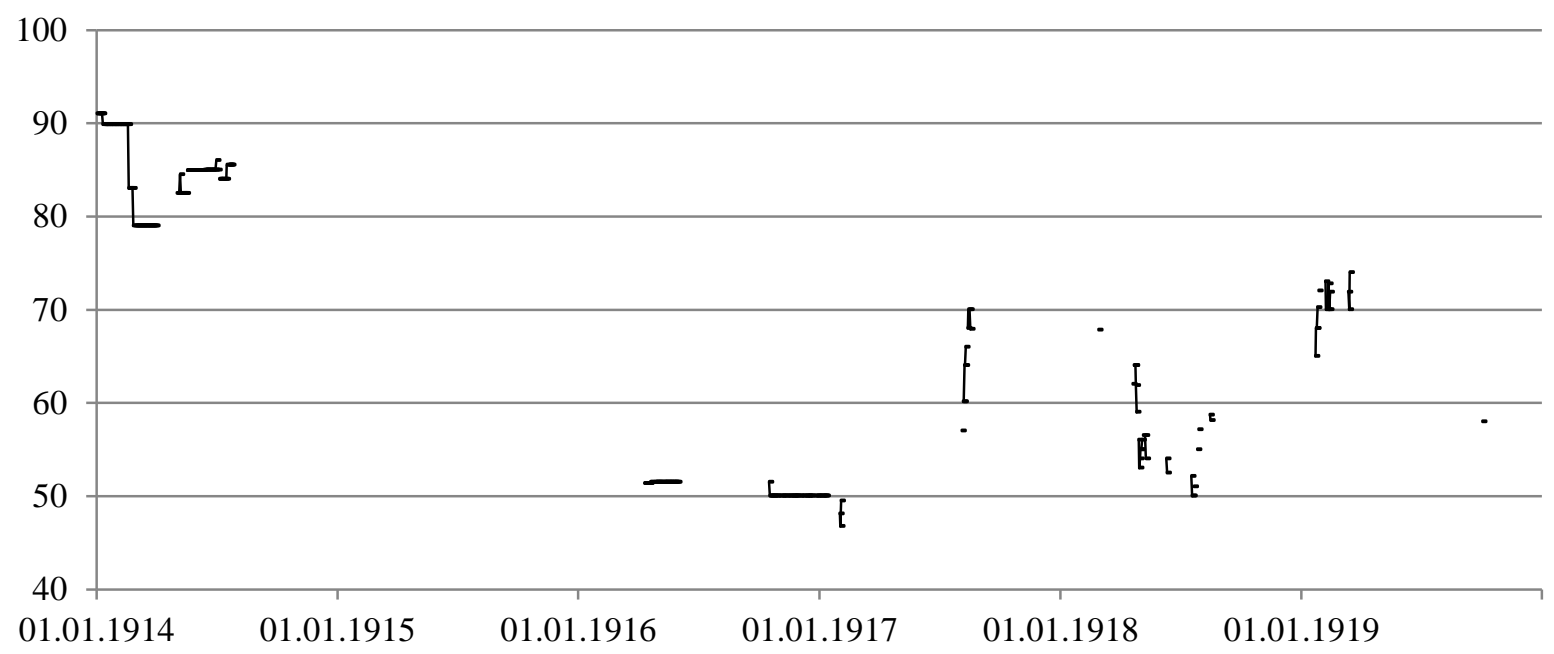


(97) Mexico - $5.0 \%$ Vera Cruz

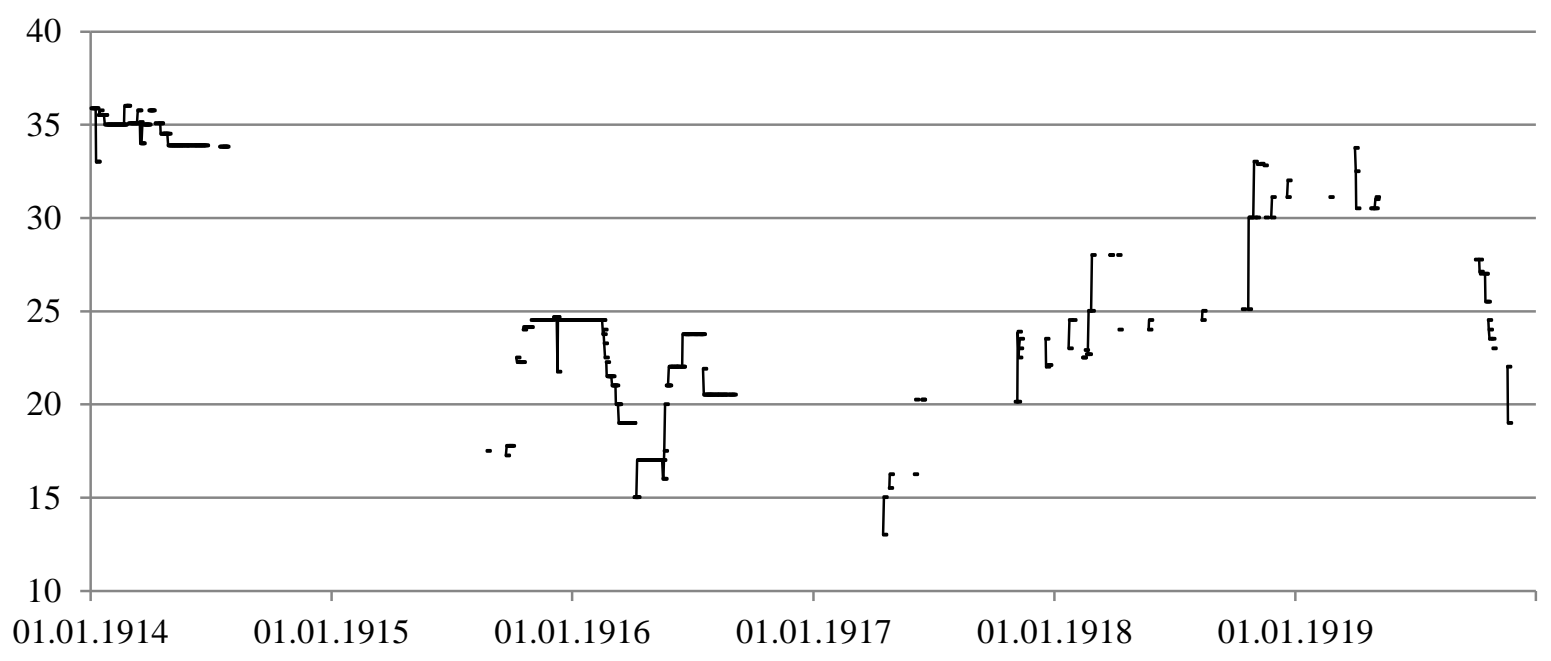

(98) Netherlands $-2.5 \%$ grootboek

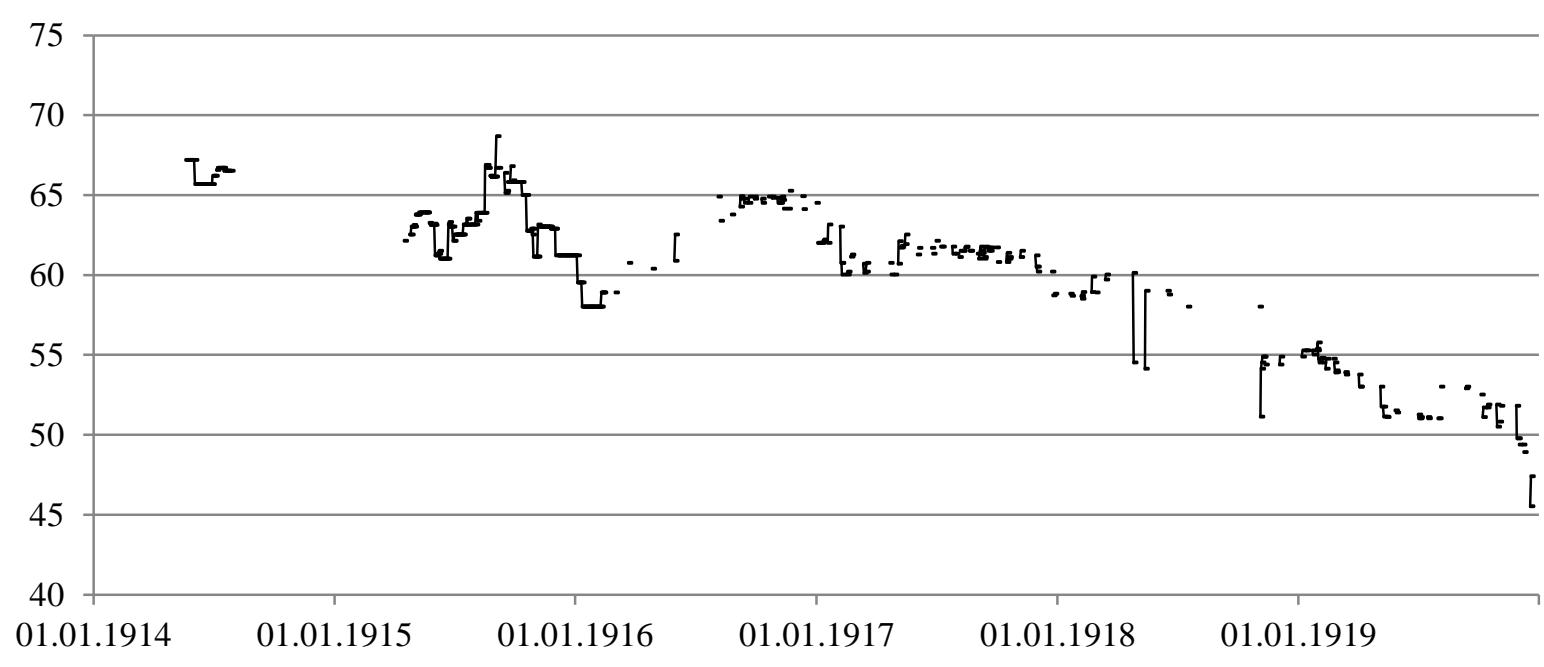

(99) Netherlands $-2.5 \%$ certificates

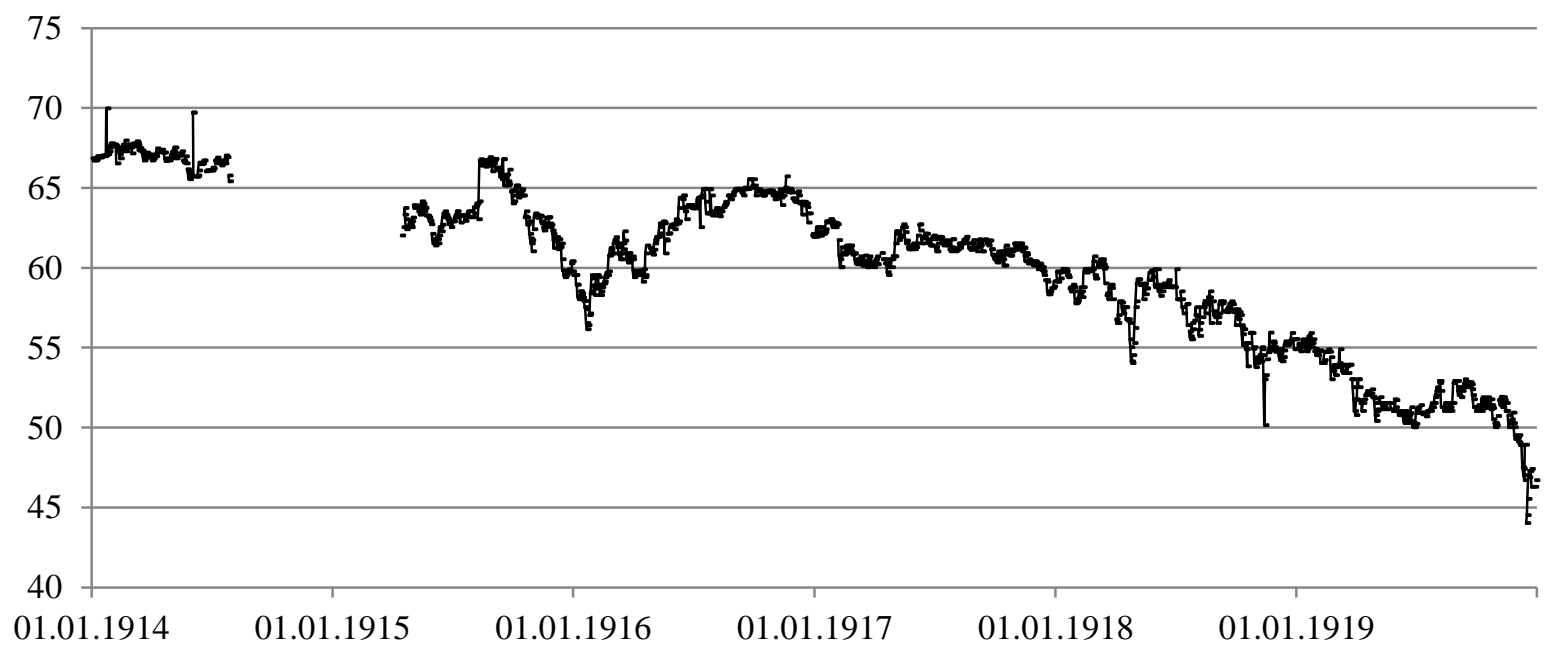

64 
(100) Netherlands $-3.0 \%$ grootboek

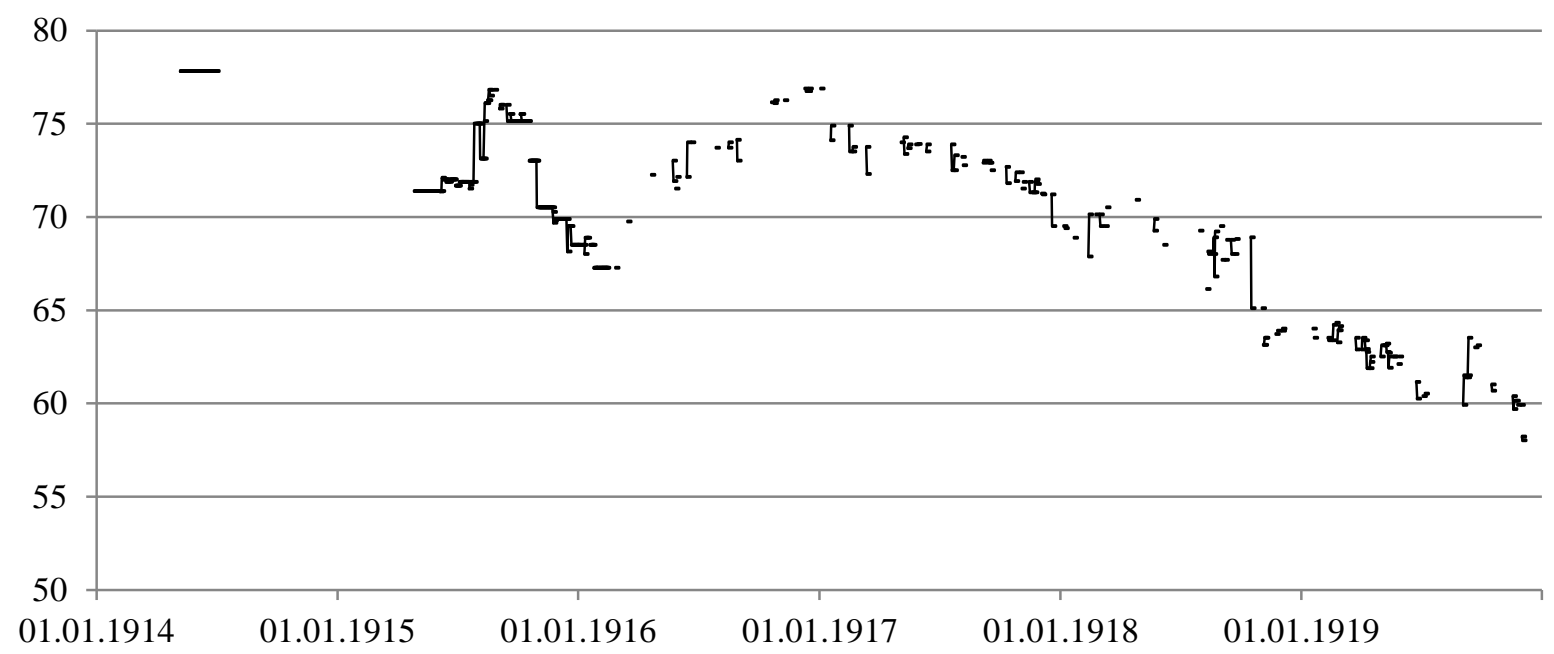

(101) Netherlands - $3.0 \%$ NWS

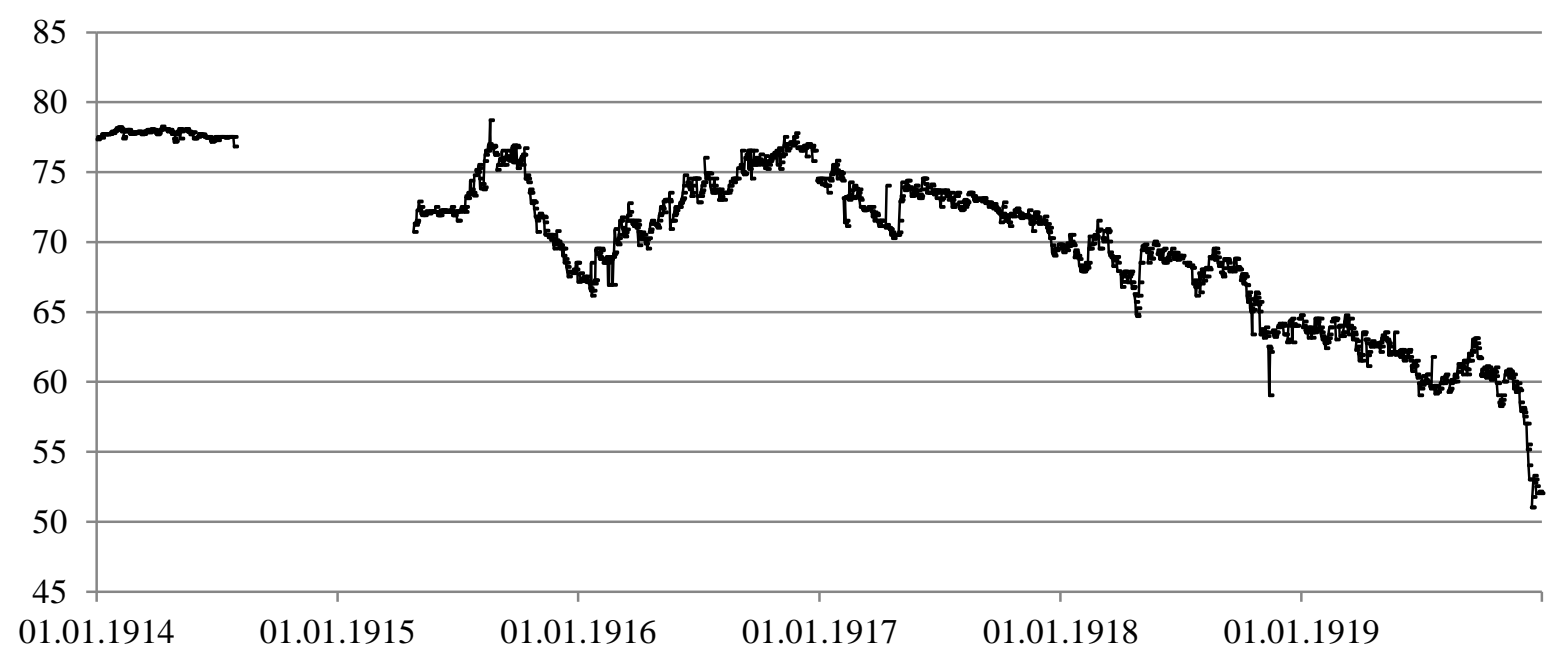

(102) Netherlands $-3.0 \%$ certificates

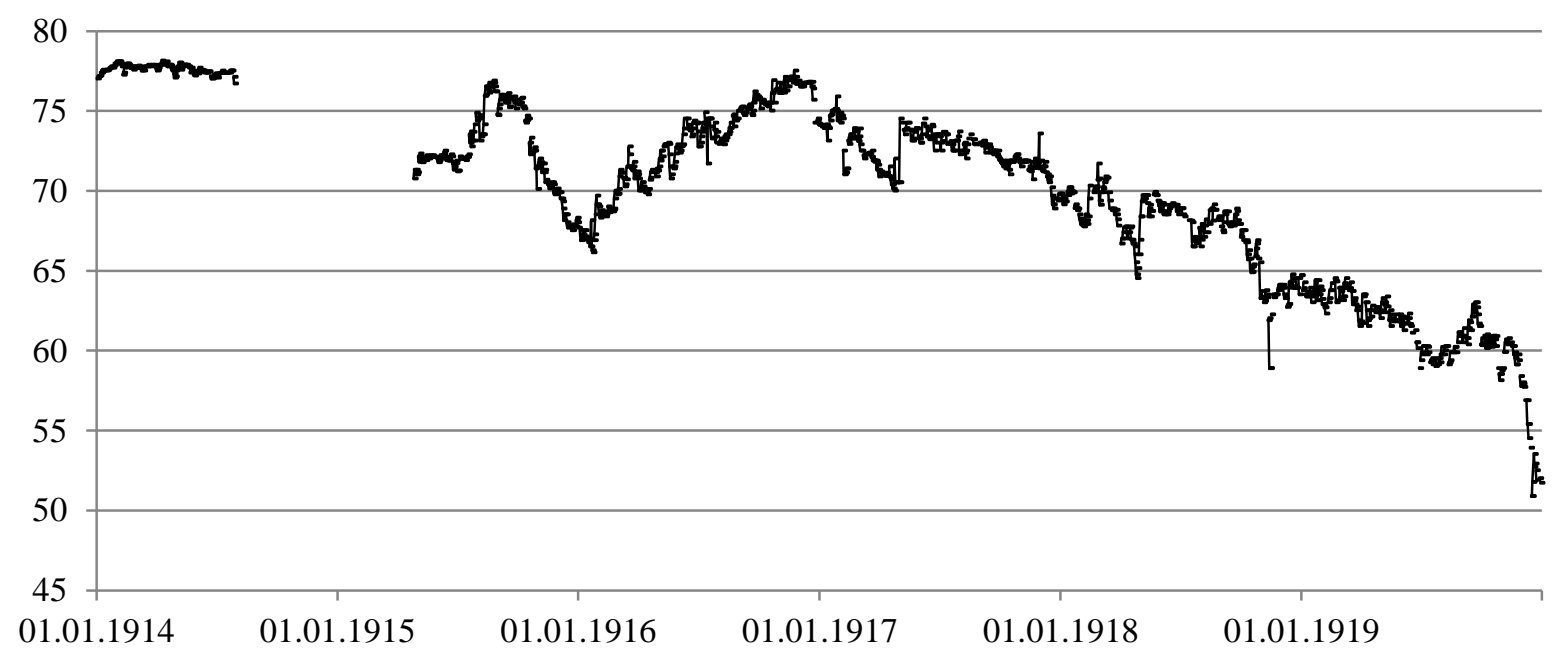


(103) Netherlands - $3.5 \%$ NWS

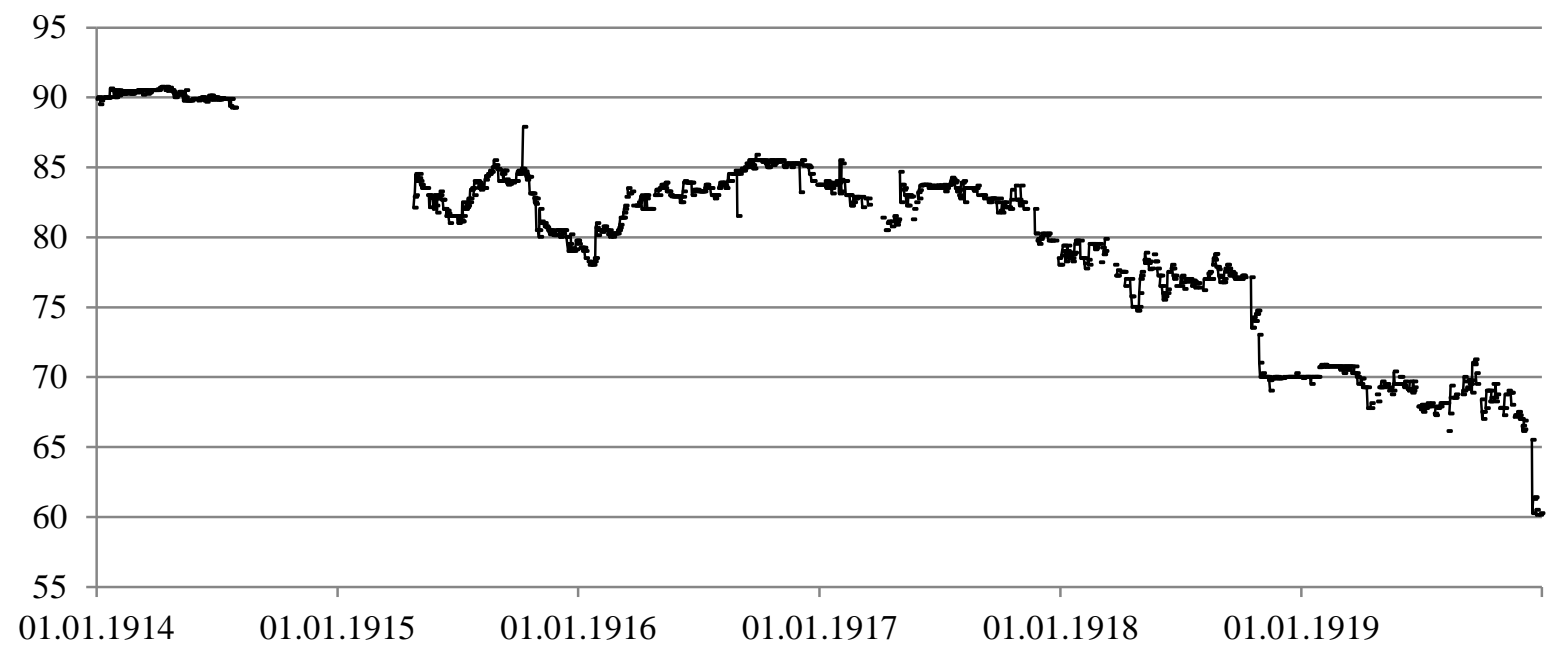

(104) Netherlands $-4.0 \%$ of 1916 (100)

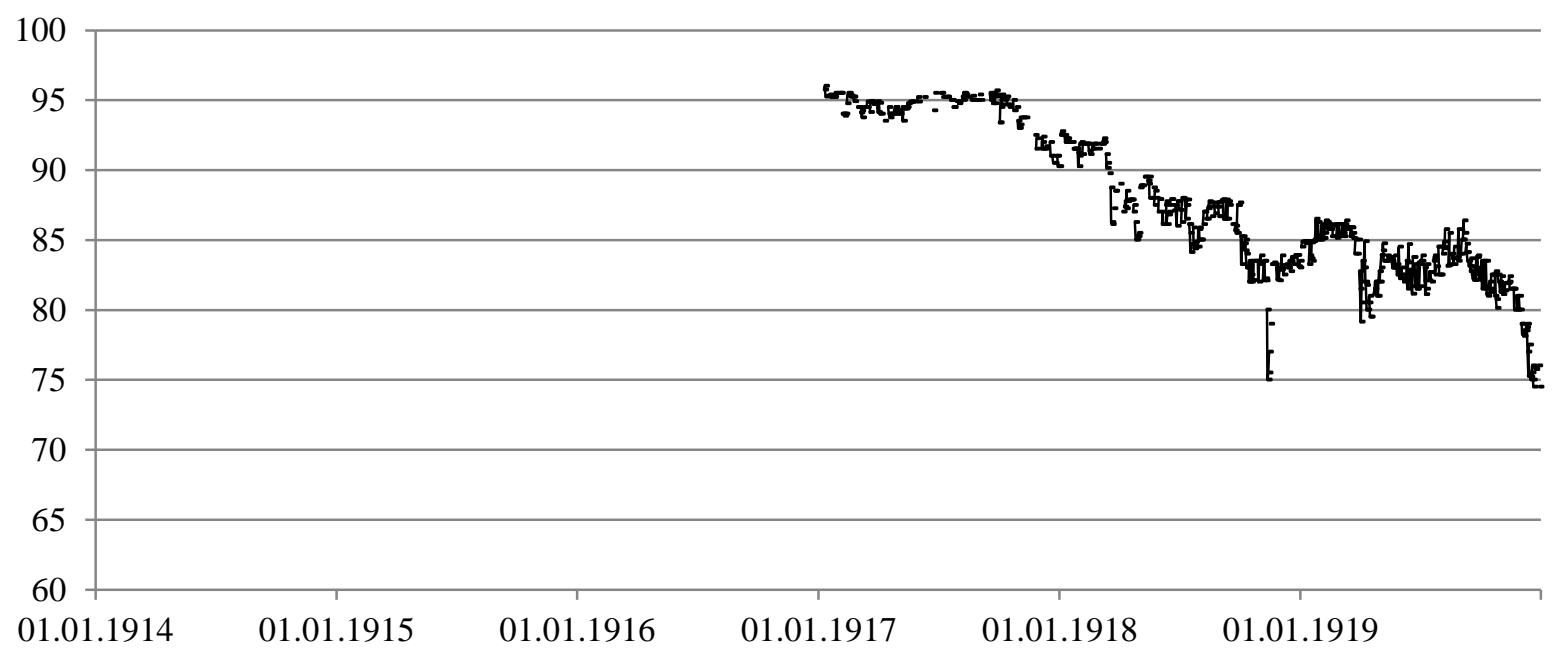

(105) Netherlands $-4.0 \%$ of 1916 (500)

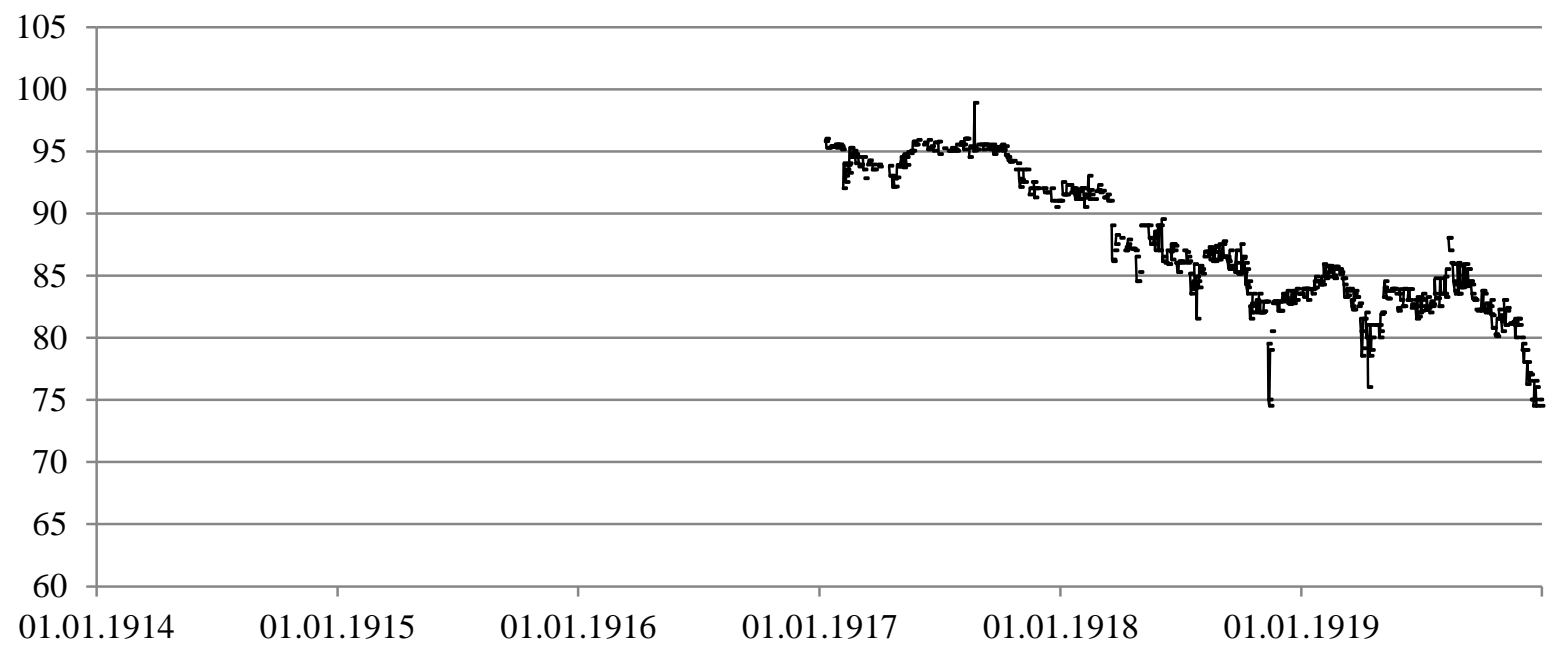


(106) Netherlands $-4.0 \%$ of $1916(1000)$

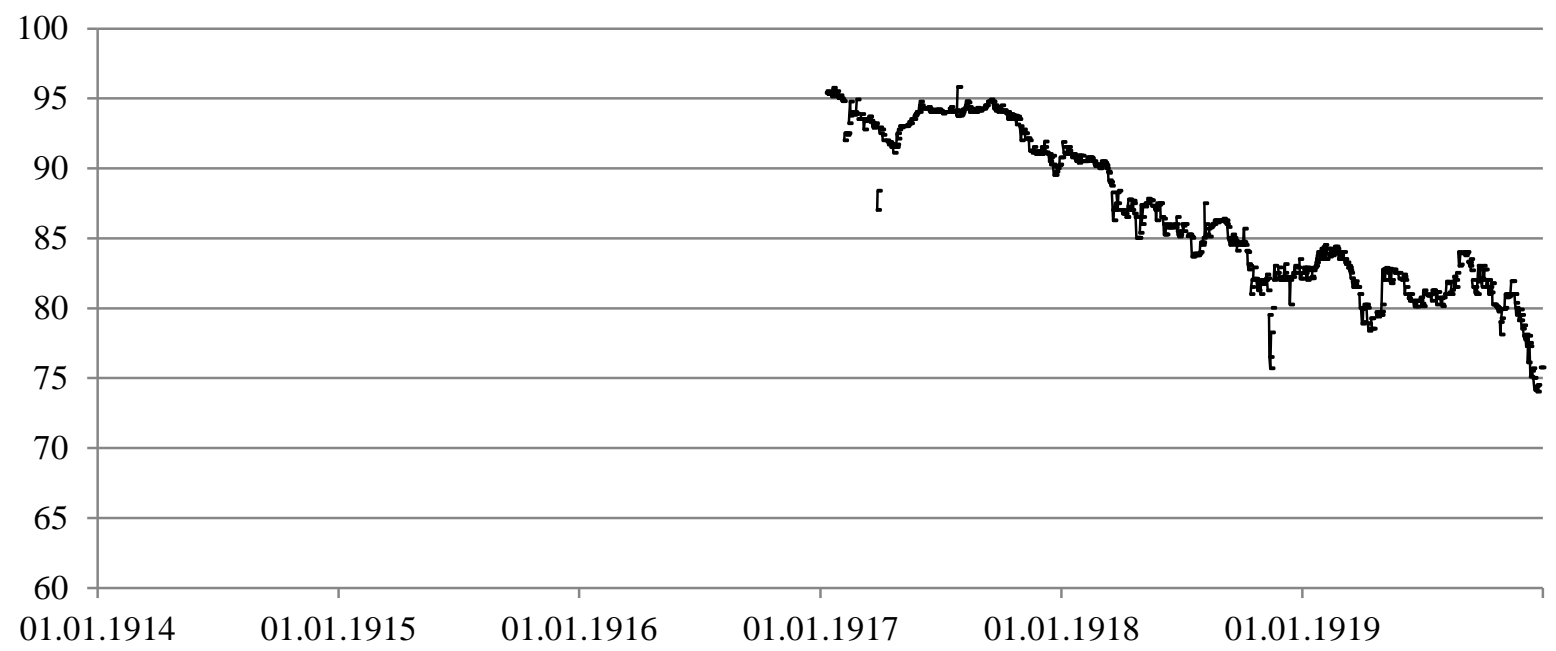

(107) Netherlands $-4.5 \%$ NWS (100)

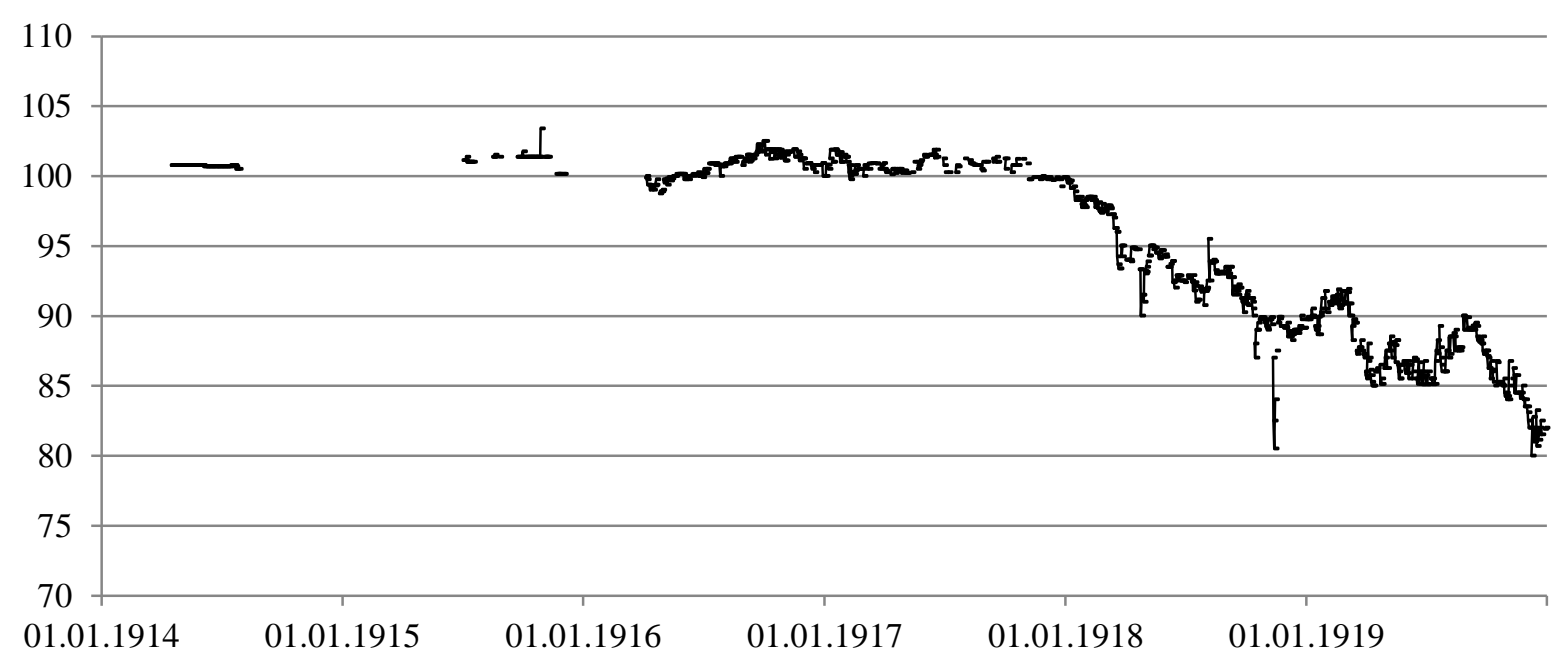

(108) Netherlands $-4.5 \%$ NWS (500)

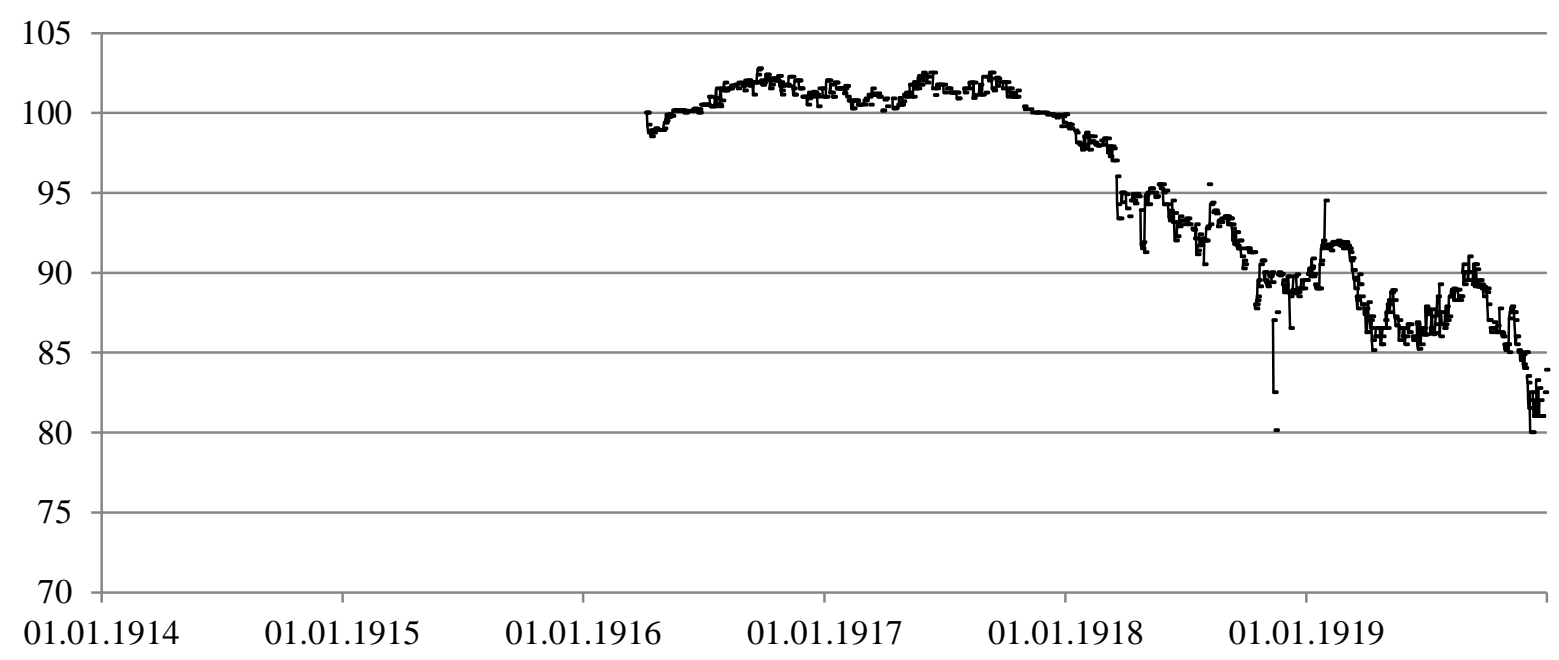


(109) Netherlands - $4.5 \%$ NWS (1 000)

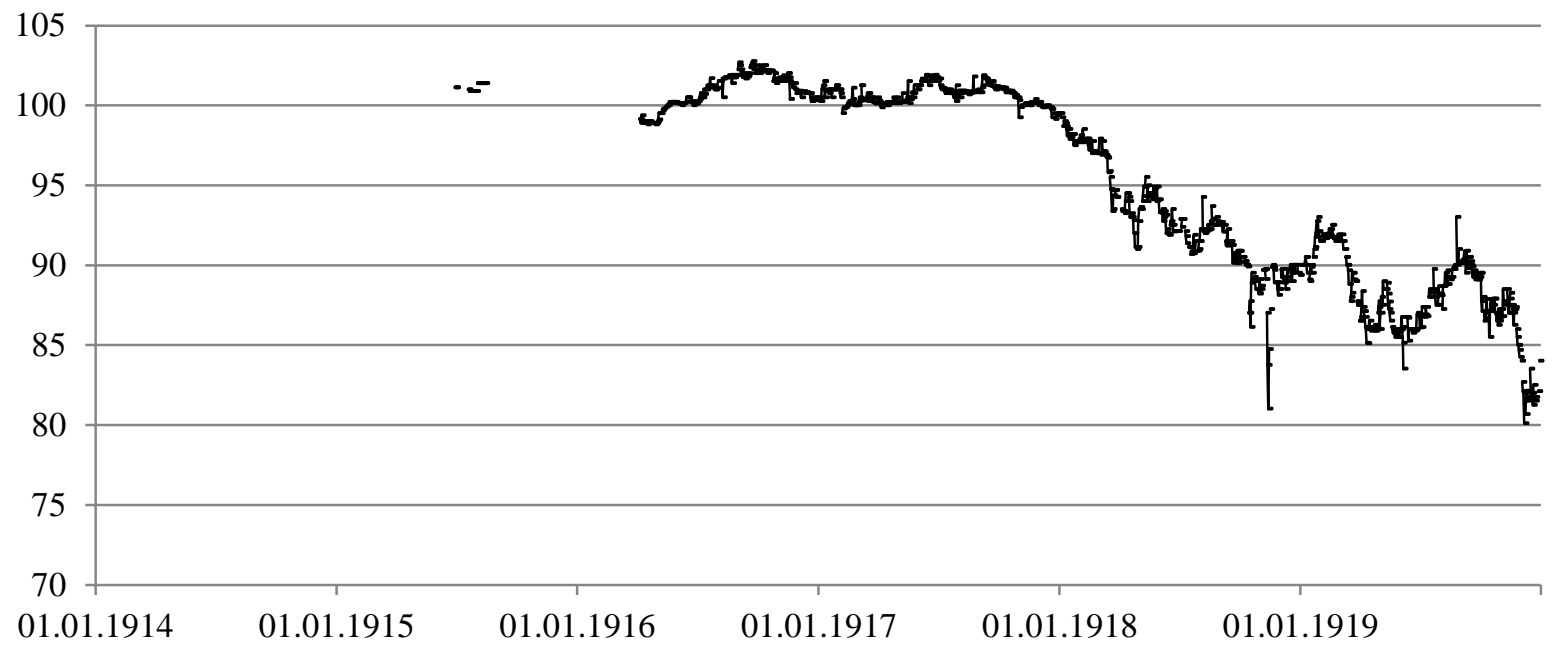

(110) Netherlands $-4.5 \%$ of 1917 (100)

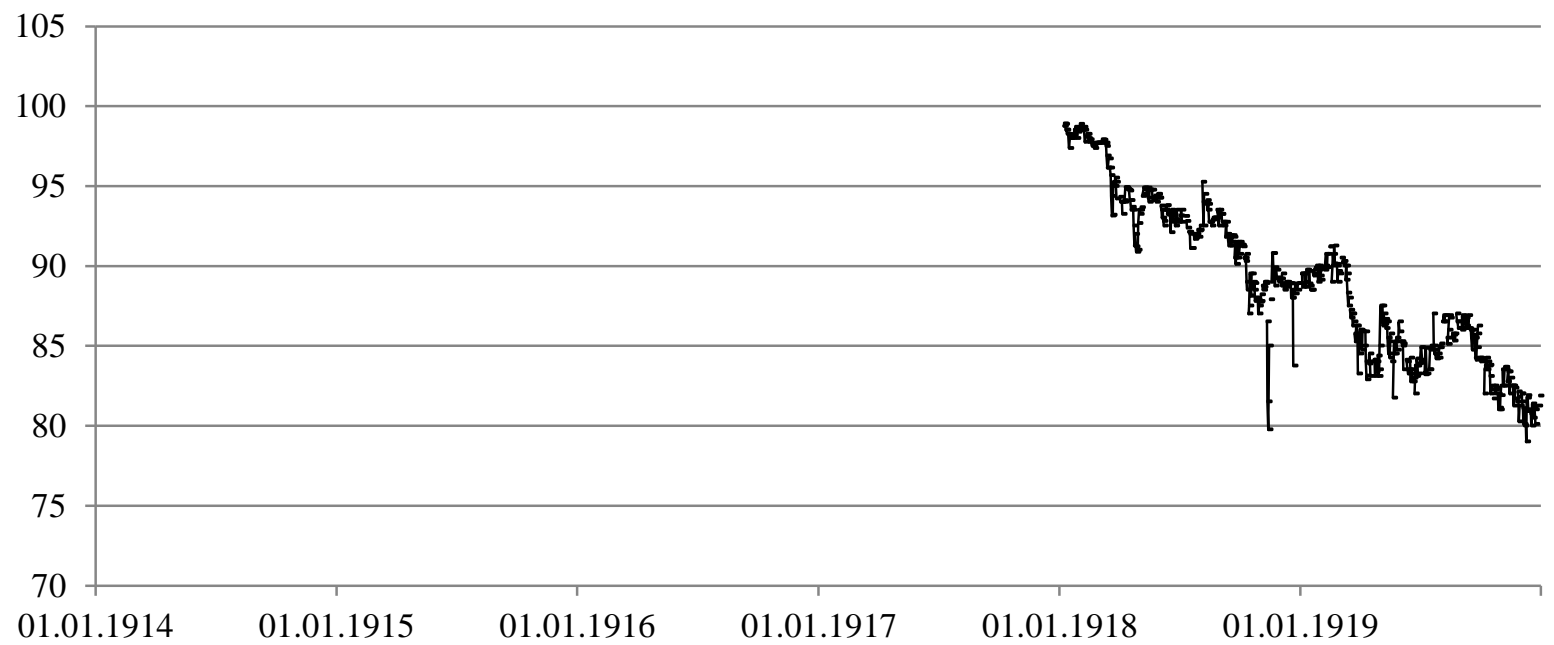

(111) Netherlands $-4.5 \%$ of 1917 (500)

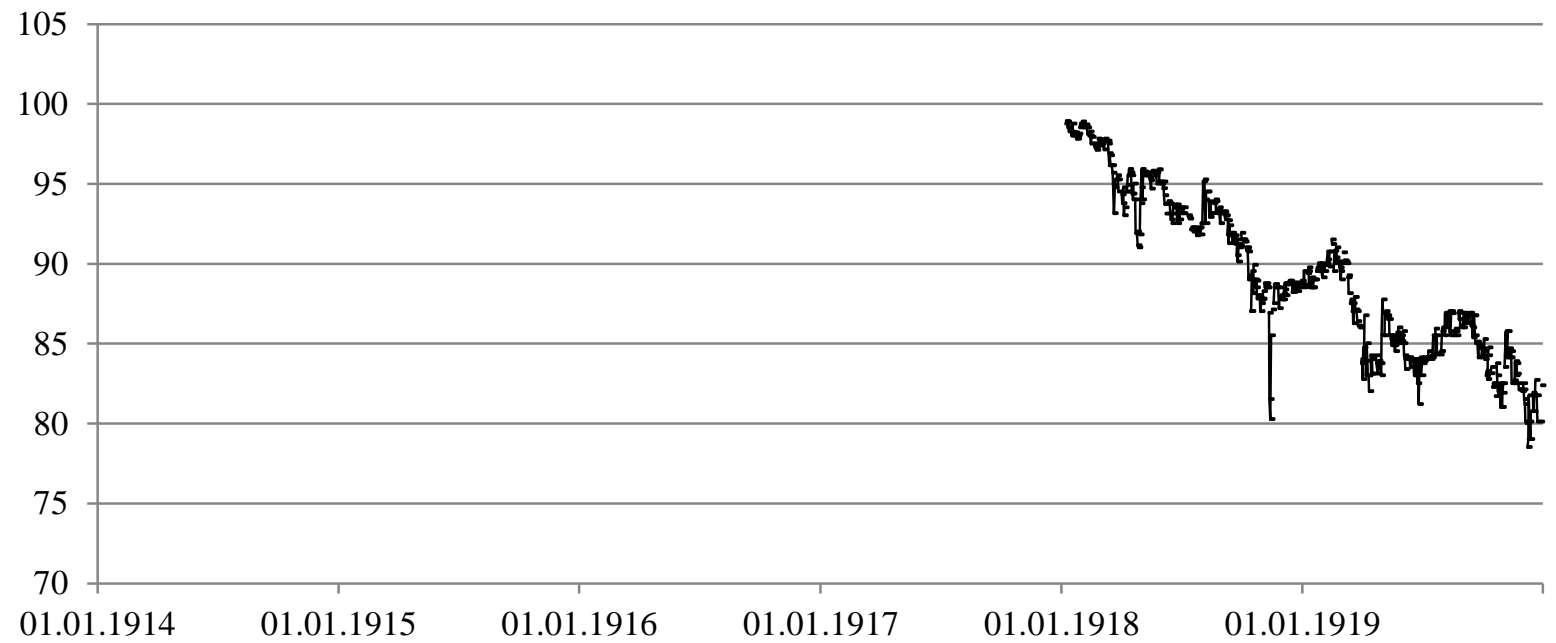


(112) Netherlands $-4.5 \%$ of 1917 (1 000)

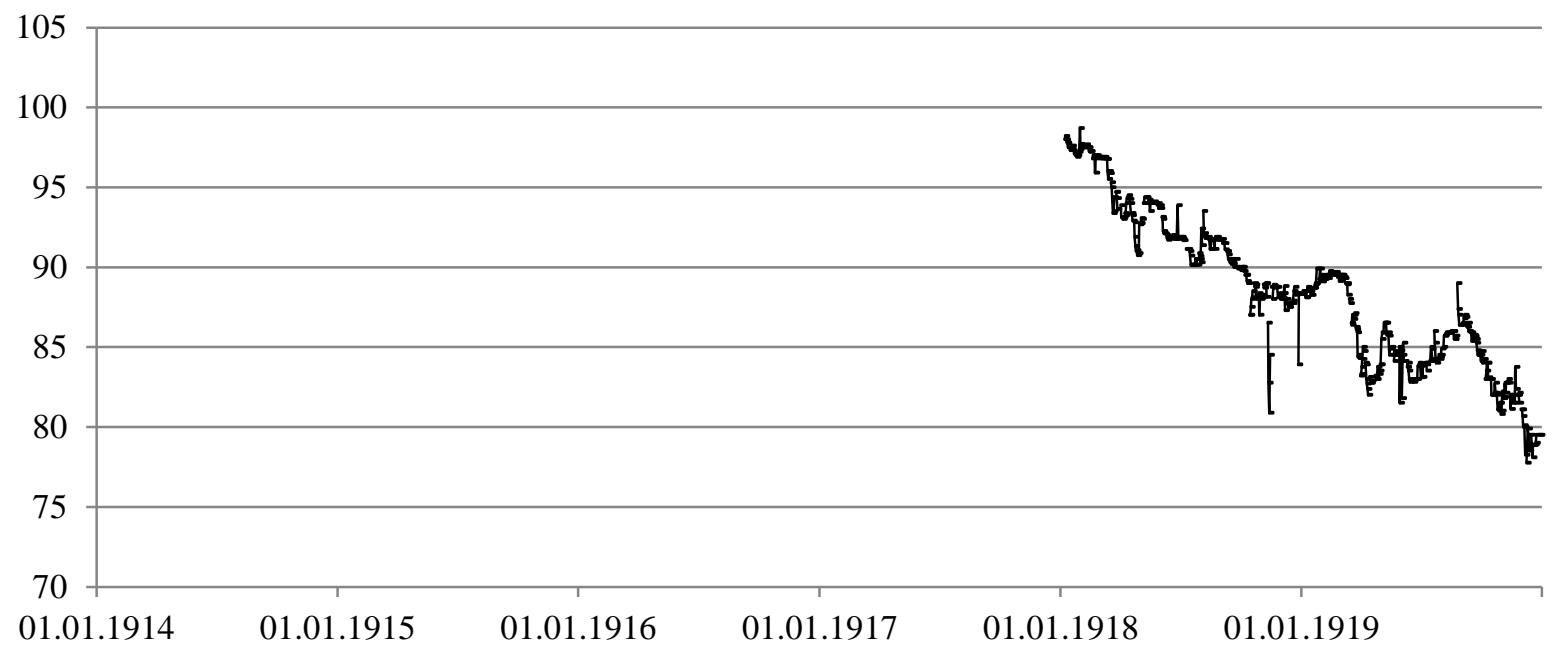

(113) Netherlands - 5.0\% NWS (100)

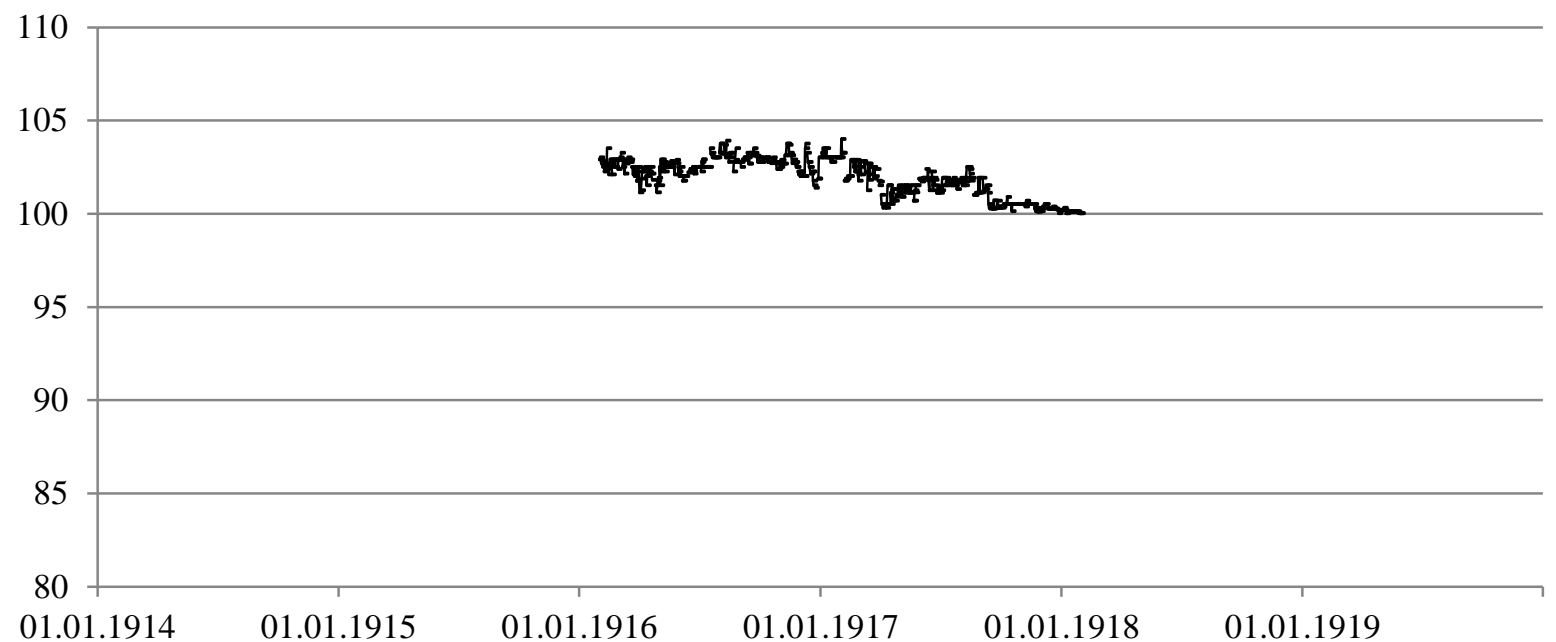

(114) Netherlands - 5.0\% NWS (200)

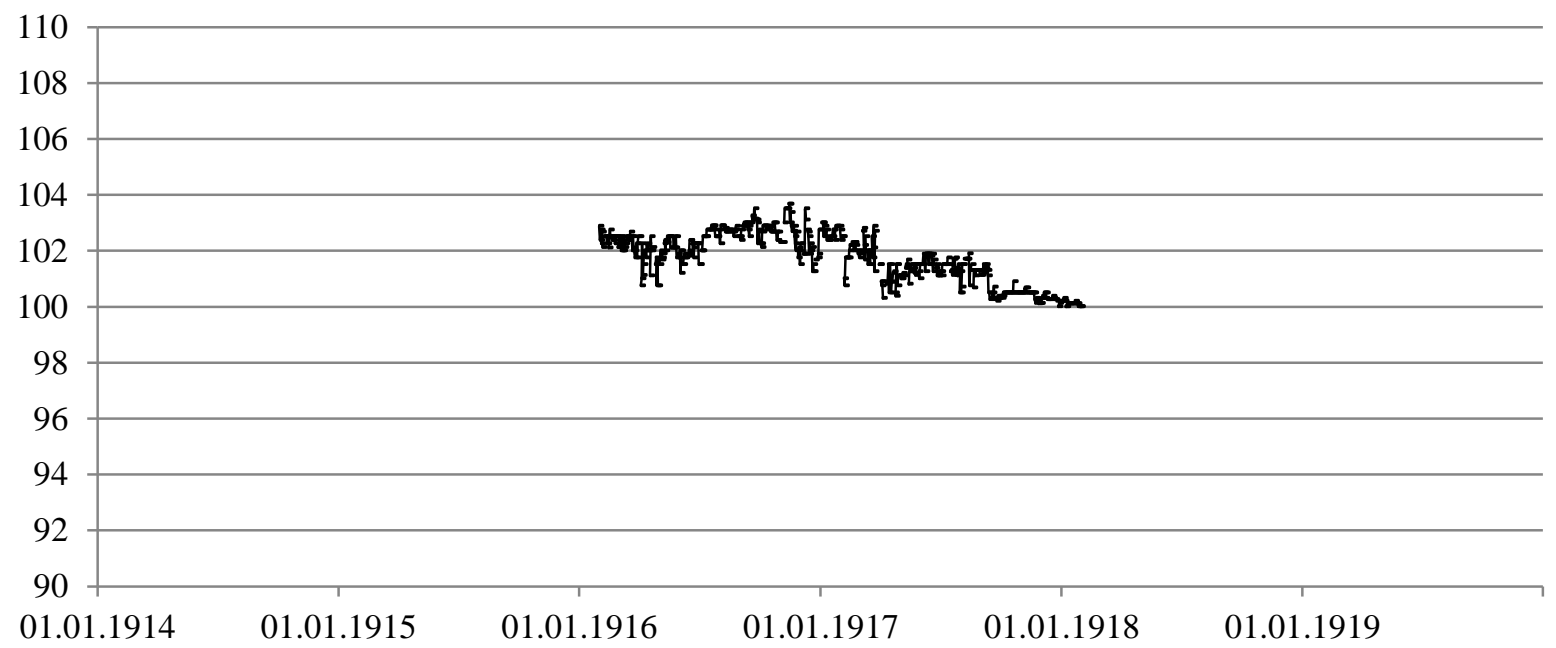


(115) Netherlands - 5.0\% NWS (100/200)

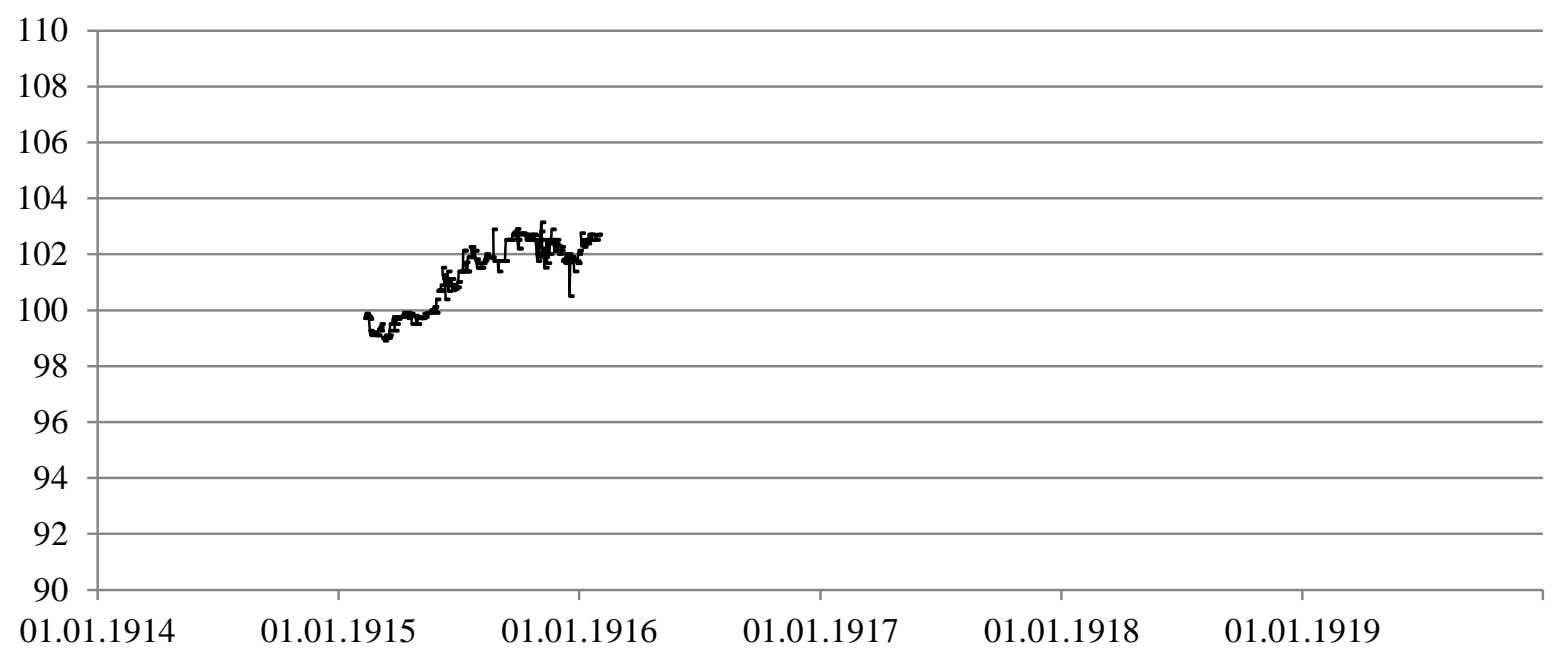

(116) Netherlands - 5.0\% NWS (500)

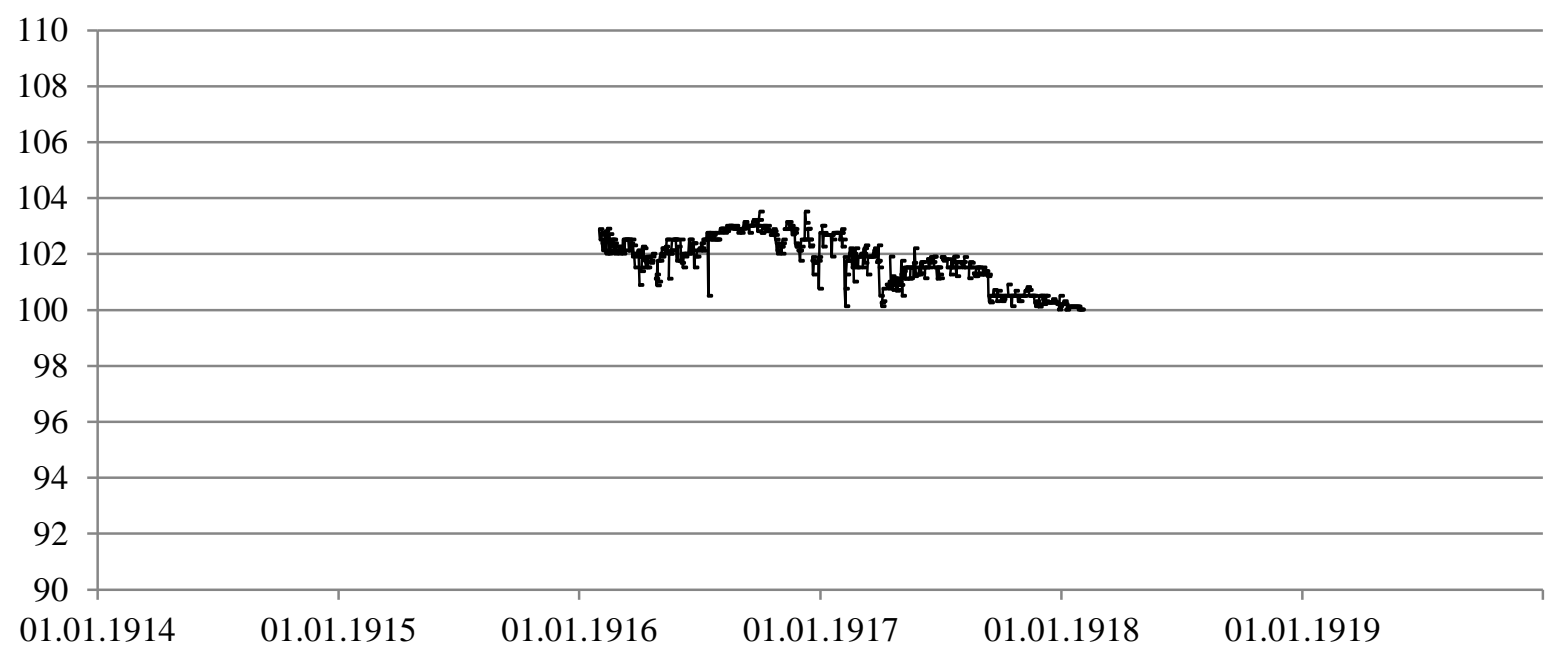

(117) Netherlands - 5.0\% NWS (1 000)

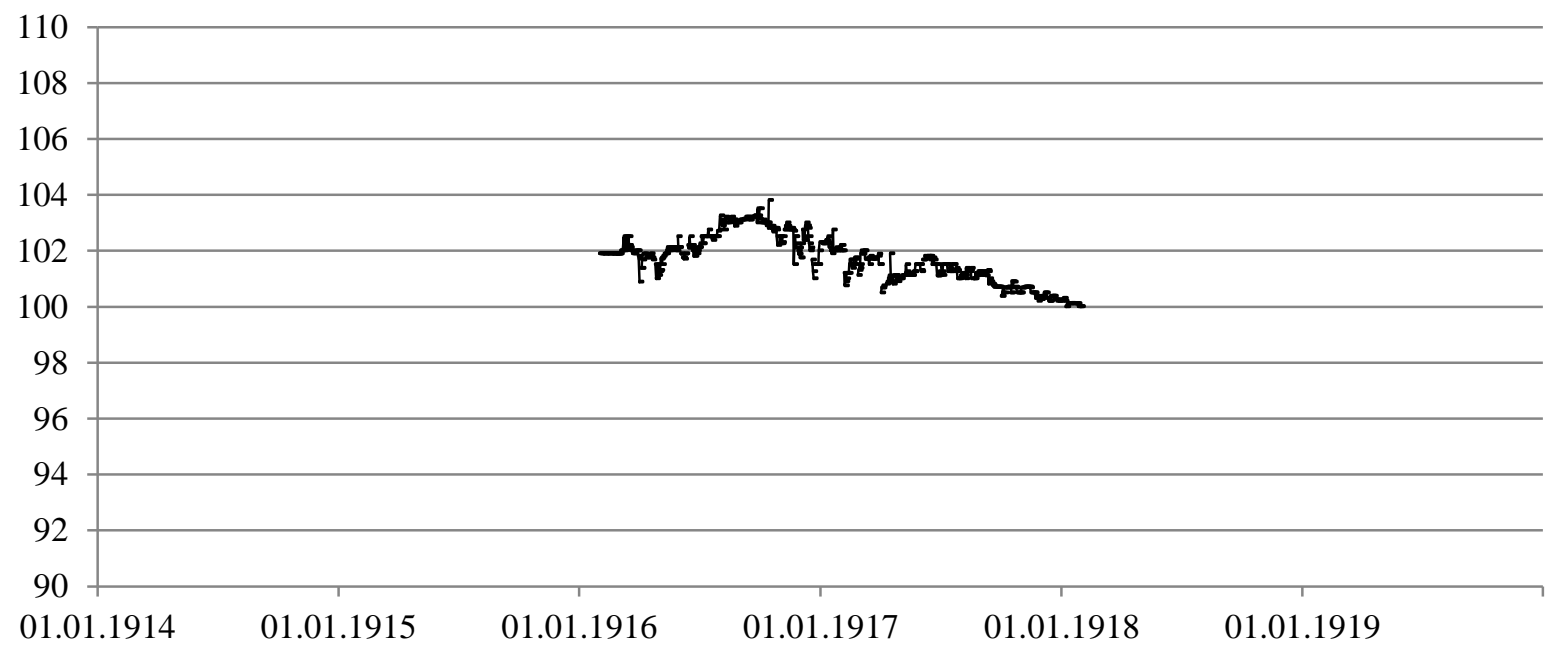


(118) Netherlands $-5.0 \%$ NWS (500/1 000)

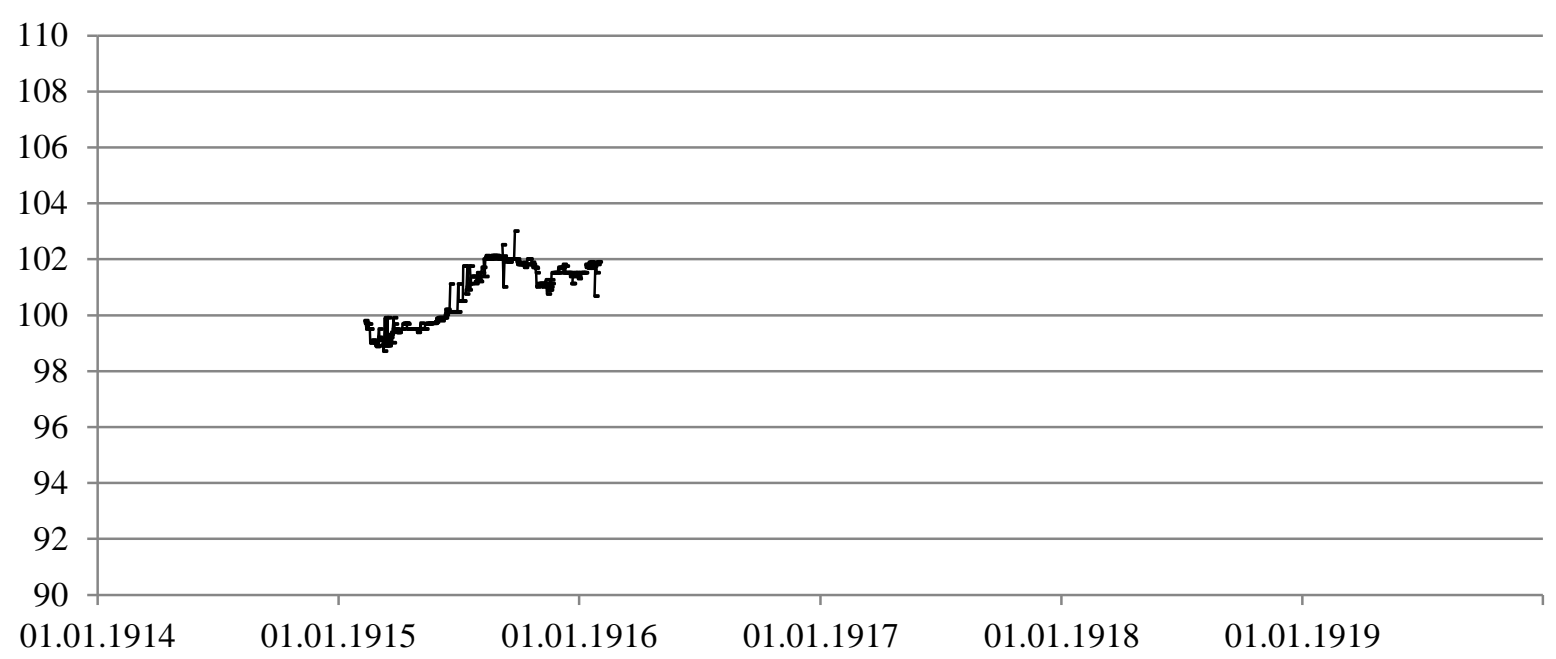

(119) Netherlands $-5.0 \%$ of 1918 (100)

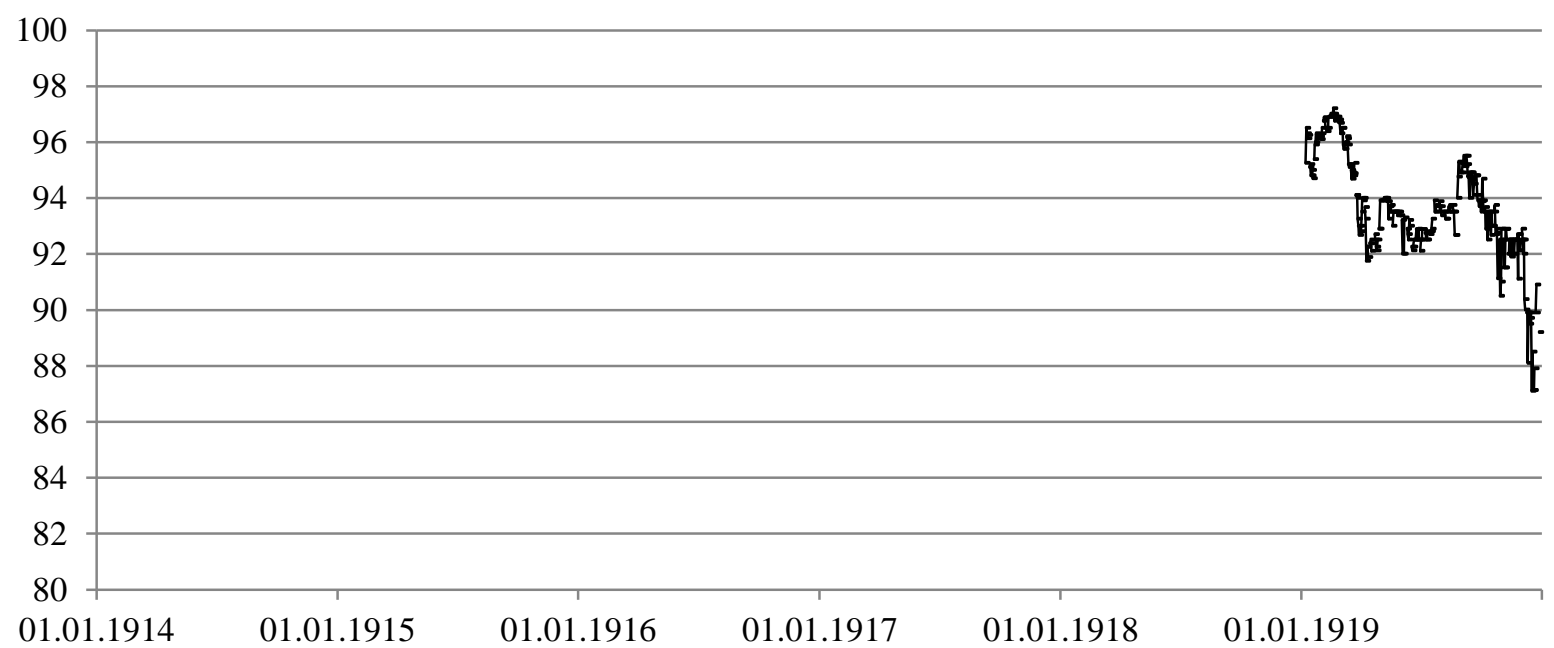

(120) Netherlands $-5.0 \%$ of 1918 (500)

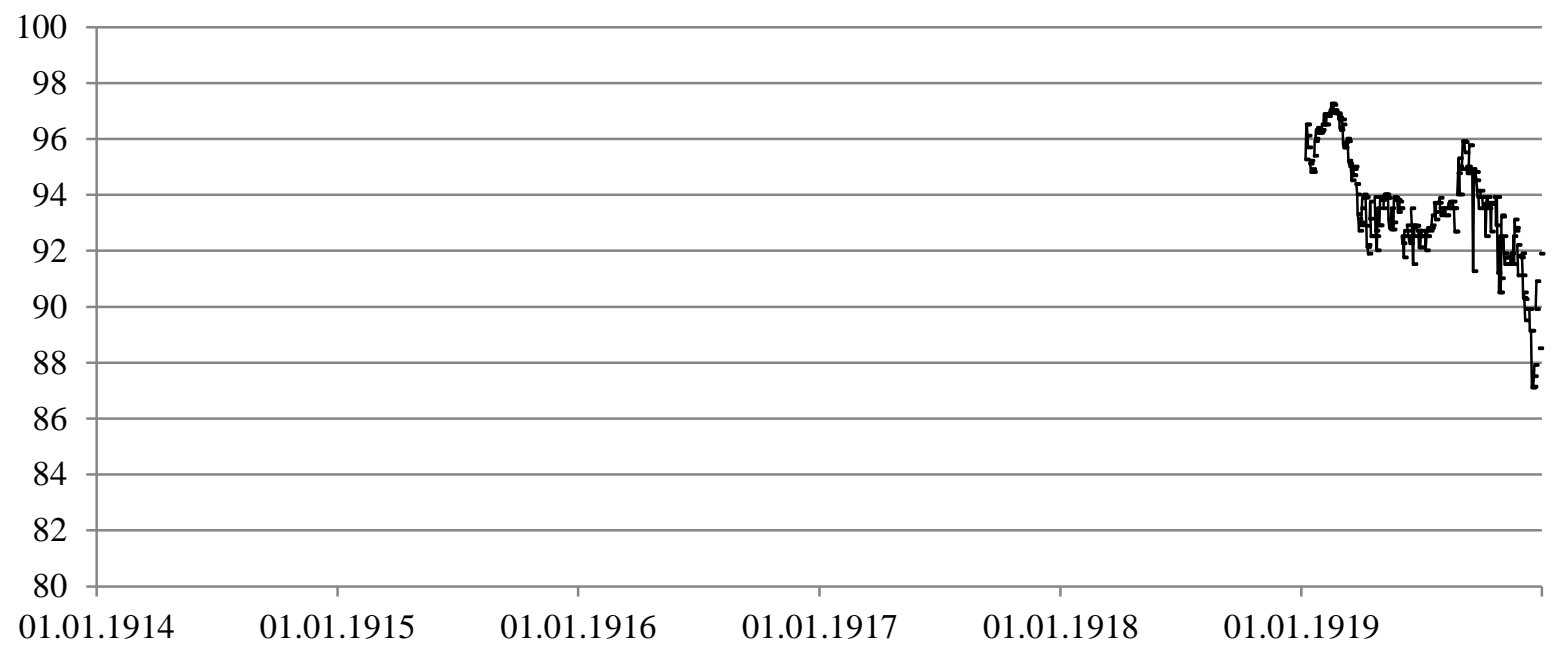


(121) Netherlands $-5.0 \%$ of $1918(1000)$

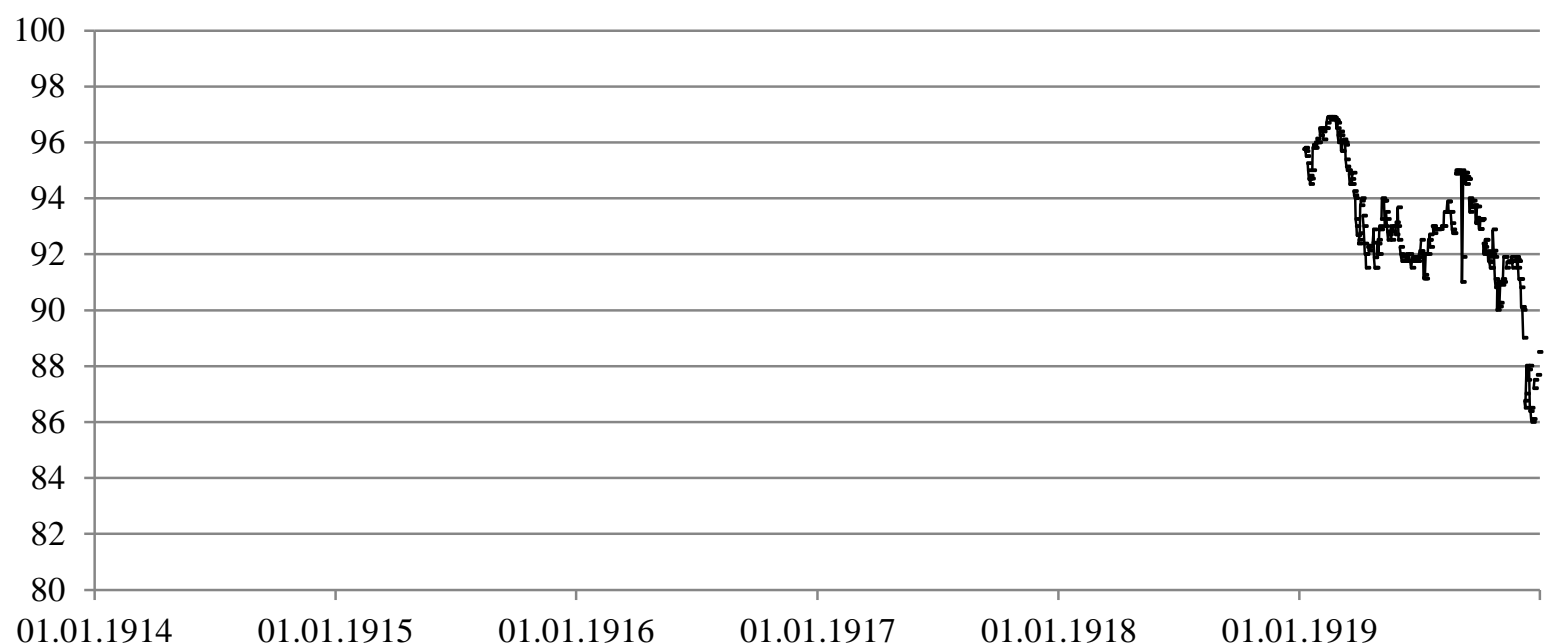

$\begin{array}{llllll}01.01 .1914 & 01.01 .1915 & 01.01 .1916 & 01.01 .1917 & 01.01 .1918 & 01.01 .1919\end{array}$

(122) Nicaragua $-5.0 \%$ of 1909

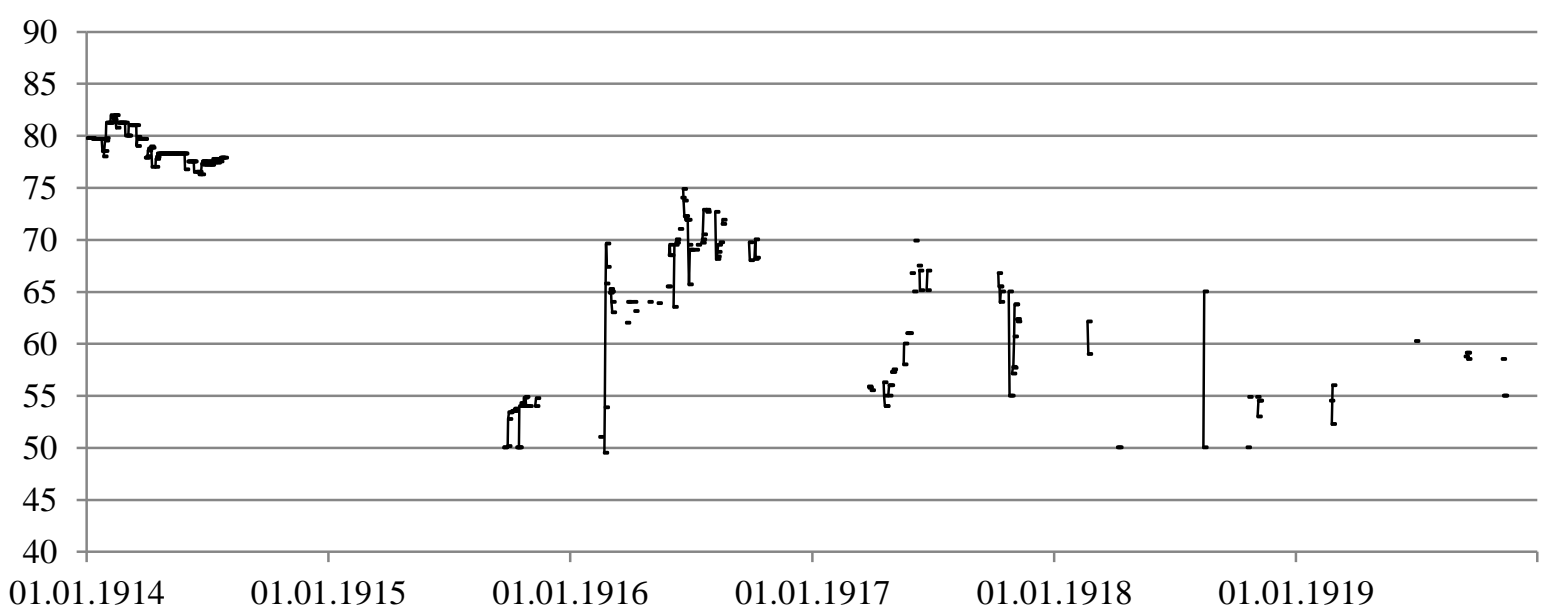

(123) Portugal $-3.0 \% 1^{\text {st }}$ series

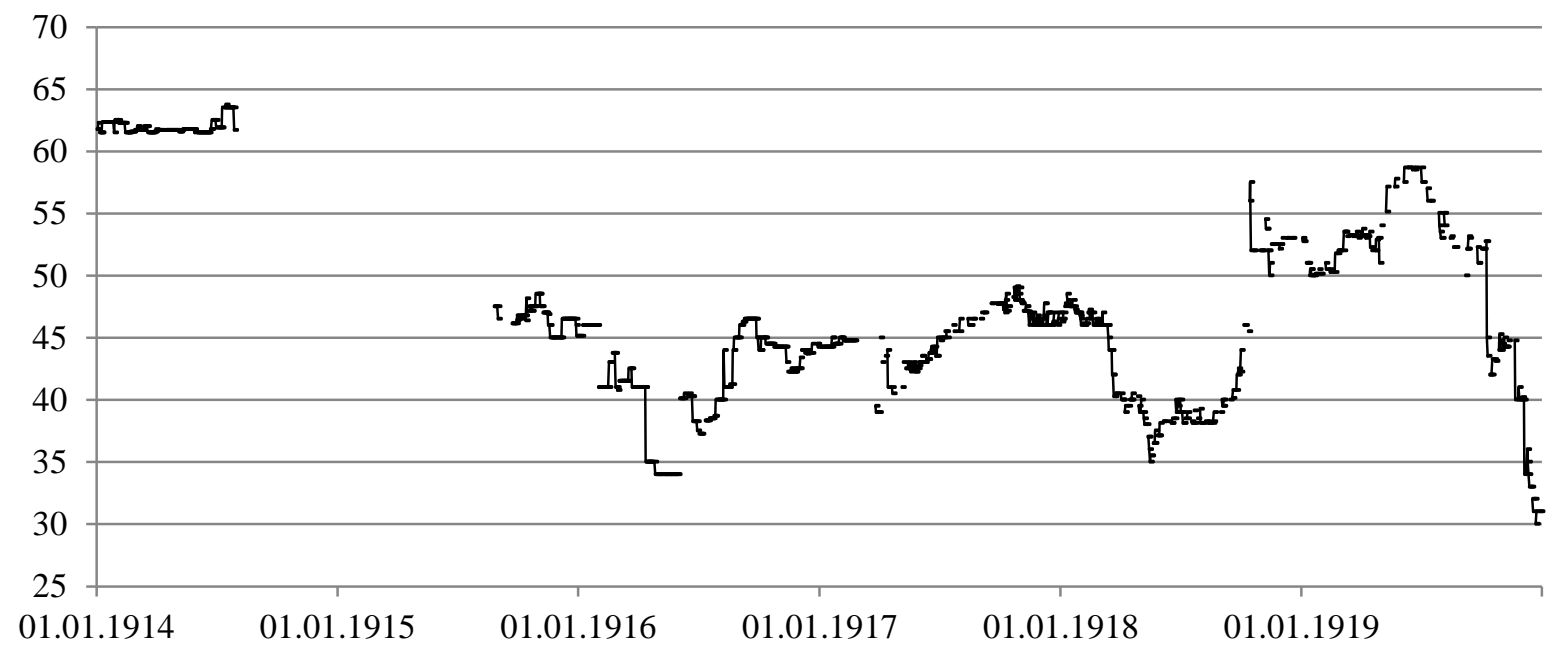


(124) Portugal $-3.0 \% 2^{\text {nd }}$ series

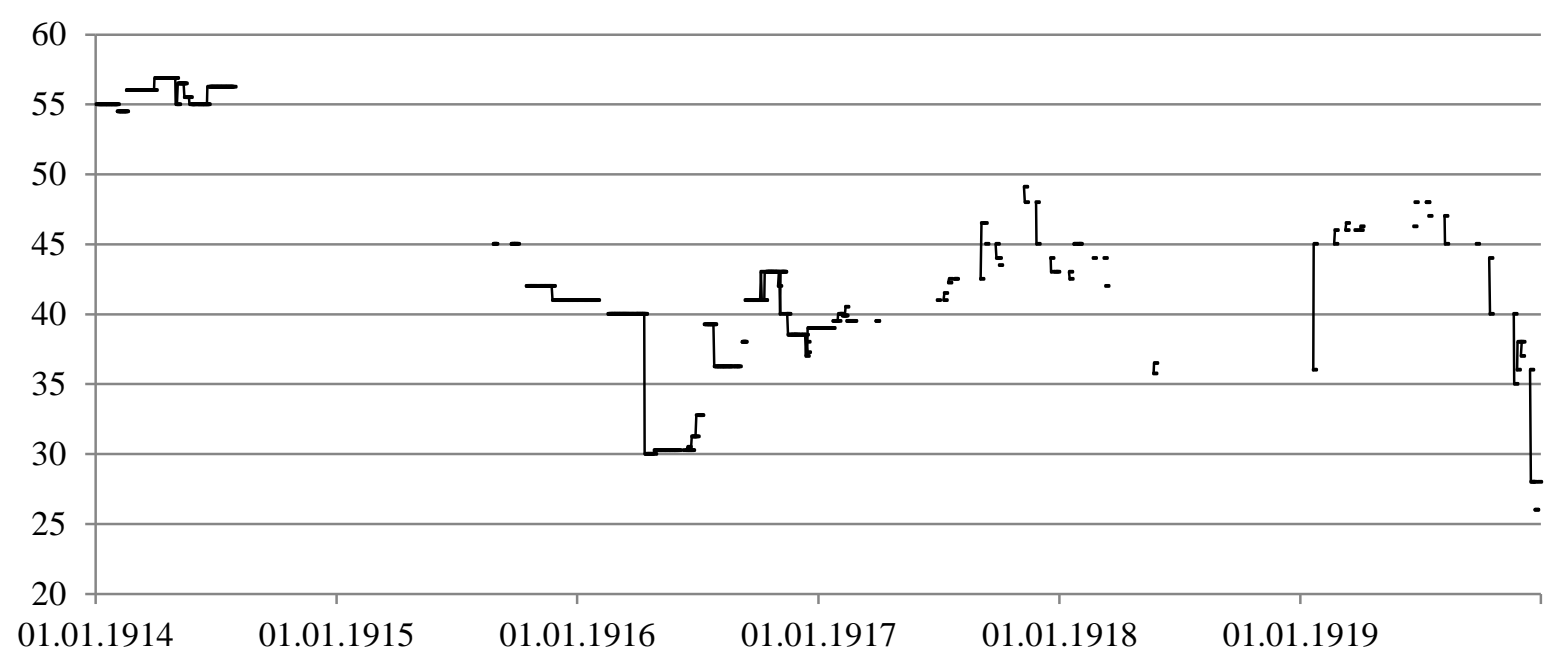

(125) Portugal $-3.0 \% 3^{\text {rd }}$ series (500)

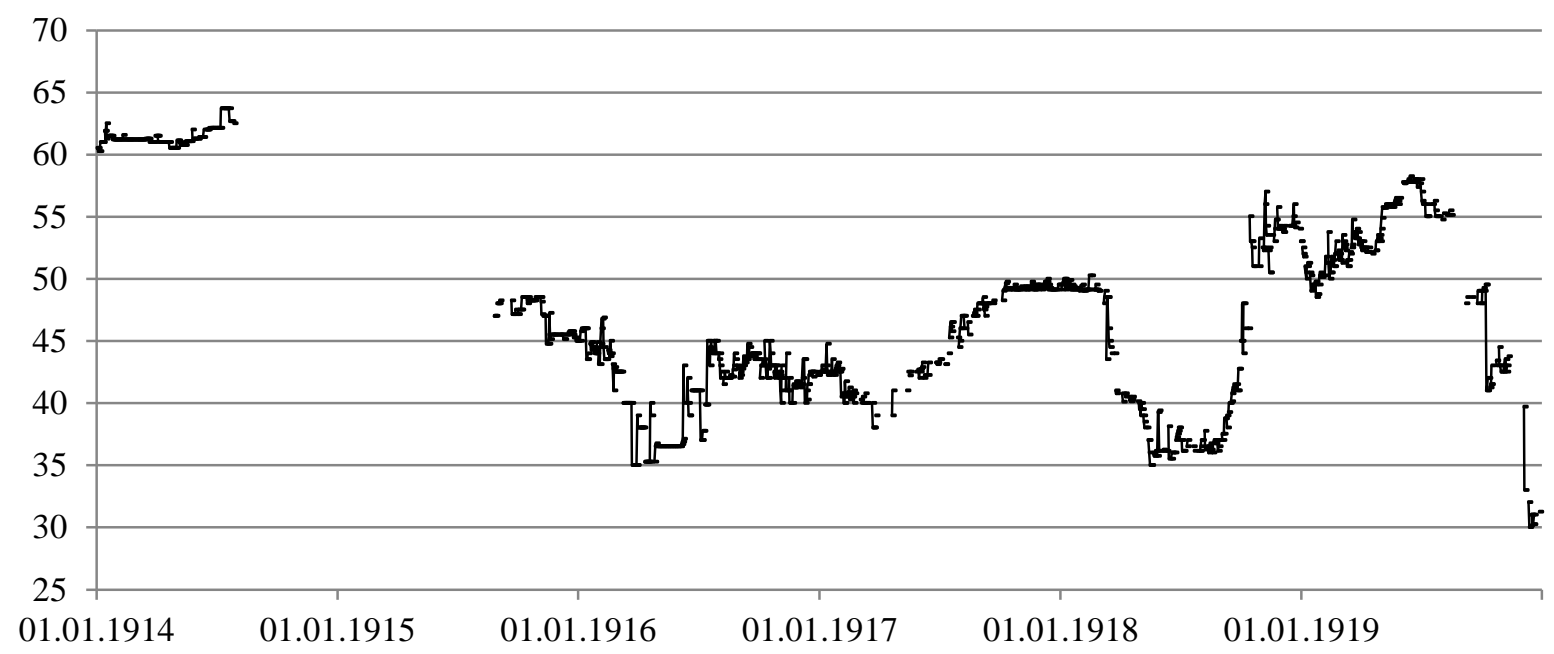

(126) Portugal $-3.0 \% 3^{\text {rd }}$ series (2 500)

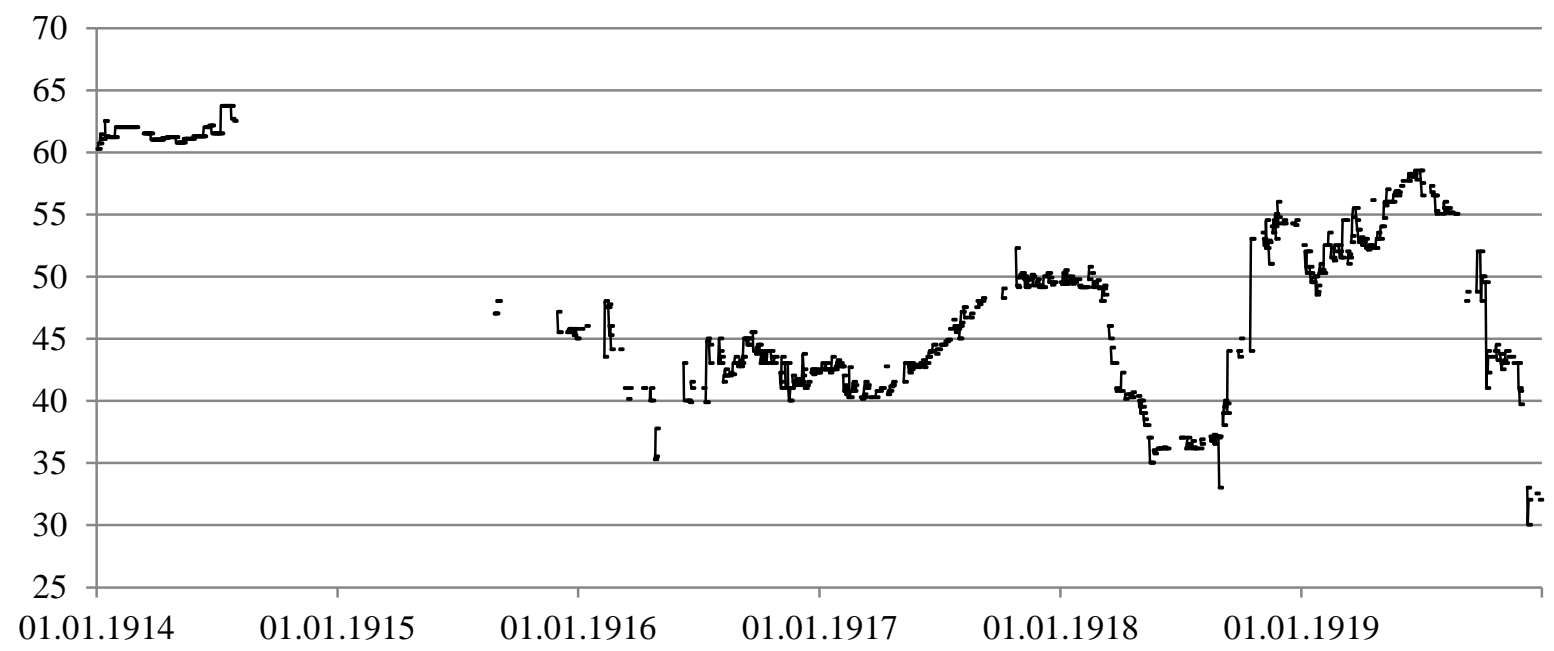


(127) Portugal $-4.5 \%$ of 1890

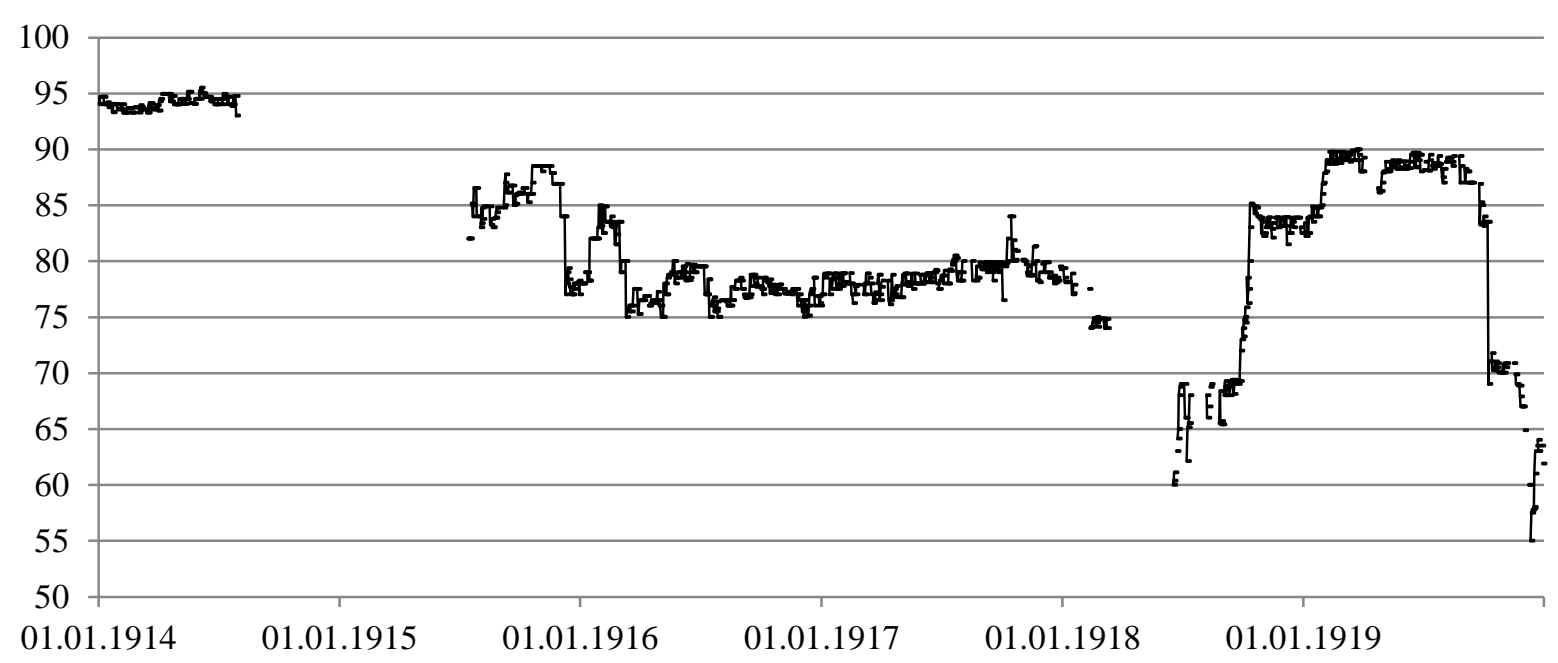

(128) Romania - 4.0 \% of 1894 (2 500/5 000)

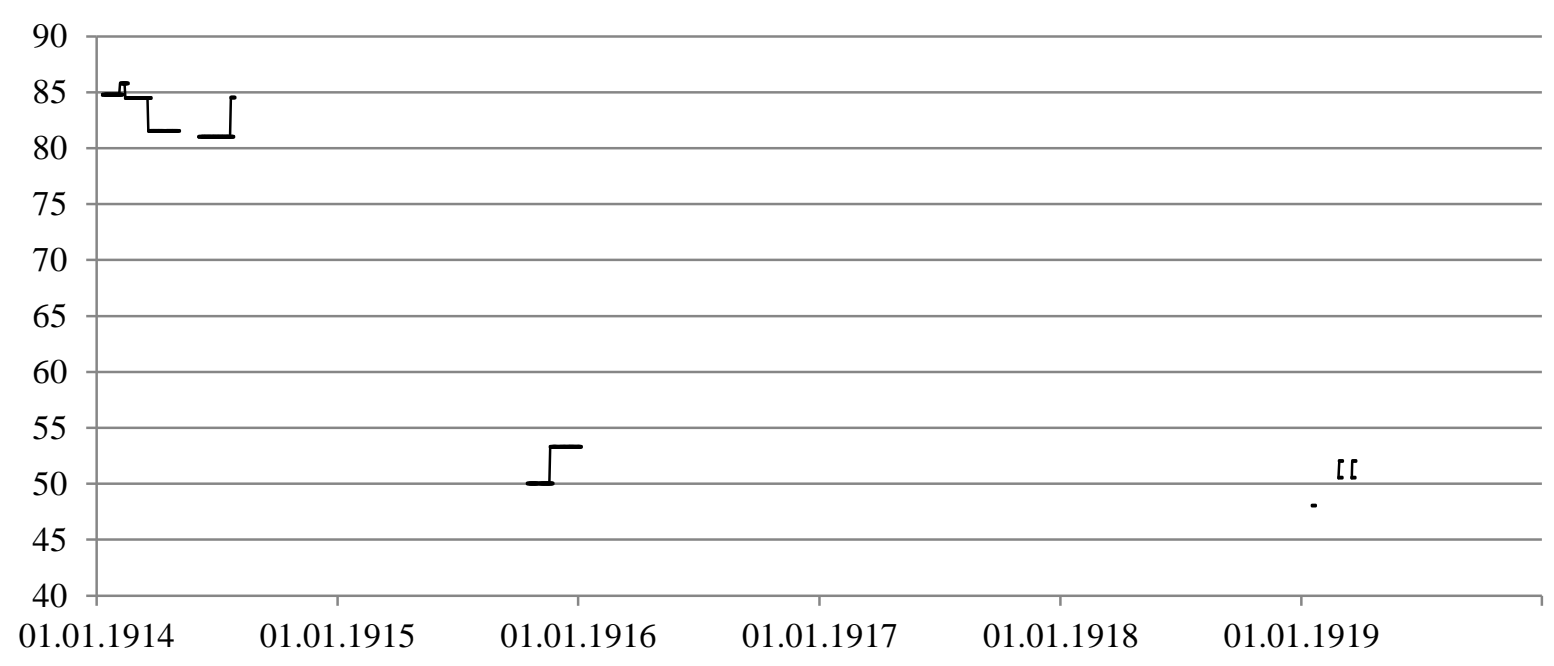

(129) Romania - $4.0 \%$ of 1910 (2 500/5 000)

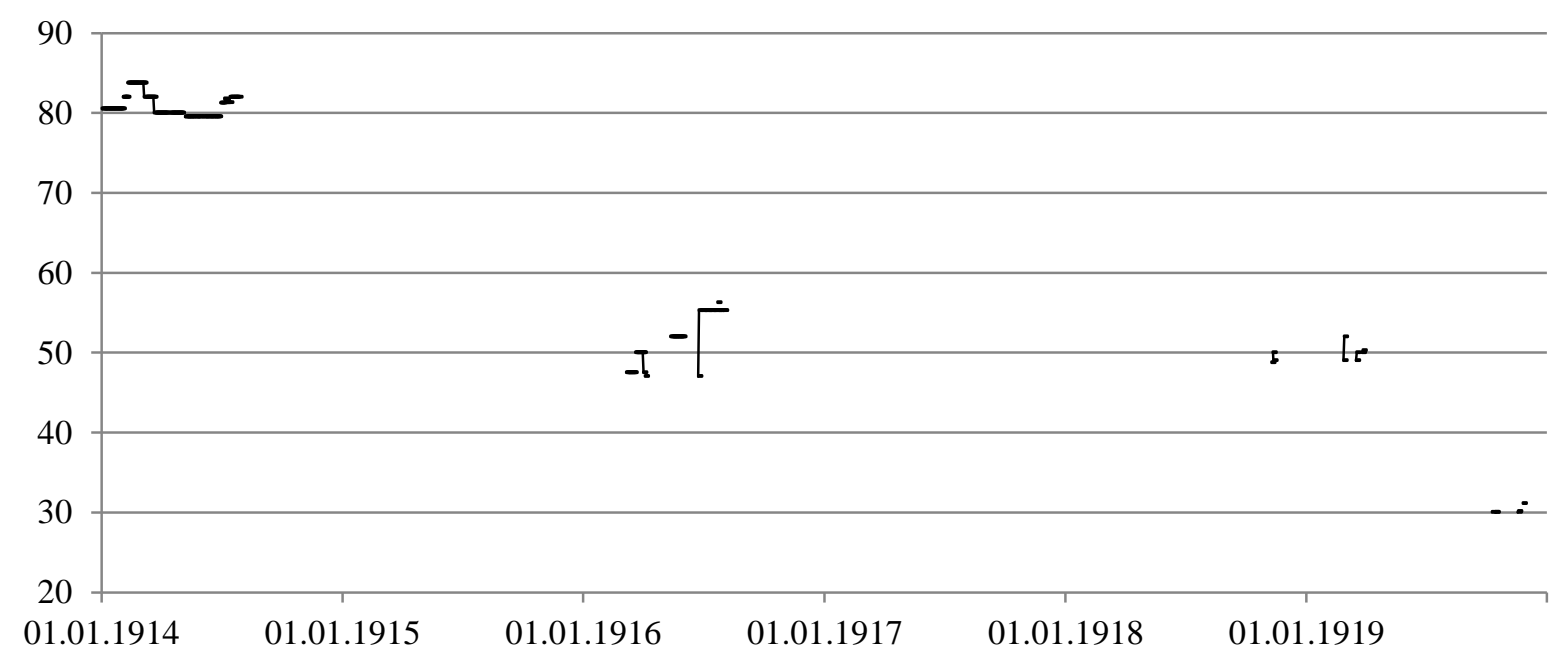




\section{(130) Romania $-4.5 \%$ of 1913}

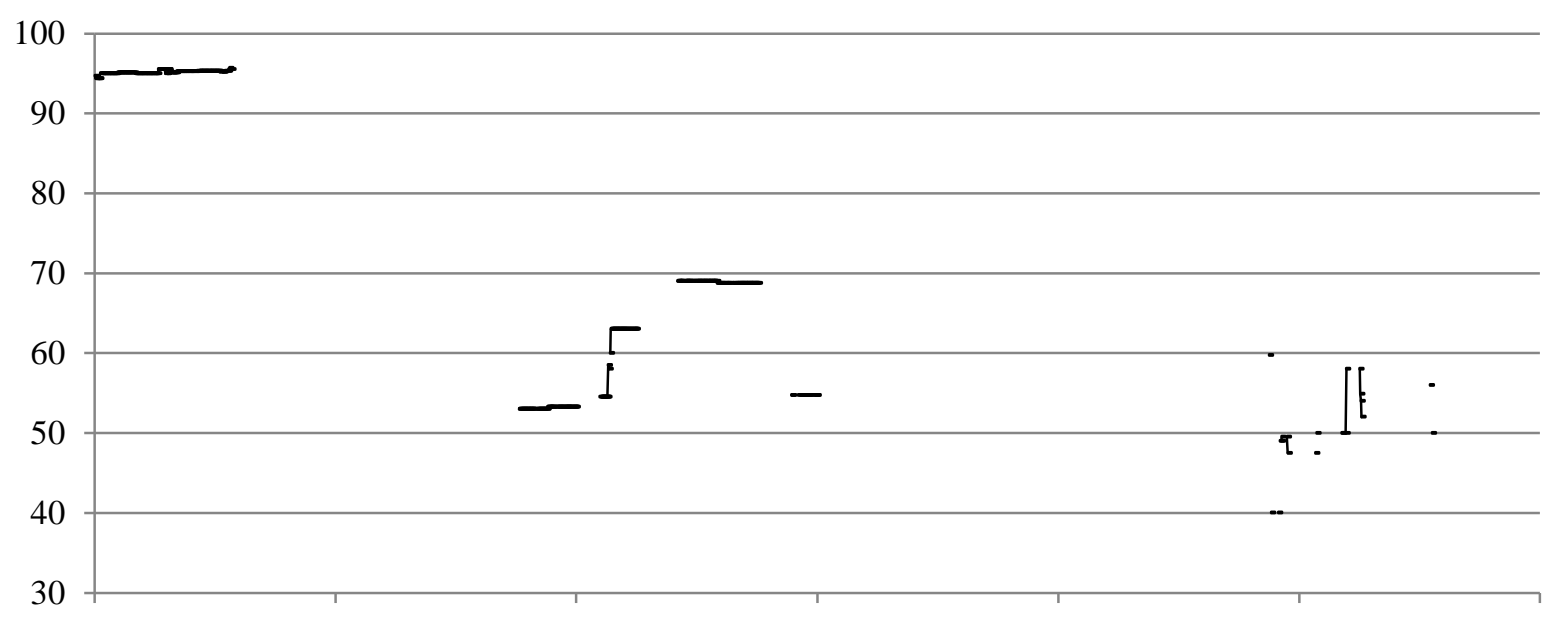

$\begin{array}{llllll}01.01 .1914 & 01.01 .1915 & 01.01 .1916 & 01.01 .1917 & 01.01 .1918 & 01.01 .1919\end{array}$

(131) Romania $-5.0 \%$ of 1903 (2 500/5 000)

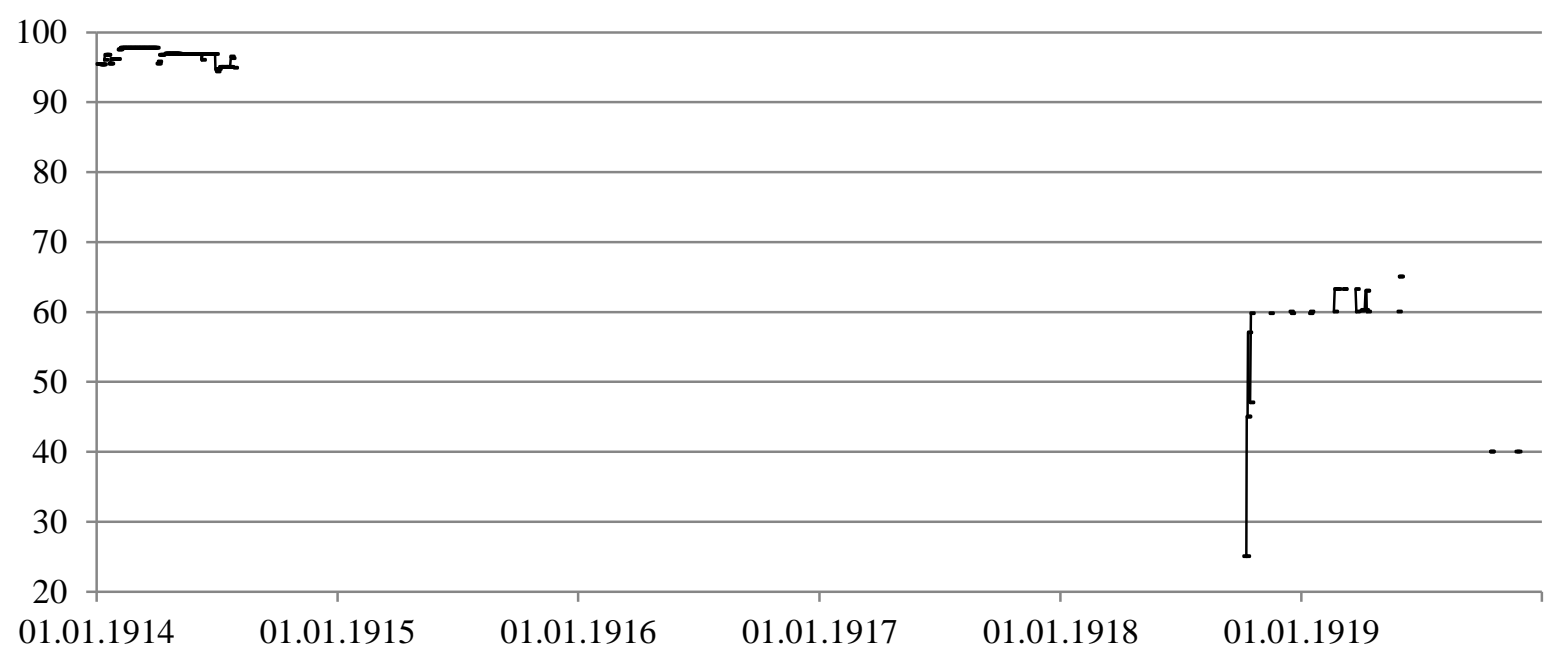

(132) Russia $-3.0 \%$ of 1880 (125)

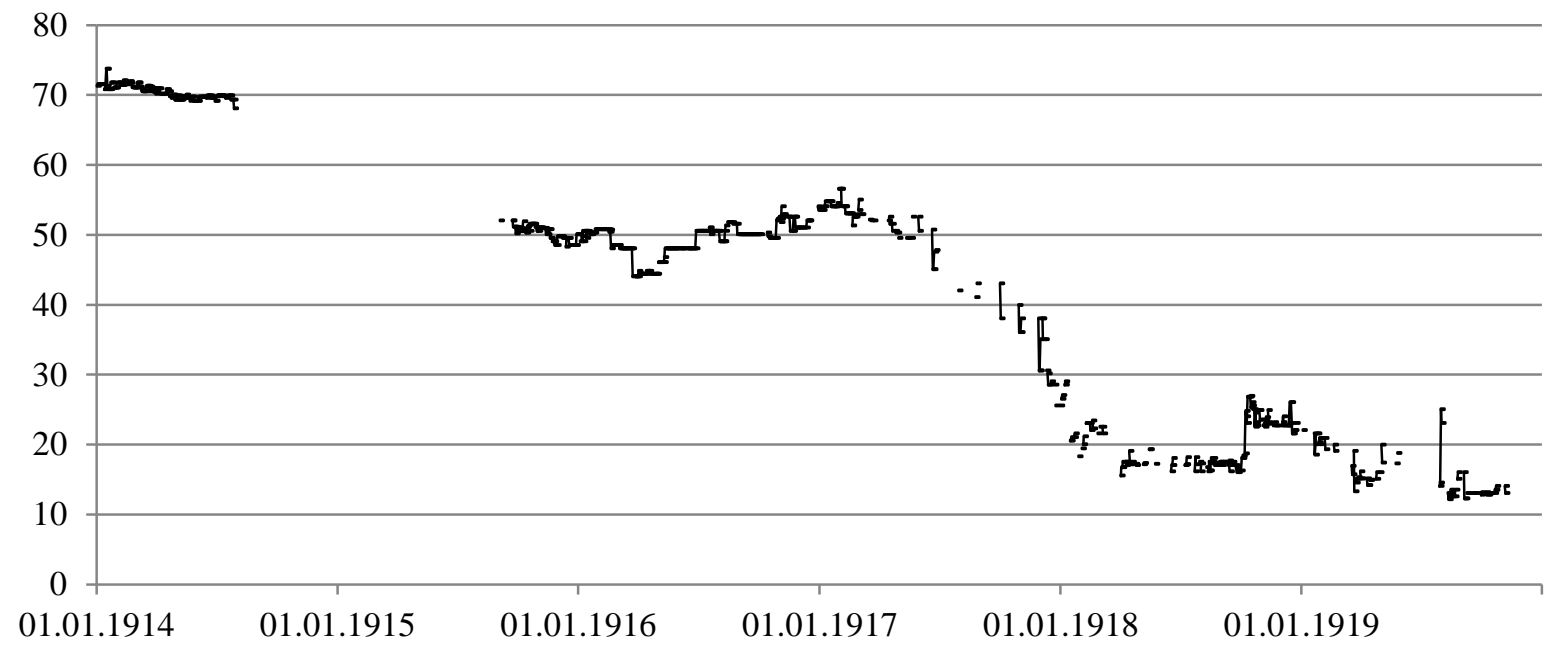


(133) Russia $-3.0 \%$ of 1880 (625)

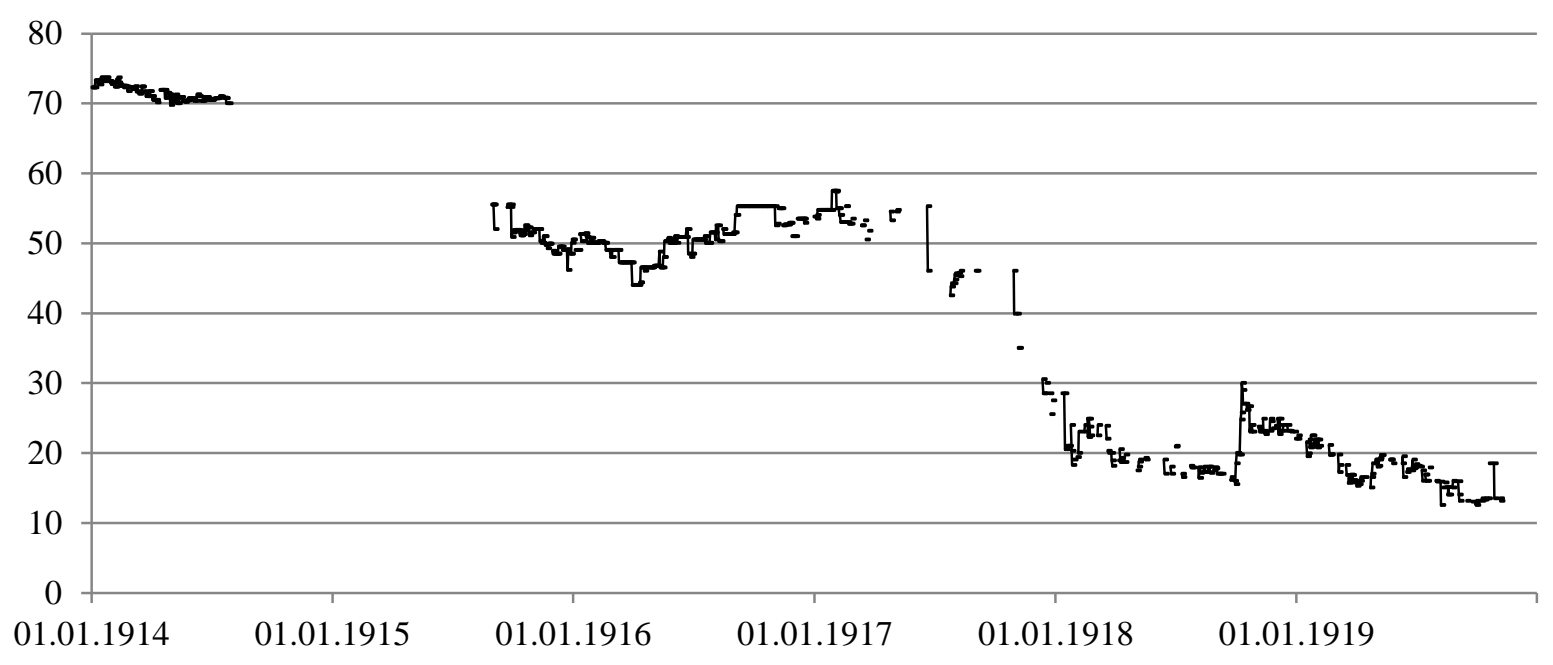

(134) Russia $-3.0 \%$ of 1882

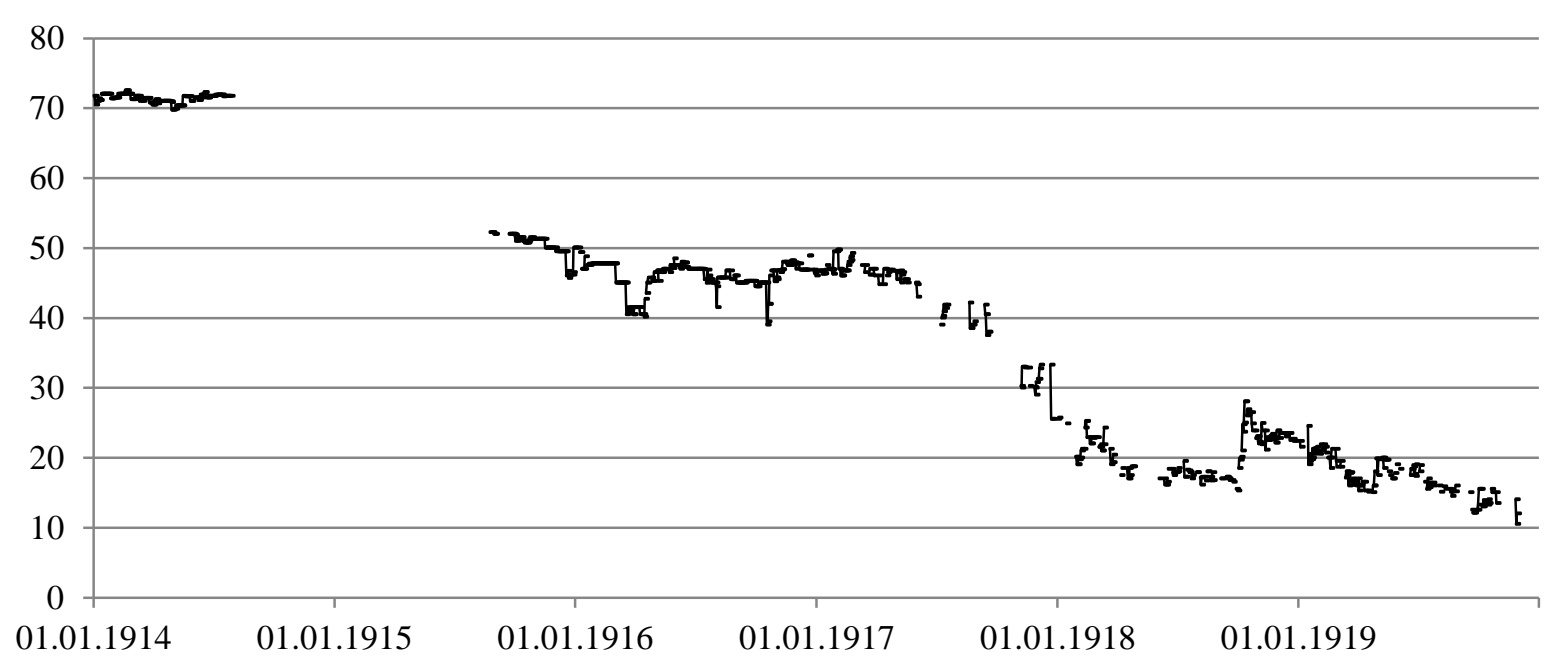

(135) Russia $-3.0 \%$ of 1889

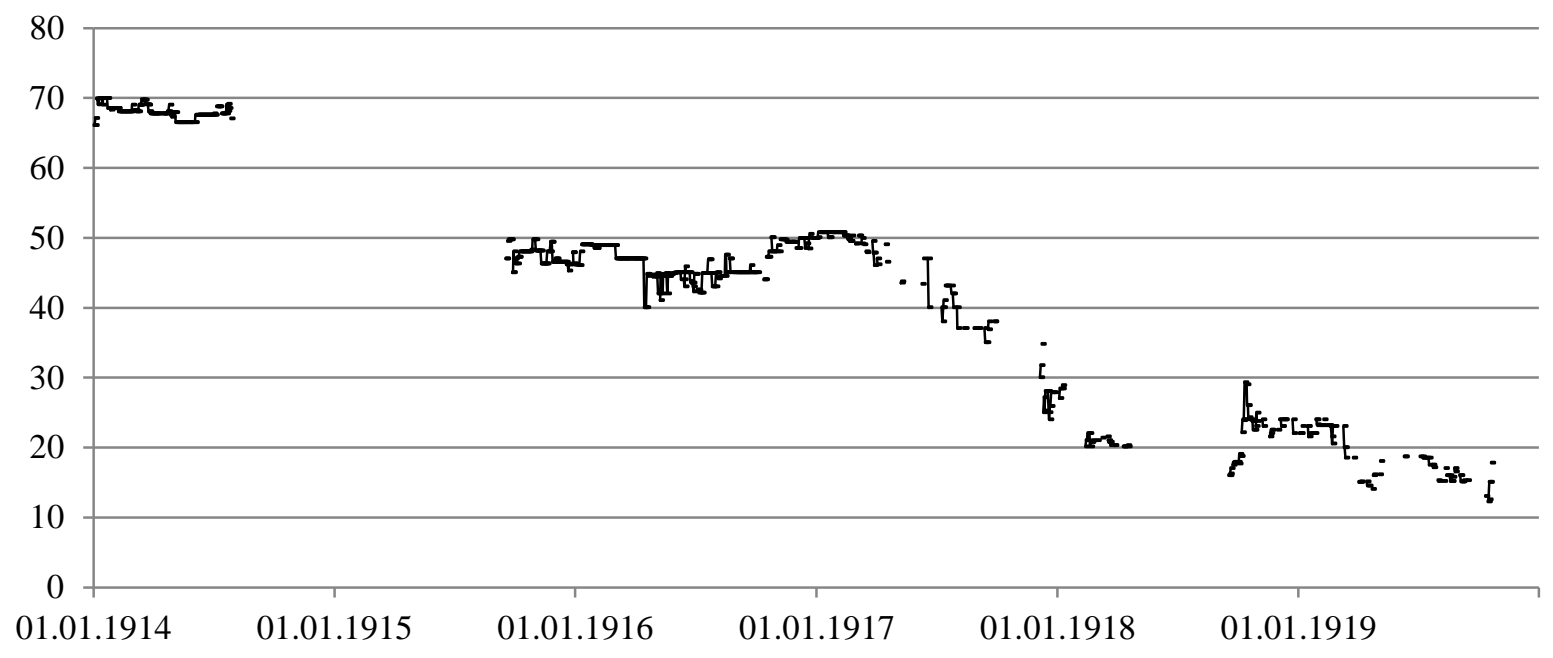

76 
(136) Russia - $3.5 \%$ (125) of 1894

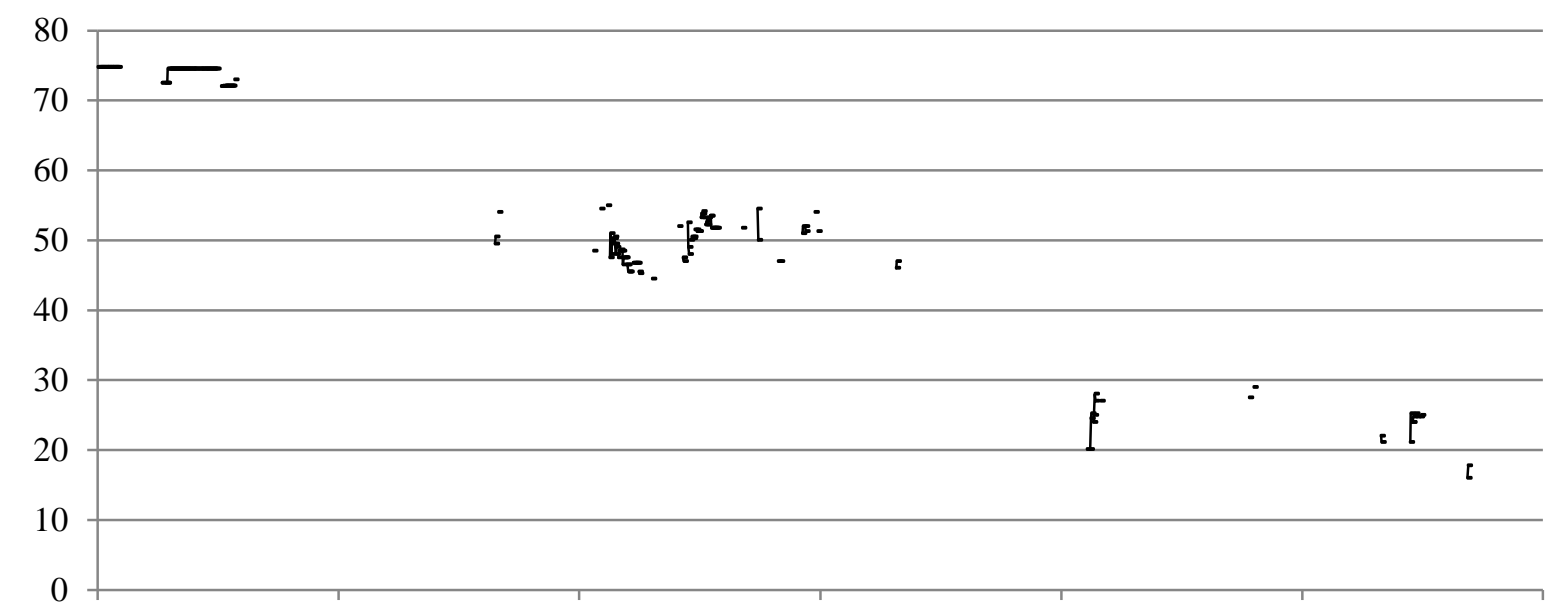

$\begin{array}{llllll}01.01 .1914 & 01.01 .1915 & 01.01 .1916 & 01.01 .1917 & 01.01 .1918 & 01.01 .1919\end{array}$

(137) Russia - $3.5 \%$ (625) of 1894

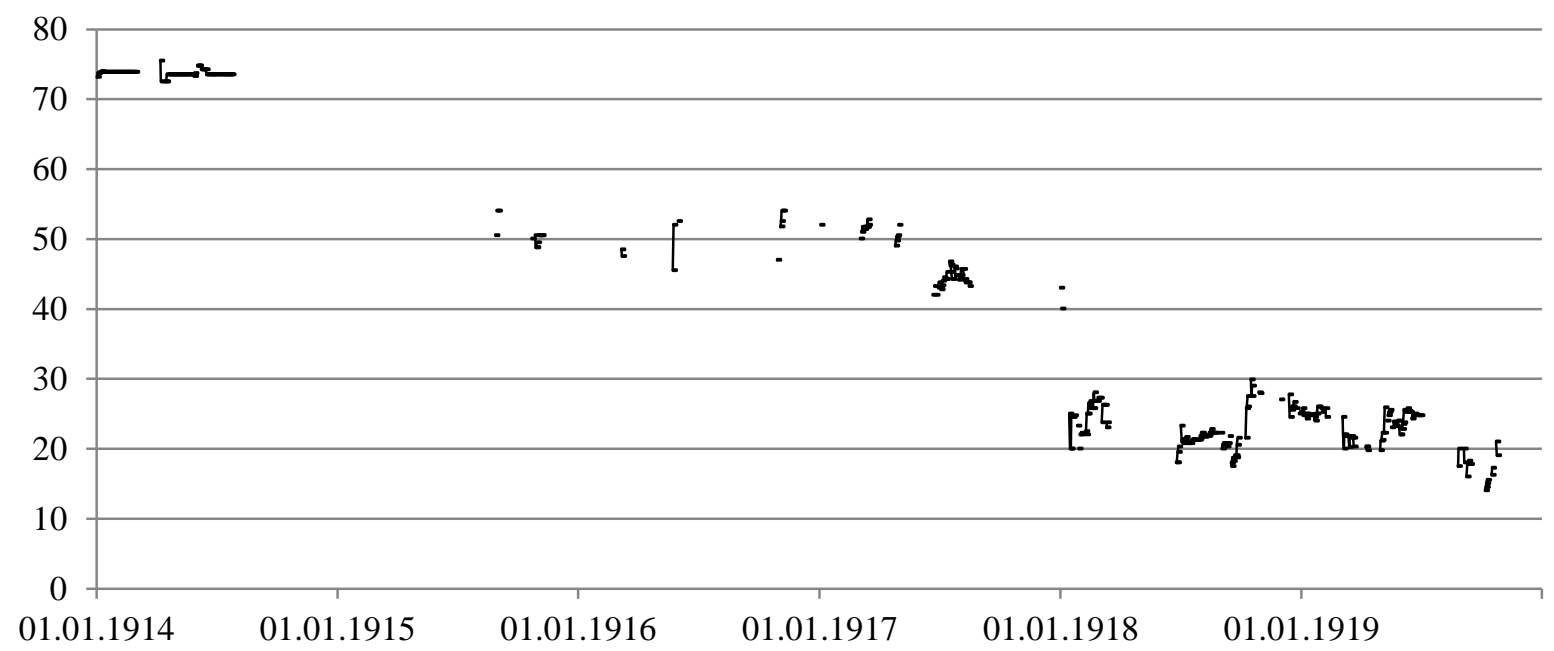

(138) Russia $-3.8 \%$ of 1898

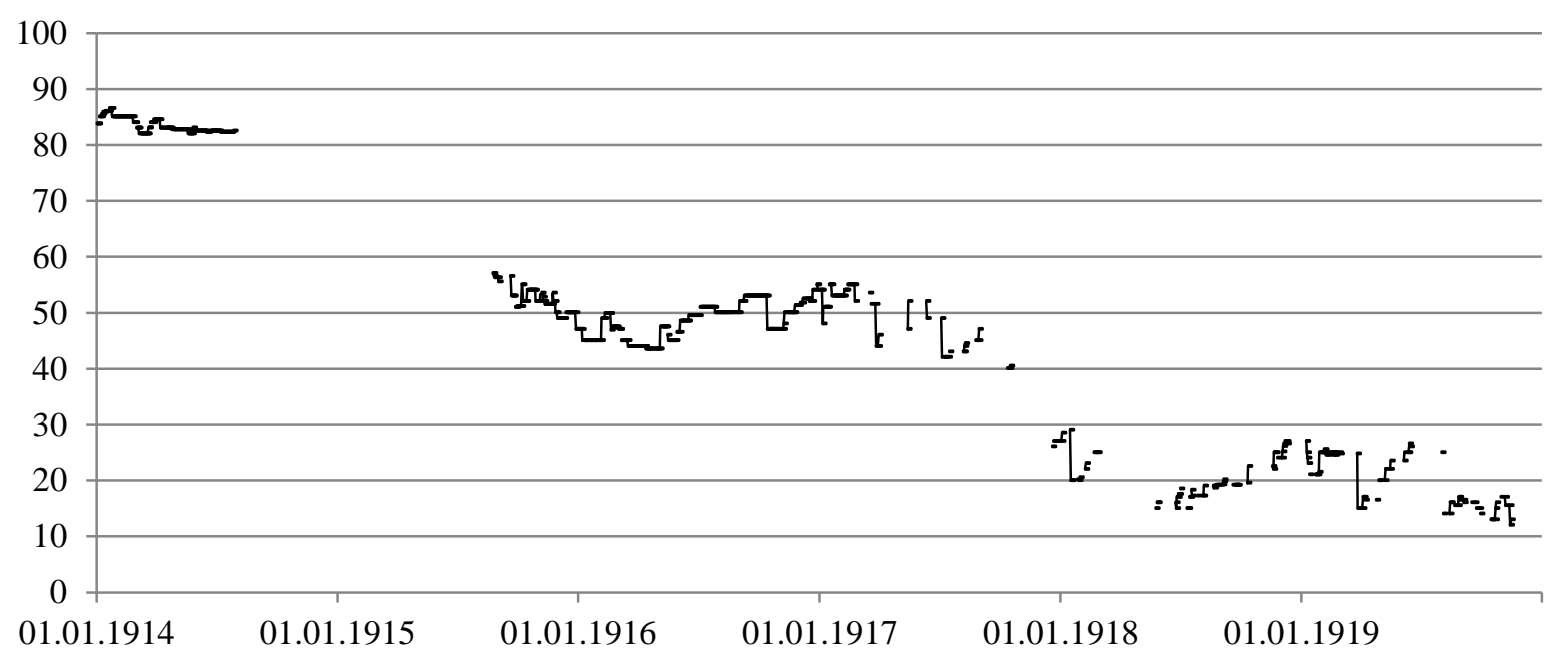


(139) Russia $-4.0 \%$ of 1861

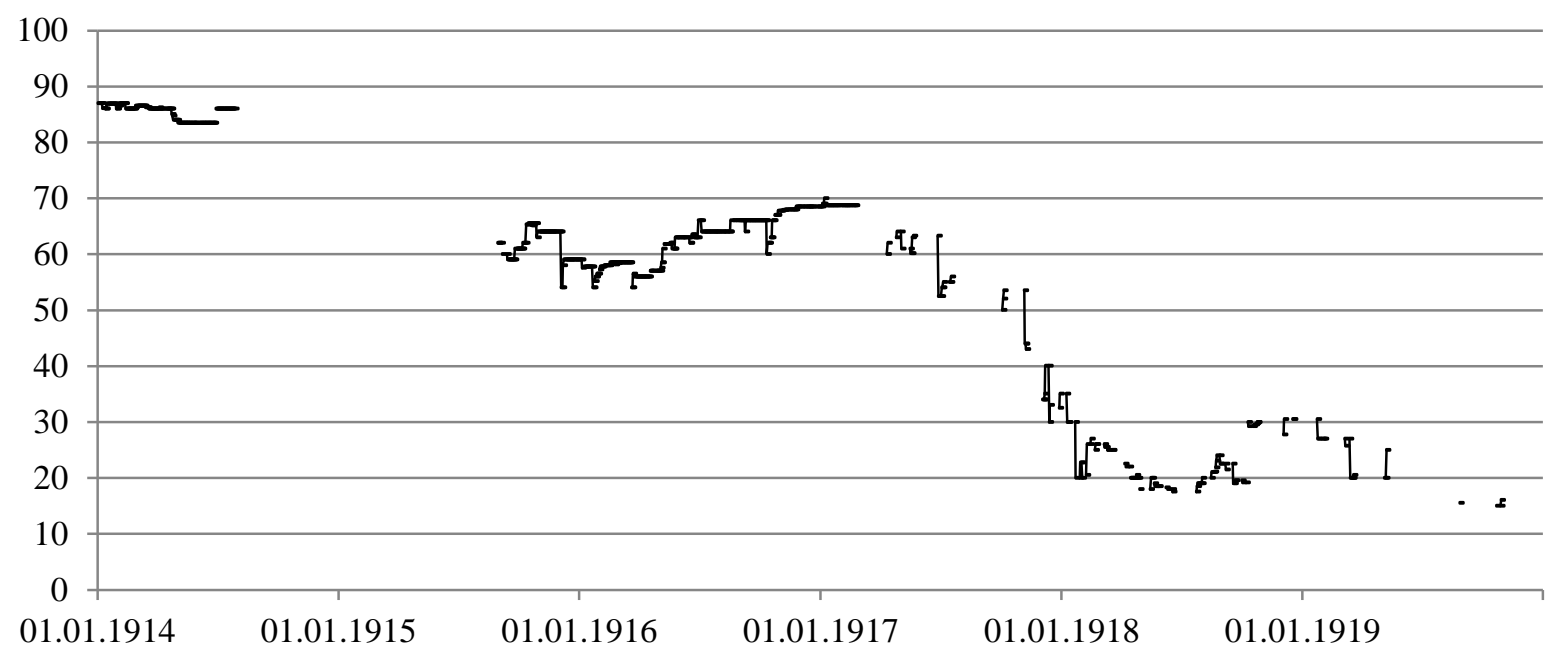

(140) Russia $-4.0 \%$ of 1888

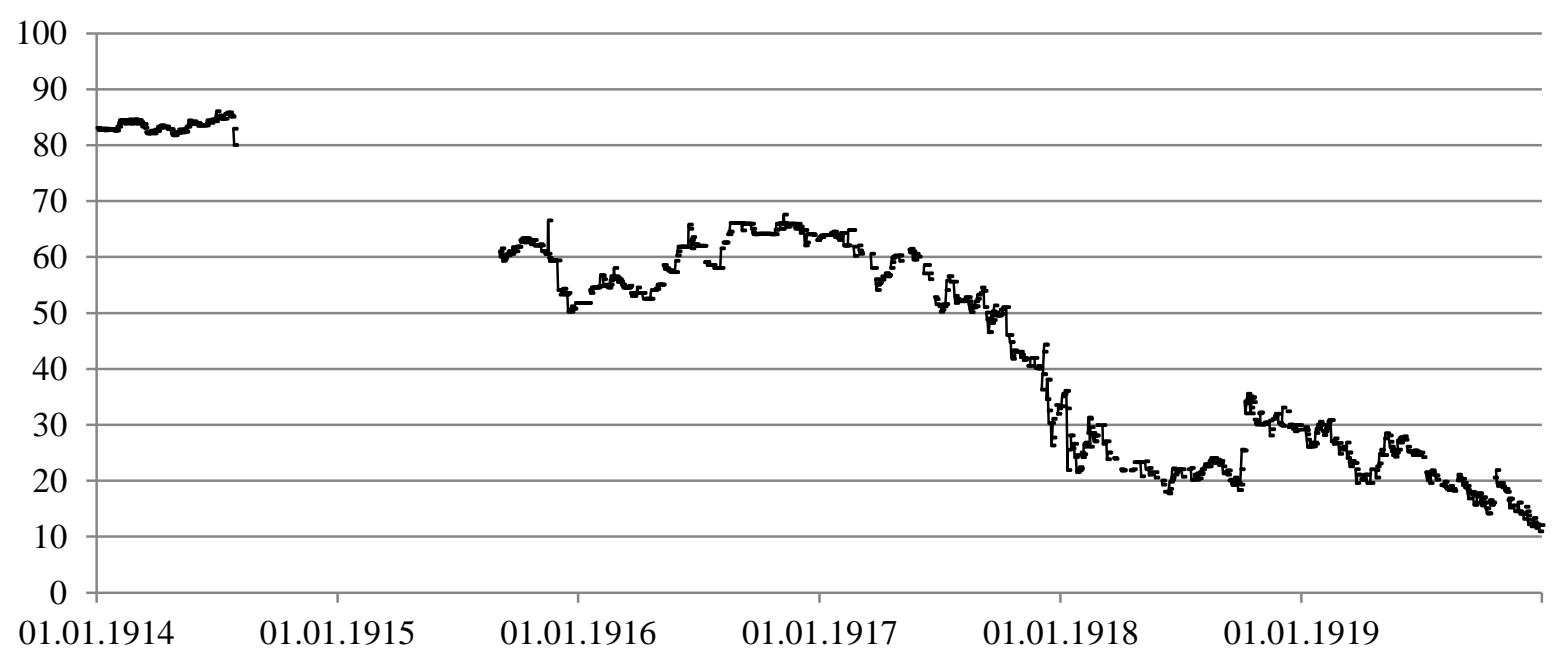

(141) Russia $-4.0 \%$ of 1890

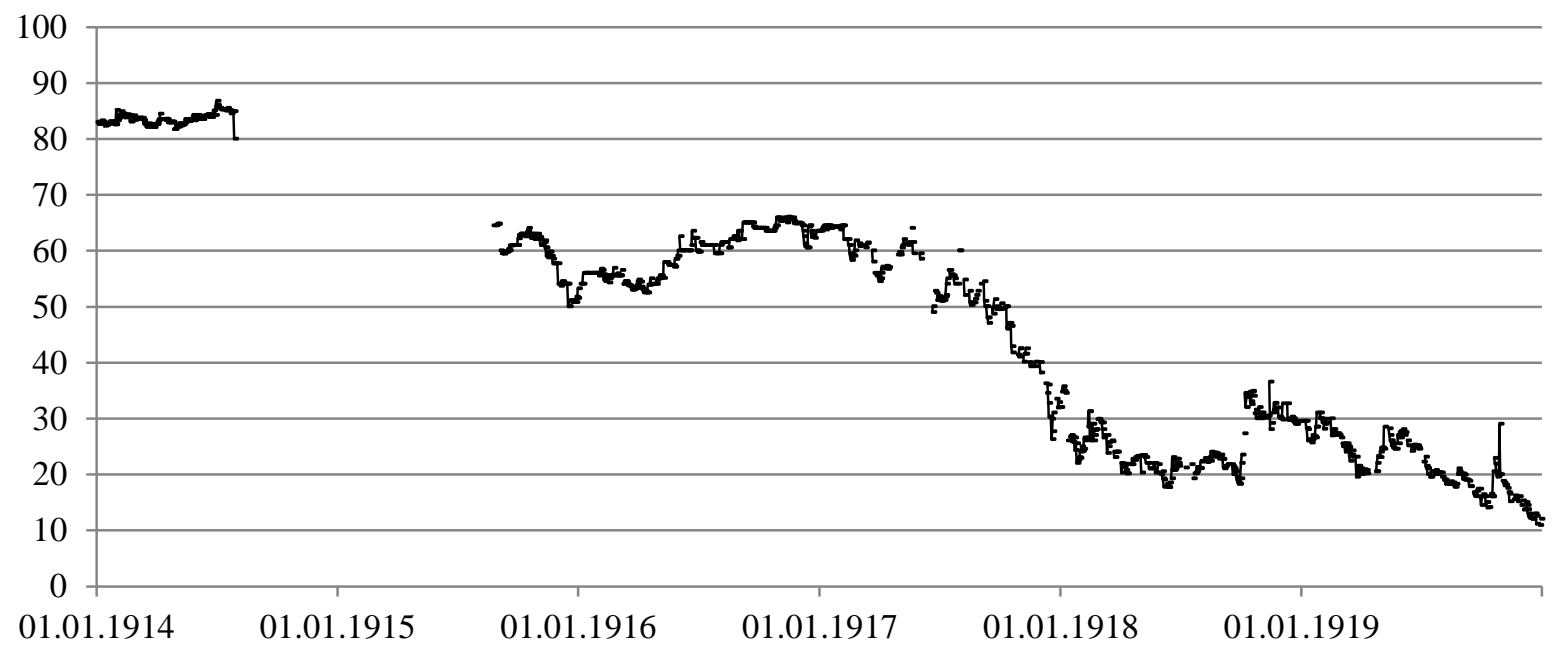


(142) Russia $-4.0 \%$ of 1898

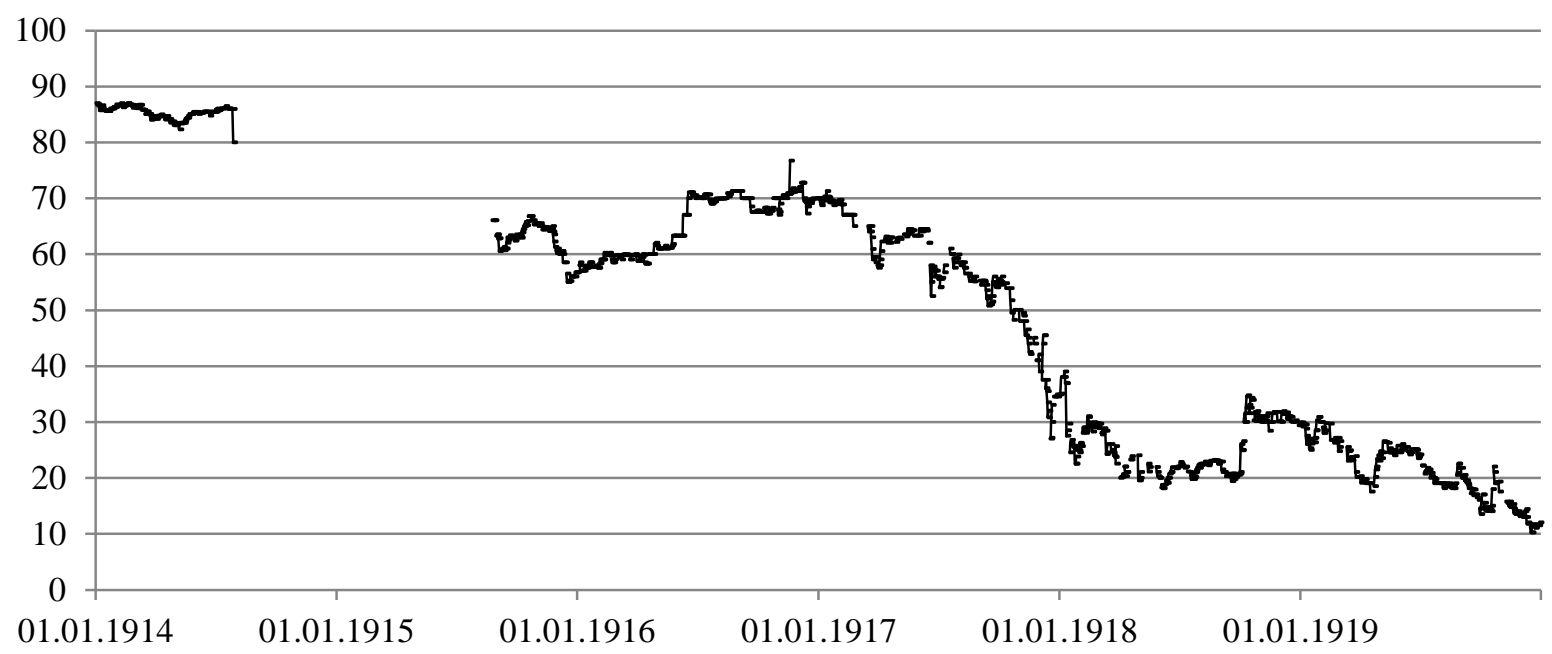

(143) Russia - $4.0 \%$ of 1867-69 (Nicolai Railway, 20)

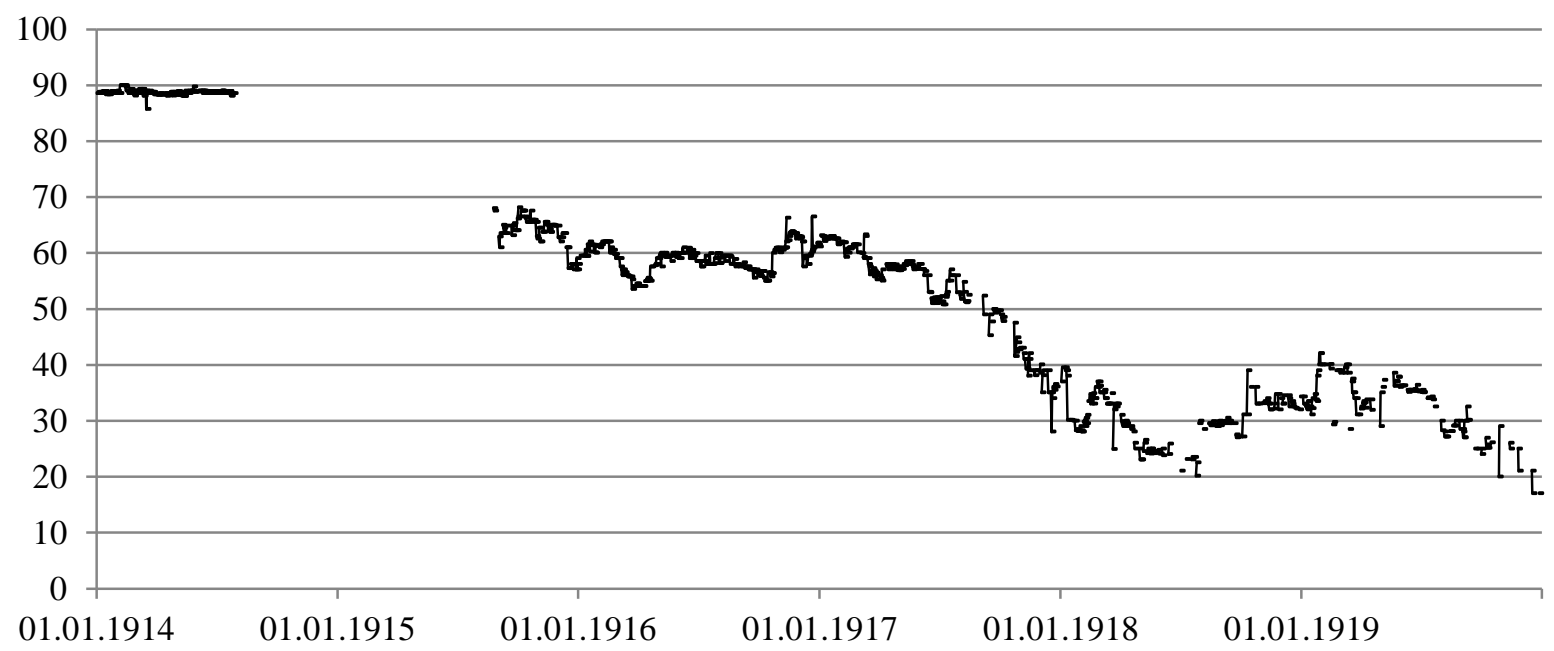

(144) Russia - 4.0 \% of 1867-69 (Nikolai Railway, 100)

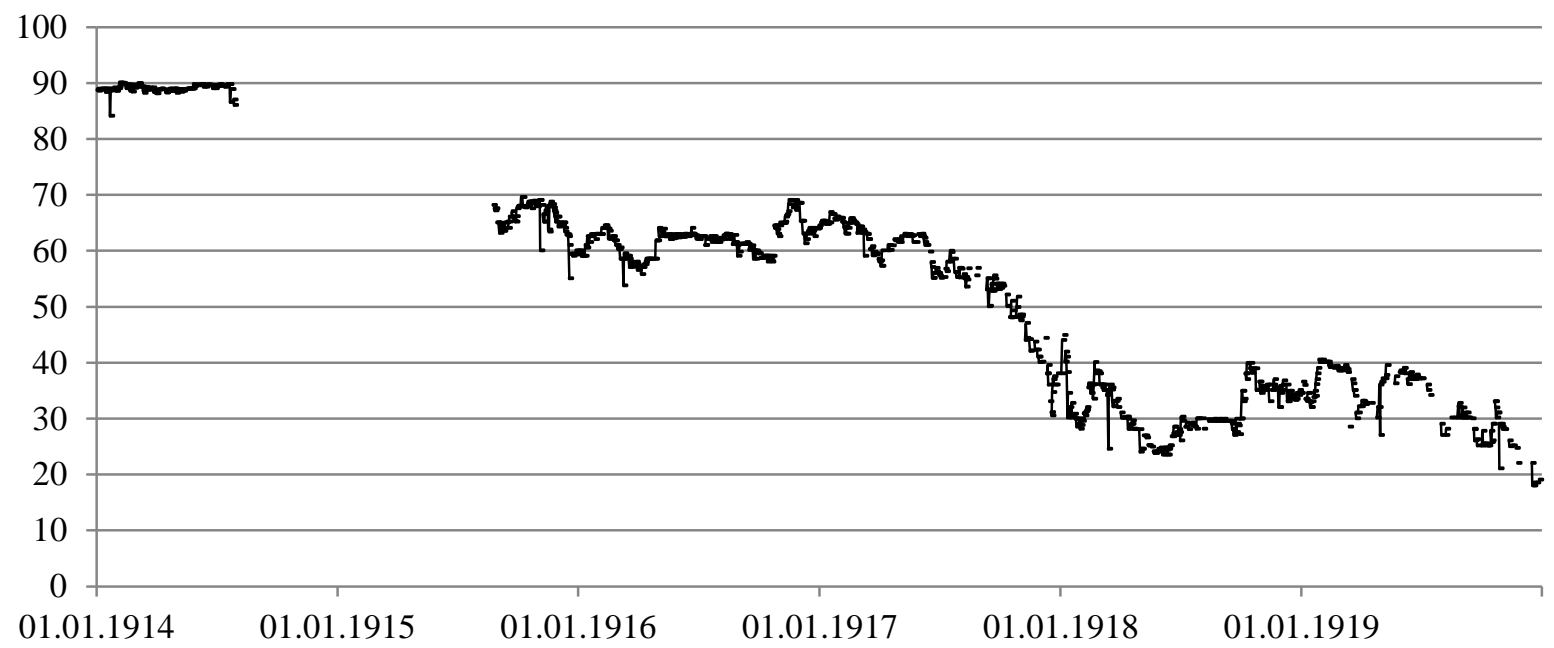


(145) Russia $-4.0 \%$ of 1880 (125)

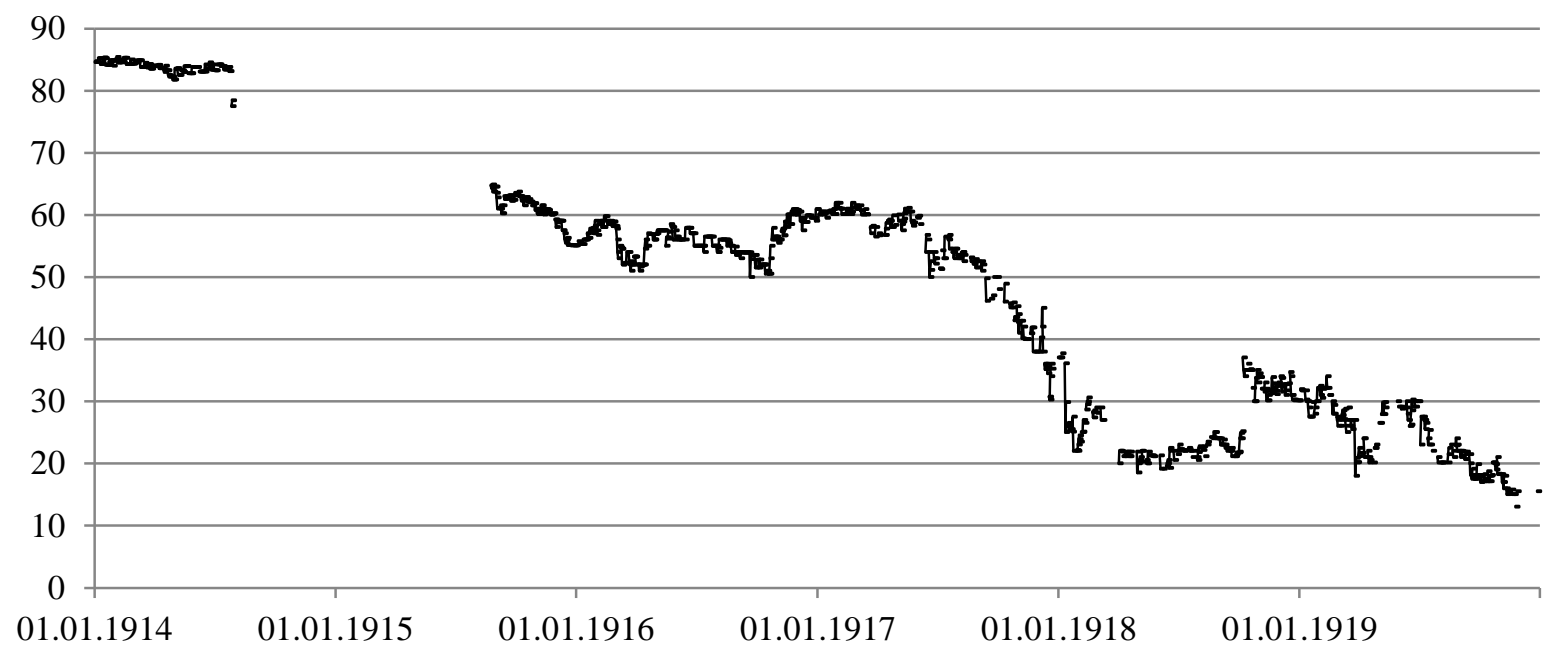

(146) Russia $-4.0 \%$ of 1880 (625)

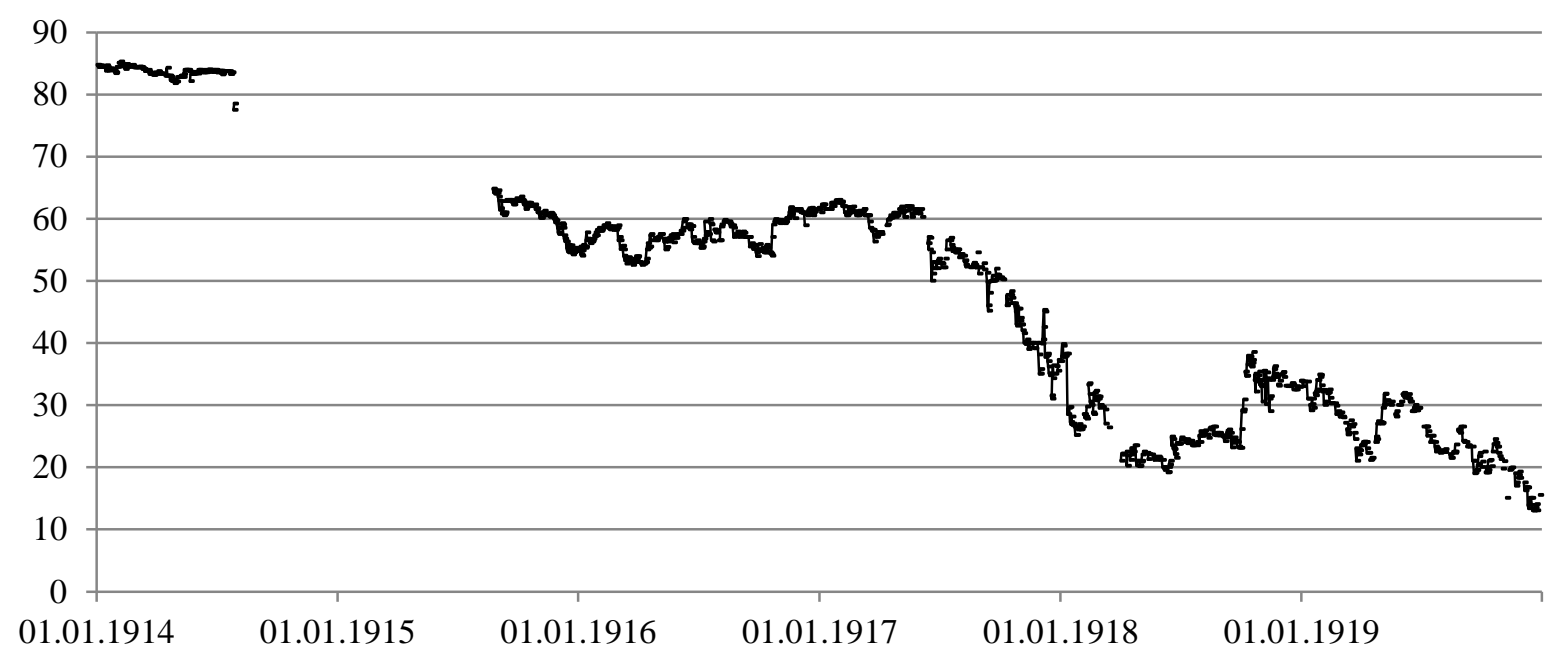

(147) Russia - $4.0 \%$ Tambov-Saratov railway

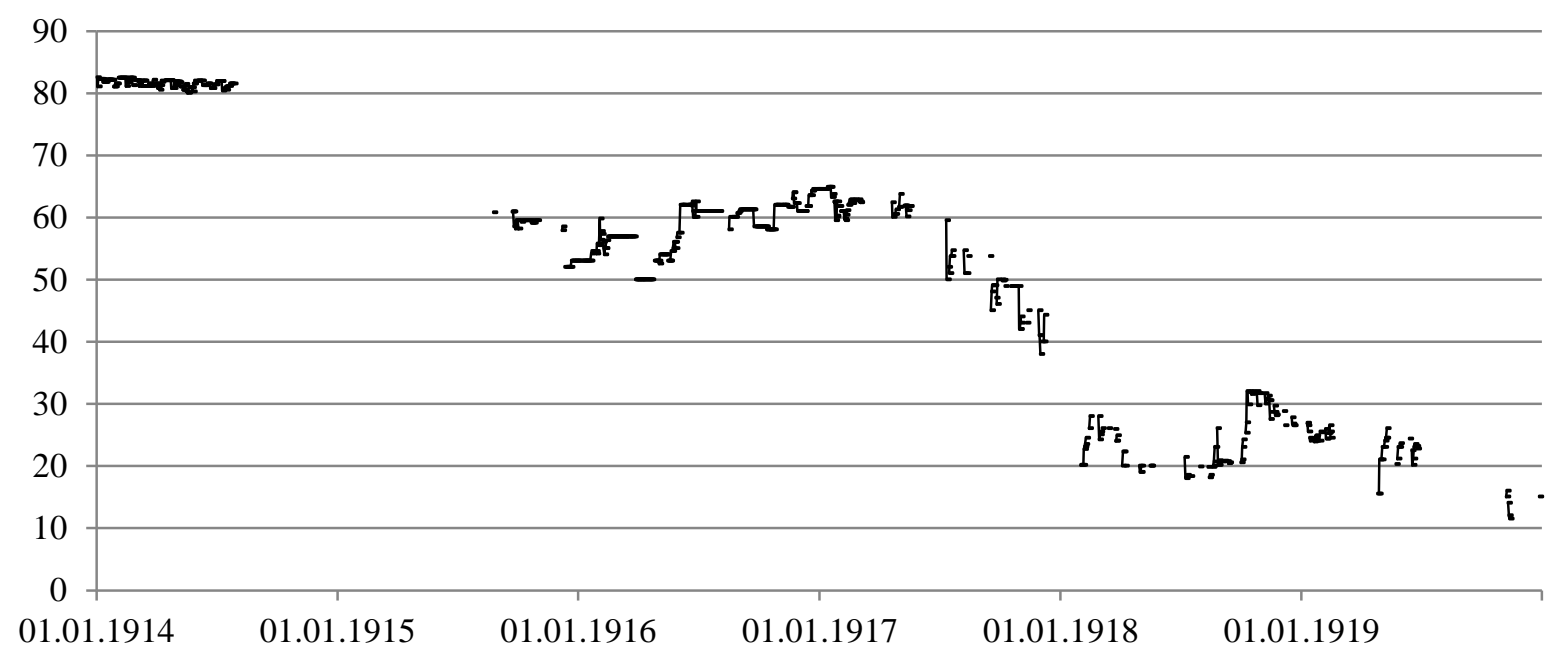


(148) Russia - $4.0 \%$ Southwest railway (125)

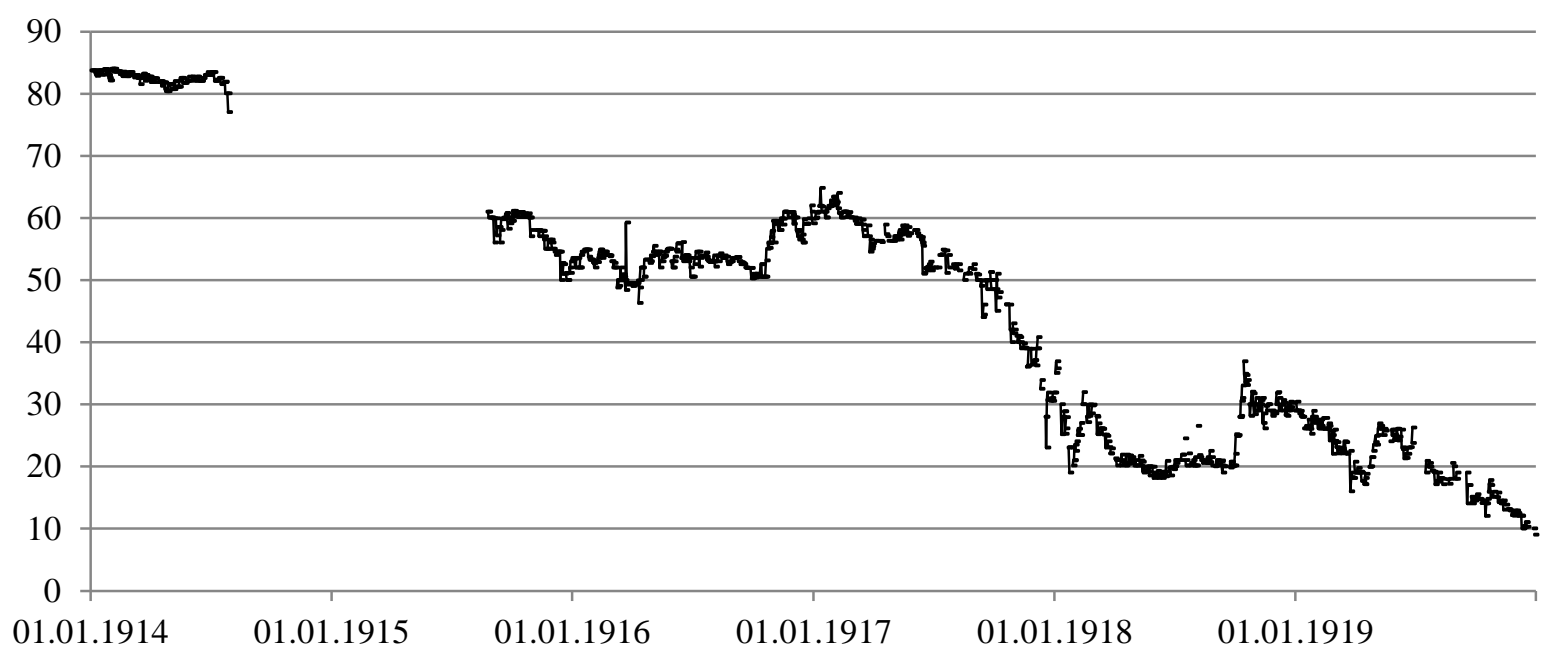

(149) Russia - $4.0 \%$ Southwest railway (625)

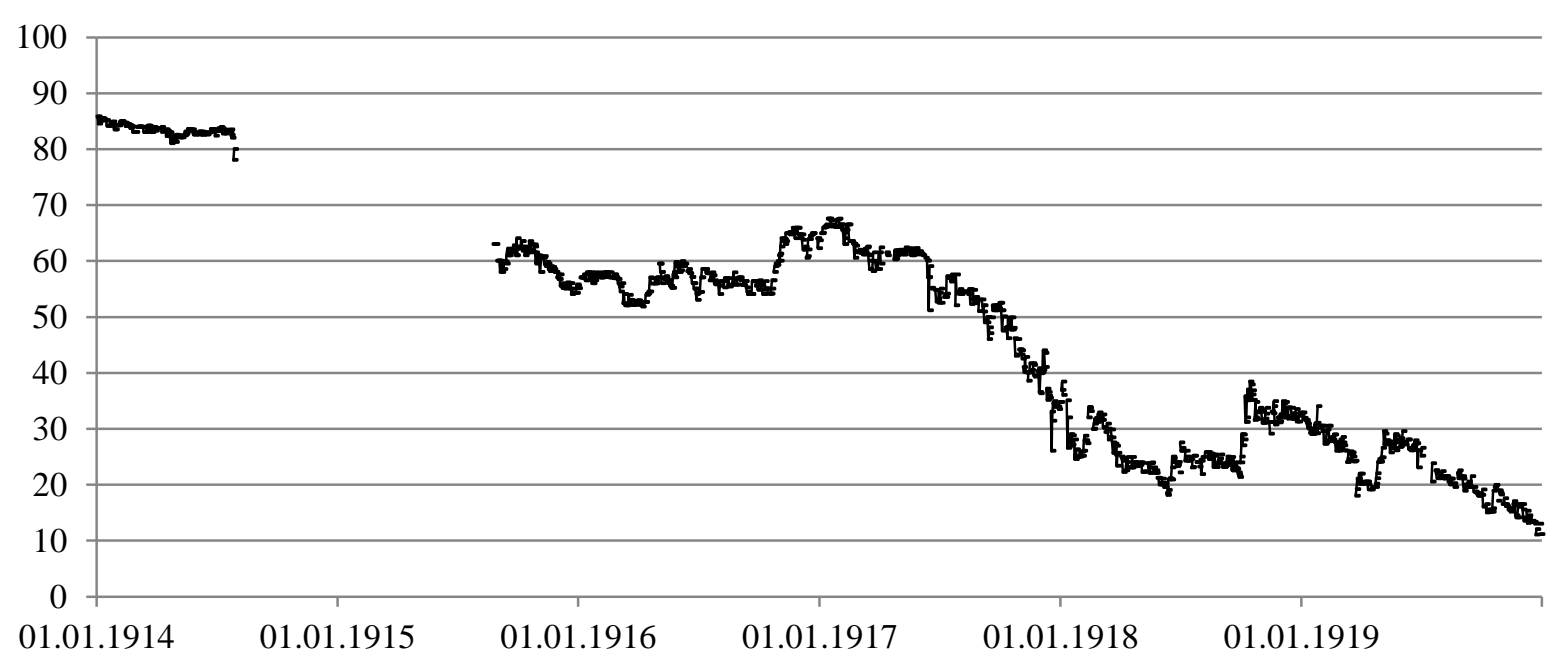

(150) Russia - $4.0 \%$ Moscow-Kursk railway

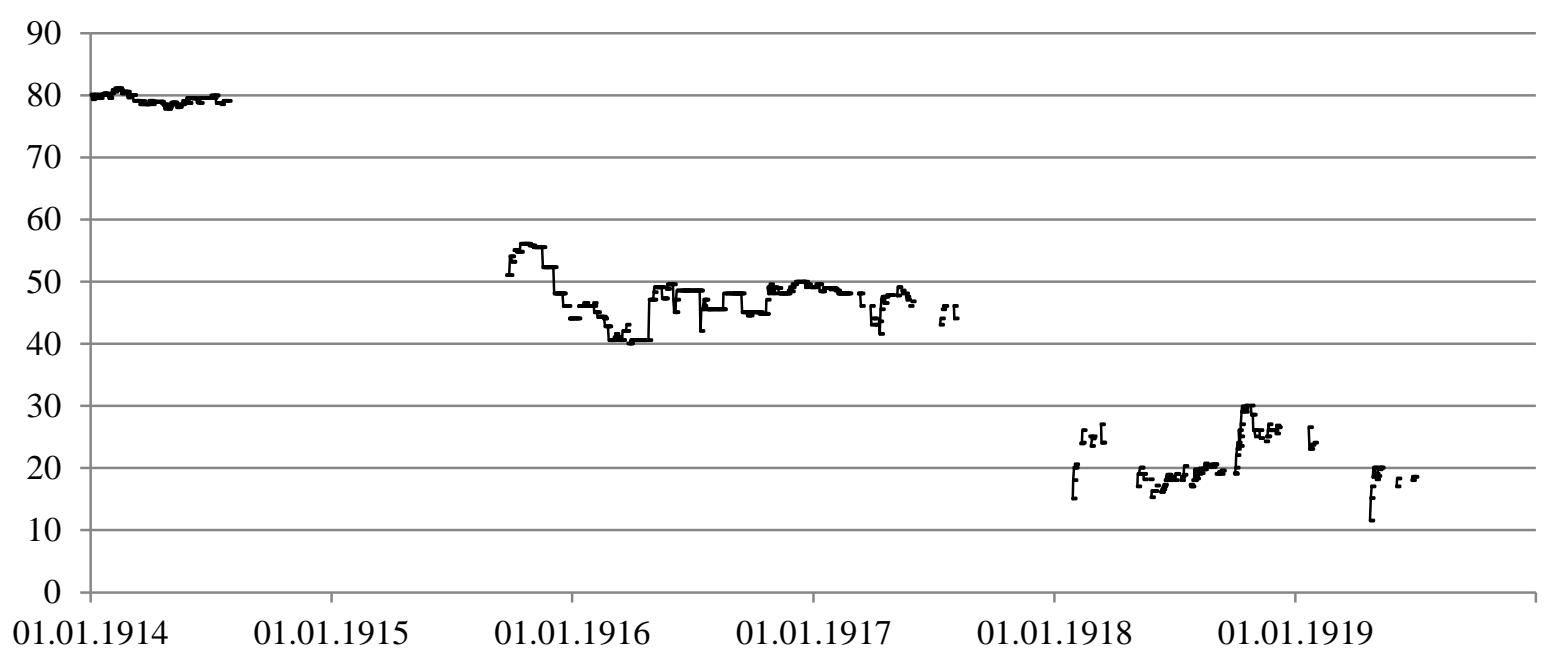

81 
(151) Russia - $4.0 \%$ Orel-G. railway of 1887

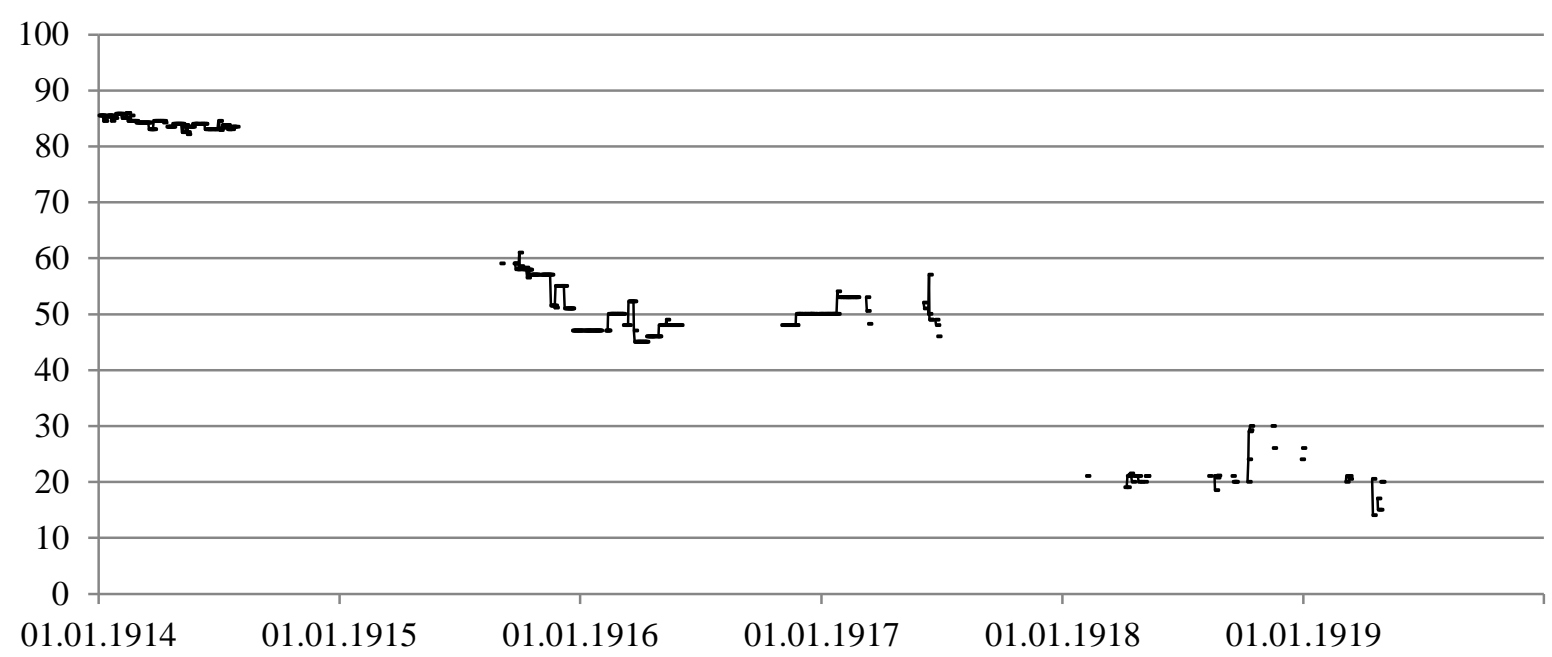

(152) Russia - $4.0 \%$ Orel-G. railway of 1889

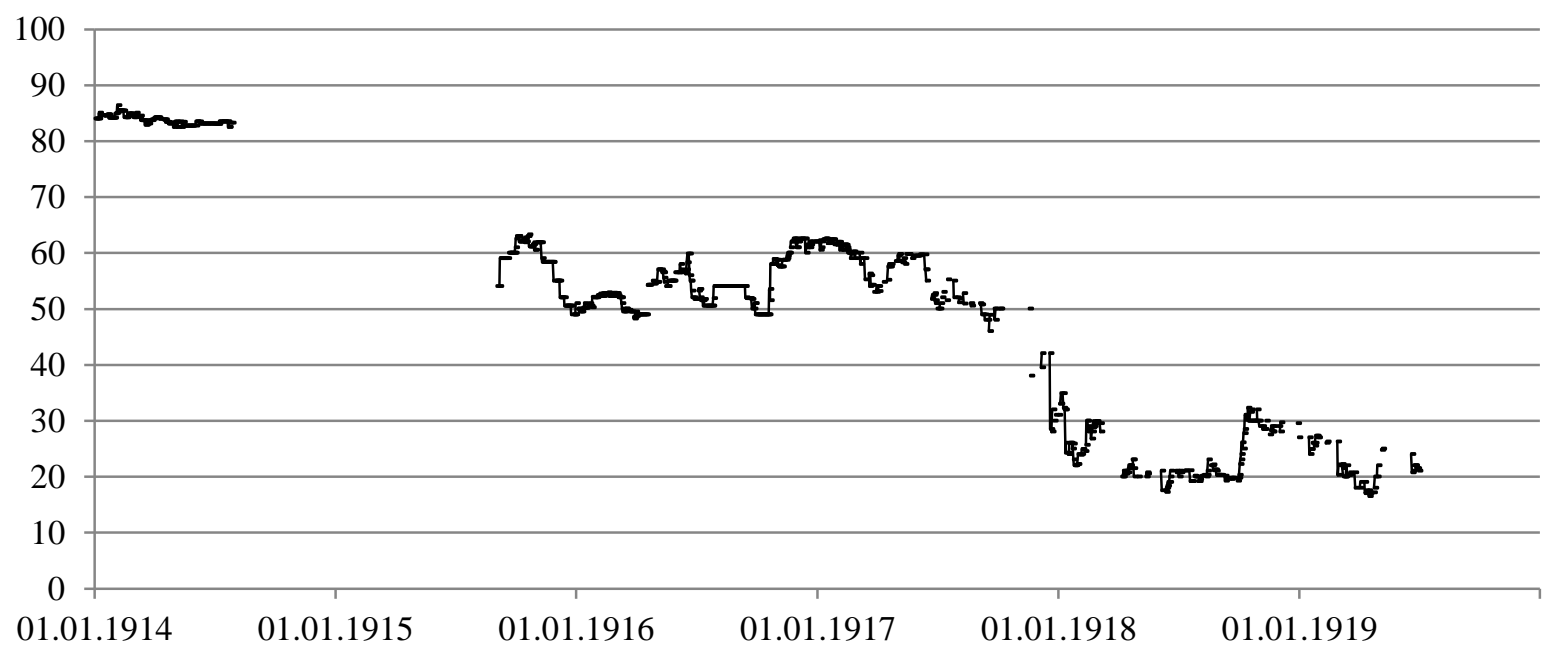

(153) Russia - 4.0 \% Kursk-Charkow railway (100)

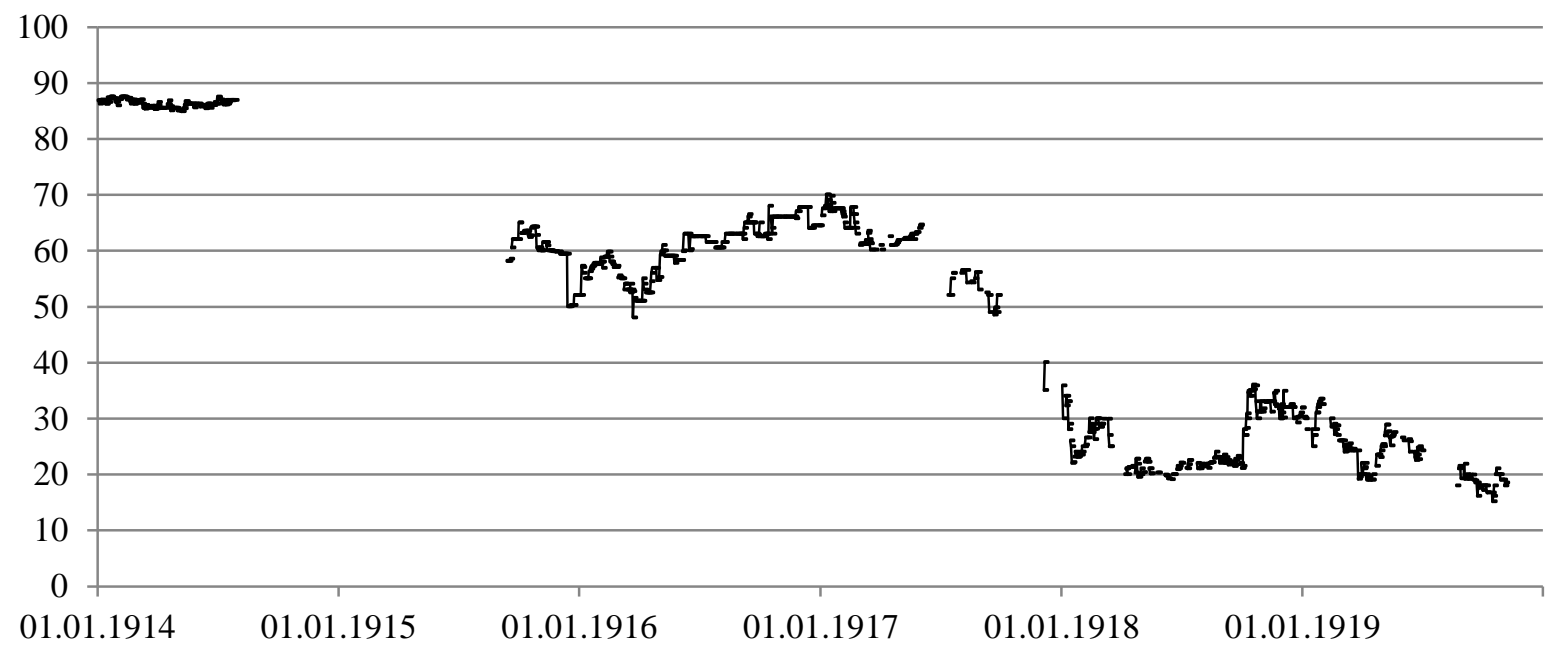


(154) Russia - 4.0 \% Kursk-Charkow Railway (600)

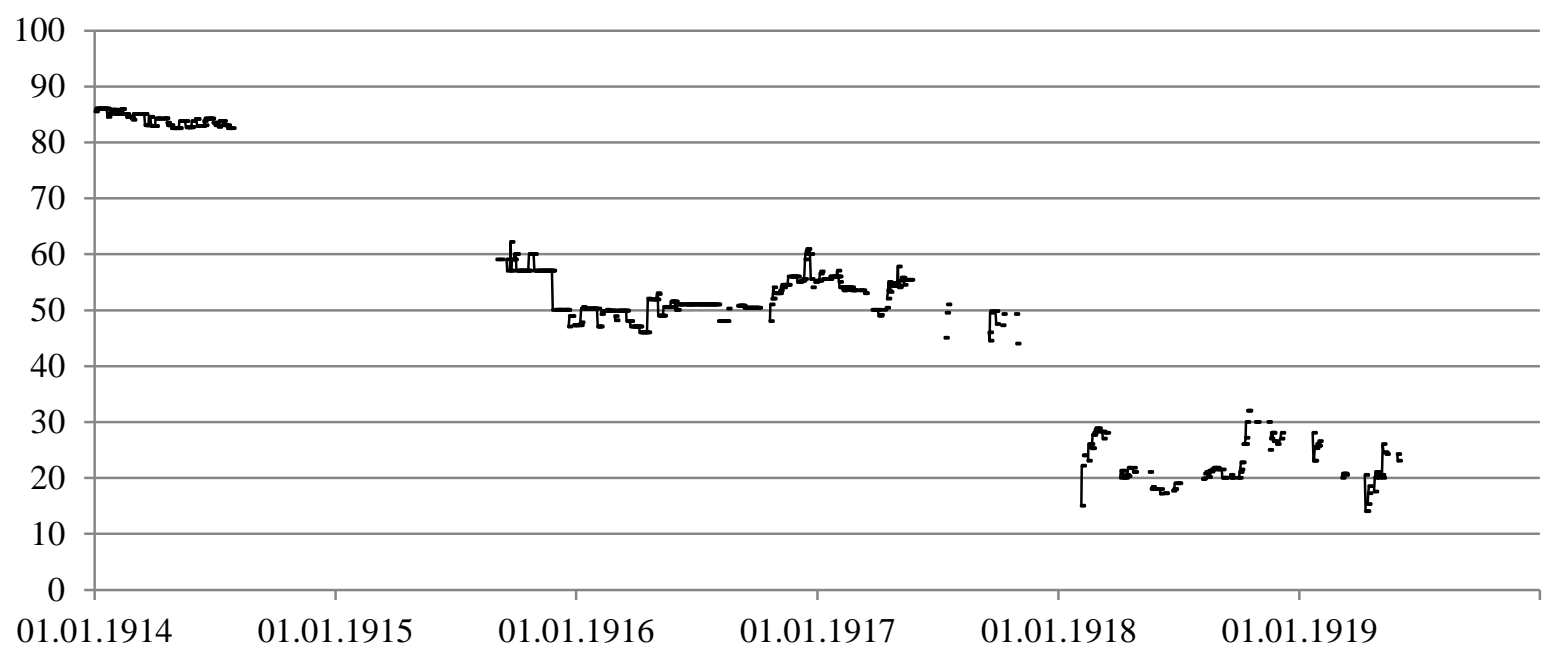

(155) Russia - $4.0 \%$ Kursk-Charkow railway (500/2 000)

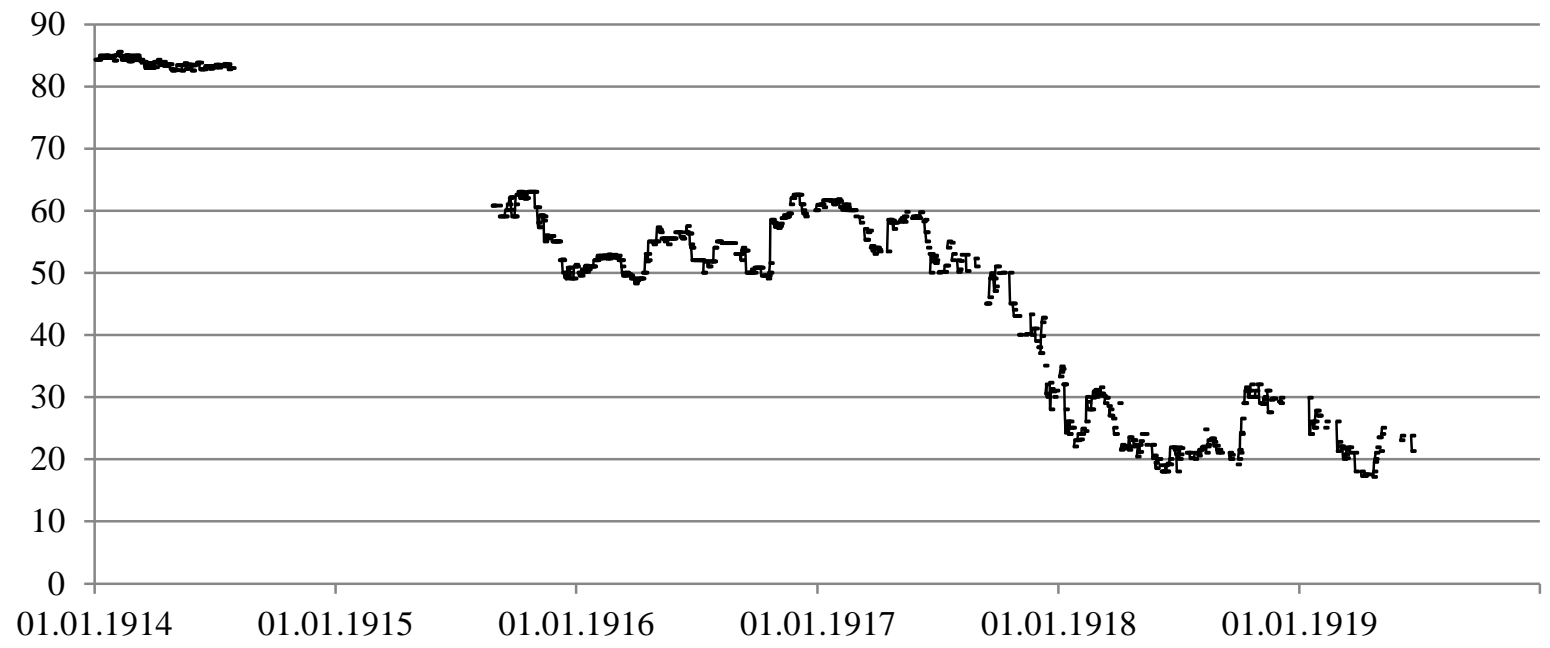

(156) Russia - 4.0 \% Kursk-Charkow railway (125)

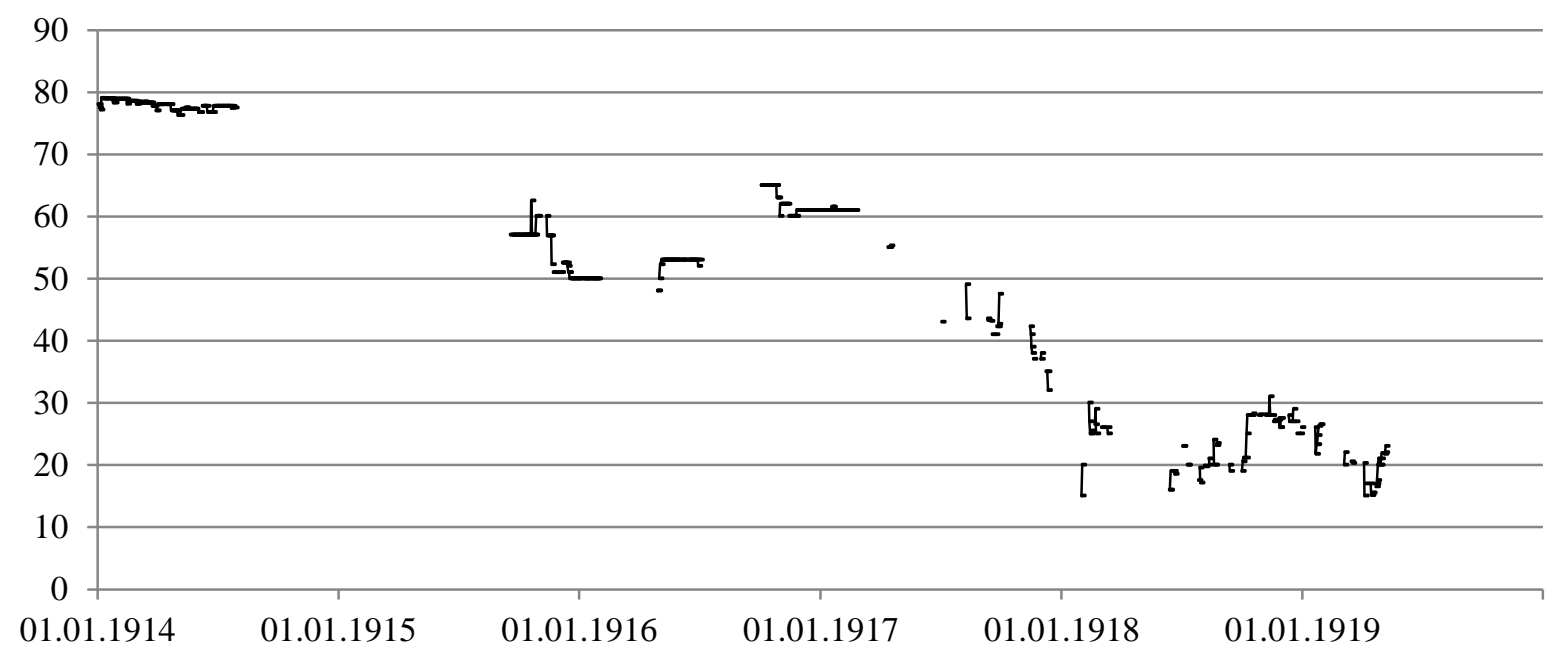


(157) Russia - $4.0 \%$ Rothschild (125) of 1889

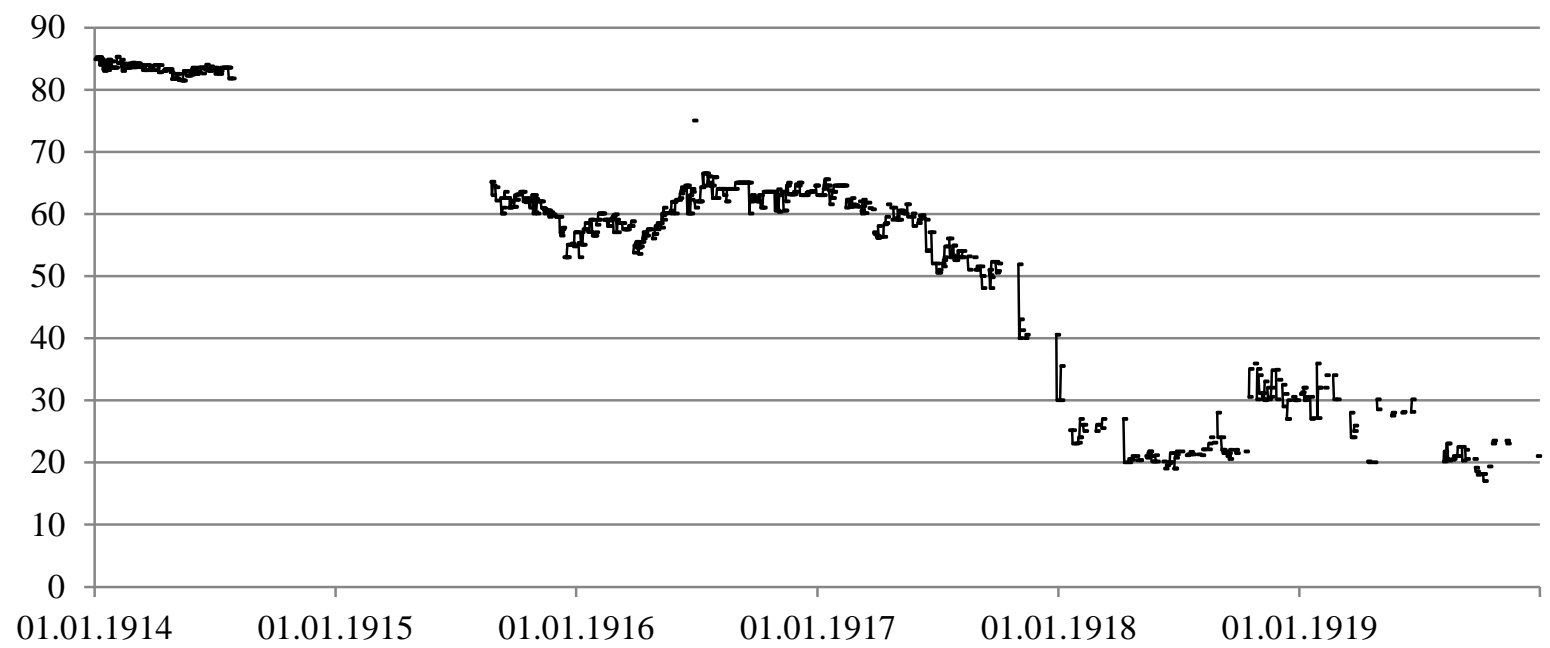

(158) Russia - $4.0 \%$ Rothschild (625) of 1889

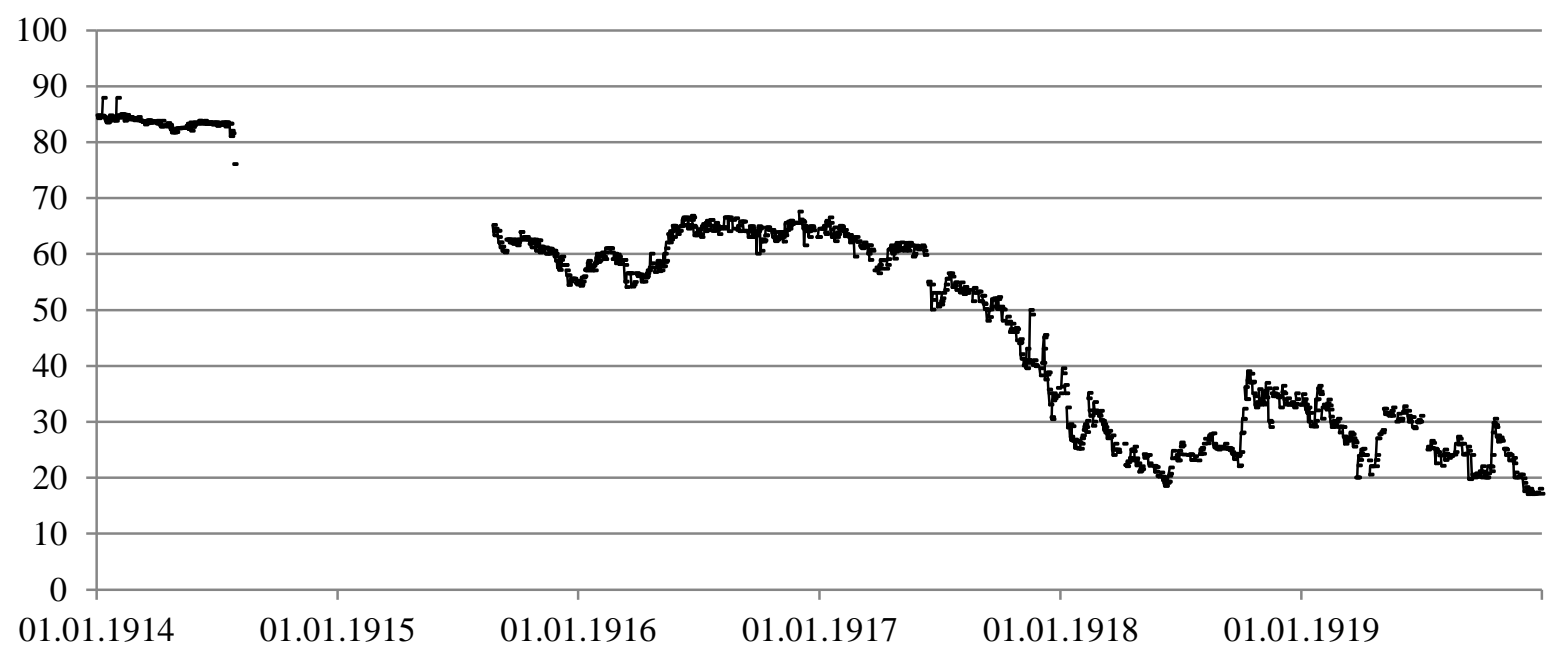

(159) Russia - $4.0 \%$ Rothschild (1 250/3 125) of 1889

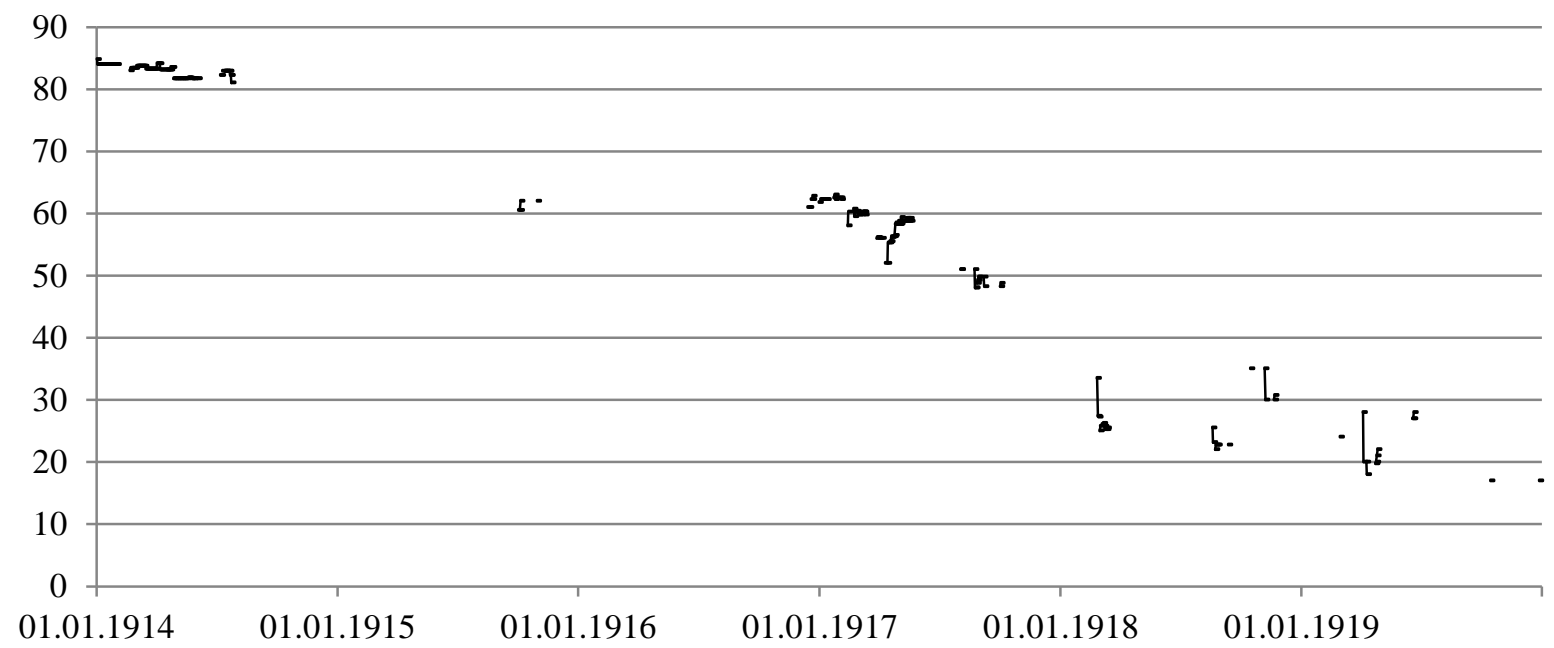


(160) Russia $-4.0 \%$ Hope \& Co (125) of 1889/90

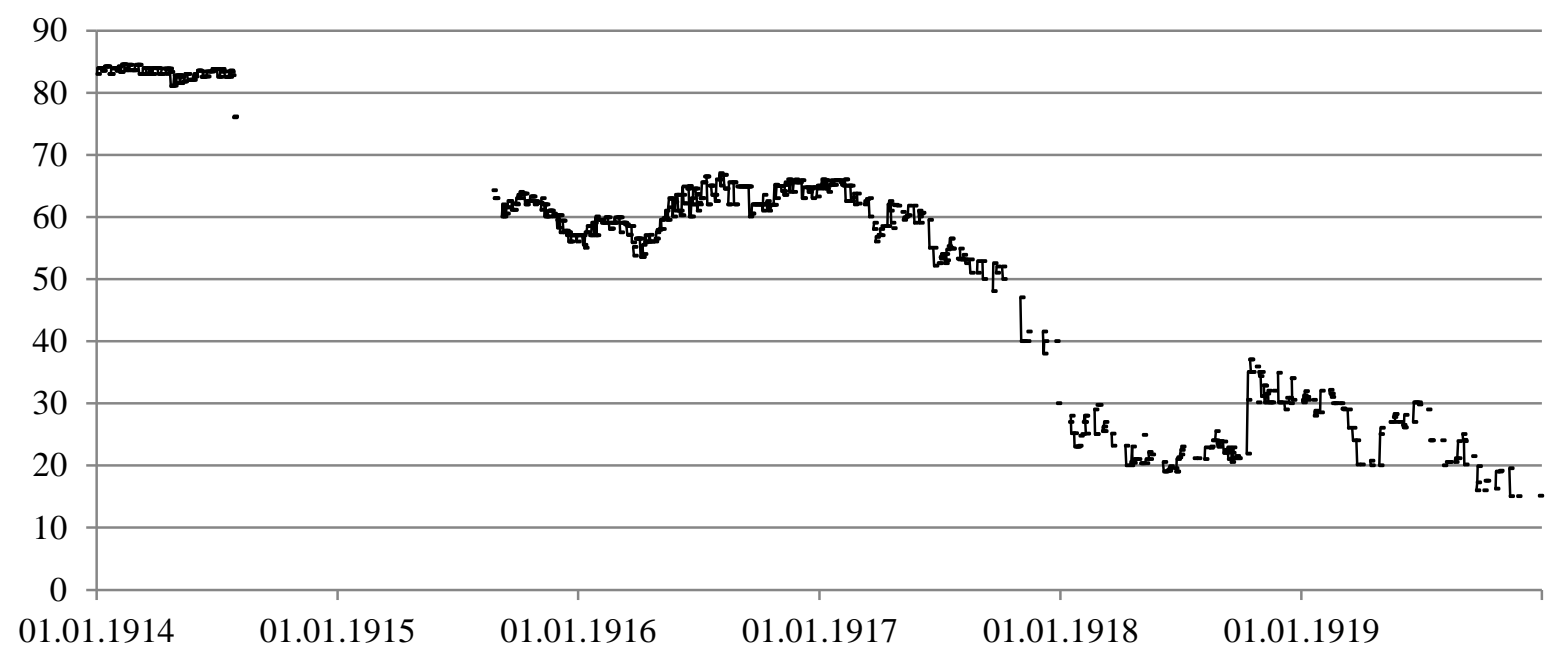

(161) Russia $-4.0 \%$ Hope \& Co (625) of 1889/90

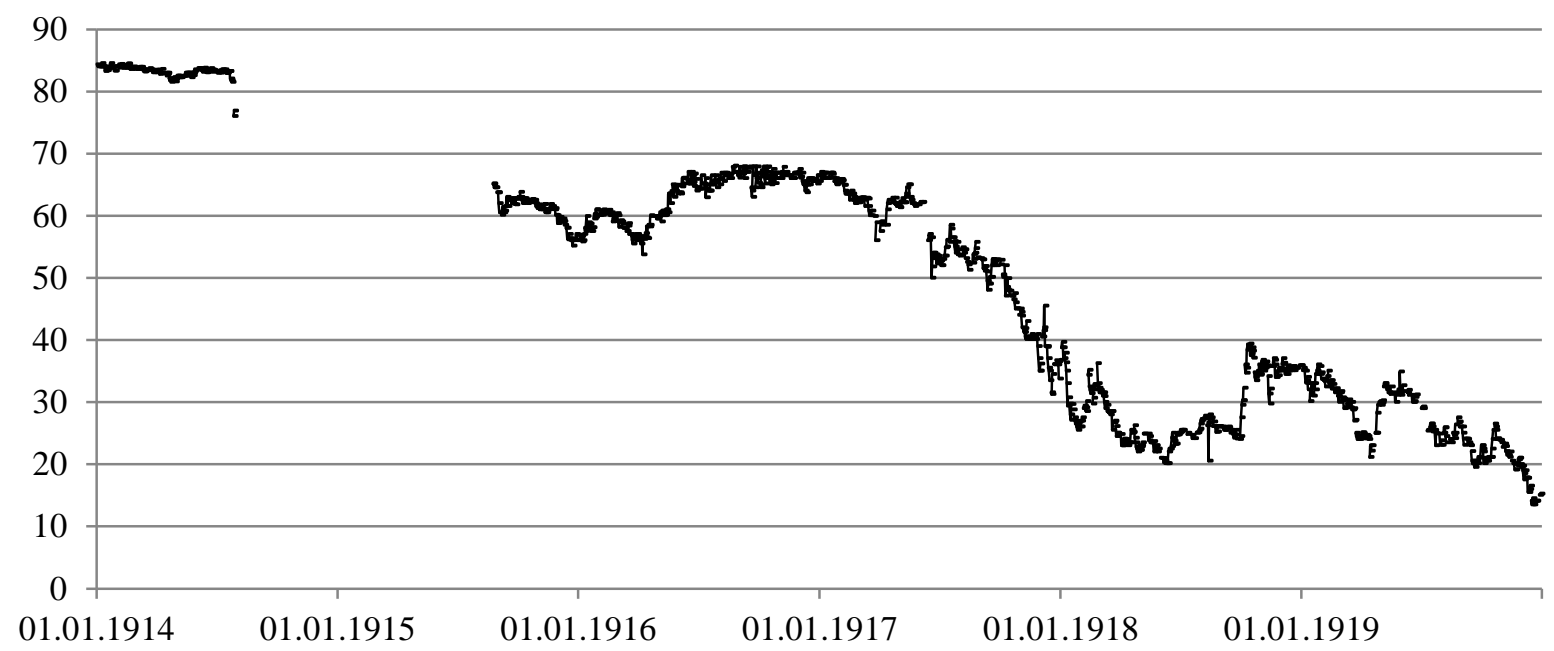

(162) Russia $-4.0 \%$ Rothschild $3^{\text {rd }}$ series (125) of 1890

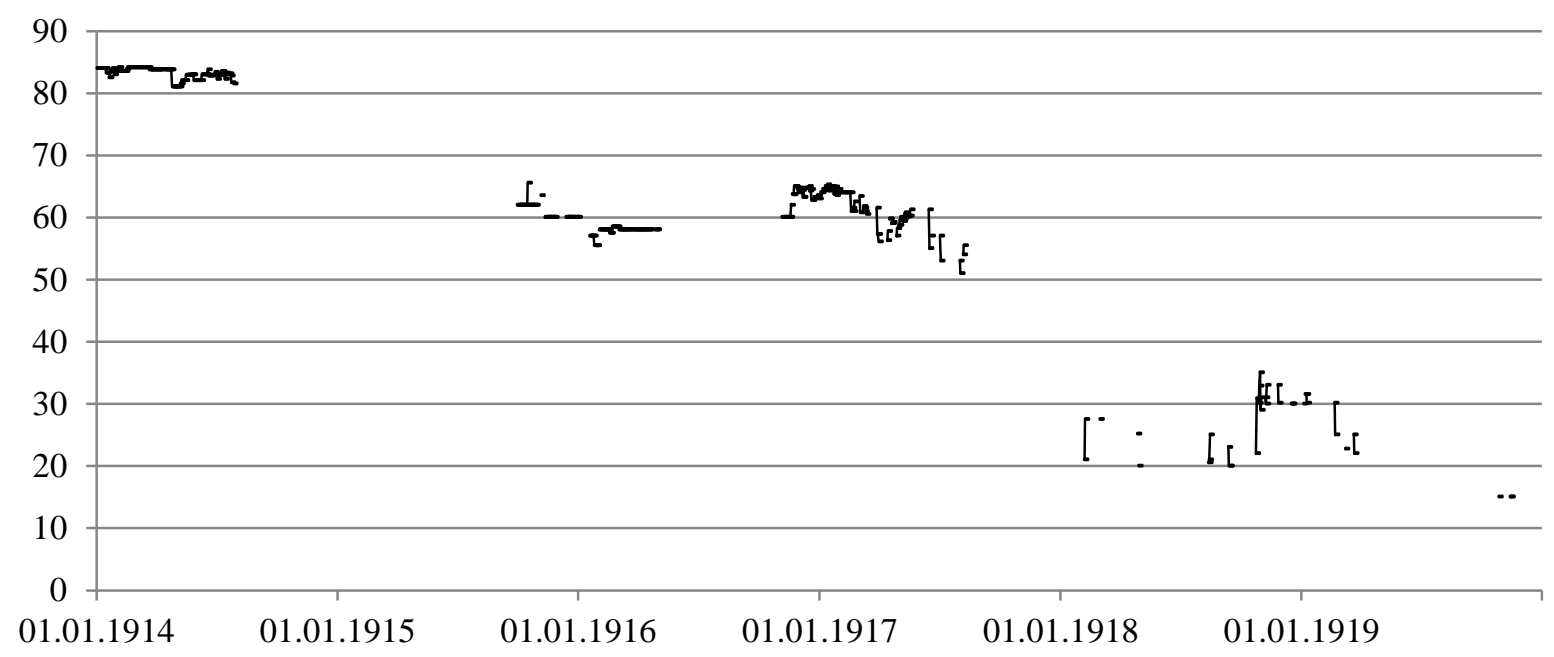


(163) Russia $-4.0 \%$ Rothschild $3^{\text {rd }}$ series (625) of 1890

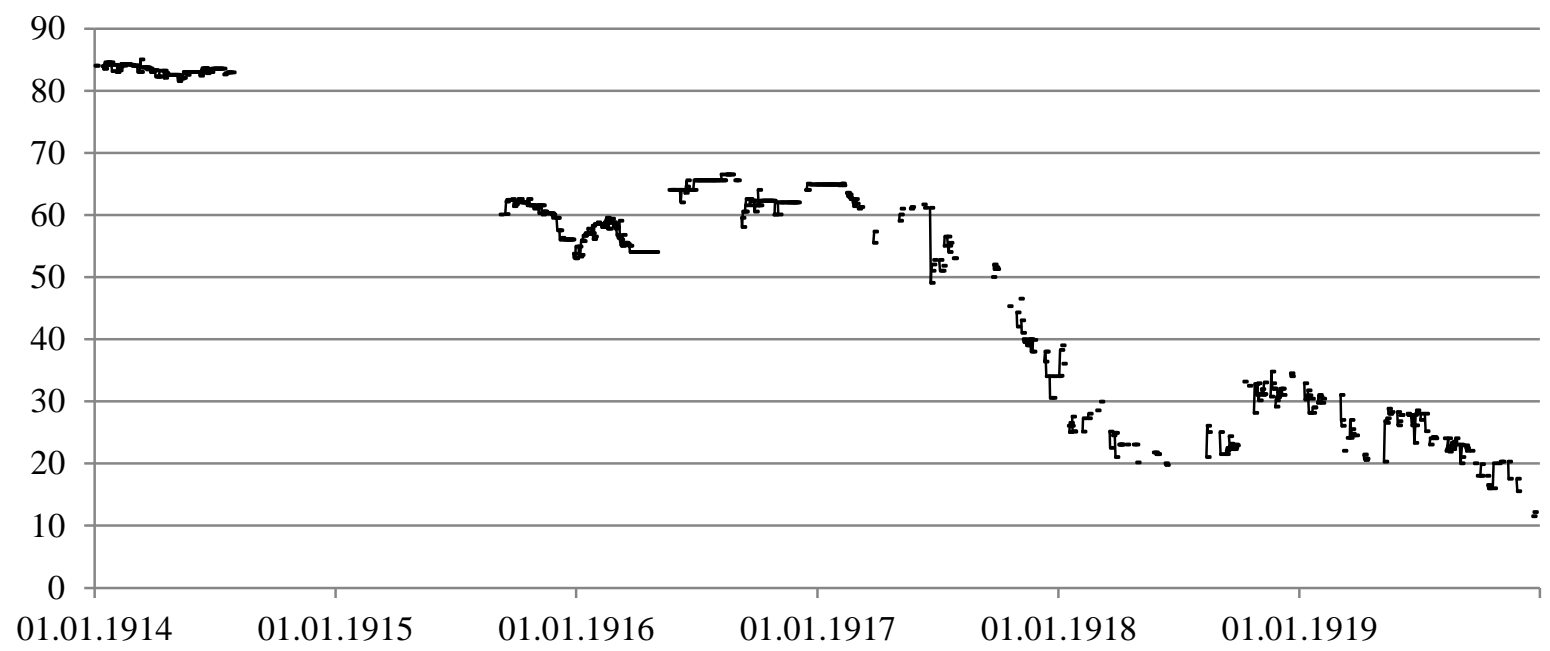

(164) Russia $-4.0 \%$ Rothschild $4^{\text {th }}$ series (125) of 1890

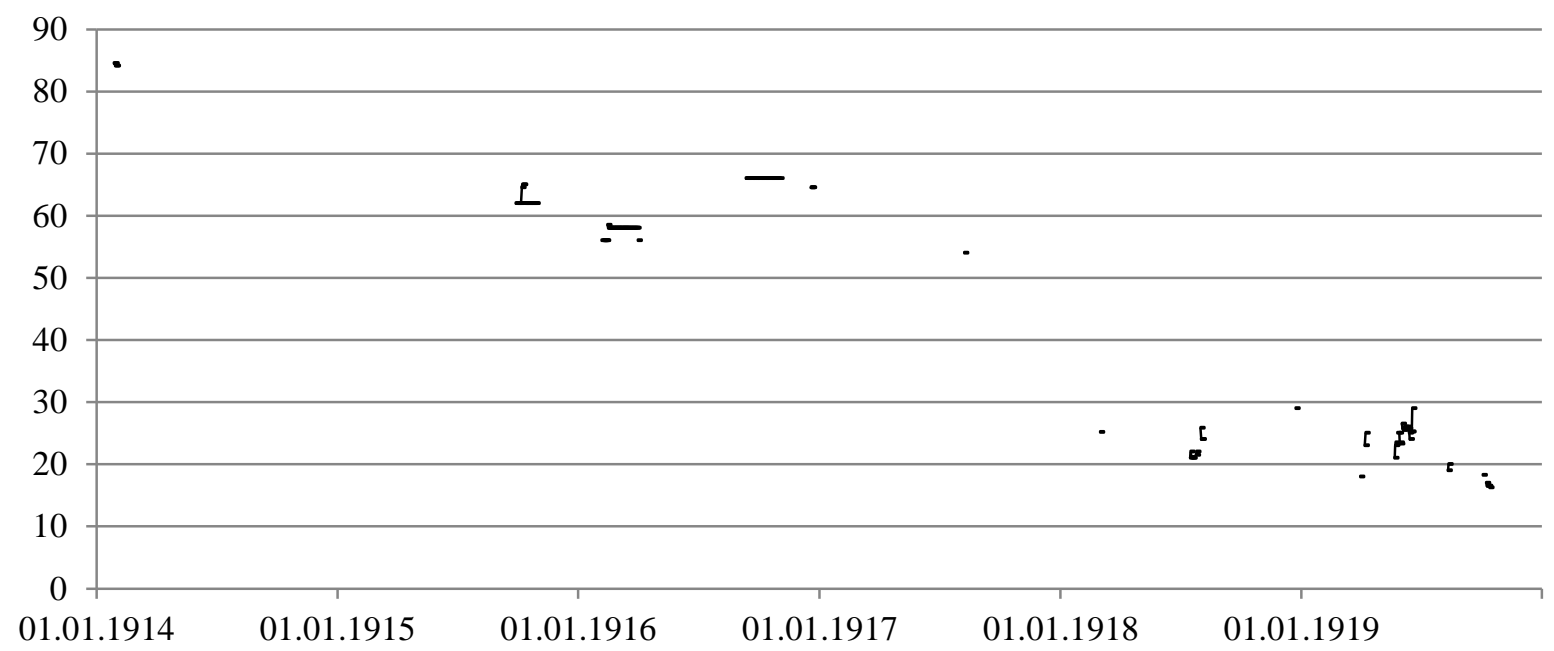

(165) Russia $-4.0 \%$ Rothschild $4^{\text {th }}$ series (625) of 1890

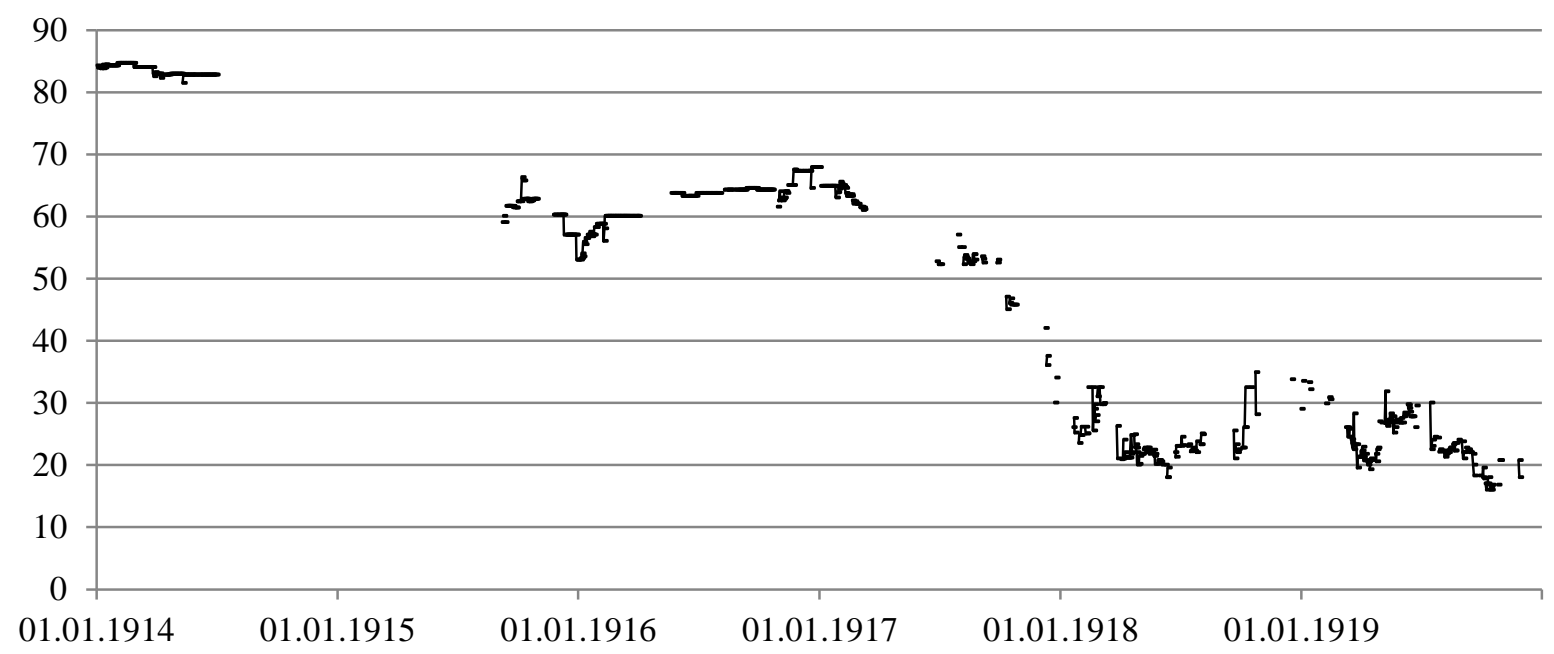


(166) Russia - $4.0 \%$ Warsaw-We. railway (125)

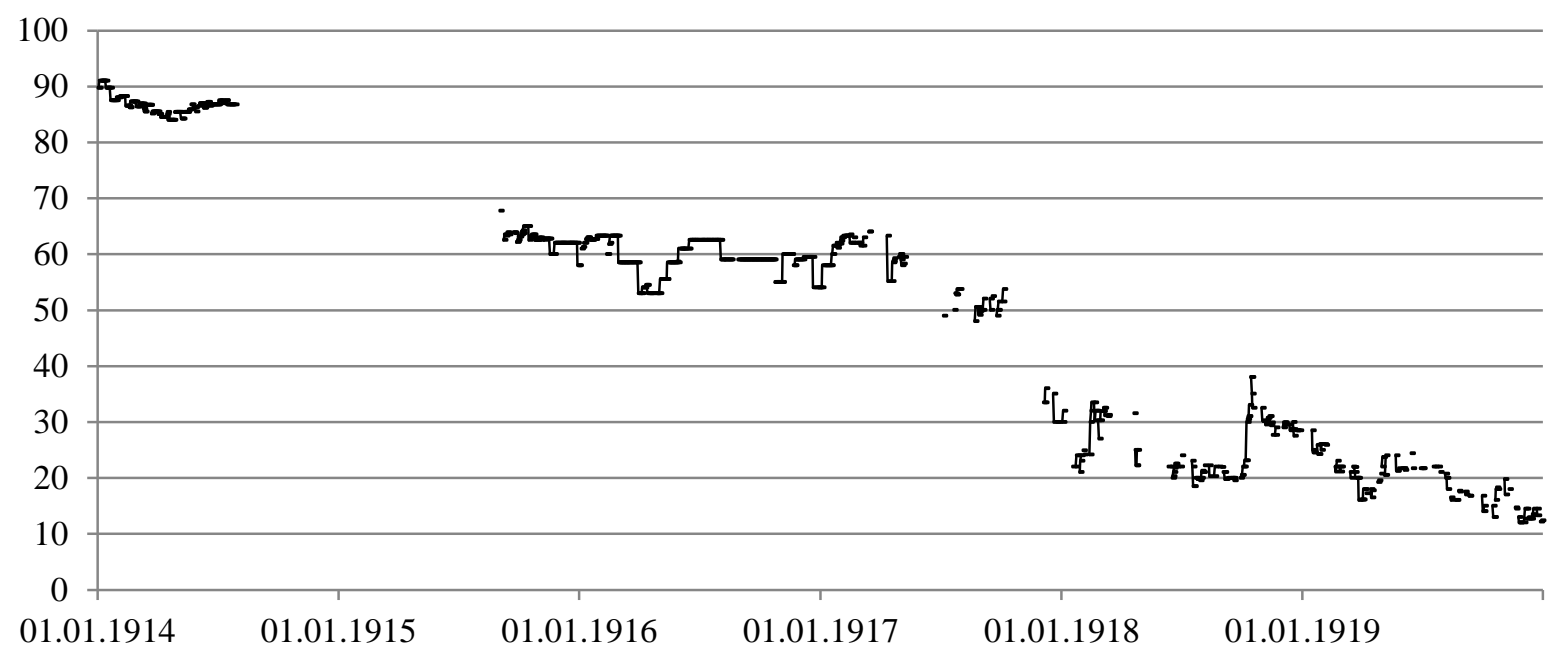

(167) Russia - $4.0 \%$ Warsaw-We. railway (625)

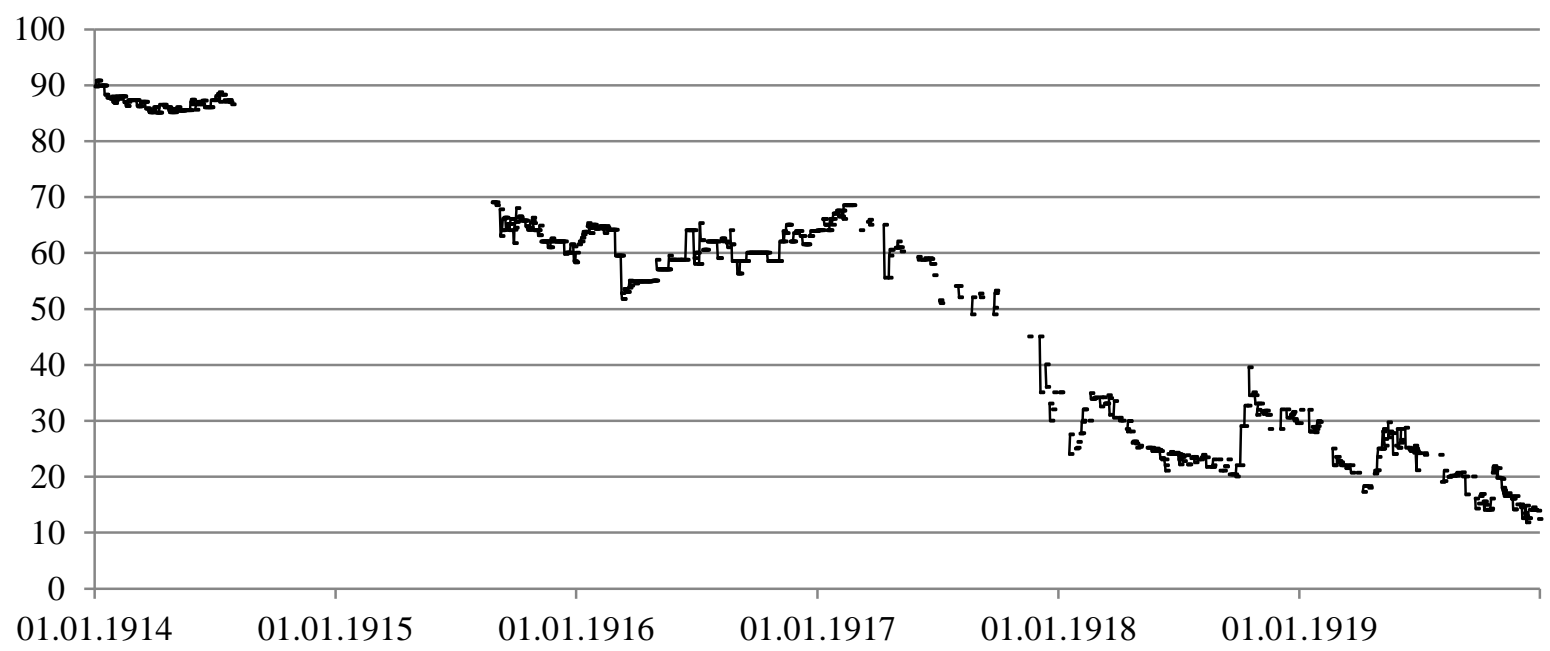

(168) Russia - $4.0 \%$ Warsaw-We. railway (1 250)

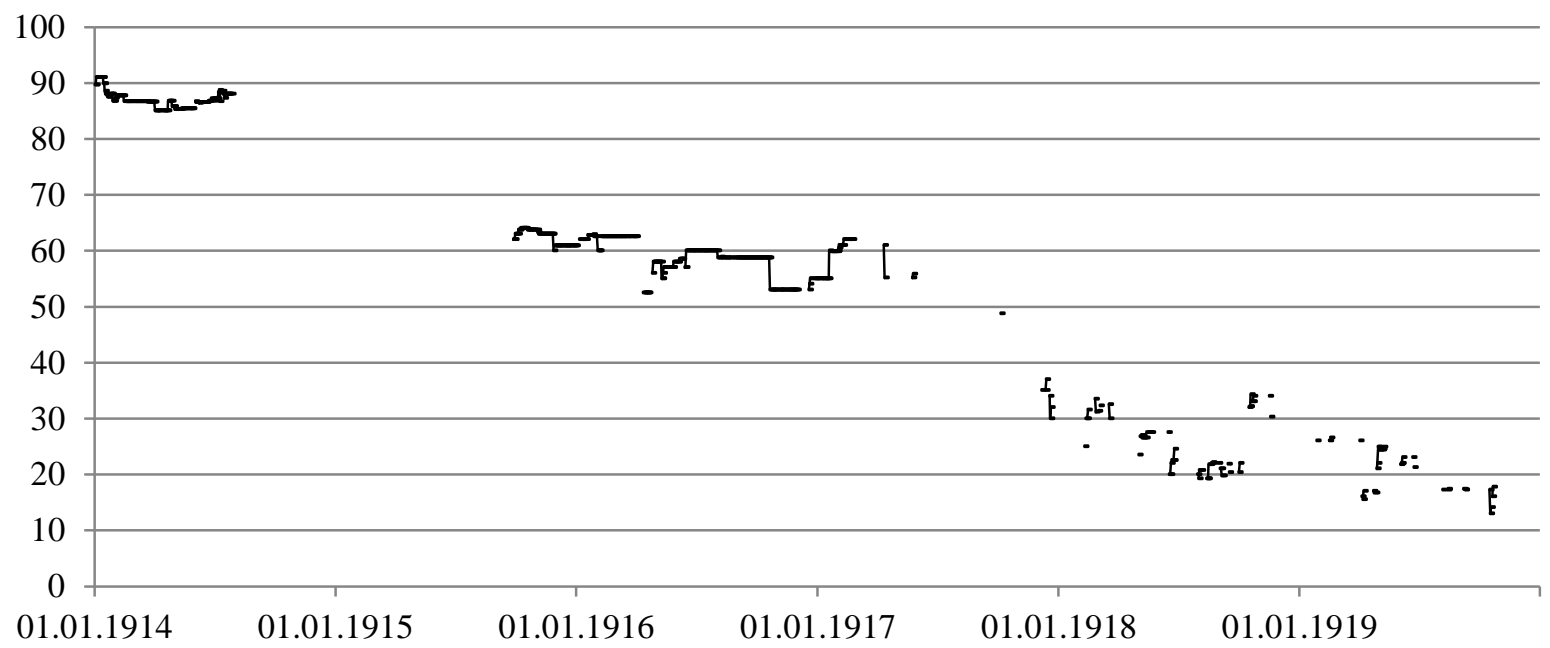


(169) Russia $-4.0 \%$ Warsaw-We. railway $7^{\text {th }}$ series

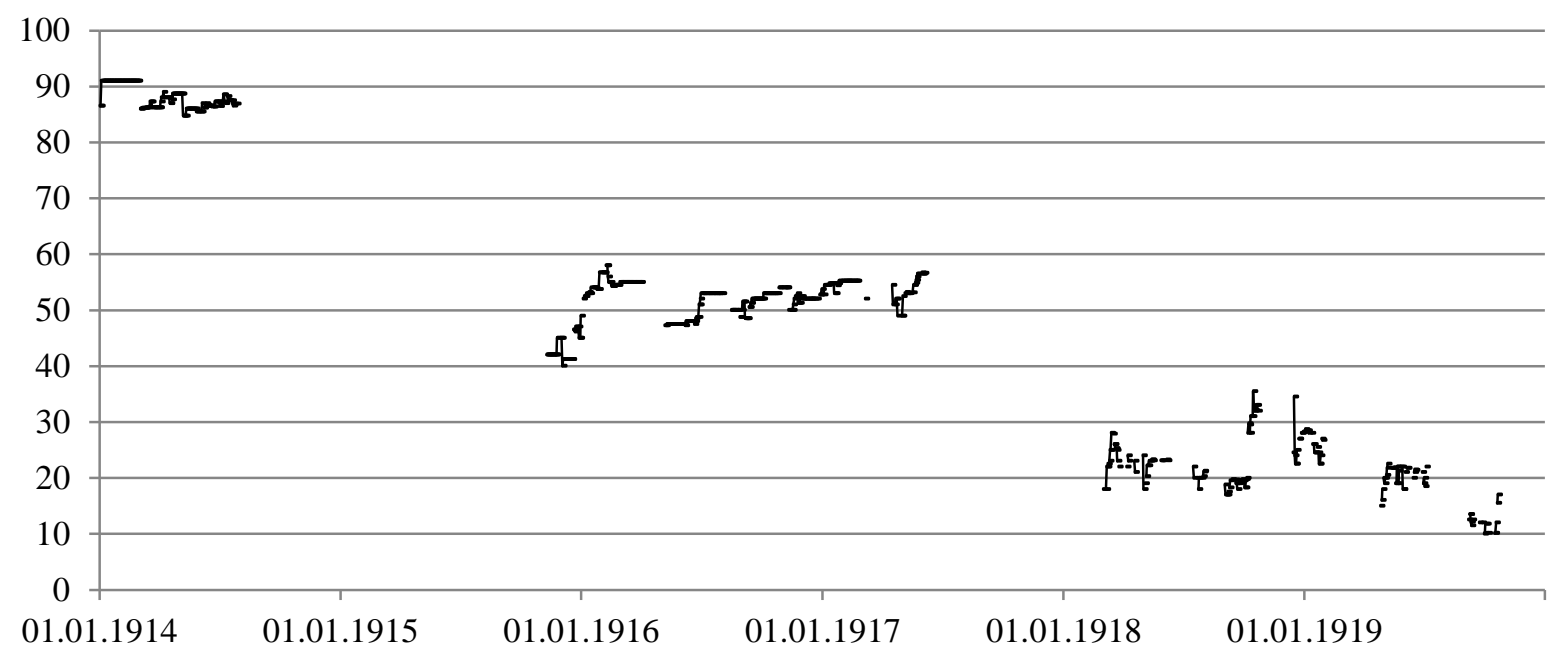

(170) Russia $-4.0 \%$ Warsaw-We. railway $9^{\text {th }}$ series

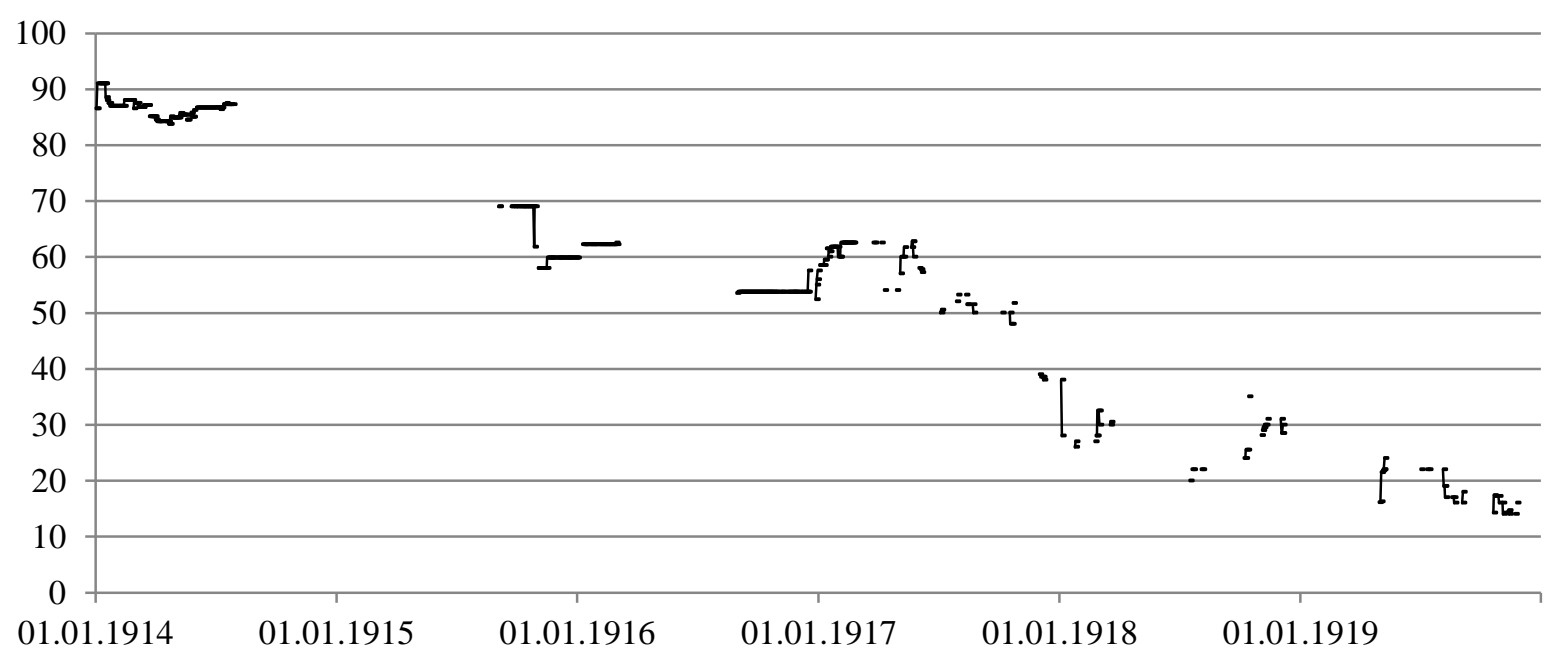

(171) Russia $-4.0 \%$ Warsaw-We. railway $10^{\text {th }}$ series

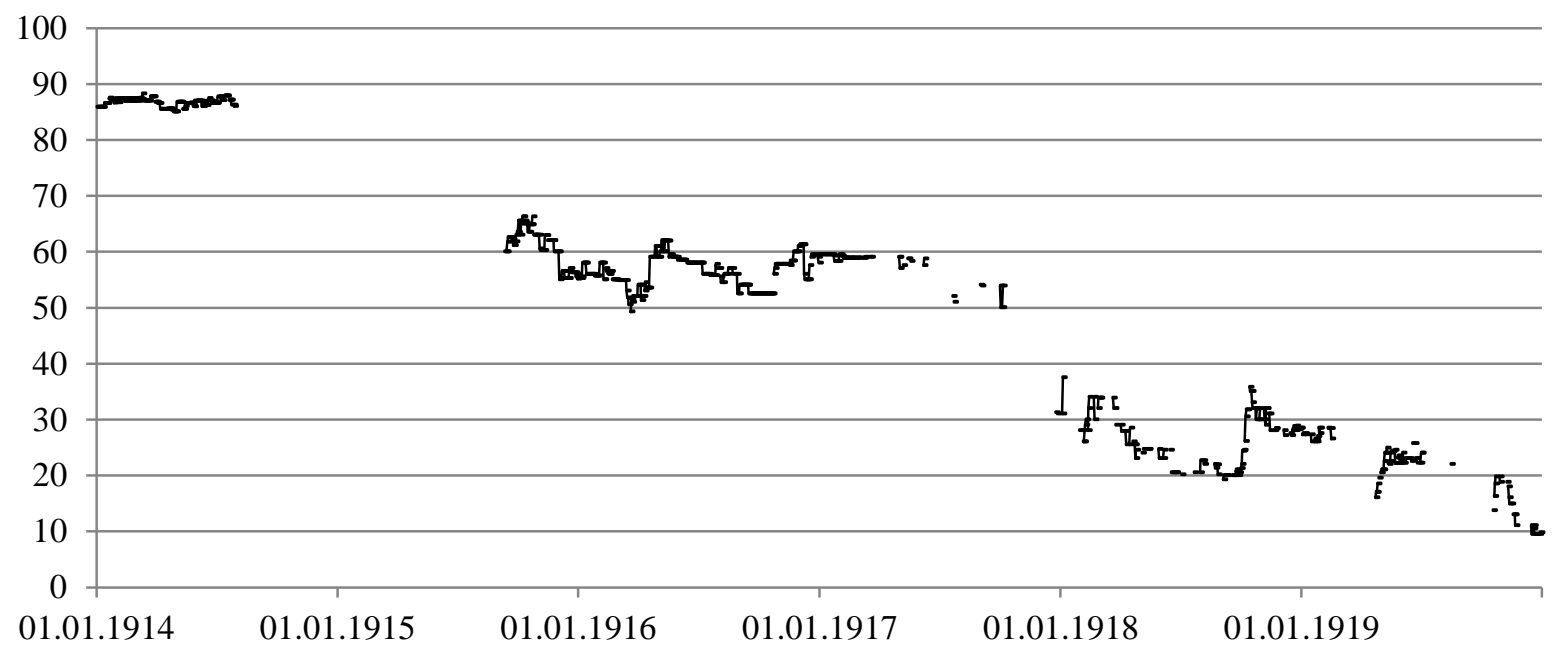


(172) Russia $-4.0 \%$ Warsaw-We. railway $11^{\text {th }}$ series

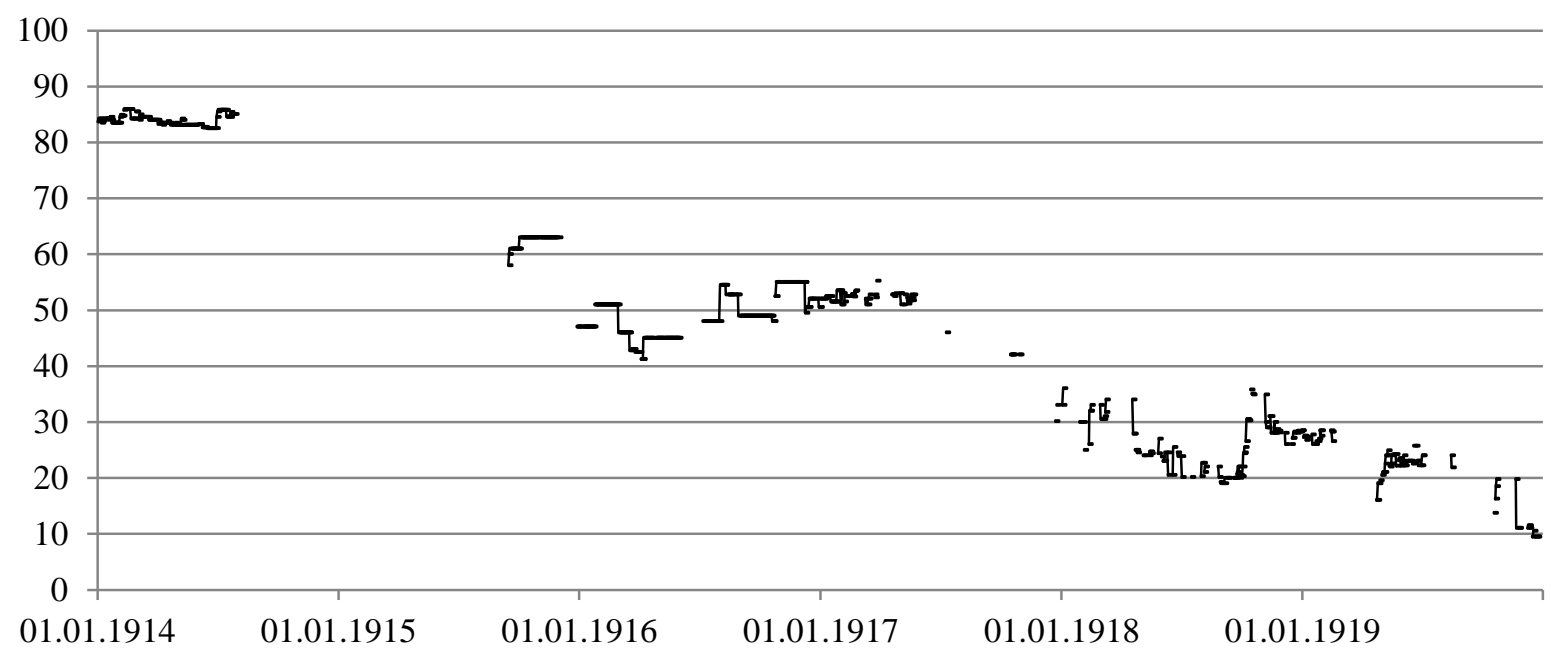

(173) Russia $-4.0 \%$ Rothschild $3^{\text {rd }}$ series (125) of 1891

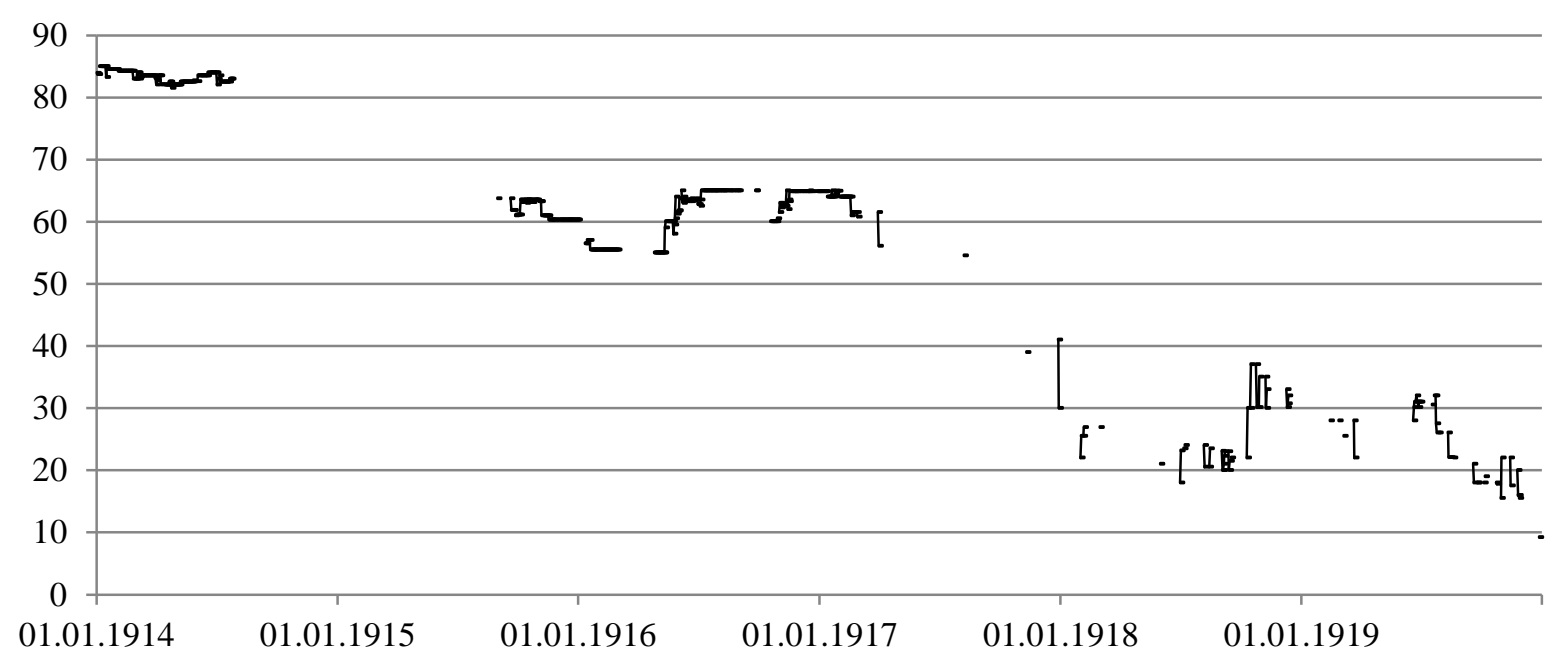

(174) Russia $-4.0 \%$ Rothschild $3^{\text {rd }}$ series (625) of 1891

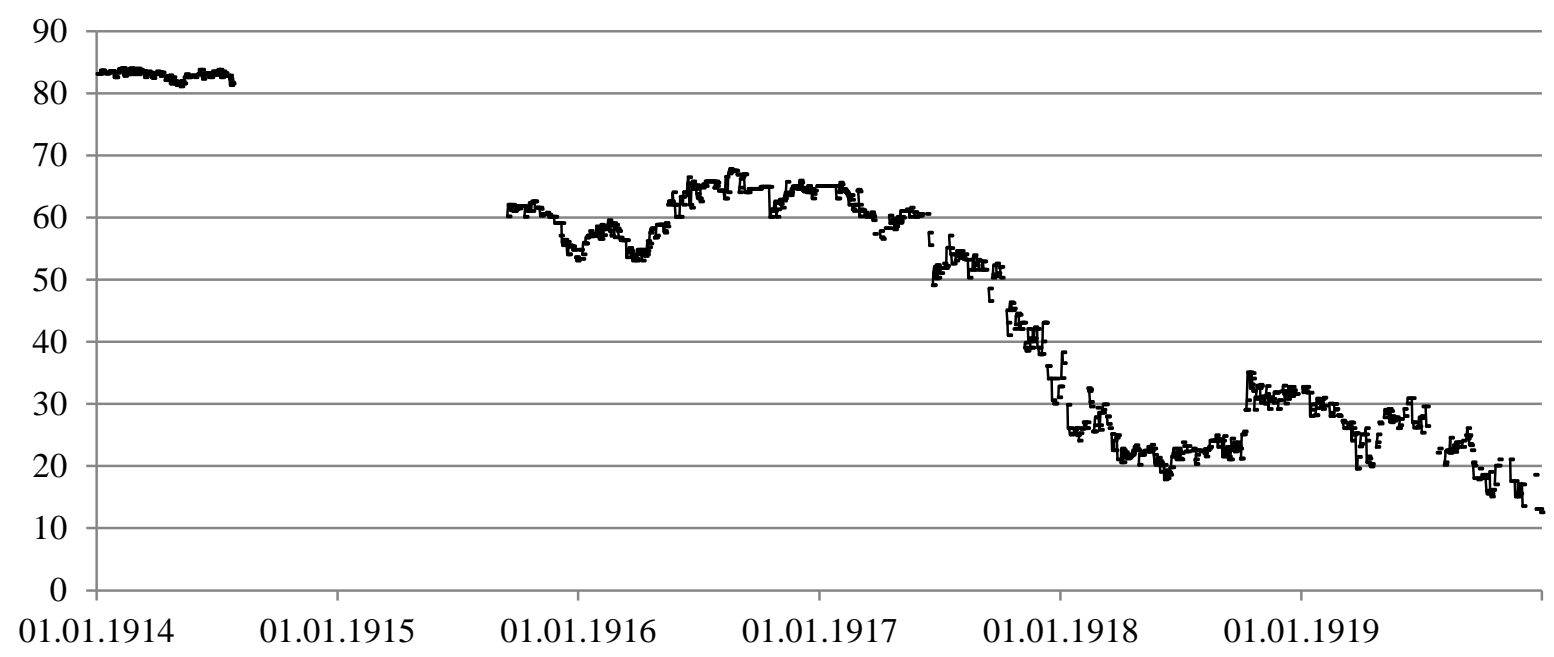


(175) Russia $-4.0 \%$ Rothschild $5^{\text {th }}$ series (125) of 1893

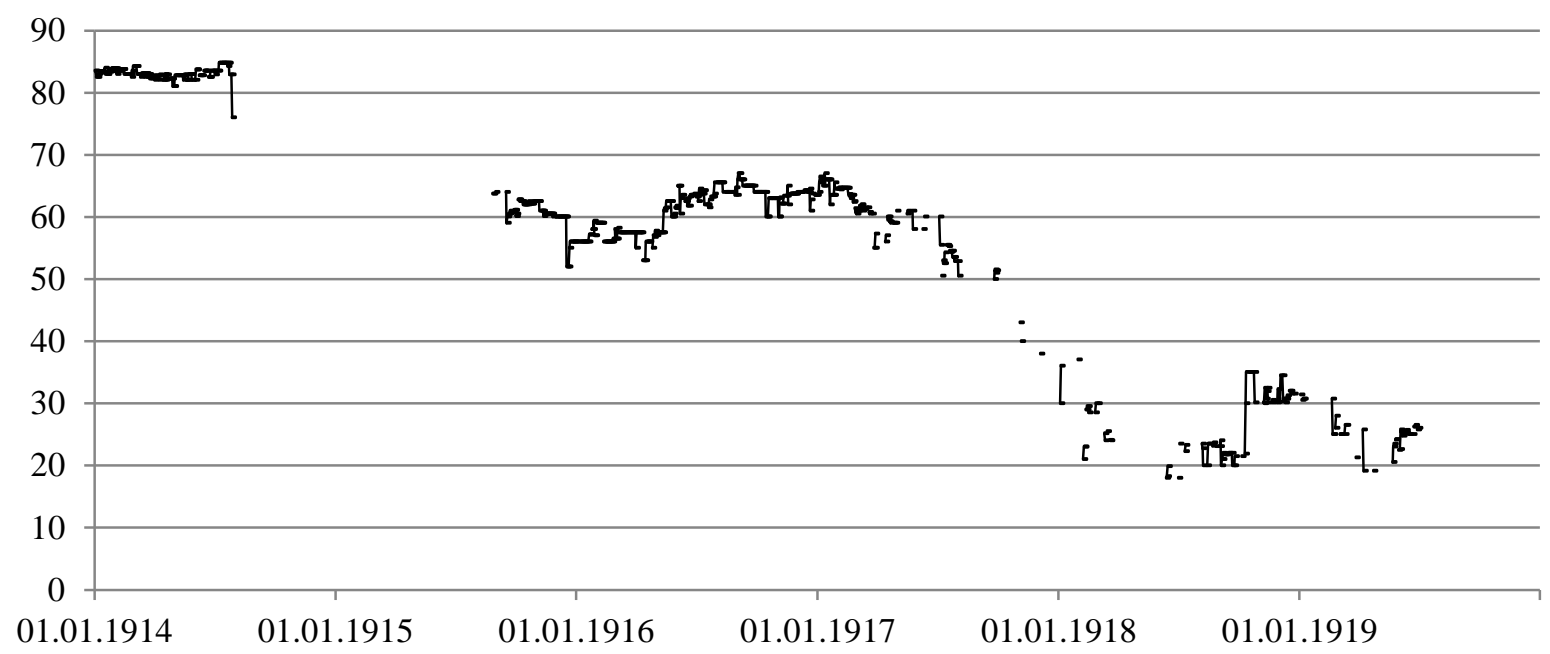

(176) Russia $-4.0 \%$ Rothschild $5^{\text {th }}$ series (625) of 1893

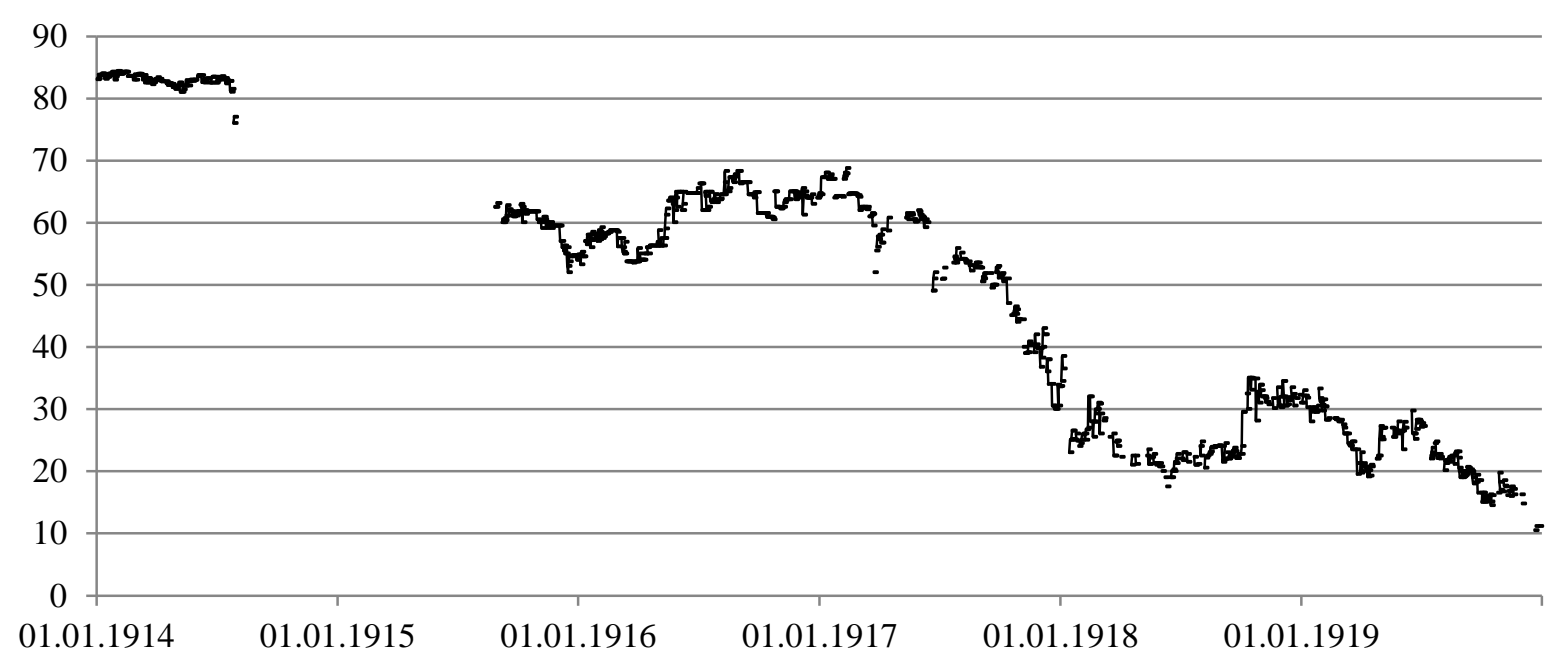

(177) Russia $-4.0 \%$ Rothschild $6^{\text {th }}$ series (125) of 1894

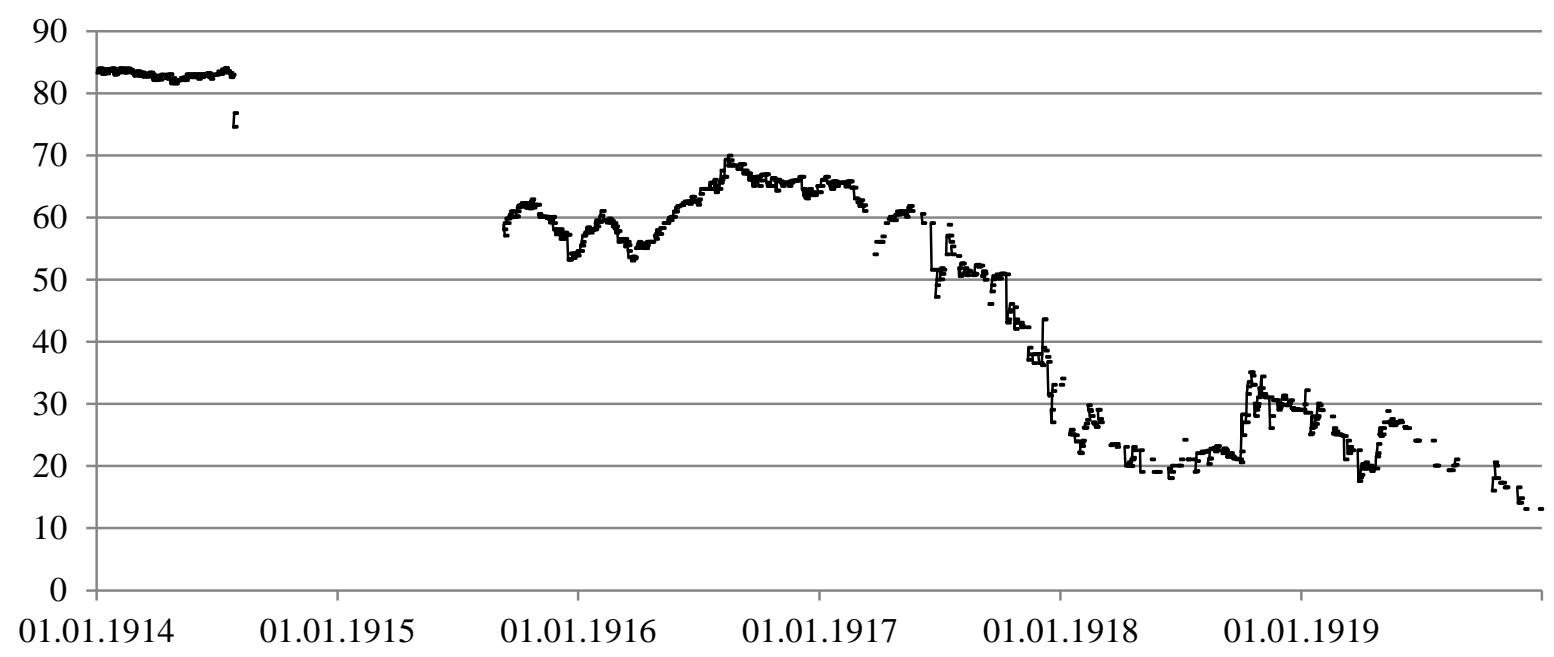


(178) Russia $-4.0 \%$ Rothschild $6^{\text {th }}$ series (625) of 1894

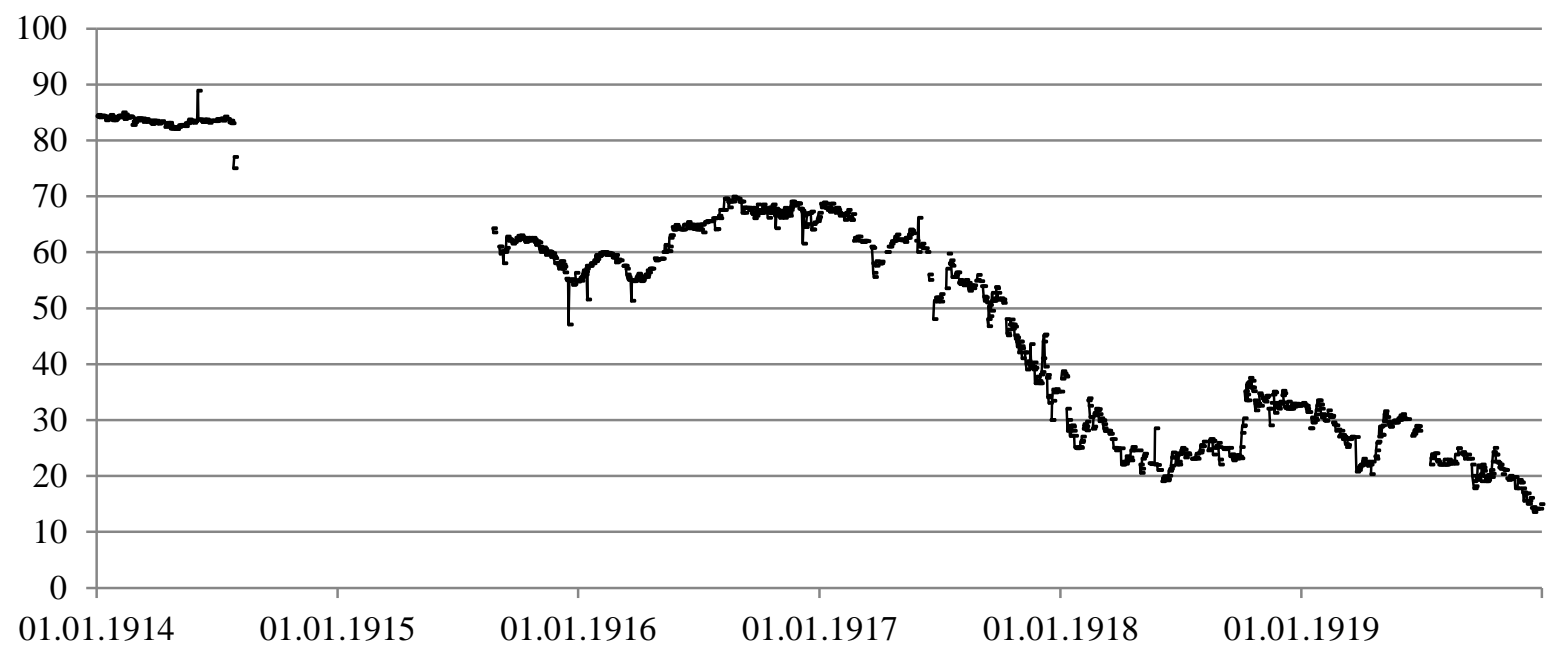

(179) Russia - 4.0 \% Donetz railway of 1894

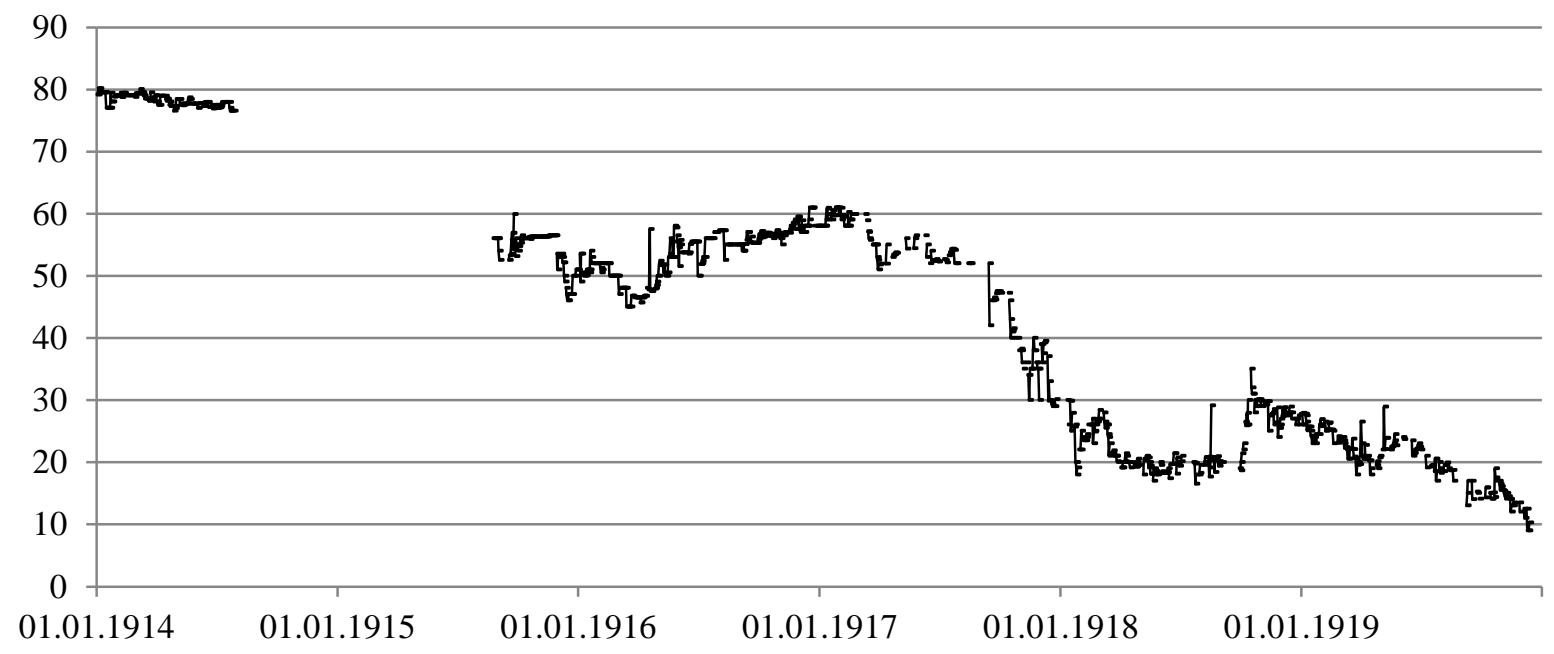

(180) Russia - $4.0 \%$ of 1894 (domestic debt)

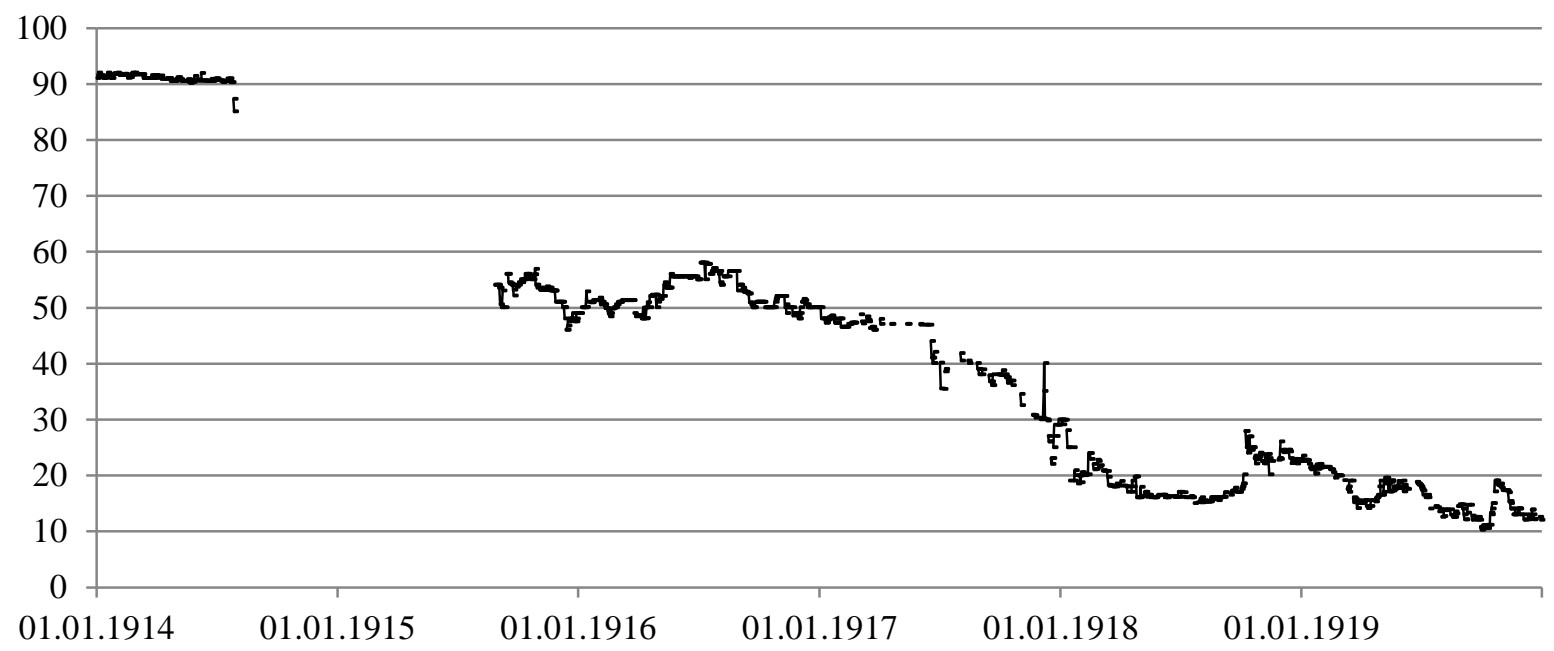


(181) Russia $-4.0 \%$ of 1894 (certificates)

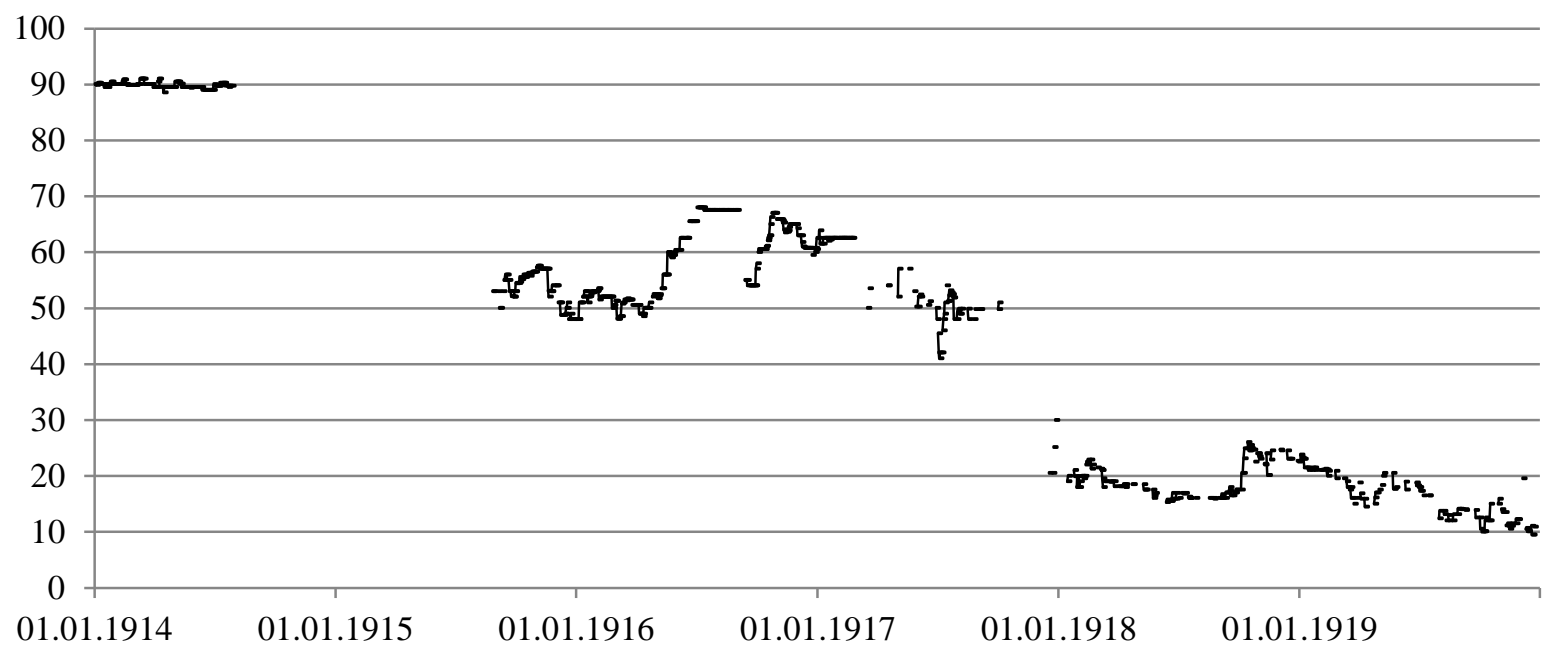

(182) Russia - 4.0 \% Orel-Viterbsk railway (125) of 1894

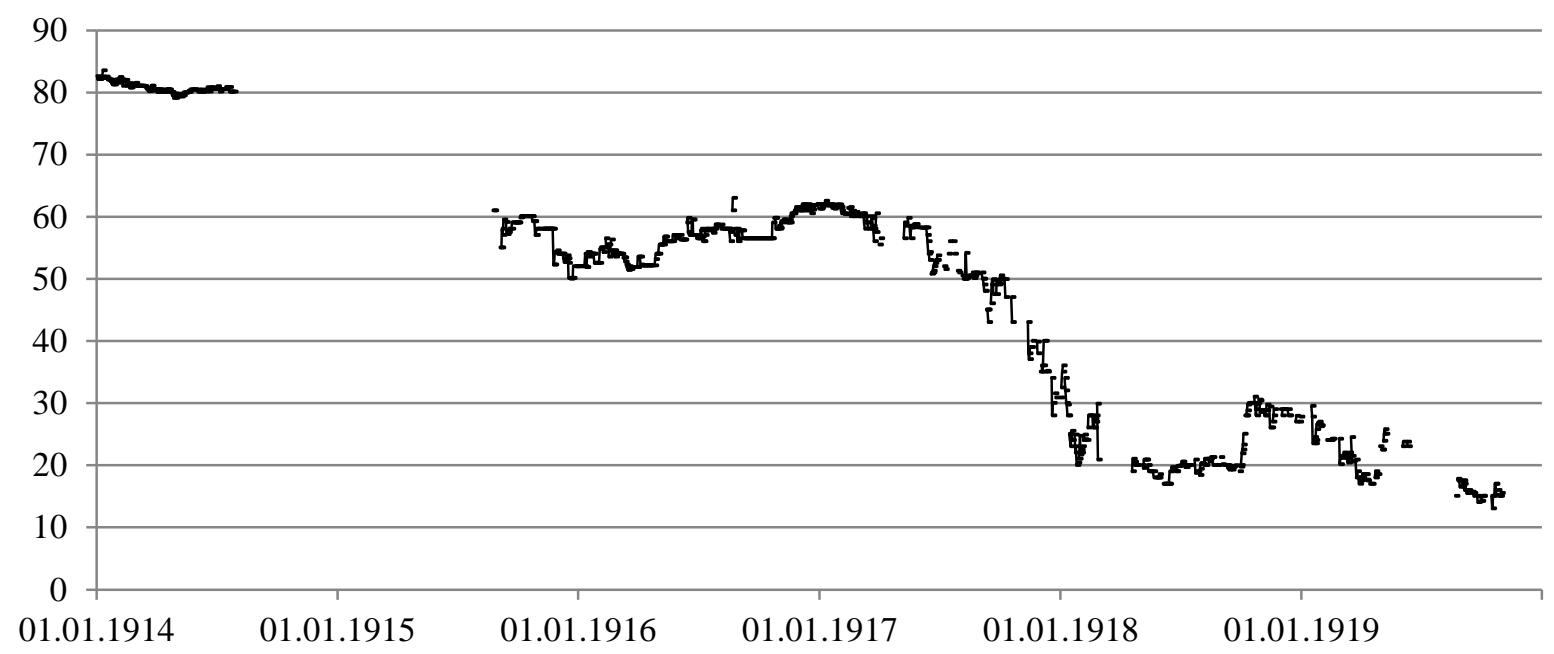

(183) Russia - 4.0 \% Orel-Viterbsk railway (625) of 1894

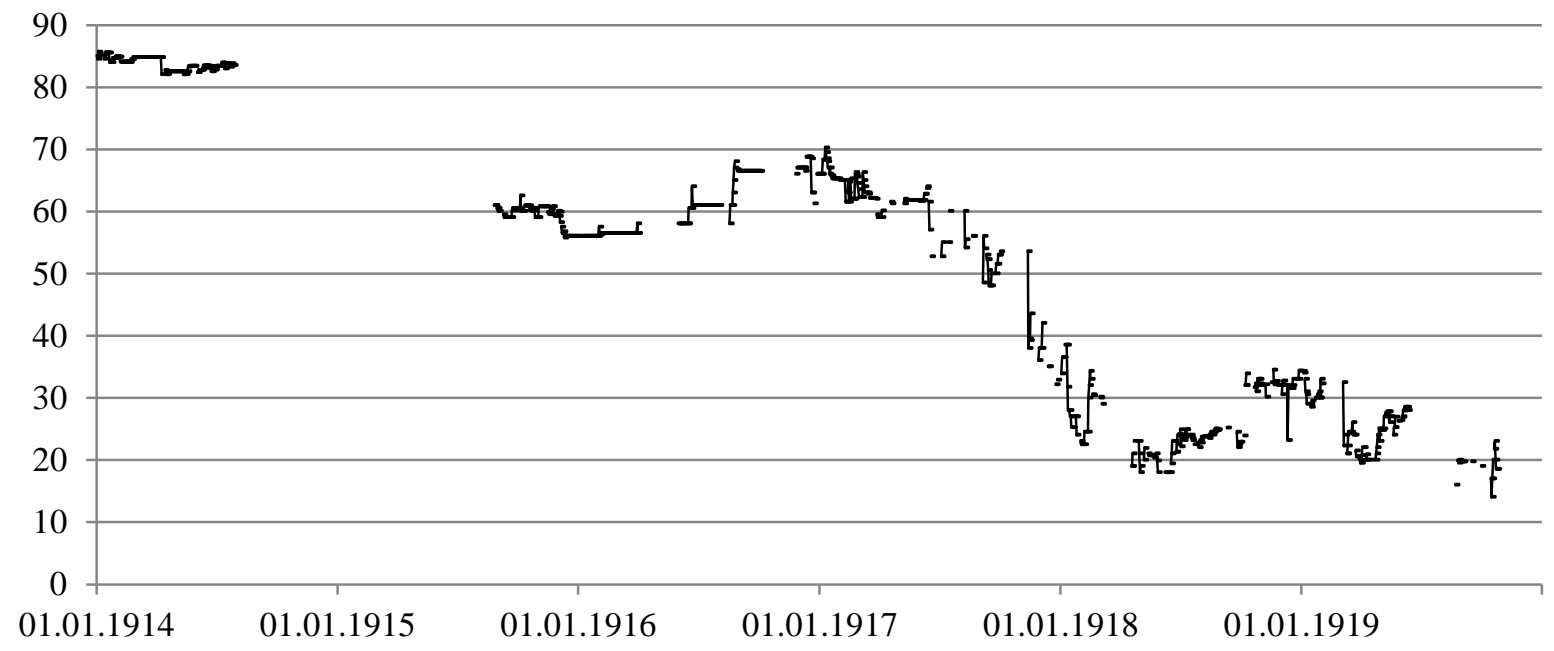


(184) Russia - 4.0 \% Moscow-Jaros. railway of 1897

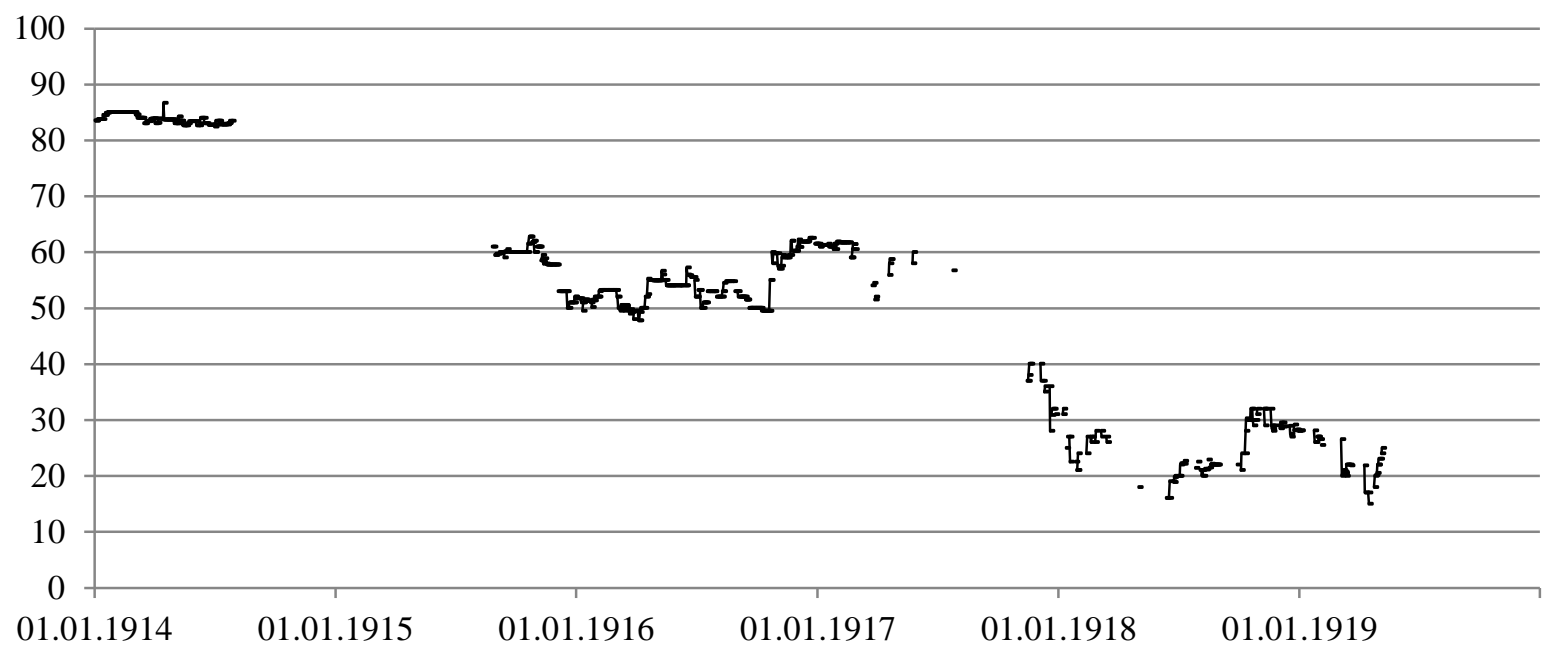

(185) Russia - $4.0 \%$ Moscow-Smolensk railway of 1899

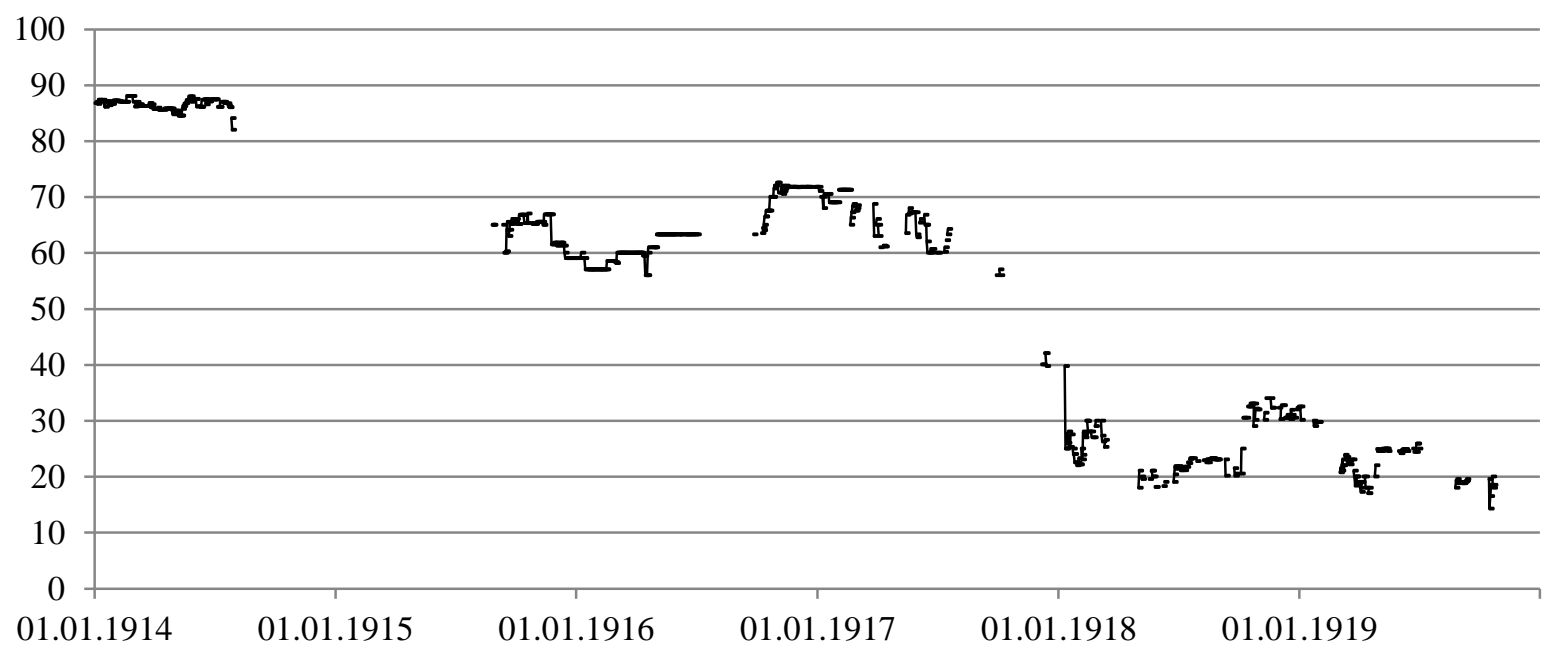

(186) Russia - $4.0 \%$ Transsiberian railway $1^{\text {st }}$ series of 1898

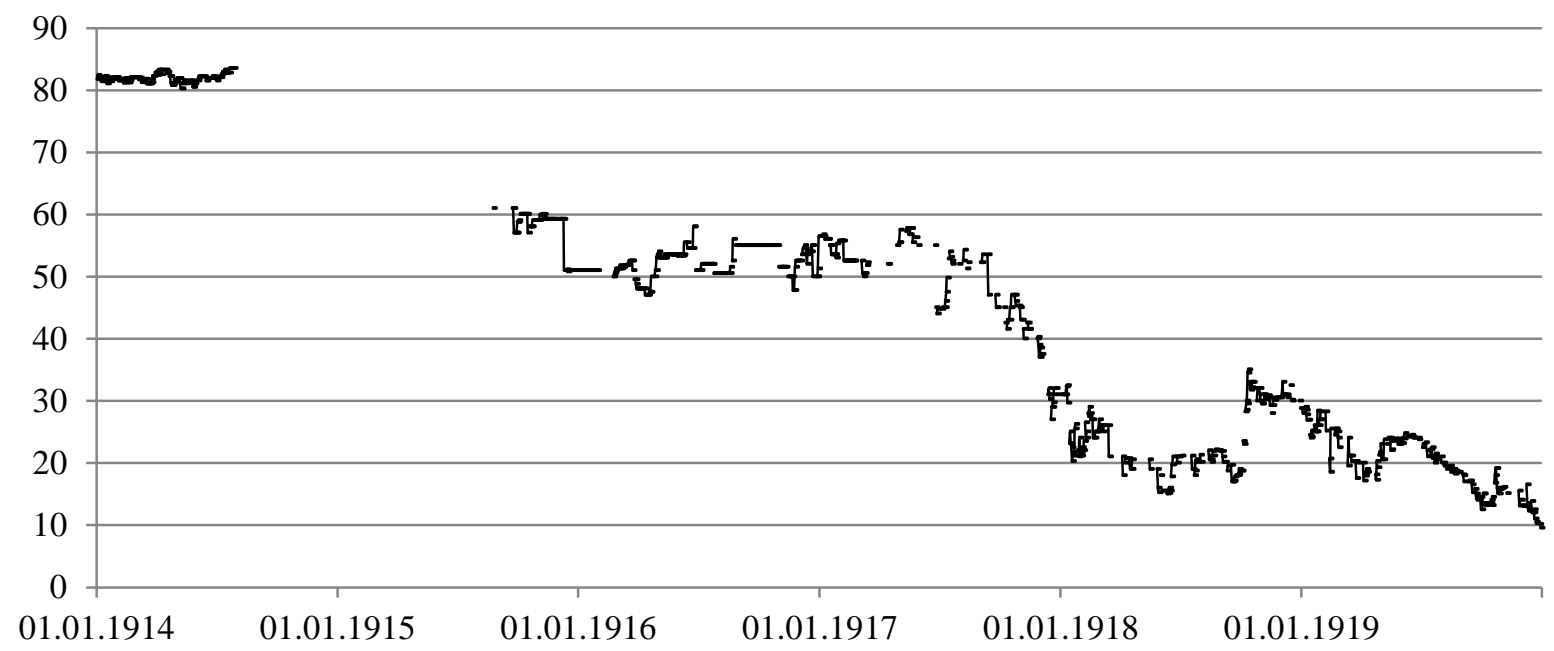


(187) Russia $-4.0 \%$ Transsiberian railway $2^{\text {nd }}$ series of 1898

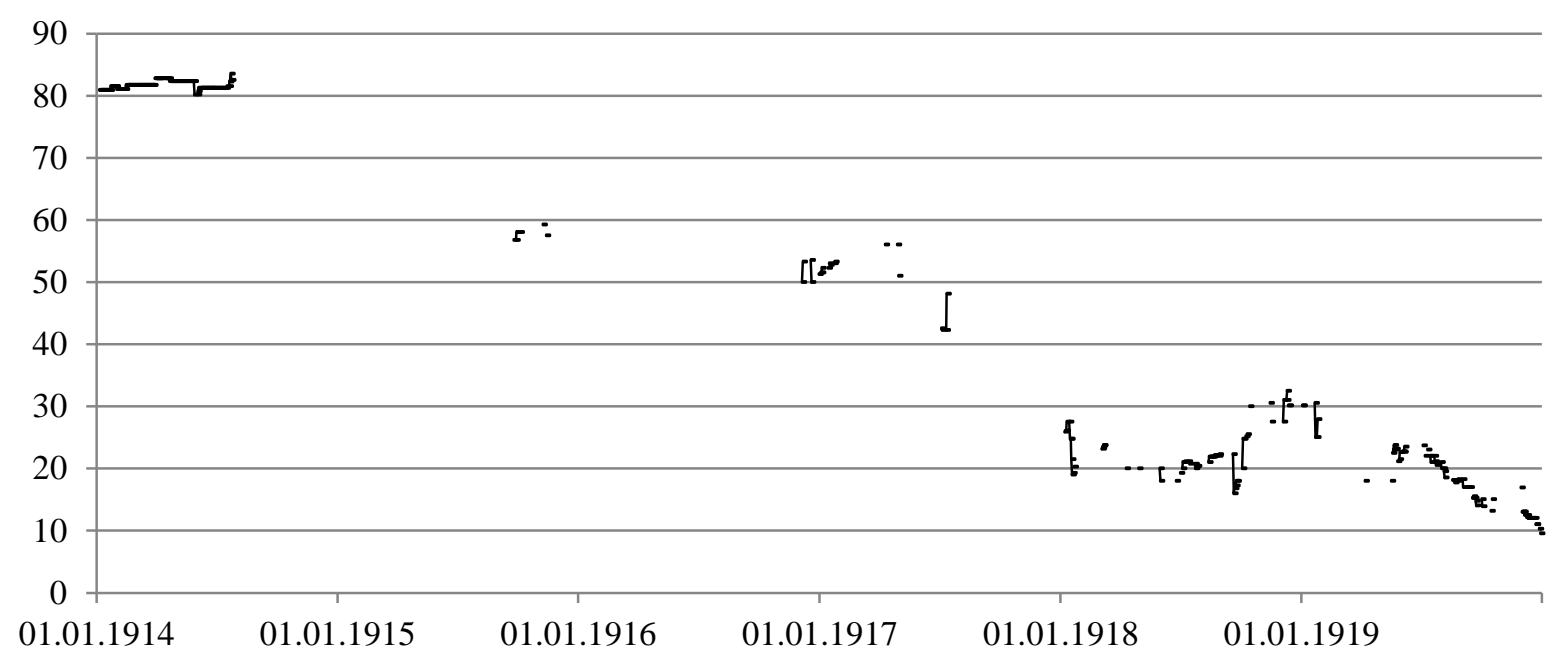

(188) Russia - $4.0 \%$ Transsiberian railway of 1902

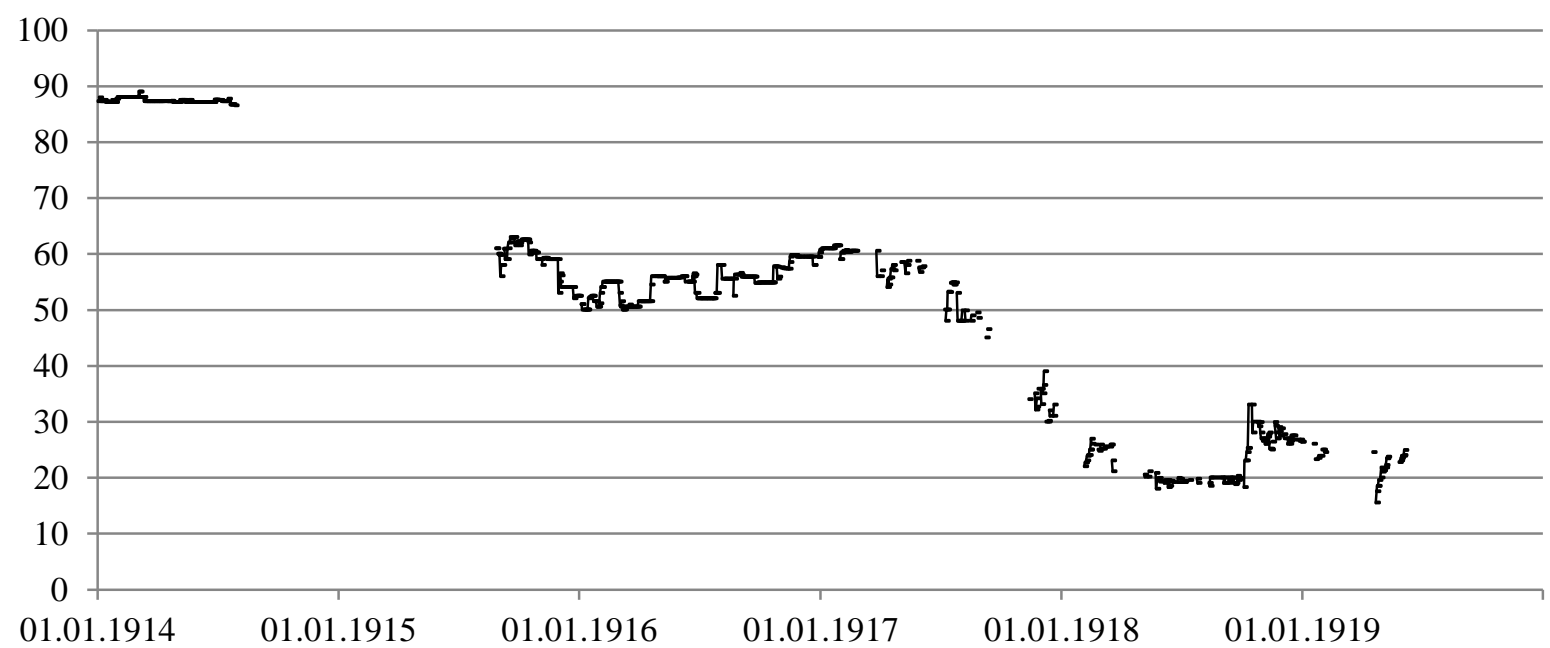

(189) Russia - $4.5 \%$ Iwang.-Domb. railway (125)

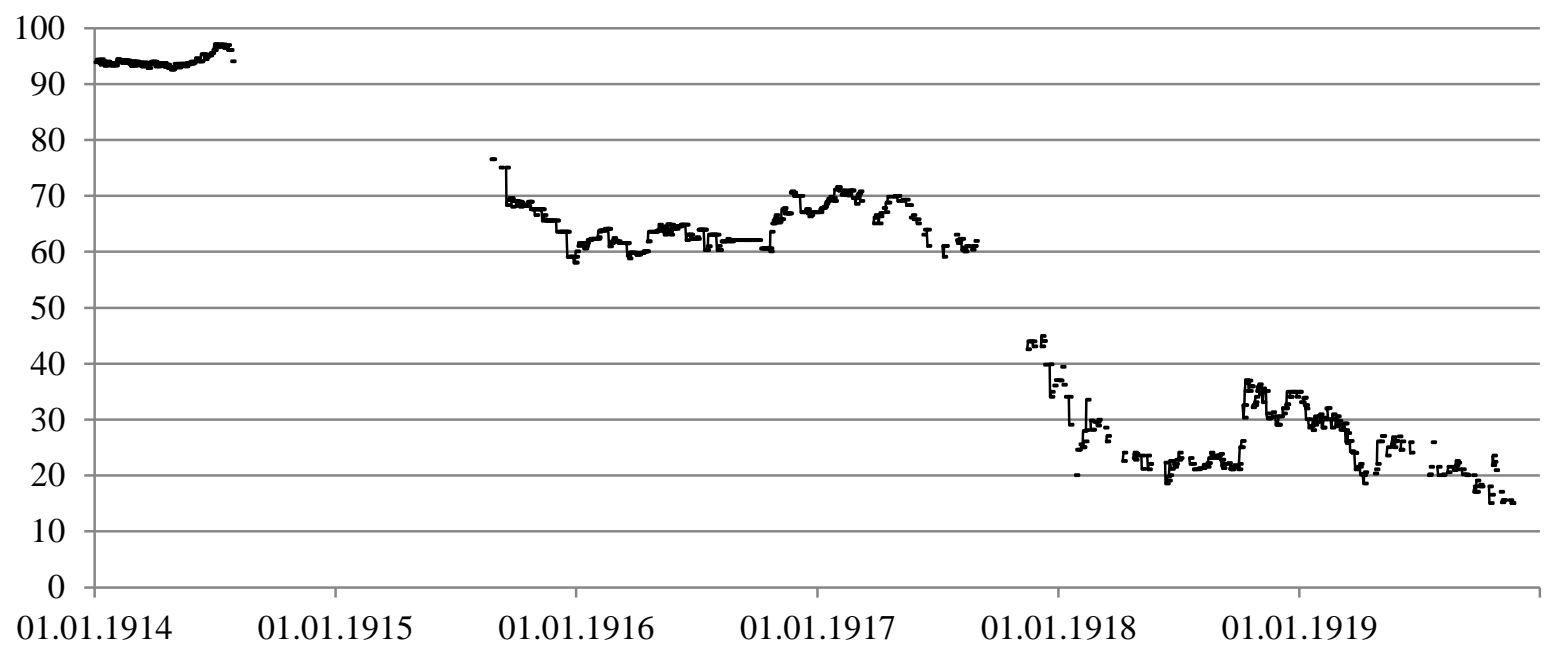


(190) Russia - $4.5 \%$ Iwang.-Domb. railway (625)

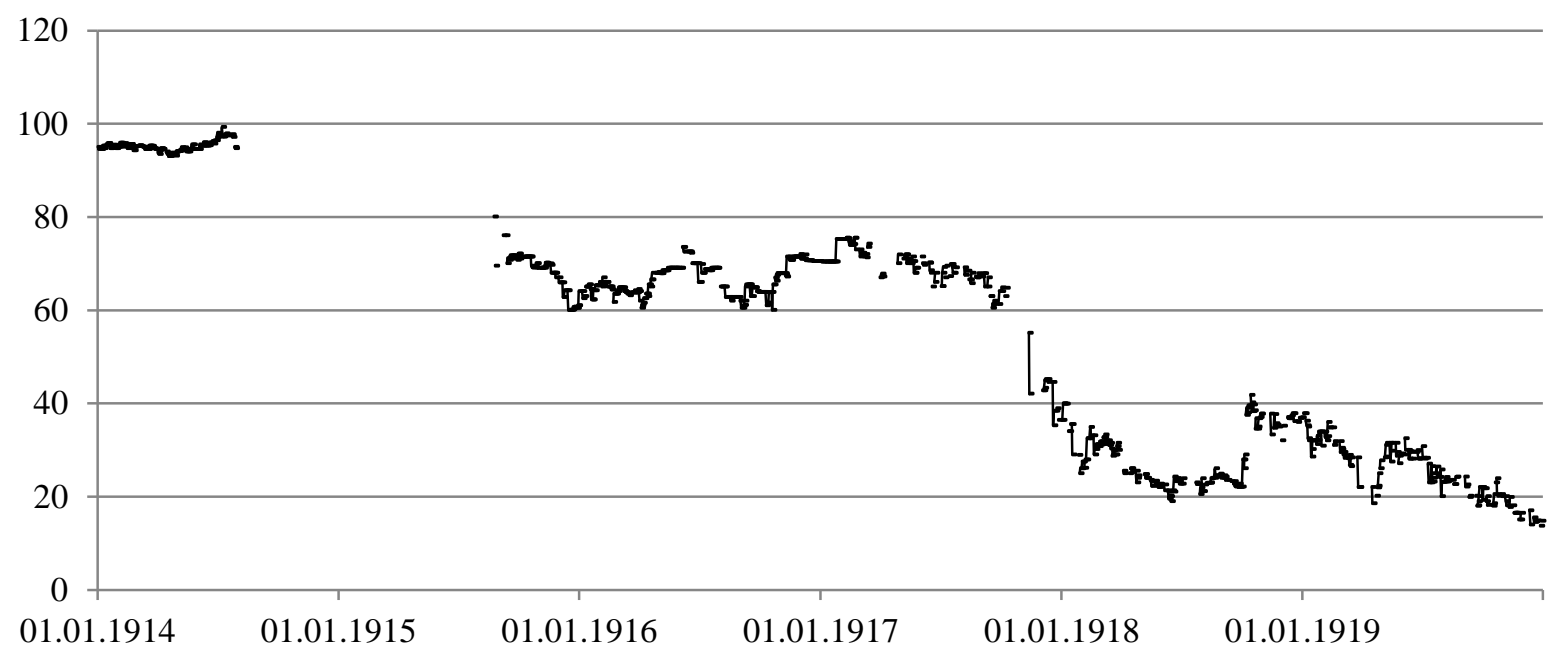

(191) Russia $-4.5 \%$ of 1905

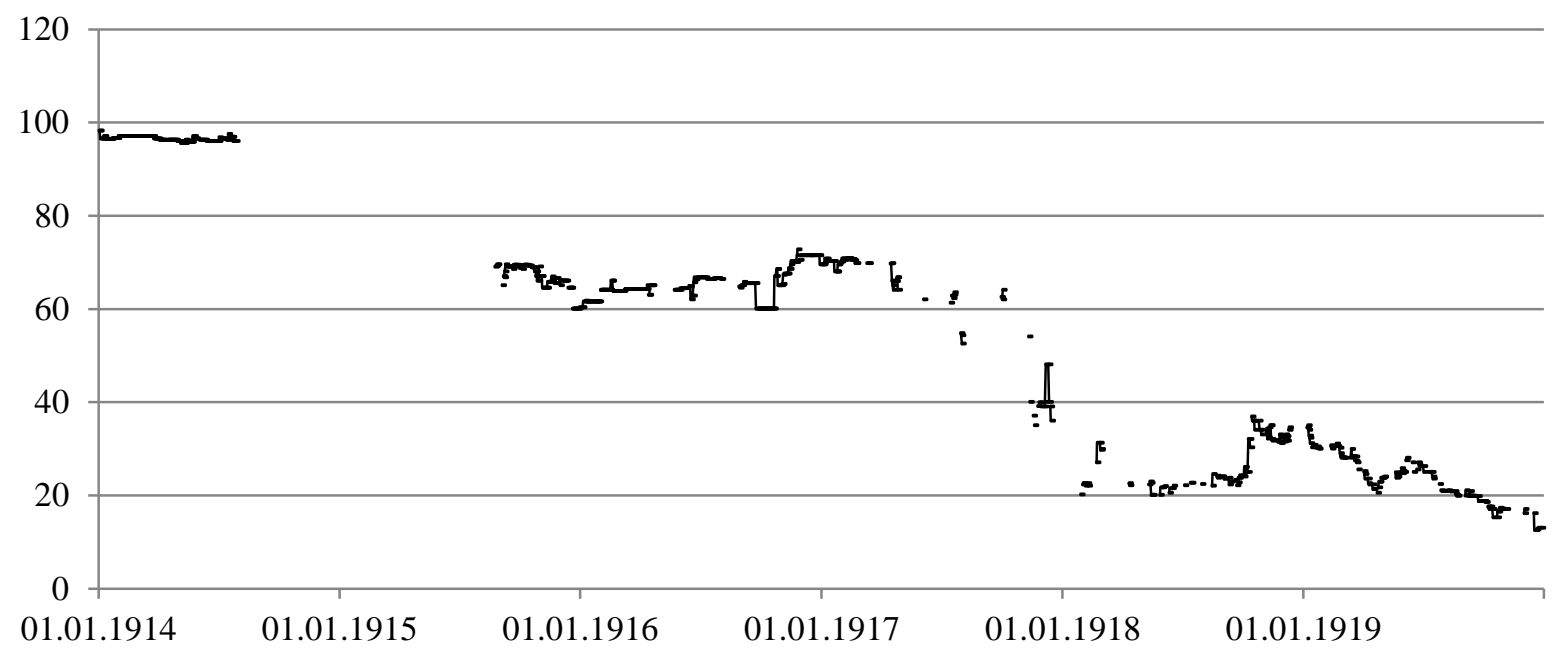

(192) Russia - $4.5 \%$ series 31-36 (500) of 1909

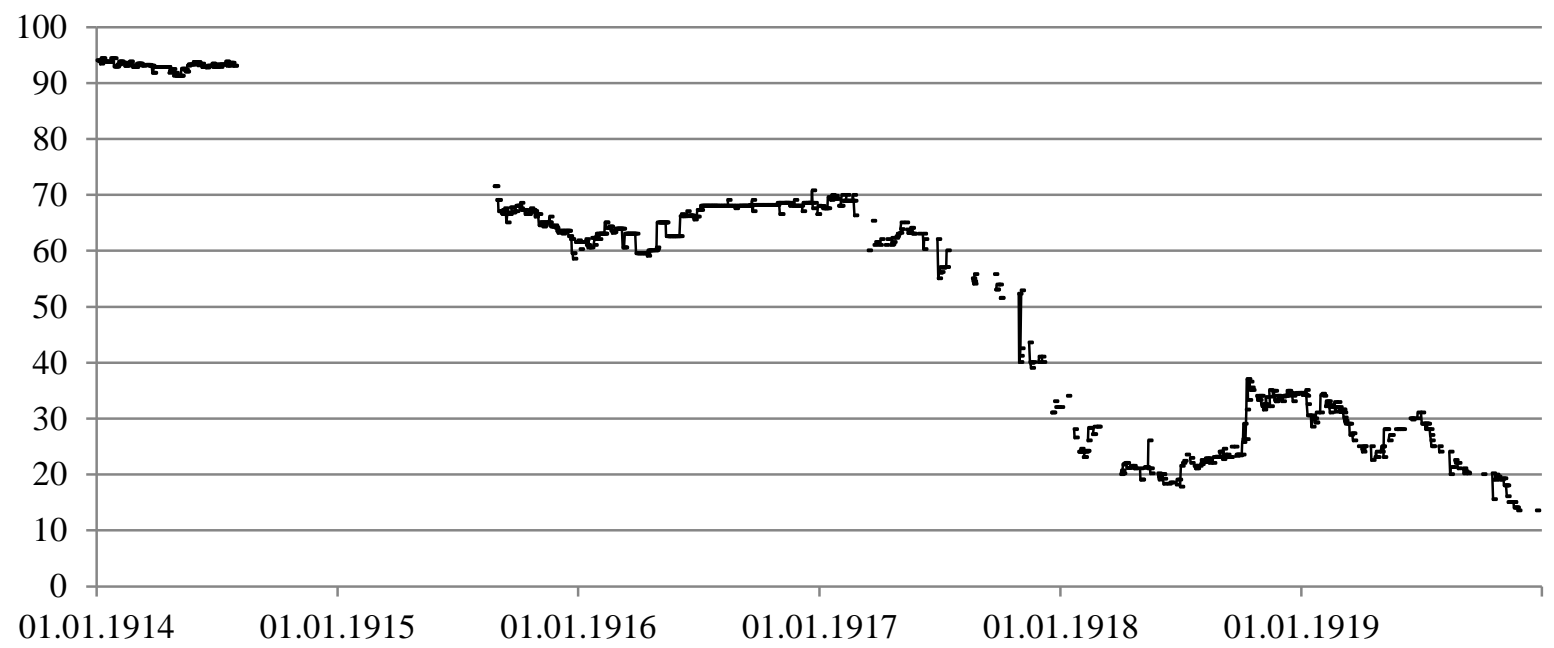


(193) Russia $-4.5 \%$ series 31-36 (2 500) of 1909

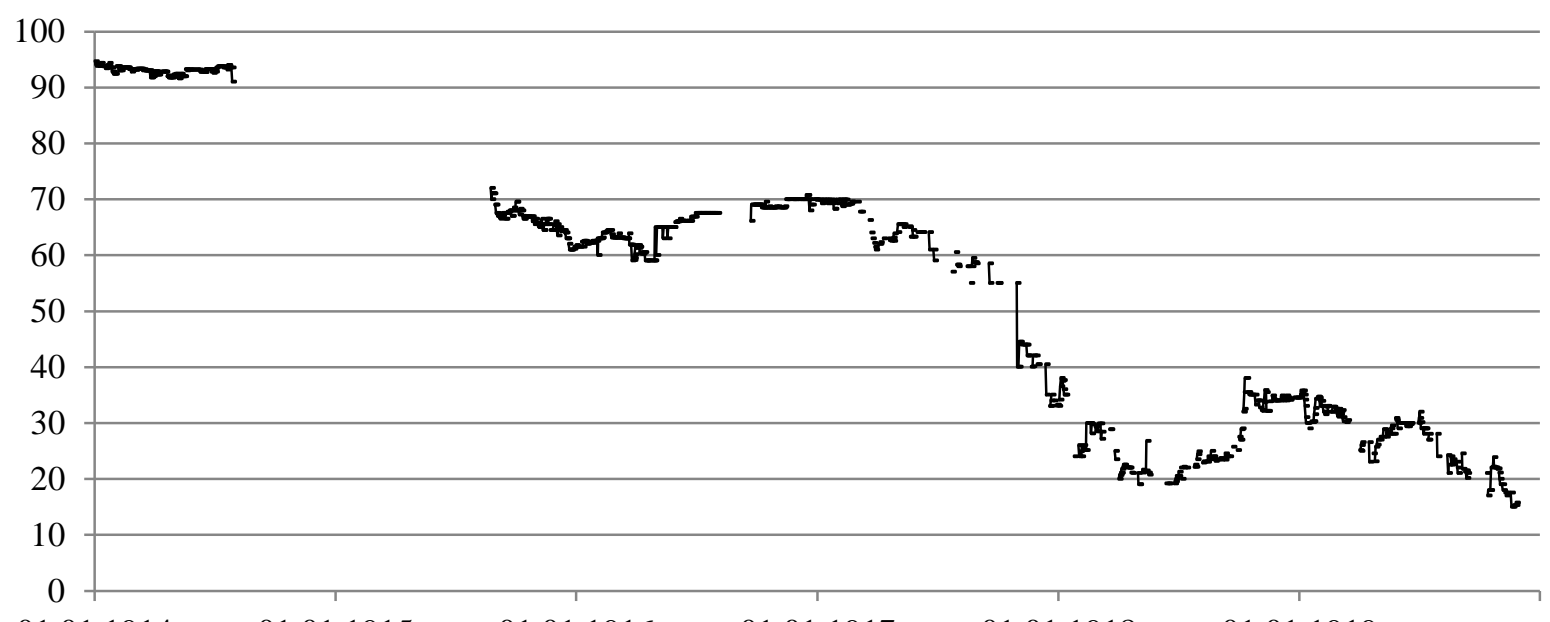

$\begin{array}{llllll}01.01 .1914 & 01.01 .1915 & 01.01 .1916 & 01.01 .1917 & 01.01 .1918 & 01.01 .1919\end{array}$

(194) Russia $-4.5 \%$ series 37 of 1909

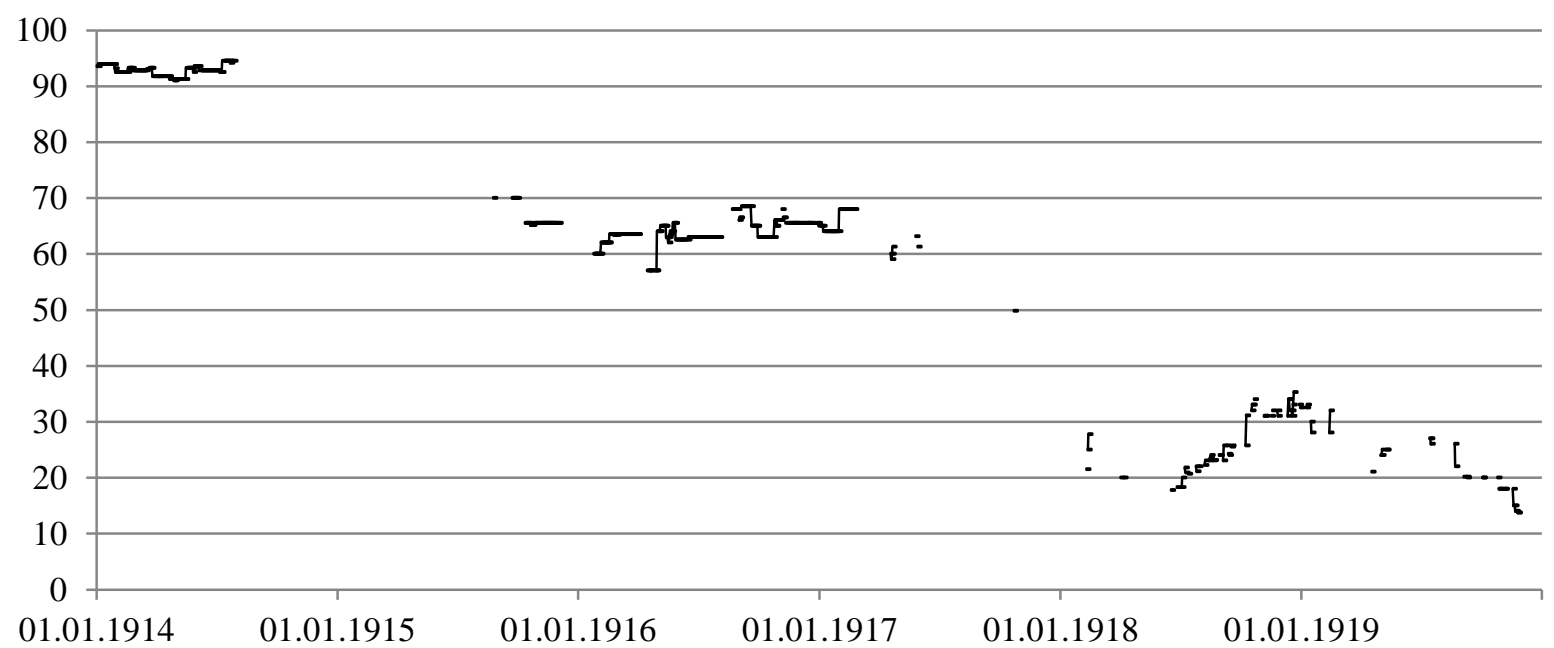

(195) Russia - 5.0 \% Hamburg of 1820

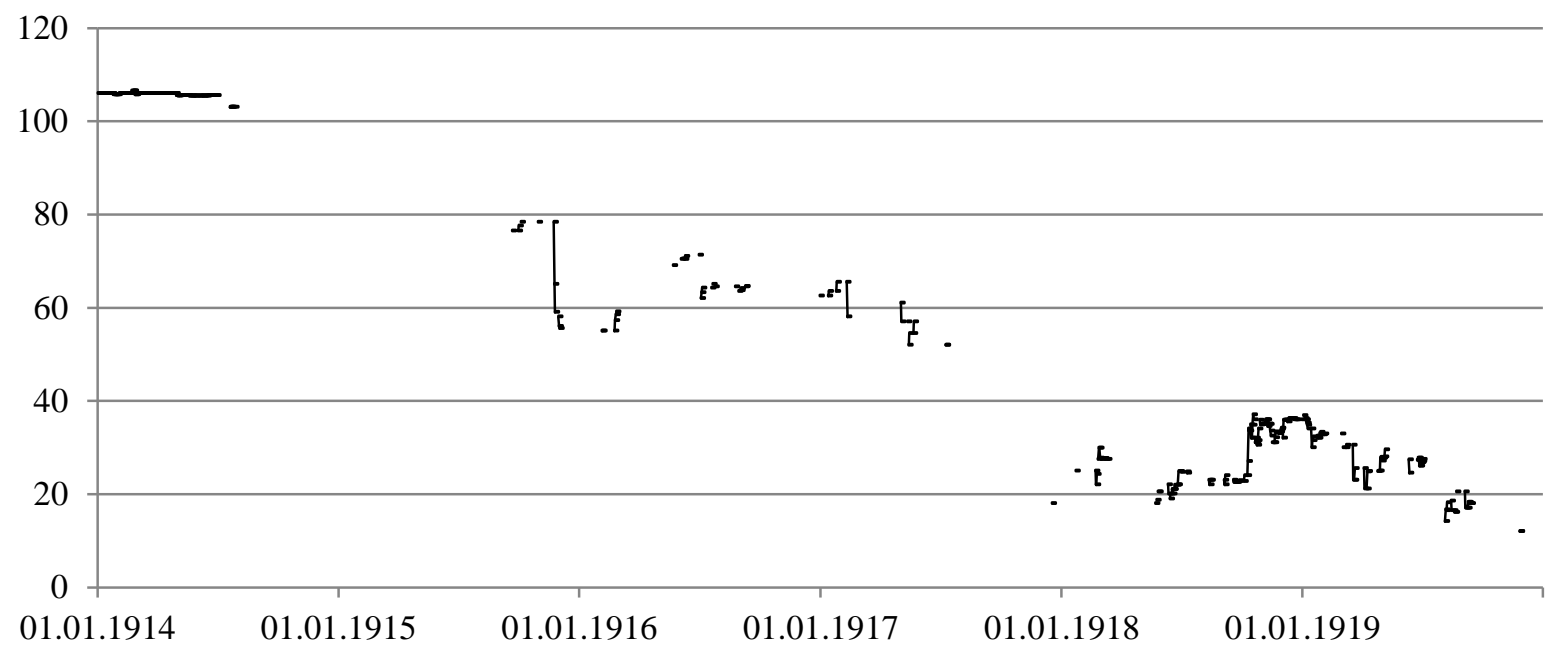


(196) Russia - 5.0 \% London of 1822

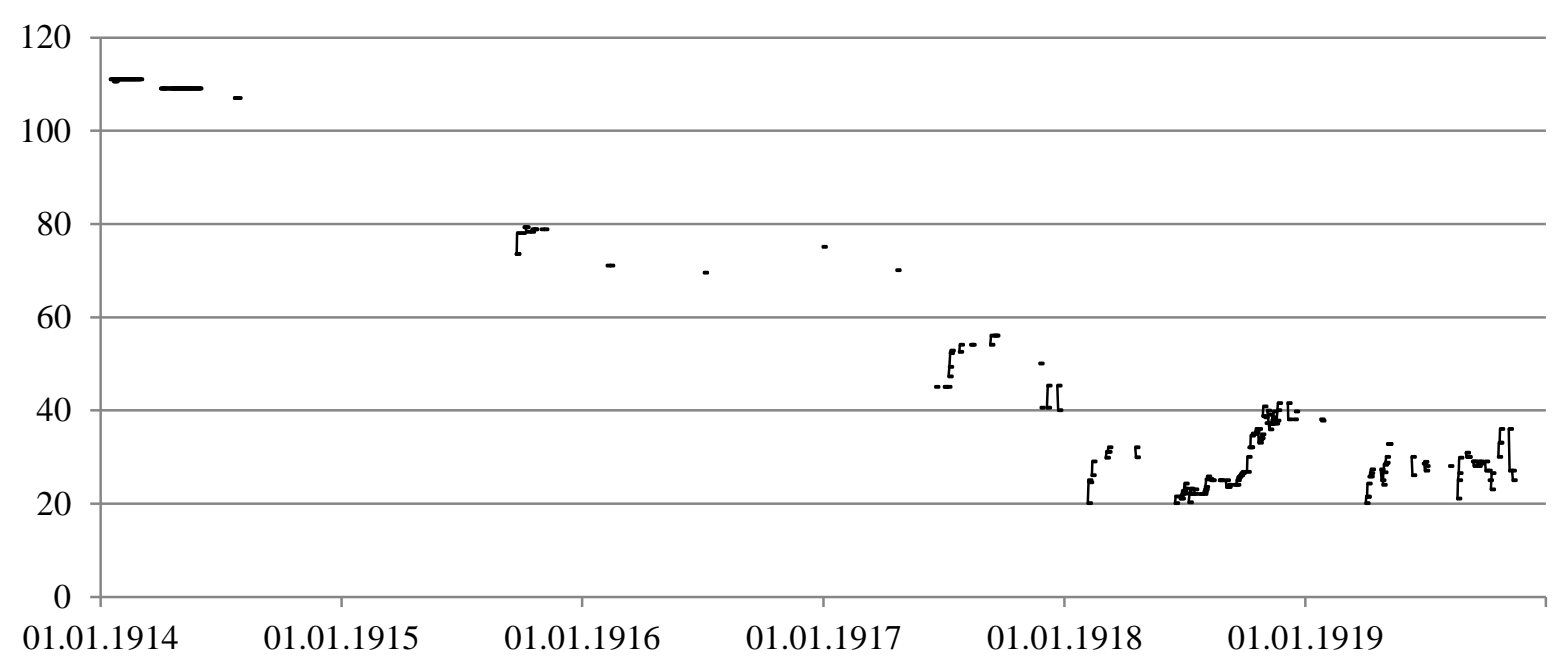

(197) Russia $-5.0 \%$ of 1906 (500)

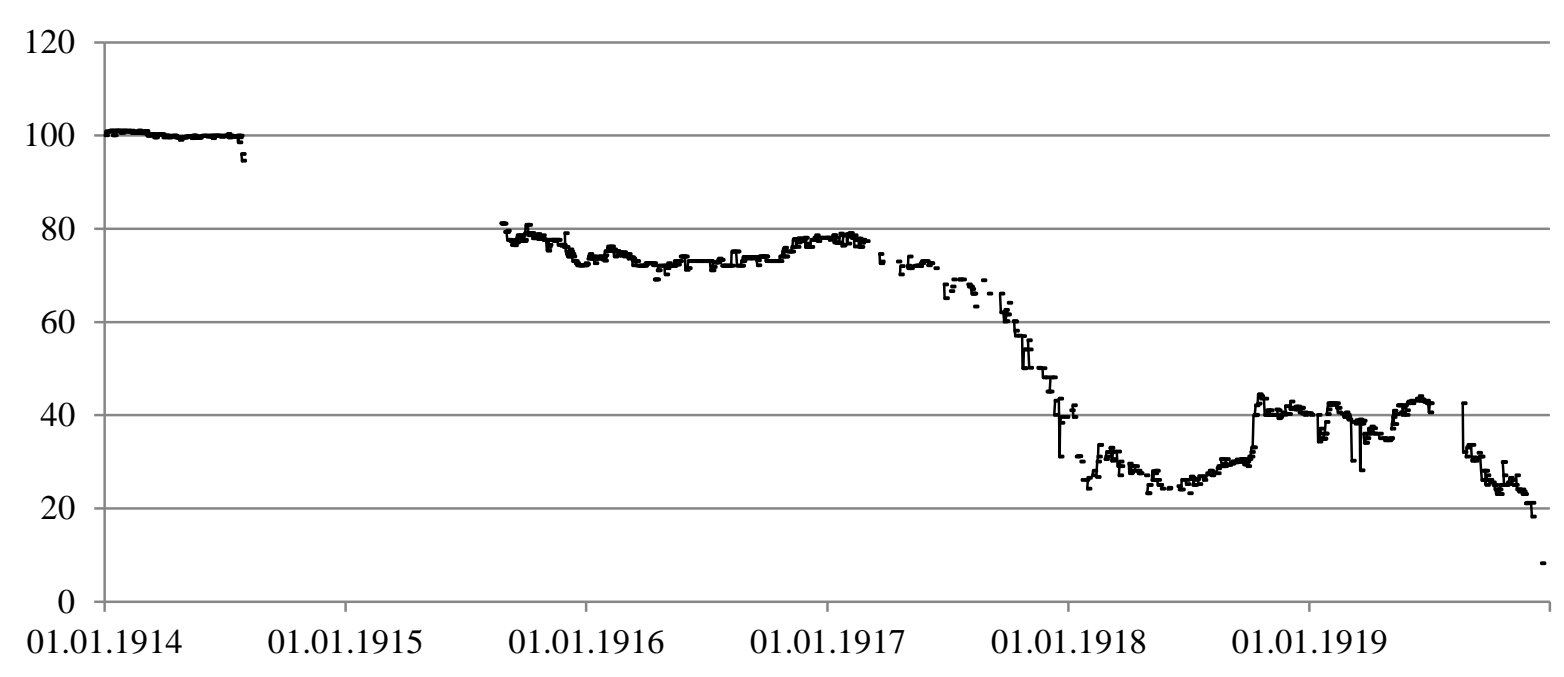

(198) Russia - 5.0 \% of 1906 (2 500/5 000)

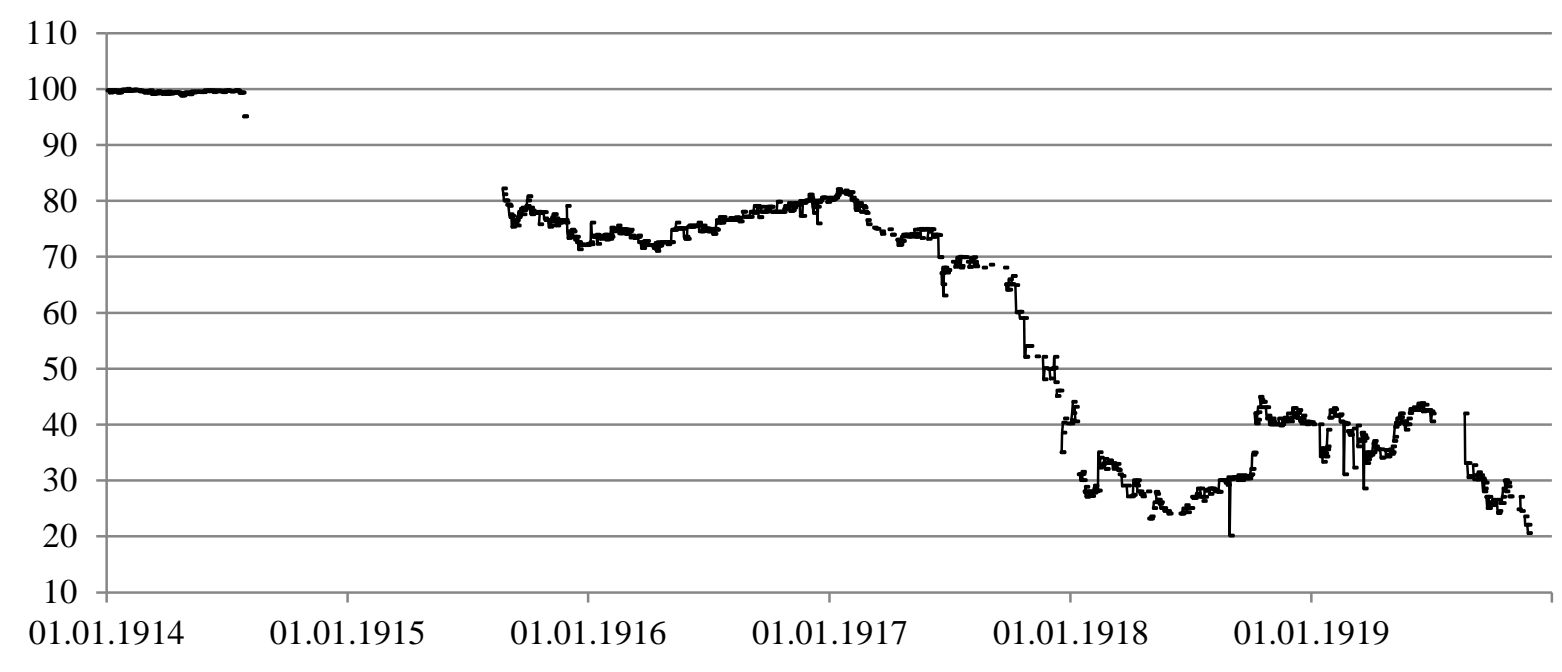


(199) Russia $-6.0 \%$ certificates

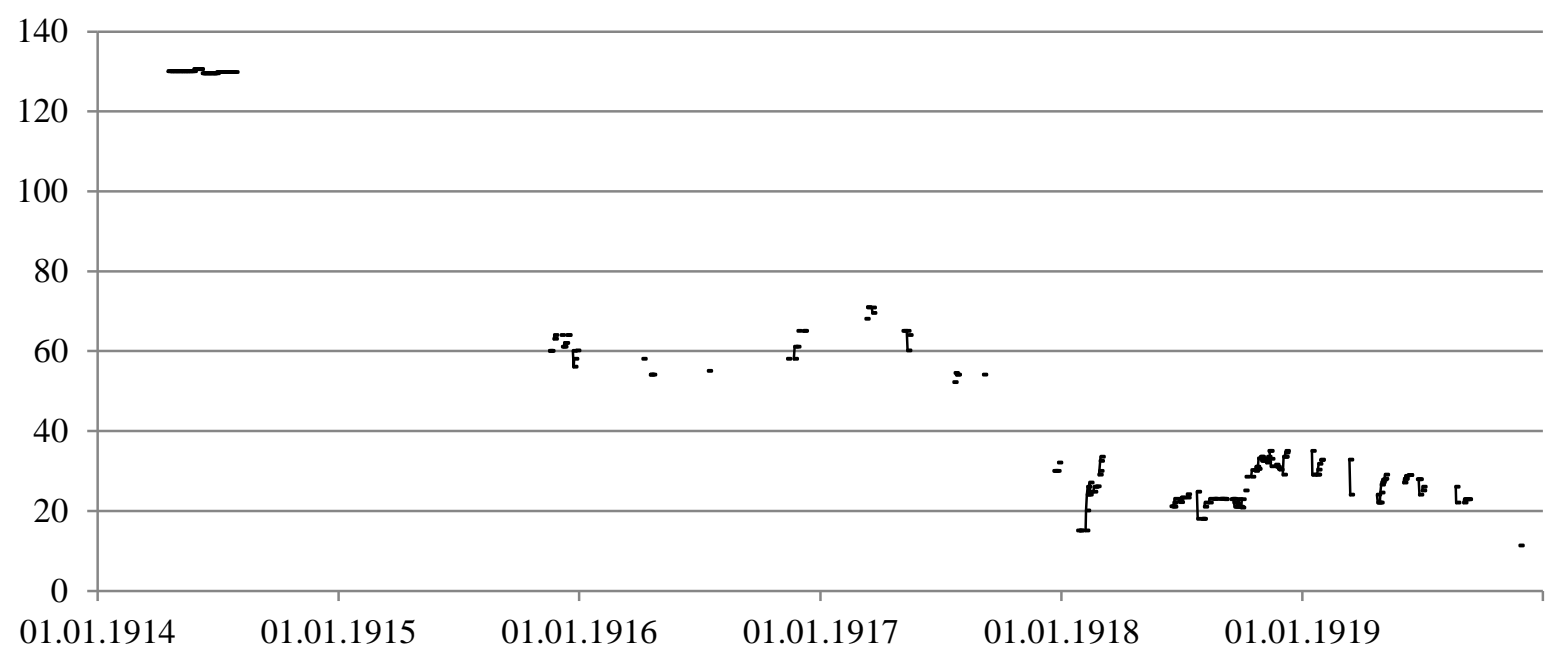

(200) Serbia $-4.0 \%$ of 1895 (500)

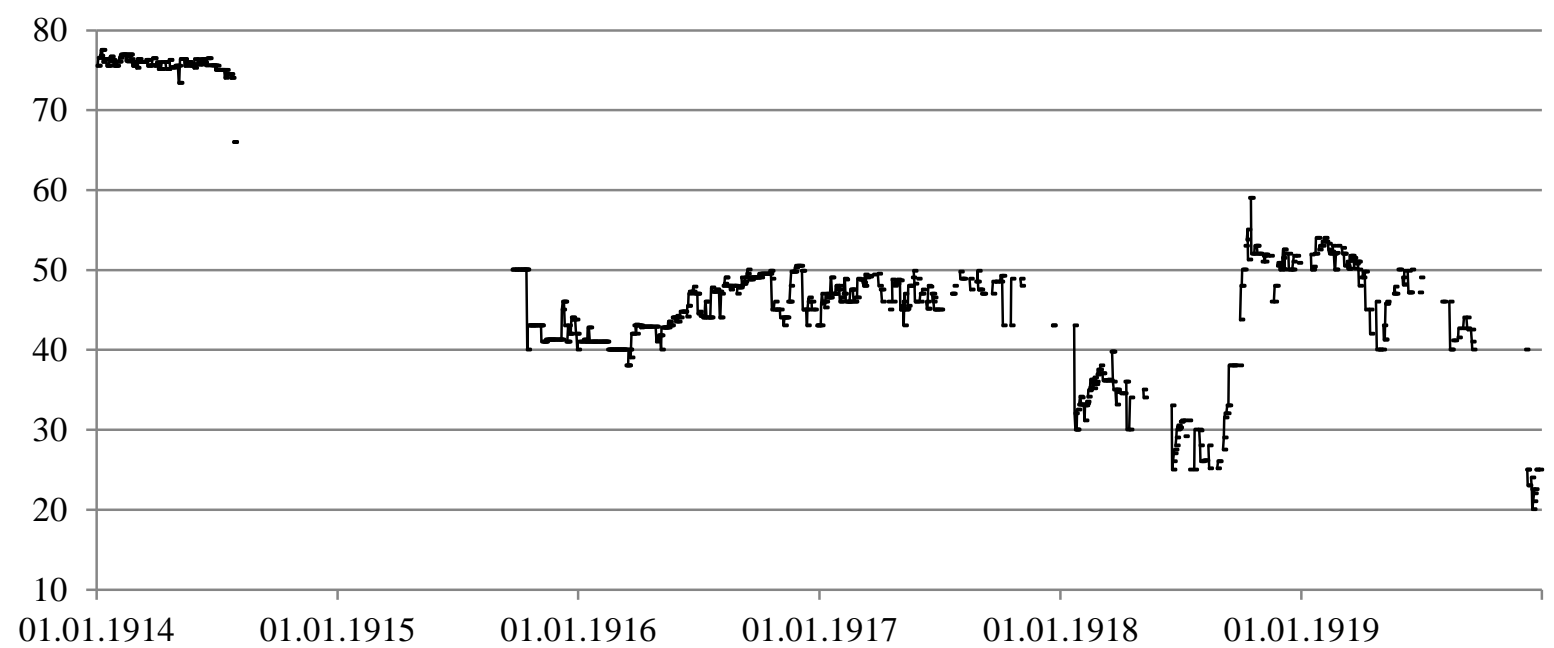

(201) Serbia $-4.0 \%$ of 1895 (2 500)

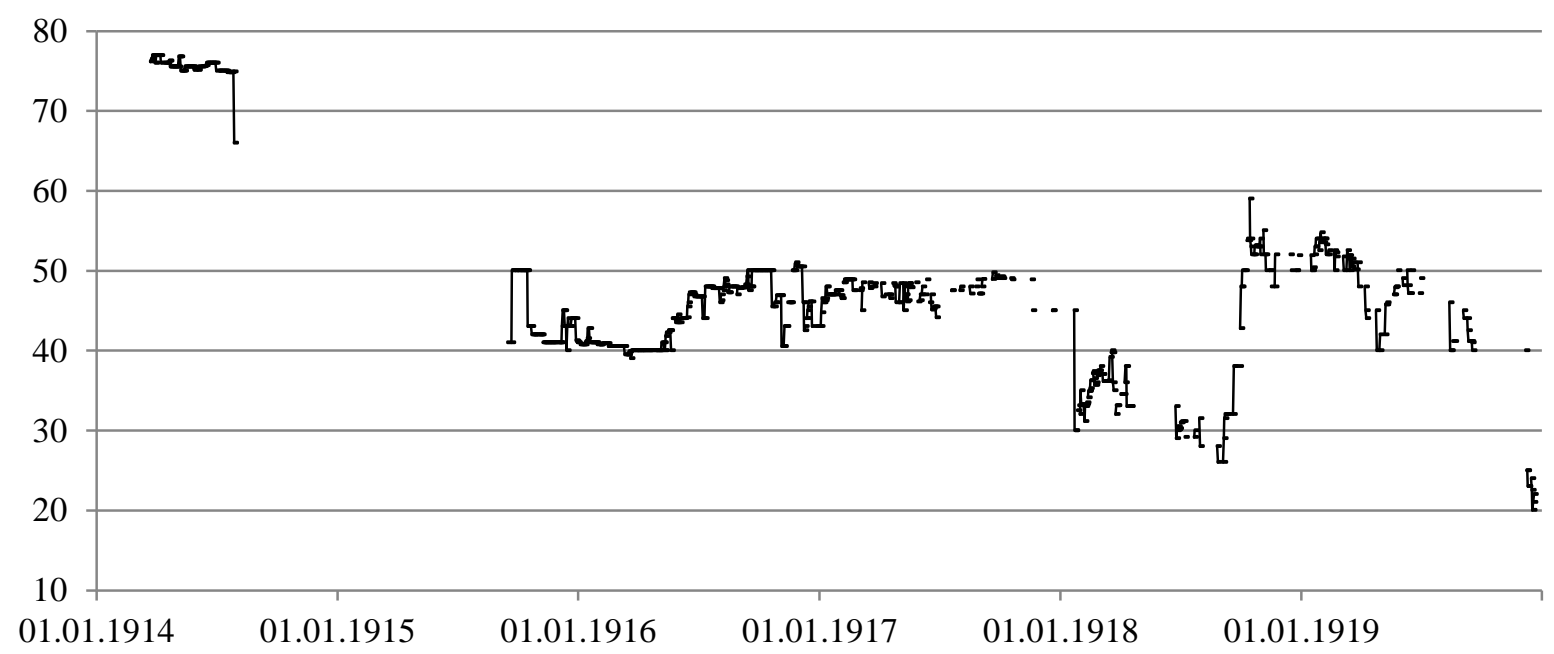


(202) Sweden $-3.5 \%$ of 1890

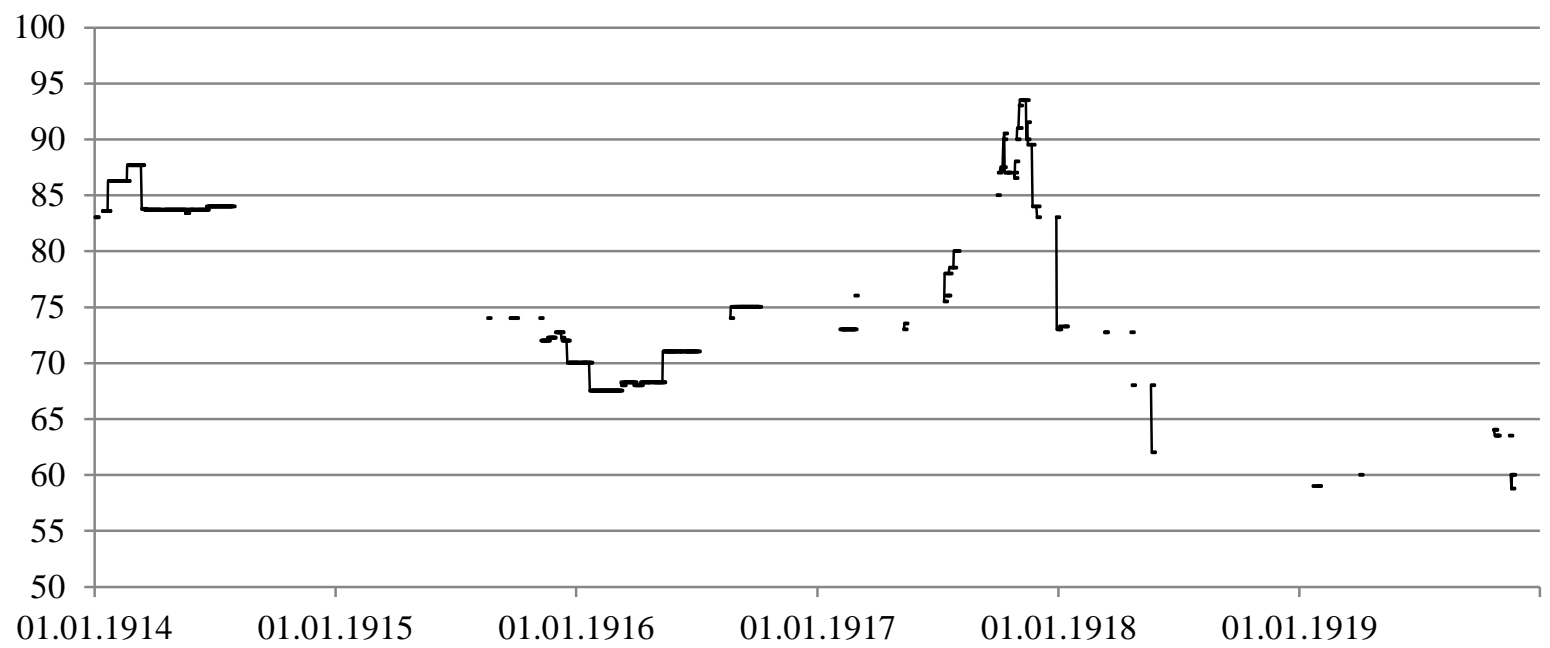

(203) Switzerland $-3.5 \%$ of $1899-1902$

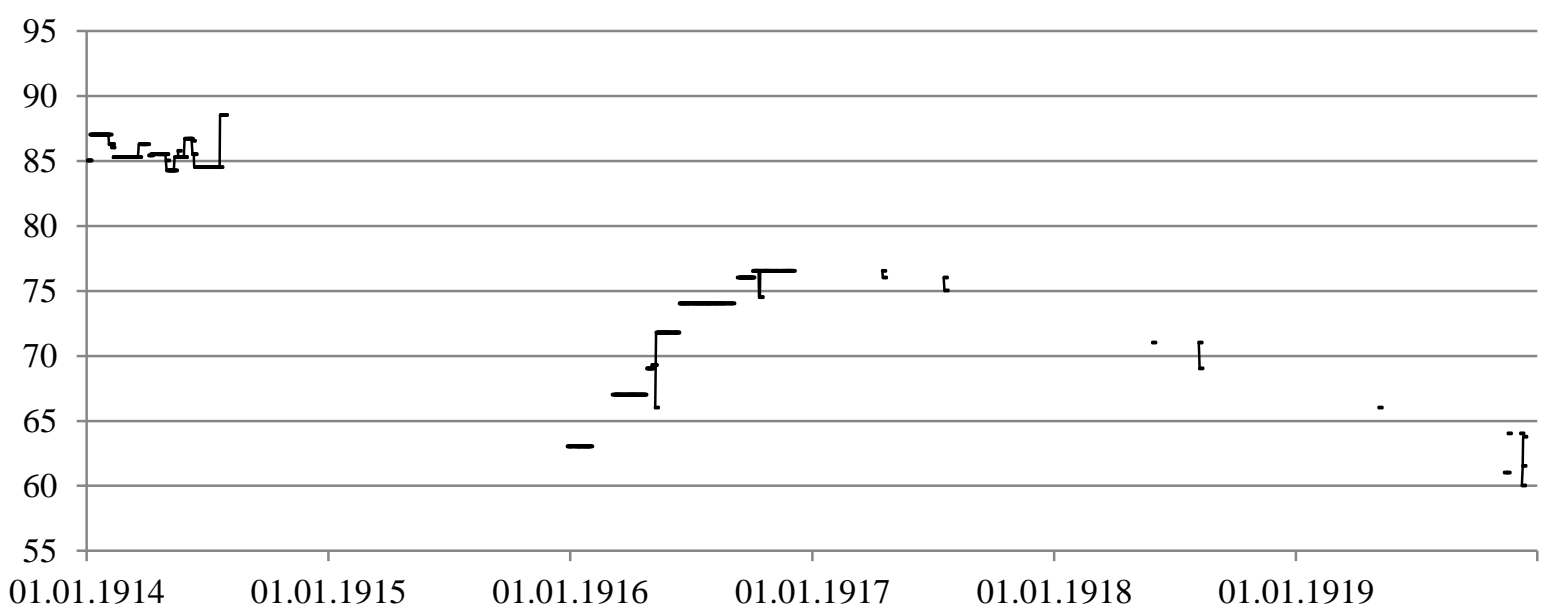

(204) Turkey $-4.0 \%$ of 1890

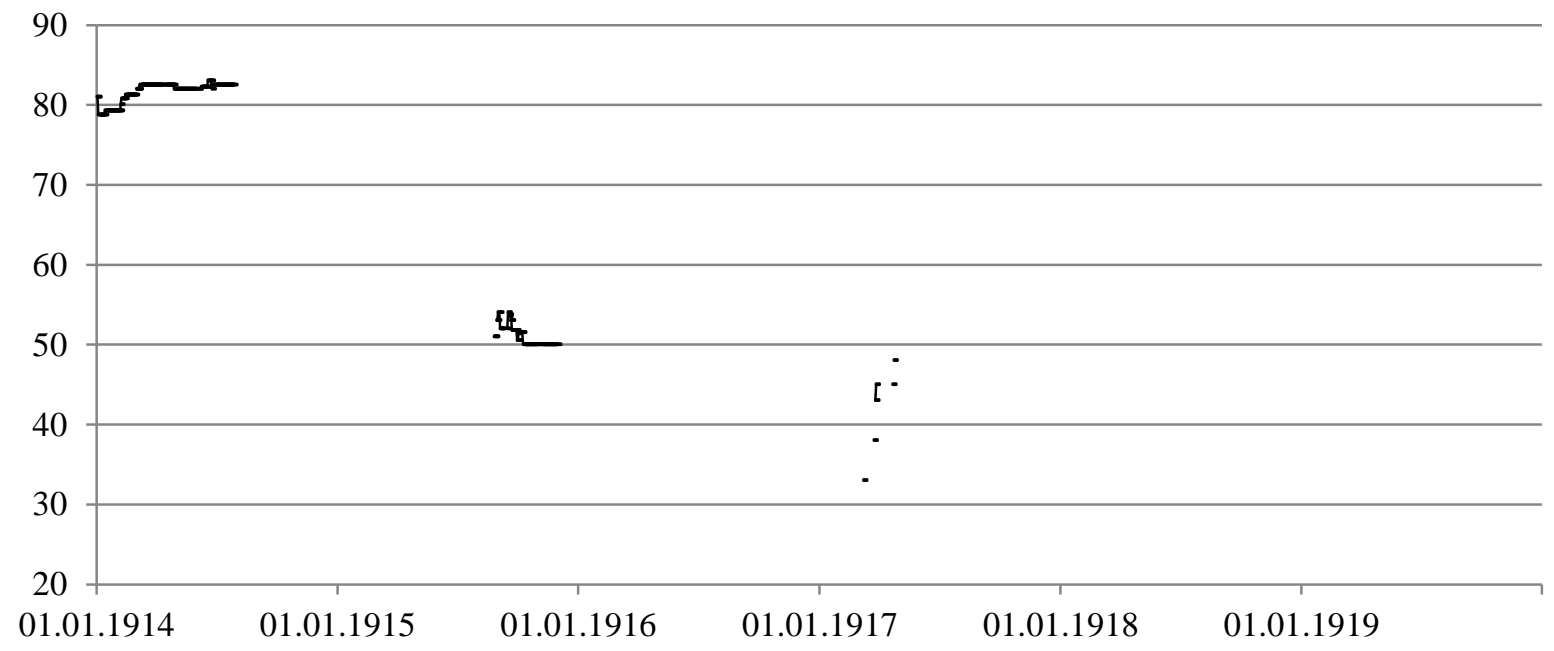


(205) Turkey $-4.0 \%$ of 1902

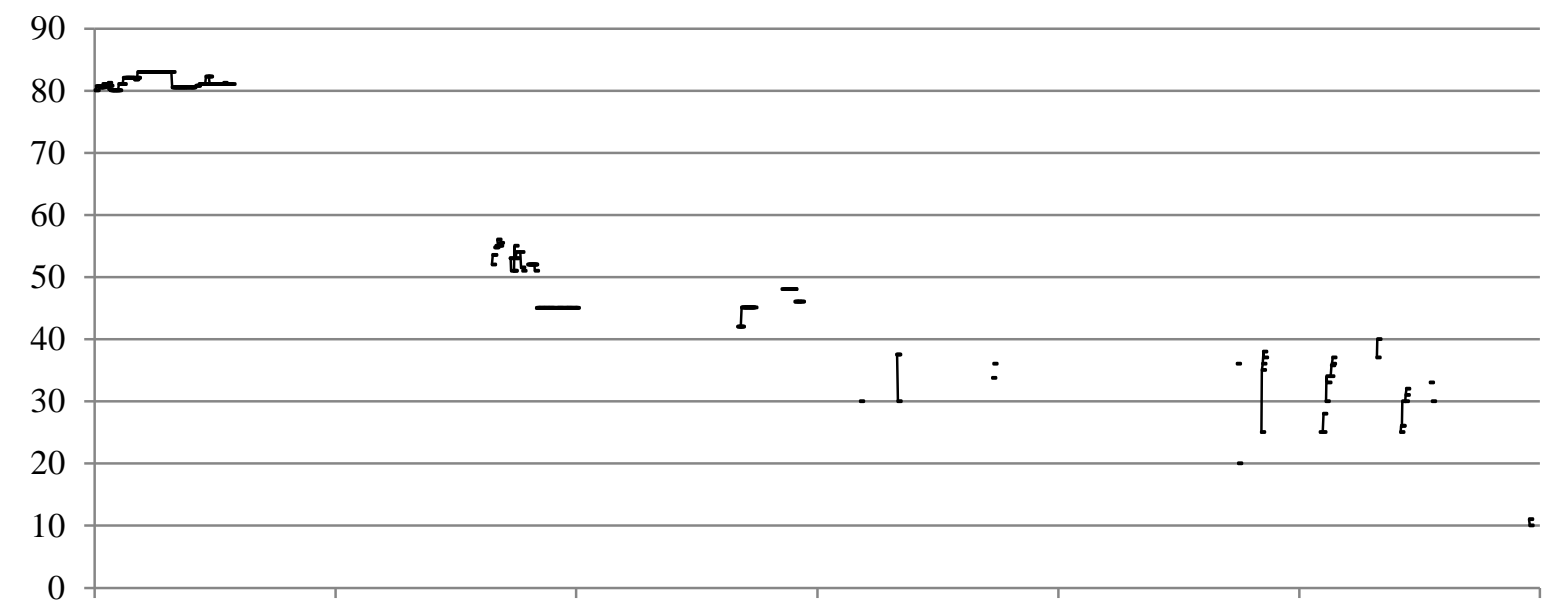

$\begin{array}{llllll}01.01 .1914 & 01.01 .1915 & 01.01 .1916 & 01.01 .1917 & 01.01 .1918 & 01.01 .1919\end{array}$

(206) Turkey $-4.0 \%$ of $1903(500)$

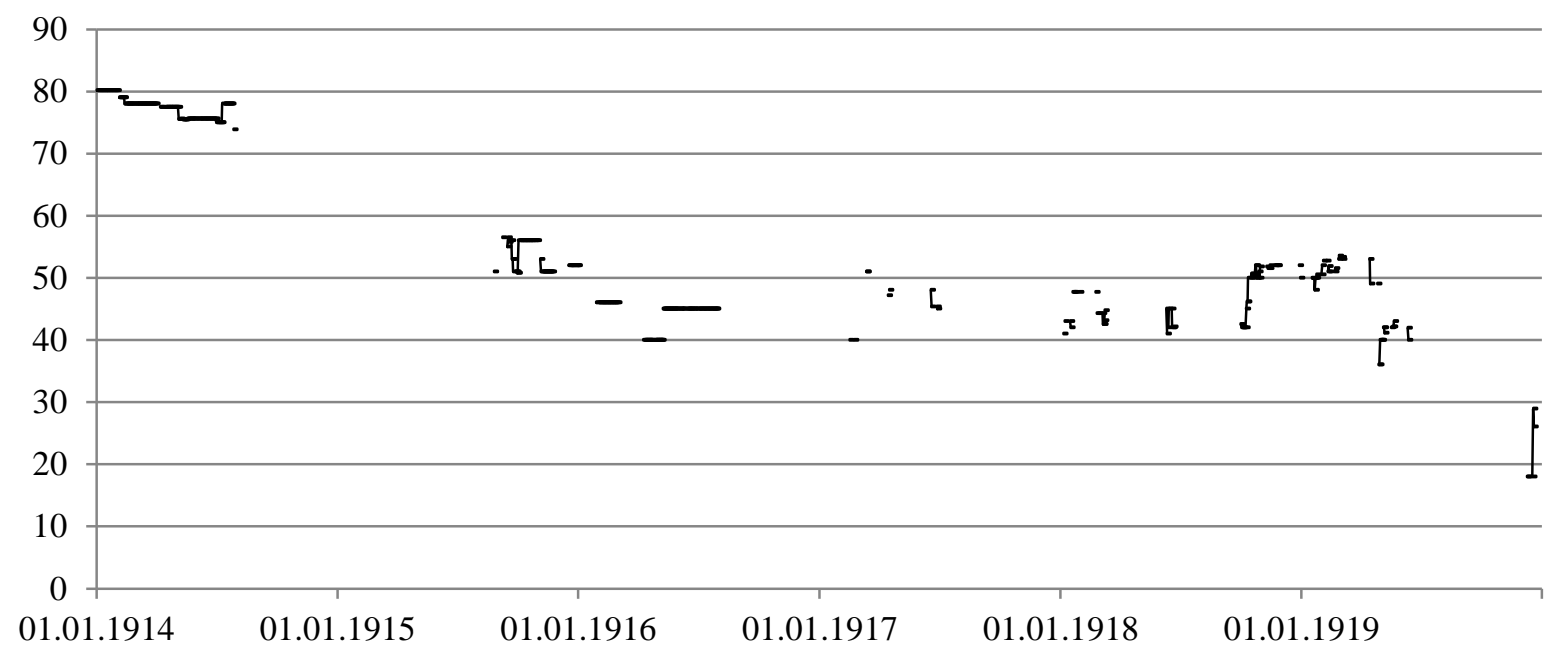

(207) Turkey $-4.0 \%$ of 1903 (2 500)

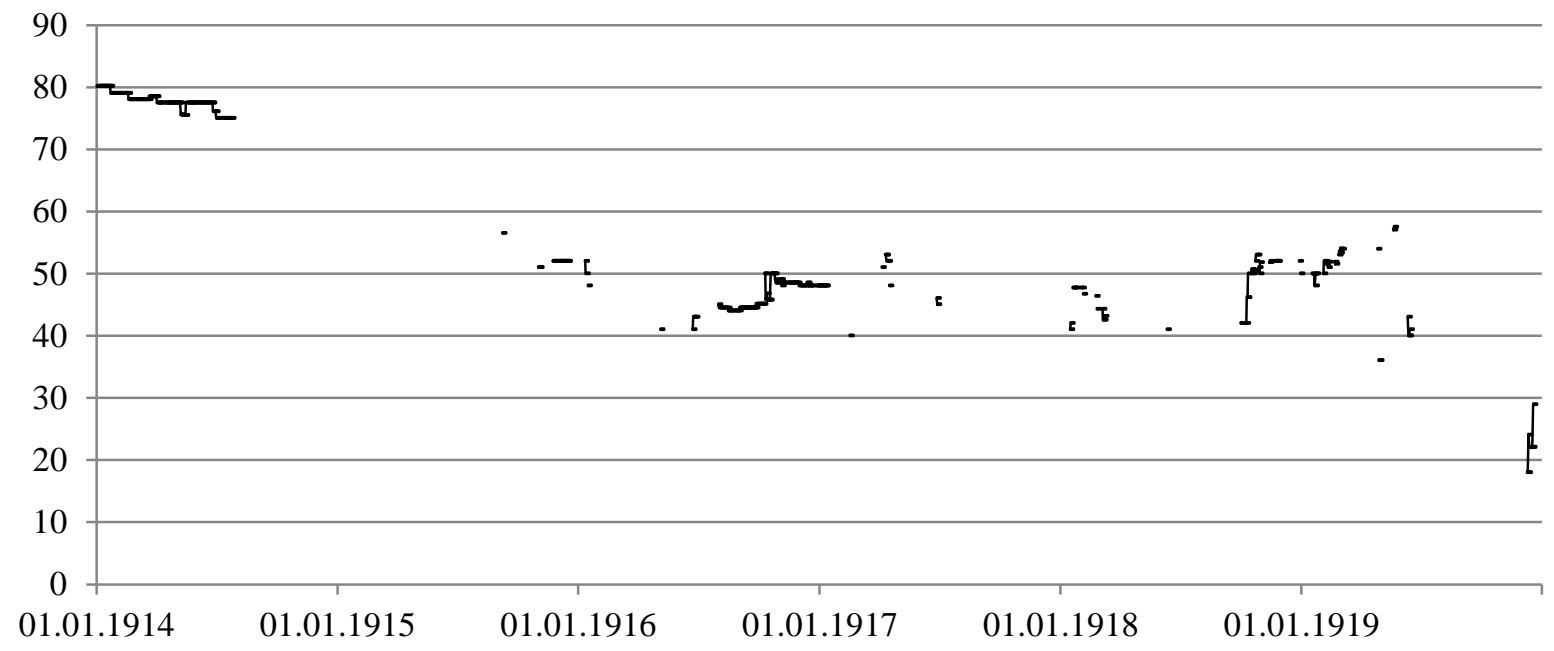


(208) Turkey $-4.0 \%$ Baghdad $1^{\text {st }}$ series of 1904

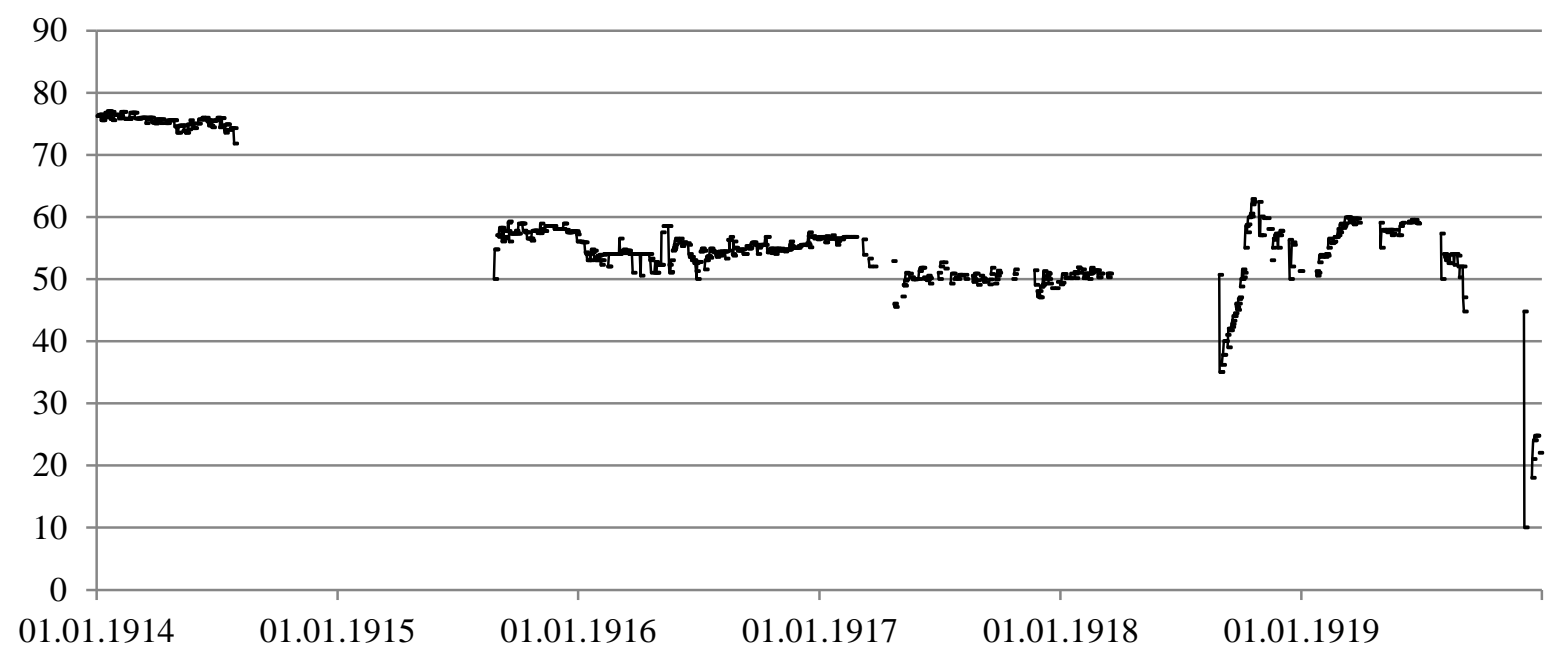

(209) Turkey $-4.0 \%$ of 1905

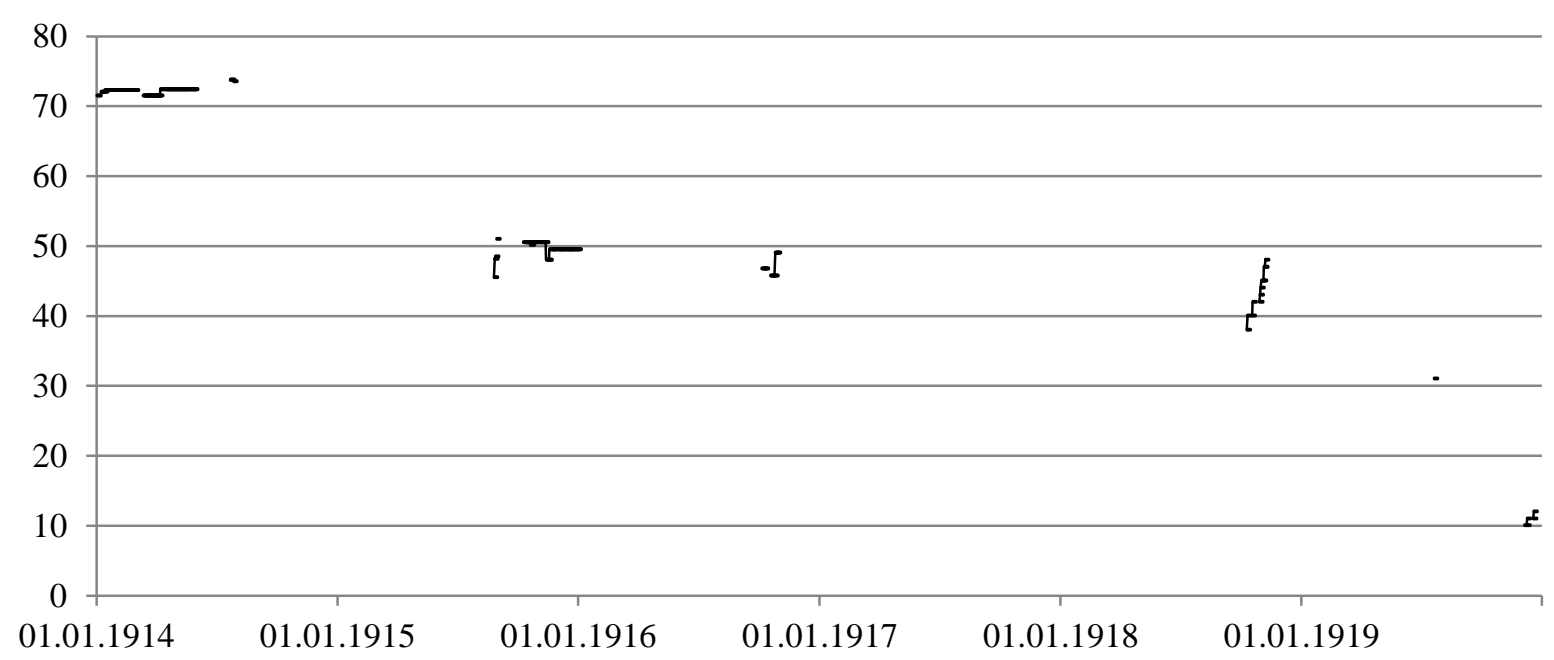

(210) Turkey $-4.0 \%$ Baghdad $2^{\text {nd }}$ series of 1910

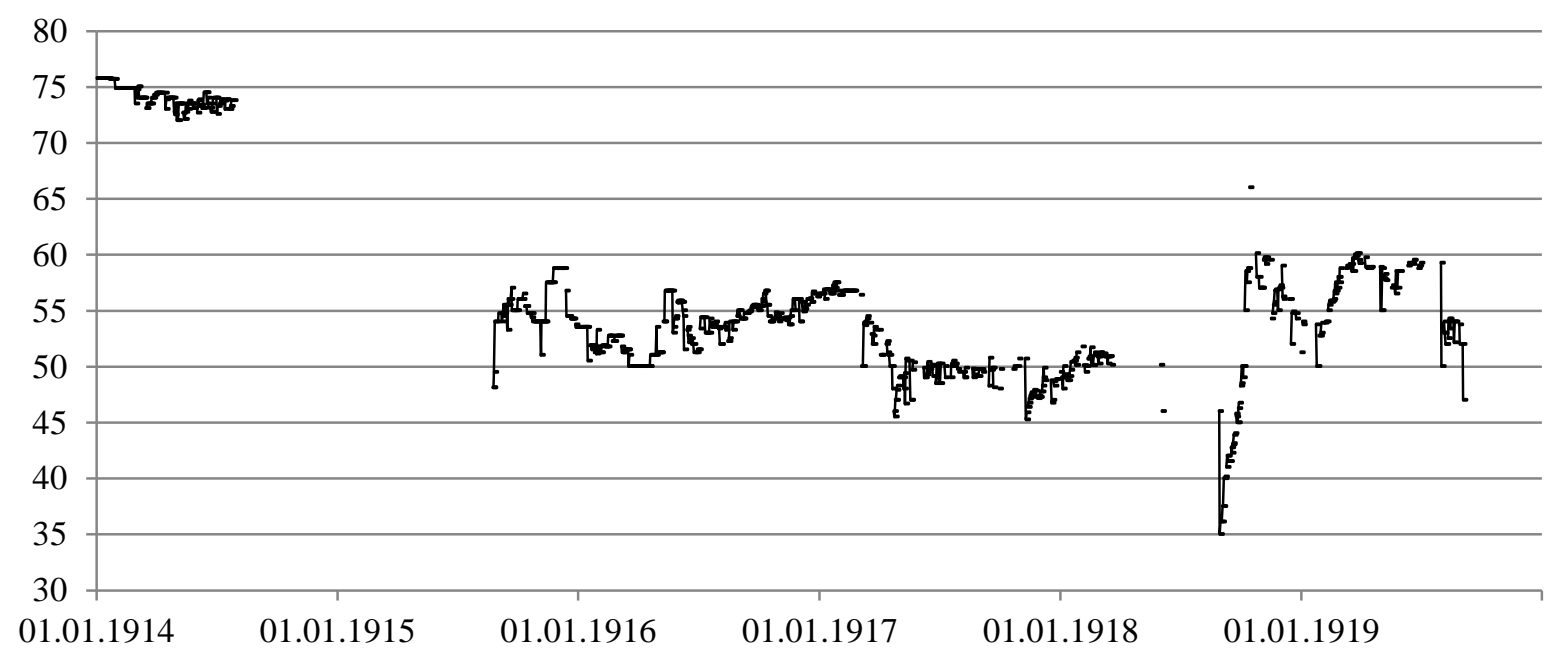


(211) Turkey $-4.0 \%$ of 1911

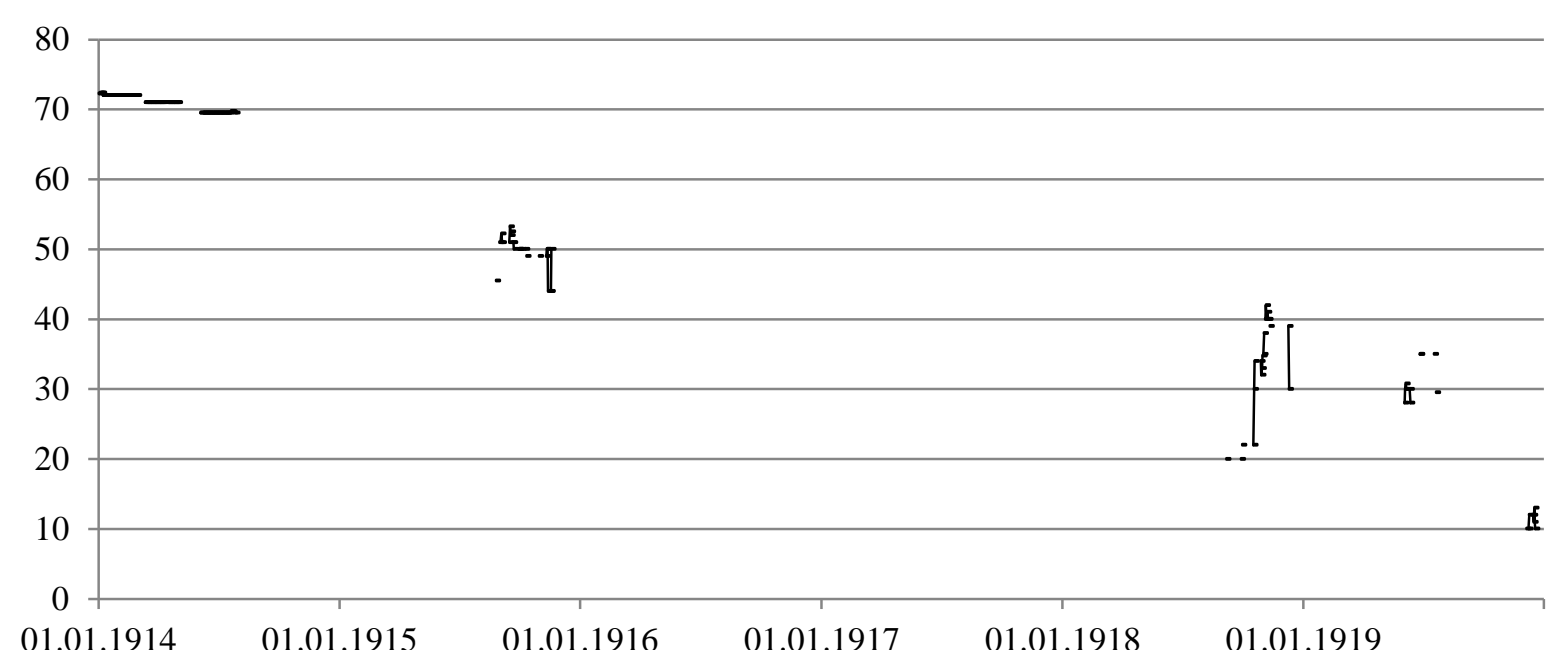

$\begin{array}{llllll}01.01 .1914 & 01.01 .1915 & 01.01 .1916 & 01.01 .1917 & 01.01 .1918 & 01.01 .1919\end{array}$

(212) Uruguay $-3.5 \%$ of 1892

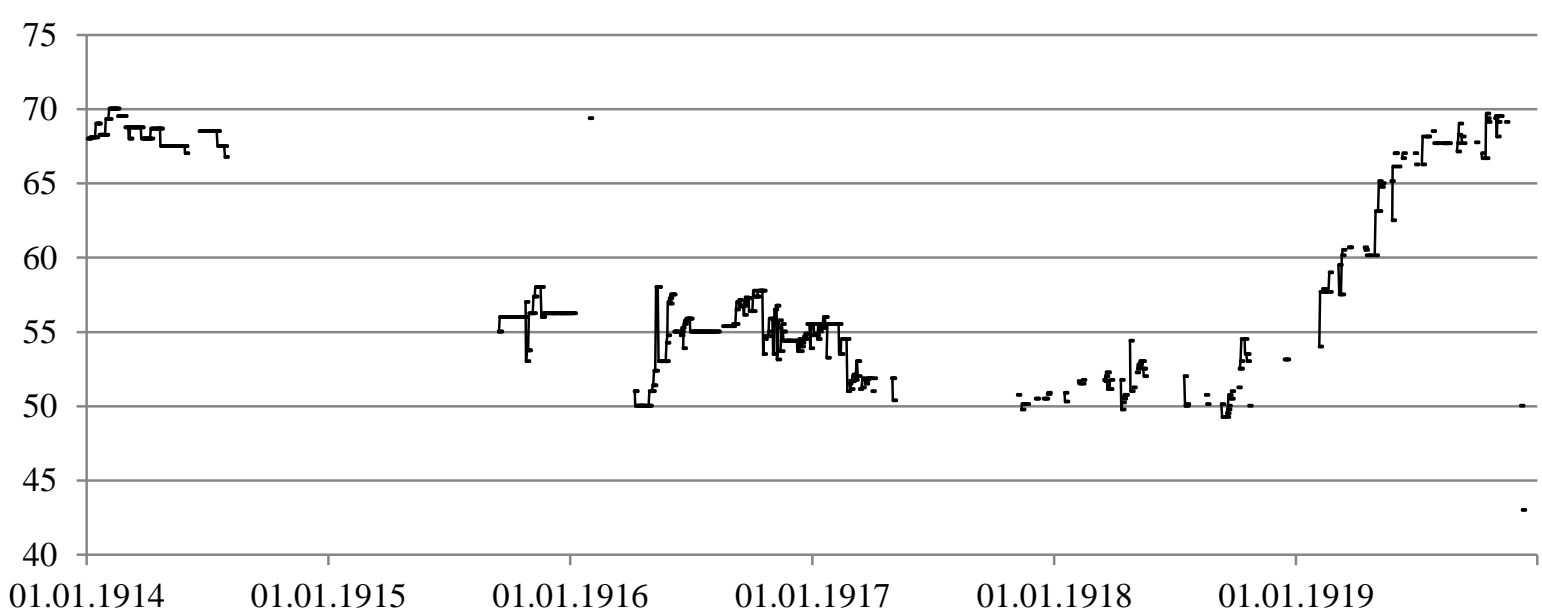

(213) Uruguay $-5.0 \%$ of 1896

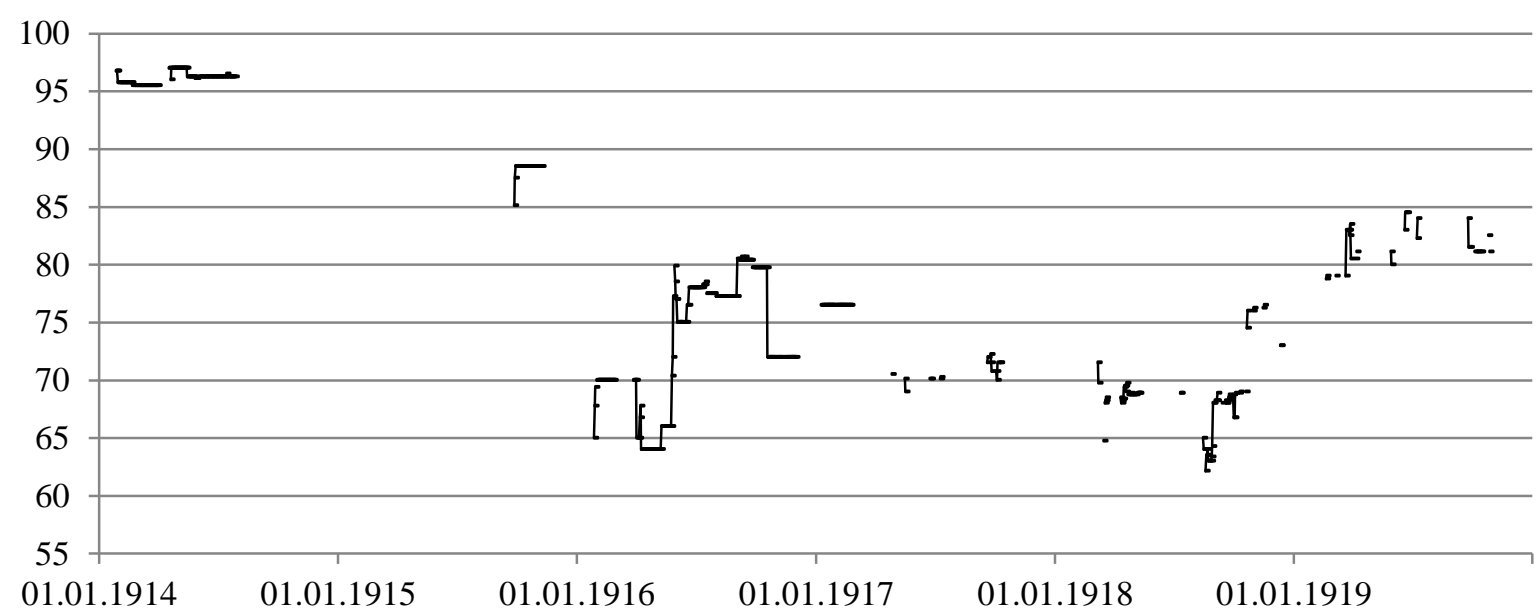


(214) Venezuela $-3.0 \%$ of 1905 (20-100)

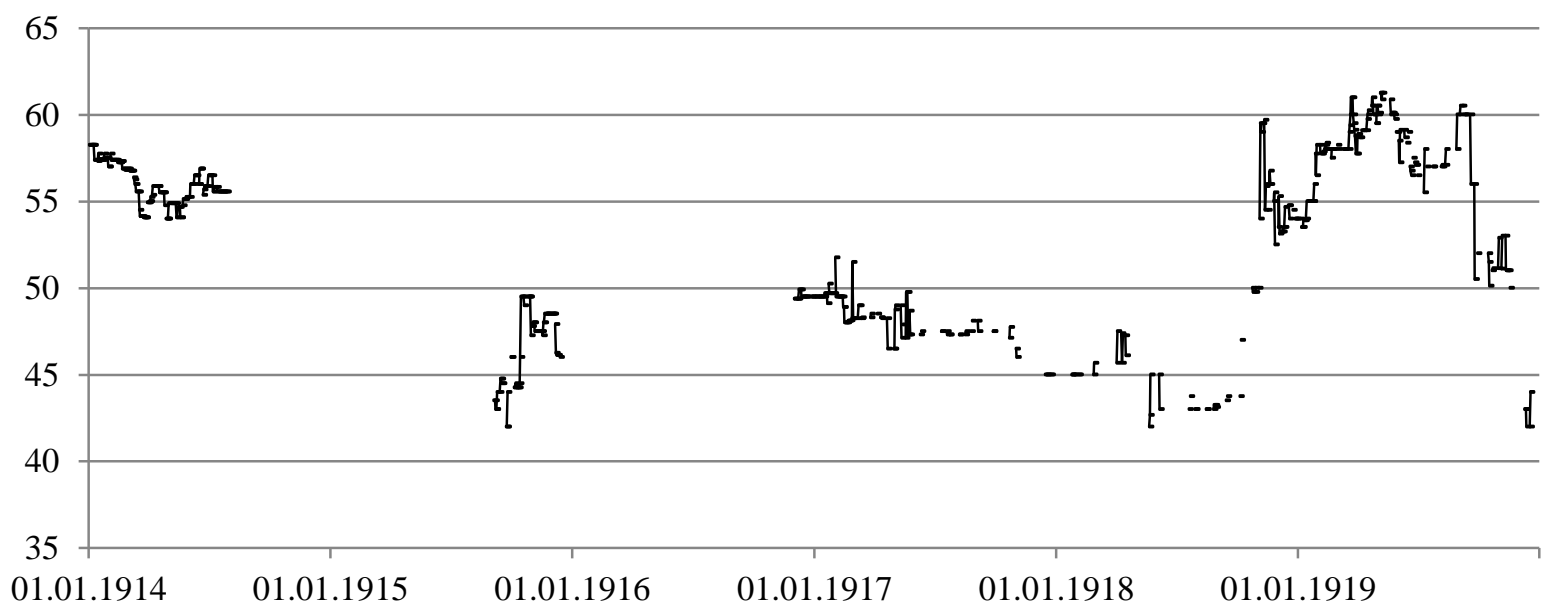

(215) Venezuela $-3.0 \%$ of 1905 (500)

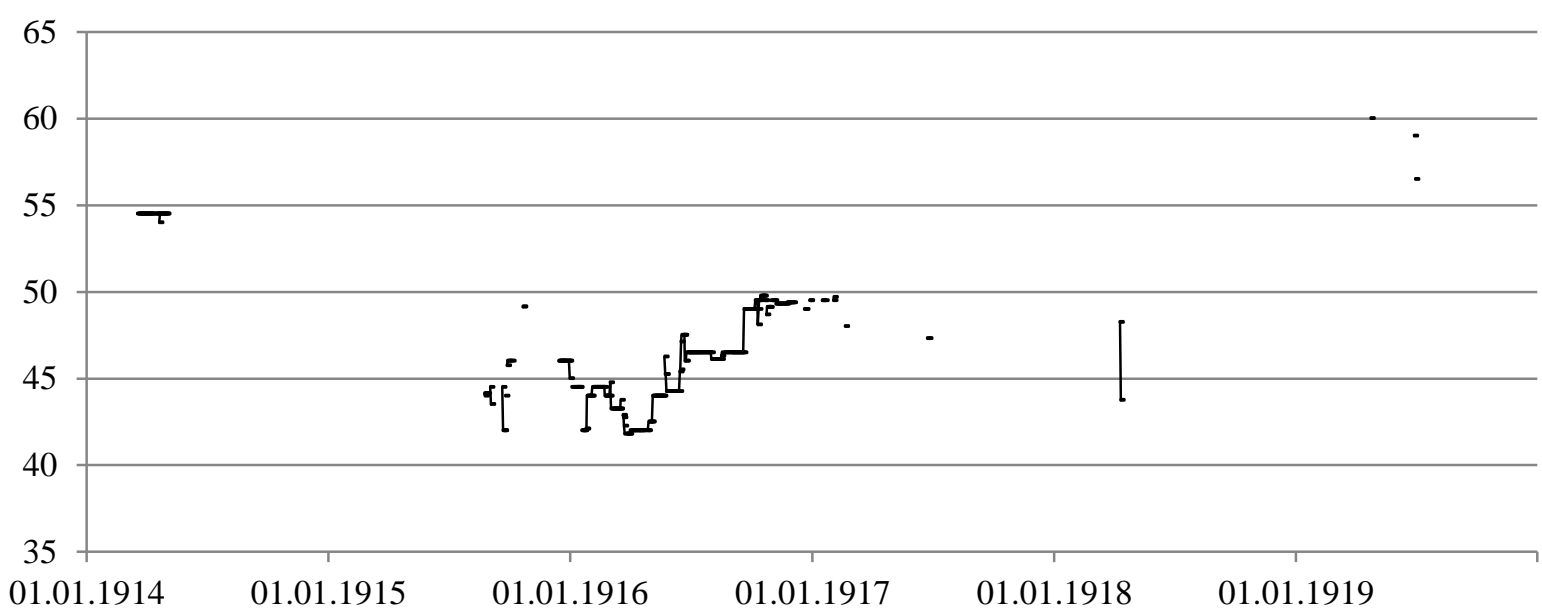

Notes: Y-axis is cut for better readability.

Sources: Cf. Chapter II. 
Figure A.2: Raw price development of English and French war bonds unofficially traded in Amsterdam over 1915-1919

(1) England - $5.0 \%$ \%1919”

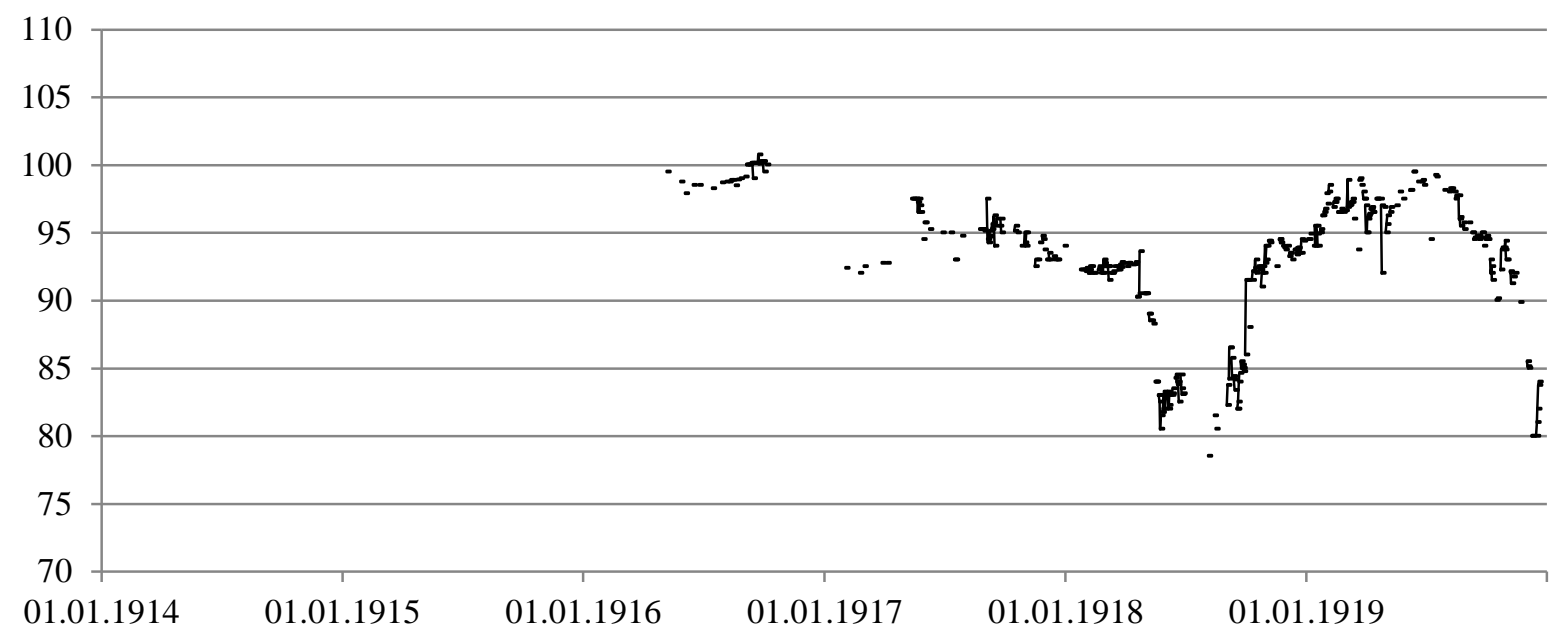

(2) England - $5.0 \%$ \% $1920 "$

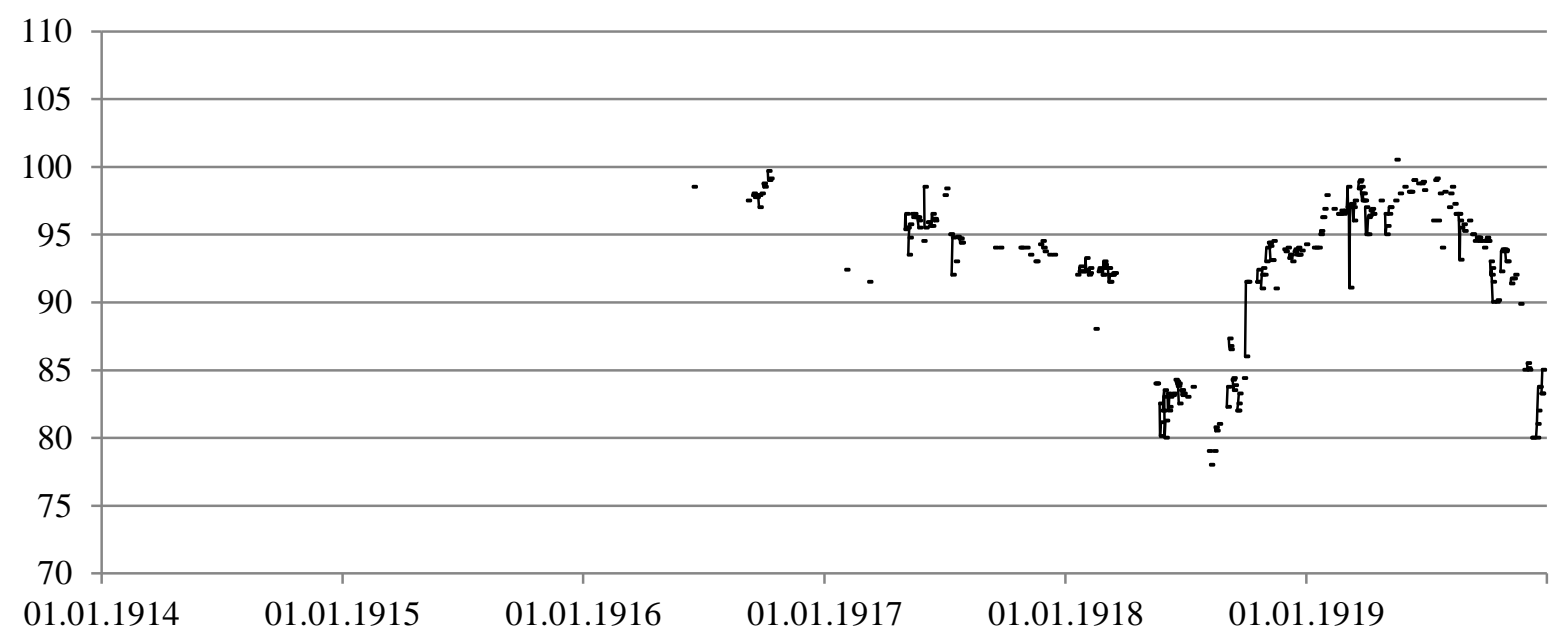

(3) England - $5.0 \%$ "1917-21"

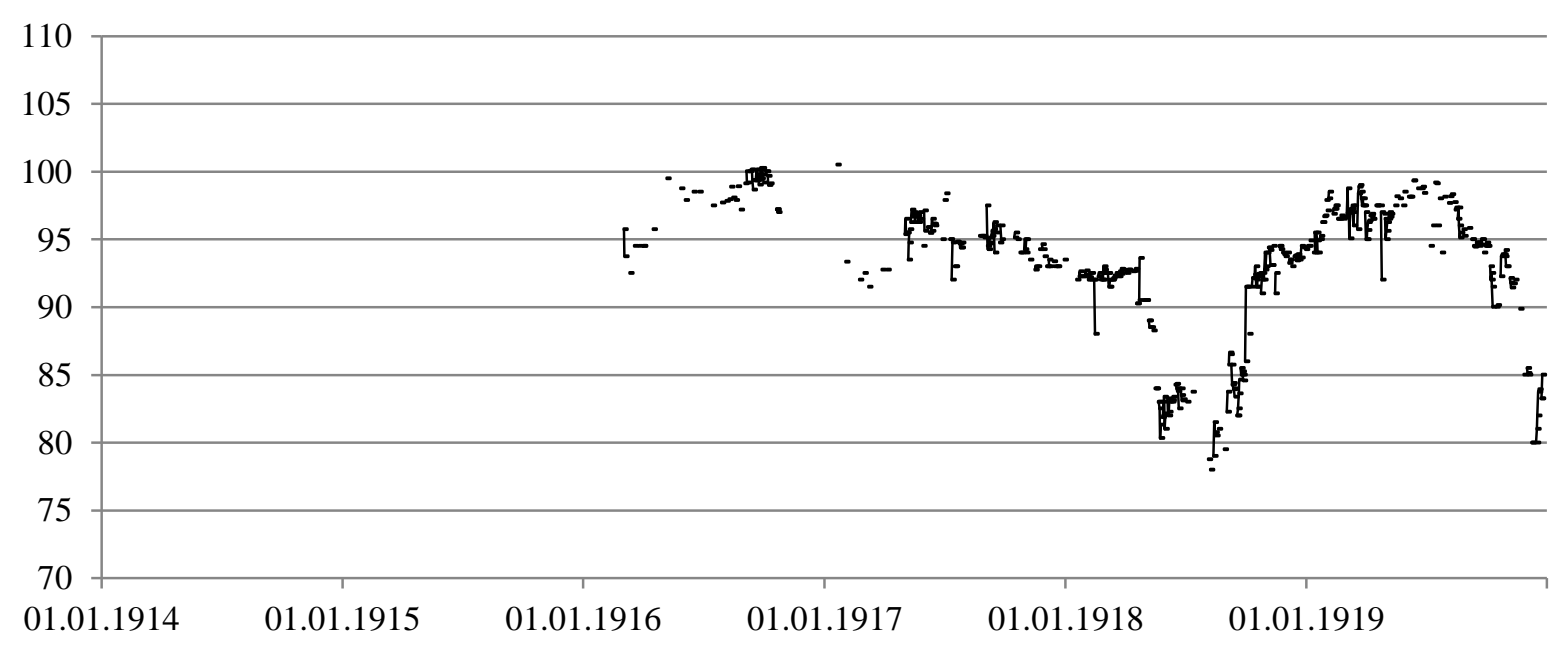


(4) England - $5.0 \%$ "1929-47"

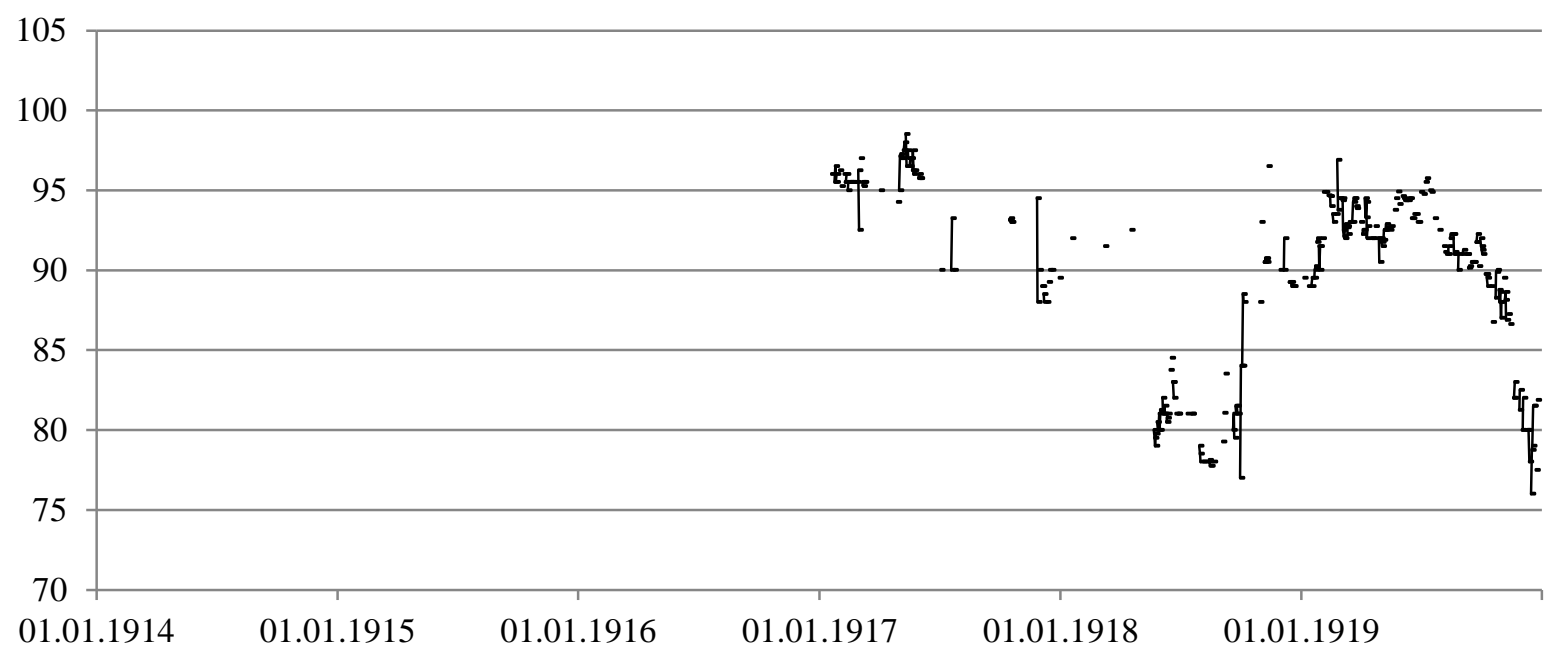

(5) England - $6.0 \%$ "1920"

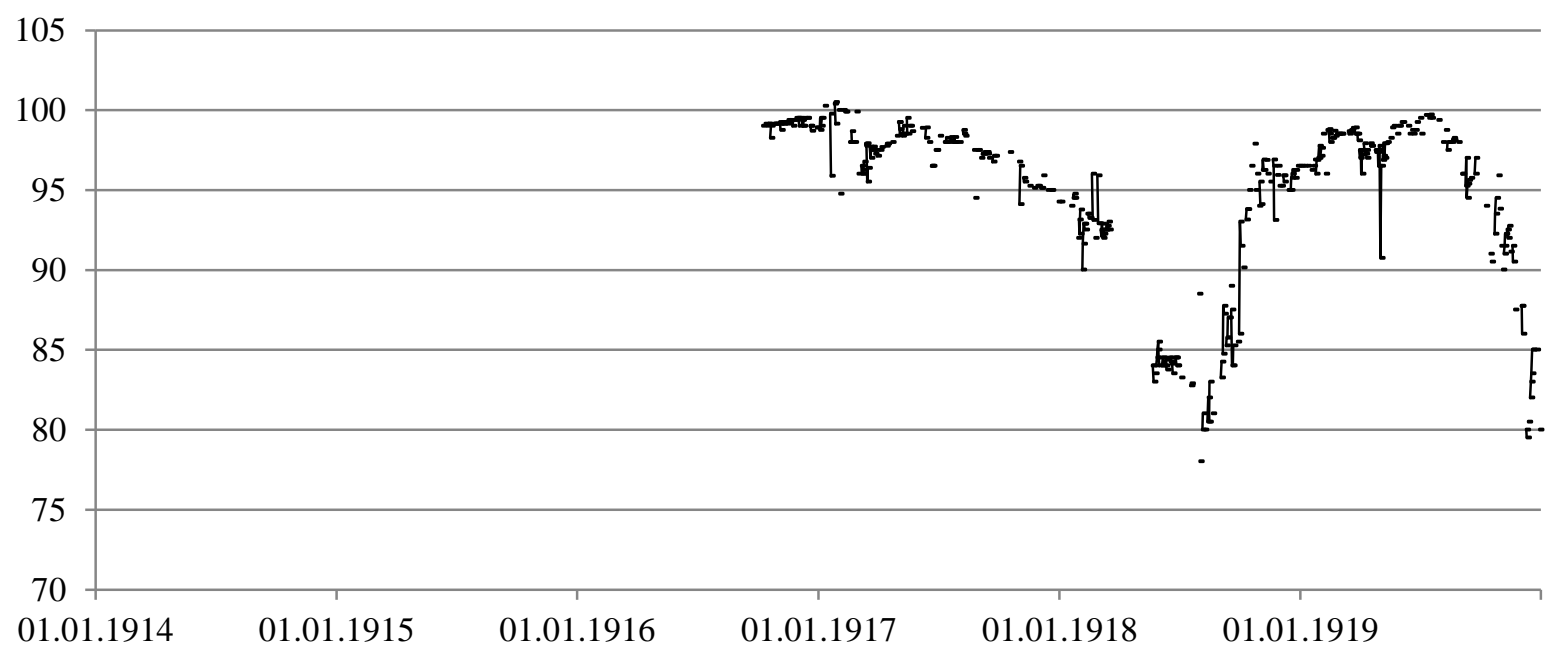

(6) England/France $-5.0 \%$

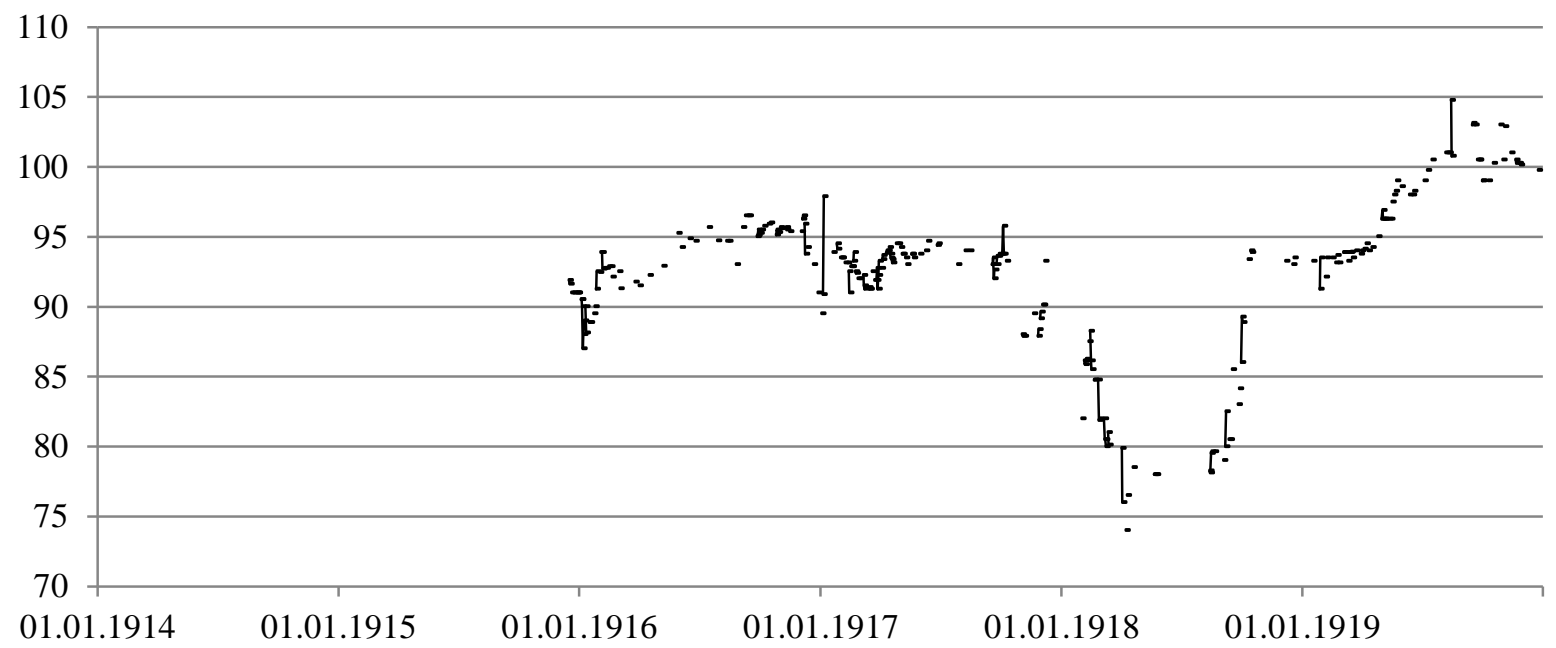


(7) France $-5.0 \%$ of 1915

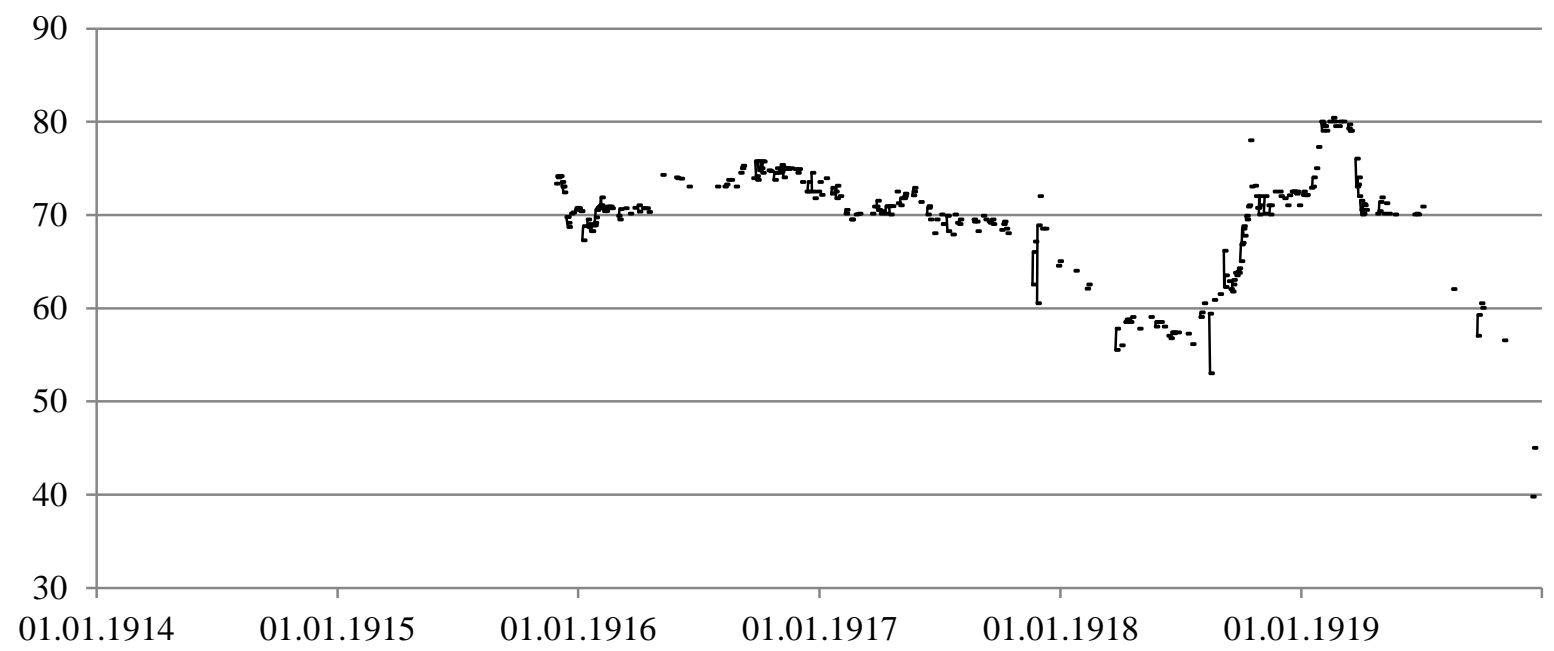

Sources: Cf, Chapter II. 


\subsection{Lowest and highest prices for selected bonds}

I was able to gather the lowest and highest prices of the actual trading day for five bonds. Figure A.3 depicts in three panels the daily effective spread - i.e., the highest minus the lowest price - for the Austrian, Dutch, and Russian bonds for which I gathered combined 1266 , 1394 , and 470 observations, respectively. The Hungarian and Ottoman bonds are not depicted as the number of observations is just too low (42 and 110, respectively). As can be gathered from the figure, the distribution of observations differs. While, for the Austrian and Russian bonds, observations lie closer to the end of the observation period, they cover the first half of the observed wartime for the Dutch bond. 
Figure A.3: The effective daily price spread for three bonds

(1) Austria $-4.0 \%$ of 1903 (Jan/Jul)

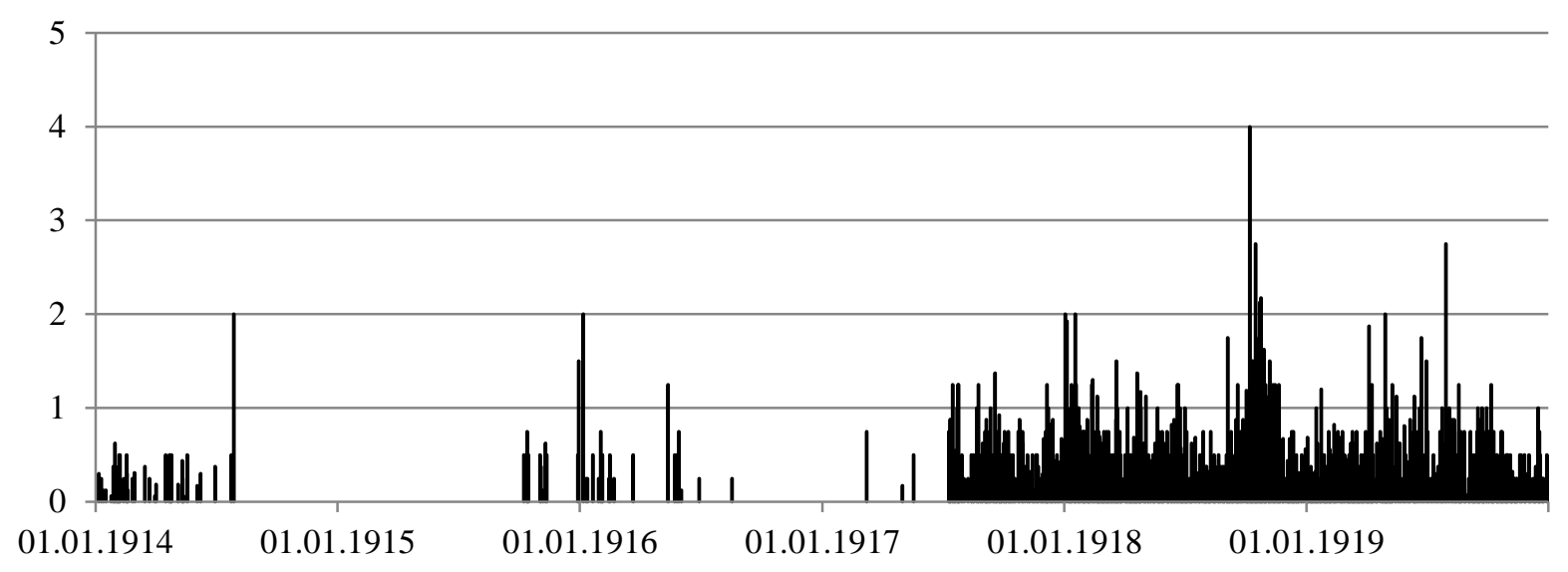

(2) Netherlands $-3.0 \%$ NWS

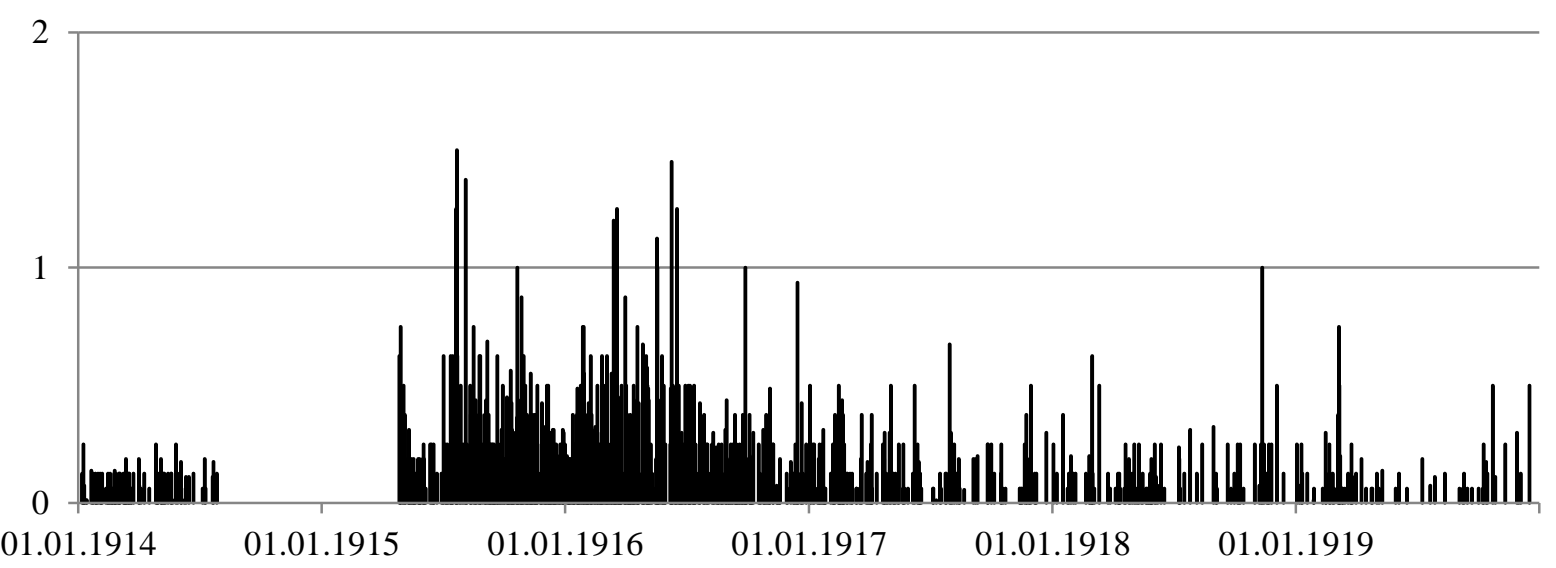

(3) Russia $-4.0 \%$ Hope \& Co (625) of $1889 / 90$

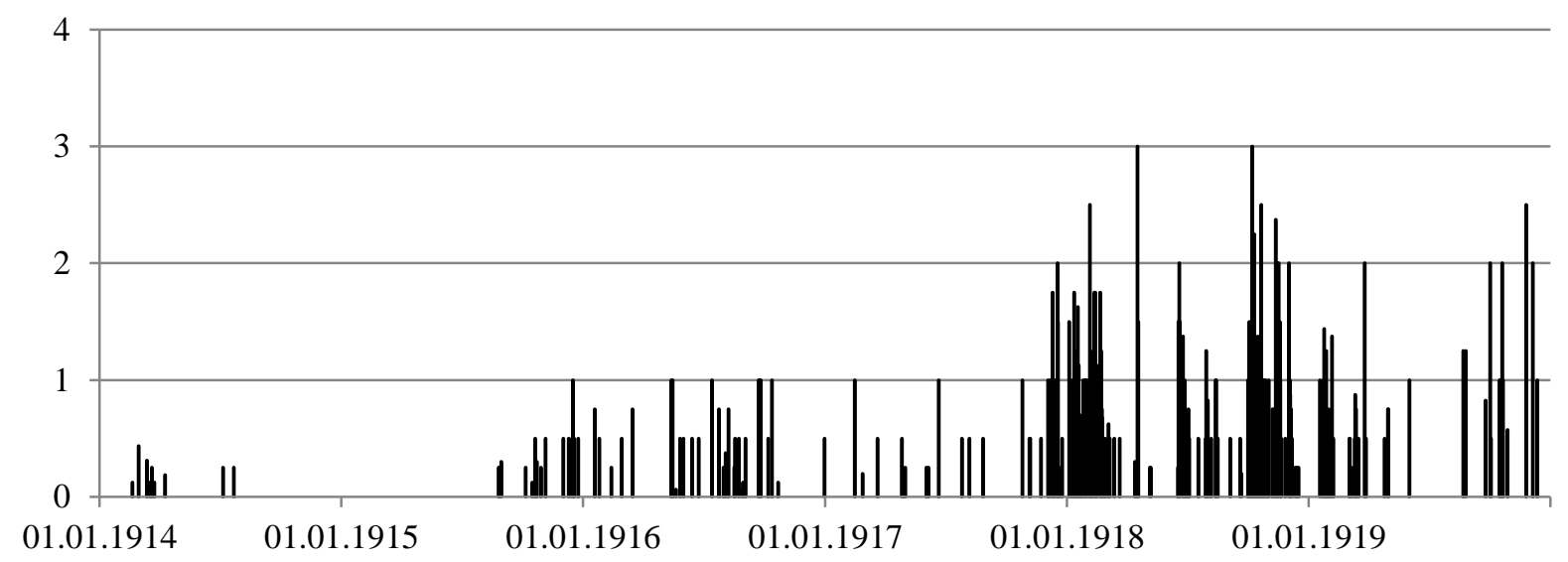

Notes: Cf. the Appendix text.

Sources: Cf. Chapter II. 


\subsection{Selected bonds' monthly raw price series in tabular form}

Tables A.4 to A.7 provide monthly time series of the most liquid bond per selected country during the war. The series are ordered by fighting status - that is, separate for the two war factions and the group of neutral countries. For the calculation and discussion of the bonds' liquidity, I refer the reader to this study's main body, especially Chapter II. The bond series are named according to the way they are named in Table A.2.

What needs to be briefly discussed here is the choice of method to collapse the daily price series, as gathered, into monthly series. There are several possibilities for doing so: Firstly, one could compute the average price per month over all available price observations. This method has the appeal that it incorporates all available price information into a single monthly price. Gaps in the resulting series will only occur for months with not a single recorded daily price and, thus, only for exceptionally illiquid bonds. However, on the downside, monthly averages are susceptible for outliers and blur the information on the timing inherent in the prices. Secondly, one could take a month's highest or lowest observed price, regardless on which day of the month it effectively occurred. The effort to create a series based on this principle is lower than in the former case. But it may complicate comparisons in the crosssection of bonds, as prices will likely not fall on the same day within a month. Thus, this procedure also blurs information on time inherent in the data. As in the former case, gaps in the series would only occur if there was not a single recorded price. Thirdly, one could take the first or the last trading day's or the mid-month day's price as being representative for the month. Prices would refer to the same exact day within a month. But the more infrequent a bond was traded, the more likely would there be gaps in the monthly series, even for month with a denser price account. Fourthly, one could just take the last recorded price for a month, no matter on which day of the month it falls or whether it is the highest or lowest price. This method reduces the occurrence of gaps in the series compared to the third method. But on the downside it may also complicate cross-sectional comparisons, as the calendar dates of the selected prices may differ.

I decided to combine methods three and four. Basically, the depicted series show the prices recorded for the stock exchange's last trading day of the respective month. If no price was recorded for the respective month at all, the last available price is given (that is, the last day with a trade); it is printed in italics, with the day of this price added in parentheses (e.g., the " $14^{\text {th" }}$ of the month). Gaps in the series only occur whenever a bond had not been traded at least for once in the respective month. Prices are rounded to one decimal place. 
Table A.4: Monthly prices on selected Central Powers' bonds (1914-1919)

\begin{tabular}{|c|c|c|c|c|}
\hline $\begin{array}{l}\text { Month/ } \\
\text { Year }\end{array}$ & $\begin{array}{c}\text { German } 3 \% \\
\text { (Apr/Oct) }\end{array}$ & $\begin{array}{c}\text { Austrian } 4 \% \\
\text { Kroner Perpetual } \\
1892(\mathrm{Jan} / \mathrm{Jul})\end{array}$ & $\begin{array}{c}\text { Ottoman } 4 \% \\
\text { Baghdad Railway } 2^{\text {nd }} \\
\text { series } 1910\end{array}$ & $\begin{array}{c}\text { Bulgarian } 5 \% \\
\text { Tobacco }\end{array}$ \\
\hline $1 / 1914$ & 76.0 & 84.6 & 74.9 & 91.7 \\
\hline $2 / 1914$ & 76.4 & 83.5 & 73.5 & 93.0 \\
\hline $3 / 1914$ & 76.7 & 82.8 & 74.4 & 93.7 \\
\hline $4 / 1914$ & 76.5 & 82.5 & 73.5 & 91.5 \\
\hline $5 / 1914$ & 76.0 & 81.7 & 73.5 & 92.7 \\
\hline $6 / 1914$ & 75.8 & 80.7 & 74.0 & 92.9 \\
\hline 7/1914 & 75.0 & 72.0 & $73.8\left(27^{\text {th }}\right)$ & $92.0\left(27^{\text {th }}\right)$ \\
\hline$\ldots$ & - & - & - & - \\
\hline$\ldots$ & - & - & - & - \\
\hline$\ldots$ & - & - & - & - \\
\hline$\ldots$ & - & - & - & - \\
\hline$\ldots$ & - & - & - & - \\
\hline$\ldots$ & - & - & - & - \\
\hline $2 / 1915$ & - & - & - & - \\
\hline $3 / 1915$ & - & - & - & - \\
\hline $4 / 1915$ & - & - & - & - \\
\hline $5 / 1915$ & - & - & - & - \\
\hline $6 / 1915$ & - & - & - & - \\
\hline $7 / 1915$ & - & - & - & - \\
\hline $8 / 1915$ & - & 56.0 & $54.0\left(27^{\text {th }}\right)$ & 75.0 \\
\hline $9 / 1915$ & 58.5 & 57.0 & 55.0 & 74.7 \\
\hline $10 / 1915$ & 58.7 & 49.5 & 54.0 & $70.0\left(28^{\text {th }}\right)$ \\
\hline $11 / 1915$ & 57.0 & 50.0 & 58.7 & 70.0 \\
\hline $12 / 1915$ & 57.0 & 43.5 & 53.5 & 54.0 \\
\hline 1/1916 & 46.0 & 44.0 & 51.2 & 57.5 \\
\hline $2 / 1916$ & 48.5 & 45.2 & 52.7 & 61.0 \\
\hline $3 / 1916$ & 42.5 & 43.9 & 50.0 & 60.0 \\
\hline 4/1916 & 42.4 & 44.2 & 51.2 & 61.9 \\
\hline $5 / 1916$ & - & 48.7 & 55.7 & $66.7\left(30^{\text {th }}\right)$ \\
\hline $6 / 1916$ & 52.0 & 44.2 & 51.5 & 73.7 \\
\hline 7/1916 & 53.0 & 45.5 & 53.4 & 71.4 \\
\hline 8/1916 & 53.0 & 43.0 & 55.0 & 69.0 \\
\hline 9/1916 & - & 41.4 & 55.0 & - \\
\hline $10 / 1916$ & - & 42.5 & 54.2 & $59.9\left(28^{\text {th }}\right)$ \\
\hline $11 / 1916$ & 50.0 & 39.0 & 56.0 & 61.0 \\
\hline $12 / 1916$ & 50.5 & 43.5 & 56.5 & 65.9 \\
\hline 1/1917 & 51.0 & 43.5 & 56.4 & $66.9\left(30^{\text {th }}\right)$ \\
\hline $2 / 1917$ & $50.0\left(24^{\text {th }}\right)$ & 39.5 & $56.7\left(22^{n d}\right)$ & $64.7\left(22^{n d}\right)$ \\
\hline $3 / 1917$ & $43.0\left(27^{\text {th }}\right)$ & 39.0 & 53.2 & 61.9 \\
\hline 4/1917 & $42.0\left(24^{\text {th }}\right)$ & 37.7 & 49.0 & 62.2 \\
\hline $5 / 1917$ & $46.0\left(22^{n d}\right)$ & $38.0\left(30^{\text {th }}\right)$ & $50.3\left(22^{n d}\right)$ & 63.0 \\
\hline $6 / 1917$ & $44.2\left(29^{\mathrm{th}}\right)$ & 35.7 & 48.5 & 62.9 \\
\hline 7/1917 & - & 38.0 & $49.5\left(30^{t h}\right)$ & 62.9 \\
\hline
\end{tabular}


Table A.4 continued

\begin{tabular}{|c|c|c|c|c|}
\hline $\begin{array}{l}\text { Month/ } \\
\text { Year }\end{array}$ & $\begin{array}{c}\text { German } 3 \% \\
\text { (Apr/Oct) }\end{array}$ & $\begin{array}{c}\text { Austrian } 4 \% \\
\text { Kroner Perpetual } \\
1892(\mathrm{Jan} / \mathrm{Jul})\end{array}$ & $\begin{array}{c}\text { Ottoman } 4 \% \\
\text { Baghdad Railway } 1^{\text {st }} \\
\text { series } 1904\end{array}$ & $\begin{array}{c}\text { Bulgarian } 5 \% \\
\text { Tobacco }\end{array}$ \\
\hline 8/1917 & $44.7\left(14^{\text {th }}\right)$ & $37.8\left(30^{\text {th }}\right)$ & $49.7\left(30^{\text {th }}\right)$ & $65.0\left(21^{s t}\right)$ \\
\hline 9/1917 & $43.0\left(13^{\text {th }}\right)$ & 38.3 & 48.0 & $64.0\left(28^{\text {th }}\right)$ \\
\hline $10 / 1917$ & $44.7\left(23^{r d}\right)$ & 37.4 & $50.7\left(29^{\text {th }}\right)$ & 64.5 \\
\hline $11 / 1917$ & 44.7 & 39.5 & 47.2 & 64.7 \\
\hline $12 / 1917$ & $48.0\left(27^{\text {th }}\right)$ & 44.7 & 49.5 & 64.2 \\
\hline $1 / 1918$ & 49.5 & 43.9 & $51.2(25 \mathrm{th}$ & $68.2\left(22^{\text {nd }}\right)$ \\
\hline $2 / 1918$ & $51.0\left(22^{n d}\right)$ & 46.5 & 50.9 & 65.0 \\
\hline $3 / 1918$ & $54.0\left(19^{\text {th }}\right)$ & 43.6 & $50.1\left(18^{t h}\right)$ & $65.9\left(15^{\text {th }}\right)$ \\
\hline 4/1918 & $53.5\left(18^{\text {th }}\right)$ & 40.5 & - & $61.5\left(15^{\text {th }}\right)$ \\
\hline $5 / 1918$ & $52.0\left(17^{\text {th }}\right)$ & 38.7 & - & - \\
\hline $6 / 1918$ & $46.5\left(28^{\text {th }}\right)$ & 32.1 & $46.0\left(3^{\text {rd }}\right)$ & $59.7\left(5^{\text {th }}\right)$ \\
\hline 7/1918 & 48.0 & 30.5 & - & $52.0\left(25^{\text {th }}\right)$ \\
\hline 8/1918 & - & 27.5 & 36.1 & $48.0\left(23^{r d}\right)$ \\
\hline $9 / 1918$ & $32.5\left(21^{s t}\right)$ & 29.7 & 48.2 & 49.0 \\
\hline $10 / 1918$ & 38.0 & 32.9 & 57.0 & 60.0 \\
\hline $11 / 1918$ & $31.2\left(29^{\text {th }}\right)$ & 28.5 & 57.0 & 62.0 \\
\hline $12 / 1918$ & $29.7\left(19^{\text {th }}\right)$ & 26.8 & 51.2 & $62.0\left(16^{\text {th }}\right)$ \\
\hline 1/1919 & $30.7\left(23^{r d}\right)$ & 31.1 & 53.9 & 56.0 \\
\hline 2/1919 & - & 28.5 & 58.7 & 52.5 \\
\hline $3 / 1919$ & $27.4\left(26^{\text {th }}\right)$ & 23.4 & $59.2\left(29^{\text {th }}\right)$ & $55.9\left(25^{\text {th }}\right)$ \\
\hline 4/1919 & $24.0\left(15^{\text {th }}\right)$ & 26.5 & 58.9 & - \\
\hline $5 / 1919$ & $30.2\left(13^{\text {th }}\right)$ & 27.5 & $58.5\left(30^{t h}\right)$ & - \\
\hline $6 / 1919$ & $31.0\left(25^{\text {th }}\right)$ & 21.7 & 59.2 & - \\
\hline 7/1919 & $30.0\left(28^{\text {th }}\right)$ & 17.7 & 59.2 & 43.0 \\
\hline 8/1919 & $19.0\left(29^{\text {th }}\right)$ & $16.5\left(28^{\text {th }}\right)$ & $52.0\left(29^{\text {th }}\right)$ & $40.4\left(19^{\text {th }}\right)$ \\
\hline 9/1919 & 17.9 & 11.7 & $47.0\left(3^{r d}\right)$ & - \\
\hline $10 / 1919$ & 16.7 & 8.5 & - & 28.5 \\
\hline $11 / 1919$ & $10.9\left(27^{\text {th }}\right)$ & 6.1 & - & $34.5\left(28^{\text {th }}\right)$ \\
\hline $12 / 1919$ & $9.5\left(27^{\text {th }}\right)$ & $5.7\left(29^{t h}\right)$ & - & $26.9\left(16^{\text {th }}\right)$ \\
\hline
\end{tabular}

Sources: Cf. Chapter II. 
Table A.5: Monthly prices on selected main Allied Powers' bonds (1914-1919)

\begin{tabular}{|c|c|c|c|c|}
\hline $\begin{array}{l}\text { Month/ } \\
\text { Year }\end{array}$ & $\begin{array}{c}\text { Russian } 4 \% \\
\text { Hope \& Co } 1889 / 90 \\
(625 r)\end{array}$ & $\begin{array}{c}\text { French } 5 \% \\
\text { War Bond } 1915\end{array}$ & $\begin{array}{c}\text { English } 5 \% \\
\text { War Bond } \\
(1915 / 16 ?)\end{array}$ & $\begin{array}{c}\text { Italian } 3.5 \% \\
1862 / 81\end{array}$ \\
\hline $1 / 1914$ & 84.0 & - & - & 92.0 \\
\hline $2 / 1914$ & 83.7 & - & - & 91.2 \\
\hline $3 / 1914$ & 83.1 & - & - & 91.2 \\
\hline $4 / 1914$ & 82.1 & - & - & - \\
\hline $5 / 1914$ & 83.5 & - & - & 90.4 \\
\hline $6 / 1914$ & 83.2 & - & - & 90.4 \\
\hline 7/1914 & 76.9 & - & - & $90.0\left(27^{\text {th }}\right)$ \\
\hline$\ldots$ & - & - & - & - \\
\hline$\ldots$ & - & - & - & - \\
\hline$\ldots$ & - & - & - & - \\
\hline$\ldots$ & - & - & - & - \\
\hline$\ldots$ & - & - & - & - \\
\hline$\ldots$ & - & - & - & - \\
\hline $2 / 1915$ & - & - & - & - \\
\hline $3 / 1915$ & - & - & - & - \\
\hline $4 / 1915$ & - & - & - & - \\
\hline $5 / 1915$ & - & - & - & - \\
\hline $6 / 1915$ & - & - & - & - \\
\hline $7 / 1915$ & - & - & - & - \\
\hline $8 / 1915$ & 63.7 & - & - & - \\
\hline $9 / 1915$ & 62.7 & - & - & 60.0 \\
\hline $10 / 1915$ & 61.2 & - & - & - \\
\hline $11 / 1915$ & 58.7 & 74.0 & - & - \\
\hline $12 / 1915$ & 56.9 & 70.7 & - & - \\
\hline 1/1916 & 60.1 & 70.9 & - & - \\
\hline $2 / 1916$ & 60.0 & 69.9 & - & $50.0\left(23^{r d}\right)$ \\
\hline $3 / 1916$ & 56.5 & 71.0 & - & $50.0\left(11^{\text {th }}\right)$ \\
\hline $4 / 1916$ & 59.5 & $70.3\left(15^{\text {th }}\right)$ & - & $50.0\left(20^{\text {th }}\right)$ \\
\hline $5 / 1916$ & 63.7 & $73.9\left(29^{\text {th }}\right)$ & $99.5\left(6^{\text {th }}\right)$ & - \\
\hline 6/1916 & 64.3 & $73.0\left(15^{\text {th }}\right)$ & $98.5\left(24^{\text {th }}\right)$ & $56.0\left(22^{n d}\right)$ \\
\hline $7 / 1916$ & 65.9 & $73.0\left(28^{t h}\right)$ & $98.7\left(28^{t h}\right)$ & - \\
\hline $8 / 1916$ & 66.1 & $73.0\left(25^{\text {th }}\right)$ & $99.0\left(25^{\text {th }}\right)$ & - \\
\hline 9/1916 & 66.9 & 74.7 & 99.5 & 60.0 \\
\hline $10 / 1916$ & $66.0\left(28^{\text {th }}\right)$ & 74.5 & $100.0\left(4^{\text {th }}\right)$ & $57.0\left(25^{\text {th }}\right)$ \\
\hline $11 / 1916$ & 67.5 & $74.9\left(29^{\text {th }}\right)$ & - & 54.0 \\
\hline $12 / 1916$ & 65.5 & 73.5 & - & $56.7\left(1^{s t}\right)$ \\
\hline 1/1917 & 65.7 & $72.0\left(30^{\text {th }}\right)$ & - & $50.0\left(18^{\text {th }}\right)$ \\
\hline 2/1917 & 62.1 & 70.1 & $92.0\left(22^{\text {nd }}\right)$ & - \\
\hline $3 / 1917$ & $58.9\left(27^{\text {th }}\right)$ & $70.5\left(30^{\text {th }}\right)$ & $92.7\left(28^{\text {th }}\right)$ & - \\
\hline 4/1917 & 61.5 & $71.2\left(28^{\text {th }}\right)$ & $92.7\left(5^{\text {th }}\right)$ & $44.0\left(10^{\text {th }}\right)$ \\
\hline $5 / 1917$ & $61.8\left(29^{t h}\right)$ & $72.9(23 t h)$ & 95.7 & $45.0\left(24^{\text {th }}\right)$ \\
\hline $6 / 1917$ & 52.5 & $69.5\left(25^{\text {th }}\right)$ & $95.0\left(27^{\text {th }}\right)$ & - \\
\hline 7/1917 & 53.5 & 69.5 & $94.7\left(27^{\text {th }}\right)$ & - \\
\hline 8/1917 & $53.1\left(28^{t h}\right)$ & $68.2\left(27^{\text {th }}\right)$ & $95.1\left(30^{t h}\right)$ & $43.0\left(28^{t h}\right)$ \\
\hline $9 / 1917$ & $52.9\left(26^{\text {th }}\right)$ & $69.0\left(19^{\text {th }}\right)$ & $95.0\left(25^{t h}\right)$ & - \\
\hline $10 / 1917$ & 45.0 & $68.0\left(11^{\text {th }}\right)$ & 95.0 & - \\
\hline $11 / 1917$ & 35.0 & $72.0\left(29^{\text {th }}\right)$ & $93.7\left(29^{\text {th }}\right)$ & - \\
\hline
\end{tabular}


Table A.5 continued

\begin{tabular}{|c|c|c|c|c|}
\hline $\begin{array}{l}\text { Month/ } \\
\text { Year }\end{array}$ & $\begin{array}{c}\text { Russian } 4 \% \\
\text { Hope \& Co } 1889 / 90 \\
(625 r)\end{array}$ & $\begin{array}{c}\text { French } 5 \% \\
\text { War Bond } 1915\end{array}$ & $\begin{array}{c}\text { English } 5 \% \\
\text { War Bond } \\
(1915 / 16 ?)\end{array}$ & $\begin{array}{c}\text { Italian } 3.5 \% \\
1862 / 81\end{array}$ \\
\hline $12 / 1917$ & 36.7 & $65.0\left(29^{\text {th }}\right)$ & $94.0\left(29^{t h}\right)$ & - \\
\hline $1 / 1918$ & 26.0 & $64.0\left(22^{\text {nd }}\right)$ & 92.1 & - \\
\hline $2 / 1918$ & 31.5 & $62.5\left(11^{\text {th }}\right)$ & 92.7 & - \\
\hline $3 / 1918$ & 25.0 & $57.7\left(26^{\text {th }}\right)$ & 92.7 & - \\
\hline $4 / 1918$ & 22.3 & $57.7\left(29^{\text {th }}\right)$ & 90.5 & - \\
\hline $5 / 1918$ & $22.5\left(28^{\text {th }}\right)$ & 58.5 & 82.0 & 22.2 \\
\hline $6 / 1918$ & 25.0 & $57.4\left(26^{\text {th }}\right)$ & $83.1\left(27^{t h}\right)$ & - \\
\hline 7/1918 & 26.5 & 59.0 & - & $25.0\left(8^{t h}\right)$ \\
\hline $8 / 1918$ & 26.0 & 61.5 (29th & $80.5\left(16^{\text {th }}\right)$ & $30.0\left(8^{t h}\right)$ \\
\hline $9 / 1918$ & 24.5 & 65.0 & 86.0 & 35.0 \\
\hline $10 / 1918$ & 35.5 & $71.0\left(30^{\text {th }}\right)$ & 93.0 & - \\
\hline $11 / 1918$ & $35.0\left(29^{\text {th }}\right)$ & $72.0\left(29^{t h}\right)$ & $93.7\left(29^{t h}\right)$ & - \\
\hline $12 / 1918$ & 35.9 & $71.0\left(27^{\text {th }}\right)$ & $94.4\left(27^{\text {th }}\right)$ & $45.0\left(6^{t h}\right)$ \\
\hline 1/1919 & 33.7 & 79.9 & $97.9\left(30^{\text {th }}\right)$ & $45.0\left(24^{\text {th }}\right)$ \\
\hline $2 / 1919$ & 31.5 & $80.0\left(27^{\text {th }}\right)$ & 96.6 & - \\
\hline $3 / 1919$ & 24.1 & 71.5 & 97.0 & - \\
\hline $4 / 1919$ & 30.1 & $71.4\left(29^{t h}\right)$ & $96.9\left(28^{\text {th }}\right)$ & $46.0\left(14^{\text {th }}\right)$ \\
\hline $5 / 1919$ & 31.1 & $70.0\left(21^{s t}\right)$ & $97.5\left(26^{\text {th }}\right)$ & $44.0\left(14^{\text {th }}\right)$ \\
\hline $6 / 1919$ & $31.2\left(23^{r d}\right)$ & $70.0\left(25^{\text {th }}\right)$ & $98.5\left(27^{\text {th }}\right)$ & - \\
\hline 7/1919 & 23.8 & $70.9\left(2^{\text {nd }}\right)$ & $98.1\left(28^{\text {th }}\right)$ & - \\
\hline $8 / 1919$ & $26.0\left(29^{t h}\right)$ & $62.0\left(18^{t h}\right)$ & $95.2\left(27^{\text {th }}\right)$ & - \\
\hline 9/1919 & 23.0 & $60.5\left(29^{\text {th }}\right)$ & 94.7 & - \\
\hline $10 / 1919$ & $23.5\left(30^{\text {th }}\right)$ & $60.0\left(1^{s t}\right)$ & 93.0 & - \\
\hline $11 / 1919$ & 19.5 & $56.5\left(3^{r d}\right)$ & $89.9\left(20^{\text {th }}\right)$ & - \\
\hline $12 / 1919$ & $15.2\left(29^{\text {th }}\right)$ & $45.0\left(18^{\text {th }}\right)$ & $84.0\left(19^{\text {th }}\right)$ & - \\
\hline
\end{tabular}

Sources: Cf Chapter II. 
Table A.6: Monthly prices on selected minor Allied Powers' bonds (1914-1919).

\begin{tabular}{|c|c|c|c|}
\hline $\begin{array}{l}\text { Month/ } \\
\text { Year }\end{array}$ & $\begin{array}{c}\text { Serbian } 4 \% \\
1895(500)\end{array}$ & $\begin{array}{c}\text { Romanian } 4 \% \\
1910(2500-5000)\end{array}$ & $\begin{array}{c}\text { Portuguese } 4.5 \% \\
\text { Tobacco } 1890\end{array}$ \\
\hline $1 / 1914$ & 76.0 & 80.5 & 93.6 \\
\hline $2 / 1914$ & 76.0 & 83.7 & 93.7 \\
\hline $3 / 1914$ & 75.5 & 80.0 & 93.4 \\
\hline $4 / 1914$ & 75.5 & 80.0 & 94.0 \\
\hline $5 / 1914$ & 76.4 & 79.5 & 94.5 \\
\hline $6 / 1914$ & 75.0 & 81.2 & 94.0 \\
\hline $7 / 1914$ & 66.0 & $82.0\left(27^{\text {th }}\right)$ & 93.0 \\
\hline$\ldots$ & - & - & - \\
\hline$\ldots$ & - & - & - \\
\hline$\ldots$ & - & - & - \\
\hline$\ldots$ & - & - & - \\
\hline$\ldots$ & - & - & - \\
\hline$\ldots$ & - & - & - \\
\hline $2 / 1915$ & - & - & - \\
\hline $3 / 1915$ & - & - & - \\
\hline $4 / 1915$ & - & - & - \\
\hline $5 / 1915$ & - & - & - \\
\hline $6 / 1915$ & - & - & - \\
\hline $7 / 1915$ & - & - & 84.0 \\
\hline $8 / 1915$ & - & - & $84.7\left(28^{\text {th }}\right)$ \\
\hline $9 / 1915$ & 50.0 & - & 86.0 \\
\hline $10 / 1915$ & 43.0 & - & 88.5 \\
\hline $11 / 1915$ & 41.2 & - & 86.9 \\
\hline $12 / 1915$ & 41.0 & - & 78.0 \\
\hline 1/1916 & $41.0\left(29^{\text {th }}\right)$ & - & 83.1 \\
\hline 2/1916 & 40.0 & - & 83.5 \\
\hline $3 / 1916$ & 43.0 & 50.0 & 76.5 \\
\hline $4 / 1916$ & 41.4 & $47.0\left(3^{r d}\right)$ & 76.0 \\
\hline $5 / 1916$ & 44.0 & $52.0\left(30^{\text {th }}\right)$ & $79.0\left(30^{\text {th }}\right)$ \\
\hline $6 / 1916$ & 44.5 & $55.2\left(29^{\text {th }}\right)$ & $79.5\left(29^{t h}\right)$ \\
\hline $7 / 1916$ & 47.2 & 55.2 & 76.5 \\
\hline 8/1916 & 44.7 & $55.2\left(1^{s t}\right)$ & 78.2 \\
\hline 9/1916 & 49.5 & - & 77.5 \\
\hline $10 / 1916$ & $45.0\left(28^{\text {th }}\right)$ & - & 77.5 \\
\hline $11 / 1916$ & 50.5 & - & 76.5 \\
\hline $12 / 1916$ & 43.0 & - & 77.0 \\
\hline $1 / 1917$ & 46.0 & - & 77.7 \\
\hline 2/1917 & $48.9\left(27^{t h}\right)$ & - & $77.9\left(22^{n d}\right)$ \\
\hline $3 / 1917$ & 48.0 & - & 77.7 \\
\hline 4/1917 & 48.7 & - & 76.7 \\
\hline $5 / 1917$ & $48.9\left(29^{t h}\right)$ & - & 78.0 \\
\hline $6 / 1917$ & 45.0 & - & 78.7 \\
\hline $7 / 1917$ & $48.0\left(23^{r d}\right)$ & - & 78.2 \\
\hline $8 / 1917$ & $47.2\left(30^{t h}\right)$ & - & $79.2\left(30^{\text {th }}\right)$ \\
\hline $9 / 1917$ & $48.5\left(25^{\text {th }}\right)$ & - & 79.7 \\
\hline $10 / 1917$ & $48.9\left(18^{\text {th }}\right)$ & - & $80.9\left(22^{n d}\right)$ \\
\hline $11 / 1917$ & $48.0\left(2^{\text {nd }}\right)$ & - & 79.7 \\
\hline
\end{tabular}


Table A.6 continued

\begin{tabular}{|c|c|c|c|}
\hline $\begin{array}{l}\text { Month/ } \\
\text { Year }\end{array}$ & $\begin{array}{c}\text { Serbian } 4 \% \\
1895(500)\end{array}$ & $\begin{array}{c}\text { Romanian } 4 \% \\
1910(2500-5000)\end{array}$ & $\begin{array}{c}\text { Portuguese } 4.5 \% \\
\text { Tobacco } 1890\end{array}$ \\
\hline $12 / 1917$ & $43.0\left(20^{\text {th }}\right)$ & - & $79.4\left(29^{t h}\right)$ \\
\hline $1 / 1918$ & 34.0 & - & $77.9\left(17^{\text {th }}\right)$ \\
\hline 2/1918 & 37.5 & - & $74.7\left(23^{r d}\right)$ \\
\hline $3 / 1918$ & 34.7 & - & - \\
\hline $4 / 1918$ & $34.0\left(16^{\text {th }}\right)$ & - & - \\
\hline $5 / 1918$ & $34.0\left(7^{t h}\right)$ & - & - \\
\hline $6 / 1918$ & 30.2 & - & $69.0\left(29^{t h}\right)$ \\
\hline $7 / 1918$ & 28.0 & - & $68.0\left(12^{\text {th }}\right)$ \\
\hline 8/1918 & $26.0\left(28^{t h}\right)$ & - & 65.4 \\
\hline 9/1918 & 43.7 & - & 74.0 \\
\hline $10 / 1918$ & $52.0\left(29^{t h}\right)$ & - & 82.2 \\
\hline $11 / 1918$ & 50.0 & $49.0\left(12^{\text {th }}\right)$ & 83.9 \\
\hline $12 / 1918$ & $50.9\left(27^{\text {th }}\right)$ & - & 82.5 \\
\hline 1/1919 & 53.0 & - & 87.9 \\
\hline 2/1919 & $53.0\left(24^{\text {th }}\right)$ & $52.0\left(27^{\text {th }}\right)$ & 89.0 \\
\hline $3 / 1919$ & 49.0 & $50.2\left(27^{\text {th }}\right)$ & 88.0 \\
\hline 4/1919 & $40.0\left(29^{t h}\right)$ & - & 87.9 \\
\hline $5 / 1919$ & $50.0\left(29^{t h}\right)$ & - & 88.9 \\
\hline $6 / 1919$ & 49.0 & - & $88.0\left(27^{\text {th }}\right)$ \\
\hline 7/1919 & - & - & 87.0 \\
\hline $8 / 1919$ & $42.7\left(27^{t h}\right)$ & - & $88.5\left(27^{t h}\right)$ \\
\hline $9 / 1919$ & $40.0\left(17^{\text {th }}\right)$ & - & 83.1 \\
\hline $10 / 1919$ & - & $30.0\left(15^{\text {th }}\right)$ & 70.0 \\
\hline $11 / 1919$ & - & $31.1\left(25^{\text {th }}\right)$ & 67.0 \\
\hline $12 / 1919$ & $25.0\left(27^{\text {th }}\right)$ & - & $61.9\left(29^{\text {th }}\right)$ \\
\hline
\end{tabular}


Table A.6 continued

\begin{tabular}{|c|c|c|c|}
\hline $\begin{array}{l}\text { Month/ } \\
\text { Year }\end{array}$ & $\begin{array}{c}\text { Chinese } 4.5 \% \\
1898\end{array}$ & $\begin{array}{c}\text { Japanese } 5.0 \% \\
1908 / 09(500 / 1000)\end{array}$ & $\begin{array}{c}\text { Brazilian } 5.0 \% \\
1914(20 / 100)\end{array}$ \\
\hline $1 / 1914$ & 92.0 & - & - \\
\hline $2 / 1914$ & 92.5 & - & - \\
\hline $3 / 1914$ & 90.7 & - & - \\
\hline $4 / 1914$ & 89.9 & - & - \\
\hline $5 / 1914$ & 90.0 & - & - \\
\hline 6/1914 & $90.9\left(29^{t h}\right)$ & - & - \\
\hline $7 / 1914$ & $91.5\left(27^{t h}\right)$ & - & - \\
\hline$\ldots$ & - & - & - \\
\hline$\ldots$ & - & - & - \\
\hline$\ldots$ & - & - & - \\
\hline$\ldots$ & - & - & - \\
\hline$\ldots$ & - & - & - \\
\hline$\ldots$ & - & - & - \\
\hline $2 / 1915$ & - & - & - \\
\hline $3 / 1915$ & - & - & - \\
\hline $4 / 1915$ & - & - & - \\
\hline $5 / 1915$ & - & - & - \\
\hline $6 / 1915$ & - & - & - \\
\hline $7 / 1915$ & - & - & $\left(65.727^{\text {th }}\right)$ \\
\hline $8 / 1915$ & $75.0\left(27^{\text {th }}\right)$ & $80.1\left(29^{t h}\right)$ & 66.1 \\
\hline 9/1915 & 74.25 & 82.2 & 68.7 \\
\hline $10 / 1915$ & 75.9 & 84.4 & 71.0 \\
\hline $11 / 1915$ & 75.7 & 83.9 & 71.1 \\
\hline $12 / 1915$ & 75.2 & 79.2 & 67.5 \\
\hline $1 / 1916$ & $68.0\left(29^{t h}\right)$ & 76.0 & 63.5 \\
\hline 2/1916 & 67.0 & 81.7 & 65.8 \\
\hline $3 / 1916$ & 620. & 80.0 & 60.5 \\
\hline 4/1916 & 64.7 & 79.0 & 61.4 \\
\hline $5 / 1916$ & $70.0\left(30^{\text {th }}\right)$ & $80.5\left(30^{\text {th }}\right)$ & 70.7 \\
\hline $6 / 1916$ & $69.0\left(29^{\text {th }}\right)$ & 83.0 & $70.7\left(29^{\text {th }}\right)$ \\
\hline 7/1916 & 69.0 & 85.9 & 71.4 \\
\hline $8 / 1916$ & $69.0\left(1^{s t}\right)$ & 86.1 & 72.9 \\
\hline 9/1916 & 61.5 & 88.0 & 76.5 \\
\hline $10 / 1916$ & 62.7 & $88.9\left(30^{\text {th }}\right)$ & 73.4 \\
\hline $11 / 1916$ & 66.9 & 89.5 & 74.1 \\
\hline $12 / 1916$ & 68.2 & 89.5 & 70.5 \\
\hline $1 / 1917$ & $68.2\left(30^{\text {th }}\right)$ & 90.1 & 72.9 \\
\hline $2 / 1917$ & $66.0\left(22^{n d}\right)$ & $89.1\left(22^{n d}\right)$ & $70.9\left(22^{n d}\right)$ \\
\hline $3 / 1917$ & $67.7\left(23^{r d}\right)$ & 87.1 & $69.2\left(30^{\text {th }}\right)$ \\
\hline $4 / 1917$ & $67.4\left(17^{\text {th }}\right)$ & $85.8\left(26^{\text {th }}\right)$ & $68.5\left(28^{\text {th }}\right)$ \\
\hline $5 / 1917$ & $68.5\left(25^{t h}\right)$ & $86.5\left(17^{\text {th }}\right)$ & 72.9 \\
\hline $6 / 1917$ & 68.2 & 87.0 & $72.4\left(28^{t h}\right)$ \\
\hline $7 / 1917$ & 66.4 & $85.0\left(2^{n d}\right)$ & 74.7 \\
\hline $8 / 1917$ & $66.7\left(1^{s t}\right)$ & $85.5\left(28^{t h}\right)$ & $75.7\left(28^{t h}\right)$ \\
\hline $9 / 1917$ & - & - & 75.7 \\
\hline $10 / 1917$ & $62.0\left(23^{r d}\right)$ & $85.2\left(26^{\text {th }}\right)$ & $74.5\left(29^{t h}\right)$ \\
\hline $11 / 1917$ & - & $85.2\left(29^{\text {th }}\right)$ & 70.0 \\
\hline
\end{tabular}


Table A. 6 continued

\begin{tabular}{|c|c|c|c|}
\hline $\begin{array}{l}\text { Month/ } \\
\text { Year }\end{array}$ & $\begin{array}{c}\text { Chinese } 4.5 \% \\
1898\end{array}$ & $\begin{array}{c}\text { Japanese } 5.0 \% \\
1908 / 09(500 / 1000)\end{array}$ & $\begin{array}{c}\text { Brazilian } 5.0 \% \\
1914(20 / 100)\end{array}$ \\
\hline $12 / 1917$ & 62.0 & $82.5\left(29^{t h}\right)$ & 71.7 \\
\hline $1 / 1918$ & 63.5 & $81.9\left(29^{\text {th }}\right)$ & $70.7\left(22^{n d}\right)$ \\
\hline 2/1918 & $63.4\left(1^{s t}\right)$ & 81.3 & 71.5 \\
\hline $3 / 1918$ & - & $79.7\left(19^{\text {th }}\right)$ & $70.9\left(19^{\text {th }}\right)$ \\
\hline 4/1918 & - & - & $65.6\left(22^{\text {nd }}\right)$ \\
\hline $5 / 1918$ & $54.0\left(13^{t h}\right)$ & $70.7\left(30^{\text {th }}\right)$ & $65.6\left(24^{\text {th }}\right)$ \\
\hline $6 / 1918$ & $53.1\left(10^{\text {th }}\right)$ & - & 66.7 \\
\hline $7 / 1918$ & - & 67.0 & 65.1 \\
\hline 8/1918 & 58.9 & $69.9\left(2^{\text {nd }}\right)$ & 67.75 \\
\hline 9/1918 & $51.7\left(26^{\text {th }}\right)$ & $70.0\left(21^{s t}\right)$ & 67.7 \\
\hline $10 / 1918$ & 63.7 & $77.9\left(23^{r d}\right)$ & $75.9\left(29^{\text {th }}\right)$ \\
\hline $11 / 1918$ & $65.1\left(22^{n d}\right)$ & $74.1\left(22^{n d}\right)$ & 74.9 \\
\hline $12 / 1918$ & - & $76.1\left(20^{\text {th }}\right)$ & 74.1 \\
\hline 1/1919 & $69.2\left(25^{\text {th }}\right)$ & $84.5\left(29^{\text {th }}\right)$ & 79.2 \\
\hline 2/1919 & $65.1\left(25^{\text {th }}\right)$ & $85.4\left(21^{s t}\right)$ & 81.0 \\
\hline $3 / 1919$ & 69.7 & - & 82.9 \\
\hline 4/1919 & $71.1\left(26^{\text {th }}\right)$ & 81.5 & 80.1 \\
\hline $5 / 1919$ & $72.7\left(8^{\text {th }}\right)$ & 84.1 & $81.1\left(29^{\text {th }}\right)$ \\
\hline $6 / 1919$ & $71.0\left(27^{\text {th }}\right)$ & $84.1\left(23^{r d}\right)$ & 81.4 \\
\hline 7/1919 & $71.1\left(11^{\text {th }}\right)$ & 87.2 & $80.0\left(28^{\text {th }}\right)$ \\
\hline 8/1919 & $70.5\left(27^{\text {th }}\right)$ & $88.2\left(26^{\text {th }}\right)$ & $80.7\left(19^{\text {th }}\right)$ \\
\hline 9/1919 & $70.7\left(4^{\text {th }}\right)$ & 83.7 & $74.5\left(25^{\text {th }}\right)$ \\
\hline $10 / 1919$ & $66.9\left(29^{\text {th }}\right)$ & $86.4\left(30^{\text {th }}\right)$ & 69.9 \\
\hline $11 / 1919$ & $62.0\left(28^{t h}\right)$ & 84.5 & $66.0\left(28^{t h}\right)$ \\
\hline $12 / 1919$ & $55.5\left(29^{t h}\right)$ & $80.6\left(29^{t h}\right)$ & $63.9\left(29^{t h}\right)$ \\
\hline
\end{tabular}

Sources: Cf. Chapter II. 
Table A.7: Monthly prices on selected neutral countries' bonds (1914-1919)

\begin{tabular}{|c|c|c|c|c|}
\hline $\begin{array}{l}\text { Month/ } \\
\text { Year }\end{array}$ & $\begin{array}{c}\text { Dutch } 3.0 \% \\
\text { NWS }\end{array}$ & $\begin{array}{c}\text { Finnish } 3.5 \% \\
1889\end{array}$ & $\begin{array}{c}\text { Swedish } 3.5 \% \\
1890\end{array}$ & Swiss $3.5 \%$ \\
\hline $1 / 1914$ & 78.1 & 81.0 & 86.2 & 87.0 \\
\hline $2 / 1914$ & 77.8 & - & 87.7 & 85.2 \\
\hline $3 / 1914$ & 77.7 & 78.2 & 83.7 & 86.2 \\
\hline 4/1914 & 77.7 & 78.5 & 83.7 & 85.0 \\
\hline $5 / 1914$ & 77.4 & 78.5 & 83.7 & 86.7 \\
\hline 6/1914 & 77.5 & - & 84.0 & 84.5 \\
\hline $7 / 1914$ & 76.8 & - & $84.0\left(27^{\text {th }}\right)$ & $88.5\left(27^{\text {th }}\right)$ \\
\hline$\ldots$ & - & - & - & - \\
\hline$\ldots$ & - & - & - & - \\
\hline$\ldots$ & - & - & - & - \\
\hline$\ldots$ & - & - & - & - \\
\hline$\ldots$ & - & - & - & - \\
\hline$\ldots$ & - & - & - & - \\
\hline $2 / 1915$ & - & - & - & - \\
\hline $3 / 1915$ & - & - & - & - \\
\hline $4 / 1915$ & 71.5 & - & - & - \\
\hline $5 / 1915$ & 72.1 & - & - & - \\
\hline $6 / 1915$ & 72.2 & - & - & - \\
\hline $7 / 1915$ & 75.0 & - & - & - \\
\hline $8 / 1915$ & 75.5 & - & $74.0\left(19^{\text {th }}\right)$ & - \\
\hline 9/1915 & 75.2 & - & 74.0 & - \\
\hline $10 / 1915$ & 70.7 & - & - & - \\
\hline $11 / 1915$ & 70.0 & - & 72.7 & - \\
\hline $12 / 1915$ & 67.1 & - & 70.0 & 63.0 \\
\hline $1 / 1916$ & 69.2 & - & $67.5\left(29^{t h}\right)$ & $63.0\left(29^{t h}\right)$ \\
\hline $2 / 1916$ & 69.8 & - & 67.5 & - \\
\hline $3 / 1916$ & 70.7 & - & 68.0 & 67.0 \\
\hline $4 / 1916$ & 71.0 & - & 68.2 & 69.0 \\
\hline $5 / 1916$ & 72.5 & - & $71.0\left(30^{t h}\right)$ & $71.7\left(30^{t h}\right)$ \\
\hline $6 / 1916$ & 72.8 & - & $71.0\left(29^{\text {th }}\right)$ & $74.0\left(29^{\text {th }}\right)$ \\
\hline 7/1916 & 73.0 & - & $71.0\left(1^{s t}\right)$ & 74.0 \\
\hline $8 / 1916$ & 75.2 & - & 75.0 & 74.0 \\
\hline $9 / 1916$ & 75.9 & - & 75.0 & 76.0 \\
\hline 10/1916 & 76.5 & - & $75.0\left(2^{n d}\right)$ & $76.5\left(28^{\text {th }}\right)$ \\
\hline 11/1916 & 76.7 & - & - & 76.5 \\
\hline $12 / 1916$ & 74.5 & - & - & - \\
\hline $1 / 1917$ & 74.7 & $38.0\left(8^{t h}\right)$ & - & - \\
\hline $2 / 1917$ & 73.7 & $42.5\left(26^{\text {th }}\right)$ & $76.0\left(26^{\text {th }}\right)$ & - \\
\hline $3 / 1917$ & 71.1 & $47.0\left(13^{\text {th }}\right)$ & - & - \\
\hline $4 / 1917$ & 70.7 & $46.5\left(21^{s t}\right)$ & - & $76.0\left(17^{t h}\right)$ \\
\hline $5 / 1917$ & 73.4 & $49.2\left(25^{\text {th }}\right)$ & $73.5\left(12^{\text {th }}\right)$ & - \\
\hline $6 / 1917$ & 73.5 & $51.0\left(19^{\text {th }}\right)$ & - & - \\
\hline $7 / 1917$ & 72.4 & - & $80.0\left(30^{\text {th }}\right)$ & $75.0\left(19^{t h}\right)$ \\
\hline $8 / 1917$ & $73.0\left(30^{\text {th }}\right)$ & -* $^{*}$ & - & - \\
\hline 9/1917 & 72.0 & - & 85.0 & - \\
\hline $10 / 1917$ & 72.0 & - & $91.0\left(30^{\text {th }}\right)$ & - \\
\hline 11/1917 & 71.5 & - & $83.0\left(29^{t h}\right)$ & - \\
\hline
\end{tabular}


Table A.7 continued

\begin{tabular}{|c|c|c|c|c|}
\hline $\begin{array}{l}\text { Month/ } \\
\text { Year }\end{array}$ & $\begin{array}{c}\text { Dutch } 3.0 \% \\
\text { NWS }\end{array}$ & $\begin{array}{c}\text { Finnish } 3.5 \% \\
1889\end{array}$ & $\begin{array}{c}\text { Swedish } 3.5 \% \\
1890\end{array}$ & Swiss $3.5 \%$ \\
\hline $12 / 1917$ & 69.8 & - & 73.0 & - \\
\hline $1 / 1918$ & 67.9 & - & $73.2\left(10^{t h}\right)$ & - \\
\hline $2 / 1918$ & 69.5 & $35.0\left(26^{\text {th }}\right)$ & - & - \\
\hline $3 / 1918$ & 67.9 & $47.0\left(25^{\text {th }}\right)$ & $72.7\left(12^{\text {th }}\right)$ & - \\
\hline $4 / 1918$ & 67.1 & - & $68.0\left(22^{n d}\right)$ & - \\
\hline $5 / 1918$ & 68.7 & - & $62.0\left(22^{n d}\right)$ & $71.0\left(29^{t h}\right)$ \\
\hline $6 / 1918$ & 69.0 & 35.1 & - & - \\
\hline 7/1918 & 66.4 & $45.0\left(17^{\text {th }}\right)$ & - & - \\
\hline $8 / 1918$ & 67.8 & - & - & $69.0\left(8^{t h}\right)$ \\
\hline $9 / 1918$ & 67.2 & - & - & - \\
\hline $10 / 1918$ & 63.4 & $46.0\left(30^{\text {th }}\right)$ & - & - \\
\hline $11 / 1918$ & 64.0 & - & - & - \\
\hline $12 / 1918$ & 64.7 & $42.0\left(17^{\text {th }}\right)$ & - & - \\
\hline $1 / 1919$ & 63.2 & $42.5\left(27^{t h}\right)$ & $59.0\left(29^{t h}\right)$ & - \\
\hline $2 / 1919$ & 63.2 & - & - & - \\
\hline $3 / 1919$ & 61.9 & - & - & - \\
\hline $4 / 1919$ & 62.1 & - & $60.0\left(2^{\text {nd }}\right)$ & - \\
\hline $5 / 1919$ & 62.2 & - & - & $66.0\left(6^{\text {th }}\right)$ \\
\hline $6 / 1919$ & 59.5 & - & - & - \\
\hline 7/1919 & 59.9 & - & - & - \\
\hline $8 / 1919$ & $61.0\left(29^{t h}\right)$ & - & - & - \\
\hline 9/1919 & 60.4 & - & - & - \\
\hline $10 / 1919$ & 58.7 & - & $63.5\left(27^{t h}\right)$ & - \\
\hline $11 / 1919$ & 57.9 & - & $60.0\left(19^{t h}\right)$ & $64.0\left(17^{\text {th }}\right)$ \\
\hline $12 / 1919$ & $52.0\left(29^{t h}\right)$ & - & - & $63.7\left(10^{\text {th }}\right)$ \\
\hline
\end{tabular}

Sources: Cf Chapter II. 


\subsection{Selected monthly exchange rates in tabular form}

Tables A.8 displays five important exchange rates which were reported in the newspapers, namely the guilder-to-mark, guilder-to-pound, guilder-to-(French)franc, guilder-to-dollar, and guilder-to-(Austrian)kroner exchange rates. In line with the procedure in Appendix 1.5, values in normal print refer to the last trading day of the month. Values in italic print do not refer due to lacking observations - to the last trading day but fall on a day within the preceding six trading days. 
Table A.8: Exchange rates of Dutch guilder to main currencies (1914-1919)

\begin{tabular}{|c|c|c|c|c|c|}
\hline $\begin{array}{l}\text { Month/ } \\
\text { Year }\end{array}$ & Guilder to mark & $\begin{array}{l}\text { Guilder to } \\
\text { pound }\end{array}$ & Guilder to franc & $\begin{array}{l}\text { Guilder to dol- } \\
\text { lar }\end{array}$ & $\begin{array}{l}\text { Guilder to kro- } \\
\text { ner }\end{array}$ \\
\hline $2 / 1914$ & 59.03 & 12.07 & 47.86 & 2.48 & 50.18 \\
\hline $3 / 1914$ & 59.09 & 12.08 & 47.99 & 2.48 & 50.27 \\
\hline $4 / 1914$ & 59.01 & 12.09 & 48.08 & 2.48 & 50.18 \\
\hline $5 / 1914$ & 59.15 & 12.12 & 48.15 & 2.48 & 50.22 \\
\hline $6 / 1914$ & 59.12 & 12.12 & 48.16 & 2.47 & 50.14 \\
\hline $7 / 1914$ & 59.15 & 12.16 & 49.40 & 2.45 & 47.00 \\
\hline $8 / 1914$ & 58.00 & 12.40 & 50.00 & 2.43 & 49.00 \\
\hline $9 / 1914$ & 54.85 & 12.04 & 48.00 & 2.41 & 46.00 \\
\hline 10/1914 & 53.90 & 11.97 & 47.60 & 2.44 & 43.50 \\
\hline $11 / 1914$ & 52.70 & 12.04 & 48.25 & 2.45 & 41.90 \\
\hline $12 / 1914$ & 54.25 & 11.99 & 47.85 & 2.46 & 42.80 \\
\hline $1 / 1915$ & 54.12 & 12.05 & 47.95 & 2.48 & 42.25 \\
\hline $2 / 1915$ & 51.30 & 12.03 & 47.40 & 2.50 & 39.50 \\
\hline $3 / 1915$ & 51.97 & 12.17 & 47.75 & 2.52 & 38.85 \\
\hline $4 / 1915$ & 51.95 & 12.13 & 47.60 & - & 38.85 \\
\hline $5 / 1915$ & 51.60 & 12.01 & 46.22 & - & 38.20 \\
\hline $6 / 1915$ & 50.70 & 11.95 & 44.60 & - & 37.85 \\
\hline $7 / 1915$ & 50.42 & 11.81 & 43.80 & - & 37.25 \\
\hline $8 / 1915$ & 50.42 & 11.62 & 42.10 & - & 37.15 \\
\hline $9 / 1915$ & 50.65 & 11.53 & 42.25 & - & 36.20 \\
\hline $10 / 1915$ & 48.92 & 11.15 & 40.40 & - & 34.55 \\
\hline $11 / 1915$ & 47.05 & 11.25 & 40.92 & - & 33.10 \\
\hline $12 / 1915$ & 42.35 & 10.79 & 38.75 & - & 29.90 \\
\hline $1 / 1916$ & 43.15 & 11.26 & 40.20 & - & 28.65 \\
\hline $2 / 1916$ & 42.32 & 11.21 & 40.05 & - & 29.75 \\
\hline $3 / 1916$ & 41.70 & 11.18 & 39.20 & - & 28.85 \\
\hline $4 / 1916$ & 44.20 & 11.38 & 40.25 & - & 30.60 \\
\hline $5 / 1916$ & 44.62 & 11.49 & 40.82 & - & 31.15 \\
\hline $6 / 1916$ & 43.77 & 11.49 & 40.85 & - & 30.40 \\
\hline 7/1916 & 43.17 & 11.51 & 40.95 & - & 29.95 \\
\hline $8 / 1916$ & 42.60 & 11.61 & 41.45 & - & 29.40 \\
\hline $9 / 1916$ & 42.52 & 11.66 & 41.87 & - & 29.00 \\
\hline 10/1916 & 42.50 & 11.62 & 41.85 & - & 27.60 \\
\hline $11 / 1916$ & 40.15 & 11.67 & 42.00 & - & 25.15 \\
\hline $12 / 1916$ & 41.20 & 11.68 & 42.10 & - & 25.75 \\
\hline $1 / 1917$ & 41.37 & 11.70 & 42.07 & - & 26.67 \\
\hline $2 / 1917$ & 40.55 & 11.80 & 42.40 & - & 25.25 \\
\hline $3 / 1917$ & 38.92 & 11.76 & 42.35 & - & 24.52 \\
\hline $4 / 1917$ & 37.65 & 11.64 & 42.82 & - & 23.60 \\
\hline $5 / 1917$ & 36.47 & 11.59 & 42.65 & - & 23.45 \\
\hline $6 / 1917$ & 34.75 & 11.57 & 42.35 & - & 21.90 \\
\hline $7 / 1917$ & 33.75 & 11.44 & 41.80 & - & 21.60 \\
\hline $8 / 1917$ & 33.17 & 11.33 & 42.25 & - & 21.15 \\
\hline 9/1917 & 32.80 & 11.31 & 40.92 & - & 20.85 \\
\hline 10/1917 & 32.55 & 10.91 & 39.75 & - & 20.65 \\
\hline 11/1917 & 36.10 & 11.00 & 40.55 & - & 22.20 \\
\hline
\end{tabular}


Table A. 8 continued

\begin{tabular}{|c|c|c|c|c|c|}
\hline $\begin{array}{l}\text { Month/ } \\
\text { Year }\end{array}$ & Guilder to mark & $\begin{array}{l}\text { Guilder to } \\
\text { pound }\end{array}$ & Guilder to franc & $\begin{array}{l}\text { Guilder to dol- } \\
\text { lar }\end{array}$ & $\begin{array}{c}\text { Guilder to kro- } \\
\text { ner }\end{array}$ \\
\hline $12 / 1917$ & 45.30 & 11.00 & 40.75 & - & 27.32 \\
\hline $1 / 1918$ & 42.10 & 10.90 & 40.25 & - & 27.15 \\
\hline 2/1918 & 43.52 & 10.61 & 38.75 & - & 28.70 \\
\hline $3 / 1918$ & 42.60 & 10.22 & 37.75 & - & 27.45 \\
\hline $4 / 1918$ & 40.69 & 9.88 & 36.15 & - & 26.15 \\
\hline $5 / 1918$ & 38.97 & 9.47 & 35.00 & - & 24.00 \\
\hline $6 / 1918$ & 34.25 & 9.34 & 34.42 & - & 20.40 \\
\hline $7 / 1918$ & 32.80 & 9.14 & 33.75 & - & 18.95 \\
\hline 8/1918 & 31.22 & 9.33 & 35.95 & - & 17.50 \\
\hline $9 / 1918$ & 32.05 & 10.11 & 38.75 & - & 17.65 \\
\hline $10 / 1918$ & 34.60 & 11.25 & 43.12 & - & 18.60 \\
\hline $11 / 1918$ & 30.25 & 11.33 & 43.55 & - & 15.75 \\
\hline $12 / 1918$ & 30.00 & 11.15 & 42.90 & - & 15.15 \\
\hline $1 / 1919$ & 28.15 & 11.50 & 44.30 & - & 14.20 \\
\hline 2/1919 & 24.27 & 11.57 & 44.35 & - & 11.55 \\
\hline $3 / 1919$ & 22.50 & 11.47 & 41.60 & - & 9.00 \\
\hline 4/1919 & 21.97 & 11.65 & 41.40 & - & 10.50 \\
\hline $5 / 1919$ & 18.40 & 11.87 & 41.00 & - & 10.40 \\
\hline $6 / 1919$ & 18.50 & 11.83 & 39.95 & - & 9.25 \\
\hline 7/1919 & 14.45 & 11.58 & 36.45 & - & 6.50 \\
\hline $8 / 1919$ & 12.20 & 11.32 & 33.50 & - & 5.70 \\
\hline $9 / 1919$ & 12.40 & 11.19 & 33.75 & - & 4.20 \\
\hline $10 / 1919$ & 8.45 & 11.02 & 29.70 & - & 2.50 \\
\hline $11 / 1919$ & 6.10 & 10.57 & 27.02 & - & 1.85 \\
\hline $12 / 1919$ & 5.50 & 10.18 & 24.90 & - & 1.52 \\
\hline
\end{tabular}

Sources: Cf. Chapter II. 


\subsection{The monthly prolongatie koers in tabular form}

Tables A.9 reports on the so-called prolongatie koers, the most important short-term interest rate in the Dutch market. As this interest rate was very volatile, under peace and war conditions alike, I decided to display the monthly median prolongatie koers instead of the rate for the last trading day. Not that the rates are rounded to one decimal place.

Table A.9: A monthly prolongatie koers series (1914-1919)

\begin{tabular}{|c|c|c|c|}
\hline Month & prolongatie koers & Month & prolongatie koers \\
\hline $1 / 1914$ & $4.4 \%$ & $1 / 1917$ & $2.7 \%$ \\
\hline $2 / 1914$ & $4.4 \%$ & $2 / 1917$ & $4.2 \%$ \\
\hline $3 / 1914$ & $3.6 \%$ & $3 / 1917$ & $2.9 \%$ \\
\hline $4 / 1914$ & $3.7 \%$ & $4 / 1917$ & $2.7 \%$ \\
\hline $5 / 1914$ & $2.9 \%$ & $5 / 1917$ & $2.2 \%$ \\
\hline $6 / 1914$ & $3.1 \%$ & 6/1917 & $2.7 \%$ \\
\hline $7 / 1914$ & $3.1 \%$ & $7 / 1917$ & $3.0 \%$ \\
\hline$\ldots$ & - & 8/1917 & $2.2 \%$ \\
\hline$\ldots$ & - & $9 / 1917$ & $2.5 \%$ \\
\hline$\ldots$ & - & $10 / 1917$ & $2.5 \%$ \\
\hline$\ldots$ & - & $11 / 1917$ & $4.0 \%$ \\
\hline$\ldots$ & - & $12 / 1917$ & $4.7 \%$ \\
\hline$\ldots$ & - & $1 / 1918$ & $3.7 \%$ \\
\hline $2 / 1915$ & $5.0 \%$ & 2/1918 & $4.2 \%$ \\
\hline $3 / 1915$ & $4.6 \%$ & $3 / 1918$ & $4.3 \%$ \\
\hline $4 / 1915$ & $4.5 \%$ & $4 / 1918$ & $4.2 \%$ \\
\hline $5 / 1915$ & $4.0 \%$ & $5 / 1918$ & $3.5 \%$ \\
\hline $6 / 1915$ & $3.5 \%$ & $6 / 1918$ & $3.2 \%$ \\
\hline $7 / 1915$ & $2.7 \%$ & 7/1918 & $3.0 \%$ \\
\hline $8 / 1915$ & $2.5 \%$ & 8/1918 & $2.5 \%$ \\
\hline $9 / 1915$ & $3.1 \%$ & $9 / 1918$ & $2.7 \%$ \\
\hline $10 / 1915$ & $3.1 \%$ & $10 / 1918$ & $3.7 \%$ \\
\hline $11 / 1915$ & $3.5 \%$ & $11 / 1918$ & $4.0 \%$ \\
\hline $12 / 1915$ & $3.2 \%$ & $12 / 1918$ & $3.7 \%$ \\
\hline 1/1916 & $2.2 \%$ & 1/1919 & $3.2 \%$ \\
\hline 2/1916 & $2.2 \%$ & 2/1919 & $3.7 \%$ \\
\hline $3 / 1916$ & $2.2 \%$ & $3 / 1919$ & $4.0 \%$ \\
\hline 4/1916 & $4.0 \%$ & 4/1919 & $4.2 \%$ \\
\hline $5 / 1916$ & $3.6 \%$ & $5 / 1919$ & $3.2 \%$ \\
\hline $6 / 1916$ & $2.5 \%$ & $6 / 1919$ & $3.0 \%$ \\
\hline 7/1916 & $2.4 \%$ & 7/1919 & $3.7 \%$ \\
\hline 8/1916 & $1.7 \%$ & 8/1919 & $4.5 \%$ \\
\hline 9/1916 & $1.5 \%$ & 9/1919 & $4.0 \%$ \\
\hline $10 / 1916$ & $2.5 \%$ & $10 / 1919$ & $4.5 \%$ \\
\hline $11 / 1916$ & $2.7 \%$ & $11 / 1919$ & $4.2 \%$ \\
\hline $12 / 1916$ & $4.0 \%$ & $12 / 1919$ & $4.7 \%$ \\
\hline
\end{tabular}

Sources: Cf. Chapter II. 


\section{Technical Appendix}

\subsection{Structural break methodology}

The procedure developed by Jushan Bai and Pierre Perron (1998, 2003a, 2003b, 2006) to detect structural breaks in a time series starts from the following general formulation with $m$ possible breaks and, thus, $m+1$ regimes - that is, periods between the breaks:

$$
y_{t}=\beta_{j} *_{z}{ }_{t}+u_{t}, t=T_{j-1}+1, \ldots, T_{j}, j=1, \ldots, m+1,
$$

with $t$ denoting the time index, $y$ denoting the dependent variable, $z$ denoting the vector of explanatory variables, $\beta_{j}$ denoting the coefficients to be estimated with least squares, and $u$ denoting the error term. The $T_{j}$ 's are the unknown breakpoints to be estimated without a priori knowledge of their location. The Bai-Perron-method allows for up to ten breakpoints to be estimated over a number of $T$ observations. The principle appeal of the procedure lies in the fact that breakpoints and coefficients on the explanatory variables possibly included are estimated simultaneously. Estimating (A.1) with least squares labels under the implicit assumption that the errors, $u$, may be distributed with different variance over the $m+1$ regimes, but that any break in the variance falls on the same date as a breakpoint, $T_{j}$.

In determining the number of breaks and their location, one can basically follow two strategies. The first strategy is called "global maximization". This procedure chooses the optimal number of breaks over the whole range of the data such that the sums-of squaredresiduals is minimized. If the number of breakpoints is pre-specified, the sums-of-squared residuals is minimized by choosing the optimal location of the breaks. If the number of breakpoints is left unspecified, a number of alternative tests may be applied to determine their number and location. The second strategy is a "sequential determination" of breaks where breakpoint tests are applied sequentially on subsets of the data. This procedure somewhat seems to resemble the approach of the slightly older method of Anindya Banerjee et al. (1992).

In this study, the sequential test of $l+1$ versus $l$ breaks is applied where the number of potential breaks $l$ is increased one by one until the null of $l$ breaks cannot be rejected any longer. While the first test on one breakpoint vs. none is performed for the whole range of data, tests for two breakpoints versus one, three breakpoints versus two and so forth are performed for subsamples until the whole range of data is screened and/or the number of ten 
breaks is reached. Technically, a sup $F_{T}(l+1 \mid l)$ test is performed for each subsample. The optimal number of breaks, $l$, is found when the sums-of-squared residuals for the $l+1$ specification is lower than for the $l$ breaks specification. Identification of the optimal number of breaks critically depends on the so-called trimming parameter, that is, the number of observations cut at the beginning and at the end of the series. It is expressed as a proportion of $T$, namely as $\varepsilon=0.05,0.10,0.15,0.20$, or. 0.25 . Using $\varepsilon=0.05$, for example, on $T=1000$ days means that the first breakpoint is allowed to occur, at the earliest, on day 51 (and the last break on day 950). In addition, the trimming parameter determines the minimum segment length between any two breaks.

The Bai-Perron-method is very flexible in that it allows the errors as well as the regressors to follow different distributions within the $m+1$ regimes. Furthermore, it is possible to correct standard errors for serial correlation and heteroscedasticity. 
2.2. Unit root tests on bond yields and additional variables

Table A.10 displays the result of a Dickey-Fuller Generalized Least Squares (DFGLS) unit root test for the series used in the analysis in Chapter III. The test is performed on the war period and on the combined war and immediate post-war period. 
Table A.10: DFGLS test on bond yields

\begin{tabular}{|c|c|c|c|c|}
\hline \multirow[t]{2}{*}{ Country and bond } & \multicolumn{2}{|c|}{ War period } & \multicolumn{2}{|c|}{ War and post-war } \\
\hline & $\begin{array}{l}\mathrm{H} 1 \text { :stationary } \\
\text { around trend }\end{array}$ & $\begin{array}{l}\text { H1: Stationary } \\
\text { around mean }\end{array}$ & $\begin{array}{l}\mathrm{H} 1 \text { :stationary } \\
\text { around trend }\end{array}$ & $\begin{array}{l}\text { H1: Stationary } \\
\text { around mean }\end{array}$ \\
\hline \multicolumn{5}{|l|}{ A. Bond yields } \\
\hline Austrian $4.0 \%$ & $-2.90(18)^{* *}$ & $-0.05(21)$ & $-0.12(23)$ & $6.06(18)$ \\
\hline Bulgarian $5.0 \%$ & $-3.09(22)^{* *}$ & $-0.94(19)$ & $-1.76(23)^{\mathrm{a}}$ & $0.58(23)$ \\
\hline German $3.0 \%$ & $-2.29(22)^{* *}$ & $-0.44(22)$ & $-0.17(16)$ & $3.23(18)$ \\
\hline Ottoman $4.0 \%$ & $-3.14(13)^{* *}$ & $-2.88(13)^{* * *}$ & $-3.14(13)^{* *}$ & $-1.84(23)^{*}$ \\
\hline English $5.0 \%$ & $-2.30(20)$ & $-1.02(11)$ & $-1.83(18)$ & $-0.51(18)$ \\
\hline French $5.0 \%$ & $-1.32(15)$ & $-0.98(15)$ & $-0.92(6)$ & $1.15(6)$ \\
\hline Italian $3.5 \%$ & $-2.54(11)^{b}$ & $-0.76(11)$ & $-2.34(11)$ & $-1.43(11)$ \\
\hline Romanian $4.0 \%$ & $-0.97(12)$ & $0.06(12)$ & $-0.98(1)^{\mathrm{c}}$ & $-0.71(1)^{\mathrm{c}}$ \\
\hline Russian $4.0 \%$ & $-1.51(19)$ & $-0.49(19)$ & $-1.51(20)$ & $0.84(8)$ \\
\hline Serbian $4.0 \%$ & $-2.35(17)^{\mathrm{a}}$ & $-1.31(17)$ & $-2.26(17)^{\mathrm{a}}$ & $-0.99(17)$ \\
\hline \multicolumn{5}{|l|}{ B. Additional variables } \\
\hline Interest rate & $-2.13(19)^{\mathrm{a}}$ & $-1.47(23)$ & $-2.30(18)^{\mathrm{a}}$ & $-1.88(18)^{\mathrm{a}}$ \\
\hline Market liquidity & $-1.92(23)^{\mathrm{a}}$ & $0.21(21)$ & $-2.00(21)^{\mathrm{a}}$ & $-0.50(21)^{\mathrm{a}}$ \\
\hline Guilder-mark exch. rate & $-2.54(23)^{*}$ & $0.23(23)$ & $-1.43(24)$ & $1.98(24)$ \\
\hline Guilder-pound exch. Rate & $-1.65(15)$ & $-1.02(15)$ & $-1.88(15)$ & $-0.65(15)$ \\
\hline Guilder-franc exch. Rate & $-0.93(17)$ & $-0.65(17)$ & $-1.20(23)$ & $1.40(23)$ \\
\hline Guilder-kroner exch. Rate & $-1.79(23)$ & $0.99(23)$ & $-1.73(23)$ & $2.46(23)$ \\
\hline Guilder-rouble exch. rate & $-2.83(23)^{* *}$ & $0.08(23)$ & $-2.99(23)^{* *}$ & $0.93(23)$ \\
\hline Municipal bond index & $-0.90(20)$ & $-0.93(20)$ & $-0.06(11)$ & $0.64(11)$ \\
\hline Share index & $-0.41(14)$ & $0.66(14)$ & $-0.68(20)$ & $1.11(20)$ \\
\hline Inflation guilder & $-10.7(20)^{* * *}$ & $-10.0(20)^{* * *}$ & $-12.0(20)^{* * *}$ & $-11.7(20)^{* * *}$ \\
\hline Inflation mark & $-11.4(23)^{* * *}$ & $-9.95(22)^{* * *}$ & $-13.5(14)^{* * *}$ & $-12.2(14)^{* * *}$ \\
\hline Inflation pound & $-16.5(7)^{* * *}$ & $-15.8(7)^{* * *}$ & $-18.2(7)^{* * *}$ & $-11.8(13)^{* * *}$ \\
\hline Inflation franc & $-7.10(20)^{* * *}$ & $-5.78(20)^{* * *}$ & $-7.12(20)^{* * *}$ & $-6.78(20)^{* * *}$ \\
\hline Inflation rouble & $-4.61(23) * * *$ & $-4.02(23) * * *$ & $-4.93(23)^{* * *}$ & $-4.02(23)^{* * *}$ \\
\hline
\end{tabular}

Notes: $* * *, * *, *$ denote significance on the one-, five- and ten-percent levels. Optimal truncation lags according to Ng-Perron sequential $t$ in parentheses. ${ }^{a}$ Stationary for lower lag number. ${ }^{b}$ Stationary for higher lag number. ${ }^{c}$ According the NG-Perron sequential $t$, the optimal lag order is zero; however, given is the test statistic for lag order one.

Sources: Author's own calculations. 
2.3. Pairwise correlations among representative bonds

Table A.11 reports the pairwise zero-order correlation coefficients for the correlation between the original raw yield series - that is, the series with gaps. The dark grey-shaded fields mark the correlations between bonds the issuers of which belonged to the same faction. The light grey-shaded fields mark the correlations across factions. 
Table A.11: Within- and cross-alliance correlations of representative bonds (raw yields)

\begin{tabular}{lllllllllllllllll}
\hline Country & AUT & GER & TUR & BUL & SER & RUS & FRA & ENG & JAP & ITA & POR & ROM & CUB & CHN & BRA & NIC \\
\hline Austria & 1.00 & .97 & .78 & .88 & .48 & .67 & .53 & .22 & -.05 & .15 & .45 & .93 & -.00 & .25 & .02 & .09 \\
Germany & .97 & 1.00 & .63 & .88 & .35 & .75 & .12 & -.05 & .01 & -.09 & .31 & .94 & .07 & .24 & -.00 & .05 \\
Ottoman Empire & .78 & .63 & 1.00 & .49 & .76 & .49 & .88 & .65 & .16 & .71 & .63 & -.23 & .13 & .44 & .22 & -.55 \\
Bulgaria & .88 & .88 & .49 & 1.00 & .53 & .73 & .59 & .34 & .05 & .62 & .47 & .94 & .03 & .46 & .03 & .06 \\
Serbia & .48 & .35 & .76 & .53 & 1.00 & .61 & .83 & .77 & .37 & .81 & .69 & .58 & .23 & .46 & .48 & .10 \\
Russia & .67 & .75 & .49 & .73 & .61 & 1.00 & .66 & .59 & .22 & .72 & .28 & .83 & .27 & .48 & -.01 & .29 \\
France & .53 & .12 & .88 & .59 & .83 & .66 & 1.00 & .73 & .39 & .96 & .63 & .55 & .34 & .50 & .42 & .29 \\
England & .22 & -.05 & .65 & .34 & .77 & .59 & .73 & 1.00 & .66 & .94 & .74 & .98 & .30 & .84 & .71 & .70 \\
Japan & -.05 & .01 & .16 & .05 & .37 & .22 & .39 & .66 & 1.00 & .89 & .01 & -.42 & .40 & .10 & .56 & .17 \\
Italy & .15 & -.09 & .71 & .62 & .81 & .72 & .96 & .94 & .89 & 1.00 & .70 & $\mathrm{n} / \mathrm{a}$ & .83 & .84 & .56 & -.14 \\
Portugal & .45 & .31 & .63 & .47 & .69 & .28 & .63 & .74 & .01 & .70 & 1.00 & .56 & .04 & .63 & .44 & -.70 \\
Romania & .93 & .94 & -.23 & .94 & .58 & .83 & .55 & .98 & -.42 & $\mathrm{n} / \mathrm{a}$ & .56 & 1.00 & -.20 & .22 & .13 & .50 \\
Cuba &. .00 & .07 & .13 & .03 & .23 & .27 & .34 & .30 & .40 & .83 & .04 & -.20 & 1.00 & .25 & .01 & -.32 \\
China & .25 & .24 & .44 & .46 & .46 & .48 & .50 & .84 & .10 & .84 & .63 & .22 & .25 & 1.00 & .25 & -.27 \\
Brazil & .02 & -.00 & .22 & .03 & .48 & -.01 & .42 & .71 & .56 & .56 & .44 & .13 & .01 & .25 & 1.00 & .12 \\
Nicaragua & .09 & .05 & -.55 & .06 & .10 & .29 & .29 & .70 & .17 & -.14 & -.70 & .50 & -.32 & -.27 & .12 & 1.00 \\
\hline
\end{tabular}

Sources: Author's own calculations. 


\subsection{An alternative DFGLS test on step one}

This alternative test on step 1 merges the war and post-war periods. The results on the pre-war period are the same as displayed in Table 38.

Table A.12: Alternative DFGLS unit root test on representative bonds' yield spread

\begin{tabular}{|c|c|c|c|c|}
\hline \multirow[t]{2}{*}{ Country and bond } & \multicolumn{2}{|c|}{ Pre-war } & \multicolumn{2}{|c|}{ War and post-war } \\
\hline & $\begin{array}{l}\mathrm{H} 1 \text { :stationary } \\
\text { around trend }\end{array}$ & $\begin{array}{l}\text { H1: Stationary } \\
\text { around mean }\end{array}$ & $\begin{array}{l}\mathrm{H} 1 \text { :stationary } \\
\text { around trend }\end{array}$ & $\begin{array}{l}\mathrm{H} 1 \text { : Stationary } \\
\text { around mean }\end{array}$ \\
\hline \multicolumn{5}{|l|}{ A. Central Powers } \\
\hline Austrian $4.0 \%$ & $-0.35(12)$ & $1.37(12)$ & $-0.98(23)$ & $5.91(18)$ \\
\hline Bulgarian $5.0 \%$ & $-1.84(3)$ & $-1.79(3)$ & $-4.57 * * *(14)$ & $-1.49(23)$ \\
\hline German $3.0 \%$ & $-1.24(10)$ & $-0.79(10)$ & $0.17(23)$ & $3.49(23)$ \\
\hline Ottoman $4.0 \%$ & $-1.83(11)$ & $-0.61(11)$ & $-4.22 * * *(22)$ & $-5.28 * * *(22)$ \\
\hline \multicolumn{5}{|l|}{ B. Allied Powers } \\
\hline Brazilian $5.0 \%$ & - & - & $-0.28(22)$ & $3.51(22)$ \\
\hline Chinese $4.5 \%$ & $-2.45^{* *}(1)^{\mathrm{a}}$ & $-2.39 * *(1)^{\mathrm{a}}$ & $-0.39(11)$ & $-0.17(11)$ \\
\hline Cuban $5.0 \%$ & $-1.99(13)$ & $-0.36(7)$ & $0.32(24)$ & $2.74(24)$ \\
\hline English $5.0 \%$ & $\mathrm{n} / \mathrm{a}$ & $\mathrm{n} / \mathrm{a}$ & $0.28(22)$ & $2.55(22)$ \\
\hline French $5.0 \%$ & $\mathrm{n} / \mathrm{a}$ & $\mathrm{n} / \mathrm{a}$ & $-2.32(11)$ & $-1.77 *(11)$ \\
\hline Italian $3.5 \%$ & $-2.05(2)$ & $-1.99(2)$ & $-1.41(17)$ & $-1.45(17)$ \\
\hline Japanese $5.0 \%$ & $-1.69(8)$ & $-0.54(12)$ & $0.46(23)$ & $3.95(23)$ \\
\hline Nicaraguan $5.0 \%$ & $-1.95(14)$ & $-1.46(14)$ & $-1.39(17)$ & $0.42(2)$ \\
\hline Portuguese $4.5 \%$ & $-1.40(14)$ & $-1.30(14)$ & $-0.57(21)$ & $2.89(20)$ \\
\hline Romanian $4.0 \%$ & $-1.36(13)$ & $-1.06(13)$ & $-3.56^{* * *}(23)$ & $-2.22 * *(23)$ \\
\hline Russian $4.0 \%$ & $-1.56(5)$ & $0.16(5)$ & $-2.75^{*}(8)$ & $0.27(11)$ \\
\hline Serbian $4.0 \%$ & $-0.71(13)$ & $0.13(13)$ & $-2.77 *(18)$ & $-2.59 * * *(18)$ \\
\hline
\end{tabular}

Notes: $* * *, * *, *$ denote significance on the one-, five- and ten-percent levels. Optimal truncation lags according to Ng-Perron sequential $t$ in parentheses. "n/a" is "not available". a According the NG-Perron sequential $t$, the optimal lag order is zero; however, given is the test statistic for lag order one.

Sources: Author's own calculations. 
Cointegration analysis is a convenient statistical approach to examine relationships among nonstationary time series. These are time series which do not have the property of mean reversion - a property that, in fact, many economic variables do not have (cf. Figures 1 and 2 in the main body of my study; the GDP figures "explode", or wander considerably, in the long term). Many regression techniques, however, require time series to have this property. In order to apply standard regression techniques, when dealing with nonstationary time series, time series are often first-differenced, as many time series have the property of being firstdifference stationary. Alternatively, one might call a first-difference stationary time series as being integrated of order one or, simply, I(1). A time series stationary in levels is then $\mathrm{I}(0)$. The basic idea of cointegration is that two (or more) non-stationary time series can still be connected in that they do not drift away too much from each other in the long term. They are said to be in equilibrium. Unit root tests help to determine if a time series is nonstationary. If a unit root is present in the time series, it is nonstationary.

Tables A.13 to A.17 illustrate how going through several statistical steps can determine whether two yield spreads as defined in the analysis in Chapter IV are connected in a long-term equilibrium. Thus, the first step of my testing procedure is to eliminate stationary time series as there can be no long-term equilibrium relationship with a non-stationary time series. The second step makes use of basic pre-tests for two time series likely being cointegrated. In order for being conintegrated, they both have to be (in our case) I(1) or, which is equivalent, be of rank one. If not, at least, one of the two pre-tests says both time yield series are of rank one, I likewise suppose that they cannot be cointegrated. Finally, in the case that both series are of rank one, I estimate Johansen-type vector error correction models to determine the equilibrium relationship. Most basically, a VECM is based (in our case) on a twoequation VAR model with one equation per series. A VAR model explains each series by its own past observations and by past observations of the other yield series. This is why we need an idea of how many lagged observations we have to include in the model. The precise parameters of the statistical relationship are not important for my approach which is why I only depict the parameters of the cointegrating vector. The cointegrating vector can be understood as being the stationary linear combination of the two non-stationary yield series. The vector can be defined in terms of the one or the other series' values. This is reflected in the fact that there are two ways of normalizing the vector's equation. I chose to impose the doublenormalization restriction to work in order for two yield series to be reliably (enough) cointe- 
grated. I also applied additional post-estimation tests for the cointegrating vector's stability. If the vector is indicated to be unstable, I dropped the pair. The tables show the country pairs addressed, the number of lags included in the pre-tests on cointegration in the VECMs, and the decisions made at each step.

Note that the lag order per country pair is specified using the "varsoc" command in STATA. The lag order is chosen according to the Akaike information criterion (AIC) and extended thereupon by one lag, as suggested by the literature. Further note that for each country pair two rows of information are depicted. The upper row is for the model with unrestricted mean, and the second for the model with unrestricted trend. One of these two models should be suggesting a valid cointegrating relationship, meaning that the double-normalization restriction is holding. I chose the model according to a comparison of the AIC (i.e., I chose the model with the lower AIC). This model is given in italics. 
Table A.13: A global test on cointegrated alliance partners - estimation summary for pairs among the Central Powers

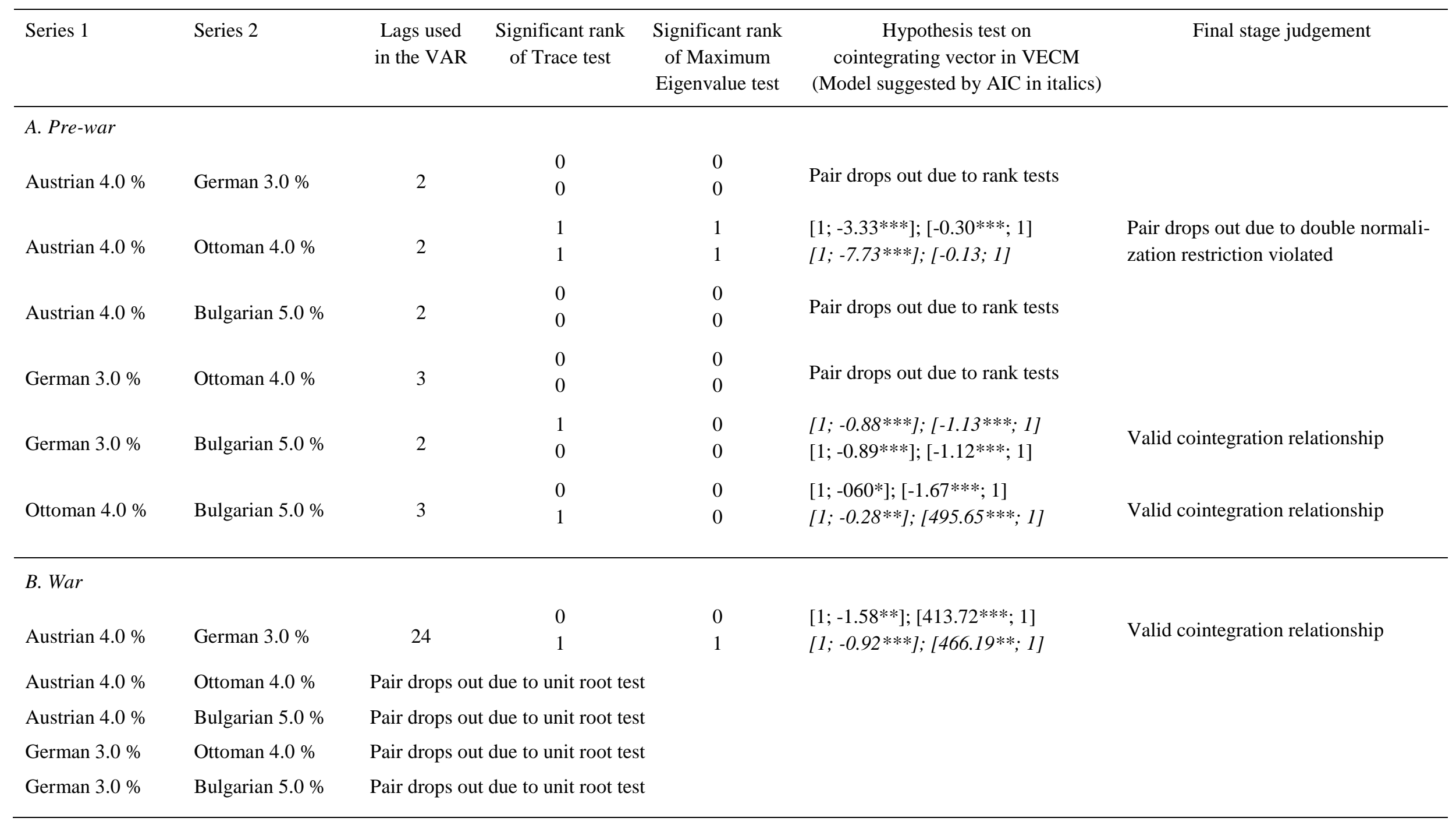


Table A.13 continued

\begin{tabular}{|c|c|c|c|c|c|c|}
\hline Series 1 & Series 2 & $\begin{array}{l}\text { Lags used } \\
\text { in the VAR }\end{array}$ & $\begin{array}{l}\text { Significant rank } \\
\text { of Trace test }\end{array}$ & $\begin{array}{l}\text { Significant rank } \\
\text { of Maximum } \\
\text { Eigenvalue test }\end{array}$ & $\begin{array}{c}\text { Hypothesis test on } \\
\text { cointegrating vector in VECM } \\
\text { (Model suggested by AIC in italics) }\end{array}$ & Final stage judgement \\
\hline Ottoman $4.0 \%$ & Bulgarian $5.0 \%$ & \multicolumn{5}{|c|}{ Pair drops out due to unit root test } \\
\hline \multicolumn{7}{|l|}{ C. Post-war } \\
\hline Austrian $4.0 \%$ & German $3.0 \%$ & 7 & $\begin{array}{l}1 \\
1\end{array}$ & $\begin{array}{l}1 \\
1\end{array}$ & $\begin{array}{l}{[1 ;-3.05 * * *] ;[134.33 * * * ; 1]} \\
{[1 ;-2.63 * * *] ;[-0.38 * * * ; 1]}\end{array}$ & Valid cointegration relationship \\
\hline Austrian $4.0 \%$ & Ottoman $4.0 \%$ & \multicolumn{4}{|c|}{ Pair drops out due to unit root test } & \\
\hline Austrian $4.0 \%$ & Bulgarian $5.0 \%$ & 20 & $\begin{array}{l}1 \\
1\end{array}$ & $\begin{array}{l}1 \\
1\end{array}$ & $\begin{array}{l}{[1 ;-59.38 * * *] ;[-41.12 * * * ; 1]} \\
{[1 ;-71.93 * * *] ;[-0.01 ; 1]}\end{array}$ & $\begin{array}{l}\text { Pair drops out due to double normali- } \\
\text { zation restriction violated }\end{array}$ \\
\hline German $3.0 \%$ & Ottoman $4.0 \%$ & \multicolumn{4}{|c|}{ Pair drops out due to unit root test } & \\
\hline German $3.0 \%$ & Bulgarian $5.0 \%$ & 2 & $\begin{array}{l}0 \\
0\end{array}$ & $\begin{array}{l}0 \\
0\end{array}$ & Pair drops out due to rank tests & \\
\hline Ottoman $4.0 \%$ & Bulgarian $5.0 \%$ & \multicolumn{4}{|c|}{ Pair drops out due to unit root test } & \\
\hline
\end{tabular}

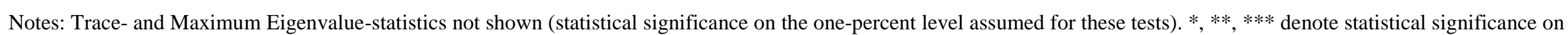
the one-, five-, and ten-per cent levels. 
Table A.14: A global test on cointegrated alliance partners - Estimation summary for pairs involving the major Allied Powers

\begin{tabular}{|c|c|c|c|c|c|c|}
\hline Series 1 & Series 2 & $\begin{array}{l}\text { Lags used } \\
\text { in the VAR }\end{array}$ & $\begin{array}{l}\text { Significant rank } \\
\text { of Trace test }\end{array}$ & $\begin{array}{l}\text { Significant rank } \\
\text { of Maximum } \\
\text { Eigenvalue test }\end{array}$ & $\begin{array}{c}\text { Hypothesis test on } \\
\text { cointegrating vector in VECM } \\
\text { (Model suggested by AIC in italics) }\end{array}$ & Final stage judgement \\
\hline \multicolumn{7}{|l|}{ A. Pre-war } \\
\hline Russian $4.0 \%$ & Serbian $4.0 \%$ & 3 & $\begin{array}{l}1 \\
1\end{array}$ & $\begin{array}{l}1 \\
1\end{array}$ & $\begin{array}{l}{[1 ;-0.72 * * *] ;[-1.39 * * * ; 1]} \\
{[1 ;-0.74 * * *] ;[-1.34 * * * ; 1]}\end{array}$ & Valid cointegration relationship \\
\hline Russian $4.0 \%$ & Italian $3.5 \%$ & 2 & $\begin{array}{l}0 \\
0\end{array}$ & $\begin{array}{l}0 \\
0\end{array}$ & Pair drops out due to rank tests & \\
\hline Russian $4.0 \%$ & Romanian $4.0 \%$ & 3 & $\begin{array}{l}0 \\
0\end{array}$ & $\begin{array}{l}0 \\
0\end{array}$ & Pair drops out due to rank tests & \\
\hline Russian $4.0 \%$ & Portuguese $4.5 \%$ & 3 & $\begin{array}{l}0 \\
0\end{array}$ & $\begin{array}{l}0 \\
0\end{array}$ & Pair drops out due to rank tests & \\
\hline Russian $4.0 \%$ & Japanese $5.0 \%$ & 7 & $\begin{array}{l}0 \\
0\end{array}$ & $\begin{array}{l}0 \\
0\end{array}$ & Pair drops out due to rank tests & \\
\hline Russian $4.0 \%$ & Chinese $4.5 \%$ & \multicolumn{5}{|c|}{ Pair drops out due to unit root test } \\
\hline \multicolumn{7}{|l|}{ B. War } \\
\hline French $5.0 \%$ & English $5.0 \%$ & 9 & $\begin{array}{l}1 \\
1\end{array}$ & $\begin{array}{l}1 \\
1\end{array}$ & $\begin{array}{l}{[1 ;-163.64 * * *] ;[-171.33 * * * ;]} \\
{[1 ;-11.10 * * *] ;[-0.09 ; 1]}\end{array}$ & Valid cointegration relationship \\
\hline French $5.0 \%$ & Russian $4.0 \%$ & 9 & $\begin{array}{l}1 \\
1\end{array}$ & $\begin{array}{l}1 \\
1\end{array}$ & $\begin{array}{l}{\left[1 ;-0.10^{* * * *}\right] ;[-10.26 * * * ; 1]} \\
{[1 ;-0.14 * * *] ;[-7.14 * * * ; 1]}\end{array}$ & Valid cointegration relationship \\
\hline French $5.0 \%$ & Serbian $4.0 \%$ & 10 & $\begin{array}{l}1 \\
0\end{array}$ & $\begin{array}{l}0 \\
0\end{array}$ & $\begin{array}{l}{[1 ;-0.26 * * *] ;[-3.80 * * * ; 1]} \\
{[1 ;-0.20 * * *] ;[-4.97 * * * ; 1]}\end{array}$ & Valid cointegration relationship \\
\hline French $5.0 \%$ & Italian $3.5 \%$ & 13 & $\begin{array}{l}0 \\
0\end{array}$ & $\begin{array}{l}0 \\
0\end{array}$ & Pair drops out due to rank tests & \\
\hline
\end{tabular}


Table A.14 continued

\begin{tabular}{|c|c|c|c|c|c|c|}
\hline Series 1 & Series 2 & $\begin{array}{l}\text { Lags used } \\
\text { in the VAR }\end{array}$ & $\begin{array}{l}\text { Significant rank } \\
\text { of Trace test }\end{array}$ & $\begin{array}{l}\text { Significant rank } \\
\text { of Maximum } \\
\text { Eigenvalue test }\end{array}$ & $\begin{array}{c}\text { Hypothesis test on } \\
\text { cointegrating vector in VECM } \\
\text { (Model suggested by AIC in italics) }\end{array}$ & Final stage judgement \\
\hline French $5.0 \%$ & Romanian $4.0 \%$ & 9 & $\begin{array}{l}1 \\
1\end{array}$ & $\begin{array}{l}1 \\
0\end{array}$ & $\begin{array}{l}{[1 ; 0.95 * * *] ;[1.05 * * * ; 1]} \\
{[1 ; 0.12] ;[8.22 * * * ; 1]}\end{array}$ & $\begin{array}{l}\text { Pair drops out due to double normali- } \\
\text { zation restriction violated }\end{array}$ \\
\hline French $5.0 \%$ & Portuguese $4.5 \%$ & 16 & $\begin{array}{l}0 \\
0\end{array}$ & $\begin{array}{l}0 \\
0\end{array}$ & Pair drops out due to rank tests & \\
\hline French $5.0 \%$ & Japanese $5.0 \%$ & Pair drops ou & due to unit root test & & & \\
\hline French $5.0 \%$ & Chinese $4.5 \%$ & 17 & $\begin{array}{l}1 \\
1\end{array}$ & $\begin{array}{l}0 \\
1\end{array}$ & $\begin{array}{l}{[;-1.90 * * *] ;[-0.52 * * * ;]} \\
{[;-4.73 * * *] ;[-0.21 ;]}\end{array}$ & $\begin{array}{l}\text { Pair drops out due to double normali- } \\
\text { zation restriction violated }\end{array}$ \\
\hline English $5.0 \%$ & Russian $4.0 \%$ & 3 & $\begin{array}{l}1 \\
1\end{array}$ & $\begin{array}{l}1 \\
1\end{array}$ & $\begin{array}{l}{[; 0.01] ;[105.43 * * * ;]} \\
{[; 0.01] ;[153.27 * * * ;]}\end{array}$ & $\begin{array}{l}\text { Pair drops out due to double normali- } \\
\text { zation restriction violated }\end{array}$ \\
\hline English $5.0 \%$ & Serbian $4.0 \%$ & 2 & $\begin{array}{l}1 \\
1\end{array}$ & $\begin{array}{l}1 \\
1\end{array}$ & $\begin{array}{l}{[1 ; 0.03 * *] ;\left[31.76^{* * *} ; 1\right]} \\
{[1 ; 0.02] ;\left[41.45^{* * * ; 1]}\right.}\end{array}$ & Valid cointegration relationship \\
\hline English $5.0 \%$ & Italian $3.5 \%$ & 2 & $\begin{array}{l}1 \\
1\end{array}$ & $\begin{array}{l}1 \\
1\end{array}$ & $\begin{array}{l}{[1 ; 0.03 * *] ;[35.47 * * * ; 1]} \\
{[1 ; 0.03 *] ;[31.03 * * * ; 1]}\end{array}$ & Valid cointegration relationship \\
\hline English $5.0 \%$ & Romanian $4.0 \%$ & 4 & $\begin{array}{l}1 \\
1\end{array}$ & $\begin{array}{l}1 \\
1\end{array}$ & $\begin{array}{l}{[1 ;-0.22 * * *] ;[-4.53 * * * ; 1]} \\
{[1 ;-0.30 * * *] ;[-3-33 * * * ; 1]}\end{array}$ & Valid cointegration relationship \\
\hline English $5.0 \%$ & Portuguese $4.5 \%$ & 3 & $\begin{array}{l}0 \\
0\end{array}$ & $\begin{array}{l}0 \\
0\end{array}$ & Pair drops out due to rank tests & \\
\hline English $5.0 \%$ & Japanese $5.0 \%$ & Pair drops ou & due to unit root test & & & \\
\hline English $5.0 \%$ & Chinese $4.5 \%$ & 4 & $\begin{array}{l}0 \\
0\end{array}$ & $\begin{array}{l}0 \\
0\end{array}$ & Pair drops out due to rank tests & \\
\hline
\end{tabular}


Table A.14 continued

\begin{tabular}{|c|c|c|c|c|c|c|}
\hline Series 1 & Series 2 & $\begin{array}{l}\text { Lags used } \\
\text { in the VAR }\end{array}$ & $\begin{array}{l}\text { Significant rank } \\
\text { of Trace test }\end{array}$ & $\begin{array}{l}\text { Significant rank } \\
\text { of Maximum } \\
\text { Eigenvalue test }\end{array}$ & $\begin{array}{c}\text { Hypothesis test on } \\
\text { cointegrating vector in VECM } \\
\text { (Model suggested by AIC in italics) }\end{array}$ & Final stage judgement \\
\hline Russian $4.0 \%$ & Serbian $4.0 \%$ & 24 & $\begin{array}{l}0 \\
0\end{array}$ & $\begin{array}{l}0 \\
0\end{array}$ & Pair drops out due to rank tests & \\
\hline Russian $4.0 \%$ & Italian $3.5 \%$ & 13 & $\begin{array}{l}0 \\
0\end{array}$ & $\begin{array}{l}0 \\
0\end{array}$ & Pair drops out due to rank tests & \\
\hline Russian $4.0 \%$ & Romanian $4.0 \%$ & 4 & $\begin{array}{l}0 \\
0\end{array}$ & $\begin{array}{l}0 \\
0\end{array}$ & Pair drops out due to rank tests & \\
\hline Russian $4.0 \%$ & Portuguese $4.5 \%$ & 3 & $\begin{array}{l}1 \\
1\end{array}$ & $\begin{array}{l}1 \\
1\end{array}$ & $\begin{array}{l}{[1 ; 65.58 * * *] ;[0.01 ; 1]} \\
{[1 ; 177.41 * * *] ;[0.00 ; 1]}\end{array}$ & $\begin{array}{l}\text { Pair drops out due to double normali- } \\
\text { zation restriction violated }\end{array}$ \\
\hline Russian $4.0 \%$ & Japanese $5.0 \%$ & Pair drops ou & due to unit root test & & & \\
\hline Russian $4.0 \%$ & Chinese $4.5 \%$ & 11 & $\begin{array}{l}1 \\
1\end{array}$ & $\begin{array}{l}1 \\
1\end{array}$ & $\begin{array}{l}{[1 ;-11.83 * * *] ;[-0.08 * * * ; 1]} \\
{[1 ;-23.12 * * *] ;[-0.04 * ; 1]}\end{array}$ & Valid cointegration relationship \\
\hline \multicolumn{7}{|l|}{ C. Post-war } \\
\hline French $5.0 \%$ & English $5.0 \%$ & 20 & $\begin{array}{l}0 \\
0\end{array}$ & $\begin{array}{l}0 \\
0\end{array}$ & Pair drops out due to rank tests & \\
\hline French $5.0 \%$ & Russian $4.0 \%$ & 20 & $\begin{array}{l}0 \\
0\end{array}$ & $\begin{array}{l}0 \\
0\end{array}$ & Pair drops out due to rank tests & \\
\hline French $5.0 \%$ & Serbian $4.0 \%$ & \multicolumn{4}{|c|}{ Pair drops out due to unit root test } & \\
\hline French $5.0 \%$ & Italian $3.5 \%$ & 4 & $\begin{array}{l}1 \\
1\end{array}$ & $\begin{array}{l}1 \\
1\end{array}$ & $\begin{array}{l}{[1 ;-0.36 * * *] ;[-2.80 * * * ; 1]} \\
{[1 ;-0.36 * * *] ;[4490.19 * * * ; 1]}\end{array}$ & Valid cointegration relationship \\
\hline French $5.0 \%$ & Romanian $4.0 \%$ & Pair drops ou & due to unit root test & & & \\
\hline
\end{tabular}


Table A.14 continued

\begin{tabular}{|c|c|c|c|c|c|c|}
\hline Series 1 & Series 2 & $\begin{array}{l}\text { Lags used } \\
\text { in the VAR }\end{array}$ & $\begin{array}{c}\text { Significant rank } \\
\text { of Trace test }\end{array}$ & $\begin{array}{l}\text { Significant rank } \\
\text { of Maximum } \\
\text { Eigenvalue test }\end{array}$ & $\begin{array}{c}\text { Hypothesis test on } \\
\text { cointegrating vector in VECM } \\
\text { (Model suggested by AIC in italics) }\end{array}$ & Final stage judgement \\
\hline French $5.0 \%$ & Portuguese $4.5 \%$ & 14 & $\begin{array}{l}0 \\
0\end{array}$ & $\begin{array}{l}0 \\
0\end{array}$ & Pair drops out due to rank tests & \\
\hline French $5.0 \%$ & Japanese $5.0 \%$ & 18 & $\begin{array}{l}0 \\
0\end{array}$ & $\begin{array}{l}0 \\
0\end{array}$ & Pair drops out due to rank tests & \\
\hline French $5.0 \%$ & Chinese $4.5 \%$ & 24 & $\begin{array}{l}0 \\
0\end{array}$ & $\begin{array}{l}0 \\
0\end{array}$ & Pair drops out due to rank tests & \\
\hline English $5.0 \%$ & Russian $4.0 \%$ & 20 & $\begin{array}{l}0 \\
0\end{array}$ & $\begin{array}{l}0 \\
0\end{array}$ & Pair drops out due to rank tests & \\
\hline English $5.0 \%$ & Serbian $4.0 \%$ & Pair drops ou & due to unit root test & & & \\
\hline English $5.0 \%$ & Italian $3.5 \%$ & 2 & $\begin{array}{l}0 \\
0\end{array}$ & $\begin{array}{l}0 \\
0\end{array}$ & Pair drops out due to rank tests & \\
\hline English $5.0 \%$ & Romanian $4.0 \%$ & Pair drops ou & due to unit root test & & & \\
\hline English $5.0 \%$ & Portuguese $4.5 \%$ & 21 & $\begin{array}{l}0 \\
0\end{array}$ & $\begin{array}{l}0 \\
0\end{array}$ & Pair drops out due to rank tests & \\
\hline English $5.0 \%$ & Japanese $5.0 \%$ & 21 & $\begin{array}{l}0 \\
0\end{array}$ & $\begin{array}{l}0 \\
0\end{array}$ & Pair drops out due to rank tests & \\
\hline English $5.0 \%$ & Chinese $4.5 \%$ & 24 & $\begin{array}{l}0 \\
0\end{array}$ & $\begin{array}{l}0 \\
0\end{array}$ & Pair drops out due to rank tests & \\
\hline Russian $4.0 \%$ & Serbian $4.0 \%$ & Pair drops ou & due to unit root test & & & \\
\hline Russian $4.0 \%$ & Italian $3.5 \%$ & 2 & $\begin{array}{l}0 \\
0\end{array}$ & $\begin{array}{l}0 \\
0\end{array}$ & Pair drops out due to rank tests & \\
\hline
\end{tabular}


Table A.14 continued

\begin{tabular}{|c|c|c|c|c|c|c|}
\hline Series 1 & Series 2 & $\begin{array}{l}\text { Lags used } \\
\text { in the VAR }\end{array}$ & $\begin{array}{c}\text { Significant rank } \\
\text { of Trace test }\end{array}$ & $\begin{array}{l}\text { Significant rank } \\
\text { of Maximum } \\
\text { Eigenvalue test }\end{array}$ & $\begin{array}{c}\text { Hypothesis test on } \\
\text { cointegrating vector in VECM } \\
\text { (Model suggested by AIC in italics) }\end{array}$ & Final stage judgement \\
\hline French $5.0 \%$ & Portuguese $4.5 \%$ & 14 & $\begin{array}{l}0 \\
0\end{array}$ & $\begin{array}{l}0 \\
0\end{array}$ & Pair drops out due to rank tests & \\
\hline French $5.0 \%$ & Japanese $5.0 \%$ & 18 & $\begin{array}{l}0 \\
0\end{array}$ & $\begin{array}{l}0 \\
0\end{array}$ & Pair drops out due to rank tests & \\
\hline French $5.0 \%$ & Chinese $4.5 \%$ & 24 & $\begin{array}{l}0 \\
0\end{array}$ & $\begin{array}{l}0 \\
0\end{array}$ & Pair drops out due to rank tests & \\
\hline English $5.0 \%$ & Russian $4.0 \%$ & 20 & $\begin{array}{l}0 \\
0\end{array}$ & $\begin{array}{l}0 \\
0\end{array}$ & Pair drops out due to rank tests & \\
\hline English $5.0 \%$ & Serbian $4.0 \%$ & Pair drops ou & due to unit root test & & & \\
\hline English $5.0 \%$ & Italian $3.5 \%$ & 2 & $\begin{array}{l}0 \\
0\end{array}$ & $\begin{array}{l}0 \\
0\end{array}$ & Pair drops out due to rank tests & \\
\hline English $5.0 \%$ & Romanian $4.0 \%$ & Pair drops ou & due to unit root test & & & \\
\hline English $5.0 \%$ & Portuguese $4.5 \%$ & 21 & $\begin{array}{l}0 \\
0\end{array}$ & $\begin{array}{l}0 \\
0\end{array}$ & Pair drops out due to rank tests & \\
\hline English $5.0 \%$ & Japanese $5.0 \%$ & 21 & $\begin{array}{l}0 \\
0\end{array}$ & $\begin{array}{l}0 \\
0\end{array}$ & Pair drops out due to rank tests & \\
\hline English $5.0 \%$ & Chinese $4.5 \%$ & 24 & $\begin{array}{l}0 \\
0\end{array}$ & $\begin{array}{l}0 \\
0\end{array}$ & Pair drops out due to rank tests & \\
\hline Russian $4.0 \%$ & Serbian $4.0 \%$ & Pair drops ou & due to unit root test & & & \\
\hline Russian $4.0 \%$ & Italian $3.5 \%$ & 2 & $\begin{array}{l}0 \\
0\end{array}$ & $\begin{array}{l}0 \\
0\end{array}$ & Pair drops out due to rank tests & \\
\hline
\end{tabular}


Table A.14 continued

\begin{tabular}{|c|c|c|c|c|c|c|}
\hline Series 1 & Series 2 & $\begin{array}{l}\text { Lags used } \\
\text { in the VAR }\end{array}$ & $\begin{array}{c}\text { Significant rank } \\
\text { of Trace test }\end{array}$ & $\begin{array}{l}\text { Significant rank } \\
\text { of Maximum } \\
\text { Eigenvalue test }\end{array}$ & $\begin{array}{c}\text { Hypothesis test on } \\
\text { cointegrating vector in VECM } \\
\text { (Model suggested by AIC in italics) }\end{array}$ & Final stage judgement \\
\hline Russian $4.0 \%$ & Romanian $4.0 \%$ & Pair drops ou & due to unit root test & & & \\
\hline Russian $4.0 \%$ & Portuguese $4.5 \%$ & 20 & $\begin{array}{l}0 \\
0\end{array}$ & $\begin{array}{l}0 \\
0\end{array}$ & Pair drops out due to rank tests & \\
\hline Russian $4.0 \%$ & Japanese $5.0 \%$ & 19 & $\begin{array}{l}0 \\
0\end{array}$ & $\begin{array}{l}0 \\
0\end{array}$ & Pair drops out due to rank tests & \\
\hline Russian $4.0 \%$ & Chinese $4.5 \%$ & 23 & $\begin{array}{l}0 \\
0\end{array}$ & $\begin{array}{l}0 \\
0\end{array}$ & Pair drops out due to rank tests & \\
\hline
\end{tabular}

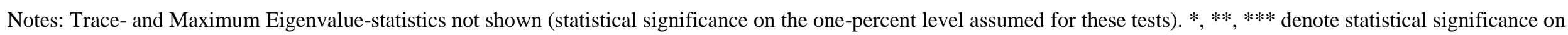
the one-, five-, and ten-per cent levels. 
Table A.15: A global test on cointegrated alliance partners - Estimation summary for pairs among the minor Allied Powers

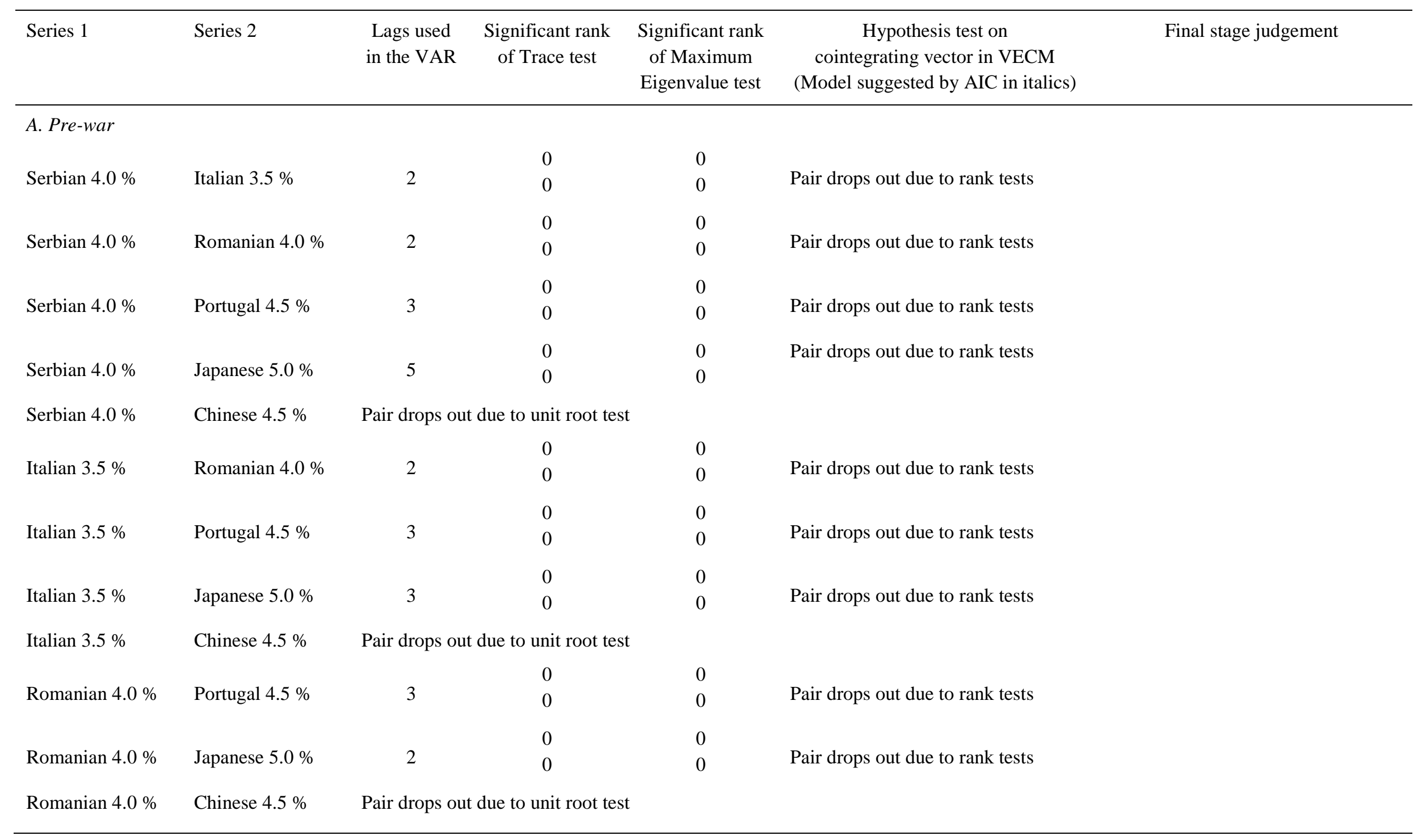


Table A.15 continued

\begin{tabular}{|c|c|c|c|c|c|c|}
\hline Series 1 & Series 2 & $\begin{array}{l}\text { Lags used } \\
\text { in the VAR }\end{array}$ & $\begin{array}{l}\text { Significant rank } \\
\text { of Trace test }\end{array}$ & $\begin{array}{l}\text { Significant rank } \\
\text { of Maximum } \\
\text { Eigenvalue test }\end{array}$ & $\begin{array}{c}\text { Hypothesis test on } \\
\text { cointegrating vector in VECM } \\
\text { (Model suggested by AIC in italics) }\end{array}$ & Final stage judgement \\
\hline Portugal $4.5 \%$ & Japanese $5.0 \%$ & 3 & $\begin{array}{l}0 \\
0\end{array}$ & $\begin{array}{l}0 \\
0\end{array}$ & Pair drops out due to rank tests & \\
\hline Portugal $4.5 \%$ & Chinese $4.5 \%$ & \multicolumn{5}{|c|}{ Pair drops out due to unit root test } \\
\hline Japanese $5.0 \%$ & Chinese $4.5 \%$ & \multicolumn{5}{|c|}{ Pair drops out due to unit root test } \\
\hline \multicolumn{7}{|l|}{ B. War } \\
\hline Serbian $4.0 \%$ & Italian $3.5 \%$ & 2 & $\begin{array}{l}0 \\
0\end{array}$ & $\begin{array}{l}0 \\
0\end{array}$ & Pair drops out due to rank tests & \\
\hline Serbian $4.0 \%$ & Romanian $4.0 \%$ & 4 & $\begin{array}{l}1 \\
0\end{array}$ & $\begin{array}{l}1 \\
0\end{array}$ & $\begin{array}{l}{[1 ; 3.09 * * *] ;[0.32 * * * ; 1]} \\
{[1 ; 2.74 * * *] ;[0.36 * * * ; 1]}\end{array}$ & $\begin{array}{l}\text { Pair drops out due to cointegrating } \\
\text { vector being unstable }\end{array}$ \\
\hline Serbian $4.0 \%$ & Portugal $4.5 \%$ & 4 & $\begin{array}{l}1 \\
1\end{array}$ & $\begin{array}{l}1 \\
1\end{array}$ & $\begin{array}{l}{[1 ; 25.97 * * *] ;[0.04 ; 1]} \\
{[1 ; 42.91 * * *] ;[0.02 ; 1]}\end{array}$ & $\begin{array}{l}\text { Pair drops out due to double normali- } \\
\text { zation restriction violated }\end{array}$ \\
\hline Serbian $4.0 \%$ & Japanese $5.0 \%$ & \multicolumn{5}{|c|}{ Pair drops out due to unit root test } \\
\hline Serbian $4.0 \%$ & Chinese $4.5 \%$ & 25 & $\begin{array}{l}0 \\
1\end{array}$ & $\begin{array}{l}0 \\
0\end{array}$ & $\begin{array}{l}{[1 ;-5.40 * * *] ;[-0.18 * * ; 1]} \\
{[1 ;-14.72 * * *] ;[207.59 * ; 1]}\end{array}$ & $\begin{array}{l}\text { Pair drops out due to cointegrating } \\
\text { vector being unstable }\end{array}$ \\
\hline Italian $3.5 \%$ & Romanian $4.0 \%$ & 4 & $\begin{array}{l}0 \\
0\end{array}$ & $\begin{array}{l}0 \\
0\end{array}$ & Pair drops out due to rank tests & \\
\hline Italian $3.5 \%$ & Portugal $4.5 \%$ & 2 & $\begin{array}{l}1 \\
1\end{array}$ & $\begin{array}{l}1 \\
1\end{array}$ & $\begin{array}{l}{[1 ; 25.01 * * *] ;[0.04 * ; 1]} \\
{\left[1 ; 15.49^{* * *}\right] ;[0.06 * ; 1]}\end{array}$ & $\begin{array}{l}\text { Pair drops out due to cointegrating } \\
\text { vector being unstable }\end{array}$ \\
\hline Italian $3.5 \%$ & Japanese $5.0 \%$ & \multicolumn{5}{|c|}{ Pair drops out due to unit root test } \\
\hline Italian $3.5 \%$ & Chinese $4.5 \%$ & 13 & $\begin{array}{l}1 \\
1\end{array}$ & $\begin{array}{l}1 \\
0\end{array}$ & $\begin{array}{l}{[1 ;-6.24 * * *] ;[-0.16 * * * ; 1]} \\
{[1 ;-8.58 * * *] ;[-0.12 * * ; 1]}\end{array}$ & Valid cointegration relationship \\
\hline
\end{tabular}


Table A.15 continued

\begin{tabular}{|c|c|c|c|c|c|c|}
\hline Series 1 & Series 2 & $\begin{array}{l}\text { Lags used } \\
\text { in the VAR }\end{array}$ & $\begin{array}{l}\text { Significant rank } \\
\text { of Trace test }\end{array}$ & $\begin{array}{l}\text { Significant rank } \\
\text { of Maximum } \\
\text { Eigenvalue test }\end{array}$ & $\begin{array}{c}\text { Hypothesis test on } \\
\text { cointegrating vector in VECM } \\
\text { (Model suggested by AIC in italics) }\end{array}$ & Final stage judgement \\
\hline Italian $3.5 \%$ & Chinese $4.5 \%$ & 13 & $\begin{array}{l}1 \\
1\end{array}$ & $\begin{array}{l}1 \\
0\end{array}$ & $\begin{array}{l}{[1 ;-6.24 * * *] ;\left[-0.16^{* * *} ; 1\right]} \\
{[1 ;-8.58 * * *] ;[-0.12 * * ; 1]}\end{array}$ & Valid cointegration relationship \\
\hline Romanian $4.0 \%$ & Portugal $4.5 \%$ & 4 & $\begin{array}{l}1 \\
1\end{array}$ & $\begin{array}{l}1 \\
1\end{array}$ & $\begin{array}{l}{[1 ;-6.71 * * *] ;[-0.15 ; 1]} \\
{[1 ; 16.04 * * *] ;[0.06 ; 1]}\end{array}$ & $\begin{array}{l}\text { Pair drops out due to double normali- } \\
\text { zation restriction violated }\end{array}$ \\
\hline Romanian $4.0 \%$ & Japanese $5.0 \%$ & Pair drops ou & due to unit root test & & & \\
\hline Romanian $4.0 \%$ & Chinese $4.5 \%$ & 4 & $\begin{array}{l}1 \\
1\end{array}$ & $\begin{array}{l}1 \\
1\end{array}$ & $\begin{array}{l}{[1 ; 2.21 * * *] ;[0.45 * * * ; 1]} \\
{[1 ; 4.85 * * *] ;[0.21 ; 1]}\end{array}$ & Valid cointegration relationship \\
\hline $\begin{array}{l}\text { Portugal } 4.5 \% \\
\text { Portugal } 4.5 \%\end{array}$ & $\begin{array}{l}\text { Japanese } 5.0 \% \\
\text { Chinese } 4.5 \%\end{array}$ & $\begin{array}{l}\text { Pair drops ou } \\
5\end{array}$ & $\begin{array}{c}\text { due to unit root test } \\
1 \\
1\end{array}$ & $\begin{array}{l}1 \\
1\end{array}$ & $\begin{array}{l}{[1 ; 0.31 * *] ;[3.24 * * * ; 1]} \\
{\left[1 ; 9.71^{* * *}\right] ;[0.10 ; 1]}\end{array}$ & Valid cointegration relationship \\
\hline Japanese $5.0 \%$ & Chinese $4.5 \%$ & Pair drops ou & due to unit root test & & & \\
\hline \multicolumn{7}{|l|}{ C. Post-war } \\
\hline Serbian $4.0 \%$ & Italian $3.5 \%$ & Pair drops ou & due to unit root test & & & \\
\hline Serbian $4.0 \%$ & Romanian $4.0 \%$ & Pair drops ou & due to unit root test & & & \\
\hline Serbian $4.0 \%$ & Portugal $4.5 \%$ & Pair drops ou & due to unit root test & & & \\
\hline Serbian $4.0 \%$ & Japanese $5.0 \%$ & Pair drops ou & due to unit root test & & & \\
\hline Serbian $4.0 \%$ & Chinese $4.5 \%$ & Pair drops ou & due to unit root test & & & \\
\hline Italian $3.5 \%$ & Romanian $4.0 \%$ & Pair drops ou & due to unit root test & & & \\
\hline Italian $3.5 \%$ & Portugal $4.5 \%$ & 3 & $\begin{array}{l}0 \\
0\end{array}$ & $\begin{array}{l}0 \\
0\end{array}$ & Pair drops out due to rank tests & \\
\hline
\end{tabular}


Table A.15 continued

\begin{tabular}{|c|c|c|c|c|c|c|}
\hline Series 1 & Series 2 & $\begin{array}{l}\text { Lags used } \\
\text { in the VAR }\end{array}$ & $\begin{array}{l}\text { Significant rank } \\
\text { of Trace test }\end{array}$ & $\begin{array}{l}\text { Significant rank } \\
\text { of Maximum } \\
\text { Eigenvalue test }\end{array}$ & $\begin{array}{c}\text { Hypothesis test on } \\
\text { cointegrating vector in VECM } \\
\text { (Model suggested by AIC in italics) }\end{array}$ & Final stage judgement \\
\hline Italian $3.5 \%$ & Japanese $5.0 \%$ & 4 & $\begin{array}{l}0 \\
0\end{array}$ & $\begin{array}{l}0 \\
0\end{array}$ & Pair drops out due to rank tests & \\
\hline Italian $3.5 \%$ & Chinese $4.5 \%$ & 2 & $\begin{array}{l}0 \\
1\end{array}$ & $\begin{array}{l}0 \\
1\end{array}$ & $\begin{array}{l}{[1 ;-1.26 * * *] ;[-0.79 * * * ; 1]} \\
{[1 ;-1.89 * * *] ;[-0.53 * * * ; 1]}\end{array}$ & Valid cointegration relationship \\
\hline Romanian $4.0 \%$ & Portugal $4.5 \%$ & Pair drops o & due to unit root test & & & \\
\hline Romanian $4.0 \%$ & Japanese $5.0 \%$ & Pair drops o & due to unit root test & & & \\
\hline Romanian $4.0 \%$ & Chinese $4.5 \%$ & Pair drops o & due to unit root test & & & \\
\hline Portugal $4.5 \%$ & Japanese $5.0 \%$ & 19 & $\begin{array}{l}0 \\
0\end{array}$ & $\begin{array}{l}0 \\
0\end{array}$ & Pair drops out due to rank tests & \\
\hline Portugal $4.5 \%$ & Chinese $4.5 \%$ & 9 & $\begin{array}{l}0 \\
0\end{array}$ & $\begin{array}{l}1 \\
0\end{array}$ & $\begin{array}{l}{\left[1 ;-0.86^{* * *}\right] ;\left[-1.16^{* * *} ; 1\right]} \\
{[1 ;-0.89 * * *] ;[-1.12 * * * ; 1]}\end{array}$ & $\begin{array}{l}\text { Pair drops out due to cointegrating } \\
\text { vector being unstable }\end{array}$ \\
\hline Japanese $5.0 \%$ & Chinese $4.5 \%$ & 6 & $\begin{array}{l}0 \\
0\end{array}$ & $\begin{array}{l}0 \\
0\end{array}$ & Pair drops out due to rank tests & \\
\hline
\end{tabular}

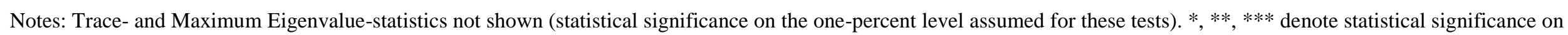
the one-, five-, and ten-per cent levels. 
Table A.16: A global test on cointegrated alliance partners - cross-alliance relationships among the major powers

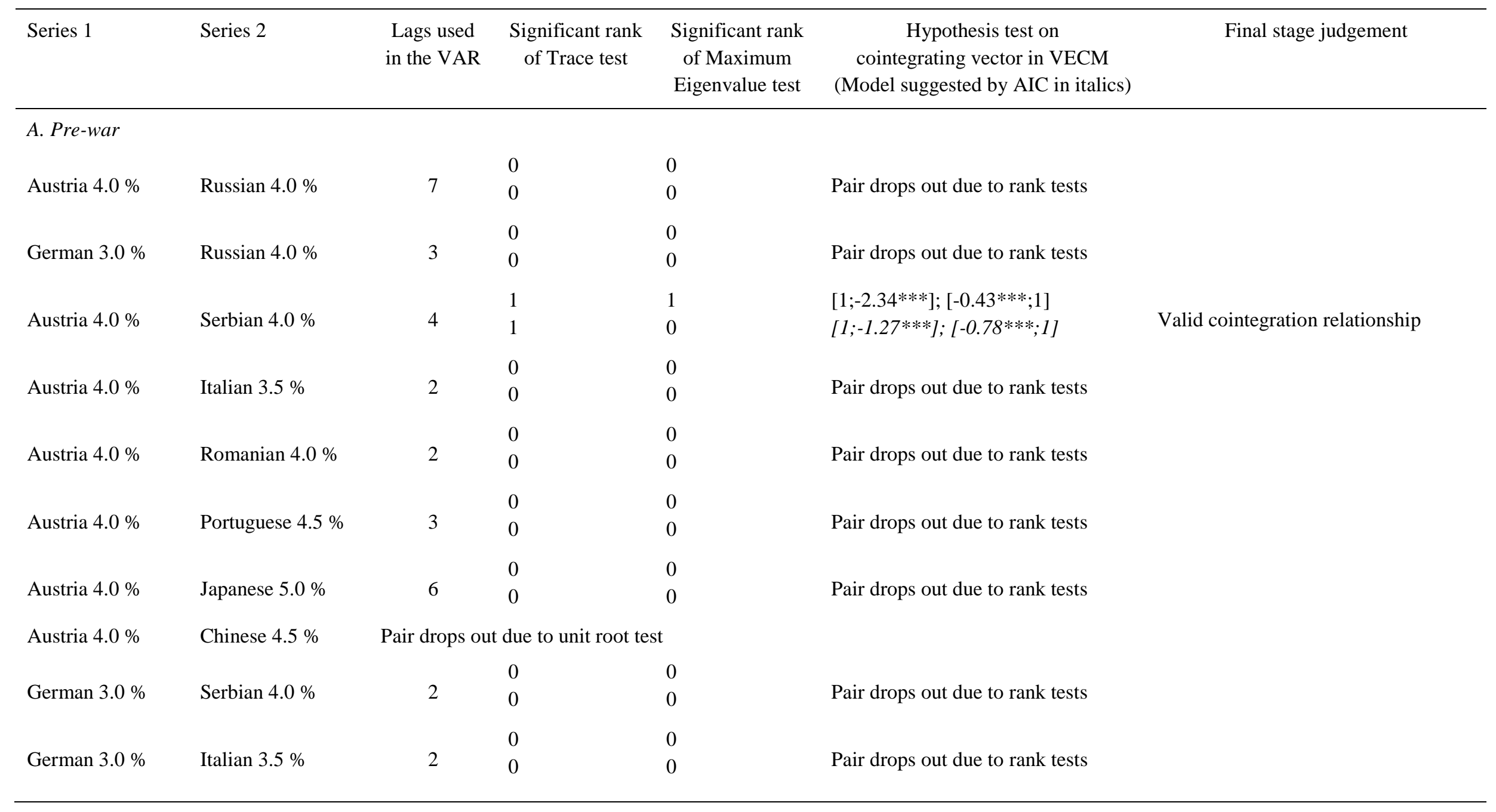


Table A.16 continued

\begin{tabular}{|c|c|c|c|c|c|c|}
\hline Series 1 & Series 2 & $\begin{array}{l}\text { Lags used } \\
\text { in the VAR }\end{array}$ & $\begin{array}{l}\text { Significant rank } \\
\text { of Trace test }\end{array}$ & $\begin{array}{l}\text { Significant rank } \\
\text { of Maximum } \\
\text { Eigenvalue test }\end{array}$ & $\begin{array}{c}\text { Hypothesis test on } \\
\text { cointegrating vector in VECM } \\
\text { (Model suggested by AIC in italics) }\end{array}$ & Final stage judgement \\
\hline \multicolumn{7}{|l|}{ A. Pre-war } \\
\hline German $3.0 \%$ & Romanian $4.0 \%$ & 2 & $\begin{array}{l}0 \\
0\end{array}$ & $\begin{array}{l}0 \\
0\end{array}$ & Pair drops out due to rank tests & \\
\hline German $3.0 \%$ & Portuguese $4.5 \%$ & 3 & $\begin{array}{l}0 \\
0\end{array}$ & $\begin{array}{l}0 \\
0\end{array}$ & Pair drops out due to rank tests & \\
\hline German $3.0 \%$ & Japanese $5.0 \%$ & 3 & $\begin{array}{l}0 \\
0\end{array}$ & $\begin{array}{l}0 \\
0\end{array}$ & Pair drops out due to rank tests & \\
\hline German $3.0 \%$ & Chinese $4.5 \%$ & \multicolumn{5}{|c|}{ Pair drops out due to unit root test } \\
\hline \multicolumn{7}{|l|}{ B. War } \\
\hline Austria $4.0 \%$ & English $5.0 \%$ & 21 & $\begin{array}{l}0 \\
1\end{array}$ & $\begin{array}{l}0 \\
1\end{array}$ & $\begin{array}{l}{[1 ; 0.87] ;\left[1.15^{* * ;} ; 1\right]} \\
{\left[1 ; 2.00^{* * *}\right] ;\left[0.50^{* * *} ; 1\right]}\end{array}$ & Valid cointegration relationship \\
\hline Austria $4.0 \%$ & French $5.0 \%$ & 10 & $\begin{array}{l}1 \\
1\end{array}$ & $\begin{array}{l}1 \\
1\end{array}$ & $\begin{array}{l}{[1 ; 17.15 * * *] ;[0.06 * * * ; 1]} \\
{[1 ; 18.62 * * *] ;[0.05 * * ; 1]}\end{array}$ & Valid cointegration relationship \\
\hline Austria $4.0 \%$ & Russian $4.0 \%$ & 11 & $\begin{array}{l}0 \\
0\end{array}$ & $\begin{array}{l}0 \\
0\end{array}$ & Pair drops out due to rank tests & \\
\hline German $3.0 \%$ & English $5.0 \%$ & 23 & $\begin{array}{l}1 \\
1\end{array}$ & $\begin{array}{l}1 \\
1\end{array}$ & $\begin{array}{l}{[1 ;-9.49 * * *] ;\left[-0.10^{* * *} ; 1\right]} \\
{[1 ;-9.70 * * *] ;[-0.10 * * * ; 1]}\end{array}$ & Valid cointegration relationship \\
\hline German $3.0 \%$ & French $5.0 \%$ & 20 & $\begin{array}{l}1 \\
1\end{array}$ & $\begin{array}{l}0 \\
1\end{array}$ & $\begin{array}{l}{\left[1 ; 0.75^{* *}\right] ;[1.33 * * * ; 1]} \\
{[1 ; 1.49 * * *] ;[0.67 * * * ; 1]}\end{array}$ & Valid cointegration relationship \\
\hline German $3.0 \%$ & Russian $4.0 \%$ & 3 & $\begin{array}{l}0 \\
1\end{array}$ & $\begin{array}{l}0 \\
1\end{array}$ & $\begin{array}{l}{[1 ; 0.05] ;[18.43 * * * ; 1]} \\
{[1 ; 0.26 * * *] ;\left[3.86^{* * * ;} ; 1\right]}\end{array}$ & Valid cointegration relationship \\
\hline Austria $4.0 \%$ & Serbian $4.0 \%$ & 10 & $\begin{array}{l}0 \\
0\end{array}$ & $\begin{array}{l}0 \\
0\end{array}$ & Pair drops out due to rank tests & \\
\hline
\end{tabular}


Table A.16 continued

\begin{tabular}{|c|c|c|c|c|c|c|}
\hline Series 1 & Series 2 & $\begin{array}{l}\text { Lags used } \\
\text { in the VAR }\end{array}$ & $\begin{array}{l}\text { Significant rank } \\
\text { of Trace test }\end{array}$ & $\begin{array}{l}\text { Significant rank } \\
\text { of Maximum } \\
\text { Eigenvalue test }\end{array}$ & $\begin{array}{c}\text { Hypothesis test on } \\
\text { cointegrating vector in VECM } \\
\text { (Model suggested by AIC in italics) }\end{array}$ & Final stage judgement \\
\hline Austria $4.0 \%$ & Italian $3.5 \%$ & 13 & $\begin{array}{l}0 \\
0\end{array}$ & $\begin{array}{l}0 \\
0\end{array}$ & Pair drops out due to rank tests & \\
\hline Austria $4.0 \%$ & Romanian $4.0 \%$ & 9 & $\begin{array}{l}0 \\
0\end{array}$ & $\begin{array}{l}0 \\
0\end{array}$ & Pair drops out due to rank tests & \\
\hline Austria $4.0 \%$ & Portuguese $4.5 \%$ & 12 & $\begin{array}{l}0 \\
0\end{array}$ & $\begin{array}{l}0 \\
0\end{array}$ & Pair drops out due to rank tests & \\
\hline Austria $4.0 \%$ & Japanese $5.0 \%$ & Pair drops ou & due to unit root test & & & \\
\hline Austria $4.0 \%$ & Chinese $4.5 \%$ & 23 & $\begin{array}{l}0 \\
1\end{array}$ & $\begin{array}{l}0 \\
1\end{array}$ & $\begin{array}{l}{[1 ;-4.01 * * *] ;[-0.25 * * * ; 1]} \\
{[1 ; 212.31 * * *] ;[0.00 ; 1]}\end{array}$ & $\begin{array}{l}\text { Pair drops out due to cointegrating } \\
\text { vector being unstable }\end{array}$ \\
\hline German $3.0 \%$ & Serbian $4.0 \%$ & 2 & $\begin{array}{l}1 \\
1\end{array}$ & $\begin{array}{l}1 \\
1\end{array}$ & $\begin{array}{l}{[1 ; 0.47 * * *] ;[2.11 * * * ; 1]} \\
{[1 ; 0.49 * * *] ;[2.01 * * * ; 1]}\end{array}$ & Valid cointegration relationship \\
\hline German $3.0 \%$ & Italian $3.5 \%$ & 2 & $\begin{array}{l}0 \\
0\end{array}$ & $\begin{array}{l}0 \\
0\end{array}$ & Pair drops out due to rank tests & \\
\hline German $3.0 \%$ & Romanian $4.0 \%$ & 23 & $\begin{array}{l}1 \\
1\end{array}$ & $\begin{array}{l}1 \\
1\end{array}$ & $\begin{array}{l}{[1 ;-0.86 * * *] ;[404.35 * * * ; 1]} \\
{[1 ;-1.18 * * *] ;[179.53 * * * ; 1]}\end{array}$ & Valid cointegration relationship \\
\hline German $3.0 \%$ & Portuguese $4.5 \%$ & 2 & $\begin{array}{l}1 \\
0\end{array}$ & $\begin{array}{l}1 \\
0\end{array}$ & $\begin{array}{l}{[1 ; 7.47 * * *] ;[0.13 * ; 1]} \\
{[1 ; 7.81 * * *] ;[0.13 * ; 1]}\end{array}$ & $\begin{array}{l}\text { Pair drops out due to cointegrating } \\
\text { vector being unstable }\end{array}$ \\
\hline German $3.0 \%$ & Japanese $5.0 \%$ & Pair drops ou & due to unit root test & & & \\
\hline German $3.0 \%$ & Chinese $4.5 \%$ & 5 & $\begin{array}{l}0 \\
0\end{array}$ & $\begin{array}{l}0 \\
0\end{array}$ & Pair drops out due to rank tests & \\
\hline
\end{tabular}


Table A.16 continued

\begin{tabular}{|c|c|c|c|c|c|c|}
\hline Series 1 & Series 2 & $\begin{array}{l}\text { Lags used } \\
\text { in the VAR }\end{array}$ & $\begin{array}{l}\text { Significant rank } \\
\text { of Trace test }\end{array}$ & $\begin{array}{l}\text { Significant rank } \\
\text { of Maximum } \\
\text { Eigenvalue test }\end{array}$ & $\begin{array}{c}\text { Hypothesis test on } \\
\text { cointegrating vector in VECM } \\
\text { (Model suggested by AIC in italics) }\end{array}$ & Final stage judgement \\
\hline \multicolumn{7}{|l|}{ C. Post-war } \\
\hline Austria $4.0 \%$ & English $5.0 \%$ & 23 & $\begin{array}{l}0 \\
0\end{array}$ & $\begin{array}{l}0 \\
0\end{array}$ & Pair drops out due to rank tests & \\
\hline Austria $4.0 \%$ & French $5.0 \%$ & 11 & $\begin{array}{l}1 \\
0\end{array}$ & $\begin{array}{l}1 \\
0\end{array}$ & $\begin{array}{l}{[1 ; 188.32 * * *] ;[-5.89 * * * ; 1]} \\
{[1 ; 25.76 * * *] ;[0.04 * * * ; 1]}\end{array}$ & $\begin{array}{l}\text { Pair drops out due to cointegrating } \\
\text { vector being unstable }\end{array}$ \\
\hline Austria $4.0 \%$ & Russian $4.0 \%$ & 13 & $\begin{array}{l}0 \\
0\end{array}$ & $\begin{array}{l}0 \\
0\end{array}$ & Pair drops out due to rank tests & \\
\hline Austria $4.0 \%$ & English $5.0 \%$ & 25 & $\begin{array}{l}0 \\
0\end{array}$ & $\begin{array}{l}0 \\
0\end{array}$ & Pair drops out due to rank tests & \\
\hline German $3.0 \%$ & French $5.0 \%$ & 3 & $\begin{array}{l}0 \\
0\end{array}$ & $\begin{array}{l}1 \\
1\end{array}$ & $\begin{array}{l}{[1 ; 7.42 * * *] ;[0.13 * * * ; 1]} \\
{\left[1 ; 9.19^{* * *}\right] ;[0.11 * * * ; 1]}\end{array}$ & Valid cointegration relationship \\
\hline German $3.0 \%$ & Russian $4.0 \%$ & 3 & $\begin{array}{l}0 \\
0\end{array}$ & $\begin{array}{l}0 \\
0\end{array}$ & Pair drops out due to rank tests & \\
\hline Austria $4.0 \%$ & Serbian $4.0 \%$ & \multicolumn{2}{|c|}{ Pair drops out due to unit root test } & & & \\
\hline Austria $4.0 \%$ & Italian $3.5 \%$ & 12 & $\begin{array}{l}0 \\
0\end{array}$ & $\begin{array}{l}0 \\
0\end{array}$ & Pair drops out due to rank tests & \\
\hline Austria $4.0 \%$ & Romanian $4.0 \%$ & \multicolumn{2}{|c|}{ Pair drops out due to unit root test } & & & \\
\hline Austria $4.0 \%$ & Portuguese $4.5 \%$ & 24 & $\begin{array}{l}0 \\
1\end{array}$ & $\begin{array}{l}0 \\
1\end{array}$ & $\begin{array}{l}{[1 ; 15.05 * * *] ;[0.07 * * * ; 1]} \\
{[1 ; 20.91 * * *] ;[0.05 * * * ; 1]}\end{array}$ & Valid cointegration relationship \\
\hline Austria $4.0 \%$ & Japanese $5.0 \%$ & 18 & $\begin{array}{l}0 \\
0\end{array}$ & $\begin{array}{l}0 \\
0\end{array}$ & Pair drops out due to rank tests & \\
\hline
\end{tabular}


Table A.16 continued

\begin{tabular}{|c|c|c|c|c|c|c|}
\hline Series 1 & Series 2 & $\begin{array}{l}\text { Lags used } \\
\text { in the VAR }\end{array}$ & $\begin{array}{l}\text { Significant rank } \\
\text { of Trace test }\end{array}$ & $\begin{array}{l}\text { Significant rank } \\
\text { of Maximum } \\
\text { Eigenvalue test }\end{array}$ & $\begin{array}{c}\text { Hypothesis test on } \\
\text { cointegrating vector in VECM } \\
\text { (Model suggested by AIC in italics) }\end{array}$ & Final stage judgement \\
\hline \multicolumn{7}{|l|}{ C. Post-war } \\
\hline Austria $4.0 \%$ & Chinese $4.5 \%$ & 23 & $\begin{array}{l}0 \\
0\end{array}$ & $\begin{array}{l}0 \\
0\end{array}$ & Pair drops out due to rank tests & \\
\hline German $3.0 \%$ & Serbian $4.0 \%$ & \multicolumn{5}{|c|}{ Pair drops out due to unit root test } \\
\hline German $3.0 \%$ & Italian $3.5 \%$ & 2 & $\begin{array}{l}0 \\
0\end{array}$ & $\begin{array}{l}0 \\
0\end{array}$ & Pair drops out due to rank tests & \\
\hline German $3.0 \%$ & Romanian $4.0 \%$ & \multicolumn{5}{|c|}{ Pair drops out due to unit root test } \\
\hline German $3.0 \%$ & Portuguese $4.5 \%$ & 3 & $\begin{array}{l}0 \\
1\end{array}$ & $\begin{array}{l}0 \\
1\end{array}$ & $\begin{array}{l}{[1 ; 5.00 * * *] ;[0.20 * * * ; 1]} \\
{[1 ; 7.74 * * *] ;[0.13 * * * ; 1]}\end{array}$ & \multirow{2}{*}{$\begin{array}{l}\text { Valid cointegration relationship } \\
\text { Valid cointegration relationship }\end{array}$} \\
\hline German $3.0 \%$ & Japanese $5.0 \%$ & 3 & $\begin{array}{l}0 \\
0\end{array}$ & $\begin{array}{l}0 \\
1\end{array}$ & $\begin{array}{l}{[1 ; 3.11 * * *] ;[0.32 * * * ; 1]} \\
{[1 ; 4.30 * * *] ;[0.23 * * * ; 1]}\end{array}$ & \\
\hline German $3.0 \%$ & Chinese $4.5 \%$ & 2 & $\begin{array}{l}0 \\
0\end{array}$ & $\begin{array}{l}0 \\
0\end{array}$ & Pair drops out due to rank tests & \\
\hline
\end{tabular}

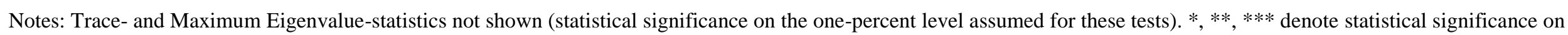
the one-, five-, and ten-per cent levels. 
Table A.17: A global test on cointegrated allies - cross-alliance relationships in major power-minor power pairs

\begin{tabular}{|c|c|c|c|c|c|c|}
\hline Series 1 & Series 2 & $\begin{array}{l}\text { Lags used } \\
\text { in the VAR }\end{array}$ & $\begin{array}{l}\text { Significant rank } \\
\text { of Trace test }\end{array}$ & $\begin{array}{l}\text { Significant rank } \\
\text { of Maximum } \\
\text { Eigenvalue test }\end{array}$ & $\begin{array}{c}\text { Hypothesis test on } \\
\text { cointegrating vector in VECM } \\
\text { (Model suggested by AIC in italics) }\end{array}$ & Final stage judgement \\
\hline \multicolumn{7}{|l|}{ A. Pre-war } \\
\hline Ottoman $4.0 \%$ & Russian $4.0 \%$ & 3 & $\begin{array}{l}0 \\
1\end{array}$ & $\begin{array}{l}1 \\
1\end{array}$ & $\begin{array}{l}{[11 ;-0.74 * * *] ;\left[265.18^{* * * *} ; 1\right]} \\
{[1 ;-0.47 *] ;[238.14 * * * ; 1]}\end{array}$ & $\begin{array}{l}\text { Pair drops out due to cointegrating } \\
\text { vector being unstable }\end{array}$ \\
\hline Bulgarian $5.0 \%$ & Russian $4.0 \%$ & 3 & $\begin{array}{l}0 \\
0\end{array}$ & $\begin{array}{l}0 \\
0\end{array}$ & Pair drops out due to rank tests & \\
\hline Ottoman $4.0 \%$ & Italian $3.5 \%$ & 2 & $\begin{array}{l}0 \\
1\end{array}$ & $\begin{array}{l}0 \\
0\end{array}$ & $\begin{array}{l}{[1 ;-0.96 * * *] ;[-1.04 * * * ; 1]} \\
{[1 ;-0.33] ;[133.81 * * * ; 1]}\end{array}$ & $\begin{array}{l}\text { Pair drops out due to double normali- } \\
\text { zation restriction violated }\end{array}$ \\
\hline Ottoman $4.0 \%$ & Romanian $4.0 \%$ & 2 & $\begin{array}{l}0 \\
0\end{array}$ & $\begin{array}{l}0 \\
0\end{array}$ & Pair drops out due to rank tests & \\
\hline Ottoman $4.0 \%$ & Chinese $4.5 \%$ & Pair drops o & due to unit root tes & & & \\
\hline Bulgarian $5.0 \%$ & Serbian $4.0 \%$ & 2 & $\begin{array}{l}0 \\
0\end{array}$ & $\begin{array}{l}0 \\
0\end{array}$ & Pair drops out due to rank tests & \\
\hline Bulgarian $5.0 \%$ & Italian $3.5 \%$ & 2 & $\begin{array}{l}0 \\
0\end{array}$ & $\begin{array}{l}0 \\
0\end{array}$ & Pair drops out due to rank tests & \\
\hline Bulgarian $5.0 \%$ & Romanian $4.0 \%$ & 3 & $\begin{array}{l}0 \\
0\end{array}$ & $\begin{array}{l}0 \\
0\end{array}$ & Pair drops out due to rank tests & \\
\hline
\end{tabular}


Table A.17 continued

\begin{tabular}{|c|c|c|c|c|c|c|}
\hline Series 1 & Series 2 & $\begin{array}{l}\text { Lags used } \\
\text { in the VAR }\end{array}$ & $\begin{array}{c}\text { Significant rank } \\
\text { of Trace test }\end{array}$ & $\begin{array}{l}\text { Significant rank } \\
\text { of Maximum } \\
\text { Eigenvalue test }\end{array}$ & $\begin{array}{c}\text { Hypothesis test on } \\
\text { cointegrating vector in VECM } \\
\text { (Model suggested by AIC in italics) }\end{array}$ & Final stage judgement \\
\hline Bulgarian $5.0 \%$ & Portuguese $4.5 \%$ & 3 & $\begin{array}{l}0 \\
0\end{array}$ & $\begin{array}{l}0 \\
0\end{array}$ & Pair drops out due to rank tests & \\
\hline Bulgarian $5.0 \%$ & Japanese $5.0 \%$ & 3 & $\begin{array}{l}0 \\
0\end{array}$ & $\begin{array}{l}0 \\
0\end{array}$ & Pair drops out due to rank tests & \\
\hline \multicolumn{7}{|l|}{ B. War } \\
\hline Ottoman $4.0 \%$ & English $5.0 \%$ & \multicolumn{5}{|c|}{ Pair drops out due to unit root test } \\
\hline Ottoman $4.0 \%$ & French $5.0 \%$ & \multicolumn{5}{|c|}{ Pair drops out due to unit root test } \\
\hline Ottoman $4.0 \%$ & Russian $4.0 \%$ & \multicolumn{5}{|c|}{ Pair drops out due to unit root test } \\
\hline Bulgarian $5.0 \%$ & English $5.0 \%$ & \multicolumn{5}{|c|}{ Pair drops out due to unit root test } \\
\hline Ottoman $4.0 \%$ & Italian $3.5 \%$ & \multicolumn{5}{|c|}{ Pair drops out due to unit root test } \\
\hline Ottoman $4.0 \%$ & Romanian $4.0 \%$ & \multicolumn{5}{|c|}{ Pair drops out due to unit root test } \\
\hline Ottoman $4.0 \%$ & Portuguese $4.5 \%$ & \multicolumn{5}{|c|}{ Pair drops out due to unit root test } \\
\hline Ottoman $4.0 \%$ & Japanese $5.0 \%$ & \multicolumn{5}{|c|}{ Pair drops out due to unit root test } \\
\hline Ottoman $4.0 \%$ & Chinese $4.5 \%$ & \multicolumn{5}{|c|}{ Pair drops out due to unit root test } \\
\hline Bulgarian $5.0 \%$ & Serbian $4.0 \%$ & \multicolumn{5}{|c|}{ Pair drops out due to unit root test } \\
\hline Bulgarian $5.0 \%$ & Italian $3.5 \%$ & \multicolumn{5}{|c|}{ Pair drops out due to unit root test } \\
\hline
\end{tabular}


Table A.17 continued

\begin{tabular}{|c|c|c|c|c|c|c|}
\hline Series 1 & Series 2 & $\begin{array}{l}\text { Lags used } \\
\text { in the VAR }\end{array}$ & $\begin{array}{c}\text { Significant rank } \\
\text { of Trace test }\end{array}$ & $\begin{array}{l}\text { Significant rank } \\
\text { of Maximum } \\
\text { Eigenvalue test }\end{array}$ & $\begin{array}{c}\text { Hypothesis test on } \\
\text { cointegrating vector in VECM } \\
\text { (Model suggested by AIC in italics) }\end{array}$ & Final stage judgement \\
\hline Bulgarian $5.0 \%$ & Romanian $4.0 \%$ & \multicolumn{5}{|c|}{ Pair drops out due to unit root test } \\
\hline Bulgarian $5.0 \%$ & Portuguese $4.5 \%$ & \multicolumn{5}{|c|}{ Pair drops out due to unit root test } \\
\hline Bulgarian $5.0 \%$ & Japanese $5.0 \%$ & \multicolumn{5}{|c|}{ Pair drops out due to unit root test } \\
\hline Bulgarian $5.0 \%$ & Chinese $4.5 \%$ & \multicolumn{5}{|c|}{ Pair drops out due to unit root test } \\
\hline \multicolumn{7}{|l|}{ C. Post-war } \\
\hline Ottoman $4.0 \%$ & English $5.0 \%$ & \multicolumn{5}{|c|}{ Pair drops out due to unit root test } \\
\hline Ottoman $4.0 \%$ & French $5.0 \%$ & \multicolumn{5}{|c|}{ Pair drops out due to unit root test } \\
\hline Ottoman $4.0 \%$ & Russian $4.0 \%$ & \multicolumn{5}{|c|}{ Pair drops out due to unit root test } \\
\hline Bulgarian $5.0 \%$ & English $5.0 \%$ & 23 & $\begin{array}{l}1 \\
1\end{array}$ & $\begin{array}{l}1 \\
1\end{array}$ & $\begin{array}{l}{[1 ; 0.36 *] ;[2.75 * * * ; 1]} \\
{[1 ; 0.08] ;[11.94 * * * ; 1]}\end{array}$ & $\begin{array}{l}\text { Pair drops out due to double normali- } \\
\text { zation restriction violated }\end{array}$ \\
\hline Bulgarian $5.0 \%$ & French $5.0 \%$ & 8 & $\begin{array}{l}1 \\
1\end{array}$ & $\begin{array}{l}0 \\
1\end{array}$ & $\begin{array}{l}{[1 ; 1.70 * * *] ;[0.59 * * * ; 1]} \\
{[1 ; 1.19 * *] ;[0.84 * * * ; 1]}\end{array}$ & Valid cointegration relationship \\
\hline Bulgarian $5.0 \%$ & Russian $4.0 \%$ & 2 & $\begin{array}{l}0 \\
0\end{array}$ & $\begin{array}{l}0 \\
0\end{array}$ & $\begin{array}{l}{[1 ;-0.42 * *] ;[-2.40 * * * ; 1]} \\
{[1 ; 0.16] ;[6.38 * * * ; 1]}\end{array}$ & $\begin{array}{l}\text { Pair drops out due to double normali- } \\
\text { zation restriction violated }\end{array}$ \\
\hline Ottoman $4.0 \%$ & Serbian $4.0 \%$ & \multicolumn{5}{|c|}{ Pair drops out due to unit root test } \\
\hline Ottoman $4.0 \%$ & Italian $3.5 \%$ & \multicolumn{5}{|c|}{ Pair drops out due to unit root test } \\
\hline Ottoman $4.0 \%$ & Romanian $4.0 \%$ & \multicolumn{5}{|c|}{ Pair drops out due to unit root test } \\
\hline Ottoman $4.0 \%$ & Portuguese $4.5 \%$ & \multicolumn{5}{|c|}{ Pair drops out due to unit root test } \\
\hline Ottoman $4.0 \%$ & Japanese $5.0 \%$ & \multicolumn{5}{|c|}{ Pair drops out due to unit root test } \\
\hline Ottoman $4.0 \%$ & Chinese $4.5 \%$ & \multicolumn{5}{|c|}{ Pair drops out due to unit root test } \\
\hline
\end{tabular}


Table A.17 continued

\begin{tabular}{|c|c|c|c|c|c|c|}
\hline Series 1 & Series 2 & $\begin{array}{l}\text { Lags used } \\
\text { in the VAR }\end{array}$ & $\begin{array}{l}\text { Significant rank } \\
\text { of Trace test }\end{array}$ & $\begin{array}{l}\text { Significant rank } \\
\text { of Maximum } \\
\text { Eigenvalue test }\end{array}$ & $\begin{array}{c}\text { Hypothesis test on } \\
\text { cointegrating vector in VECM } \\
\text { (Model suggested by AIC in italics) }\end{array}$ & Final stage judgement \\
\hline Bulgarian $5.0 \%$ & Serbian $4.0 \%$ & \multicolumn{2}{|c|}{ Pair drops out due to unit root test } & & Pair drops out due to rank tests & \\
\hline Bulgarian $5.0 \%$ & Italian $3.5 \%$ & 2 & $\begin{array}{l}0 \\
0\end{array}$ & $\begin{array}{l}0 \\
0\end{array}$ & & \\
\hline Bulgarian $5.0 \%$ & Romanian $4.0 \%$ & \multicolumn{2}{|c|}{ Pair drops out due to unit root test } & & & \\
\hline Bulgarian $5.0 \%$ & Japanese $5.0 \%$ & 2 & $\begin{array}{l}0 \\
0\end{array}$ & $\begin{array}{l}0 \\
0\end{array}$ & Pair drops out due to rank tests & \\
\hline Bulgarian $5.0 \%$ & Chinese $4.5 \%$ & 2 & $\begin{array}{l}0 \\
0\end{array}$ & $\begin{array}{l}0 \\
0\end{array}$ & Pair drops out due to rank tests & \\
\hline
\end{tabular}

Notes: Trace- and Maximum Eigenvalue-statistics not shown (statistical significance on the one-percent level assumed for these tests). *,**,*** denote statistical significance on the one-, five-, and ten-per cent levels. 